
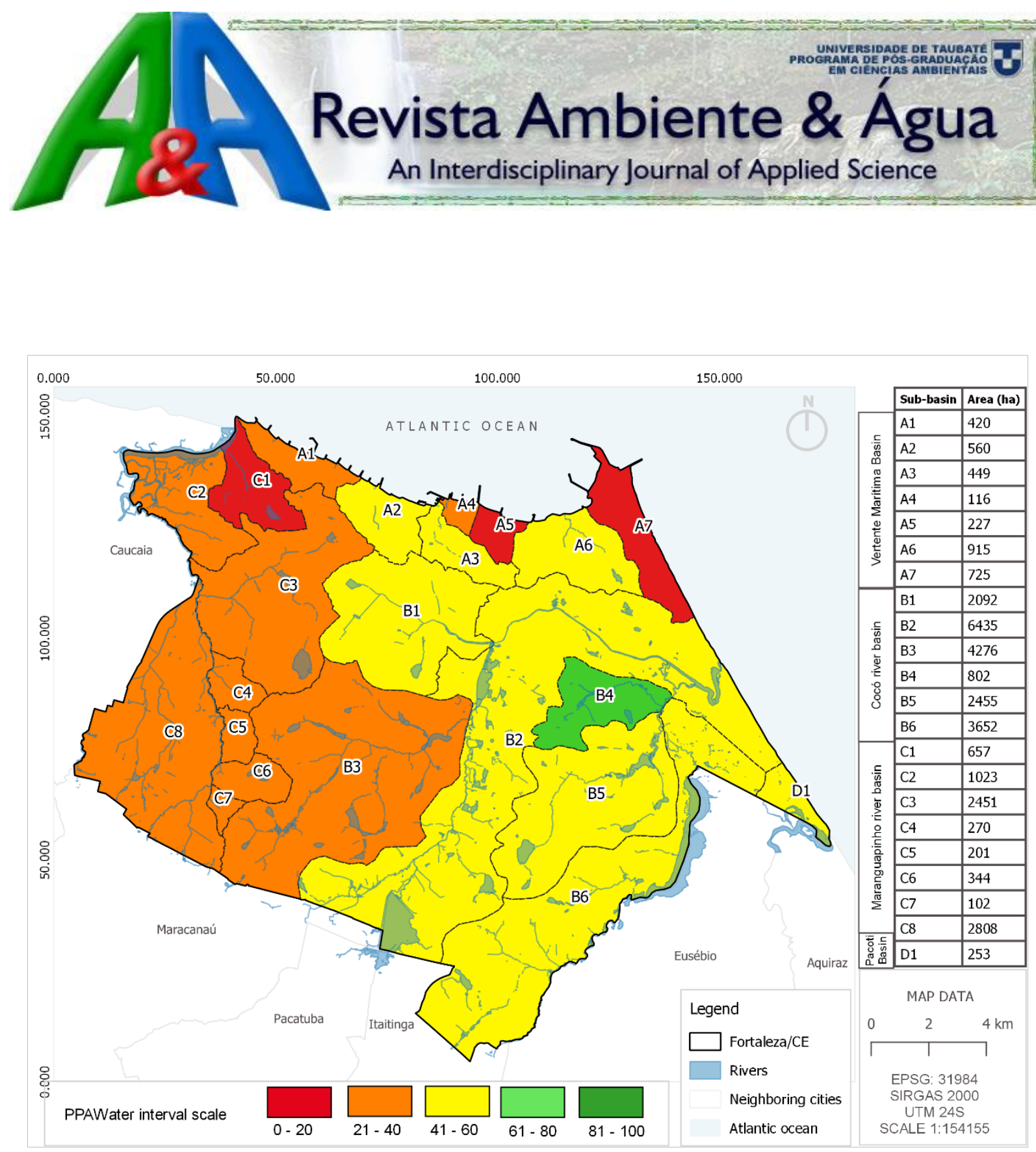

ISSN = 1980-993X (Online)

http://www.ambi-agua.net

$61^{\text {th }}$ Edition of Revista Ambiente \& Água - An Interdisciplinary Journal of Applied Science, Taubaté, V. 16, N. 1, p. 1-16 Jan/Feb. 2021. (doi:10.4136/ambi-agua.v16.n1) 


\section{EDITORIAL BOARD}

\section{Editors}

Getulio Teixeira Batista (Emeritus Editor) Universidade de Taubaté - UNITAU, BR

Nelson Wellausen Dias (Editor-in-Chief), Fundação Instituto Brasileiro de Geografia e Estatística - IBGE, BR

Ana Aparecida da Silva Almeida

Marcelo dos Santos Targa

Andrea Giuseppe Capodaglio

Arianna Callegari

Antonio Teixeira de Matos

Apostol Tiberiu

Claudia M. dos S. Cordovil

Dar Roberts

Giordano Urbini

Gustaf Olsson

Hélio Nobile Diniz

Ignacio Morell Evangelista

János Fehér

Julio Cesar Pascale Palhares

Luis Antonio Merino

Maria Cristina Collivignarelli

Massimo Raboni

Petr Hlavínek

Richarde Marques da Silva

Stefan Stanko

Teresa Maria Reyna

Yosio Edemir Shimabukuro

Zhongliang Liu Beijing

Text Editor

Reference Editor

Peer-Reviewing Process

System Analyst

Secretary and Communication

\section{Associate Editors}

Universidade de Taubaté (UNITAU), BR

Universidade de Taubaté (UNITAU), BR

\section{Editorial Commission}

University of Pavia, ITALY

Università degli Studi di Pavia, ITALY

Universidade Federal de Minas Gerais (UFMG), BR

University Politechnica of Bucharest, Romênia

Centro de estudos de Engenharia Rural (CEER), Lisboa, Portugal

University of California, Santa Barbara, United States

University of Insubria, Varese, Italy

Lund University, Lund, Sweden

Inst. Geológico, Sec. do Meio Amb. do Est. de SP (IG/SMA), BR

University Jaume I- Pesticides and Water Research Institute, Spain

Debrecen University, Hungary

Embrapa Pecuária Sudeste, CPPSE, São Carlos, SP, BR

Institute of Regional Medicine, National University of the Northeast, Corrientes, Argentina

University of Pavia, Depart. of Civil Engineering and Architecture, Italy

LIUC - University "Cattaneo", School of Industrial Engineering, Italy

Brno University of Technology República Tcheca

Universidade Federal da Paraíba (UFPB), BR

Slovak Technical University in Bratislava Slovak, Eslováquia

Universidad Nacional de Córdoba, Argentina

Instituto Nacional de Pesquisas Espaciais (INPE), BR

University of Technology, China

Theodore D`Alessio, FL, USA, Maria Cristina Bean, FL, USA

Liliane Castro, Bibliotecária - CRB/8-6748, Taubaté, BR

Marcelo Siqueira Targa, UNITAU, BR

Tiago dos Santos Agostinho, UNITAU, BR

Luciana Gomes de Oliveira, UNITAU, BR

\section{Library catalog entry by Liliane Castro CRB/8-6748}

Revista Ambiente \& Água - An Interdisciplinary Journal of Applied Science / Instituto de Pesquisas Ambientais em Bacias Hidrográficas. Taubaté. v. 16, n.1 (2006) - Taubaté: IPABHi, 2021.

Quadrimestral (2006 - 2013), Trimestral (2014 - 2016), Bimestral (2017), Publicação Contínua a partir de Janeiro de 2018.

Resumo em português e inglês.

ISSN 1980-993X

1. Ciências ambientais. 2. Recursos hídricos. I. Instituto de Pesquisas Ambientais em Bacias Hidrográficas.

CDD - 333.705

CDU - (03)556.18 


\section{TABLE OF CONTENTS}

\section{COVER:}

The Permanent Preservation Area (PPA) Water index is intended to assess the level of degradation of urban water resources. Its unique feature is not to employ water quality monitoring data, usually unavailable in developing countries. In contrast, it employs easy-to-apply innovative territorial information available in existing databases. The example presented in the map shows the result of PPA Water Index applied to the municipality of Fortaleza, CE, Brazil, categorized in five PPA management levels: Unconcerned (red), Inefficient (orange), Regular (yellow), Concerned (light green), and Efficient (dark green) management of PPAs. Source: VASCONCELOS, F.D.M. et al. Quality index of permanent preservation areas of urban water resources: PPAWater. Rev. Ambient. Água, Taubaté, vol. 16 n. 1, p. 1-16, 2021. doi:10.4136/ambi-agua.2589

\section{ARTICLES}

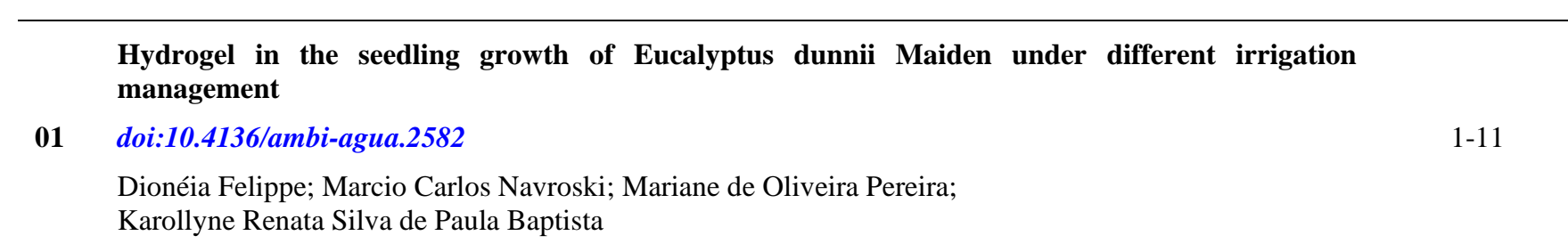
Performance evaluation and coefficients of reliability for waste stabilization ponds in northeast Brazil

02 doi:10.4136/ambi-agua.2571

Matheus Sales Alves; Fernando José Araújo da Silva; André Luís Calado Araújo; Erlon Lopes Pereira

Aquatic entomofauna and biotic index along the Pindo Grande River, Montano Bajo Forest, in
Pastaza Province, Ecuador
doi:10.4136/ambi-agua.2563
Maria Alexandra Endara; Demián Hinojosa-Garró

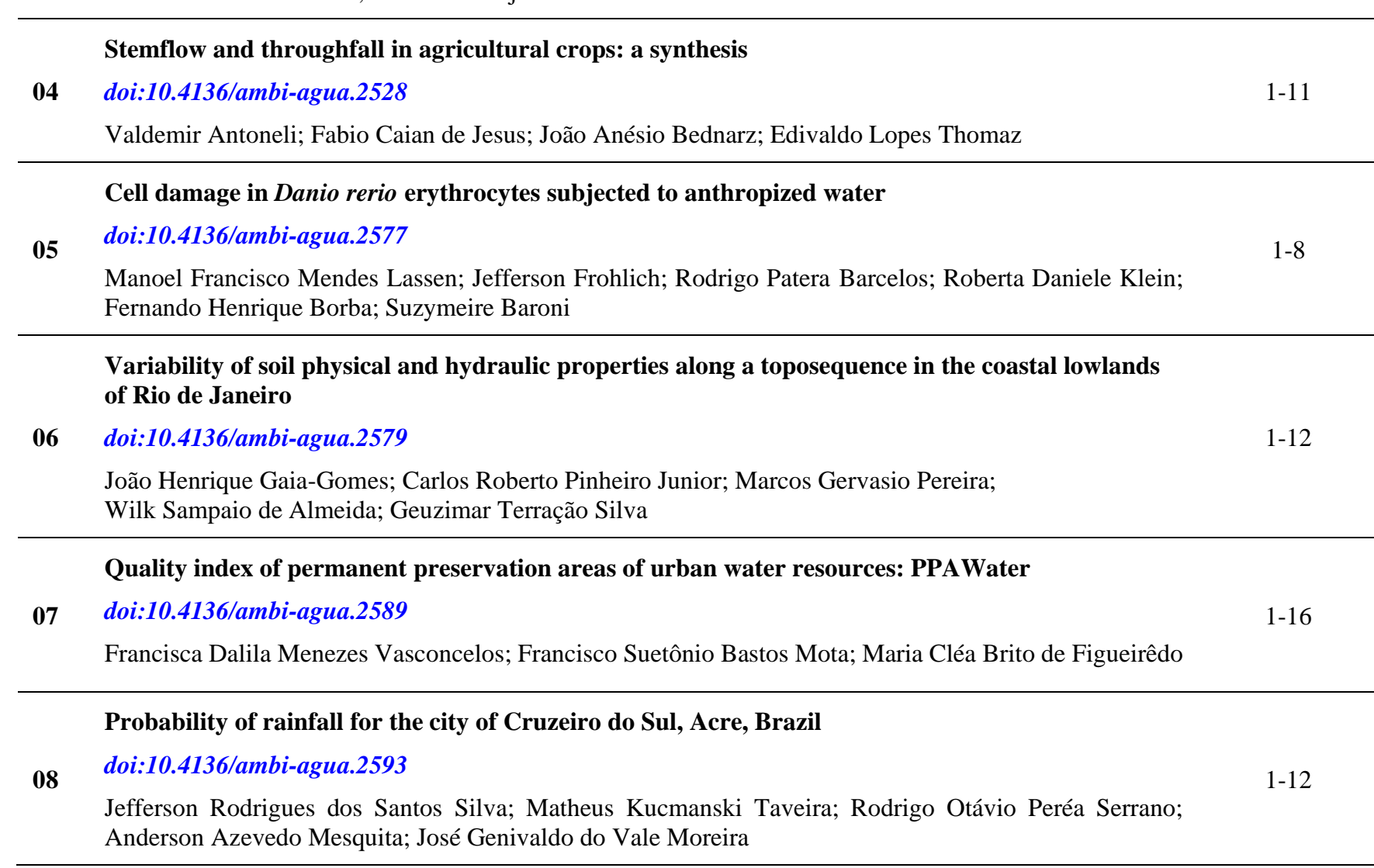


Wastewater reuse in irrigation: short-term effect on soil carbon and nitrogen stocks in Brazilian semi-arid region

09

doi:10.4136/ambi-agua.2623

Marcus Metri Corrêa; Marília Costa Cavalcanti; Dário Costa Primo; Fernando Cartaxo Rolim Neto;

Jean Manuel Martins; Rômulo Simões Cezar Menezes; Antonio Celso Dantas Antonino;

Isaque de Souza Mendes; Lívia Regina dos Santos Medeiros

A predictive growth model for Yarrowia lipolytica ATCC 9773 in wastewater

10 doi:10.4136/ambi-agua.2629

Arnulfo Antonio Tarón Dunoyer; Rafael Emilio González Cuello; Fredy Colpas Castillo

Physiological responses of inoculated and uninoculated peanuts under saline stress

11

doi:10.4136/ambi-agua.2643

Antonio Fabio da Silva Lima; Max Ferreira dos Santos; Matheus Lima Oliveira;

Geocleber Gomes de Sousa; Paulo Furtado Mendes Filho; Lucas Nunes da Luz

The role of food/microorganism ratio in denitrification reactors: how it affects the sizing and operation of the denitrification process

12

doi:10.4136/ambi-agua.2656

Renato Gavasci; Francesco Lombardi; Massimo Raboni

Probability distribution of heavy rainfall and determination of IDF in the city of Caruaru - PE

doi:10.4136/ambi-agua.2555

13 Kevin Matheus Correia Mendes; Aline Lima de Oliveira; Lucas Ravellys Pyrrho de Alcântara;

Adriana Thays Araújo Alves; Severino Martins dos Santos Neto; Artur Paiva Coutinho;

Suzana Maria Gico Lima Montenegro; José Moura Soares; Antonio Celso Dantas Antonino

Simulation of nitrate and potassium concentrations in soil solution using parametric models and Hydrus-2D

14 doi:10.4136/ambi-agua.2606

Beatriz Santos Conceição; Eugênio Ferreira Coelho; João José da Silva Junior;

José Antonio do Vale Sant'Ana; Mauro Aparecido Martinez

Assessing glyphosate concentrations in six reservoirs of Paraíba do Sul and Guandu River Basins in southeast Brazil

15 doi:10.4136/ambi-agua.2615

Carolina da Silva Cristofaro; Christina Wyss Castelo Branco; Maria Isabel de Almeida Rocha;

Samira da Guia Mello Portugal

\section{Hydrological modeling in a basin of the Brazilian Cerrado biome}

16

doi:10.4136/ambi-agua.2639

Jéssica Assaid Martins Rodrigues; Alberto Carlos de Oliveira Andrade; Marcelo Ribeiro Viola;

Danton Diego Ferreira; Carlos Rogério de Mello; Michael Silveira Thebaldi 


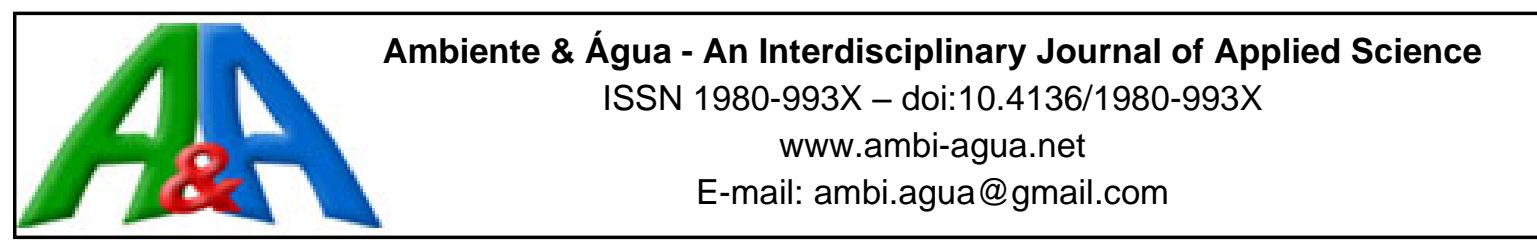

\title{
Hydrogel in the seedling growth of Eucalyptus dunnii Maiden under different irrigation management
}

\author{
ARTICLES doi:10.4136/ambi-agua.2582
}

Received: 29 Apr. 2020; Accepted: 03 Dec. 2020

\section{Dionéia Felippe ${ }^{(D}$; Marcio Carlos Navroski ${ }^{D}$; \\ Mariane de Oliveira Pereira ${ }^{\circledR}$; Karollyne Renata Silva de Paula Baptista*}

Departamento de Engenharia Florestal. Programa de Pós-graduação em Engenharia Florestal. Universidade do Estado de Santa Catarina (UDESC), Avenida Luiz de Camões, n 2090, CEP: 88520-000, Lages, SC, Brazil.

E-mail: dioneia.felippe@gmail.com, marcio.navroski@udesc.br, maripereira.florestal@gmail.com *Corresponding author. E-mail: karollyne-silva@hotmail.com

\begin{abstract}
This study evaluated the effect of using hydrogel in the planting of Eucalyptus dunnii seedlings in pots, under different water-management regimens. Seedlings of approximately 25 $\mathrm{cm}$ height were planted in pots filled with $4.5 \mathrm{~L}$ of soil. The experiment was of Completely Randomized Design, in a $2 \times 3$ factorial, with absence and presence of hydrogel related to different water-management regimens (irrigation only in planting, every 3 to 6 days). From planting until the $47^{\text {th }}$ day the seedlings were evaluated for the symptoms of water stress, chlorophyll content and gas exchange. Finally, the development of the plants was evaluated using the root dry weights and shoots, as well as by determining the water retention curve. As a result, the use of the polymer yielded an increase in water retention and a delay in the symptoms of drought stress, consequently increasing chlorophyll levels. One can observe the direct effect gas exchange of this kind, where recovery of the variables analyzed $24 \mathrm{~h}$ after irrigation was visible. Reviews of dry biomass demonstrated that treatment with the use of hydrogel showed the best development. However, the use of hydro retainer polymer increased the quality of Eucalyptus dunnii seedlings, besides being an alternative planting method in dry periods of the year.
\end{abstract}

Keywords: hydro retainer polymer, symptoms of water stress, water management.

\section{Hidrogel no crescimento de mudas de Eucalyptus dunnii Maiden Submetidas a diferentes manejos de irrigação}

\section{RESUMO}

Objetivou-se avaliar o efeito do hidrogel no plantio de mudas de Eucalyptus dunnii em vasos, relacionados com diferentes manejos hídricos. Utilizou-se mudas de aproximadamente $25 \mathrm{~cm}$ de altura plantadas em vasos preenchidos com 4,5 L de solo. $\mathrm{O}$ experimento foi realizado em DIC, esquema fatorial $2 \times 3$, com ausência e presença de hidrogel relacionados aos manejos hídricos (irrigação somente no plantio, a cada três e seis dias). Do plantio até o $47^{\circ}$ dia foram realizadas avaliações da sintomatologia do estresse hídrico, teores de clorofila e trocas gasosas. Avaliou-se o desenvolvimento das mudas através da biomassa seca radicular e da parte aérea, além da determinação da curva de retenção de água. Como resultado, o uso do polímero proporcionou um aumento na retenção de água, e um atraso nos sintomas de estresse hídrico, 
aumentando assim os níveis de clorofila. Houve efeito direto nas trocas gasosas, sendo visível a recuperação das variáveis analisadas, $24 \mathrm{~h}$ após a irrigação. Avaliações da biomassa demonstraram que os tratamentos com o uso do hidrogel, apresentaram melhor desenvolvimento. $\mathrm{O}$ uso do polímero aumentou a qualidade das mudas, sendo uma alternativa de plantio em épocas secas do ano.

Palavras-chave: manejo hídrico, polímero hidroretentor, sintomatologia do estresse hídrico.

\section{INTRODUCTION}

A combination of several factors is necessary for the plantation of productive forests, such as site-adapted genetic materials, favorable edaphoclimatic conditions, proper use of management techniques and high-standard seedlings (Davide and Faria, 2008). Among the most widely cultivated forestry species in Brazil, the genus Eucalyptus stands out, currently occupying 6.97 million hectares of planted forest area, representing $71.9 \%$ of the total (IBA, 2020).

Soil and humidity conditions are dominant factors in the forest establishment, because they affect both planting and regeneration of plants (Sarvas et al., 2007). However, one of the main causes of mortality rates of forestry seedlings species, just after transplant, is their inability to stay properly hydrated (Thomas, 2008).

The use of hydro retainer polymers as soil humidity conditioners may therefore be beneficial. According to Mendonça et al. (2013), a "hydro retainer polymers" is a polymer that helps mainly in water retention for newly planted seedlings, increasing water availability for crops and local productivity, and minimizing production costs, contributing to the viability of planting throughout the year.

Based on this, the objective of this experiment was to evaluate the effects of hydrogel on Eucalyptus dunnii seedlings with different water-management regimens.

\section{MATERIALS AND METHODS}

The experiment was conducted in the greenhouse of the Santa Catarina State University Forest Nursery, located at coordinates $27^{\circ} 47^{\prime} 33.62^{\prime \prime} \mathrm{S}$ e $50^{\circ} 18^{\prime} 4.60^{\prime \prime} \mathrm{W}$, with an approximate altitude of 900 meters above sea level.

According to the Köppen classification, the climate of the municipality of Lages (Santa Catarina) is humid mesothermal with a mild summer (Cfb-temperate). The annual average temperature is $15^{\circ} \mathrm{C}$ and the annual average precipitation stands between 1300 and $1500 \mathrm{~mm}$.

The Eucalyptus dunnii seedlings used were grown from seed, and after being properly developed for planting, with a height close to $25 \mathrm{~cm}$ and at least $2 \mathrm{~mm}$ of stump diameter, were transferred to vases containing soil classified as Aluminium Humic Cambisol. Analysis (0-40 $\mathrm{cm})$ showed the soil had the following chemical assignments: $\mathrm{pH}: 4.7$; SMP: 4.9; Ca: 2.2 $\left(\mathrm{cmolc} / \mathrm{dm}^{3}\right) ; \mathrm{Mg}: 1.2\left(\mathrm{cmolc} / \mathrm{dm}^{3}\right) ; \mathrm{Al}: 4.9\left(\mathrm{cmolc} / \mathrm{dm}^{3}\right) ; \mathrm{H}+\mathrm{Al}: 9.6\left(\mathrm{cmolc} / \mathrm{dm}^{3}\right) ;$ effective CEC (Cation Exchange Capacity): $13.1\left(\mathrm{cmolc} / \mathrm{dm}^{3}\right)$; Aluminium saturation: 58.2\%; base saturation: 26.8\%; Clay: 47.6\%; P (Mehlich): $3.7\left(\mathrm{mg} / \mathrm{dm}^{3}\right) ; \mathrm{K}: 48.0\left(\mathrm{mg} / \mathrm{dm}^{3}\right) ; \mathrm{Cu}$ (Mehlich): 1.8 $\left(\mathrm{mg} / \mathrm{dm}^{3}\right)$ and $\mathrm{Zn}$ (Mehlich): 3.4 .

To simulate field conditions, we used polyethylene pots with 5-liter capacity and 4.5 liters of previously unsealed and dry soil. After filling with soil, the pots were watered until they reached field capacity (approximately 1.5 liters). Then a hole of approximately $300 \mathrm{~cm}^{3}$ was manually opened in the center of each pot for planting. In the treatments using hydrogel, 250 $\mathrm{mL}$ were added in the hydrated form before seedling planting. Hydration was performed with running well water 30 minutes before the planting; the hydrogel dosage used was $3 \mathrm{~g} \mathrm{~L}^{-1}$. After the hole opening, with or without hydrogel, began the planting of Eucalyptus dunnii seedlings. 
After planting, besides the $1500 \mathrm{~mL}$ to moisten the soil, $250 \mathrm{~mL}$ of water were added to each pot for the treatments without hydrogel, to compensate for the volume added by the hydrogel to the other treatments. For the treatments with irrigation, $250 \mathrm{~mL}$ of water were added in each pot, following the previously set frequency, according to each treatment. All irrigation treatments received $250 \mathrm{~mL}$ of water during the course of the experiment. This value was obtained by the average field capacity of the experiment by Felippe et al. (2016). The irrigation of the pots was carried out manually, with the amount of water measured in a beaker, and after carefully pouring over the soil (pot), an attempt was made to spread it as much as possible over the entire surface.

The experimental design was the Completely Randomized, in bifactorial scheme, where the " $\mathrm{A}$ " factor levels referred to presence or absence of hydrogel, and the " $\mathrm{B}$ " factor levels are referred to water management (only at planting, intervals of three and six days between each irrigation). Ten replicates composed of one plant from each replication were used.

\subsection{Water retention curve}

To determine the water retention curve, we used five soil samples with the presence of hydrogel incorporated to the substrate and five samples with the absence of the hydrogel, totaling ten samples, collected in cylindrical rings of approximately $50 \mathrm{~cm}^{3}$, in order to preserve the maximum original soil structure. The available soil water content was calculated by subtracting the soil volumetric humidity value corresponding to the field capacity (FC), obtained at the water tension of $10 \mathrm{kPa}$, by the humidity value at the permanent withering point (PWP), obtained at the tension of $1500 \mathrm{kPa}$, according to Moniz (1972). From these limits, it was possible to determine the water storage capacity available in the soil (Bergamaschi et al., 1992).

In the laboratory, the samples with preserved structure were initially saturated by capillarity for 24 hours with a water layer of approximately $3 \mathrm{~cm}$ and then weighed. The samples were subsequently submitted to a sand column to obtain the humidity at the equilibrium tensions of 1, 6 and $10 \mathrm{kPa}$ (Reinert and Reichert, 2006) and at the tensions of 33, 100, 500, 1000 and $1500 \mathrm{kPa}$ in Richards pressure chambers (Klute, 1986). The volumetric humidity of the samples was obtained by the relation between the amount of retained water at a determined tension and the volume of the cylinder. At the end the samples were taken to the drying oven for about two days, where the soil dry weight was obtained, also estimating the density of the soil (Blake and Hartge, 1986). During the elaboration of the soil water retention curve with the addition of hydrogel, the variation of the sample volume was not considered as the humidity varied according to the expansion of the hydrogel.

With the humidity values at the tensions of 1, 6, 10,33,100, 500, 1000 and $1500 \mathrm{kPa}$, the soil water retention curve was adjusted, using the Van Genuchten (1980) model through the SWRC (Soil Water Retention Curve) software.

\subsection{Physiological analysis}

Until the $47^{\text {th }}$ day after planting, daily evaluations of water stress symptoms, chlorophyll contents and greenhouse temperature verification were performed. For visual symptomatology, analysis criterion of Navroski et al. (2014) was adopted, noting the number of days the plant remained in each condition: SEM- days without symptoms (turgid plant, visually vigorous, with no evidence of water deficit); SLM- days with mild withering symptoms; SMM- days with moderated symptoms (plant in permanent withered state, with curved and darkened apex); SSM- days with severe wilting symptoms (dry leafs/in abscission). For survival, the code PPV was adopted - the number of days the plant remained alive.

Chlorophyll content was obtained using the portable chlorophyll meter SPAD-502 (Minolta Camera Co. Ltd.), measured in two physiologically mature leaves on opposite sides, in the middle portion of the plant top, the leaves were marked for further measures. From the 
four readings, the average was calculated using the portable chlorophyll meter itself. The measurements were performed in ten repetitions, in all treatments, always in the pre-irrigation period.

Gas exchange evaluations were performed only in treatments with presence and absence of hydrogel, with a frequency of three days of irrigation, using five repetitions, and it was not possible to evaluate the other treatments, due to mortality that gradually occurred during the experiment. The evaluations were performed using an Infrared Gas Analyzer portable photosynthesis meter (Li-6400xt), determining the assimilation values of $\mathrm{CO}_{2}(A)$, stomatal conductance $\left(g_{s}\right)$, transpiration $(E)$, relation between intercellular and atmospheric concentration $\mathrm{CO}_{2}(\mathrm{Ci} / \mathrm{Ca})$ and water-use efficiency (WUE). The water-use efficiency (WUE) was obtained by dividing $A$ by $E$. Inside the greenhouse, the plants received, during the measurements, an irradiance of approximately $900 \mathrm{mmol}$ of photons $\mathrm{m}^{-2} \mathrm{~s}^{-1}$. Gas exchange evaluation was performed immediately before and 24 hours after irrigation, and 43 days after planting and the start of intermittent irrigation. Assessments on both days began around 8:00 am.

\subsection{Dry biomass}

At the end of the experiment (48 days), by a destructive method, the aerial and root biomass of the plants was manually collected. Collection was performed only in treatments that received intermittent irrigation, in the frequencies of three and six days, regardless of the absence or presence of the hydrogel. These were separated and stored in paper bags, kept in a forced air circulation oven $\left(65 \pm 3^{\circ} \mathrm{C}\right)$ until they reached constant mass, after weighing to determine the dry matter content by using a precision balance $(0.01 \mathrm{~g})$.

\subsection{Statistical Analysis}

After confirming the normality and homogeneity of the data of the analyzed variables, a parametric variance analysis was performed at a 5\% error probability level. When the value of "F" was significant, the qualitative treatments had their averages compared by the Scott-Knott test or t-test, at $5 \%$ probability of error. The SISVAR software was used to perform the data analysis and for graphics the Origin Pro 9 and the Graphed 8 softwares were used.

\section{RESULTS AND DISCUSSION}

\subsection{Available water retention curve}

By determining the soil's water retention curve, it was found that the use of hydrogel incorporated in the soil caused a significant in the amount of water retention when compared to the same soil with the absence of the polymer, although this increase was more evident at tensions below $10 \mathrm{kPa}$ (Figure 1). In any case, the addition of hydro-retaining polymers positively influenced the soil water-storage capacity.

The field capacity (FC) was higher $\left(0.427 \mathrm{~m}^{3} \mathrm{~m}^{-3}\right)$ in the presence of hydrogel than in the absence $\left(0.349 \mathrm{~m}^{3} \mathrm{~m}^{-3}\right)$. Regarding the permanent wilting point (PWP), hydrogel presence promoted inferior results when soil received the polymer $\left(0.189 \mathrm{~m}^{3} \mathrm{~m}^{-3}\right)$ compared to when it did not $\left(0.206 \mathrm{~m}^{3} \mathrm{~m}^{-3}\right)$. As a result, the available soil water storage capacity (WSC) was higher in the presence of the polymer $\left(0.238 \mathrm{~m}^{3} \mathrm{~m}^{-3}\right)$ compared to the absence $\left(0.143 \mathrm{~m}^{3} \mathrm{~m}^{-3}\right)$, resulting in a relative increase of $66 \%$. The available water storage capacity increased due to the hydroretaining polymer having a greater activity in ion exchange capacity with the soil solution, as it has a larger diffuse double layer than the sandy particles that are predominant in the soil used in the experiment. Therefore, it is expected that this effect will be more pronounced in sandytextured soils, as in the present study, than in clayey-textured soils. 


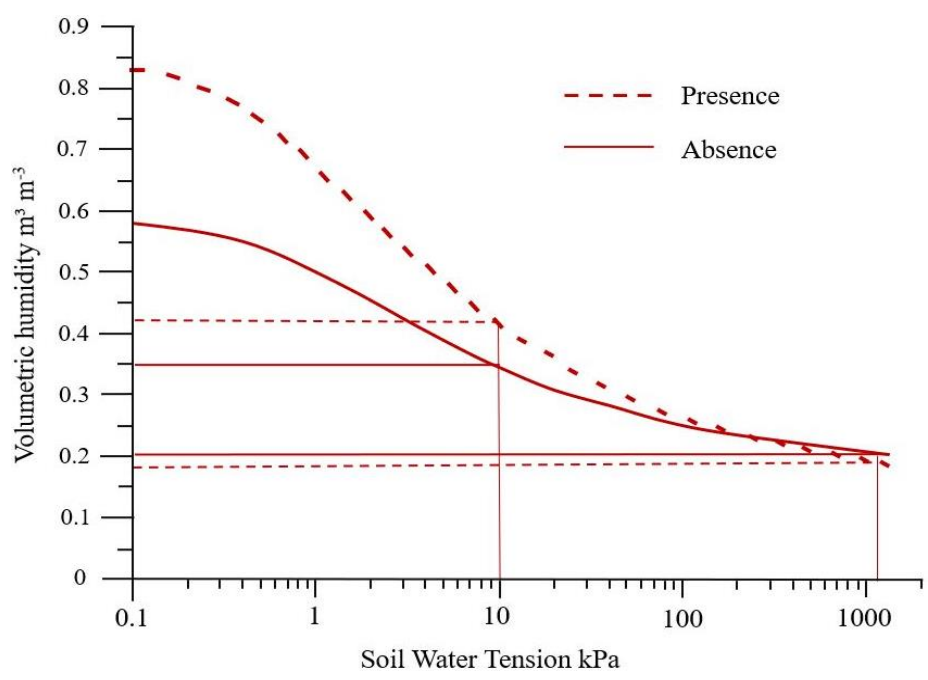

Figure 1. Soil water retention curve in Aluminium Humic Cambisol, with the absence $\left(0 \mathrm{~g} \mathrm{~L}^{-1}\right)$ and presence of hydrogel $\left(3 \mathrm{~g} \mathrm{~L}^{-1}\right)$, subjected to tensions of $1,6,10,33$ and $100,500,1000$ and $1500 \mathrm{kPa}$.

This result can be explained by the high water absorption capacity of the hydrogel. According to Prevedello and Loyola (2007), the hydrogel has the capacity to absorb 150 to 400 times its dry mass and can be used to increase water storage capacity, minimizing problems associated with irregular or deficient water availability of water in the soil, when it may negatively affect plant development.

\subsection{Photosynthetic analysis}

Analyzing the hydrogel efficiency before irrigation and 24 hours afterwards, with the absence or presence of this polymer in the cultivation soil, the direct effect on gas exchange of this species can be observed (Table 1). Overall, there was no significant difference in the results of photosynthetic analyses collected prior to irrigation using the hydrogel. However, there was a difference $(\mathrm{p}<0.05)$ when analyses occurred 24 hours after irrigation. It was observed that the treatments without hydrogel presented the best values for all analyzed variables.

This fact can be explained by the drought-tolerance mechanism that the plant develops at the cellular level where the production or accumulation of osmotically active solutes occurs, a process known as "osmotic adjustment," in order to maintain turgor and water potential balance in the cell (Nunes, 2007). For Serraj and Sinclair (2002), this mechanism allows the survival of the water-deficient plant, but does not maintain plant growth and productivity.

Table 1. Liquid $\mathrm{CO}_{2}$ assimilation $(A)$, stomatal conductance $\left(g_{s}\right)$, transpiration $(E)$, relation between intercellular and atmospheric $\mathrm{CO}_{2}$ concentration $(\mathrm{Ci} / \mathrm{Ca})$, and water use efficiency (WUE) in Eucalyptus dunnii before, and 24 hours after irrigation and with or without hydrogel in the soil.

\begin{tabular}{ccccccc}
\hline \multirow{2}{*}{ Period } & \multirow{2}{*}{ Hydrogel } & $A$ & $g_{s}$ & $E$ & $\mathrm{Ci} / \mathrm{Ca}$ & WUE \\
\cline { 3 - 7 } & & $\mu \mathrm{mol} \mathrm{m} \mathrm{s}^{-2} \mathrm{~s}^{-1}$ & $\mathrm{~mol} \mathrm{~m}^{-2} \mathrm{~s}^{-1}$ & $\mathrm{mmol} \mathrm{m}^{-2} \mathrm{~s}^{-1}$ & $\mathrm{~mol} \mathrm{~mol}$ & $\mu \mathrm{mol} \mathrm{mmol}^{-1}$ \\
\hline Before & With & $2.44 \mathrm{Aa}^{*}$ & $0.016 \mathrm{Aa}$ & $0.247 \mathrm{Aa}$ & $0.337 \mathrm{Aa}$ & $9.82 \mathrm{Ba}$ \\
Before & Without & $2.89 \mathrm{Aa}$ & $0.021 \mathrm{Aa}$ & $0.335 \mathrm{Aa}$ & $0.429 \mathrm{Aa}$ & $8.06 \mathrm{Aa}$ \\
After & With & $5.38 \mathrm{Ab}$ & $0.043 \mathrm{Aa}$ & $0.949 \mathrm{Ab}$ & $0.422 \mathrm{Aa}$ & $5.79 \mathrm{Ab}$ \\
After & Without & $8.18 \mathrm{Bb}$ & $0.092 \mathrm{Bb}$ & $1.563 \mathrm{Bb}$ & $0.557 \mathrm{Bb}$ & $5.59 \mathrm{Ab}$ \\
\hline $\mathrm{CV}(\%)$ & & 21.5 & 19.2 & 20.4 & 26.1 & 16.8 \\
\hline
\end{tabular}

*Averages followed by the same letter, uppercase for hydrogel and lowercase for period do not differ between each other by t-test (0.05). 
Irrespective of the presence or not of irrigation, the plants with the absence of the hydroretaining polymer presented the best physiological performance, presenting the better stomatal control and consequently higher values of $\mathrm{A}, \mathrm{E}$ and $\mathrm{Ci} / \mathrm{Ca}$.

With the addition of the polymer, $A, E$ and $g_{s}$ recovery was visible 24 hours after irrigation, demonstrating that $A$ limitation probably occurred due to stomatal limitation, given the rapid recovery. These results show that all physiological processes of the cell are directly or indirectly affected by water supply. However, Agaba et al. (2011), state that the hydrogel's ability to hold and make water available more slowly may favor the ability of seedlings to return to normal after water stress has occurred.

As for the $W U E$ values, they maintained their higher values in the presence of hydrogel, both before irrigation and 24 hours after it. This fact may be justified due to the strategy that the plant develops to tolerate the water deficit. The control of plant water loss by stomatal closure keeps the water potential and relative leaf water content high (Souza et al., 2004). As a consequence, there are restrictions (or reductions) in stomatal conductance and gas exchange, which reduces the rate of transpiration and assimilation of $\mathrm{CO}_{2}$ as observed.

The first and most sensitive response to water deficit is the decrease in turgidity, through which stomata closure, photosynthesis reduction and cell elongation decrease, especially in extension (Larcher, 2006). This stress caused by water deficiency is produced by both soil water limitation and excessive transpiration loss in relation to root absorption, and these processes are influenced by environmental factors and plant characteristics such as species or genotype (Sant'Anna, 2009).

\subsection{Chlorophyll}

The chlorophyll level of Eucalyptus dunnii leaves in both treatments (presence and absence) presented statistically higher averages (t-test) regarding the use of hydrogel in the three irrigation frequencies, and the highest rates were observed in the treatments with the presence of this polymer (Figure 2).

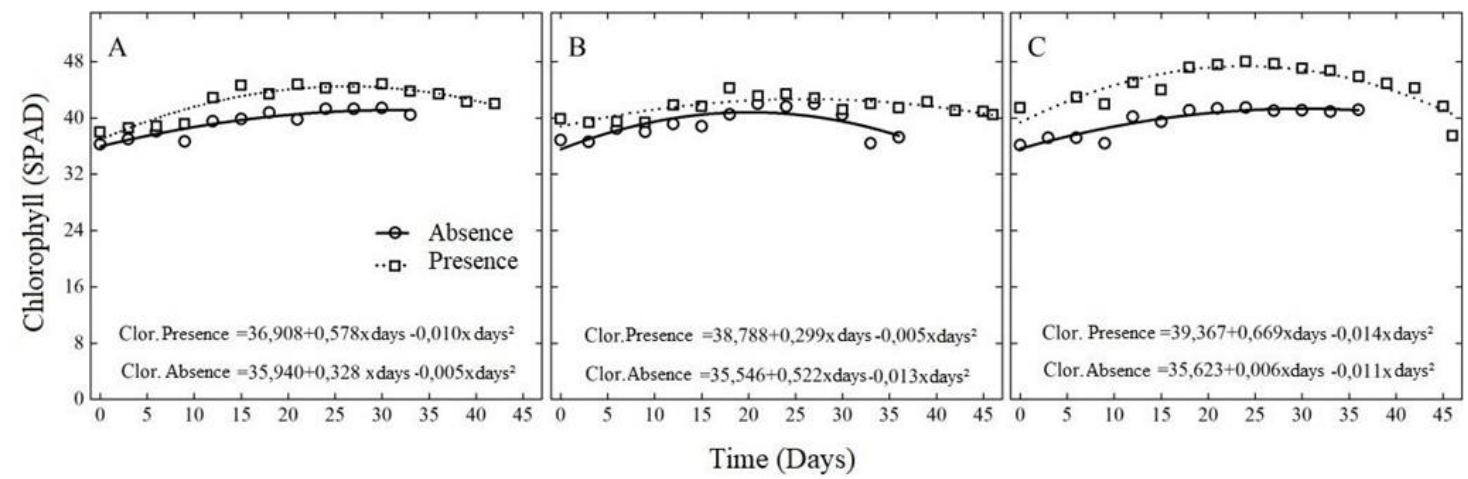

Figure 2. Chlorophyll content in plants as a function of the presence or absence of hydrogel and different irrigation frequencies. A-irrigation only at planting; B-irrigation every 3 days; Cirrigation every 6 days.

In the analysis of chlorophyll between irrigation frequencies, it was not possible to perceive behavior change between treatments. The chlorophyll content over time showed a quadratic behavior, with values close to 35 at the beginning of the experiment, reaching 45-48 around 25 days and decreasing again to close to 40 at the end of evaluation (47 days). And at all periods and over time, the values were higher for hydrogel treatment, as already discussed.

With these results, it is believed that the addition of this polymer possibly decreases nutrient loss by leaching (Navroski et al., 2015b), providing higher photosynthetic rate due to higher nitrogen contents, where this nutrient is directly linked to higher photosynthetic rate of the plant. In this sense, for the soil with higher water availability the mineralization rate of 
organic matter increases in relation to the soil with lower humidity, thus making a larger amount of nitrogen available to the plant.

Tohidi-Moghadam et al. (2009), studying the response of six canola genotypes to water stress and hydrogel application, observed that water deficiency also reduced the chlorophyll content and that under the field conditions the hydrogel increased the performance of physiological characters, water deficiency and absence of hydrogel led to a decrease in all parameters evaluated. According to these authors, these results may be related to the reduction of photosynthesis and also chlorophyll content.

\subsection{Symptomatology}

Analyzing the irrigation frequencies for the classification days without symptoms (WOT), the obtained data showed there was interaction $(p<0,05)$ between the factors of the evaluated variables. There was no effect of the presence or absence of hydrogel on irrigation use only at planting. In the presence of hydrogel, the frequencies of 3 and 6 days showed a relatively high gain without the appearance of symptoms, compared to the absence of this polymer, which increased the time for the emergence of stress compared to irrigation only at planting, demonstrating once again that the use of hydrogel responds positively to water scarcity in the soil.

No interaction was observed between hydrogel use and irrigation frequency in the evaluation of plants with mild withering symptoms (MWS), independent of irrigation frequency. With the presence of hydrogel, Eucalyptus dunnii seedlings remained more days without the onset of water stress, delaying the appearance of symptoms at all levels, compared to the absence of the polymer, where symptoms appeared much earlier (Table 2).

Regarding irrigation in the presence of the polymer, the frequency of 6 days showed a gain in days without the onset of these symptoms. Not using it, even with irrigation, there was no accelerated occurrence of these symptoms. It is noteworthy that at this stress level the seedlings still have a total physiological condition to recover in the occurrence of rain. The use of irrigation had a positive effect, as expected, and at the frequency of 3 days there was the greatest delay in the onset of symptoms.

In the appearance of the moderate withering symptoms class (MWS), where the plant was close to the permanent wilting point, the analyzed data showed that there was interaction between the factors of the variables. In this class, there was also a delay in stress symptoms when hydrogel was present.

In the class of severe withering symptoms (SWS) where, according to Navroski et al. (2014), at this level of stress a recovery of the plant with new irrigations or rainfall is already difficult, the hydrogel still continued to be efficient, and there was a delay of more than five days in the onset of these symptoms when using irrigation only in the planting, in relation to not using it.

These results corroborate the findings of Navroski et al. (2014) in the study of the influence of the hydro retainer polymer on the survival of Eucalyptus dunnii seedlings under different water-management regimens, where its use mitigated water scarcity in the soil, allowing the delay of water deficit symptoms, with its influence being greater when irrigation was performed less frequently.

It's important to highlight that, in the implantation of Eucalyptus forests, it is usually observed that the most critical period for the loss of seedlings due to lack of water is in the first 20 days, when the plant is being established and its root system is still in formation (Fernández et al., 2010). In the field planting, it can be assumed that in cases where irrigation is frequent, or where rainfall is higher, the use of the polymer could be discarded (Navroski et al., 2015a). However, under less frequent rain or more-spaced irrigation, the use of hydrogel may be recommended. 
Table 2. Averages results of duration of symptoms of water stress, in days, evaluated from planting until the $47^{\text {th }}$ day after planting Eucalyptus dunnii in pots, due to the presence or absence of hydrogel and different irrigation frequencies, where: WOT - no withering symptoms; MLS - mild withering symptoms; MWS - moderate withering symptoms; SWS - severe withering symptoms and PRA - plants remained alive.

\begin{tabular}{cccccc}
\hline \multirow{2}{*}{ Variable } & & \multicolumn{3}{c}{ Appearance of stress symptoms (days) } & \\
\cline { 3 - 5 } & & \multicolumn{3}{c}{ Irrigation frequency } & \\
\cline { 3 - 5 } & & Averages \\
\cline { 3 - 5 } WOT $^{* * *} *$ & Absence & $23.10 \mathrm{aB}$ & $24.80 \mathrm{bB}$ & $31.70 \mathrm{bA}$ & \\
& Presence & $24.10 \mathrm{aC}$ & $34.12 \mathrm{aB}$ & $44.90 \mathrm{aA}$ & 26.54 \\
& Average & 23.60 & 29.21 & 38.30 & \\
\hline \multirow{2}{*}{ MLS } & Absence & 27.10 & 32.70 & 44.00 & 34.60 \\
& Presence & 31.00 & 34.33 & 46.00 & 37.20 \\
& Average & $29.05 \mathrm{~B}$ & $33.47 \mathrm{~B}$ & $45.00 \mathrm{~A}$ & \\
\hline \multirow{2}{*}{ MWS } & Absence & $32.00 \mathrm{bC}$ & $36.50 \mathrm{bB}$ & $44.50 \mathrm{aA}$ & 37.66 \\
& Presence & $36.50 \mathrm{aB}$ & $45.56 \mathrm{aA}$ & $46.00 \mathrm{aA}$ & 42.58 \\
& Average & 34.25 & 40.78 & 45.25 & \\
\hline \multirow{2}{*}{ SWS } & Absence & $35.40 \mathrm{bC}$ & $40.80 \mathrm{bB}$ & $44.70 \mathrm{aA}$ & 40.30 \\
& Presence & $41.70 \mathrm{aB}$ & $46.00 \mathrm{aA}$ & $46.00 \mathrm{aA}$ & 44.52 \\
& Average & 38.55 & 43.26 & 45.35 & \\
\hline \multirow{2}{*}{ PRA } & Absence & $35.40 \mathrm{bC}$ & $40.80 \mathrm{bB}$ & $44.70 \mathrm{aA}$ & 40.30 \\
& Presence & $41.70 \mathrm{aB}$ & $45.55 \mathrm{aA}$ & $46.00 \mathrm{aA}$ & 44.37 \\
& Average & 38.55 & 43.18 & 45.35 & \\
\hline
\end{tabular}

* Averages followed by the same letter, uppercase letter in the line (ScottKnott test), and lowercase in the column (t-test) do not differ from each other at $5 \%$ probability of error.

In the evaluation of the number of days the plants remained alive (PRA), it was noticed that the use of hydrogel presented a difference when irrigation occurred every 6 days and only at planting. In this case, with the presence of the hydrogel in the soil, an increase of approximately 5 to 6 days in which they remained alive was obtained, thus justifying the expenses with the use of the polymer.

In the use of post-planting irrigations, frequently no significant effect of hydrogel was observed. This may indicate that the use of hydrogel is beneficial in delaying seedling mortality when frequent or infrequent irrigation is used only at planting, allowing a gain of a few days waiting for rain to occur.

\subsection{Dry biomass}

The results showed that for the root dry mass variable, the hydrogel interaction and irrigation frequency time was not significant $(p>0.05)$, there was only difference for the isolated factors. In the presence of hydrogel, there was a significant difference, where the root dry mass was higher, presenting $2.17 \mathrm{~g}$ and in the absence only $1.12 \mathrm{~g}$. As expected, the addition of the hydrogel contributed to the development of Eucalyptus dunnii seedlings, presenting a significant increase in root dry mass. Eloy et al. (2013) state that this variable is of great importance in the development of plants, since when there is a good rooting, they have a greater potential for growth and field survival. 
In the evaluation of the presence of hydrogel, within the frequencies of 3 and 6 days, there was no significant difference. These results indicate that regardless of irrigation time, the use of hydrogel favored the increase of root dry mass of seedlings. In the absence of the hydrogel, there was a significant difference between the frequencies, where the frequency of 3 days had $1.97 \mathrm{~g}$ of root dry mass and for the frequency of irrigation of 6 days the root dry mass was lower, with 1.33 grams.

For the variable dry mass of the aerial parts, the hydrogel interaction and irrigation frequency were not significant $(\mathrm{p}>0.05)$. In the presence of hydrogel there was significant difference, and the highest values were found for the treatment with hydrogel, in which the dry mass of the aerial parts was higher (4.35 g), compared to the absence $(2.34 \mathrm{~g})$.

For the frequency of irrigation, there was a significant difference, and in the frequency of 3 days the dry mass of the aerial parts was higher $(3.99 \mathrm{~g})$ compared to the frequency of 6 days $(2.7 \mathrm{~g})$. The results indicate that the use of hydrogel incorporated into the soil and associated with different irrigation frequencies positively influenced the development of aerial parts of Eucalyptus dunnii seedlings.

\section{CONCLUSION}

- The use of hydrogel promotes a significant increase in water retention in the soil, allowing the delay of water deficit symptoms, although the effect of retention was greater at lower tensions (less than $10 \mathrm{kPa}$ ).

- The presence of the hydro retainer polymer in the soil presents higher averages for morphological characteristics, and in general decreased symptoms of water deficit in plants.

- There is a direct effect on gas exchange, with recovery of the variables analyzed 24 hours after irrigation. However, plants grown in the absence of the hydrogel exhibit the best physiological performance, so further studies should be conducted (preferably in the field) to understand physiological processes.

- In general, the hydrogel allows the reduction of the frequency of irrigation, showing a better result when the plants are under water restriction.

\section{REFERENCES}

AGABA, H.; ORIKIRIZA, L. J. B.; OBUA, J.; KABASA, J. D.; WORBES, M.; HÜTTERMANN, A. Hydrogel amendment to sandy soil reduces irrigation frequency and improves the biomass of Agrostis stolonifera. Agricultural Sciences, v. 2, n. 4, p. 544550, 2011. https://dx.doi.org/10.4236/as.2011.24071

BERGAMASCHI, H.; BERLATO, M. A.; MATZENAUER, R.; FONTANA, D. C.; CUNHA, G. R.; SANTOS, M. L. V.; FARIAS, J. R. B.; BARNI, N. A. Agrometeorologia aplicada à irrigação. Porto Alegre: Editora da Universidade, 1992. 125p.

BLAKE, G. R.; HARTGE, K. H. Bulk density. In: KLUTE, A. (ed.). Methods of soil analysis: physical and mineralogical methods. $2^{\text {nd }}$ Madison: American Society of Agronomy, Soil Science Society of America, 1986. p. 363-375.

DAVIDE, A. C.; FARIA, J. M. R. Viveiros florestais. In: DAVIDE, A. C.; SILVA, E. A. A. Produção de sementes e mudas de espécies florestais. Lavras: Universidade Federal de Lavras, 2008. p. 83-124.

ELOY, E.; CARON, B. O.; SCHMIDT, D.; BEHLING, A.; SCHWERS, L.; ELLI, E. F. Avaliação da qualidade de mudas de Eucalyptus grandis utilizando parâmetros morfológicos. Revista Floresta, v. 43, n. 3, p. 373 - 384, 2013. 
FELIPPE, D.; NAVROSKI, M.; SAMPIETRO, J. A.; FRIGOTTO, T.; ALBUQUERQUE. J. A.; MOTA, C. S.; PEREIRA, M. O. Efeito do hidrogel no crescimento de mudas de Eucalyptus benthamii submetidas a diferentes frequências de irrigação. Floresta, v. 46, n. 2, p. 215-225, 2016. http://dx.doi.org/10.5380/rf.v46i2.43920

FERNÁNDEZ, M.; TAPIAS, R.; ALESSO, P. Adaptación a la sequía y necesidades hídricas de Eucalyptus globulus Labill. en Huelva. Boletín del CIDEU, v. 9, n. 8, p. 31-41, 2010.

IBÁ. Relatório IBÁ $2020 . \quad$ Available https://iba.org/datafiles/publicacoes/relatorios/relatorio-iba-2020.pdf. Access: 09 Nov. 2020 .

KLUTE, A. Water retention: Laboratory methods. In: KLUTE, A. Methods of soil analysis: physical and mineralogical methods. $2^{\text {nd }}$ Madison: American Society of Agronomy, Soil Science Society of America, 1986. p.635-660.

LARCHER, W. Ecofisiologia vegetal. São Carlos: Rima, 2006, p. 531.

MENDONÇA, T. G.; URBANO, V. R.; PERES, J. G.; SOUZA, C. F. Hidrogel como alternativa no aumento da capacidade de armazenamento de água no solo. Water Resources and Irrigation Management, v. 2, n. 2, p. 87-92, 2013.

MONIZ, A. C. Elementos de pedologia. São Paulo: USP; Polígono, 1972.

NAVROSKI, M. C.; ARAÚJO, M. M.; FIOR, C. S.; CUNHA, S. F.; BERGHETTI, A. L. P.; PEREIRA, M. O. Uso de hidrogel possibilita redução da irrigação e melhora o crescimento inicial de mudas de Eucalyptus dunnii Maiden. Scientia Forestalis, v. 43, n. 106, p. 467-476, 2015a.

NAVROSKI, M. C.; ARAÚJO, M. M.; REININGER, L. R. S.; MUNIZ, M. F. B.; PEREIRA, M. O. Influência do hidrogel no crescimento e no teor de nutrientes das mudas de Eucalyptus dunnii. Revista Floresta, v. 45, n. 2, p. 315 - 328, 2015b. http://dx.doi.org/10.5380/rf.v45i2.34411

NAVROSKI, M. C.; ARAÚJO, M. M.; CUNHA, F. S.; BERGHETTI, A. L. P.; PEREIRA, M. O. Influência do polímero hidroretentor na sobrevivência de mudas de Eucalyptus dunnii sob diferentes manejos hídricos. Revista Nativa, v. 02, n. 02, p. 108-113, 2014. https://doi.org/10.31413/nativa.v2i2.1571

NUNES, C. M. J. Caracterização da resposta ao déficit hídrico de linhas transgênicas de Medicago trunculata cv. Jemalong. 2007. 64f. Dissertação (Mestrado em Biologia Celular e Biotecnologia) - Universidade de Lisboa, Lisboa, 2007.

PREVEDELLO, C. L.; LOYOLA, J. M. T. Efeito de polímeros hidroretentores na infiltração da água no solo. Scientia Agraria, v. 8, n. 3, p. 313-317, 2007. http://dx.doi.org/10.5380/rsa.v8i3.8592

REINERT, D. J.; REICHERT, J. M. Coluna de areia para medir a retenção de água no solo: protótipos e testes. Ciência Rural, v. 36, p. 1931-1935, 2006. https://doi.org/10.1590/S0103-84782006000600044

SANT'ANNA, H. L. S. Aspectos fisiológicos de variedades de citros submetidas à deficiência hídrica progressiva. 2009. 84 f. Dissertação (Mestrado em Fitotecnia) Curso de Pós-Graduação em Ciências Agrárias, Universidade Federal do Recôncavo da Bahia, Cruz das Almas, 2009. 
SARVAS, M.; PAVLENDA, P.; TAKÁCOV, E. Effect of hydrogel application on survival and growth of pine seedlings in reclamations. Journal of Forest Science, v. 5, n. 53, p. 204209, 2007.

SERRAJ, R.; SINCLAIR, R.T. Osmolyte accumulation: can it really help increase crop yield under drought conditions? Plant Cell Environment, v. 25, p. 333-341, 2002. https://doi.org/10.1046/j.1365-3040.2002.00754.x

SOUZA, R. P.; MACHADO, E. C.; SILVA, J. A. B.; LAGOA, A. M. M. A; SILVEIRA, J. A. G. Photosynthetic gas exchange, chlorophyll fluorescence and some associated metabolic changes in cowpea (Vigna unguiculata) during water stress and recovery. Environmental and Experimental Botany, n. 51, p. 45-56, 2004. https://doi.org/10.1016/S0098-8472(03)00059-5

THOMAS, D. S. Hydrogel applied to the root plug off subtropical eucalypt seedlings halves transplant death following planting. Forest Ecology and Management, n. 255, p. 13051314, 2008. https://doi.org/10.1016/j.foreco.2007.10.035

TOHIDI-MOGHADAM, H. R.; SHIRANI-RAD A. H.; NOUR-MOHAMMADI G.; HABIBI D.; MODARRES-SANAVY, S. A. M.; MASHHADI-AKBAR-BOOJAR, M.; DOLATABADIAN, A. Response of six oilseed rape genotypes to water stress and hydrogel application. Pesquisa Agropecuária Tropical, v. 39, n. 3, p. 243-250, 2009.

VAN GENUCHTEN, M. T. A closed-form equation for predicting the hydraulic conductivity of unsaturated soils. Soil Science Society of America Journal, v. 44, p. 892-898, 1980. https://doi.org/10.2136/sssaj1980.03615995004400050002x1999 


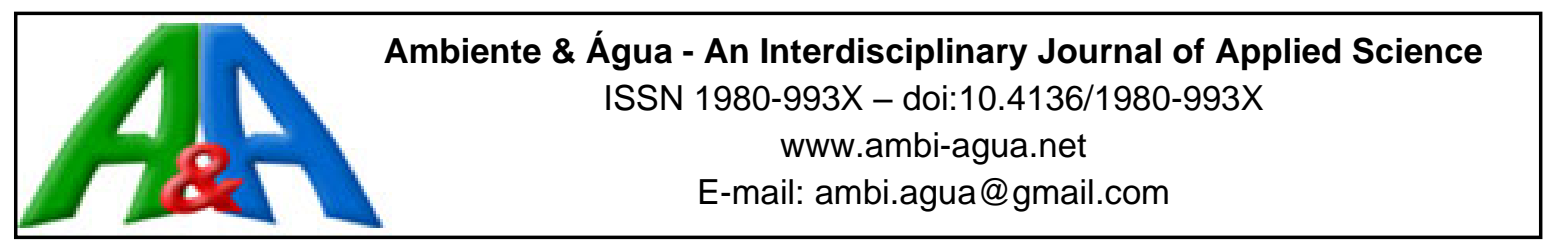

\title{
Performance evaluation and coefficients of reliability for waste stabilization ponds in northeast Brazil
}

\author{
ARTICLES doi:10.4136/ambi-agua.2571 \\ Received: 04 May 2020; Accepted: 24 Nov. 2020 \\ Matheus Sales Alves ${ }^{1 * i D}$; Fernando José Araújo da Silva1 ${ }^{1 D}$; \\ André Luís Calado Araújo ${ }^{2}$; Erlon Lopes Pereira ${ }^{1}$ \\ ${ }^{\mathbf{1} D e p a r t a m e n t o ~ d e ~ E n g e n h a r i a ~ H i d r a ́ u l i c a ~ e ~ A m b i e n t a l ~(D H E E) . ~ U n i v e r s i d a d e ~ F e d e r a l ~ d o ~ C e a r a ́ ~(U F C), ~}$ \\ Rua do Contorno, s/n, Bloco 713, CEP: 60451-970, Fortaleza, CE, Brazil. \\ E-mail: fjas@deha.ufc.br, erlonlopes@gmail.com \\ ${ }^{2}$ Diretoria de Recursos Naturais. Instituto Federal de Educação, Ciência e Tecnologia do Rio Grande do Norte \\ (IFRN), Avenida Senador Salgado Filho, n 1559, CEP: 59015-000, Natal, RN, Brazil. \\ E-mail: andre.calado@ifrn.edu.br \\ *Corresponding author. E-mail: matheus.sales.ufv@gmail.com
}

\begin{abstract}
This paper assesses the reliability of Waste Stabilization Ponds (WSP) and proposes an alternative approach to WSP design based on the calculation of coefficient of reliability (COR) from an acceptable measure of violation of discharge standards. For that, data were collected from 10 full-scale systems operating in Northeast Brazil. All systems receive predominantly domestic effluent and are composed of one facultative pond and two serial maturation ponds. Different levels of restriction for effluent discharge were considered regarding the parameters: BOD, COD, total suspended solids, ammonia and thermotolerant coliforms. The Log-normal Probability Distribution Function (PDF) was able to represent the behavior of the concentration data in the effluent and, therefore, allowed the COR calculation. The COR was obtained from the coefficient of variation $(\mathrm{CV})$ of the concentrations and the standardized normal variable associated with a 95\% probability of non-exceedance. The observed dispersion of the results proved to be detrimental to the adoption of a single COR value for the evaluated parameters. In addition, the comparison between observed and design/operational concentration for optimal performance showed that the $95 \%$ reliability scenario represents a less achievable target for WSP systems.
\end{abstract}

Keywords: effluent quality, reliability, waste stabilization ponds.

\section{Avaliação do desempenho e coeficientes de confiabilidade de lagoas de estabilização no nordeste do Brasil}

\section{RESUMO}

Este trabalho tem como objetivo avaliar a confiabilidade de Lagoas de Estabilização e propor uma abordagem alternativa à concepção destes sistemas baseada no cálculo do coeficiente de confiabilidade (CDC) com base numa medida aceitável de violação das normas de lançamento. Para tal, foram coletados dados de 10 sistemas em escala real que operam no Nordeste do Brasil. Todos os sistemas recebem efluentes predominantemente domésticos e são compostos por uma lagoa facultativa e duas lagoas de maturação em série. Foram considerados 
diferentes níveis de restrição para o lançamento de efluentes no que diz respeito aos parâmetros: DBO, DQO, Sólidos Suspensos Totais, Amônia total e Coliformes Termotolerantes. A Função de Distribuição de Probabilidade Log-normal (FDP) mostrou-se apta para representar o comportamento dos dados de concentração no efluente e, portanto, permitiu o cálculo do CDC. O CDC foi obtido a partir do coeficiente de variação $(\mathrm{CV})$ das concentrações e da variável normal padronizada associada a uma probabilidade de $95 \%$ de não excedência. A dispersão observada dos resultados de CDC revelou-se prejudicial à adopção de um único valor para os parâmetros avaliados. Além disso, a comparação entre a concentração observada e a concentração de projeto/operacional para um desempenho ótimo mostrou que o cenário de $95 \%$ de confiabilidade representa um objetivo pouco factível para os sistemas de lagoas de estabilização.

Palavras-chave: confiabilidade, lagoas de estabilização, qualidade dos efluentes.

\section{INTRODUCTION}

Benedetti et al. (2010) defined the reliability of a wastewater treatment plant (WWTP) as the probability of the effluent concentrations to comply with specified discharge standards or treatment objectives during a given period of time. Equation 1:

$$
\text { Reliability }=1-p(\text { effluent concentration }>\text { effluent requirement })
$$

The probability (p) of the standard or a target being exceeded in the effluent depends on the distribution function describing the quality parameters concentrations. In this sense, the right-skewed probabilistic distributions are particularly common when the analyzed mean data are low, present large variance, and cannot be negative (Limpert et al., 2001), such as WWTP effluents.

Thus, Niku et al. (1979) based themselves on the lognormal distribution in order to develop the coefficient of reliability (COR), an index that relates the mean concentration of a parameter to the quality standards to be complied with a required reliability level. The COR was developed based on TSS and BOD data from activated sludge systems, wastewater treatment processes with high degree of mechanization and operational flexibility. This method is recommended for use by the USEPA (Niku and Schroeder, 1981) and recognized in the technical literature (Tchobanoglous et al., 2003; Oliveira and Von Sperling, 2008; OwusuAnsah et al., 2015; Andraka, 2019).

Later, comparative reliability studies by Oliveira and Von Sperling (2008) and Alderson et al. (2015) provided the COR of several wastewater treatment processes in Brazil. Still, few discussions were held on the practical applicability of COR results in natural systems with passive operation, such as Waste Stabilization Ponds (WSP), or consider different levels of restriction for discharge standards into water bodies. According to Weirich et al. (2011), the discharge standards are based on scientific criteria of water quality and the risk of significant adverse effects on the receiving water bodies. However, the imposition of regulatory limits that do not consider the regional socio-economic, institutional and climatic conditions may prevent the adoption of certain treatment technologies.

Based on the above, this study evaluated the performance and the coefficients of reliability (COR) for full scale WSP systems operating in Northeast Brazil. It also analyzes compliance with different criteria for effluent discharge and proposes an alternative approach for the design of WSPs based on the COR. We hope that the considerations of this study may contribute both in the design of new systems and in the definition of reasonable discharge standards by regulatory agencies. 


\section{MATERIALS AND METHODS}

\subsection{Waste Stabilization Pond systems and data collection}

Data from 10 WSP systems in the state of Rio Grande do Norte, Northeast Brazil, were used to develop this study (Table 1). The spatial distribution of the systems integrates different climatic conditions within the state, from tropical rainfall to semi-arid (Köppen classification), with average temperatures above $20^{\circ} \mathrm{C}$ and average annual precipitation between 400 and 1200 mm.

Table 1. Location and general characterization of the WSP systems studied.

\begin{tabular}{|c|c|c|c|c|c|}
\hline WSP & Location & Designation & Start of operation & $\begin{array}{l}\text { Flow rate } \\
\left(\mathrm{m}^{3} \mathrm{~d}^{-1}\right)\end{array}$ & $\begin{array}{l}\text { Hydraulic retention } \\
\text { time }(\mathrm{d})\end{array}$ \\
\hline Caiçara & $\begin{array}{c}5^{\circ} 45^{\prime} 27^{\prime \prime} \mathrm{S} \\
35^{\circ} 59^{\prime} 44^{\prime \prime} \mathrm{W}\end{array}$ & $\mathrm{S} 1$ & 2002 & 108 & 29.7 \\
\hline Ilha de Santana & $\begin{array}{c}5^{\circ} 07^{\prime} 17^{\prime \prime} \mathrm{S} \\
36^{\circ} 38^{\prime} 09 ” \mathrm{~W}\end{array}$ & $\mathrm{~S} 2$ & 1996 & 3940 & 17.1 \\
\hline Passagem de Pedras & $\begin{array}{c}5^{\circ} 11,53 ” \mathrm{~S} \\
37^{\circ} 18,44 ” \mathrm{~W}\end{array}$ & $\mathrm{~S} 3$ & 2009 & 492 & 118.0 \\
\hline Cidade & $\begin{array}{c}6^{\circ} 26^{\prime}, 22^{\prime \prime} \mathrm{S} \\
35^{\circ} 13,18 ” \mathrm{~W}\end{array}$ & $\mathrm{~S} 4$ & 2002 & 253 & 13.7 \\
\hline Pipa & $\begin{array}{c}6^{\circ} 14^{\prime} 17^{\prime \prime} \mathrm{S} \\
35^{\circ} 04^{\prime} 02 ” \mathrm{~W}\end{array}$ & S5 & 2003 & 646 & 18.4 \\
\hline Ponta Negra & $\begin{array}{c}5^{\circ} 53^{\prime} 31^{\prime \prime} \mathrm{S} \\
35^{\circ} 11^{\prime} 04^{\prime \prime} \mathrm{W}\end{array}$ & S6 & 2001 & 7615 & 24.9 \\
\hline Sítio Santana & $\begin{array}{c}6^{\circ} 45^{\prime} 58^{\prime \prime} \mathrm{S} \\
36^{\circ} 43^{\prime} 52^{\prime \prime} \mathrm{W}\end{array}$ & S7 & 2002 & 170 & 29.4 \\
\hline Santo Antônio & $\begin{array}{c}6^{\circ} 18^{\prime} 45^{\prime \prime} \mathrm{S} \\
35^{\circ} 28^{\prime} 24 ” \mathrm{~W}\end{array}$ & S8 & 2004 & 300 & 78.0 \\
\hline Coqueiros & $\begin{array}{c}5^{\circ} 47^{\prime}, 39 ” \mathrm{~S} \\
35^{\circ} 18,34 ” \mathrm{~W}\end{array}$ & S9 & $*$ & 260 & 43.5 \\
\hline Touros & $\begin{array}{c}5^{\circ} 12^{\prime} 15^{\prime \prime} \mathrm{S} \\
35^{\circ} 27^{\prime} 30^{\prime \prime} \mathrm{W}\end{array}$ & $\mathrm{S} 10$ & 2000 & 810 & 33.6 \\
\hline
\end{tabular}

* Information not found.

The selection of the wastewater treatment plants considered the proper operation and the existence of preliminary treatment units (bar screen, grit chambers and Parshall flume). All receive mainly domestic effluent and are composed of a facultative pond (FP) followed by two series maturation ponds (MP1 and MP2) (Table 2).

Table 2. Morphometric characteristics of the ponds.

\begin{tabular}{cccccccccc}
\hline & \multicolumn{3}{c}{ Depth $(\mathrm{m})$} & \multicolumn{3}{c}{ Area $\left(\mathrm{m}^{2}\right)$} & \multicolumn{3}{c}{ Length $(\mathrm{m}) /$ Width $(\mathrm{m})$} \\
\hline & FP & MP1 & MP2 & FP & MP1 & MP2 & FP & MP1 & MP2 \\
\hline S1 & 1.50 & 1.40 & 1.40 & 1119 & 546 & 546 & 2.50 & 1.20 & 1.20 \\
S2 & 2.00 & 1.50 & 1.50 & 22950 & 7200 & 7200 & 2.80 & 2.00 & 2.00 \\
S3 & 2.00 & 1.50 & 1.50 & 17775 & 7505 & 7505 & 2.80 & 1.20 & 1.20 \\
S4 & 2.00 & 1.50 & 1.50 & 1352 & 260 & 260 & 2.00 & 2.60 & 2.60 \\
S5 & 2.00 & 1.50 & 1.50 & 4600 & 896 & 896 & 2.90 & 3.50 & 3.50 \\
S6 & 2.00 & 1.50 & 1.50 & 52510 & 28028 & 28548 & 3.80 & 1.40 & 1.90 \\
S7 & 1.30 & 1.20 & 1.20 & 2698 & 703 & 551 & 1.90 & 2.10 & 2.60 \\
S8 & 2.00 & 1.50 & 1.50 & 8418 & 2287 & 2090 & 2.30 & 1.60 & 2.80 \\
S9 & 2.00 & 1.90 & 1.90 & 3024 & 1386 & 1386 & 1.70 & 0.80 & 0.80 \\
S10 & 1.10 & 1.00 & 1.00 & 12876 & 6552 & 6552 & 2.40 & 0.90 & 0.90 \\
\hline
\end{tabular}

Rev. Ambient. Água vol. 16 n. 1, e2571 - Taubaté 2021 
Each system was evaluated with a minimum monthly frequency for a period of one year, on different days of the week, totaling 157 collections. The methodology described in APHA et al. (2012) was used for the characterization of affluents and effluents of each pond with respect to the following parameters: Biochemical Oxygen Demand of filtered (BODf) and unfiltered samples (BOD), Chemical Oxygen Demand of filtered (CODf) and unfiltered samples (COD), total suspended solids (TSS), total ammonia (TAM) and thermotolerant coliforms (TTC). The choice of these parameters is justified by their environmental relevance and by the fact that they are usually contemplated in the legislation that deals with effluent discharge standards.

\subsection{Determination and exclusion of outliers}

Knowing that extreme or unusual values can affect the analysis of the data behaviour, it was decided to identify and exclude outliers. For this, an empirical rule based on the interquartile range of the data set (Von Sperling et al., 2020) was used, according to Equations 2 and 3. All values below the lower limit or above the upper limit were considered outliers and therefore excluded from the analyzed data set.

$$
\begin{aligned}
& L_{\text {up }}=Q_{3}+1,5 \times\left(Q_{3}-Q_{1}\right) \\
& L_{\text {low }}=Q_{1}-1,5 \times\left(Q_{3}-Q_{1}\right)
\end{aligned}
$$

Which: $Q_{3}=$ Third quartile; $Q_{1}=$ First quartile.

\subsection{Compliance with final effluent quality standards}

The concentration data in the final effluent of the $10 \mathrm{WSP}$ was compared with the discharge limits of CONAMA Resolution $n^{\circ} 430 / 2011$ (Conama, 2011) and the levels of restriction for discharge standards proposed by Morais et al. (2019) based on the analysis of Brazilian state legislation (Table 3).

Table 3. Restriction levels for effluent discharge standards adapted from Morais et al. (2019).

\begin{tabular}{ccc}
\hline Parameter & Very Restrictive & Less Restrictive \\
\hline COD $\left(\mathrm{mg} \mathrm{L}^{-1}\right)$ & $<120$ & $>200$ \\
BOD $\left(\mathrm{mg} \mathrm{L}^{-1}\right)$ & $<60$ & $>90$ \\
TSS $\left(\mathrm{mg} \mathrm{L}^{-1}\right)$ & $<100$ & $>150$ \\
TAM $\left(\mathrm{mg} \mathrm{L}^{-1}\right)$ & $<5$ & $>20$ \\
TTC $\left(\mathrm{CFU} 100 \mathrm{~mL}^{-1}\right)$ & $<10^{4}$ & $>10^{5}$ \\
\hline
\end{tabular}

\subsection{Adherence test and coefficient of reliability (COR) calculation}

The methodology developed by Niku et al. (1979) is based on the log-normality of data. The Kolmogorov-Smirnov (K-S) test was applied to evaluate the adherence of effluent concentrations to the log-normal probability distribution $(\alpha=0.05)$. Although several statistical inference techniques are known to analyze data adherence (Kolmogorov-Smirnov, Chi-square, Anderson-Darling and Lilliefors), the K-S test was selected because of its simplicity and because it is the most recommended for small samples $(\mathrm{n} \leq 30)$.

The coefficients of reliability (COR) were calculated for the quality parameters from the coefficients of variation (CV) of the effluent concentrations and the standardized normal variable associated with a probability of non-exceedance of $95 \%$, according to the sequence presented in Figure 1. 


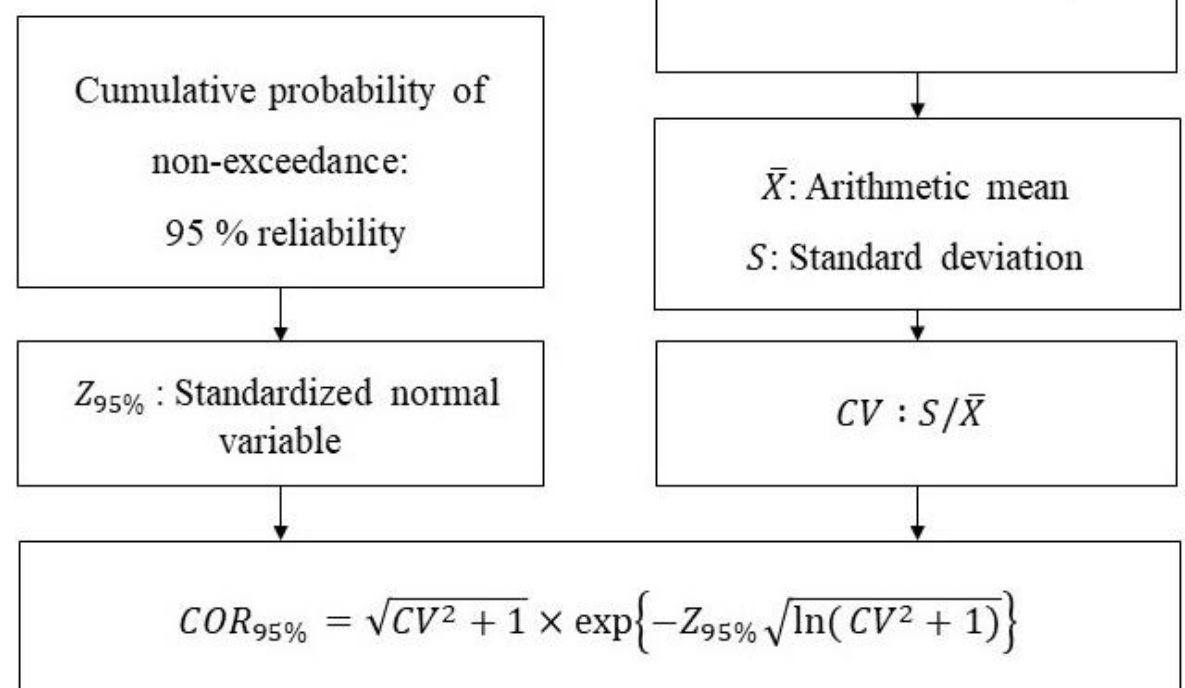

Figure 1. Calculation procedure for coefficients of reliability (COR).

Once the CDC of each parameter was obtained, the design/operational values (Mx) that result in compliance with the discharge standards (Xs) during $95 \%$ of the time, were calculated by Equation 4 for all ponds in the series. Thus, the closer the observed mean concentrations are to the calculated COR concentrations, the closer the WSP systems are to the desired reliability level.

$$
M x=(C D C) \times X s
$$

Which:

Mx: mean parameter concentration.

Xs: Quality target or standard set by some environmental legislation.

COR: coefficients of reliability.

\section{RESULTS AND DISCUSSION}

\subsection{Compliance with quality standards in the final effluent}

Figures 2 and 3 present the Box-plot graphs of concentrations in the final effluents and the percentages of compliance with the different quality standards established for BOD and COD, considering filtered and unfiltered samples.

Despite the difference between flow rates, hydraulic retention times and geometric relations of the units, the systems showed similar behavior in terms of BOD and COD removal efficiency. The average removal efficiency was between $79 \%$ and $89 \%$ for BOD and between $78 \%$ and $87 \%$ for COD. Therefore, all systems complied with the minimum $60 \%$ removal established by the Brazilian federal standard (Conama, 2011) based on filtered BOD samples.

Nevertheless, low percentages of compliance with BOD and COD limits were observed when unfiltered samples are considered (Figure 2.b and 2.a). This is due to the unfiltered material contributing up to $56 \%$ of BOD and $67 \%$ of COD. This high content of particulate organic matter in the effluent can be attributed to the algal biomass present in the pond effluent, which may or may not cause an oxygen demand in receiving waters. 

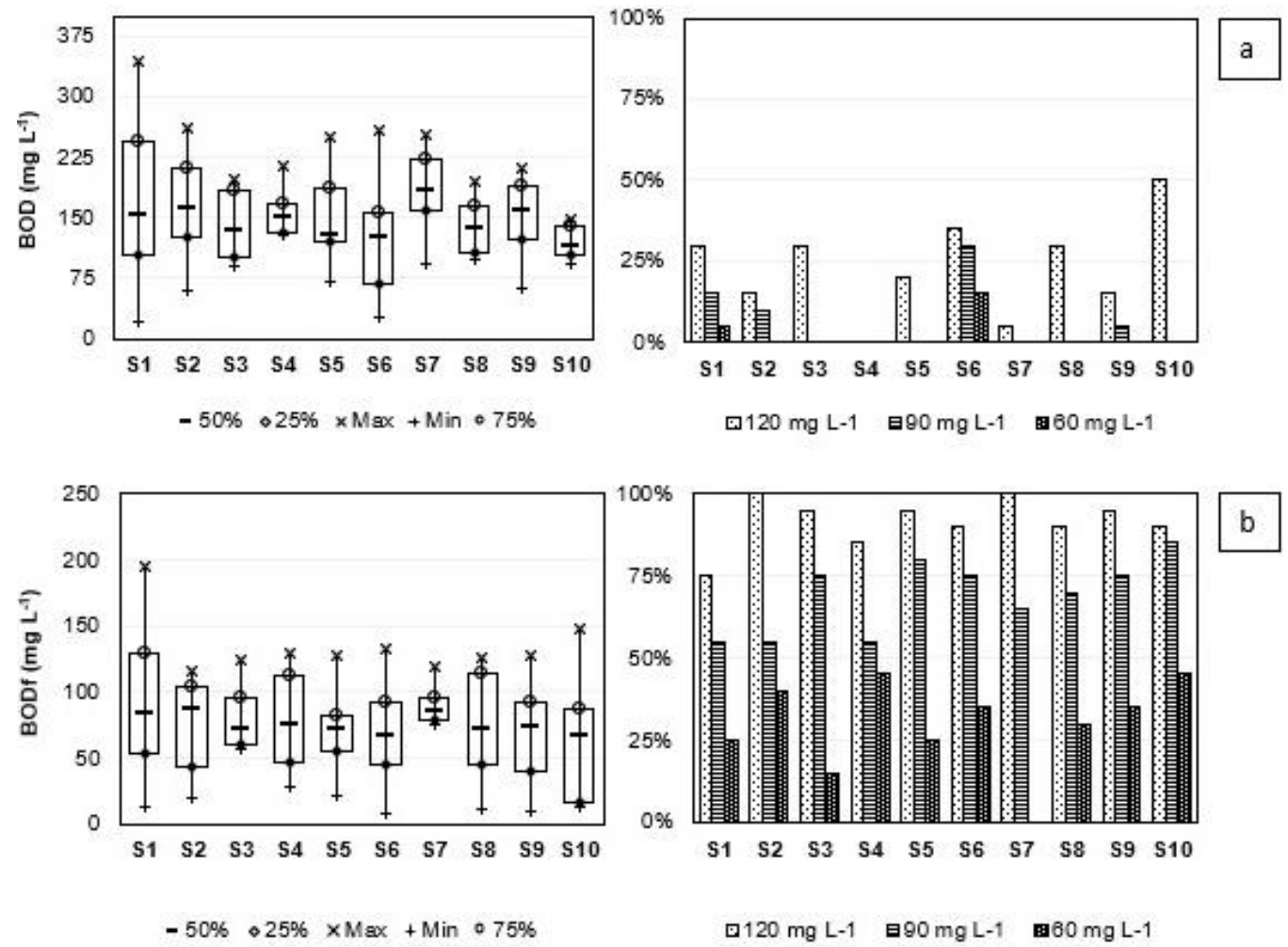

Figure 2. Box-plot graph with the final concentrations and percentages of samples that complied with the quality standards for BOD (a) and BODf (b).
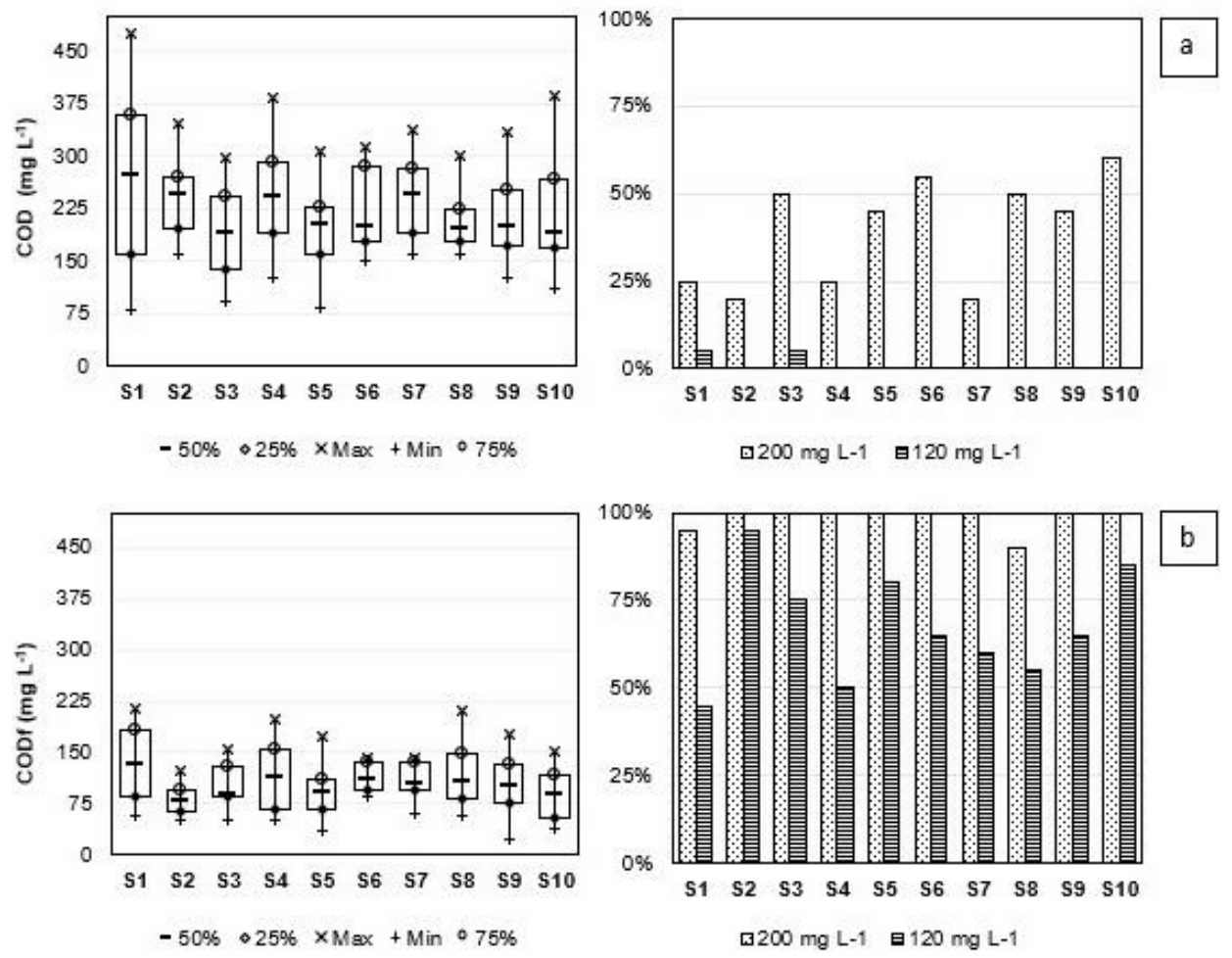

Figure 3. Box-plot graph with the final concentrations and percentages of samples that complied with the quality standards for COD (a) and CODf (b).

Figure 4 presents the box-plot graph of concentrations in the final effluents and the percentages of compliance with the two restriction levels for discharge standards for total suspended solids - TSS, thermotolerant coliforms - TTC, total ammonia - TAM. 

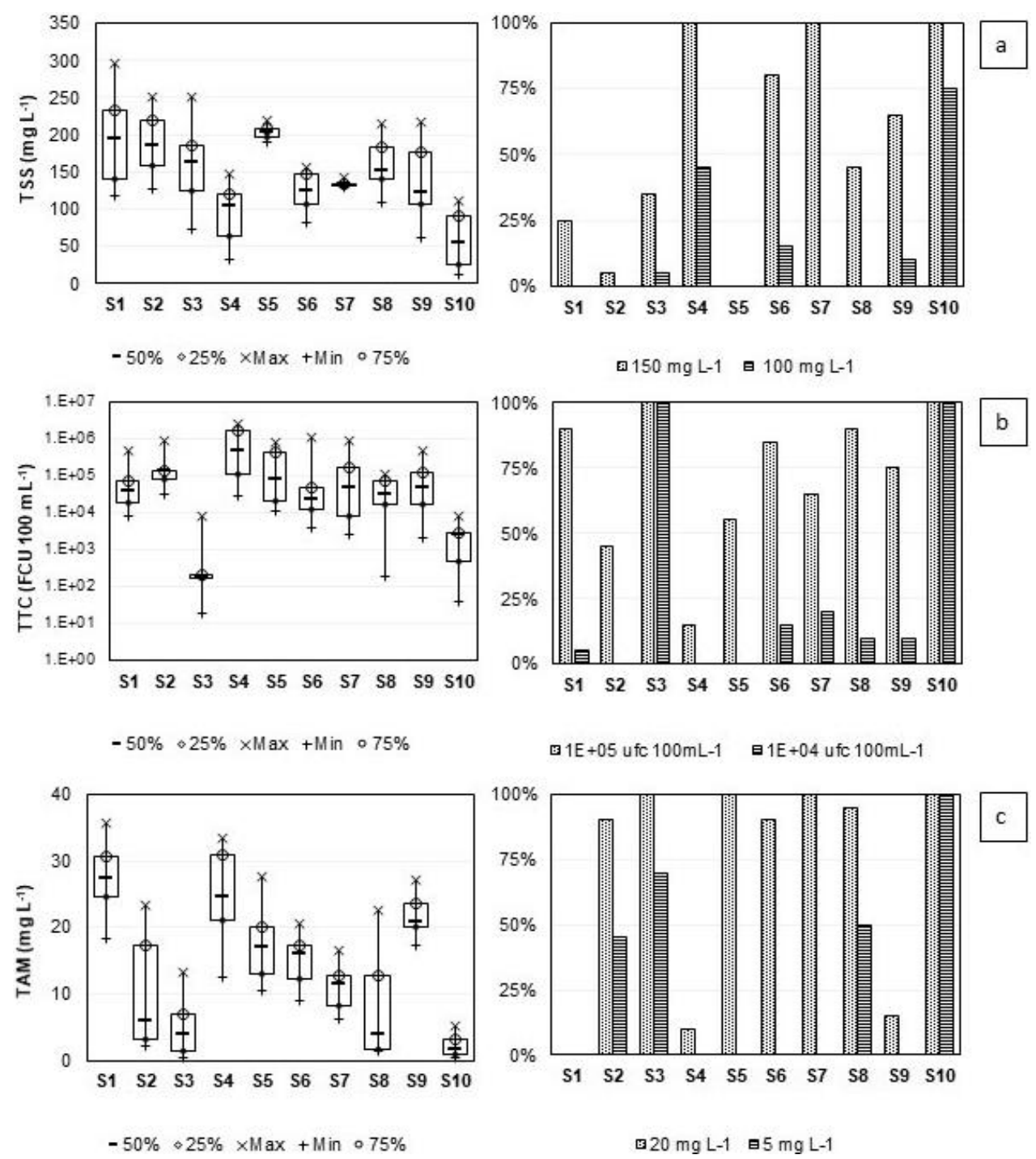

Figure 4. Box-plot graph with the final concentrations and percentages of samples that complied with the quality standards for TSS (a), TTC (b) and TAM (c).

For total suspended solids (4.a), the concentration in the final effluent range from $59 \mathrm{mg}$ $\mathrm{L}^{-1}$ to $204 \mathrm{mg} \mathrm{L}^{-1}$, with average removal efficiencies below $70 \%$. In the final effluent of S3 and S5 increases of $98 \%$ and $62 \%$ were observed in relation to the raw effluent sewage. As BOD and suspended solids are closely related in the treatment (Weirich et al., 2011), it is possible that these results are also associated with algae growth in the ponds. Overall, the WSP systems proved to be unable to comply with the $100 \mathrm{mg} \mathrm{L}^{-1}$ limit in the final effluent (Figure 4.a). Mara (2003) argues that many rivers in developing countries have a "naturally" high suspended solids concentration and therefore it would not make sense to establish stricter standards than the already existing concentration in the receiving water.

The systems presented thermotolerant coliform removal efficiencies between two (99\%) to four logarithmic units (99.99\%). The geometric mean of coliforms ranged from $9.3 \times 10^{2} \mathrm{CFU}$ $100 \mathrm{~mL}^{-1}$ to $8.7 \times 10^{5} \mathrm{CFU} 100 \mathrm{~mL}^{-1}$. Figure $4 . \mathrm{b}$ shows low percentages of compliance with the target of $1.0 \times 10^{4} \mathrm{CFU} 100 \mathrm{~mL}^{-1}$. There is a semi-quantitative relationship between the density of the indicator organism and the presence of pathogens in the effluent. Although the federal standard (Conama, 2011) does not specify a limit for coliforms to be discharged into watercourses, the use of untreated water by rural and peri-urban communities (Mara, 2003) added to the low water availability in the semi-arid region of northeastern Brazil overcomes the need to achieve low counts in the final effluent. 
For ammonia, removal efficiencies ranged from $29 \%$ to $94 \%$. For similar systems in operation in the Northeast, Silva et al. (2011) reported ammonia removals between 30 and $80 \%$. The final effluents presented average ammonia concentrations between $2.0 \mathrm{mg} \mathrm{L}^{-1}$ and $27.2 \mathrm{mg}$ $\mathrm{L}^{-1}$. Only S2, S3, S8 and S10 had ammonia concentrations in the final effluent below the more restrictive quality standard of $5 \mathrm{mg} \mathrm{L}^{-1}$ (Figure 4.c). Considering a scenario of reuse of these effluents in agriculture, the availability of nutrients can be considered as a favorable aspect for crop growth.

The observed variations in performance and final effluent quality illustrate the need for WSP systems to be designed to produce an average effluent concentration well below discharge standards. Thus, the coefficient of reliability (COR) proposed by Niku et al. (1979) presents itself as an attractive methodological alternative by relating the mean effluent concentration values to the standard to be complied with based on an acceptable measure of risk or violation.

\subsection{Coefficient of reliability (COR)}

Figure 5 presents the box-plot graphs of coefficients of Variation (CV) and COR per parameter over the pond series.

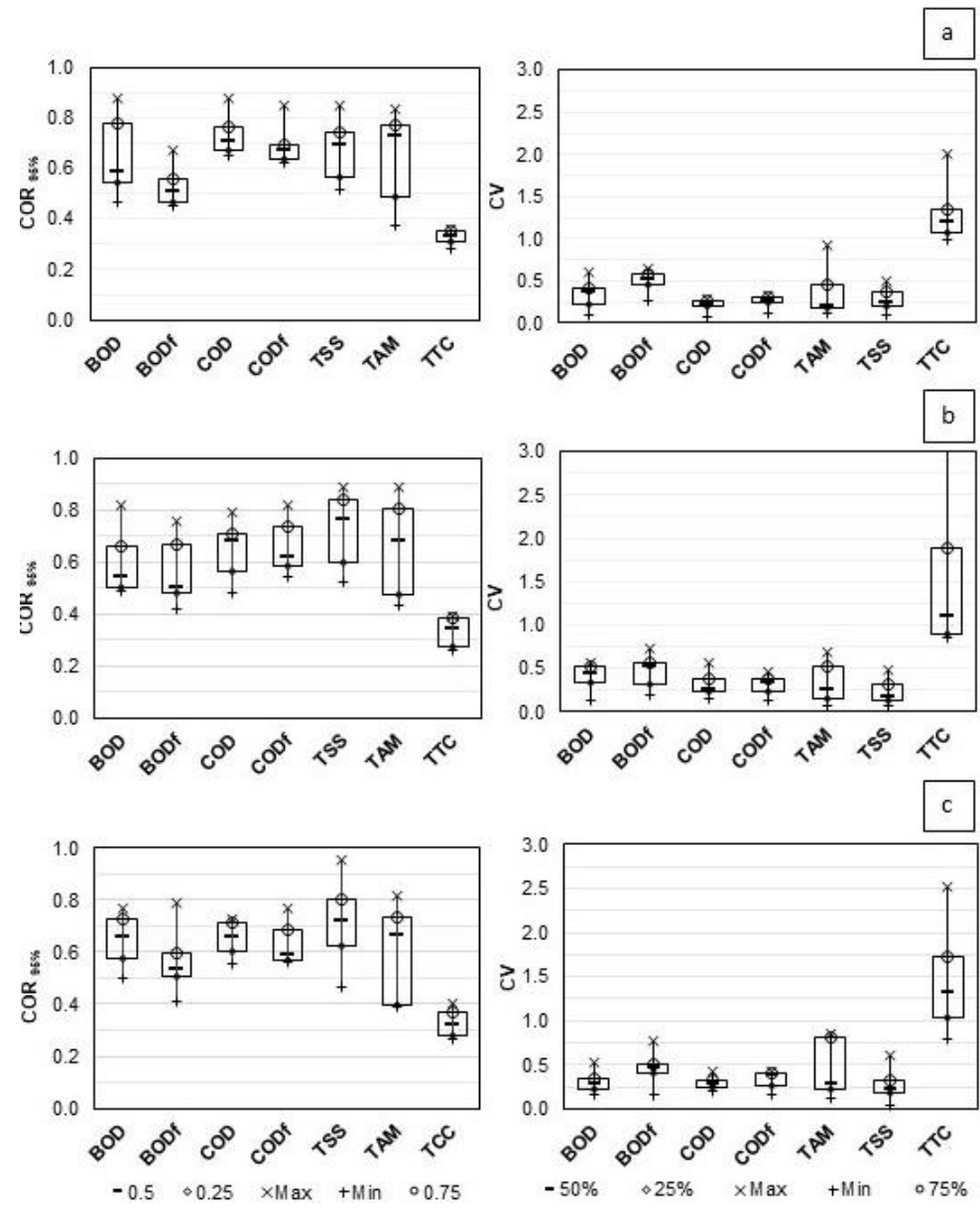

Figure 5. Box-plot of the coefficient of variation (CV) expressed non-dimensionally and the coefficient of reliability (COR) per parameter in the effluent of FP (a), MP1 (b), MP2 (c), calculated for a $95 \%$ reliability level.

The K-S adherence test did not reject the hypothesis of representation of sample concentration data by the log-normal probability distribution ( $\mathrm{p}$-value $>0.05$ ), which allowed the use of the methodology developed by Niku et al. (1979). Several studies have reported that the log-normal probability distribution describes the behavior of BOD and TSS data in WWTP 
effluents (Dean and Forsythe, 1976; Niku et al., 1979; 1981; Oliveira and Von Sperling, 2008; Owusu-Ansah et al., 2015). Although Log-normal is presented as a reference for WWTP effluent statistics, Kumar Gupta and Shrivastava (2006) and Vera et al. (2011) argue that other distributions also provide a good description of the data. In these cases, the proposed methodology would not be applicable and the effluent value distribution should be treated independently.

For the $95 \%$ reliability level, the COR values decrease with the CV increase. Non parametric tests (Kruskal-Wallis) concluded that, for the same parameter, the COR values do not differ statistically between the ponds $(\mathrm{p}<0.05)$. Contrary to what Alderson et al. (2015) states, a low COR value does not necessarily imply the malfunctioning of the treatment plant, but simply indicates less stable operational conditions due to the greater variability of data expressed by the $\mathrm{CV}$. For thermotolerant coliforms, the fact that the microbiological indicator count ranges according to many orders of magnitude explains CV values above 1.0.

Figure 5 illustrates the degree of scattering (dispersion) of COR data around the measure of centrality. It is noted that the reliability coefficient itself suffers from the fluctuation of effluent treatment technology data. The variable or combination of variables responsible for the fluctuation of effluent quality differs from plant to plant, and may be the result of design, operation or both. This is detrimental to the adoption of a single representative COR of the treatment technology because it can lead to unrealistic predictions by not considering the coefficient range of variation.

\subsection{Design concentration and coefficient of reliability application}

Since WSP systems do not have adjustable controls once in operation, the potential for use of the COR lies in the design stage:

Example 1: Consider the discharge standard of $120 \mathrm{mg} \mathrm{L}^{-1}$ for COD to be met in the final effluent of the secondary maturation pond. For a COR value between 0.73 and 0.55 (Figure 5.c), the pond design should consider a final average COD concentration between 88 and 66 $\mathrm{mg} \mathrm{L}^{-1}$ to comply with the norm limit during $95 \%$ of the time. Notice that as the parameter's COR decreases, the average design concentration decreases accordingly.

Also, by working with the results of other similar WWTP, the use of the COR allows the introduction of a probabilistic safety factor in deterministic models based on the assumption of steady state:

Example 2: Suppose a parameter that can be modeled according to first order kinetics, such as organic matter (Sun and Saeed, 2009; Silva et al., 2010), ammoniacal nitrogen (Camargo Valero and Mara, 2010; Bastos et al., 2018) and coliforms (Macedo et al., 2011). The mass balance in the first order models consists of an overall reaction rate equation coupled with boundary conditions of the reactor flow patterns, resulting in a conceptually simple model (Ho et al., 2017). These flow patterns are often considered as the idealized regimes of complete-mix or plug-flow, the theoretical limits within which all reactors fit. Once the final concentration $(M x)$ required to meet a certain quality standard $(X s)$ is known, the required hydraulic retention time $(H R T)$ can be calculated from the affluent concentration (Mo) and the model kinetic coefficient $(k)$ (Figure 6).

The applicability of COR depends on the capacity of the technology to achieve the desired reliability level related to the discharge standard. The distance from the $95 \%$ reliability scenario is shown in Figure 7 by the ratio of the observed mean concentration $(\bar{X})$ and the mean design concentration $(\mathrm{Mx})$ for each pond in the series. For a ratio equal to 1, the observed effluent concentration for the parameter coincides with the required design value. Except for the CODf in the final effluent and ammonia with less restrictive standards, the observed ratios were much higher than 1. This suggests that the $95 \%$ reliability scenario is not feasible and that less restrictive discharge limits should be applied to the parameters considered in this study. 


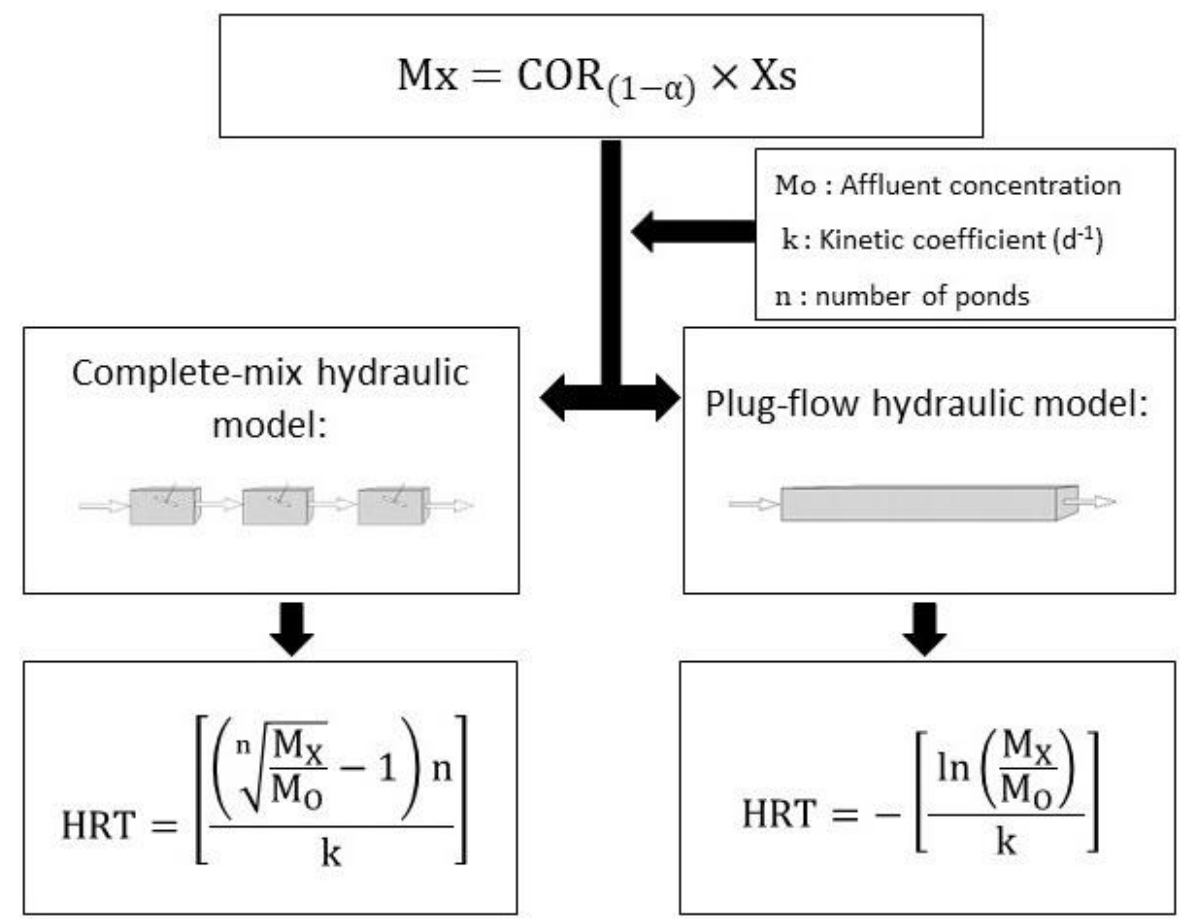

Figure 6. A stepwise approach for the design of Waste Stabilization Ponds from the coefficient of reliability (COR) and design concentration $(M x)$, calculated for a $(1-\alpha) \%$ reliability level.
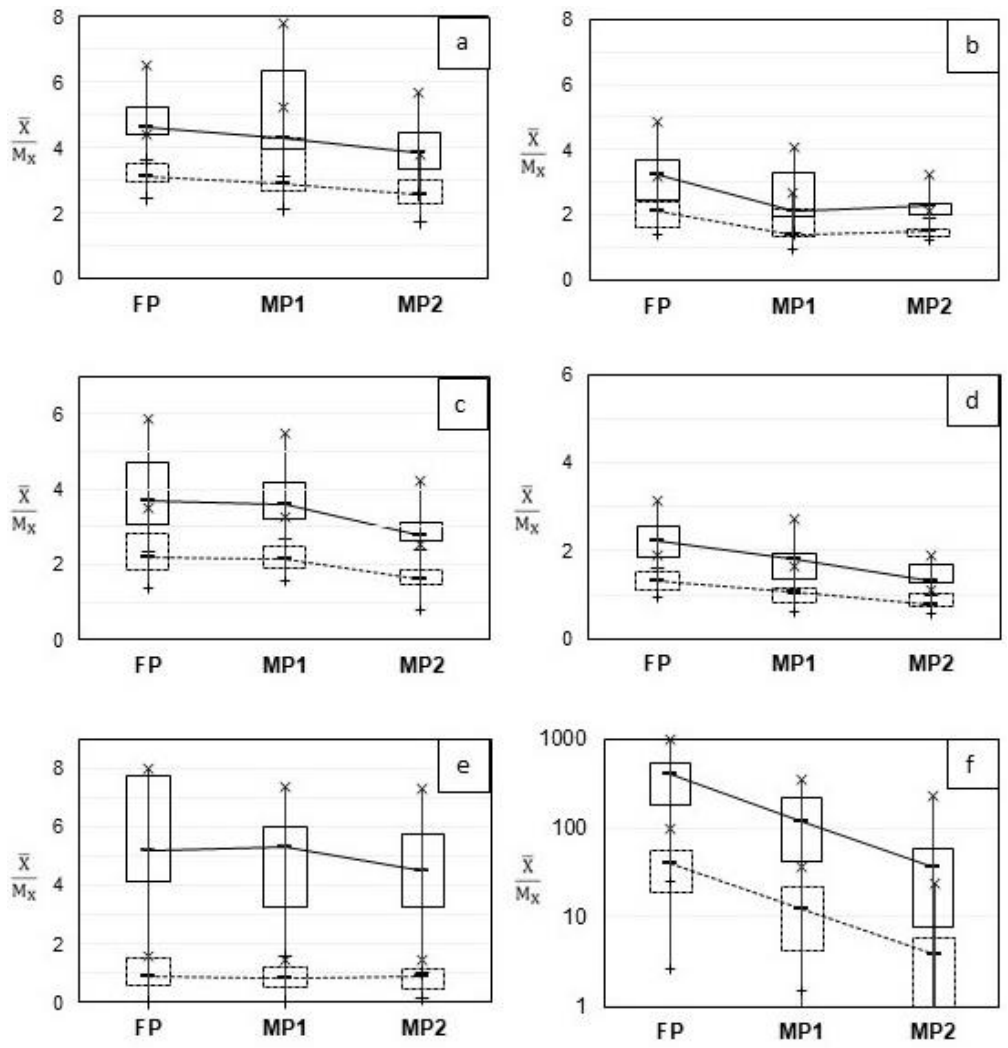

Figure 7. Ratio of observed $(\bar{X})$ and project $(\mathrm{Mx})$ concentrations for BOD (a), BODf (b), COD (c), CODf (d), TAM (e), and TTC (f) with 95\% reliability level, considering restrictive (continuous line) and less restrictive (dashed line) limits. 


\section{CONCLUSIONS}

The 10 Waste Stabilization Pond (WSP) systems in northeastern Brazil showed great variability in complying with the quality standards established for the final effluent. The particulate material attributed to algae interfered negatively in the percentages of compliance with the stipulated limits for BOD and COD. Furthermore, the systems showed difficulty and, in several cases, total inability to achieve restrictive discharge standards for thermotolerant coliforms and ammonia.

The potential for using the coefficients of reliability (COR) in the design of similar WSP systems was discussed, considering the accommodation of the expected variability in the effluent. The K-S test, applied as an "eliminatory" criterion, showed that the lognormal distribution function is able to describe the concentration data set. Compared to other quality parameters, thermotolerant coliforms presented the highest coefficients of variation and, therefore, the lowest COR values. The dispersion observed in the COR results is detrimental to the use of a single value for a given parameter that is representative of the technology. Except for COD of filtered samples and ammonia, the observed mean concentrations proved to be much higher than those required to ensure a $95 \%$ reliability scenario. Therefore, when applying the methodology discussed here, the variability of the COR and the ability of the technology to achieve the established level of reliability must always be considered.

\section{ACKNOWLEDGMENT}

The authors acknowledge the financial support given by CAPES and CNPq.

\section{REFERENCES}

ALDERSON, M. P.; SANTOS, A. B. dos; MOTA FILHO, C. R. Reliability analysis of lowcost, full-scale domestic wastewater treatment plants for reuse in aquaculture and $\begin{array}{llllll}\text { agriculture. Ecological Engineering, v. 82, p. 6-14, } 2015 . & \end{array}$ https://dx.doi.org/10.1016/j.ecoleng.2015.04.081

ANDRAKA, D. Reliability Evaluation of Wastewater Treatment Plant Impact on the Receiving Waters. Journal of Ecological Engineering, v. 20, n. 8, p. 226-231, 2019. https://dx.doi.org/10.12911/22998993/111713

APHA; AWWA; WEF. Standard Methods for the examination of water and wastewater. $22^{\text {nd }}$ ed. Washington, 2012. $1496 \mathrm{p}$.

BASTOS, R. K. X.; RIOS, E. N.; SÁNCHEZ, I. A. Further contributions to the understanding of nitrogen removal in waste stabilization ponds. Water Science and Technology, v. 77, n. 11, p. 2635-2641, 2018. https://dx.doi.org/10.2166/wst.2018.218

BENEDETTI, L.; DE KEYSER, W.; NOPENS, I.; VANROLLEGHEM, P. A. Probabilistic modelling and evaluation of wastewater treatment plant upgrades in a water quality-based evaluation context. Journal of Hydroinformatics, v. 12, n. 4, p. 380-395, 2010. https://dx.doi.org/10.2166/hydro.2010.011

CAMARGO VALERO, M. A.; MARA, D. D. Ammonia volatilization in waste stabilization ponds: a cascade of misinterpretations? Water Science \& Technology, v. 61, n. 3, p. 555-561, 2010. https://dx.doi.org/10.2166/wst.2010.856 
CONAMA (Brasil). Resolução ${ }^{\circ} 430$ de 13 de maio 2011. Dispõe sobre as condições e padrões de lançamento de efluentes, complementa e altera a Resolução no 357, de 17 de março de 2005, do Conselho Nacional do Meio Ambiente-CONAMA. Diário Oficial [da] União: seção 1, Brasília, DF, n. 92, p. 89, 16 maio 2011.

DEAN, R. B.; FORSYTHE, S. L. Estimating the reliability of advanced waste treatment - Part 1. Water \& Sewage Works, v. 123, n. 6, p. 87-89, 1976.

HO, L. T.; VAN ECHELPOEL, W.; GOETHALS, P. L. M. Design of waste stabilization pond systems: A review. Water Research. v. 123, p. 236-248, 2017. https://dx.doi.org/10.1016/j.watres.2017.06.071

KUMAR GUPTA, A.; SHRIVASTAVA, R. K. Uncertainty Analysis of Conventional Water Treatment Plant Design for Suspended Solids Removal. Journal of Environmental $\begin{array}{lllllll}\text { Engineering, } & \text { v. } 132, \quad \text { n. } 11, \quad \text { p. } 1413-1421,\end{array}$ https://dx.doi.org/10.1061/(ASCE)0733-9372(2006)132:11(1413)

LIMPERT, E.; STAHEL, W.; ABBT, M. Log-normal distributions across the sciences: keys and clues. Bioscience, v. 51, n. 5, p. 341-352, 2001.

MACEDO, S. L.; ARAÚJO, A. L. C.; PEARSON, H. W. Thermo-tolerant coliform bacteria decay rates in a full-scale waste stabilization pond system in Northeast Brazil. Water Science and Technology, v. 63, n. 6, p. 1321-1326, 2011. https://dx.doi.org/10.2166/wst.2011.110

MARA, D. Domestic Wastewater Treatment in Developing Countries. London: Earthscan, 2003.

MORAIS N. W. S.; DOS SANTOS A. B. Análise dos padrões de lançamento de efluentes em corpos hídricos e de reúso de águas residuárias de diversos estados do Brasil. Revista DAE, v. 215, n. 67, p. 40-55, 2019.

NIKU, S.; SCHROEDER, E. D.; SAMANIEGO, F. J. Performance of activated sludge process and reliability-based design. Journal Water Pollution Control Association, v. 51, n. 12, p. 2841-2857, 1979.

NIKU, S.; SCHROEDER, E. D. Factors affecting effluent variability from activated sludge processes. Journal Water Pollution Control Association, v. 53, n. 5, p. 546-559, 1981.

OWUSU-ANSAH, E. D. J.; SAMPSON, A.; AMPONSAH, S. K.; ABAIDOO, R. C.; HALD, T. Performance, Compliance and Reliability of Waste Stabilization Pond: Effluent Discharge Quality and Environmental Protection Agency Standards in Ghana. Research Journal of Applied Sciences, Engineering and Technology, v. 11, p. 1293-1302, 2015. https://dx.doi.org/10.19026/rjaset.10.1825

OLIVEIRA, S. C.; VON SPERLING, M. Reliability analysis of wastewater treatment plants. $\begin{array}{llllllll}\text { Water Research. } & \text { v. } 42, \quad \text { n. } 4, & \text { p. } & 1182-1194,\end{array}$ https://dx.doi.org/10.1016/j.watres.2007.09.001

SILVA, F. J. A.; SOUZA R. O. de; CASTRO, F. J. F. de; ARAÚJO, A. L. C. Prospectus of waste stabilization ponds in Ceará, Northeast Brazil. Water Science and Technology, v. 63, n. 6, p. 1265-1270, 2011. https://dx.doi.org/10.2166/wst.2011.106 
SILVA, F. J. A., SOUZA, R. O; ARAÚJO, A. L. C. Revisiting the Influence of Loading on Organic Material Removal in Primary Facultative Ponds. Brazilian Journal of Chemical Engineering, v. 27, n. 1, p. 63-69, 2010. https://dx.doi.org/10.1590/S010466322010000100005

SUN, G.; SAEED, T. Kinetic modelling of organic matter removal in 80 horizontal flow reed beds for domestic sewage treatment. Process biochemistry, v. 44, n. 7, p. 717-722, 2009. https://dx.doi.org/10.1016/j.procbio.2009.03.003

TCHOBANOGLOUS, G.; BURTON, F. L.; STENSEL, H. D. Wastewater engineering. Treatment and reuse. 4th ed. New York: McGraw-Hill Education, 2003.

VERA, I.; GARCÍA, J.; SÁEZ, K.; MORAGAS, L.; VIDAL, G. Performance evaluation of eight years' experience of constructed wetland systems in Catalonia as alternative treatment for small communities. Ecological Engineering, v. 37, n. 2, p. 364-371, 2011. https://dx.doi.org/10.1016/j.ecoleng.2010.11.031

VON SPERLING, M.; VERBYLA, M. A.; OLIVEIRA, S. M. A. C. Assessment of Treatment Plant Performance and Water Quality Data: A Guide for Students, Researchers and Practitioners. IWA Publishing, 2020. https://dx.doi.org/10.2166/9781780409320

WEIRICH, S. R.; SILVERSTEIN, J.; RAJAGOPALAN, B. Effect of average flow and capacity utilization on effluent water quality from US municipal wastewater treatment facilities.

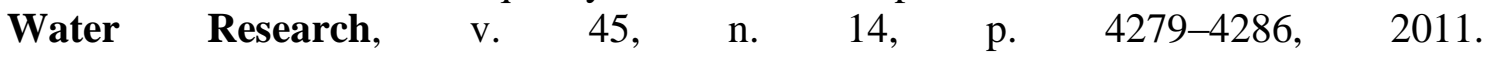
https://dx.doi.org/10.1016/j.watres.2011.06.002 


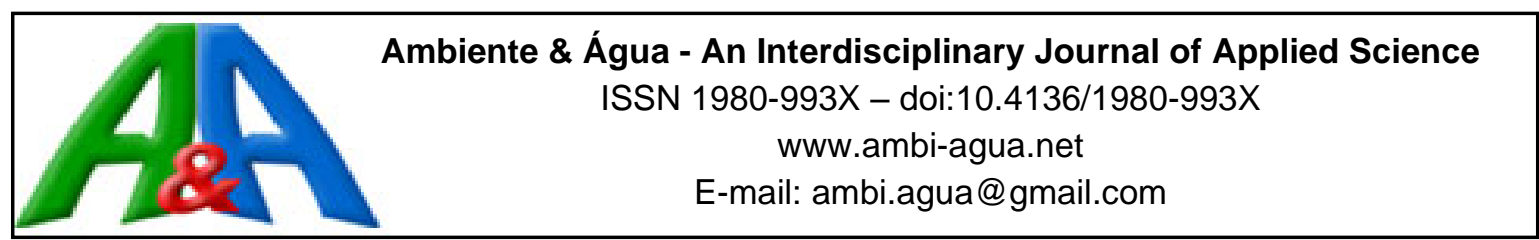

\title{
Aquatic entomofauna and biotic index along the Pindo Grande River, Montano Bajo Forest, in Pastaza Province, Ecuador
}

\author{
ARTICLES doi:10.4136/ambi-agua.2563
}

Received: 21 Apr. 2020; Accepted: 03 Nov. 2020

\begin{abstract}
Maria Alexandra Endara1 ${ }^{1}$; Demián Hinojosa-Garró ${ }^{2 *}$
${ }^{1}$ Departamento de Ingeniería Ambiental. Universidad Tecnológica Equinoccial (UTE), Avenida Mariscal Sucre, s/n, y Mariana de Jesús, Quito, Ecuador. E-mail: maria.endara@ute.edu.ec ${ }^{2}$ Centro de Estudios en Desarrollo Sustentable y Aprovechamiento de la Vida Silvestre (CEDESU). Laboratorio en Ecología Acuática y Monitoreo Ambiental. Universidad Autónoma de Campeche, Avenida Héroe de Nacozari, n480, 4079, San Francisco de Campeche, Campeche, México.

*Corresponding author. E-mail: dhinojos@uacam.mx
\end{abstract}

\begin{abstract}
Pindo Grande River water quality was analyzed during rainy seasons of 2014 and 2017 and dry seasons of 2015 and 2016. Specimens were collected using surber net, kick net and manual stone collection, from five different sites along the river. In the laboratory, specimens were identified to the lowest possible taxonomic level. Taxon richness, abundance, diversity, trophic niches, and Biological Monitoring Working Party for Colombia (BMWP/Col) index were assessed. A total of 1,695 specimens belonging to 95 taxa were collected, including 57 taxa in rainy seasons and 38 taxa in dry seasons. Class Insecta was the most abundant (98.6\%). Richness was highest $(3,427)$ at M1000 collection sites in rainy and dry seasons and varied from moderate to high (13-35) at other sites. All sampling sites had medium diversity, and organisms belonged to three trophic categories: herbivores, detritivores, and predators. Environmental water quality was medium at most sites $(\mathrm{BMWP} / \mathrm{Col}=102-150)$. All sites exhibited good conservation status $(\mathrm{BMWP} / \mathrm{Col}=192-152)$ in the rainy season; only two sites presented medium conservation status $(B M W P / c o l=93-67)$ in the dry season. Principal component analysis indicated that main variables associated with sites were $\mathrm{NO}_{3}$ and COD in upstream areas in the rainy season and $\mathrm{O}_{2}$ in the dry season. Downstream areas were grouped based on depth and width of the river in the rainy season and on $\mathrm{pH}, \mathrm{PO}_{4}$, and conductivity in the dry season. According to analysis, the Pindo Grande River has preserved epibenthic communities; it is an oxygenated stream, but its habitats have been gradually affected by anthropogenic activities.
\end{abstract}

Keywords: diversity, environmental conditions, macroinvertebrates.

\section{Entomofauna aquática e índice de qualidade biótica do Rio Pindo Grande, Floresta Montano Baixo Pastaza - Equador}

\section{RESUMO}

A comunidade de macroinvertebrados aquáticos do Rio Pindo Grande foi analisada, na época chuvosa de 2014 e 2017; e época seca de 2015 e 2016, na Estação Biológica Pindo Mirador. Os Macroinvertebrados foram coletados com rede Surber, rede de chute e coleta manual, em cinco pontos ao longo do rio. No laboratório, eles foram identificados até o menor 
nível taxonômico possível. Calculou-se: riqueza (S), abundância, diversidade ( $\left.\mathrm{H}^{\prime}\right)$, níveis tróficos e índice BMWP/Col. Foram coletados 1695 indivíduos pertencentes a 95 espécies; 57 na estação chuvosa e 38 na estação seca. A classe Insecta abrangeu a maioria dos organismos (98.6\%). O ponto M1000 teve maior riqueza (34-27 espécies) nas duas épocas climáticas, enquanto os pontos restantes apresentaram valores que flutuavam de moderado a alto (13-35 espécies). Todos os pontos obtiveram média diversidade e organismos distribuídos em três categorias tróficas: herbívoros, detritívoros y predadores. A maioria dos locais tinha média qualidade (BMWP/Col s 102-150). Na estação chuvosa, todos os sítios obtiveram um bom estado de conservação (BMWP / Col 192-152), enquanto, na estação seca, apenas dois locais tinham médio estado de conservação (BMWP/Col 93-67). A Análise de Componentes Principais (ACP), determinou que as variáveis primárias associadas aos locais foram: a montante em época de chuvas de $\mathrm{NO}_{3}$ e DQO, na estação seca o $\mathrm{O}_{2}$. Os locais rio abaixo na estação chuvosa, foram agrupados com base na profundidade e largura do rio, em tempo seco $\mathrm{PH}, \mathrm{PO}_{4}$ e condutividade. Se determinou uma comunidade macro-bentônica saudável e variação, frente as atividades antrópicas.

Palavras-chave: condição ambiental, diversidade, macroinvertebrados.

\section{INTRODUCTION}

Benthic macroinvertebrates represent one of the most suitable groups for the purposes of evaluating the quality of aquatic ecosystems, due to their ubiquity as a functional feeding group and the ability of some groups to withstand hypoxic conditions (López-López and Sedeño-Díaz, 2015). They may be particularly powerful indicators of water quality, as they are not difficult to distinguish in the laboratory, are present throughout all seasons, frequently live for more than one year, have restricted mobility, and are integrators of ecological conditions (Plafkin et al., 1989; Khatri and Tyagi, 2015).

Disturbance through variable flow regimes is a prime factor controlling macroinvertebrate communities in running water (Stanford and Ward, 1983; Reice et al., 1990). Tropical streams are generally highly influenced by regular floods (Covich, 1988). Jacobsen and Encalada (1998) suggested that flow related instability of tropical Andes streams was the main feature structuring the invertebrate fauna, while other site characteristics were less important. In addition, Bojsen and Jacobsen (2003) found that the total macroinvertebrate density generally differed between wet and dry seasons.

There are several studies that have used macroinvertebrate communities to assess the effect of organic waste on the coastal streams of South American countries (Selvanayagam and Abril, 2015). Most of them have been carried out in Colombia, Chile, Argentina, Uruguay, Peru, Brazil, and Bolivia but only a few in Ecuador and none in its tropical coastal streams (Selvanayagam and Abril, 2015). Therefore, data on the current status of lotic water bodies and discussions about their conservation are limited.

The Biological Monitoring Working Party for Colombia (BMWP/Col) index (Roldán, 2003) has shown that it is ideal for determining water quality in foothill ecosystems, as more than $97 \%$ of the recorded macroinvertebrate families are included in this index (Arroyo and Encalada, 2009).

The Pindo Grande River supplies drinking water to thousands of families. Water from this river is treated and distributed to approximately 1,350 homes in Cantón Mera and 3,750 homes in Canton Pastaza (Torres, 2006). Despite its importance to local communities, this river has been severely affected by deforestation, cultivation of Naranjilla (Solanum quitoense) and babaco (Carica pentagona) crops (Ríos and Borgtoft, 1994; Rivas, 2015), and cattle farming in the vicinity of the riverbed (Torres, 2006). 
To assess changes in functional structure and facilitate disentangling the effects of disturbance on macroinvertebrate communities in the Ecuadorian Amazon Region, the quality of the Pindo Grande River water around Pindo Mirador Biological Station was studied using macroinvertebrate-based bioassessments (BMWP/Col) for two seasons (wet and dry). The results are expected to serve as the basis for conservation and management strategies of these water sources by the local authorities and residents.

\section{MATERIALS AND METHODS}

\subsection{Study site}

The Pindo Grande River is located in Pastaza Province, Cantón Mera, Ecuador, in the northwestern region of Pastaza Province, eastern Ecuador (Rageot and Albuja, 1994). This river, situated at the eastern foothills of the Andes, in the Habitagua Protective Forest and Vegetation sector 2,800 m above sea level, traverses Cantón Mera and Pastaza and flows into the Puyo River, in the Unión Base sector, and along with the Alpayacu and Tashupi Rivers, forms the smaller tributaries of the Pastaza River Basin, occupying an area of $160,688 \mathrm{~km}^{2}$ (Pastaza, 2015). The annual rainfall ranges from 1,500 to 4,000 $\mathrm{mm}$, with the highest rainfall recorded in July and August. The temperature varies from 20 to $25^{\circ} \mathrm{C}$, with a relative humidity of $86 \%$ (UTE, 2015). The study area along the river was located 1100-1200 m above sea level, and sampling was conducted during the rainy (July 2014 and May 2017) and dry (February 2015 and August 2016) seasons, at five collection sites located along the ecological gradient of the river and included crops, pastures, and a preserved forest. The selection of the sampling points along the river was made based on changes in riparian vegetation, riverbank substrate and composition, as well as human activities. The coordinates and altitudes were recorded using a GPS (Garmin, Oregon 550, USA). Figure 1:

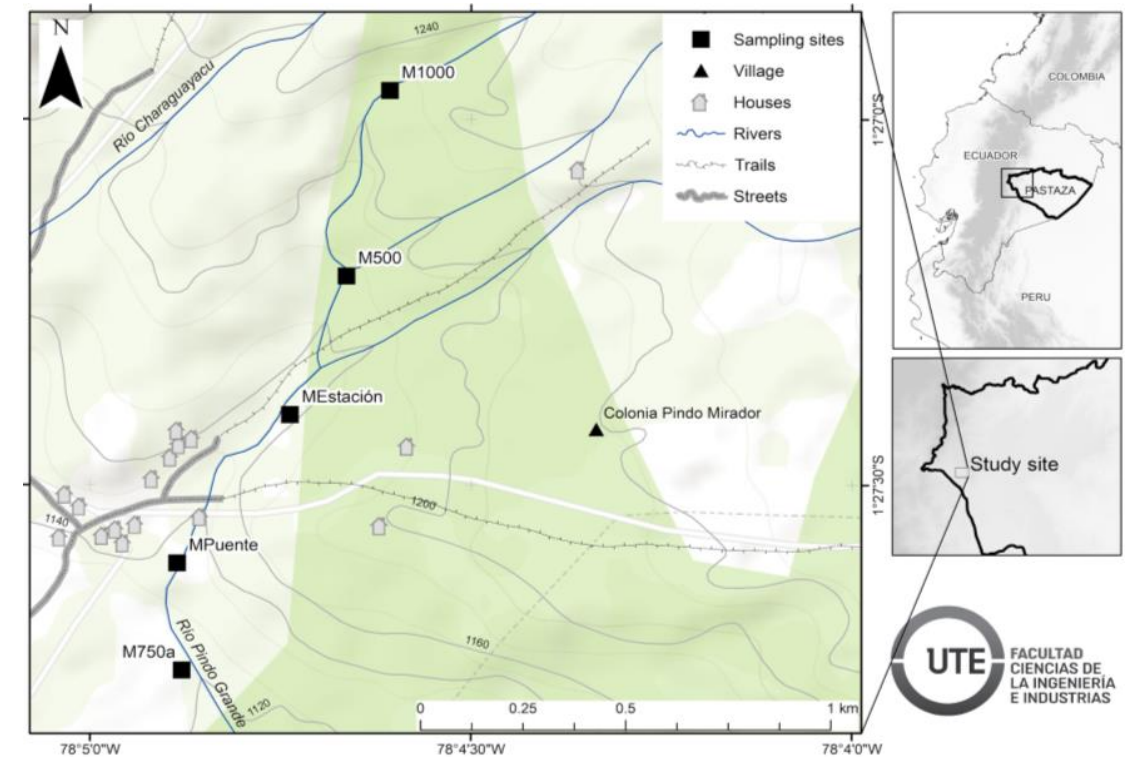

Figure 1. Study area and sampling sites at the lower basin of the Pindo Grande River, Ecuador.

M1000 (01 $\left.26^{\prime} 57.624^{\prime \prime} \mathrm{S} / 78^{\circ} 04^{\prime} 36.4651^{\prime \prime} \mathrm{W}\right)$ sandy substrate with stones, gravel and little detritus; moderately torrential, transparent waters, with $20 \mathrm{~m}$ tall trees, bushes and ferns.

M500 (01 $\left.{ }^{\circ} 27^{\prime} 12.8514^{\prime \prime} \mathrm{S} / 78^{\circ} 04^{\prime} 39.8714^{\prime \prime} \mathrm{W}\right)$ sandy substrate with stones, small rocks and detritus; moderately torrential, clear waters. Vegetation that covers the riverbank has $30 \mathrm{~m}$ high trees, shrubs, ferns and herbaceous plants. One hundred meters below there is a water catchment infrastructure. 
Mestación ( $\left.01^{\circ} 27^{\prime} 24.2418^{\prime \prime} \mathrm{S} / 7^{\circ} 04^{\prime} 44.317^{\prime \prime} \mathrm{W}\right)$, sandy benthos with stones, small rocks, gravel, fallen logs and little detritus, torrential flow with transparent waters. Shore banks have secondary vegetation, composed of ornamental plants, small shrubs, grass, and small trees (10 $\mathrm{m})$ with few epiphytes.

Mpuente (0127'36.4187" S / 7804'53.1894" W), sandy-clayey benthos with stones covered with brown algae, few rocks and gravel; moderately torrential, slightly cloudy waters. Shore banks have crops of wild cane, small palms, few trees and shrubs. People from the surrounding communities walk across the bridge.

M750a (0127'45.2007" S / 78 04'52.8225" W), sandy-clayey benthos with stones covered with brown algae and gravel; torrential flow, slightly cloudy waters. Both shores have wild cane crops, small palms, few trees and shrubs. There are houses and farms around the river.

\subsection{Field study}

Ten collection points were established at random, at each sampling site, a $50 \mathrm{~m}$ long transect was established parallel to the river bank. Macroinvertebrates were collected for $1 \mathrm{~min}$, simultaneously using a surber net (Garie and McIntosh, 1986; Roldán, 1988), kick net (Roldán, 1988), and manual stone collection (Walteros-Rodriguez and Paiba-Alzate, 2010), to cover all possible microhabitats and associated species (Abarca Morales, 2007). The collected organisms were transferred to plastic bags with $70 \%$ ethanol (Jacobsen and Encalada, 1998), which were then sealed (Muzaffar and Colbo, 2002) and labeled for later identification in the laboratory.

At each sampling site, the width and depth of the river were measured using a $50 \mathrm{~m} \mathrm{TP}$ 50ME fiberglass measuring tape (Truper). The $\mathrm{pH}$, temperature, conductivity, and dissolved oxygen were determined in situ during the second sampling period (August 2016 and May 2017), using a multiparameter equipment (HQ40d, HACH, USA). Chemical oxygen demand (COD), 5-day biochemical oxygen demand ( $\left.\mathrm{BOD}_{5}\right), \mathrm{PO}_{4}$, and $\mathrm{NO}_{3}$ were also determined for this sampling period, using a spectrophotometer (DR 2800, HATCH, USA), at the UTE University Environmental Engineering Laboratory.

Table 1 shows the parameters analyzed and the methods used by the Standard Methods for the Examination of Water and Wastewater and the Alpha American Water Works Association.

Table 1. Methods used to analyze chemicals and nutrients, and the associated references.

\begin{tabular}{ccc}
\hline Parameters & Units & Method \\
\hline Temperature & ${ }^{\circ} \mathrm{C}$ & APHA- 5550 B \\
pH & & HACH-8156 \\
Conductivity & $\left(\mu \mathrm{S} / \mathrm{cm}^{2}\right)$ & HACH-8160 \\
$\mathrm{COD}$ & $(\mathrm{mg} / \mathrm{L})$ & HACH-800 \\
$\mathrm{BOD}_{5}$ & $(\mathrm{mg} / \mathrm{L})$ & APHA-5210 D \\
$\mathrm{PO}_{4}$ & $(\mathrm{mg} / \mathrm{L})$ & HACH-8190 \\
Nitrates & $(\mathrm{mg} / \mathrm{L})$ & HACH-8507 \\
\hline
\end{tabular}

\subsection{Laboratory analyses}

In the laboratory, the collected specimens were separated from the substrate, first using a sieve and then with tweezers, and were then washed with water and $70 \%$ ethanol. Separated specimens were then transferred to $3 \mathrm{~mL}$ test tubes (smaller specimens) or $100 \mathrm{~mL}$ plastic bottles (larger specimens).

Macroinvertebrates were identified to the lowest possible taxonomic level, using a binocular stereoscopic microscope (ZM-AB-ST2; 10. ocular, 1. and 4. objective), and dichotomous keys (Merrit et al., 2008; Roldán, 1988; Fernández and Domínguez, 2001; Roldán, 
2003; Salles, 2006; Domínguez and Fernández, 2009; Hamada et al., 2014). Identified specimens were deposited following the specimen preservation protocol of the Zoology Museum of the Pontifical Catholic University of Ecuador Patent No. 11-2016-FAU-DPAP-MA and Collection No. QCAZI 214 831-214886.

\subsection{Data analyses}

Total species richness was calculated using an abundance estimator (Jackknife 1), with 100 randomizations, in EstimateS Version 8.20. Richness $(\mathrm{S})$, abundance $(\mathrm{N})$, and relative abundance (\%) were also calculated (Carrera and Fierro, 2001; Moreno, 2001). The ShannonWiener index was calculated using BIODAP software (Moreno, 2001). Trophic niches were classified into three categories: herbivores, detritivores, and predators (Chará-Serna et al., 2010). The BMWP/Col. index (Roldán, 1988) and Sorensen's (qualitative) similarity coefficient (Magurran, 1988) were used to assess water quality. Principal Component Analysis (PCA) was used as a method to cluster sites according to shared physicochemical characteristics.

\section{RESULTS}

\subsection{Physicochemical parameters}

The physicochemical parameters analyzed at the sampling sites in August 2016 and May 2017 are shown in Table 2. Physicochemical data for the study sites were classified as either upstream or downstream from the MEstación site during the dry and rainy seasons, using principal component analysis (PCA). PCA classified M1000 and M500 as upstream and downstream, respectively, and healthy environments, whereas MEstación, MPuente, and ME750a were classified as downstream and disrupted environments, in both sampling seasons. PCA explained $73 \%$ of data variance. The sampling sites were grouped into upstream or downstream by season (Figure. 2). $\mathrm{NO}_{3}$ and $\mathrm{COD}$ were associated with upstream areas in the rainy season, while $\mathrm{O}_{2}$ in the dry season. In contrast, the downstream areas were grouped based on the depth and width of the river in the rainy season, and on $\mathrm{pH}, \mathrm{PO}_{4}$, and conductivity variations in the dry season (Figure 2).

Table 2. Physicochemical characteristics of the water column at the five sampling sites along the Pindo Grande River in the rainy and wet seasons.

\begin{tabular}{|c|c|c|c|c|c|c|c|c|c|c|}
\hline \multirow{2}{*}{$\begin{array}{c}\text { Physicochemical } \\
\text { parameter }\end{array}$} & \multicolumn{5}{|c|}{ Rainy season (2017) } & \multicolumn{5}{|c|}{ Dry season (2016) } \\
\hline & M100 & M500 & $\begin{array}{c}\text { M } \\
\text { estación }\end{array}$ & $\begin{array}{c}\mathrm{M} \\
\text { puente }\end{array}$ & M750a & M100 & M500 & $\begin{array}{c}\text { M } \\
\text { estación }\end{array}$ & $\begin{array}{c}\mathrm{M} \\
\text { puente }\end{array}$ & M750a \\
\hline $\mathrm{pH}$ & 6.5 & 6.5 & 6.5 & 5.7 & 6.5 & 7.0 & 7.0 & 8.0 & 8.0 & 8.0 \\
\hline $\begin{array}{c}\text { Temperature } \\
\left({ }^{\circ} \mathrm{C}\right)\end{array}$ & 19.7 & 19.5 & 19.6 & 19.8 & 19.8 & 20.6 & 20.6 & 20.7 & 20.7 & 20.7 \\
\hline $\begin{array}{l}\text { Conductivity } \\
\left(\mu \mathrm{S} / \mathrm{cm}^{2}\right)\end{array}$ & 41.7 & 47.7 & 42.7 & 54.5 & 54.5 & 43.6 & 43.6 & 52.7 & 52.1 & 52.1 \\
\hline $\begin{array}{l}\text { Dissolved } \mathrm{O}_{2} \\
(\mathrm{mg} / \mathrm{L})\end{array}$ & 7.4 & 7.4 & 7.12 & 7.15 & 7.15 & 8.3 & 8.3 & 7.39 & 7.65 & 7.65 \\
\hline $\mathrm{COD}(\mathrm{mg} / \mathrm{L})$ & 47 & 47 & 11 & 4 & 4 & 65 & 65 & 14 & 2 & 2 \\
\hline $\mathrm{BOD}_{5}(\mathrm{mg} / \mathrm{L})$ & 7.16 & 7.16 & 5.57 & 6.47 & 6.47 & 6.16 & 6.16 & 6.88 & 6.37 & 6.37 \\
\hline $\mathrm{PO}_{4}(\mathrm{mg} / \mathrm{L})$ & 0.078 & 0.078 & 0.112 & 0.436 & 0.436 & 0.083 & 0.083 & 0.090 & 0.514 & 0.514 \\
\hline Nitrates (mg/L) & 0.313 & 0.313 & 0.310 & 0.021 & 0.021 & 0.241 & 0.241 & 0.270 & 0.011 & 0.011 \\
\hline
\end{tabular}

Source: Vinueza (2017). COD, chemical oxygen demand; BOD $_{5}$, 5-day biochemical oxygen demand. 


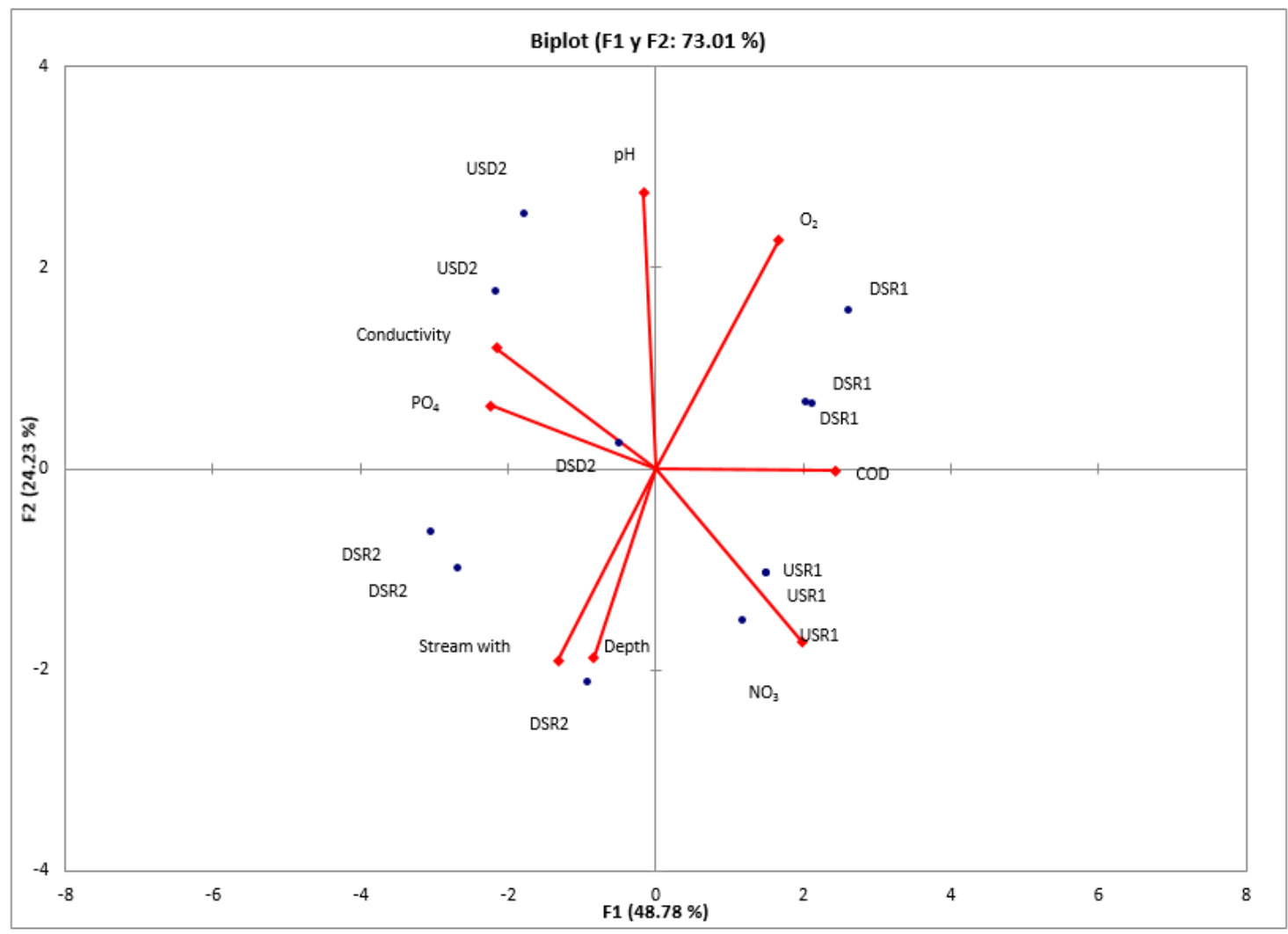

Figure 2. Principal Component Analysis (PCA) for the main physicochemical variables recorded at the sampling sites in the Pindo Grande River. USR= upstream rains, DSR = downstream rains, USD = upstream dry, DSD = downstream dry. $1=1$ st year sampling and 2 $=2$ nd year sampling.

\subsection{Taxon richness, abundance, and diversity}

A total of 1,052 individuals were collected during the rainy season, belonging to four classes, 12 orders, 36 families, and 57 morphospecies. Class Insecta represented $98.6 \%$ of the total sample, with order Trichoptera being the most abundant (478 individuals, and order Lepidoptera being the least abundant (three individuals, 0.29\%). Classes Arachnida, Crustacea, and Tricladida were rare, represented by only one taxon each, with a few, 1, and 13 individuals, respectively (Table 3 ).

In the dry season, 643 individuals were collected, and classified into two classes, 10 orders, 24 families, and 38 morphospecies. Class Insecta comprised $98.5 \%$ of the total sample, with order Ephemeroptera being the most abundant, whereas class Tricladida was represented by only one taxon $(0.16 \%)$ with 10 individuals (Table 4). Genus Rhagovelia of family Veliidae was the most abundant in the rainy season, whereas genus Thraulodes of family Leptophlebiidae was the most abundant in the dry season.

Richness at the sampling points ranged from 21 to 35 taxa in the rainy season (Table 3 ), and from 13 to 27 taxa in the dry season (Table 4). The comparison of the curve of total sampled morphospecies (57 and 38) at the two time points with the curve estimated using Jackknife 1 (75 and 50) indicated that the sampling effort, using the three methodologies (Surber net, kick net, and manual stone collection), resulted in $76 \%$ of the local aquatic macroinvertebrate richness being collected.

The Shannon-Wiener index values at M1000, M500, and MEstación were intermediate in the rainy season, corresponding to $2.53,2.58$, and 2.38 , respectively. The sampling sites with the highest and lowest Shannon-Wiener index values were M750a (2.97) and MPuente (2.26), respectively (Figure 3). 
Table 3. Abundance of different taxa collected during the rainy season of 2014 and 2017 at the five sampling sites along the Pindo Grande River, Pastaza Province, Ecuador.

\begin{tabular}{|c|c|c|c|c|c|c|c|}
\hline \multirow{2}{*}{ Family } & \multicolumn{7}{|c|}{ Rainy season } \\
\hline & M1000 & M500 & MEstación & MPuente & M750a & Total & $\%$ \\
\hline Lymnessiidae & 1 & 0 & 0 & 0 & 0 & 1 & 0.1 \\
\hline Palaemonidae & 0 & 1 & 0 & 0 & 0 & 1 & 0.1 \\
\hline Blattidae & 0 & 0 & 0 & 0 & 0 & 0 & 0 \\
\hline Elmidae & 13 & 6 & 9 & 1 & 17 & 46 & 4.4 \\
\hline Psephenidae & 9 & 18 & 14 & 5 & 11 & 57 & 5.4 \\
\hline Ptilodactylidae & 21 & 13 & 13 & 7 & 8 & 62 & 5.9 \\
\hline Scirtidae & 0 & 1 & 0 & 0 & 0 & 1 & 0.1 \\
\hline Chironomidae & 0 & 0 & 0 & 46 & 1 & 47 & 4.5 \\
\hline Simuliidae & 0 & 1 & 1 & 1 & 0 & 3 & 0.3 \\
\hline Tipulidae & 0 & 1 & 1 & 47 & 1 & 50 & 4.8 \\
\hline Baetidae & 21 & 16 & 15 & 101 & 10 & 163 & 15.5 \\
\hline Euthyplociidae & 7 & 0 & 0 & 0 & 0 & 7 & 0.7 \\
\hline Leptohyphidae & 28 & 17 & 16 & 148 & 11 & 220 & 20.9 \\
\hline Leptophlebiidae & 56 & 33 & 31 & 249 & 21 & 390 & 37.1 \\
\hline Corixidae & 0 & 0 & 0 & 0 & 1 & 1 & 0.1 \\
\hline Gerridae & 0 & 0 & 0 & 0 & 5 & 5 & 0.5 \\
\hline Naucoridae & 0 & 0 & 0 & 0 & 6 & 6 & 0.6 \\
\hline Veliidae & 1 & 0 & 0 & 1 & 34 & 36 & 3.4 \\
\hline Pyralidae & 1 & 2 & 0 & 0 & 0 & 3 & 0.3 \\
\hline Corydalidae & 8 & 0 & 0 & 2 & 4 & 14 & 1.3 \\
\hline Coenagrionidae & 3 & 2 & 3 & 1 & 2 & 11 & 1.0 \\
\hline Gomphidae & 1 & 0 & 0 & 0 & 0 & 1 & 0.1 \\
\hline Libellulidae & 4 & 2 & 3 & 1 & 2 & 12 & 1.1 \\
\hline Megapodagrionidae & 5 & 2 & 3 & 1 & 2 & 13 & 1.2 \\
\hline Platystictidae & 5 & 0 & 0 & 0 & 0 & 5 & 0.5 \\
\hline Polythoridae & 6 & 2 & 1 & 1 & 0 & 10 & 1.0 \\
\hline Perlidae & 7 & 1 & 4 & 0 & 3 & 15 & 1.4 \\
\hline Calamoceratidae & 11 & 4 & 3 & 0 & 0 & 18 & 1.7 \\
\hline Helicopsychidae & 1 & 0 & 23 & 1 & 2 & 27 & 2.6 \\
\hline Hydrobiosidae & 0 & 1 & 0 & 0 & 0 & 1 & 0.1 \\
\hline Hydropsychidae & 12 & 5 & 26 & 1 & 2 & 46 & 4.4 \\
\hline Hydroptilidae & 12 & 6 & 26 & 1 & 2 & 47 & 4.5 \\
\hline Leptoceridae & 25 & 12 & 75 & 3 & 6 & 121 & 11.5 \\
\hline Odontoceridae & 0 & 0 & 1 & 0 & 0 & 1 & 0.1 \\
\hline Philopotamidae & 21 & 0 & 0 & 2 & 1 & 24 & 2.3 \\
\hline Xiphocentronidae & 1 & 0 & 1 & 1 & 0 & 3 & 0.3 \\
\hline Planariidae & 1 & 2 & 0 & 7 & 3 & 13 & 1.2 \\
\hline Total abundance & 340 & 130 & 258 & 120 & 204 & 1052 & 165.1 \\
\hline Total richness & 34 & 26 & 27 & 21 & 35 & 57 & \\
\hline
\end{tabular}


Table 4. Abundance of different taxa collected during the dry season of 2015 and 2016 at the five sampling sites along the Pindo Grande River, Pastaza Province, Ecuador.

\begin{tabular}{|c|c|c|c|c|c|c|c|}
\hline \multirow{2}{*}{ Family } & \multicolumn{7}{|c|}{ Dry season } \\
\hline & M1000 & M500 & MEstación & MPuente & M750a & Total & $\%$ \\
\hline Blattidae & 1 & 0 & 0 & 0 & 0 & 1 & 0.2 \\
\hline Elmidae & 25 & 3 & 2 & 3 & 0 & 33 & 5.1 \\
\hline Psephenidae & 6 & 2 & 0 & 6 & 0 & 14 & 2.2 \\
\hline Ptilodactylidae & 4 & 24 & 2 & 4 & 10 & 44 & 6.8 \\
\hline Chironomidae & 45 & 0 & 2 & 0 & 0 & 47 & 7.3 \\
\hline Simuliidae & 3 & 0 & 0 & 0 & 0 & 3 & 0.5 \\
\hline Tipulidae & 48 & 0 & 2 & 0 & 0 & 50 & 7.8 \\
\hline Baetidae & 100 & 24 & 6 & 4 & 10 & 144 & 22.4 \\
\hline Leptohyphidae & 148 & 24 & 8 & 4 & 10 & 194 & 30.2 \\
\hline Leptophlebiidae & 248 & 48 & 14 & 8 & 20 & 338 & 52.6 \\
\hline Corydalidae & 0 & 0 & 0 & 3 & 0 & 3 & 0.5 \\
\hline Coenagrionidae & 0 & 0 & 0 & 3 & 0 & 3 & 0.5 \\
\hline Libellulidae & 0 & 0 & 0 & 3 & 0 & 3 & 0.5 \\
\hline Megapodagrionidae & 0 & 0 & 0 & 3 & 0 & 3 & 0.5 \\
\hline Platystictidae & 1 & 1 & 0 & 0 & 0 & 2 & 0.3 \\
\hline Polythoridae & 2 & 0 & 2 & 1 & 0 & 5 & 0.8 \\
\hline Perlidae & 6 & 3 & 3 & 0 & 2 & 14 & 2.2 \\
\hline Calamoceratidae & 0 & 2 & 0 & 0 & 2 & 4 & 0.6 \\
\hline Helicopsychidae & 0 & 0 & 1 & 0 & 0 & 1 & 0.2 \\
\hline Hydrobiosidae & 0 & 0 & 1 & 1 & 0 & 2 & 0.3 \\
\hline Hydropsychidae & 0 & 2 & 2 & 1 & 2 & 7 & 1.1 \\
\hline Hydroptilidae & 0 & 2 & 3 & 2 & 2 & 9 & 1.4 \\
\hline Leptoceridae & 0 & 4 & 7 & 4 & 4 & 19 & 3.0 \\
\hline Odontoceridae & 0 & 0 & 0 & 0 & 0 & 0 & 0 \\
\hline Philopotamidae & 44 & 1 & 0 & 0 & 0 & 45 & 7.0 \\
\hline Planariidae & 1 & 7 & 0 & 1 & 1 & 10 & 1.6 \\
\hline Total abundance & 475 & 266 & 105 & 109 & 133 & 1,088 & 169.2 \\
\hline Total richness & 27 & 19 & 14 & 17 & 13 & 38 & 25.0 \\
\hline
\end{tabular}

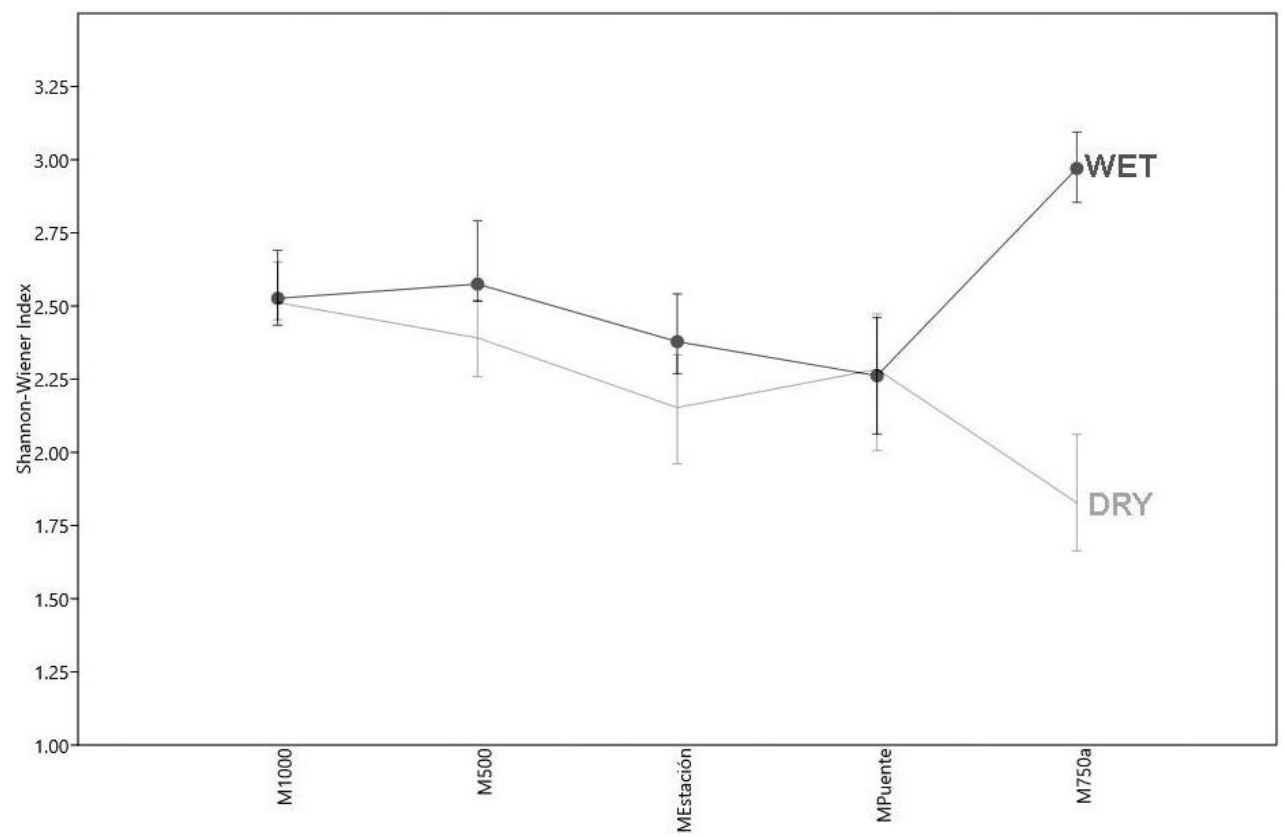

Figure 3. Shannon-Wiener diversity index at the five sampling sites along the Pindo Grande River in the rainy (RS) and dry (DS) seasons of 2014 and 2017. 
The comparison of taxon richness by sampling site and season indicated that M1000 and M500 sites had significantly higher richness in the rainy seasons, than those located downstream of the river in the dry season (MPuente and M750a) $(t=2.9 ; D F=4 ; p<0.05)$ (Tables 3 and 4).

\subsection{Trophic groups}

For predator species, 145 individuals were collected in the rainy season (13.8\%) and 52 $(8.1 \%)$ in the dry season, 734 detritivore individuals $(69.8 \%)$ were collected in the rainy season and 527 individuals $(82.0 \%)$ in the dry season. In the rainy season, 173 individuals $(16.4 \%)$ were classified as herbivores and $64(10.0 \%)$ in the dry season.

\subsection{Water quality assessment by BMWP/Col index}

The macroinvertebrate community at the sampling sites included representative organisms of three water quality classes (Table 5). Most species (15) were recorded in environments with medium-quality water, followed by environments with high-quality (12.2) and poor-quality water (1.2) (Table 5). All sampled sites had high BMWP/Col values, except M750a in the dry season, which exhibited the lowest index value.

Table 5. BMWP/Col index and classification of the five sampling sites along the Pindo Grande River in the rainy and dry seasons.

\begin{tabular}{|c|c|c|c|c|c|c|}
\hline \multicolumn{4}{|c|}{ Rainy season } & \multicolumn{3}{|c|}{ Dry season } \\
\hline Sampling Points & $\begin{array}{l}\mathrm{BMWP} / \mathrm{Col} \\
\text { index }\end{array}$ & Quality & Water condition & $\begin{array}{c}\mathrm{BMWP} / \mathrm{Col} \\
\text { index }\end{array}$ & Quality & Status \\
\hline M1000 & 192 & Good & Very clean & 126 & Good & Very clean \\
\hline M500 & 162 & Good & Very clean & 113 & Good & Very clean \\
\hline MEstación & 149 & Good & Very clean & 93 & Acceptable & Slightly contaminated \\
\hline MPuente & 152 & Good & Very clean & 102 & Good & Clean \\
\hline M750a & 152 & Good & Very clean & 67 & Acceptable & Slightly contaminated \\
\hline
\end{tabular}

\subsection{Similarity index and Sorensen's coefficient}

M1000 presented the highest species similarity in aquatic macroinvertebrate communities between the rainy and dry seasons, followed by M500 and MPuente, with values higher than $50 \%$, whereas species similarity at MEstación and M750a was low. M1000 exhibited the highest species similarity in aquatic macroinvertebrate communities between sampling years, followed by M500 and MPuente, with values higher than 50\%, whereas species similarity at MEstación and M750a was low (<50\%).

\section{DISCUSSION}

\subsection{Physicochemical parameters}

Physical-chemical data allowed us to perform and compare variations among sites and seasons using a principal component analysis (PCA). A significant difference could be observed between the points that have higher (MEstation, MPuent, and ME750a) and lower (M1000 and M500) human activity; the same results were found by Rodríguez-Badillo et al. (2016); Parreira de Castro et al. (2018); Macedo et al. (2016) and Selvanayagam and Abril (2016).

The physicochemical parameters $\mathrm{NO}_{3}, \mathrm{COD}, \mathrm{pH}, \mathrm{PO} 4, \mathrm{O} 2$, conductivity, depth and width of the Pindo Grande River were associated with up and downstream fluctuations as result of seasonality, having a significant influence on its macrobenthic community. The same results were found by Selvanayagam and Abril (2016) and by Bojsen and Jacobsen (2003). In freshwater ecosystems such as lakes, rivers and streams, dissolved oxygen concentrations will vary by season, location and water depth. The high concentration of oxygen helps in metabolizing organic matter along the river's journey (Payne, 1986). 


\subsection{Taxon richness, abundance, and diversity}

A different taxon composition was found between the macroinvertebrates collected in wet and dry seasons. These results are in accordance with those obtained by Ríos-Touma et al. (2011), who reported significant differences in the macroinvertebrate community between the rainy and dry seasons, including changes in community composition, richness, abundance, and diversity as result of stochastic variation in the ecosystems.

The number of sensitive morphospecies with strict ecological requirements was higher in the rainy season than in the dry season, in contrast to the findings of Jacobsen and Encalada (1998) and Giacometti and Bersosa (2006), who reported higher species and specimen numbers in the dry season. This difference might be explained by the fact that these studies were conducted in different ecological areas, and the diversity and abundance of macroinvertebrates are known to be associated with the riverine vegetation of the sampled area (Righi-Cavallaro Ocampo et al., 2010).

Shannon-Wiener indices tended to decrease between the sites M1000 and MPuente, which may be due to changes in variables such as $\mathrm{PO}_{4}$ and $\mathrm{O}_{2}$ concentrations, conductivity, and COD, as shown by the PCA. The sampling sites were clustered based on species distribution (upstream and downstream) and anthropogenic activity, in which the latter may result in less favorable environmental conditions for macroinvertebrate development (Hinojosa-Garro et al., 2010). Changes in water quality could modify species composition, particularly those that are sensitive to pollution (Rodriguéz-Badillo et al., 2016). In contrast, several morphospecies, including members of Chironomidae, Hexatoma spp., and Parapoynx spp., are known to benefit from environmental changes and/or anthropogenic disturbance (Mykrä and Heino, 2017), as it was observed in the M750a and Mpuente sites.

\subsection{Trophic groups}

In healthy aquatic ecosystems, detritivores predominate, followed by herbivores and predators (Chará-Serna et al., 2010; Barrios et al., 2015). Of these trophic categories, detritivores were the most abundant at all sampling sites in the present study. Therefore, the study area can be considered to be in a healthy condition (Cummins et al., 2005; Jyväsjärvi et $a l ., 2013)$. This could be because there still are forested areas at the riverbank of Pindo Grande River, and according to Bojsen and Jacobsen (2003) the vegetation cover contributes to have a good macroinvertebrate community.

\subsection{Water quality assessment by BMWP/Col index}

All sampled sites had high BMWP/Col values, except M750a in the dry season, which exhibited the lowest index value. These values, along with the analysis of sensitivity to pollution and/or environmental disturbance, indicated that the BMWP/Col index did not reflect the real conditions prevalent at the collection sites. This may be due to the fact that in the BMWP/Col index, organisms are identified to the family level, and variations in the tolerance of taxa within the same family are unknown (Bispo et al., 2002; Bonada et al., 2004; Tomanova and Tedesco, 2007; Domínguez and Fernández, 2009; Forero et al., 2014).

The sites with the highest BMWP/Col index were M1000 and M500, which were characterized by the presence of diverse communities consisting of sensitive organisms with strict ecological requirements, such as Anacroneuria spp. In contrast, MEstación had the lowest index within the category, probably owing to the direct influence of water collection activities, which may affect the substrate, water flow, and aquatic vegetation in the area. However, this site was classified as healthy, based on the observations made in the two seasons, suggesting that environmental disturbances were punctual and associated with climatic conditions, or that this index did not reflect these disturbances.

Site MPuente presented a less diverse macrobenthic community dominated by organisms 
tolerant to habitat changes. However, these changes were not significant because the BMWP/Col index indicated good environmental quality, despite the anthropic activities prevalent in adjoining areas. This result is consistent with that of Carrera and Fierro (2001), Terneus et al. (2012), and Abril et al. (2015).

Although the macroinvertebrate community was well characterized in the present study, inter-annual samplings are necessary to determine species changes due to variations in ecological flow, variations in environmental conditions and anthropogenic impacts prevalent in this lotic system (Jacobsen, 2003; Encalada and Ríos, 2011; Ríos-Touma et al., 2012).

\section{CONCLUSIONS}

The study found that the water quality of the Pindo Grande River is in good condition and exhibited ideal characteristics to develop epibenthic communities, resulting from welloxygenated streams with different substrates; however, these habitats seem to be gradually affected by anthropogenic activities, according to the PCA carried out, which classified the data into two clusters due to anthropic influence observed in the river.

The physical and chemical parameters that most influenced the macroinvertebrate community in the Pindo Grande River were $\mathrm{NO}_{3}, \mathrm{COD}, \mathrm{pH}, \mathrm{PO}_{4}, \mathrm{O}_{2}$, conductivity, depth and width. It could also be observed as an influence of dry and rainy seasons; finding lower water quality in the dry season at point M750a; these results are consistent with Encalada and Rios (2011). It is necessary to carry out systematic sampling campaigns to establish a monitoring strategy in this important biological area of Ecuador.

It is recommended that the biotic index BMWP/Col be used in the Ecuadorian Amazon Region; however, caution needs to be taken with those cosmopolitan abundant species that might interfere with the index values in this ecological region of Ecuador.

\section{ACKNOWLEDGEMENTS}

This research was funded by the UTE University (Project Number 007-2014-IC-FAUDPAP-MAE).

\section{REFERENCES}

ABARCA MORALES, H. El uso de macroinvertebrados como bioindicadores de la calidad de agua. Biocenosis, v. 20, p. 1-2, 2007.

ABRIL, R.; RODRÍGUEZ, L.; PUALACÍN, R. L.; SALAZAR, J. S. Impactos ambientales generados por el dique del río Pindo en Shell cantón Mera. Revista Amazónica Ciencia y Tecnología, v. 3, n 3, p. 258-283, 2015.

ARROYO, C.; ENCALADA, A. C. Evaluación de la calidad de agua a través de macroinvertebrados bentónicos e índices biológicos en ríos tropicales en bosque de neblina montano. ACI Avances en Ciencias e Ingenierías, v. 1, n. 1, 2009. https://doi.org/10.18272/aci.v1i1.4

BARRIOS, M.; RODRÍGUEZ-OLARTE, D.; GARCÍA E. Índice de integridad de los ecosistemas fluviales con base a las comunidades de insectos acuáticos en el río Misoa de la cuenca del lago de Maracaibo, Venezuela. Entomotropica, v. 30, n. 8, p. 69-83, 2015.

BISPO, P. C.; FROEHLICH, C. G.; OLIVEIRA, L. G. Spatial distribution of Plecoptera nymphs in streams of a mountainous area of Central Brazil. Brazilian Journal of Biology, v. 62, n. 3, p. 409-417, 2002. https://doi.org/10.1590/S1519-69842002000300003 
BOJSEN, B. H.; JACOBSEN, D. Effects of deforestation on macroinvertebrate diversity and assemblage structure in Ecuadorian Amazon streams. Hydrobiologie, v. 158, n. 3, p. 317-342, 2003. https://doi.org/10.1127/0003-9136/2003/0158-0317

BONADA, N.; ZAMORA-MUÑOZ, C.; RIERADEVALL, M.; PRAT, N. Trichoptera (Insecta) collected in Mediterranean River basins of the Iberian Peninsula: Taxonomic remarks and notes on ecology. Graellsia, v. 60, n. 1, p. 41-69, 2004.

CHARÁ-SERNA, A.; CHARÁ, J.; ZÚÑIGA, M.; PEDRAZA, G.; GIRALDO, L. Clasificación trófica de insectos acuáticos en ocho quebradas protegidas de la ecorregión cafetera colombiana. Universitas Scientiarium, v. 15, n. 1, p. 27-36, 2010.

CARRERA, C.; FIERRO, K. Manual de monitoreo los macroinvertebrados acuáticos como indicadores de la calidad del agua. Quito: EcoCiencia Publishers, 2001. 67 p.

COVICH, A. Geographical and Historical Comparisons of Neotropical Streams: Biotic Diversity and Detrital Processing in Highly Variable Habitats. Journal of the North American Benthological Society, v. 7, n. 9, p. 361-386, 1988. https://doi.org/10.2307/1467297

CUMMINS, K. W.; MERRITT, R. W.; ANDRADE, P. C. N. The use of invertebrate functional groups to characterize ecosystem attributes in selected streams and rivers in southeast Brazil. Studies on Neotropical Fauna and Environment, v. 40, n. 1, p. 71-90, 2005. https://doi.org/10.1080/01650520400025720

DOMÍNGUEZ, E.; FERNÁNDEZ, H. R. Macroinvertebrados bentónicos sudamericanos, Sistemática y Biología. Tucumán: Fundación Miguel Lillo Publishers, 2009. 656 p.

ENCALADA, A.; RÍOS, B. Aprendizaje de las cuencas altoandinas: Proyecto FUCARA: Quito: Laboratorio de Ecología Acuática; USFQ Publishers, 2011.

FERnÁnDEZ, H.; DOMÍNGUEZ, E. Guía para la Determinación de los Artrópodos Bentónicos Sudamericanos. Tucumán: Universitaria de Tucumán Publishers, 2001. 282 p.

FORERO, L.; LONGO, M.; RAMÍREZ, J.; CHALAR, G. Índice de calidad ecológica con base en macroinvertebrados acuáticos para la cuenca del río Negro (ICERN-MAE), Colombia. Revista Biología Tropical, v. 62, n. 2, p. 233-247, 2014.

GARIE, H.; MCINTOSH, A. Distribution of benthic macroinvertebrates in a stream exposed to urban runoff. Journal of the American Water Resources Association, v. 22, n. 3, p. 447-455, 1986. https://doi.org/10.1111/j.1752-1688.1986.tb01899.x

GIACOMETTI, J. C.; BERSOSA, F. Macroinvertebrados acuáticos y su importancia como bioindicadores de calidad del agua en el río Alambi. Boletín Técnico, Serie Zoologica, v. 6, p. 17-32, 2006.

HAMADA, N.; NESSIMIAN, J.; QUERINO, R. Insetos aquáticos na Amazônia brasileira: taxonomia, biologia e ecologia. Manaus: INPA, 2014. $711 \mathrm{p}$.

HINOJOSA-GARRO, D.; MASON, F.; UNDERWOOD, J. C. Effects of macrophyte spatial architecture on periphyton and macroinvertebrate community structure in shallow water bodies under contrasting land management. Fundamental and Applied Limnology, v. 177, n. 1, p. 19-37, 2010 
JACOBSEN, D.; ENCALADA, A. The macroinvertebrate fauna of Ecuadorian Highland streams in the wet and dry seasons. Archiv für Hidrobiologie, v. 142, n. 1, p. 53-70, 1998.

JACOBSEN, D. Altitudinal changes in diversity of macroinvertebrates from small streams in the Ecuadorian Andes. Archiv für Hydrobiologie, v. 158, n. 2, p. 145-167, 2003.

JYVÄSJÄRVI, J.; BOROS, G.; JONES, R. I.; HÄMÄLÄINEN, H. The importance of sedimenting organic matter, relative to oxygen and temperature, in structuring lake profundal macroinvertebrate assemblages. Hydrobiologia, v. 709, n. 1, p. 55-72, 2013. https://doi.org/10.1007/s10750-012-1434-0

KHATRI, N.; TYAGI, S. Influences of natural and anthropogenic factors on surface and groundwater quality in rural and urban areas. Frontiers in Life Science, v. 8, n. 1, p. 23 39, 2015. https://dx.doi.org/10.1080/21553769.2014.933716

LÓPEZ-LÓPEZ, E., SEDEÑO-DÍAZ, J. E. Biological Indicators of Water Quality: The Role of Fish and Macroinvertebrates as Indicators of Water Quality. In: ARMON, R.; HÄNNINEN, O. (eds.). Environmental Indicators. Dordrecht: Springer, 2015. https://doi.org/10.1007/978-94-017-9499-2_37

MACEDO, D. R.; HUGHES, R. M.; FERREIRA, W. R.; FIRMIANO, K. R.; SILVA, D. R. O.; LIGEIRO, R.; KAUFMANN P. R.; CALLISTO, M. Development of a benthic macroinvertebrate multimetric index (MMI) for Neotropical Savanna headwater streams. $\begin{array}{llllll}\text { Ecological Indicators, } & \text { v. 64, } & \text { p. }\end{array}$ https://doi.org/10.1016/j.ecolind.2015.12.019

MAGURRAN, A. E. Ecological diversity and its measurement. New Jersey: Princeton University Press, 1988. p. 179.

MERRITT, R.; CUMMINS, K.; BERG, M. An introduction to the aquatic insects of North America. USA: Kendall/Hunt, 2008. 1158 p.

MORENO, C. E. Métodos para medir la Biodiversidad. Zaragoza: M\&T-Manuales y Tesis SEA, 2001. vol. 1. 84 p.

MUZAFFAR, S.; COLBO, M. The effects of sampling technique on the ecological characterization of shallow, benthic macroinvertebrate communities in two Newfoundland ponds. Hidrobiología, v. 477, n. 1-3, p. 31-39, 2002. https://doi.org/10.1023/A:1021008526284

MYKRÄ, H.; HEINO, J. Decreased habitat specialization in macroinvertebrate assemblages in anthropogenically disturbed streams. Ecological Complexity, v. 31, p. 181-188, 2017. https://doi.org/10.1016/j.ecocom.2017.07.002

PARREIRA DE CASTRO D.; DOLÉDEC, S.; CALLISTO, M. Land cover disturbance homogenizes aquatic insect functional structure in neotropical savanna streams. $\begin{array}{llllll}\text { Ecological Indicators, } & \text { v. } & \text { 84, } & \text { p. } & \text { 573-582, }\end{array}$ https://doi.org/10.1016/j.ecolind.2017.09.030

PASTAZA. Gobierno Autónomo Descentralizado. Plan de desarrollo y ordenamiento territorial de la Provincia de Pastaza al año 2025. Actualización 2015. Pastaza, 2015. $217 \mathrm{p}$.

PAYNE, A. I. The ecology of tropical lakes and rivers. Washington, DC.: OSTI, 1986. 
PLAFKIN, J. L.; BARBOUR, M. T.; PORTER, K. D.; GROSS, S. K.; HUGHES, R. M. Rapid bioassessment protocols for use in streams and rivers: benthic macroinvertebrates and fish. EPA v. 444. Washington, DC: USEPA Office of Water, 1989. p. 4-89- 001.

RAGEOT, R.; ALBUJA, L. Mamíferos de un sector de la Alta Amazonía Ecuatoriana (Mera, Provincia de Pastaza). Politécnica, v. 19, n. 2, p. 165-208, 1994.

REICE, S. R.; WISSMAR, R. C.; NAIMAN, R. J. Disturbance regimes, resilience, and recovery of animal communities and habitats in lotic ecosystems. Environmental Management, v. 14, p. 647-659, 1990. https://doi.org/10.1007/BF02394715

RIGHI-CAVALLARO OCAMPO, K.; SPIES, M. R.; SIEGLOCH, A. E. Composição da fauna de Ephemeroptera, Plecoptera e Trichoptera na bacia do Rio Miranda, Estado do Mato Grosso do Sul, Brasil. Biota Neotropica, v. 10, n. 2, p. 253-260, 2010. https://dx.doi.org/10.1590/S1676-06032010000200028

RÍOS, M.; BORGTOFT, P. Las Plantas y el Hombre: Memorias del Primer Simposio Ecuatoriano de Etnobotánica y Botánica Económica. Quito: Abya Yala, 1994. 436 p.

RÍOS-TOUMA, B.; ENCALADA, A. C.; PRAT, N. Macroinvertebrate assemblages of an Andean high-altitude tropical stream: the importance of season and flow. International review of hydrobiology, v. 96, n. 6, p. 667-685, 2011. https://doi.org/10.1002/iroh.201111342

RÍOS-TOUMA, B.; PRAT, N.; ENCALADA, A. C. Invertebrate drift and colonization processes in a tropical Andean stream. Aquatic Biology, v. 14, n. 3, p. 233-246, 2012. https://doi.org/10.3354/ab00399

RIVAS, J. Análisis preliminar de los servicios ecosistémicos de la cuenca media del río Pastaza, Ecuador. 2015. (Unpublished Bachelor's thesis) Pontificia Universidad Católica del Ecuador, Quito, 2015.

RODRÍGUEZ-BADILLO, L.; RÍOS-GUAYASAMÍN, P.; ESPINOSA-CHICO, M.; CEDEÑO, P.; JIMÉNEZ, G. Water quality characterization of benthonic macroinvertebrates of Puyo river, Ecuadorian Amazonia. Hidrobiologica, v. 26, n. 3, p. 497-507, 2016.

ROLDÁN, G. Guía para el Estudio de los Macroinvertebrados Acuáticos del Departamento de Antioquia. Bogotá: Presencia, 1988. 228 p.

ROLDÁN, G. Bioindicación de la calidad de agua en Colombia: uso del método BMWP/Col. Colombia: Universidad de Antioquia, 2003. 170 p.

SALLES, F. As Ninfas de Ephemeroptera (Insecta) ocurrentes no Brasil. Tese (Programa de Post grado en Entomología para obtención del Título de Doctor en Ciencias) Universidade Federal de Viçosa, Viçosa, 2006.

SELVANAYAGAM, M. Use of Benthic Macro Invertebrates as a Biological Indicator in Assessing Water Quality of River Puyo, Puyo, Pastaza, Ecuador. American Journal of Life Sciences, v. 4, n. 1, p. 1, 2016. https://doi.org/10.11648/j.ajls.20160401.11

SELVANAYAGAM, M.; ABRIL, R. Water Quality Assessment of Piatua River Using Macroinvertebrates in Puyo, Pastaza, Ecuador. American Journal of Life Sciences, v. 3, n. 3, p. 167, 2015. https://doi.org/10.11648/j.ajls.20150303.17 
STANFORD, J. A.; WARD, J. V. Insect Species Diversity as a Function of Environmental Variability and Disturbance in Stream Systems. In: BARNES, J. R.; MINSHALL, G. W. (eds.). Stream Ecology. Boston: Springer, 1983. https://doi.org/10.1007/978-1-46133775-1_11

TERNEUS, E.; RACINES, M. J.; HERNÁNDEZ, K. Evaluación ecológica del Río Lliquino a través de macroinvertebrados acuáticos, Pastaza-Ecuador. Revista de Ciencias, v. 16, p. 31-45, 2012.

TORRES, V. Centro de interpretación y senderos Zuma Huasi. (Bachelor's Thesis) Universidad de Especialidades Turísticas, Quito, 2006.

TOMANOVA, S.; TEDESCO, P. Tamaño corporal, tolerancia ecológica y potencial de bioindicación de la calidad del agua de Anacroneuria spp. (Plecoptera: Perlidae) en América del Sur. Revista de Biología Tropical, v. 55, n. 1, p. 67-81, 2007.

UNIVERSIDAD TECNOLÓGICA EQUINOCCIAL. Estación Biológica Pindo Mirador. Quito: Gráficas Iberia, 2015. 131p.

VINUEZA, M. Utilización de macroinvertebrados y parámetros físicoquímicos para evaluaciones ecológicas en ecosistemas acuáticos de la Estación Biológica Pindo Mirador. (Bachelor's thesis) Universidad Tecnológica Equinoccial, Quito, 2017.

WALTEROS-RODRÍGUEZ，J. M.; PAIBA-ALZATE，J. E. Estudio preliminar de la comunidad de macroinvertebrados acuáticos en la Reserva Forestal Torre Cuatro. Boletín Científico. Centro de Museos. Museo de Historia Natural, v. 14, n. 1, p. 137-149, 2010. 


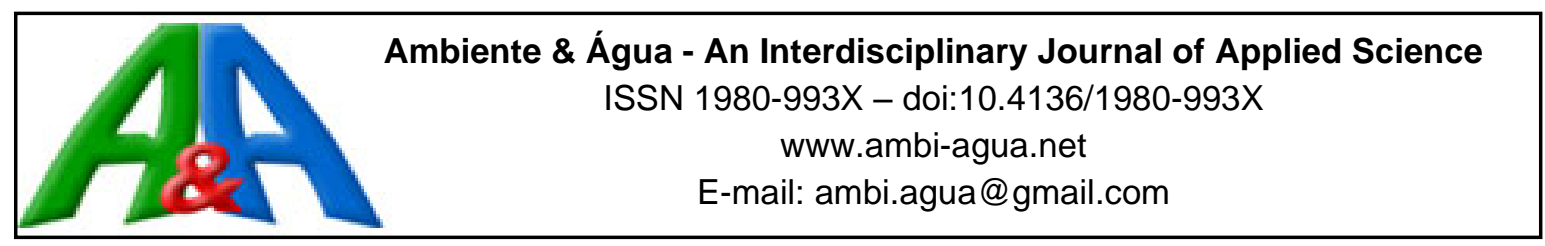

\title{
Stemflow and throughfall in agricultural crops: a synthesis
}

\author{
ARTICLES doi:10.4136/ambi-agua.2528
}

Received: 05 Feb. 2020; Accepted: 24 Nov. 2020

\author{
Valdemir Antoneli ${ }^{1 *}$; Fabio Caian de Jesus ${ }^{1}$; \\ João Anésio Bednarzi ${ }^{1}$; Edivaldo Lopes Thomaz ${ }^{2}$ iD \\ ${ }^{1}$ Departamento de Geografia. Universidade Estadual do Centro-Oeste (Unicentro), Rua Professora Maria Roza \\ Zanon de Almeida, s/n, CEP: 84505-677, Campus de Irati, Irati, PR, Brazil. \\ E-mail: fabiocaian.geografia@gmail.com,joaogeo2013@gmail.com \\ ${ }^{2}$ Departamento de Geografia. Universidade Estadual do Centro-Oeste (Unicentro), Alameda Élio Antonio Dalla \\ Vecchia, nº 838, CEP: 85040-167, Campus Cedeteg, Guarapuava, PR, Brazil. \\ E-mail: thomaz@unicentro.br \\ *Corresponding author. E-mail: vaantoneli@gmail.com
}

\begin{abstract}
The interception of rainwater in annual and perennial agriculture has been the object of several studies in the last decades. However, scant attention has been paid to where this research has taken place and which principal crops have been studied. The objective of this research is to perform a bibliometric analysis of one hundred articles from the last forty years found in the Scopus database to analyze their spatial distribution according to continent and country and quantify the research carried out on annual and perennial crops. Also, the main methods used to investigate the stemflow and throughfall of water in commercial crops are described. Our analysis indicates that the northern hemisphere has the most research on the subject and 35\% of the research took place in Asia. Most of the research into annual crops (56\%) was carried out in maize (Zea mays L.). There has been a significant increase in commercial (annual) agricultural research in the last decade. The stemflow had the most amplitude between the values in the annual crops. This may be related to morphological and ecophysiological changes throughout the plant cycle. For perennial crops, stemflow values were like forests. It has become more important than ever to consider a scenario of global climate change stemflow and throughfall research in agricultural areas, or at least the data need to be revised in the face of new climatic conditions.
\end{abstract}

Keywords: annual crop, bibliometric analysis, interception, perennial crop.

\section{Fluxo de tronco e atravessamento de água em culturas agrícolas: uma síntese}

\section{RESUMO}

O atravessamento da água da chuva em agriculta (temporária e perene), têm se tornado objeto de diversos estudos nas últimas décadas. Entretanto, pouca atenção tem se dado para identificar onde essas pesquisas têm sido desenvolvidas e quais as principais culturas têm sido pesquisadas. O objetivo dessa pesquisa é realizar uma análise bibliométrica de 100 artigos dos últimos 40 anos encontrados na base de dados Scopus para analisar a distribuição espacial dos estudos de acordo com continente e países; quantificar as pesquisas realizadas em culturas temporárias e perenes; descrever os principais métodos utilizados na investigação do stemflow 
e throughfall da água em culturas comerciais. Ao término dessa pesquisa observamos que o hemisfério norte indicou o maior número de pesquisas sobre o tema e $35 \%$ das pesquisas foram desenvolvidas na Ásia. A maior parte das pesquisas em cultura temporária $(56,1 \%)$ foram realizadas no cultivo de milho (Zea mays $L$.). Houve aumento significativo das pesquisas na agricultura comercial (temporária) na última década. O stemflow indicou maior amplitude entre os valores nas culturas temporárias. Esta condição pode estar relacionada a mudança morfológicas e ecofisiológicas ao longo do ciclo da planta. Já nas culturas perene os valores de stemflow foram similares as florestas. Considerando um cenário de mudanças climáticas, os resultados das pesquisas sobre atravessamento e fluxo de tronco em áreas agrícolas tornou-se mais importante do que nunca, ou pelo menos os dados precisam ser revisados diante de novas condições climáticas.

Palavras-chave: análise bibliométrica, atravessamento, cultura anual, cultura perene.

\section{INTRODUCTION}

Vegetation plays a fundamental role in the hydrological dynamics of a given area, being responsible for the first portioning of rainwater (Togashi et al., 2012). When water reaches the vegetation canopy, a part is intercepted and evaporated during and after the rainfall (Fan et al., 2014). The water that crosses the vegetation is redistributed and reaches the ground through interception, which consists of throughfall (dripping from the canopy and free interception) and stemflow (Germer, 2013; Van Stam and Gordon, 2018).

Rainwater interception varies greatly among climatic regions, as it depends on factors such as vegetation characteristics (Herwitz, 1985), meteorological conditions (Andre et al., 2008), rainfall characteristics (Yuan and Gao, 2016), and the three-dimensional geometry of the canopy structure (Bialkowski and Buttle, 2015), among others.

There is a considerable range of research in the literature that focuses on hydrological dynamics in forests with an emphasis on stemflow and throughfall (Germer, 2013, Liang et al., 2011, Zhang et al., 2017). These data are required to calculate water availability in river watersheds (Czikowsky and Fitzjarrald, 2009).

"Stemflow" means all water and solute that reaches the soil through the stem of the plant (Zhao et al., 2020). The volume of water that reaches the soil through the stemflow varies from 5 to $10 \%$ (Levia Jr. and Frost, 2006) and affects only the soil portion located close to the trunk (Brecciaroli et al., 2012). "Throughfall" is the fraction of rain that reaches vegetation soil through the canopy of vegetation, which can occur through free fall (open places in the canopy of the plant) or through the dripping of leaves (Levia Jr. and Frost, 2006; Gasparoto et al., 2014). However, throughfall has received more attention than stemflow because of the scarce hydrological significance of the latter (Tobón Marin et al., 2000).

In spite of the extensive discussion about the influence of vegetation on the stemflow and throughfall in the most diverse forest fragments, little attention has been given to research that evaluates the stemflow and throughfall in different crops in the agricultural landscape.

Understanding the stemflow and throughfall in different crops is an essential tool for several studies: (Frasson and Krajewski, 2011), for instance, soil moisture distribution (Hornbuckle et al., 2008), soil erosion management (Bui and Box, 1992), and irrigation control (Steiner et al., 1983), among others. However, some issues have been neglected, such as the main types of crop used to analyze hydrological dynamics and how each crop responds to the process of rainwater interception.

Therefore, this review aims to inventory the research carried out in stemflow and throughfall of rainwater in agricultural areas. In addition, there is specific focus on: a) the spatial distribution of the studies according to continent and country; b) quantifying the research 
carried out on perennial and annual crops; c) describing the main methods used to investigate stemflow and throughfall in commercial crops; and d) a critical evaluation of the results obtained over forty years of research, in the face of the current challenges of global climate change and research needs as well.

\section{MATERIALS AND METHODS}

To carry out this research, the Scopus database was used to identify research related to the themes of throughfall and stemflow in different types of annual and perennial crops. It is important to note that annual crops are those with a short seasonal cycle, which are replanted every year. Perennial or semi perennial, e.g., sugar cane crops do not require yearly planting and are usually assigned a minimum duration of four years.

The database search field identified articles containing the words " throughfall and stemflow" in the titles, keywords, and abstracts. A bibliometric analysis was carried out with 100 articles (all in English) about the stemflow and throughfall in agriculture. The goal of the study was not to search for all available studies. Instead, research articles from the last forty years were selected.

Only research results referring to stemflow and throughfall in annual and perennial agriculture were included. Therefore, the measurement period (annual or seasonal values), monitoring length and number of events measured were not considered. Moreover, articles that did not measure stemflow and throughfall at the same time were considered. Some articles in annual crops did not measure the stemflow; however they indicated a value below $5 \%$. The articles used in perennial crops were classified into monoculture and agroforestry. The method for obtaining stemflow and throughfall data was separated. Most articles used direct measurement to collect data in the field and other articles used modeling to obtain data. The second case was considered in the present study.

The data were organized based on the frequency of the subjects researched and grouped by type of crops. The articles were classified as: a) perennial crops, such as coffee (Coffea), sugar cane (Saccharum officinarum), cocoa (Theobroma cacao), rubber tree (Hevea brasiliensis), citrus (Citrus X sinensis), apple (Malus domestica), banana (Musa acuminate), palm (Bactris gasipaes), olive (Olea europaea), grapes (Vitis vinifera L.), pomegranate (Punica granatum), clove (Syzygium aromaticum), cassava (Manihot esculenta), cashew (Anacardium occidentale) and nut tree (Bertholletia excels); and, b) annual crops: corn (Zea mays), soybean (Glycine max), wheat (Triticum), potato (Solanum tuberosum), cotton (Gossypium), rapeseed (Brassica napus), brussels sprouts (Brassica oleracea var. gemmifera), millet (Pennisetum glaucum), beet (beta. L), alfalfa (Medicago sativa L.) and sorghum (Sorghum bicolor). All the data collected were spatialized worldwide to understand where the studies had been conducted and which are the most prominent regions.

\section{RESULTS}

\subsection{The spatialization of research on stemflow and throughfall in different crops and its evolution in the last decades}

Studies on the stemflow and throughfall in different crops (annual and perennial) have been frequent in recent decades. However, the vast majority are concentrated in a small number of countries. About $70 \%$ of the surveys were conducted in temperate regions and only $30 \%$ in tropical areas. In temperate regions, research on annual crops predominates, whereas in tropical areas, research on perennial crops is more frequent (Figure 1).

Among the articles analyzed, $43 \%$ refer to the stemflow and throughfall in perennial crops and $57 \%$ in annual crops. Of this total, 35\% are in Asia, 22\% in North America, $18 \%$ in Europe, $14 \%$ in South America, 5\% in Central America, 4\% in Africa and 2\% in Oceania. 


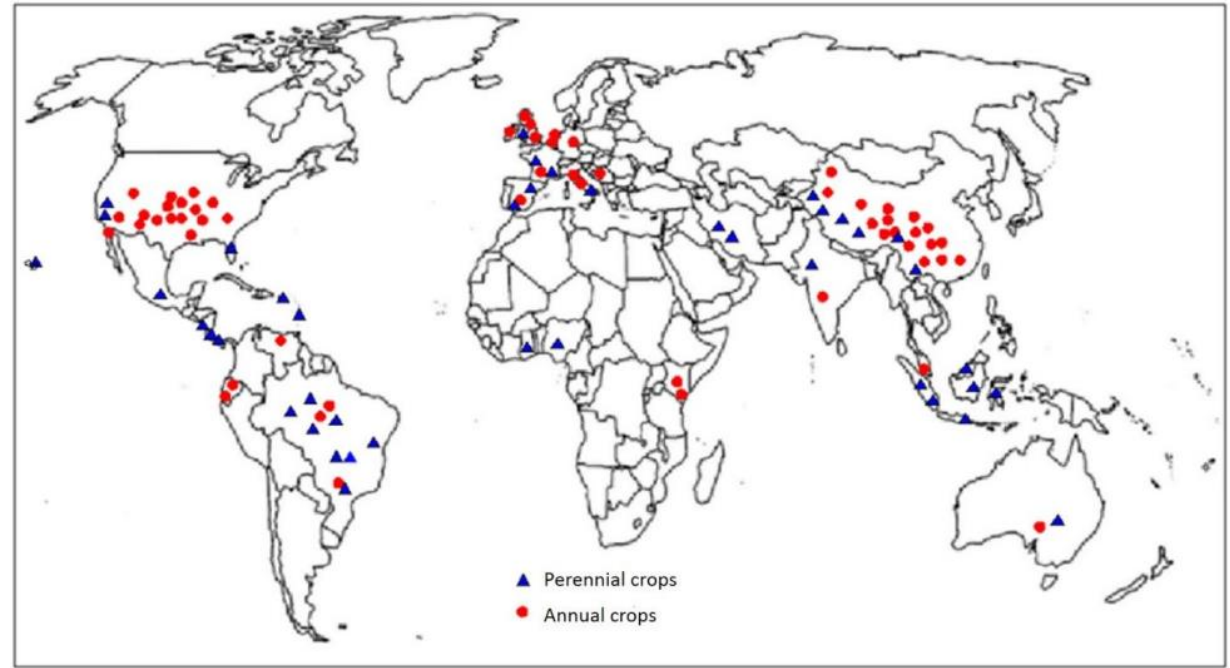

Figure 1. Distribution of research on stemflow and throughfall.

Source: Based on Van Stan and Gordon (2018).

In Asia, $67 \%$ of the research was carried out in China and $17 \%$ in Indonesia. In Europe, there is a wider distribution of studies across countries. Among the 18 papers registered on the continent, $23 \%$ (4 surveys) were conducted in the United Kingdom. Spain, Italy, and France account for $16 \%$ each (three surveys in each country). There were 22 surveys in North America, of which 21 (95\%) were in the United States. In South America, 14 surveys were found; 78\% of these were carried out in Brazil. Central America, Africa, and Oceania had the smallest number of studies (five, four and two, respectively) (Figure 2).

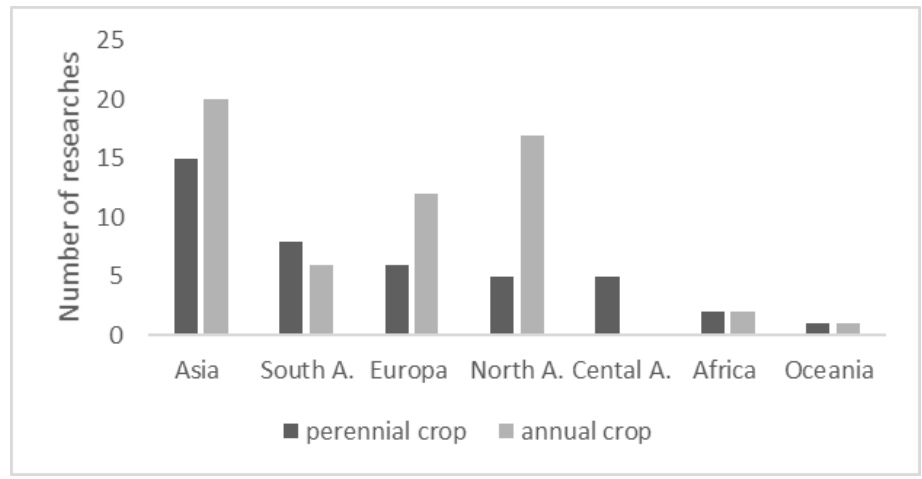

Figure 2. The amount of research into annual and perennial crops in each continent.

Most of the research on stemflow and throughfall in Asia, Europe, and North America involved annual crops (Figure 1). The biggest difference was in North America, where $77 \%$ of the research was carried out on annual crops. In Central America, five studies were identified, which all dealt with perennial crops. Countries such as Indonesia and Brazil had the highest percentage of research into perennial cultivation (100\% and $73 \%$, respectively).

An analysis of the evolution of research on the subject over the last forty years (1979 to 2019) evidences some intensification in the last decade (Table 1), mainly regarding annual crops. Among the studies completed during the analyzed period, $48 \%$ were from the decade of 2010.

Between the decades of 1980 and 2000, research into perennial crops was noteworthy; there were 34 studies in that period. On the other hand, in the same period, only 18 studies on annual crops were found. In the last decade, there was a $150 \%$ increase in research of annual crops, while for perennial crops the increase was $35 \%$. 
Table 1. Distribution of research in stemflow and throughfall in the last decades.

\begin{tabular}{|c|c|c|c|c|c|c|}
\hline \multirow{2}{*}{ Decades } & \multicolumn{2}{|c|}{ Perennial crop } & \multicolumn{2}{|l|}{ Annual crop } & \multirow{2}{*}{ Total studies } & \multirow{2}{*}{$(\%)$} \\
\hline & Number of studies & $(\%)$ & Number of studies & $(\%)$ & & \\
\hline 1980 & 9 & 15.7 & 3 & 7.0 & 12 & 12.0 \\
\hline 1990 & 8 & 14.0 & 5 & 11.6 & 13 & 13.0 \\
\hline 2000 & 17 & 29.8 & 10 & 23.3 & 27 & 27.0 \\
\hline 2010 & 23 & 40.3 & 25 & 58.1 & 48 & 48.0 \\
\hline Total & 57 & 100.0 & 43 & 100.0 & 100 & 100.0 \\
\hline
\end{tabular}

\subsection{Types of crops studied and their stemflow and throughfall rate}

Among all the research observed in annual crops, $56 \%$ was carried out on maize, followed by soybean at $12 \%$, and wheat and potato $7 \%$. Of the total research done on maize, $31 \%$ was developed in China (10 studies) and 28\% (9 studies) in the United States.

When analyzing the research into perennial crops, it is evident that there is a greater diversity of crops without one type predominating, unlike studies of annual crops. Plants such as coffee, rubber, cacao, and citrus had the highest percentages (11\% each).

The diversity of annual and perennial crops and their characteristics affect the stemflow and throughfall rate. The data found in perennial crops are similar to those observed in forests, due to the similarity of some species (Table 2). However, the data on annual crops show variations due to the structure and morphology of each species, mainly concerning the vegetative stage of the plant.

Table 2. Stemflow and throughfall rate in annual and perennial crops.

\begin{tabular}{|c|c|c|c|c|c|}
\hline Annual crops & Number of studies & Stemflow (\%) & Amplitude & Throughfall (\%) & Amplitude \\
\hline Corn & 32 & $11-49$ & 4.5 & $58-82$ & 1.4 \\
\hline Soybean & 7 & $3-23$ & 7.6 & $57-92$ & 1.6 \\
\hline Wheat & 4 & $3-20$ & 6.6 & $70-89$ & 1.3 \\
\hline Potato & 4 & $08-46$ & 2.3 & $54-70$ & 1.3 \\
\hline Cotton & 4 & $5-13$ & 2.6 & $62-81$ & 1.3 \\
\hline Rapeseed & 2 & $3-19$ & 6.3 & $40-65$ & 1.6 \\
\hline Brussels Sprout & 1 & $0.8-6$ & 7.5 & $71-98$ & 1.2 \\
\hline Millet & 1 & $10-19$ & 1.9 & $70-82$ & 1.1 \\
\hline Beet & 1 & $18-40$ & 2.2 & $56-70$ & 1.2 \\
\hline Alfalfa sprouts & 1 & $12-22$ & 1.8 & $65-80$ & 1.2 \\
\hline Sorghum & 1 & $5-19$ & 3.8 & $62-75$ & 1.2 \\
\hline Perennial crop: & Number of studies & Stemflow (\%) & Amplitude & Throughfall (\%) & Amplitude \\
\hline Coffee* & 5 & $1-14$ & 14 & $50-90$ & 1.8 \\
\hline Rubber tree* & 5 & $1.1-9.2$ & 8.4 & $64-85$ & 1.3 \\
\hline Citrus & 5 & $0.5-4.7$ & 9.4 & $82-92$ & 1.1 \\
\hline Cocoa* & 5 & $0.2-9.1$ & 45 & $76-90$ & 1.2 \\
\hline Palm * & 5 & $5-16$ & 3.2 & $70-83$ & 1.1 \\
\hline Banana & 4 & $6-26$ & 1.4 & $61-74$ & 1.2 \\
\hline Apple & 3 & $0.8-10$ & 12.5 & $50-84$ & 1.7 \\
\hline Olive & 3 & $1.5-24$ & 16 & $56-70$ & 1.2 \\
\hline Sugar cane & 2 & $19-25$ & 1.3 & $31-58$ & 1.9 \\
\hline Grapes & 1 & $2-6$ & 3.0 & $65-85$ & 1.1 \\
\hline Pomegranate & 1 & $3-10$ & 3.3 & $71-80$ & 1.1 \\
\hline Clove & 1 & $0.9-5$ & 5.5 & $63-87$ & 1.3 \\
\hline Cassava & 1 & $0.5-4$ & 8.0 & $79-92$ & 1.1 \\
\hline Cashew & 1 & $1-3$ & 3.0 & $65-80$ & 1.2 \\
\hline Nut tree* & 1 & $1-5$ & 1.3 & $72-89$ & 1.2 \\
\hline
\end{tabular}

Note $^{1}$ : The rates indicated refer to the means extracted from the articles analyzed.

* Some studies used in this type of crop were carried out in agroforestry (see text below). 
The highest stemflow in annual crops were observed in soybean and wheat, with an amplitude of 6.6 and 7.6 respectively. However, potato and maize crops had the highest stemflow rates $(20-46 \%$ and $11-49 \%)$. Of the perennial crops, cocoa had the greatest amplitude (45), while banana and sugarcane cultivation indicated the highest stemflow values. The amplitude of the throughfall between the annual and perennial crops was similar. However, soybean had the highest variation among the annual crops (57-92\%). Coffee and sugar cane had the highest amplitudes (19 and 18 respectively). However, the highest throughfall values were observed in citrus crops (82-92\%).

Some types of perennial crops used in this research were developed in monoculture or agroforestry. Among the 43 studies on perennial cultivation used in this work, 10 (23.2\%) were carried out in agroforestry ( 2 studies on coffee crops, 2 on palms, 2 on rubber, 3 on cocoa and 1 on Nut trees).

\subsection{Stemflow and throughfall methods and models for data collection.}

Different approaches have been used to collect stemflow and throughfall data in agriculture, including modeling (Levia Jr. and Frost, 2003), and using simple or even automated equipment (Dunkerley, 2014). The characteristics of each crop, both annual and perennial, allowed these methods to be adapted in various ways. We emphasize that the measurement of throughfall and stemflow in different crops is a critical phase in understanding water availability in the soil, since an error in data collection may over- or sub-estimate the results.

A predominance of the spiral collector method $(65 \%)$ for measuring stemflow data from perennial and annual crops was noticed. The funnel method involving the non-spiral stem was used in $10 \%$ of the studies (Figure 3). It should be taken into consideration that this method was used in stems with a diameter $\leq 15 \mathrm{~cm}$, like sugarcane and coffee. Although modeling is not a primary method of data collection, $25 \%$ of selected articles used equations and models to estimate hydrological processes. It is important to note that some perennial crops species resemble native forests. In this case, some studies estimate stemflow to be less than $5 \%$ of the precipitation (Levia Jr. and Frost, 2003).

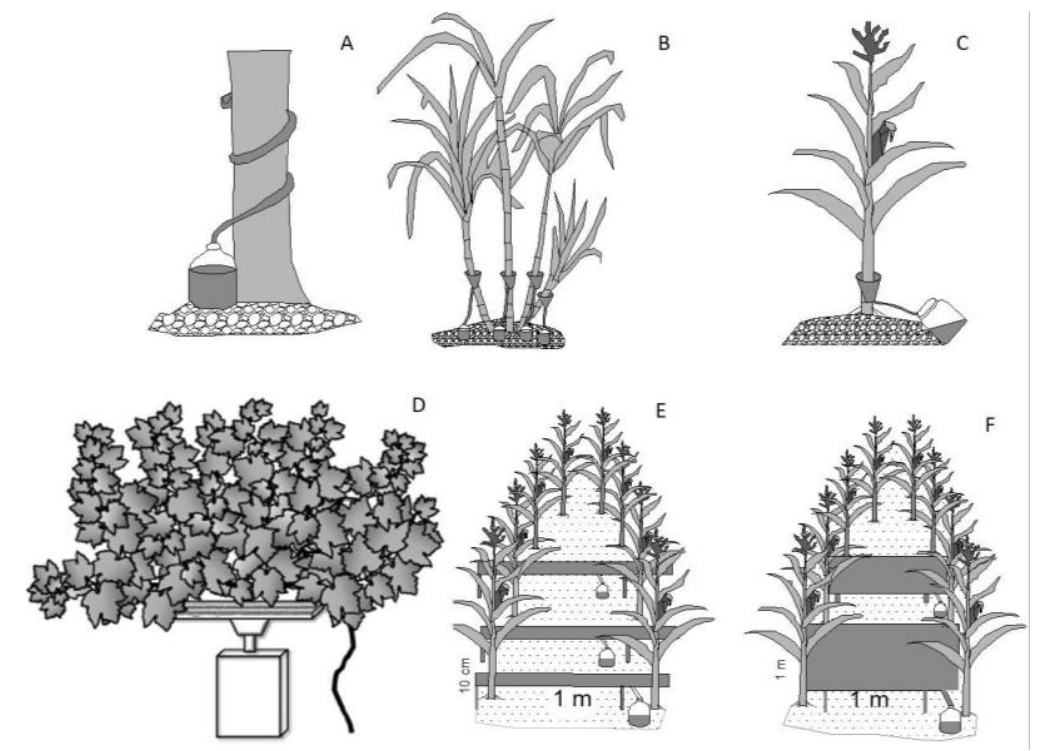

Figure 3. Different methods of stemflow and throughfall collection in perennial and annual crops.

Note: A and B) stemflow collector in perennial crops; C) stemflow collector in annual crops; D) throughfall collector in perennial crop; $\mathrm{E}$ and $\mathrm{F})$ throughfall collector in annual crops (E = 10x100 cm collectors; F) $100 \times 100 \mathrm{~cm}$ collectors). 
To measure throughfall, $70 \%$ of the research used funnel-type collectors, $20 \%$ used collecting gutters of different shapes and sizes, and $10 \%$ used equations and models, including the Rutter model (Rutter et al., 1971) and the Gash model (Gash, 1979). It is noteworthy that $86 \%$ of the surveys of perennial crops used natural rainfall, and only $14 \%$ used simulated rain. The simulation allows greater control of variables such as the intensity and duration of rainfall (Sousa Jr. et al., 2017), according to the objective of the study.

In annual crops, $53 \%$ of the studies were carried out with simulated rainfall, both in the field and in the laboratory, and $47 \%$ with natural rainfall. To measure the stemflow, $84 \%$ of the research used the funnel method on the plant stem, and 16\% used modeling.

\section{DISCUSSION}

The results of this inventory show that research on the stemflow and throughfall in agricultural areas is concentrated in the Northern Hemisphere. This trend may be due to commercial agriculture in this region having a longer history than other continents. Moreover, the tradition of scientific research and the production of physical-mathematical models for soil and water management in agricultural systems requires primary data. Despite the Brazilian agricultural expansion into different ecosystems, research on stemflow and throughfall is still incipient, especially in commercial crops. We believe that the reasons for this are varied: a focus on soil management to increase productivity; the belief that the no-tillage system serves a conservationist agriculture; the physical-mathematical models imported from other regions of the world are calibrated / applied without the need to produce primary data. Finally, agricultural research thinking on soil conservation is grounded in the Universal Soil Loss Equation, where the factor of vegetation cover is widespread and can, therefore, influence research on this subject (Barreto et al., 2009), among other possibilities. Therefore, there is an enormous deficit of studies in hydrological processes, particularly stemflow and throughfall, in the Brazilian territory.

Annual crops were the most researched in the last decade, as the extension of annual crops such as soybean, corn, and wheat, among others, is higher compared to perennial crops. This increase in research can be attributed to the growth in global demand for food in recent decades (FAO, 2019). Besides, its short cycle and the morphological and ecophysiological changes throughout its development implies variations in stemflow and throughfall according to the phases (Levia and Germer, 2015). Consequently, studies are intensified to represent stemflow and throughfall appropriately at each stage. Furthermore, for example, to monitor and model contaminant transfer processes in agricultural areas, the development phase of the crop is critical. On the other hand, in many cases, perennial crops have less morphological and ecophysiological changes when they reach maturity (e.g. coffee, rubber trees, olive trees, citrus trees, others). Perennial crops were the most studied in the past, and this should have been enough to provide reliable information for soil and water management, especially the throughfall. However, it is possible to verify the absence of studies in some agroforestry systems, e.g., yerba mate (Illex paraguariensis).

Despite the reasonable number of studies of both types of cultivation carried out worldwide, the variability in the hydrological processes measured is enormous (see Table 2). This variation is more considerable for stemflow than throughfall. Indeed, stemflow is significant in both annual and perennial crops. The hydrological processes in agricultural areas by this process should not be neglected. Therefore, soil and water conservation modeling, as well as studies of the transfer of contaminants in agricultural watersheds, may face difficulties because the data in the literature on this process is variable. Therefore, stemflow studies in different ecosystems, climates and agricultural crops are necessary.

Conversely, data on throughfall is more stable; that is, it shows less variability. It is interesting to note that the average minimum throughfall, $60 \%$ and $63 \%$, and the maximum, 
$80 \%$ and $82 \%$, are equivalent for annual and perennial crops, respectively. So, in hydrological terms, it is a mistake to think that a cotton or soybean plant, for example, intercepts less rain than orange or rubber trees.

Methods to measure stemflow and throughfall are not particularly varied or sophisticated, facilitating the standardization of measurement methods. In annual crops, it is more difficult to measure the stemflow, especially in species where the stem is not ligneous, such as: alfalfa sprouts, wheat, sorghum, beet, among others. However, there is extensive variation in this process. Annual crops are flexible in the use of rainfall simulators to measure stemflow and throughfall. The use of simulators means annual crops can be measured throughout their cycle, and it is possible to evaluate the effects of morphological and ecophysiological changes on hydrological processes. Meanwhile, perennial crops, especially the larger ones (i.e., height and canopy projection), are more dependent on natural rainfall measurements. Therefore, the methods are adjusted to the morphological and ecophysiological characteristics of the crops being evaluated.

Over the course of forty years of stemflow and throughfall studies, we observed several objectives, including understanding the hydrological process (Levia Jr. and Frost, 2003; Dugas, 1990); soil erosion (Zheng et al., 2019; Antoneli et al., 2018), soil water balance (Canone et al., 2017), the transfer of contaminants (Ranalli and Macalady, 2010), and others. However, in a scenario of global climate change (Pachauri et al., 2014), stemflow and throughfall research in agricultural areas has become more important than ever, or at least the data needs to be revised in the face of new climatic conditions. It is necessary to understand how crops, pastures, and agroforestry will respond hydrologically to climate change and how that will affect the water, nutrient and contaminant circulation in soils, hillslopes and watersheds.

Over the Brazilian territory, climate change may be different. For example, in southern Brazil, rainfall is expected to increase (PBMC, 2013), while in the Amazon region droughts may be prevalent (Marengo and Espinoza, 2016; Malhi et al., 2008). The Brazilian Panel on Climate Change (PBMC, 2013), estimates that the Brazilian territory may have: a) altered temperature and rain patterns; b) changes in annual rainfall patterns; c) increased plant growth and evapotranspiration; and d) increases in water deficit (droughts). Consequently, the migration of crops between edaphoclimatic zones may occur. Changes in climate allied to changes in land use, especially agricultural intensification, can affect hydrological processes, water quality and quantity, and ecosystem services in watersheds (Foley et al., 2005). Therefore, given these scenarios, studies on stemflow and throughfall in Brazilian agricultural landscape are needed, above all, with a perspective that goes beyond the simple vision of soil and water management.

\section{CONCLUSION}

Temperate regions indicated a higher number of studies (70\%), with a predominance of studies on annual crops. Only $30 \%$ of the studies were carried out in tropical regions, with a predominance on perennial crops. The USA and China carried out the largest number of studies on annual crops. This trend may be due to commercial agriculture and a greater incentive in researching primary data to develop equations and models.

The stemflow shows the greatest variation compared to throughfall. This hydrological process in agricultural areas cannot be neglected, especially when using modeling to quantify the variables that interfere with hydrological processes in watersheds.

Most of the research on throughfall and stemflow in annual crops were carried out through rain simulation. In perennial crops, data were collected with natural rain.

In annual crops, it is necessary to make several measurements along the cultivation cycle, as each plant phase can respond differently to hydrological processes. 


\section{REFERENCES}

ANDRE, F.; JONARD, M.; PONETTE, Q. Influence of species and rain event characteristics on stemflow volume in a temperate mixed oak-beech stand. Hydrological. Process, $n$. 22, p. 4455-4466, 2008. https://doi.org/10.1002/hyp.7048

ANTONELI, V. LENATORVICZ, H.H.; BEDNARZ, J.A.; PULIDO-FERNÁNDEZ, M.; BREVIK, E.C.; CERDÀ, A.; RODRIGO-COMINO, J. Rainfall and land management effects on erosion and soil properties in traditional Brazilian tobacco plantations. Hydrological Sciences Journal, v. 63, n. 7, p. 1008-1019, 2018. https://doi.org/10.1080/02626667.2018.1472379

BARRETTO, A. G. D. O. P.; LINO, J. S.; SPAROVEK, G. Bibliometrics of Brazilian research on accelerated soil erosion: institutions, themes, space and chronology. Revista Brasileira de Ciência do Solo, v. 33, n. 6, p. 1845-1854, 2009. http://dx.doi.org/10.1590/S0100-06832009000600033

BIALKOWSKI, R.; BUTTLE, J. M. Stemflow and throughfall contributions to soil water recharge under trees with differing branch architectures. Hydrological. Process, v. 29, p. 4068-4082, 2015. https://doi.org/10.1002/hyp.10463

BRECCIAROLI, G. S.; COCCO, A.; AGNELLI, F.; COURCHESNE, G.; CORTI. From rainfall to throughfall in a maritime vineyard. Science of the Total Environment, v. 438, p. 174-188, 2012. https://doi.org/10.1016/j.scitotenv.2012.08.044

BUI, E. N.; BOX, J. R. Stemflow, rain throughfall and erosion under canopies of corn and sorghum. Soil Science Society of America Journal, v. 56, p. 242-247, 1992. https://doi.org/10.2136/sssaj1992.03615995005600010037x

CANONE, D.; PREVIATI, M.; FERRARIS, S. Evaluation of stemflow effects on the spatial distribution of soil moisture using TDR monitoring and an infiltration model. Journal of $\begin{array}{llllll}\text { Irrigation and Drainage Engineering, v.143, n. } & 2017 .\end{array}$ https://doi.org/10.1061/(ASCE)IR.1943-4774.0001120

CZIKOWSKY, M. J.; FITZJARRALD, D. R. Detecting rainfall interception in an Amazonian rain forest with eddy flux measurements. Journal of Hydrology, n. 377, p. 92-105, 2009. https://doi.org/10.1016/j.jhydrol.2009.08.002

DUGAS, W. M. Comparative measurement of stem flow and transpiration in cotton. Theoretical and Applied Climatology, n. 42, v. 4, p. 215-221, 1990. https://doi.org/10.1007/BF00865981

DUNKERLEY, D. Stemflow production and intra storm rainfall intensity variation: an experimental analysis using laboratory rainfall simulation. Earth Surface Processes and Landforms, v. 39, n. 13, p. 1741-1752, 2014. https://doi.org/10.1002/esp.3555

FAN, J. L.; OESTERGAARD, K. T.; GUYOT, A.; LOCKINGTON, D. A. Measuring and modeling rainfall interception losses by a native Banksia woodland and an exotic pine plantation in subtropical coastal Australia. Journal of Hydrology, v. 515, p. 156-165, 2014. https://doi.org/10.1016/j.jhydrol.2014.04.066

FAO. Website. Available at: http://www.fao.org/home/en/. Access: 08 Oct. 2019.

FOLEY, J. A.; DEFRIES, R.; ASNER, G. P.; BARFORD, C.; BONAN, G.; CARPENTER, S. R.; CHAPIN, F. S.; COE, M. T.; DAILY, G. C.; GIBBS, H. K. Global consequences of land use. Science, v. 309, p. 570-574, 2005. https://dx.doi.org/10.1126/science.1111772 
FRASSON, R. P de M.; KRAJEWSKI, W. F. Characterization of the drop-size distribution and velocity-diameter relation of the throughfall under the maize canopy. Agricultural and Forest Meteorology, v. 151, n. 9, p. 1244-1251, 2011. https://doi.org/10.1016/j.agrformet.2011.05.001

GASH, J. An analytical model of rainfall interception by forest. Quarterly Journal of the $\begin{array}{lllllll}\text { Royal Meteorological Society, } & \text { v. } 1979 .\end{array}$ https://doi.org/10.1002/qj.49710544304

GASPAROTO, E. A. G.; TONEllo, K. C.; ShInZATO, E. T.; VAlEnTE, R. D. A. Throughfall in different forest stands of Iperó, São Paulo. CERNE, v. 20, n. 2, p.303309, 2014. http://dx.doi.org/10.1590/01047760.201420021260

GERMER, S. Development of near-surface perched water tables during natural and artificial stemflow generation by babassu palms. Journal of Hydrology, v. 507, p. 262-272, 2013. https://doi.org/10.1016/j.jhydrol.2013.10.026

HERWITZ, S. R. Interception storage capacities of tropical rainforest canopy trees. Journal of Hydrology, v.77, p. 237-25, 1985. https://doi.org/10.1016/0022-1694(85)90209-4

HORNBUCKLE, J. W.; GOODWIN, I.; CHRISTEN, E. W.; ZANDONA, R. Development of a real time spatial assessment tool for grapevine canopy vigour and water stress. Acta $\begin{array}{llllll}\text { Horticulturae, } & \text { v. } & 792, & \text { p. } & 355-361 . & 2008 .\end{array}$ https://doi.org/10.17660/ActaHortic.2008.792.41

LEVIA JR., D. F.; FROST, E. E. Variability of throughfall volume and solute inputs in wooded ecosystems. Progress in Physical Geography: Earth and Environment, v. 30, p. 605632, 2006. https://doi.org/10.1177\%2F0309133306071145

LEVIA JR., D. F.; FROST, E. E. A review and evaluation of stemflow literature in the hydrologic and biogeochemical cycles of forested and agricultural ecosystems. Journal of Hydrology, v. 274, p.1-29, 2003. https://doi.org/10.1016/S0022-1694(02)00399-2

LEVIA, D. F.; GERMER, S. A review of stemflow generation dynamics and stemflowenvironment interactions in forests and shrublands. Reviews of Geophysics, v. 53, p. 673-714, 2015. https://doi.org/10.1002/2015RG000479

LIANG, W. L.; KOSUGI, K.; MIZUYAMA, T. Soil water dynamics around a tree on a hillslope with or without rainwater supplied by stemflow. Water Resources Research, v. 47, p. 1-16, 2011. https://doi.org/10.1029/2010WR009856

MALHI, Y.; ROBERTS, J. T.; BETTS, R. A.; KILLEEN, T. J.; LI, W.; NOBRE, C. A. Climate change, deforestation, and the fate of the Amazon. Science, v. 319, p. 169-172, 2008. https://dx.doi.org/10.1126/science.1146961

MARENGO, J. A.; ESPINOZA, J. C. Extreme seasonal droughts and floods in Amazonia: causes, trends and impacts. International Journal of Climatology, v. 36, p.1033-1050, 2016. https://doi.org/10.1002/joc. 4420

PACHAURI, R. K.; ALLEN, M. R.; BARROS, V. R.; BROOME, J.; CRAMER, W.; CHRIST, R.; CHURCH, J. A.; CLARKE, L.; DAHE, Q.; DASGUPTA, P. Climate change 2014: synthesis report. Contribution of Working Groups I, II and III to the fifth assessment report of the Intergovernmental Panel on Climate Change, Ipcc. Geneva, 2014. 
PBMC. First National Assessment Report of the Brazilian Panel on Climate Change. Impacts, Vulnerabilities and Adaptation. Executive Summary of GT2. Rio de Janeiro, 2013.

RANALLI, A. J.; MACALADY, D. L. The importance of the riparian zone and in-stream processes in nitrate attenuation in undisturbed and agricultural watersheds - A review of the scientific literature. Journal of Hydrology, v. 389, n. 3-4, p. 406-415, 2010. https://doi.org/10.1016/j.jhydrol.2010.05.045

RUTTER, A.; KERSHAW, K.; ROBINS, P.; MORTON, A. A predictive model of rainfall interception in forest. I. Derivation of the model from observation in a plantation of Corsican pine. Agricultural Meteorology, v. 9, p. 367-384, 1971. https://doi.org/10.1016/0002-1571(71)90034-3

SOUSA JR., S. F de.; MENDES, T. A.; SIQUEIRA, E. Q de. Development and calibration of a rainfall simulator for hydrological studies. RBRH, v. 22, p. 45 -59, 2017. https://doi.org/10.1590/2318-0331.0217170015

STEINER, J. L.; KANEMASU, E. T.; CLARK, R. N. Spray losses and partitioning of water under a center pivot sprinkler system. Transactions of the ASAE, v. 26, n. 4, p. 11281134, 1983.

TOBÓN MARIN, C.; BOUTEN, W.; SEVINK. J. Gross rainfall and its partitioning into throughfall, stemflow and evaporation of intercepted water in four forest ecosystems in western Amazonia. Journal of Hydrology, v. 23, n. 7, p. 40-57, 2000. https://doi.org/10.1016/S0022-1694(00)00301-2

TOGASHI, H. F.; MONTEZUMA, R. de C. M.; LEITE, A. F. Gross rainfall and throughfall in three secondary succession gradients of atlantic rain forest on Pedra Branca massif, Rio de Janeiro. Revista Árvore, v. 36, n. 5, p. 907-918, 2012. https://doi.org/10.1590/S010067622012000500013

VAN STAN, J. T.; GORDON, D. A. Mini-Review: Stemflow as a Resource Limitation to NearStem Soils. Frontiers in Plant Science, v. 9, p. 1-7, 2018. https://doi.org/10.3389/fpls.2018.00248

YUAN, C.; GAO, G.; FU, B. Stemflow of a xerophytic shrub (Salix psammophila) in northern China: Implication for beneficial branch architecture to produce stemflow. Journal of Hydrology, v. 539, p. 577-588, 2016. https://doi.org/10.1016/j.jhydrol.2016.05.055

ZHANG, Y. F.; WANG, X. P.; PAN, R.; YAN-XIA, H. Stemflow volume per unit rainfall as a good variable to determine the relationship between stemflow amount and morphological metrics of shrubs. Journal of Arid Environments, v.141, p.1-6, 2017. https://doi.org/10.1016/j.jaridenv.2017.02.002

ZHAO, L.; FANG, Q.; TANG, Y.; YANG, H.; YANG, T.; ZHENG, H. Stemflow contributions to soil erosion around the stem base under simulated maize-planted and rainfall conditions Agricultural and Forest Meteorology, v. 281, n. 107814, 2020. https://doi.org/10.1016/j.agrformet.2019.107814

ZHENG, J.; JUNLIANG, F.; ZHANG, F.; YANA, S.; WUA, Y.; J LUA, J.; GUO, J.; CHENG, M.; PEIC, Y. Throughfall and stemflow heterogeneity under the maize canopy and its effect on soil water distribution at the row scale. Science of the Total Environment, v. 660, p.1367-1382. 2019. https://doi.org/10.1016/j.scitotenv.2019.01.104 


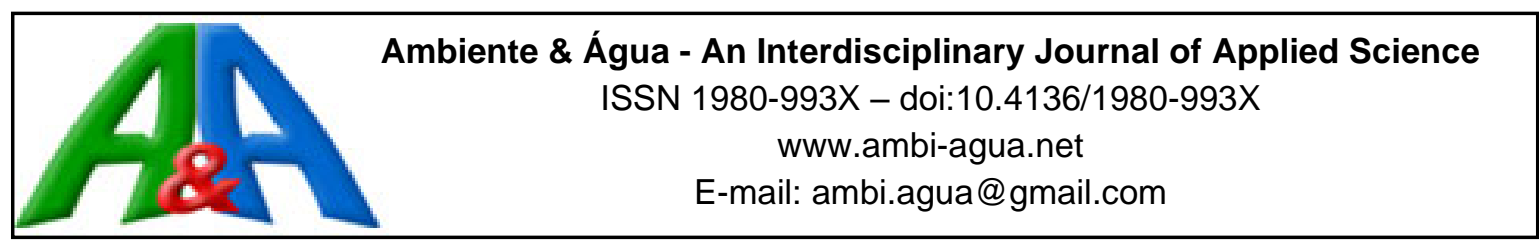

\title{
Cell damage in Danio rerio erythrocytes subjected to anthropized water
}

\author{
ARTICLES doi:10.4136/ambi-agua.2577
}

Received: 27 May 2020; Accepted: 03 Nov. 2020

\author{
Manoel Francisco Mendes Lassen ${ }^{1}$; Jefferson Frohlich² ${ }^{2}$; \\ Rodrigo Patera Barcelos ${ }^{3}$; Roberta Daniele Klein ${ }^{1}$; \\ Fernando Henrique Borba ${ }^{1 D}$; Suzymeire Baroni ${ }^{1 * i D}$
}

\begin{abstract}
${ }^{1}$ Programa de Pós-Graduação em Ambiente e Tecnologias Sustentáveis (PPGATS). Universidade Federal da Fronteira Sul (UFFS), Rua Major Antônio Cardoso, n 590, CEP: 97900-000, Cerro Largo, RS, Brazil. E-mail: manoellassen@gmail.com,roberta.klein@uffs.edu.br, fernando.borba@uffs.edu.br ${ }^{2}$ Departamento de Ciências Biológicas. Universidade Federal da Fronteira Sul (UFFS), Rua Major Antônio Cardoso, n 590, CEP: 97900-000, Cerro Largo, RS, Brazil. E-mail: frohlichjeffer@gmail.com ${ }^{3}$ Programa de Pós-Graduação em Biologia Comparada. Universidade Estadual de Maringá (UEM), Avenida Colombo, nº 5790, CEP: 87020-900, Maringá, PR, Brazil. E-mail: rodrigo.barcelos@uffs.edu.br

*Corresponding author. E-mail: suzymeire.baroni@uffs.edu.br
\end{abstract}

\begin{abstract}
Several factors can lead to alterations of water quality in aquatic environments, leading to numerous consequences for the organisms that inhabit it. The water bodies located in the northwest region of Rio Grande do Sul periodically receive pollutants that may have genotoxic, cytotoxic and mutagenic properties, which affect the genetic integrity of organisms living there. This research analyzed the cytological responses of Danio rerio exposed to anthropized fresh water from the Ijuí River by the micronucleus method as well as by observing nuclear abnormalities in their erythrocytes. The data collected demonstrated higher values of erythrocytes with NA than with $\mathrm{MN}$, suggesting that the cells are efficient in the repair mechanisms required when facing genotoxic substances.
\end{abstract}

Keywords: cytological responses, micronuclei, nuclear abnormalities.

\section{Danos celulares em eritrócitos Danio rerio submetidos à água antropizada}

\section{RESUMO}

Vários fatores podem levar a alterações da qualidade da água em ambientes aquáticos, levando a inúmeras consequências para os organismos que os habitam. Os corpos d'água localizados na região noroeste do Rio Grande do Sul recebem periodicamente poluentes que podem conter propriedades genotóxicas, citotóxicas e mutagênicas, que afetam a integridade genética dos organismos que ali vivem. Esta pesquisa teve como objetivo analisar as respostas citológicas de Danio rerio exposto à água doce antropizada do rio Ijuí pelo método do micronúcleo, bem como pela observação de anormalidades nucleares em seus eritrócitos. Os dados coletados demonstraram valores maiores de eritrócitos com NA do que com $\mathrm{MN}$, sugerindo que as células são eficientes nos mecanismos de reparo necessários ao enfrentamento de substâncias genotóxicas.

Palavras-chave: anormalidades nucleares, micronúcleos, respostas citológicas.

This is an Open Access article distributed under the terms of the Creative Commons Attribution License, which permits unrestricted use, distribution, and reproduction in any medium, provided the original work is properly cited. 


\section{INTRODUCTION}

The demographic census performed by the Brazilian Institute of Geography and Statistics (IBGE) indicates that the Brazilian population increased by approximately 20 times more in 2011 than in the year 1872. In the face of uncontrolled population growth, higher harvest rates are essential for meeting food demand.

Higher harvest rates are obtained through various methods, with the abusive use of pesticides being one of the most debated in the current decade. Use of pesticides in agriculture results in increased pesticide residues in food for human and animal consumption. These pesticides are a mixture of several compounds that consist of active substances which undergo biodegradation in soil and water (Czaja et al., 2020). Together with rain, the resulting substances can return to the soil, groundwater and surface water, where they undergo more transformations. These transformations continue in farm animals that are processed into food for human consumption.

Due to leaching, creeks and rivers located near large crop areas are one of the main destinations for pesticides, especially during rainy periods. According to Spadotto et al. (2004), leaching of pesticides tends to contaminate surface water and, in some cases, also groundwater. Therefore, these water resources are characterized as the final destination for some pesticides, which leads to contamination of springs (Kasper et al., 2018; Ramos et al., 2020).

Fish are commonly used organisms for biosensors in aquatic ecosystems, through the use of micronucleus (MN) analysis and nuclear abnormalities (NA) in their peripheral erythrocytes. The MN test is recognized as one of the preferred methods for assessing genetic damage in organisms, as it allows the detection of alterations caused by both clastogenic agents, responsible for chromosomal breakage, and aneugenic agents, which induce aneuploidy or chromosomal segregation abnormalities (Dalzochio et al., 2016; 2019; Ansari et al., 2011; Dearfield et al., 2002).

Danio rerio is a test organism popularly known as the zebrafish; it is a freshwater teleost, from the Cyprinidae Family, which reaches about three to four centimeters long as an adult. Danio rerio has attracted the attention of the scientific community as its management, breeding, reproduction, resistance and genetics are good parameters for use as a model organism (Barbazuk et al., 2000).

Danio rerio has been used as a model to test the action of pesticides in terms of genotoxicity, and these results have been extrapolated to the human genome (Hawkey et al., 2020). Thus, this study analyzed genotoxic data from Danio rerio placed in water samples from the referred anthropized points on the Ijui River (RS).

\section{MATERIAL AND METHODS}

\subsection{Period and sampling points}

Initially, four points on the Ijuí River were chosen for the collection of water to be used in the tests with Danio rerio.

The Ijuí River is located in the northwest region of Rio Grande do Sul State, between the coordinates $28^{\circ} 00^{\prime} \mathrm{S}$ to $29^{\circ} 05^{\prime} \mathrm{S}$ and $53^{\circ} 11^{\prime} \mathrm{W}$ to $55^{\circ} 21^{\prime} \mathrm{W}$ (Rio Grande do Sul, 2020), and begins with the confluence of the rivers Palmeira, Caxambu and Fiúza, near the municipality of Panambi (RS). It is the main river of the Ijuí Basin, which has an area of $10,703.78 \mathrm{~km}^{2}$ and is composed of 36 municipalities with various economic activities, including the presence of industries as well as extensive agricultural areas with high grain productivity. The basin consists of 12 more rivers that cut through cities and agricultural areas until they flow directly into the Ijuí River (Figure 1 and Table 1).

Rev. Ambient. Água vol. 16 n. 1, e2577 - Taubaté 2021 


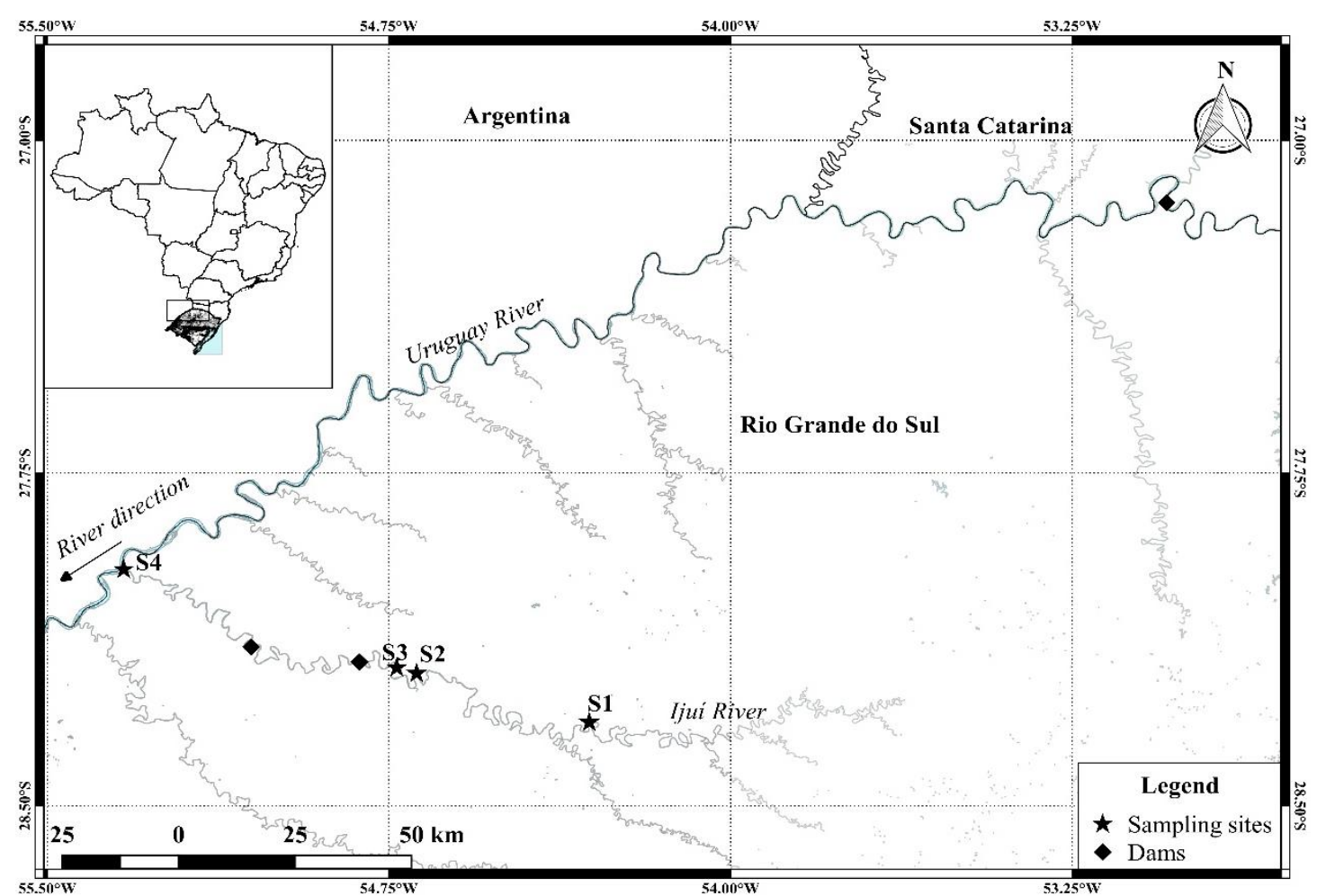

Figure 1. Location of the sampling points.

Source: Own construction, 2019.

Table 1. Coordinates of the water collection points on the Ijuí River with characteristics of their surrounding environments.

\begin{tabular}{|c|c|c|}
\hline Point (P) & Coordinates & Location Characteristics \\
\hline $\mathrm{P} 1$ & $\begin{array}{l}28^{\circ} 18^{\prime} 50.74^{\prime \prime} \mathrm{S} \\
54^{\circ} 18^{\prime} 38.39^{\prime \prime} \mathrm{W}\end{array}$ & $\begin{array}{l}\text { Absence of riparian forest and the reception of industrial and urban } \\
\text { effluents. }\end{array}$ \\
\hline $\mathrm{P} 2$ & $\begin{array}{l}28^{\circ} 11^{\prime} 53.20^{\prime \prime} \mathrm{S} \\
54^{\circ} 41^{\prime} 25.47^{\prime \prime} \mathrm{W}\end{array}$ & $\begin{array}{l}\text { Absence of riparian forest, close to swine and livestock areas in addition to } \\
\text { extensive agricultural areas upstream. }\end{array}$ \\
\hline $\mathrm{P} 3$ & $\begin{array}{l}28^{\circ} 11^{\prime} 19.26^{\prime \prime} \mathrm{S} \\
54^{\circ} 43^{\prime} 58.56^{\prime \prime} \mathrm{W}\end{array}$ & $\begin{array}{l}\text { Absence of riparian forest, with swine, livestock and agriculture areas. This } \\
\text { point is located at the São José Hydroelectric Dam - Ijuí Energia S.A,and is } \\
\text { therefore characterized as a lentic ecosystem. }\end{array}$ \\
\hline $\mathrm{P} 4$ & $\begin{array}{l}27^{\circ} 58 ' 0.62^{\prime \prime} \mathrm{S} \\
55^{\circ} 19^{\prime} 57.82^{\prime \prime} \mathrm{W}\end{array}$ & $\begin{array}{l}\text { Absence of riparian forest and with great livestock activity. This point is } \\
\text { located at the mouth of the Ijuí River, which flows into the Uruguay River. }\end{array}$ \\
\hline
\end{tabular}

Sampling was carried out in a dry period. Danio rerio used in this research were obtained from a local aquarium at Cerro Largo, ten fish were used per test totaling 40 individuals. The fish were acclimatized for one week in aquariums with a capacity of 20 liters, 10 specimens per aquarium, in the Laboratory of Genetics and Molecular Biology of UFFS - Cerro Largo - RS. Following the acclimatization period, the $D$. rerio specimens were placed in the water collected from the four different points on the Ijuí River for $96 \mathrm{hrs}$. The fish were fed ad libitum under controlled temperature and Biochemical Oxygen Demand (BOD) conditions, as recommended by CONCEA Normative Resolution 34.

\subsection{Preparation of the blood films}

Following the $96 \mathrm{hr}$ period, the fish were sedated and euthanized according to the method approved by CEUA / n 589216051 through Eugenol. Blood was collected by puncture in the 
caudal artery using glass capillaries with EDTA (Ethylene Diaminetetraacetic Acid) for the preparation of blood smears. One slide was made per individual totaling ten slides per collection. The blood smear slides were dried at room temperature, fixed in methanol $(100 \%)$ for 20 minutes and stored for later staining.

\subsection{Staining of the blood films}

The methodology of MN slide confection followed Feulgen's protocol with Schiff staining and Fast-Green counterstaining.

The procedure comprised the following steps: (i) hydrolysis in $\mathrm{HCl}(5 \mathrm{~N})$ for five minutes; (ii) wash with distilled water; (iii) staining with Schiff reactive for two hours in the absence of light; (iv) wash with distilled water; (v) counterstaining with Fast-Green; (vi) wash with distilled water and (vii) drying.

\subsection{Erythrocyte count and observational analysis}

The observation and analysis of the slides were performed using an Olympus Optical Microscope with oil immersion lens (1000x maximum magnification). Three thousand cells per fish were counted and the presence of MN and NA were verified (Figure 1). The NA was classified into five groups according to the method of Carrasco et al. (1990) and Bebbled, Lobed, Notched, Vacuolated and Karyorrhexis by Ramirez (2000).

\subsection{Statistical Analysis}

The Kruskal-Wallis test for nonparametric data was chosen for analysis of the results, with a significance level of $5 \%(\mathrm{p}<0.05)$.

\section{RESULTS AND DISCUSSION}

No deaths or abnormal behaviors of the fish were observed during the testing period. The results were obtained through exposure of the zebrafish specimens to water collected at the sampling point in the Ijuí River and to clean control water.

The physicochemical parameters analysis of the collected water, as well as of the control water, is shown in Table 2. As can be verified in Table 2, the collected samples were not significantly different from the control according to the CONAMA Resolution 357/2005. The value for dissolved $\mathrm{O}_{2}$ in point 3 is well below that of the other collection points; however, this value was still within the parameters established by CONAMA. This low value for dissolved $\mathrm{O}_{2}$ is believed to be related to the fact that it is an area of lentic ecosystem, as shown in Table 1 .

Table 2. Physicochemical parameters of the aquarium water at the time of zebrafish euthanasia.

\begin{tabular}{lccccc}
\hline Parameter & Control & Point 1 & Point 2 & Point 3 & Point 4 \\
\hline $\mathrm{PH}$ & 8.42 & 8.2 & 7.74 & 7.9 & 7.3 \\
Conductivity $(\mu \mathrm{S})$ & 282 & 230 & 167.2 & 284 & 140.2 \\
Dissolved O2 $(\mathrm{mg} / \mathrm{L})$ & 9.9 & 9.7 & 5.1 & 11.3 & 12.8 \\
$\mathrm{H}_{2} \mathrm{O}$ Temperature $\left({ }^{\circ} \mathrm{C}\right)$ & 22.5 & 22.5 & 27.4 & 24.1 & 22 \\
Ambient & 24 & 24 & 28 & 20 & 24 \\
Temperature $\left({ }^{\circ} \mathrm{C}\right)$ & & & & & \\
\hline
\end{tabular}

Source: Own construction, 2019. 
The data for $\mathrm{MN}$ and NA, verified in 3,000 erythrocytes per fish kept in control and anthropized water, are presented in Figure 2.

As can be seen in Figure 2, the fish exposed to water from the four points on the Ijuí River demonstrated increased numbers of NA when compared to the fish subjected to control water. A slight increase in the development of NA was noticeable in the fish exposed to water from Point 2 that was statistically significant in relation to both the control group and Points 3 and 4 .

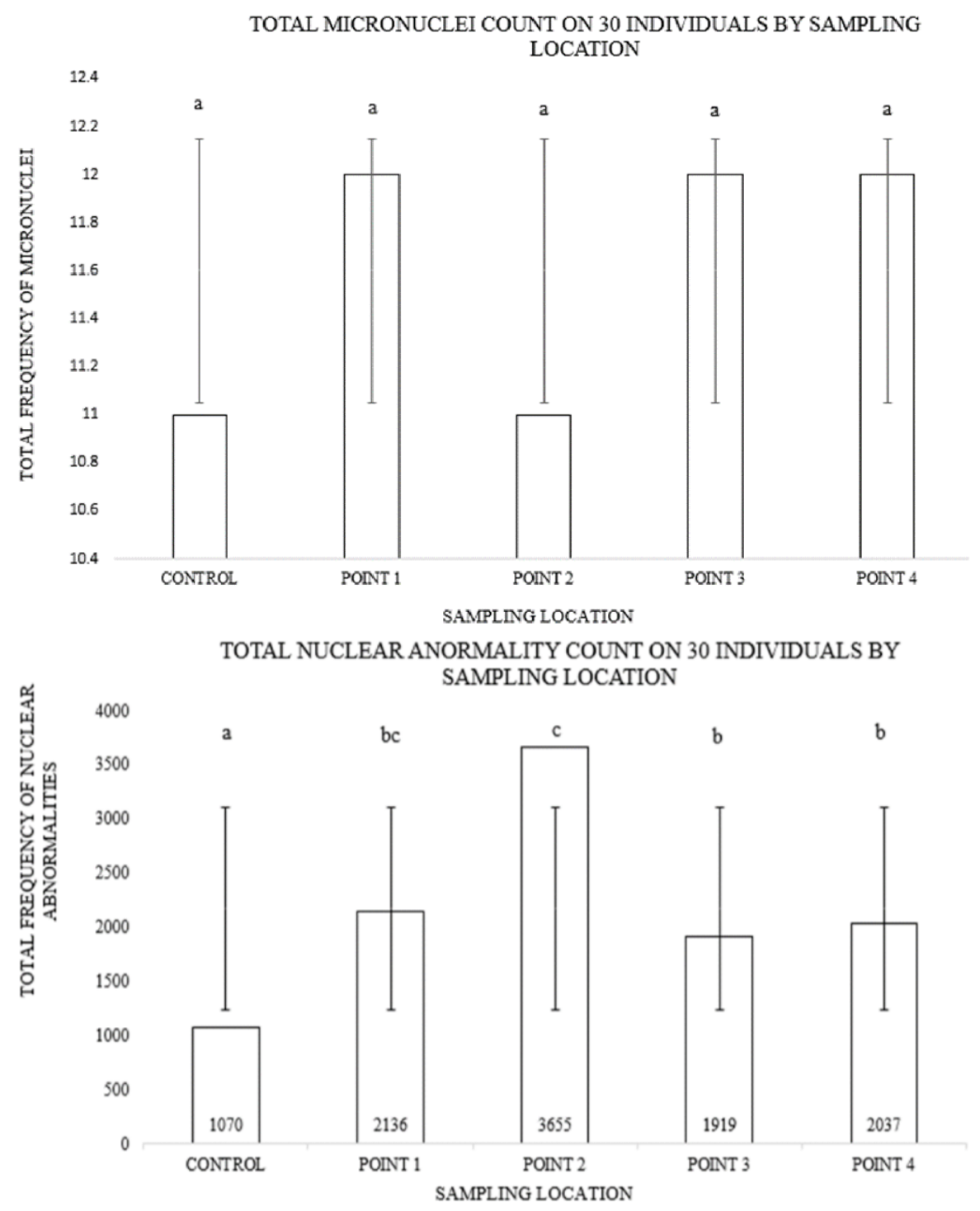

Figure 2. Absolute frequencies of micronuclei observed in 3,000 zebrafish erythrocytes (per aquarium), kept in control and anthropized fresh water. Values of MN and NA analyzed in 10 individuals of each test.

Source: Own construction, 2019.

Another important observation is that water from Point 3 had different characteristics from the other points as it was from a lentic ecosystem. However, this factor did not affect the final result of the NA number when compared to the other points with similar characteristics (Points 1 and 4).

The NA found in the analyzed erythrocytes are presented in Figure 3.

Industrial and agricultural effluents usually have clastogenic substances in their composition that can cause chromosomal breakage and dysfunctions of the mitotic spindles, resulting in the emergence of MN (Thomé et al., 2016). However, when applied to the KruskalWallis test, the MN values of the four test points were not statistically different from the control 
group, indicating that the water pollution of the Ijuí River does not cause genetic alterations at the level of $\mathrm{MN}$, which is characterized as damage that is no longer repairable.

The average emergence of $\mathrm{MN}$ in the tests was approximately one per 2,500-2,800 cells. According to Thomé et al. (2016), values less than or equal to $1 \mathrm{MN}$ per 1,000 cells are reported as an occurrence of endogenous origin in the organisms. The $\mathrm{MN}$ data were not statistically significant, however, the occurrence of this type of alteration is an event that cannot be repaired, thus the events that precede the establishment of $\mathrm{MN}$ are evidenced in the NA values, as shown in Table 2.

The MN test is simple to apply and enables the detection of genotoxic effects caused by several factors that organisms may be exposed to in their habitats (Alsabti and Mercalfe, 1995). However, MN can only be detected in extreme cases in which the repair system is unable to function. Additionally, this test detects damage from both clastogenic agents, responsible for chromosomal breaks, and aneugenic agents, which induce aneuploidy or abnormal chromosomal segregation (Ansari et al., 2011).

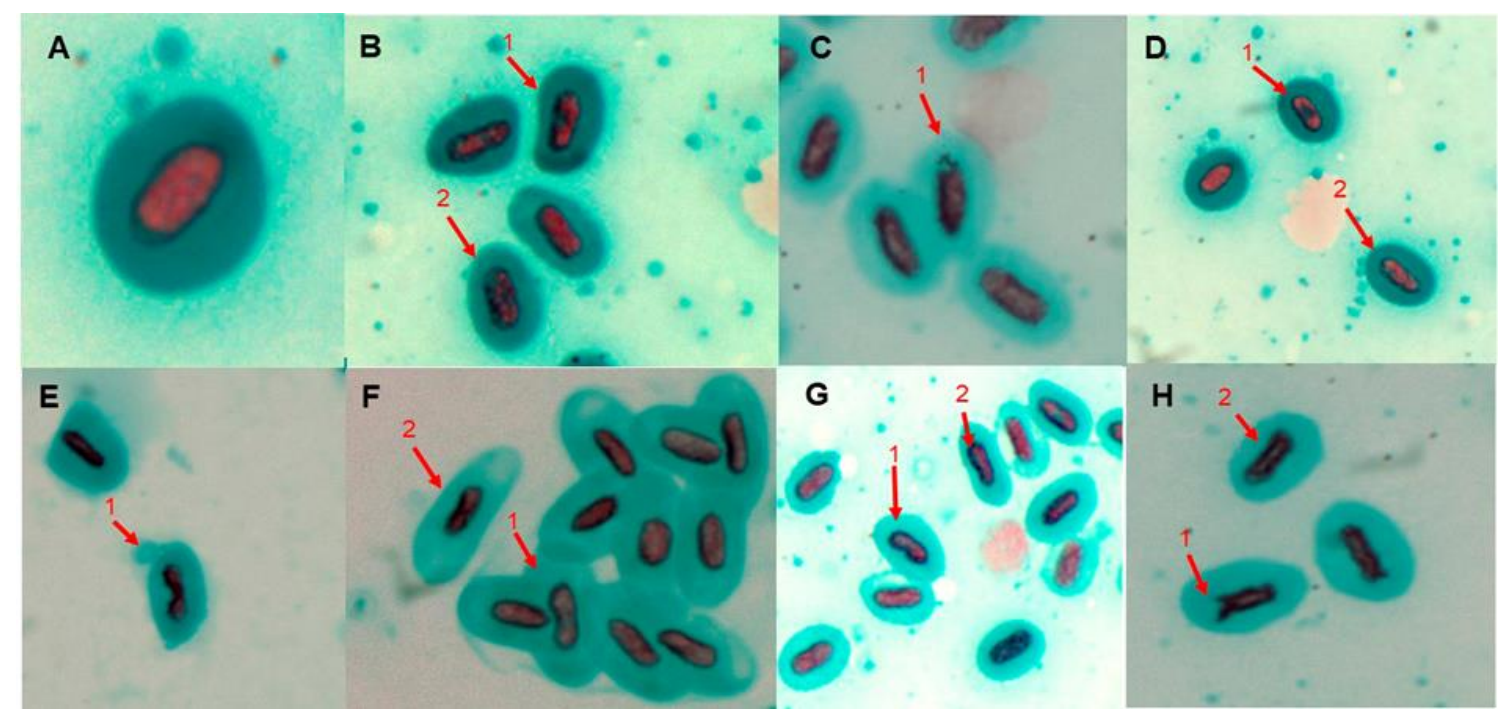

Figure 3. Images of the abnormalities found in blood erythrocytes of Danio rerio subjected to water collected from the four points on the Ijuí River.

Caption: (A) Normal erythrocyte; (B) 1- Notched; 2 - Karyorrhexis; (C) 1 - Chromosome detachment - Micronuclei; (D) 1 - Vacuolated; 2 - Karyorrhexis; (E) 1 - Lobbed; (F) 1 - Lobbed; 2 - Blebbed; (G) 1 - Notched; 2 - Blebbed; (H) 1 - Chromosomal detachment - Micronuclei; 2 Blebbed.

Source: Own construction, 2019.

Thus, this protocol has the potential to analyze events that precede the emergence of MN. However, it should be noted that compounds capable of interacting with DNA are not restricted exclusively to the effects of mutagenic substances, as there are genotoxic substances that, in addition to interacting with genetic material, also have the ability to interact with other cellular components, such as spindle fibers during cell division as well as cell enzymes, such as topoisomerase, causing nuclear changes.

It is worth noting the difference in the number of abnormalities seen between Points 2 and 3 , since these points are located in the same municipality and have the shortest distance between them. According to Thomé et al. (2016), rivers have a self-purification capacity, meaning that, when anthropic effluents are discharged, rivers and other watercourses have the ability to restore their natural characteristics in an attempt to promote self-purification.

Several characteristics may interfere in the self-purification of a river, including the average depth, watercourse speed, width and dissolved oxygen concentration. Furthermore, 
within a watercourse, it is possible to have segmentation in the self-purification zones; that is to say that, in the course there are variations between clean waters, which precede the effluent discharge zone, and a new stretch of water recovery after this point, where dissolved oxygen is introduced into the aquatic ecosystem and, soon after, the clean water zone arises again (Von Sperling and Chernicharo, 2005). Thus, it can be suggested that clastogenic substances present in Point 2 may not be carried to Point 3.

Considering that several species of fish have fundamental importance for both human ingestion and food chains, they are widely used as bioindicators. Moreover, the fact that fish respond very quickly to contamination exposure, even in small concentrations (similar to mammals), makes $D$. rerio an excellent laboratory model for studying the clastogenic potential of effluents resulting from anthropic activities (Thomé et al., 2016).

\section{CONCLUSIONS}

The anthropized water from the Ijuí River collected from all four of the analyzed points demonstrated the potential to induce clastogenic events in a zebrafish model. The data collected demonstrated higher values of erythrocytes with NA than with MN, suggesting that the cells are efficient in the repair mechanisms required when facing genotoxic substances.

\section{REFERENCES}

AL-SABTI, K.; MERCALFE, C. D. Fish micronuclei for assessing genotoxicity in water. Mutation research, v. 343, p. 121 135, 1995. https://doi.org/10.1016/01651218(95)90078-0

ANSARI, R. A.; RAHMAN, S.; KAUR, M.; ANJUM, S.; RAISUDDIN, S. In vivo cytogenetic and oxidative stress-inducing effects of cypermethrin in freshwater fish, Channa punctata Bloch. Ecotoxicology and Environmental Safety, v. 74, p. 50-156, 2011. https://doi.org/10.1016/j.ecoenv.2010.08.036

BARBAZUK, W. B.; KORF, I.; KADAVI, C.; HEYEN, J.; TATE, S.; WUN, E.; BEDELL, J. A.; MCPHERSON, J. D.; JOHNSON, S. L. The syntenic relationship of the zebrafish and human genomes. Genome research, v. 10, n. 9, p. 1351-1358, 2000. https://dx.doi.org/10.1101/gr.144700

CARRASCO, K.R.; TILBURY, K. L.; MAYERS, M. S. Assessment of the piscine micronuclei test in situ biological indicator of chemical contaminants effects. Canadian Journal of Fisheries and Aquatic Science, v. 47, p. 2123-2136, 1990. https://doi.org/10.1139/f90237

CZAJA, K.; STRUCINSKI P.; KORCZ, W.; MINORCZYK, M.; HEMIK, A.; WIADROWSKA, B. Alternative toxicological methods for establishing residue definitions applied for dietary risk assessment of pesticides in the European Union. Food and Chemical Toxicology, v. 137, 2020. https://doi.org/10.1016/j.fct.2020.111120

DALZOCHIO, T.; RODRIGUES, G. Z. P.; PETRY, I. E.; GEHLEN, G.; SILVA, L. B. Use of biomarkers to assess the health of aquatic exosystem in Brazil: a review. International Aquatic Research, v. 8, n. 4, p. 283-98, 2016. https://doi.org/10.1007/s40071-016-01479

DALZOCHIO, T.; SOUZA, M. S.; SIMÕES, L. A. R.; SILVA, G. J. H.; RODRIGUES, G. Z. P.; ANDRIGUETI, N. B.; SILVA, L. B. Impact of Anthropogenic activities on water quality of the Paranhana River, Southern Brazil. Brazilian Archives of Biology and Technology, v. 62, 2019. http://dx.doi.org/10.1590/1678-4324-2019180523 
DEARFIELD, L. K.; CIMINO, N. C.; MAUER, I.; VALCOVIC, L. R. Genotoxicity risk assessment: a proposed classification strategy. Mutation Research/Genetic Toxicology

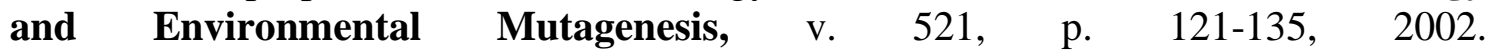
https://doi.org/10.1016/S1383-5718(02)00236-X

HAWKEY, A. B.; GLAZER, L.; DEAN, C. et al. Adult exposure to insecticides causes persistent behavioral and neurochemical alterations in zebrafish. Neurotoxicology and Teratology, 2020. https://doi.org/10.1016/j.ntt.2019.106853

KASPER, N.; BARCELOS, R. P.; MATTOS, M.; BARONI, S. Impact of anthropic activities on eukaryotic cells in cytotoxic test. Revistaa Ambiente \& Água, v. 13, n. 3, p. 1-10, 2018. https://doi.org/10.4136/ambi-agua.2107

RAMIREZ, A. Análise de células metanucleadas de alcoólicos portadores de carcinomas orais. 2000. 56f. Dissertação (Mestrado em Biologia) - Universidade de São Paulo, São Paulo, 2000.

RAMOS, L. P. N.; LEITE, D. M.; OLIVEIRA, A. S. L.; FARIAS, C. B. M.; DAHMER, N.; KARSBURG, I. V. Evaluation of the cytotoxic and genotoxic effect of Allium cepa L. (Amaryllidaceae) root cells after exposure in water samples of five lakes of Alta Floresta, State of Mato Grosso. Revista Ambiente \& Água, v. 15, n. 1, 2020. https://doi.org/10.4136/ambi-agua.2463

RIO GRANDE DO SUL. Secretária do Meio Ambiente e Infraestrutura. U090 - Bacia Hidrográfica do Rio Ijuí. Available at: https://www.sema.rs.gov.br/u090-baciahidrografica-do-rio-ijui. Access: 25 Jan. 2020.

SPADOTTO, C. A. et al. Monitoramento do risco ambiental de agrotóxicos: princípios e recomendações. Jaguariúna: Embrapa Meio Ambiente, 2004. 29p.

THOMÉ, R. G.; SILVA, P. M.; SANTOS, H. B. Avaliação de genotoxidade da água de um rio urbano utilizando estudo de células sanguíneas de Danio rerio. Conexão Ciência (Online), v. 11, n. 2, p. 9-16, 2016.

VON SPERLING, M.; CHERNICHARO, C. A. L. Biological wastewater treatment in warm climate regions. London: IWA publishing, 2005. 810p. Vol. 1. 


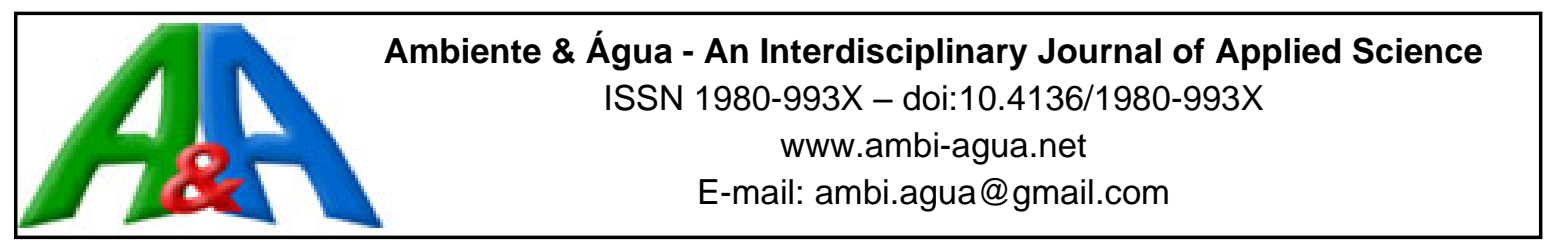

\title{
Variability of soil physical and hydraulic properties along a toposequence in the coastal lowlands of Rio de Janeiro
}

\author{
ARTICLES doi:10.4136/ambi-agua.2579 \\ Received: 15 May 2020; Accepted: 18 Dec. 2020 \\ João Henrique Gaia-Gomes ${ }^{1}$; Carlos Roberto Pinheiro Junior ${ }^{1}$ (D); \\ Marcos Gervasio Pereira ${ }^{1 *}$; Wilk Sampaio de Almeida ${ }^{2}$; \\ Geuzimar Terração Silva1 ${ }^{10}$
}

\begin{abstract}
${ }^{1}$ Instituto de Agronomia. Departamento de Solos. Universidade Federal Rural do Rio de Janeiro (UFRRJ), Rodovia BR-465, km 7, CEP: 23897-000, Seropédica, RJ, Brazil.

E-mail: gaia.gomes.pgeaamb@gmail.com, robertojrpinheiro@gmail.com, terracaoufrrj@gmail.com ${ }^{2}$ Instituto Federal de Educação, Ciência e Tecnologia de Rondônia (IFRO), Rodovia RO-257, km 13, CEP: 76870-000, Zona Rural, Ariquemes, RO, Brazil. E-mail: wilk.almeida@ifro.edu.br *Corresponding author. E-mail: mgervasiopereira01@gmail.com
\end{abstract}

\begin{abstract}
Soil physical and hydraulic properties are interdependent, and soil-use planning and management are complicated by the high variability of these attributes. The current study assessed the variability of physical and hydraulic properties of soils along a toposequence located in a forest fragment under spontaneous regeneration in the coastal lowlands of Rio de Janeiro. Four soil profiles were selected, and samples were collected from surface and subsurface horizons for determination of moisture content, bulk density, macroporosity, microporosity, hydraulic conductivity, texture, and soil resistance to penetration (measured using benchtop and field penetrometers). Exploratory and principal component analyses were performed, and descriptive parameters and Pearson's correlation coefficients were calculated. In A horizons of profiles 3 (Planossolo) and 4 (Gleissolo), clay contents ranged from 59.0 to $577.0 \mathrm{~g} \mathrm{~kg}^{-1}$, moisture contents from 1.5 to $16.4 \%$, and microporosity from 10.4 to $46.2 \%$, respectively. Field- and laboratory-measured penetration resistances showed a stronger association with profile 1 (Argissolo); however, values were not sufficiently high to limit root development. The variability in soil physical and hydraulic properties in short slopes is high, mainly in terms of hydraulic conductivity, moisture, microporosity, and clay content. The greater variability of soil physical and hydraulic properties in lowland is attributed to clay and silt fractions, microporosity, and moisture content. The increment in clay content with depth increases bulk density and resistance to root penetration.
\end{abstract}

Keywords: edaphic attributes, soil-landscape relationship, soil quality indicators.

\section{Variabilidade de atributos físico-hídricos em uma topossequência na Baixada Litorânea Fluminense}

\section{RESUMO}

Os atributos físico-hídricos do solo são interdependentes e o planejamento e o manejo do solo são dificultados devido à alta variabilidade desses atributos. O presente estudo objetivou avaliar a variabilidade dos atributos físico-hídricos em uma topossequência inserida em área de 
regeneração espontânea na Baixada Litorânea Fluminense. Foram selecionados quatro perfis, e nestas coletadas amostras nos horizontes superficiais e subsuperficiais para quantificação dos valores da umidade, densidade do solo, macroporosidade, microporosidade, condutividade hidráulica, granulometria e resistência do solo à penetração (com penetrômetro de bancada e em campo). Foi realizada a análise exploratória e calculados os parâmetros descritivos, o teste de correlação de Pearson e a análise dos componentes principais. Nos horizontes A, o teor de argila variou de 59,0 a $577,0 \mathrm{~g} \mathrm{~kg}^{-1}$, a umidade de 1,5 a $16,4 \%$ e a microporosidade 10,4 a 46,2\%, entre os perfis P3 (Planossolo) e P4 (Gleissolo). A resistência à penetração nos dois métodos esteve mais relacionada com o perfil 1 (Argissolo), entretanto, os valores máximos não restringem o desenvolvimento das raízes. A variabilidade dos atributos físico-hídricos em vertentes de pequeno comprimento é alta, principalmente para os atributos condutividade hidráulica, umidade, microporosidade, e argila do solo. Na baixada a maior variabilidade dos atributos físico-hídricos é explicada pelos atributos argila, microporosidade, silte e umidade. $\mathrm{O}$ incremento de argila em profundidade aumenta a densidade e a resistência do solo à penetração das raízes.

Palavras-chave: atributos edáficos, indicadores de qualidade do solo, relação solo-paisagem.

\section{INTRODUCTION}

Our understanding of water flows in natural and anthropized ecosystems depends on the precise characterization of soil hydrological processes (Alagna et al., 2016; Pavão et al., 2019). Because this type of characterization requires a thorough knowledge of soil physical and hydraulic properties, it is essential to determine the variability of these attributes in the environment. As discussed by several authors (Cambardella et al., 1994; Santos et al., 2016; Pavão et al., 2019; Ferreira et al., 2020), soil formation processes and anthropogenic actions enhance the variability in soil attributes.

It is of fundamental importance that studies involving the characterization of soils and their potential, as well as the environmental weaknesses in view of the different types of use that can occur in the different segments of landscapes that are special to a particular region. Studies of this nature contribute both to the understanding of fragile ecosystems, constantly occurring to environmental degradation, and to future work to characterize coastal plains (Coelho et al., 2010).

When assessing the environmental vulnerability of the coastal plain of Caravelas (BA) as a subsidy to environmental planning, the authors Souza and Vale (2016) concluded that studies like these can be used to guide management policies for coastal areas and contribute to the new occupations and economic and social development are compatible with environmental preservation.

There are several challenges in assessing the variability in soil porosity, particle size, particle size distribution, bulk density, resistance to penetration, least-limiting water range, compression index, aggregate stability, and hydraulic conductivity. According to Oliveira et al. (2015), most limitations arise from the large extension of study sites and the large number of samples and high costs consequently associated with these investigations.

Considering the above-mentioned soil physical attributes, Stefanoski et al. (2013) argued that soil hydraulic conductivity is one of the best indicators of soil quality because it can reveal structural differences between soil profile layers. In a study investigating the physical and hydraulic properties and organic carbon content of an Argissolo under different management systems for 23 years, Hickmann et al. (2012) found that management effects were more pronounced in the surface layer. Ferreira et al. (2020), in investigating the effects of 23 years of direct planting on aggregate formation and soil organic matter in rainy and dry seasons, 
concluded that soil aggregation is a simple, low-cost, repeatable, and easy-to-understand indicator of changes in soil physical conditions.

Despite the importance of soil physical and hydraulic properties to the understanding of major ecosystem processes (Pavão et al., 2019), the variability of these attributes along slopes still requires further investigation. Therefore, this study aimed to assess the variability of soil physical and hydraulic properties along a toposequence in the coastal lowlands of Rio de Janeiro.

\section{MATERIAL AND METHODS}

The study area is located on the campus of the Federal Rural University of Rio de Janeiro, Seropédica, Rio de Janeiro Metropolitan Region, Brazil. The climate is tropical wet and dry (Aw in the Köppen climate classification system), with rainfall events concentrated during November to March. The mean annual precipitation is $1213 \mathrm{~mm}$, and the mean annual temperature is $24.5^{\circ} \mathrm{C}$ (Alvares et al., 2013). The geology of the area is dominated by acidic rocks from the Southern Paraíba Complex, such as gneisses and granites. The region belongs to the coastal plains of Sepetiba Bay, characterized by a slightly undulating relief with small variations in elevation (Muehe et al., 2006).

A toposequence of soils under regenerating Atlantic forest was selected for the study. Four trenches were opened at different locations of the landscape, each spaced about $40 \mathrm{~m}$ apart (Figure 1).

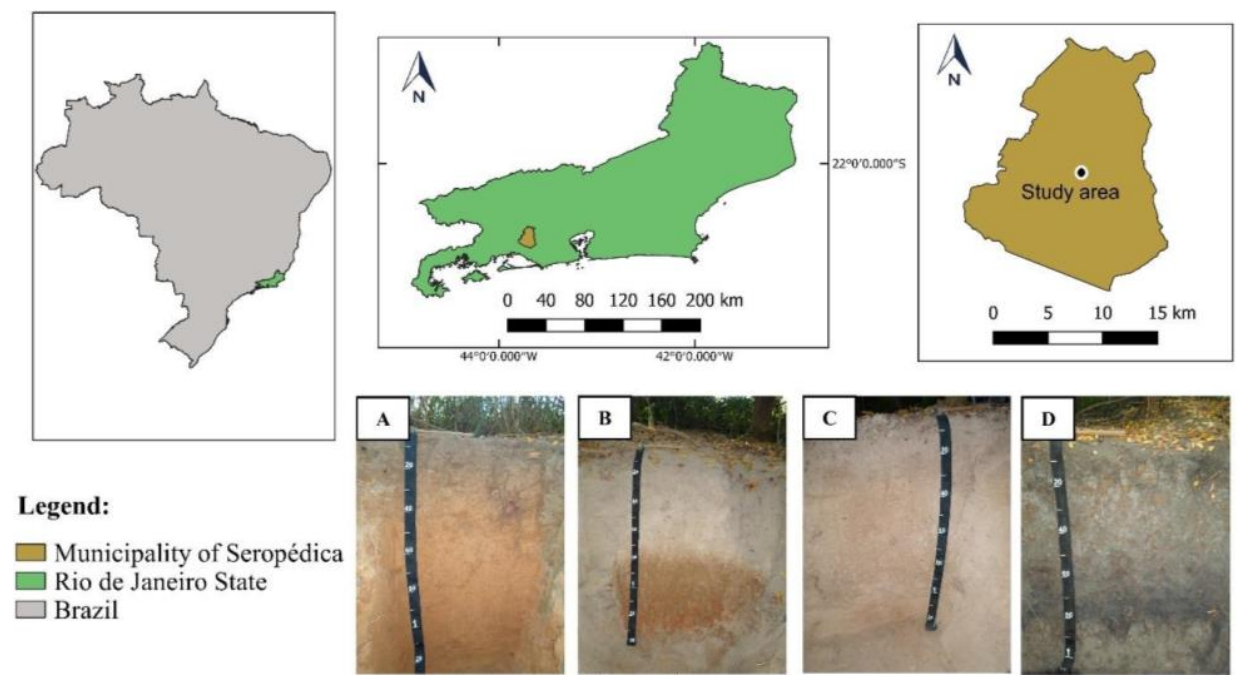

Figure 1. Location map of the study area showing the evaluated soil profiles in the upper (A), middle (B), and lower thirds (C) of the slope and lowland (D).

Morphological characteristics of soil profiles were described according to criteria proposed by Santos et al. (2015), and soil types were classified in accordance with the Brazilian Soil Classification System (Santos et al., 2018) and the general information about sampling sites and soil morphological and textural properties are presented in Table 1.

Disturbed samples were collected from surface and subsurface diagnostic horizons for color, structural, and textural analyses. Four undisturbed samples were collected using an Uhland soil sampler. Sampling depth was defined on the basis of horizon thickness; collections were performed from the central part of the horizon for increased representativeness of soil attributes.

Gravimetric moisture content, bulk density, macroporosity, microporosity, and saturated hydraulic conductivity were determined according to Teixeira et al. (2017). Analysis of soil penetration resistance was performed by two methods using four replications. Laboratory- 
measured penetration resistance was determined using a Tecnal Te-096 benchtop penetrometer, and field-measured penetration resistance was assessed using an impact penetrometer, according to Stolf (1991). Particle size analysis was performed by the pipette method (Teixeira et al., 2017) to determine sand, silt, and clay contents.

Table 1. Morphological and textural properties of soil profiles evaluated in the study.

\begin{tabular}{|c|c|c|c|}
\hline Horizon & Depth $(\mathrm{cm})$ & Moist color & Soil structure \\
\hline \multicolumn{4}{|c|}{ Profile 1 (Argissolo Vermelho-Amarelo, upper third of slope, elevation $42 \mathrm{~m}$, slightly undulating $8 \%$ and well drained) } \\
\hline A & $0-9$ & $5 Y R 3 / 2$ & Strong, fine and medium, granular \\
\hline $\mathrm{AB}$ & $9-18$ & $5 Y R 3 / 3$ & Strong, fine and medium, granular \\
\hline $\mathrm{BA}$ & $18-30$ & $5 Y R 4 / 3$ & Strong, fine, subangular blocky \\
\hline Bt1 & $30-52$ & $5 Y R 4 / 6$ & Strong, fine, subangular blocky \\
\hline $\mathrm{Bt} 2$ & $52-75$ & $5 \mathrm{YR} 4 / 6$ & Strong, fine, subangular blocky \\
\hline Bt3 & $75-102$ & $5 Y R 5 / 4$ & Strong, fine, subangular blocky \\
\hline Bt4 & $102-116^{+}$ & $5 Y R 5 / 6$ & Strong, fine, subangular blocky \\
\hline \multicolumn{4}{|c|}{ Profile 2 (Argissolo Amarelo, middle third of slope, elevation $41 \mathrm{~m}$, slightly undulating $12 \%$ and moderately drained) } \\
\hline A & $0-7$ & $10 \mathrm{YR} 4 / 2$ & Weak to moderate, fine, granular \\
\hline $\mathrm{AE}$ & $7-17$ & $10 Y R 5 / 2$ & Weak to moderate, fine, granular \\
\hline E1 & $17-44$ & $10 Y R 5 / 4$ & Weak, fine, granular \\
\hline E2 & $44-80$ & $10 Y R 5 / 4$ & Weak, fine, granular \\
\hline Bt1 & $80-102$ & $10 \mathrm{YR} 5 / 5$ & Moderate, fine, subangular blocky \\
\hline $\mathrm{Bt} 2$ & $102-134^{+}$ & $10 \mathrm{YR} 4 / 6$ & Moderate, fine, subangular blocky \\
\hline \multicolumn{4}{|c|}{ Profile 3 (Planossolo Háplico, lower third of slope, elevation 39 m, slightly undulating 4\% and imperfectly drained) } \\
\hline A1 & $0-14$ & $10 \mathrm{YR} 4 / 2$ & Weak, fine, granular \\
\hline $\mathrm{A} 2$ & $14-31$ & $10 \mathrm{YR} 4 / 2$ & Weak, fine, granular \\
\hline $\mathrm{AE}$ & $31-54$ & $10 Y R 5 / 4$ & Weak, fine, granular \\
\hline E1 & $54-71$ & $10 Y R 5 / 4$ & Single grain \\
\hline E2 & $71-96$ & $10 Y R 5 / 4$ & Single grain \\
\hline $\mathrm{Bt}$ & $96-128$ & 10YR 6/4 & Moderate, fine, subangular blocky \\
\hline $\mathrm{BC}$ & $128-164^{+}$ & $10 \mathrm{YR} 6 / 2$ & Weak to moderate, fine, subangular blocky \\
\hline \multicolumn{4}{|c|}{ Profile 4 (Gleissolo Háplico, lowland, elevation 38 m, slightly undulating 1\% and poorly drained) } \\
\hline A & $0-7$ & 10YR 3/1 & Strong, very fine, angular blocky \\
\hline $\mathrm{AB}$ & $7-16$ & $10 \mathrm{YR} 4 / 1$ & Strong, very fine, angular blocky \\
\hline $2 \mathrm{Bg} 1$ & $16-41$ & N 5 & Strong, fine, angular blocky \\
\hline $2 \mathrm{Bg} 2$ & $41-55$ & N 5 & Strong, fine, angular blocky \\
\hline $2 \mathrm{Bg} 3$ & $55-66$ & N 5 & Strong, fine, angular blocky \\
\hline $3 \mathrm{Bg} 4$ & $66-88$ & $\mathrm{~N} 4$ & Strong, fine, angular blocky \\
\hline $4 \mathrm{BC}$ & $88-105^{+}$ & 10YR 5/1 & Strong, fine, angular blocky \\
\hline
\end{tabular}


All statistical analyses were conducted using the $\mathrm{R}$ statistical software (R Core Team, 2020). Data were analyzed for normality of distribution and homogeneity of variance by the Shapiro-Wilk test (Shapiro and Wilk, 1965) and Bartlett's test (Bartlett, 1937), respectively, at $p<0.05$. The following parameters were calculated: minimum, maximum, mean, median, skewness, kurtosis, and coefficient of variation (CV). CV values were categorized according to criteria proposed by Pimentel-Gomes and Garcia (2002): CV < 10\%, low; $10<\mathrm{CV}<20 \%$, average; $20<\mathrm{CV}<30 \%$, high; and $\mathrm{CV}>30 \%$, very high.

Correlations between physical and hydraulic attributes of $\mathrm{A}$ and $\mathrm{B}$ horizons were determined by Pearson's correlation test at $p<0.05$. Hierarchical cluster analysis was performed using a hierarchical method, using Euclidean distance $(\%)$ as a measure of similarity between records and Ward's method, as clustering strategy. The grouping analysis was complemented with that of principal component analysis (PCA), that was used to reduce the dimensionality of the dataset without losing information and facilitate interpretation of data independence. According to Hongyu et al. (2015), PCA linearly combines variables of the original dataset into principal components (PCs). The first PC explains the greatest amount of variance in the dataset, and each successive PC explains less.

\section{RESULTS AND DISCUSSION}

Descriptive statistics of physical and hydraulic properties of A and B horizons along a toposequence in Rio de Janeiro, are presented in Table 2.

Table 2. Descriptive statistics of physical and hydraulic properties of surface and subsurface horizons along a toposequence in the coastal lowlands of Rio de Janeiro.

\begin{tabular}{|c|c|c|c|c|c|c|c|c|c|c|}
\hline \multirow{2}{*}{ Variable } & $\mathrm{PR}_{\mathrm{F}}$ & $\mathrm{PR}_{\mathrm{L}}$ & K & Macro & Micro & $\mathrm{Bd}$ & GM & Sand & Clay & Silt \\
\hline & \multicolumn{2}{|c|}{$\mathrm{MPa}$} & $\mathrm{cm} \mathrm{h}^{-1}$ & \multicolumn{2}{|c|}{$\%$} & $\mathrm{Mg} \mathrm{m}^{-3}$ & $\%$ & & $\mathrm{~g} \mathrm{~kg}^{-1}$ & \\
\hline \multicolumn{11}{|c|}{ A horizons } \\
\hline Minimum & 0.60 & 0.70 & 0.86 & 0.85 & 9.10 & 0.70 & 1.40 & 181.00 & 58.00 & 72.00 \\
\hline Mean & 1.08 & 1.43 & 35.00 & 23.18 & 20.52 & 1.15 & 9.80 & 631.30 & 234.81 & 133.88 \\
\hline Median & 1.20 & 1.30 & 24.15 & 28.28 & 12.00 & 1.25 & 10.25 & 742.50 & 151.50 & 109.50 \\
\hline Maximum & 1.50 & 2.40 & 99.20 & 31.08 & 47.70 & 1.40 & 18.30 & 861.00 & 578.00 & 242.00 \\
\hline $\mathrm{CV}(\%)$ & 34.47 & 43.42 & 100 & 41.97 & 75.20 & 21.41 & 63.09 & 44.79 & 91.48 & 50.93 \\
\hline Skewness & -0.33 & 0.44 & 0.62 & -1.27 & 1.22 & -0.62 & -0.21 & -0.92 & 0.94 & 0.84 \\
\hline Kurtosis & -1.33 & -1.63 & -1.10 & 0.28 & -0.48 & -1.07 & -1.61 & -0.87 & -0.84 & -0.97 \\
\hline$W$ & $0.82^{\mathrm{ns}}$ & $0.88^{\mathrm{ns}}$ & $0.86^{\mathrm{ns}}$ & 0.68 & 0.64 & $0.86^{\mathrm{ns}}$ & $0.87^{\mathrm{ns}}$ & 0.72 & 0.73 & 0.76 \\
\hline \multicolumn{11}{|c|}{ B horizons } \\
\hline Minimum & 1.00 & 1.70 & 0.00 & 6.20 & 6.40 & 0.90 & 1.10 & 73.00 & 151.00 & 60.00 \\
\hline Mean & 2.63 & 4.18 & 9.33 & 18.45 & 22.14 & 1.27 & 17.29 & 456.00 & 430.40 & 113.62 \\
\hline Median & 2.45 & 2.90 & 3.30 & 18.55 & 18.77 & 1.30 & 13.90 & 532.00 & 373.50 & 115.50 \\
\hline Maximum & 5.00 & 8.80 & 30.50 & 28.50 & 46.09 & 1.60 & 39.90 & 687.00 & 824.00 & 163.00 \\
\hline CV (\%) & 61.07 & 58.61 & 58,60 & 46.10 & 60.20 & 19.73 & 82.90 & 53.37 & 58.89 & 33.18 \\
\hline Skewness & 0.097 & 0.79 & 1.27 & 0.84 & 0.57 & -0.27 & 0.70 & -0.84 & 0.70 & 0.70 \\
\hline Kurtosis & -2.08 & -0.96 & -0.47 & -0.69 & -1.28 & -0.69 & -0.82 & -0.90 & -0.84 & -1.19 \\
\hline$W$ & $0.87^{\mathrm{ns}}$ & $0.84^{\mathrm{ns}}$ & 0.65 & $0.90^{\mathrm{ns}}$ & $0.80^{\mathrm{ns}}$ & $0.89^{\text {ns }}$ & $0.82^{\mathrm{ns}}$ & 0.78 & 0.81 & 0.78 \\
\hline
\end{tabular}

$\mathrm{PR}_{\mathrm{F}}$, field-measured penetration resistance; $\mathrm{PR}_{\mathrm{L}}$, laboratory-measured penetration resistance; $K$, hydraulic conductivity; Macro, macroporosity; Micro, microporosity; Bd, bulk density; GM, gravimetric moisture content; $\mathrm{CV}$, coefficient of variation; $W$, Shapiro-Wilk test; ns, not significant $(p>0.05)$. 
Soil physical and hydraulic properties showed an asymmetric distribution (Table 3). Fieldmeasured penetration resistance, macroporosity, and gravimetric moisture content in A horizons had negative skewness values, as bulk density and sand content in both horizons. This indicates a greater proportion of values above the mean. Other parameters had positive skewness, indicating that most values were below the mean. Symmetric distributions are those in which mean and median values are close to each other.

Table 3. Mean physical and hydraulic properties of surface and subsurface horizons along a toposequence in the coastal lowlands of Rio de Janeiro.

\begin{tabular}{|c|c|c|c|c|c|c|c|c|c|c|}
\hline \multirow{2}{*}{ Profile } & $\mathrm{PR}_{\mathrm{F}}$ & $\mathrm{PR}_{\mathrm{L}}$ & $K$ & Macro & Micro & $\mathrm{Bd}$ & GM & Sand & Clay & Silt \\
\hline & \multicolumn{2}{|c|}{$\mathrm{MPa}$} & $\mathrm{cm} \mathrm{h}^{-1}$ & \multicolumn{2}{|c|}{$\%$} & $\mathrm{Mg} \mathrm{m}^{-3}$ & $\%$ & \multicolumn{3}{|c|}{$\mathrm{g} \mathrm{kg}^{-1}$} \\
\hline \multicolumn{11}{|c|}{ A horizons } \\
\hline $\mathrm{P} 1$ & 1.3 & 2.3 & 86.3 & 27.9 & 14.2 & 1.1 & 14.3 & 226.5 & 636.5 & 137.0 \\
\hline $\mathrm{P} 2$ & 1.5 & 0.9 & 43.2 & 30.1 & 11.2 & 1.4 & 7.0 & 76.8 & 848.0 & 75.3 \\
\hline P3 & 0.6 & 0.9 & 10.5 & 29.5 & 10.4 & 1.4 & 1.5 & 59.0 & 858.3 & 82.8 \\
\hline P4 & 0.9 & 1.6 & 0.0 & 10.3 & 46.2 & 0.8 & 16.4 & 577.0 & 182.5 & 240.5 \\
\hline \multicolumn{11}{|c|}{ B horizons } \\
\hline $\mathrm{P} 1$ & 3.9 & 4.4 & 29.9 & 22.9 & 19.4 & 1.2 & 16.1 & 416.3 & 455.5 & 128.3 \\
\hline P2 & 4.4 & 7.9 & 3.2 & 14.2 & 17.2 & 1.6 & 12.1 & 330.5 & 608.3 & 61.3 \\
\hline P3 & 1.2 & 2.1 & 3.9 & 28.0 & 7.1 & 1.4 & 1.5 & 152.5 & 686.3 & 161.3 \\
\hline $\mathrm{P} 4$ & 1.0 & 2.3 & 0.3 & 8.7 & 44.8 & 0.9 & 39.5 & 822.3 & 74.0 & 103.8 \\
\hline
\end{tabular}

$\mathrm{PR}_{\mathrm{F}}$, field-measured penetration resistance; $\mathrm{PR}_{\mathrm{L}}$, laboratory-measured penetration resistance; $K$, hydraulic conductivity; Macro, macroporosity; Micro, microporosity; $\mathrm{Bd}$, bulk density; GM, gravimetric moisture content.

The Shapiro-Wilk test showed that most parameters were not normally distributed, with the exception of sand, clay, and silt contents in both horizons; macroporosity and microporosity in A horizons; and hydraulic conductivity in B horizons. However, according to Carvalho et al. (2002), theoretical skewness and kurtosis values close to 0 and 3, respectively, indicate a normal distribution. Therefore, variables showed a tendency to normality.

Bulk density in both horizons and silt content in B horizons had high CV values $(20<\mathrm{CV}$ $<30 \%$ ) (Pimentel-Gomes and Garcia, 2002). All other parameters had very high CV values (>30\%). In A horizons, the highest CV values (>60\%) were observed for moisture content, microporosity, clay content, and hydraulic conductivity, indicating heterogeneity along the toposequence. Such results are likely associated with the pedogenesis of the environments (Oliveira et al., 2015).

The sand content of A horizons ranged from $59.0 \mathrm{~g} \mathrm{~kg}^{-1}$ in P3 (Planossolo) to $577.0 \mathrm{~g} \mathrm{~kg}^{-1}$ in $\mathrm{P} 4$ (Gleissolo); moisture content, from $1.5 \%$ in $\mathrm{P} 3$ to $16.4 \%$ in P4; and microporosity, from $10.4 \%$ in P3 to $46.2 \%$ in P4 (Table 3). These high variations were observed despite the short distance between profiles (about $40 \mathrm{~m}$ ).

The PCA biplot presented in Figure 2A shows the distribution of physical and hydraulic attributes along axes 1 and 2. The two PCs explained together $92.20 \%$ of the variance in soil properties. PC1 explained $68.50 \%$ of the variance, and PC2 explained $23.70 \%$. The percentages of variance explained were higher than the minimum recommended for soil studies (Campos et $a l ., 2013)$. This means that the variability expressed within the sample perimeter has been sufficiently answered and expressed. 
(A)

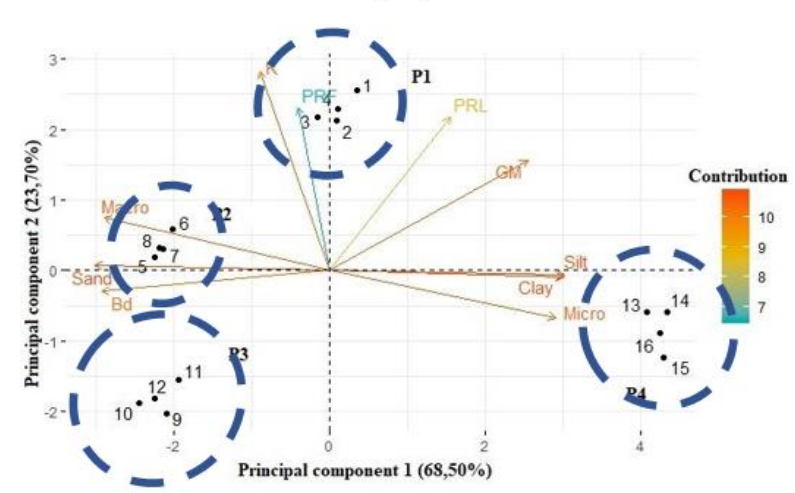

(B)

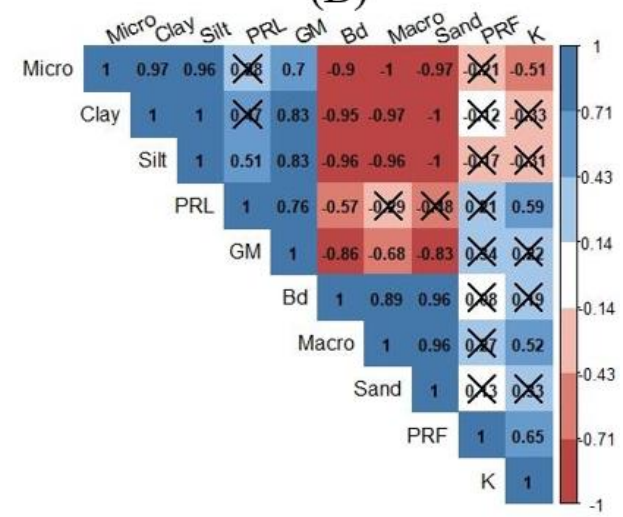

(C)

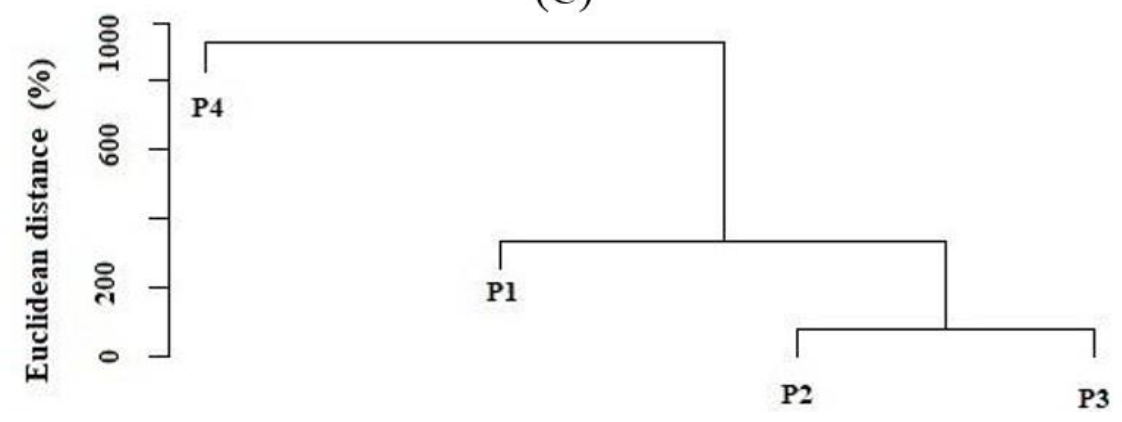

Figure 2. Principal component analysis biplot (A), Pearson correlation matrix (B), and Hierarchical cluster analysis for physical and hydraulic attributes of A horizons along a toposequence. P1-P4, soil profiles; Bd, bulk density; Macro, macroporosity; Micro, microporosity $\mathrm{GM}$, gravimetric moisture content; $K$, hydraulic conductivity; $\mathrm{PR}_{\mathrm{F}}$, field-measured penetration resistance; $\mathrm{PR}_{\mathrm{L}}$, laboratory-measured penetration resistance. Correlations marked with an $\mathrm{X}$ are not significant $(p<0.05)$.

Silt and clay content, and microporosity of A horizons were strongly associated with PC 1 with scores of high correlations of $0.99 ; 0.99 ; 0.96$, respectively (Figure 2A), and P4, probably because fine particle deposition is generally higher in lowlands than in slopes (Miotti et al., 2013; Santos et al., 2016). This phenomenon favors the formation of small pores (Miotti et al., 2013), which explains the high correlation $(r=0.97)$ between clay content and microporosity (Figure 2B). Although P4 was located near the water table, which would favor high moisture contents, and was associated with microporosity, gravimetric moisture content was not only associated with $\mathrm{P} 4$ but also with $\mathrm{P} 1$. The mean gravimetric moisture contents of $\mathrm{P} 1$ and $\mathrm{P} 4$ were similar (Table 3); however, GM showed a high positive correlation with PC1. The dark color of the A horizon of P1 can be attributed to its high organic carbon content (Table 1), as organic carbon favors the formation of a strongly developed granular structure, contributing to water retention (Loss et al., 2014; Rabot et al., 2018).

The profiles P2 and P3 were plotted on the negative side of PC1. These profiles, particularly P2, were related to sand content, bulk density, and macroporosity, with high negative scores correlations with PC1, $-0.99,-0.96,-0.95$, respectively (Figure 2A). Although $\mathrm{P} 2$ and $\mathrm{P} 3$ were positively associated with bulk density, the highest value was $1.4 \mathrm{Mg} \mathrm{m}^{-3}$ (Table 3 ), lower than that considered critical for crop root development (Reichert et al., 2009; Collares et al., 2011). Macroporosity and sand content were strongly correlated ( $r=0.96)$ (Figure 2B), whereas macroporosity and hydraulic conductivity were moderately correlated $(r=0.54)$ (Figure 2B). Even though macropores facilitate the flow of water in soil, hydraulic conductivity was more associated with P1, with high positive correlation, 0.93 with PC2 (Figure 2A). This result is probably due to the strongly developed granular structure of $\mathrm{P} 1$, contributing to the regulation of water infiltration and retention in the soil (Rabot et al., 2018). These findings 
reinforce the importance of determining the morphological characteristics of soil horizons in physical-hydraulic studies. Field- and laboratory-measured penetration resistances were associated with P1, but values were not high enough to affect root development (Costa et al., 2012; Drescher et al., 2012). Both parameters contributed little to the variance in soil properties of A horizons.

For the cluster analysis for A horizon along the toposequence (Figure 2C), the formation of three large groups with a connection distance of around $1000 \%$ was observed. In this horizon, P4 distanced itself $(\sim 1000 \%)$ from the other profiles forming an isolated group, while the profile P1 with dissimilarity of approximately $400 \%$, formed a second group; profiles P2 and P3 joined in a third group with a maximum distance between them of approximately $100 \%$.

PCA of physical and hydraulic properties of B horizons revealed two PCs, which together explained $85.80 \%$ of the variance in the dataset. PC1 explained $57.10 \%$ of the variance; and PC2, 28.70\% (Figure 3A). P4 was plotted far from other profiles, on the negative side of PC1, and was associated with clay content, microporosity, and gravimetric moisture content, with high score correlations, $-0.98,-0.99$ and -0.99 , respectively. These parameters were almost 2fold higher than those of the other profiles (Table 3). Such results are attributed to the high deposition of silt in lowlands and the proximity to the water table.

(A)

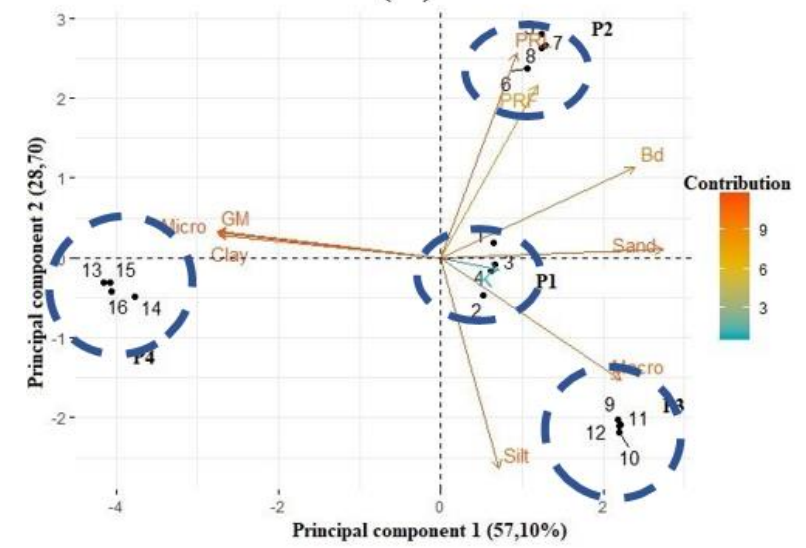

(B)

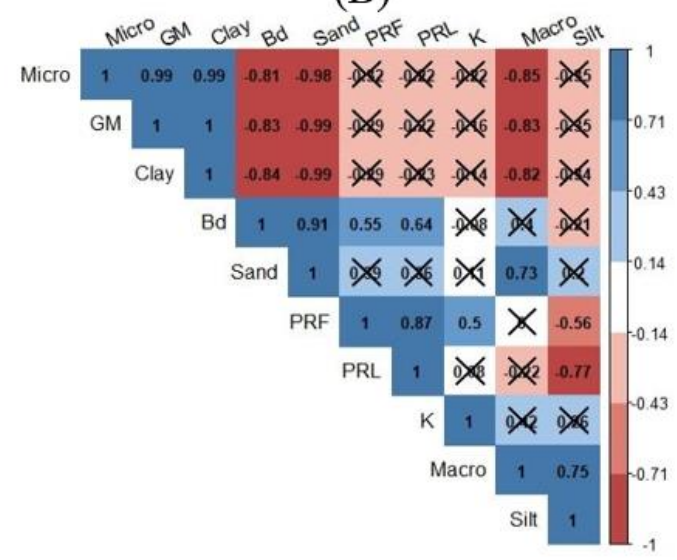

(C)

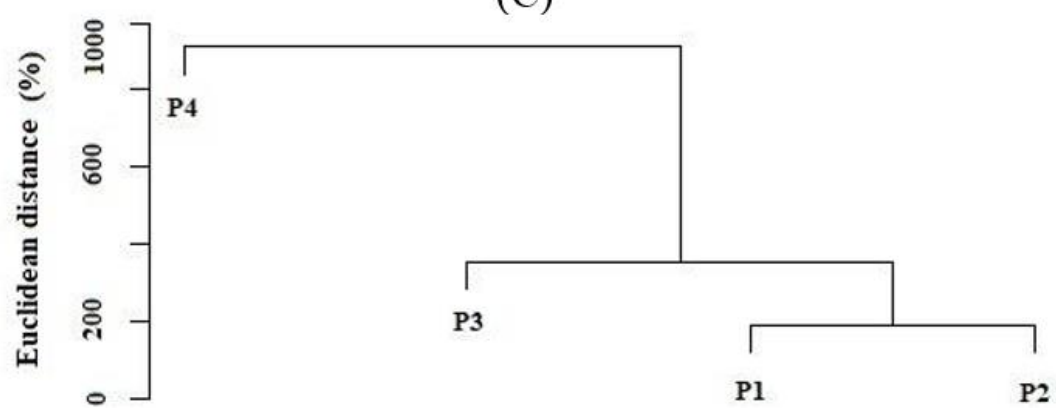

Figure 3. Principal component analysis biplot (A), Pearson correlation matrix (B), and Hierarchical cluster analysis for physical and hydraulic attributes of B horizons along a toposequence. P1-P4, soil profiles; Bd, bulk density; Macro, macroporosity; Micro, microporosity GM, gravimetric moisture content; $K$, hydraulic conductivity; $\mathrm{PR}_{\mathrm{F}}$, field-measured penetration resistance; $\mathrm{PR}_{\mathrm{L}}$, laboratory-measured penetration resistance. Correlations marked with an X are not significant $(p<$ $0.05)$.

Correlations between microporosity, moisture content, and clay content were very strong, ranging from 0.99 to 1 (Figure 3B). Hydraulic conductivity was negatively associated with $\mathrm{P} 4$, in agreement with the low value observed in the profile $\left(0.3 \mathrm{~cm} \mathrm{~h}^{-1}\right)$. The parameter was more associated with P1 because of the profile's well-developed structure. Nevertheless, hydraulic 
conductivity contributed little to the PCs, with the highest correlation value associated with the PC1 (0.25).

Sand content was related to P2 and P3, as both profiles had similar sand contents, with high positive scores correlation with PC1 (0.98). However, macroporosity was more strongly associated with $\mathrm{P} 3$ and $\mathrm{PC} 1$, with positive score correlation of 0.79 . Silt content was also associated with P3; silt and sand contents in P3 added to $850 \mathrm{~g} \mathrm{~kg}^{-1}$, whereas, in P2, the sum of silt and sand fractions was $670 \mathrm{~g} \mathrm{~kg}^{-1}$. Furthermore, silt and macroporosity were strongly correlated $(r=0.75)$, explaining the high association between macroporosity and P3.

Laboratory-measured penetration resistance was higher than field-measured resistance in all B horizons, but parameters were strongly correlated $(r=0.87)$. Penetration resistance was associated with $\mathrm{P} 2$, in which resistance values were considered critical to root development (Costa et al., 2012; Drescher et al., 2012). Although bulk density was moderately correlated with laboratory-measured $(r=0.64)$ and field-measured $(r=0.55)$ penetration resistance, the parameter was also associated with P2. These parameters were correlated positively with the PC2, 0.92 and 0.77 , respectively. The mean bulk density in P2 was $1.6 \mathrm{Mg} \mathrm{m}^{-3}$. The high bulk density and penetration resistance observed in P2 is likely associated with translocation and deposition of clay in the pores of subsurface layers, as evidenced by the difference in clay contents between A and B horizons (76.8 and $330.5 \mathrm{~g} \mathrm{~kg}^{-1}$, respectively). The densification process is responsible for increasing root penetration resistance (Cortez et al., 2011), which explains the association of penetration resistances with $\mathrm{P} 2$. The $\mathrm{Bd}$ showed a positive correlation with PC1 (0.85).

For the cluster analysis for A horizon along the toposequence (Figure 3C), the formation of three large groups with a connection distance of around $1000 \%$ was observed. In this horizon, P4 distanced itself $(\sim 1000 \%)$ from the other profiles forming an isolated group, while the profile P3 with dissimilarity of approximately $400 \%$, formed a second group; profiles P1 and $\mathrm{P} 2$ joined in a third group with a maximum distance between them of approximately $100 \%$.

\section{CONCLUSIONS}

1. Soil physical and hydraulic properties vary greatly along short slopes, particularly hydraulic conductivity, moisture content, microporosity, and clay content.

2. The high variability in soil physical and hydraulic attributes can be explained by differences in clay content, microporosity, and silt content in A horizons and clay content, microporosity, and moisture content in B horizons.

3. An increase in clay content with depth leads to an increase in density and penetration resistance.

4. Among the profiles analyzed, P4 showed greater dissimilarity from the others, for both depths studied.

\section{REFERENCES}

ALAGNA, V.; BAGARELlO, V.; DI PRIMAS, S.; IOVINO, MASSIMO. Determining hydraulic properties of a loam soil by alternative infiltrometer techniques. Hydrological Process, v. 30, p. 263-275, 2016. https://doi.org/10.1002/hyp.10607

ALVARES, C. A; STAPE, J. L.; SENTELHAS, P. C.; DE MORAES, G.; LEONARDO, J.; SPAROVEK, G. Köppen's climate classification map for Brazil. Meteorologische Zeitschrift, v. 22, n. 6, p. 711-728, 2013. https://doi.org/10.1127/0941-2948/2013/0507

BARTLETT, M. S. Properties of sufficiency and statistical tests. Proceedings of the Royal Society of London, v. 160, p. 268-282, 1937. https://doi.org/10.1098/rspa.1937.0109 
CAMBARDELLA, C. A; MOORMAN, T. B.; NOVAK, J. M.; PARKIN, T. B.; KARLEN, D. L.; TURCO, R. F.; KONOPKA, A. E. Field-scale variability of soil properties in central Iowa soils. Soil Science Society of America Journal, v. 58, p. 1501-1511, 1994. https://doi.org/10.2136/sssaj1994.03615995005800050033x

CAMPOS, M. C. C.; RIBEIRO, M. R.; SOUZA JUNIOR, V. S.; RIBEIRO FILHO, M. R.; AQUINO, R. E.; OLIVEIRA, I. A. Superfícies geomórficas e atributos do solo em uma topossequência de transição Várzea-Terra Firme. Bioscience Journal, v. 29, n. 5, p. 132$142,2013$.

CARVALHO, J. R. P.; SILVEIRA, P. M.; VIEIRA, S. R. Geoestatística na determinação da variabilidade espacial de características químicas do solo sob diferentes preparos. Pesquisa Agropecuária Brasileira, v. 37, p. 1151-1159, 2002. https://doi.org/10.1590/S0100-204X2002000800013

COELHO, M. R.; MARTINS, V. M.; TORRADO, P. V.; SOUZA, C. R. de G.; Perez, X. L. O.; VÁZQUEZ, F. M. Relação solo-relevo-substrato geológico nas restingas da planície costeira do estado de São Paulo. Revista Brasileira de Ciência do Solo, v. 34, p. 833846, 2010. https://doi.org/10.1590/S0100-06832010000300025

COLlARES, G. L.; REINERT, D. J.; REICHERT, J. M.; KAISER, D. R. Compactação superficial de Latossolos sob integração lavoura: pecuária de leite no noroeste do Rio Grande do Sul. Ciência Rural, v. 41, n. 2, p. 246-250, 2011. https://doi.org/10.1590/S0103-84782011000200011

CORTEZ, J. W.; ALVES, A. D. S.; MOURA, M. R. D. M.; OLSZECSKI, N.; NAGAHAMA, H. J. Atributos físicos do Argissolo Amarelo do semiárido nordestino sob sistemas de preparo. Revista Brasileira de Ciência do Solo, v. 35, n. 4, p. 1207-1216, 2011. https://doi.org/10.1590/S0100-06832011000400014

COSTA, M. A. T.; TORMENA, C. A.; LUGÃO, S. M. B.; FIDALSKI, J.; NASCIMENTO, W. G. D.; MEDEIROS, F. M. D. Resistência do solo à penetração e produção de raízes e de forragem em diferentes níveis de intensificação do pastejo. Revista Brasileira de Ciência do Solo, v. 36, n. 3, p. 993-1004, 2012. https://doi.org/10.1590/S010006832012000300029

DRESCHER, M. S.; ELTZ, F. L. F.; DENARDIN, J. E.; FAGANELLO, A.; DRESCHER, G. L. Resistência à penetração e rendimento da soja após intervenção mecânica em latossolo vermelho sob plantio direto. Revista Brasileira de Ciência do Solo, v. 36, n. 6, p. 18361844, 2012. https://doi.org/10.1590/S0100-06832012000600018

FERREIRA, C. R.; SILVA NETO, E. C.; PEREIRA, M. G.; NASCIMENTO GUEDES, J.; ROSSET, J. S.; ANJOS, L. H. C. Dynamics of soil aggregation and organic carbon fractions over 23 years of no-till management. Soil \& Tillage Research, v. 198, p. 104533, 2020. https://doi.org/10.1016/j.still.2019.104533

HICKMANN, C.; COSTA, L. M.; SCHAEFER, C. E. G. R.; FERNANDES, R. B. A.; ANDRADE, C. D. L. T. Atributos físico-hídricos e carbono orgânico de um Argissolo após 23 anos de diferentes manejos. Revista Caatinga, v. 25, n. 1, p. 128-136, 2012. https://periodicos.ufersa.edu.br/index.php/caatinga/article/view/2114/pdf 
HONGYU, K.; SANDANIELO, V. L. M.; OLIVEIRA JUNIOR, G. J. Principal Component Analysis: theory, interpretations and applications. Engineering and Science, v. 1, n. 5, p. 83-90, 2015. https://doi.org/10.18607/ES20165053

LOSS, A.; PEREIRA, M. G.; COSTA, E. M.; BEUTLER, S. J. Frações granulométricas e oxidáveis de matéria orgânica sob diferentes sistemas de uso do solo, no Paraná, Brasil. $\begin{array}{lllllll}\text { Bioscience Journal, } & \text { v. } & 30, & \text { n. } & 1, & 2014 .\end{array}$ http://www.seer.ufu.br/index.php/biosciencejournal/article/view/15041/13681

MIOTTI, A. A.; COSTA, M. C. G.; FERREIRA, T. O.; ROMERO, R. E. Profundidade e atributos físicos do solo e seus impactos nas raízes de bananeiras. Revista Brasileira de Fruticultura, v. 35, n. 2, p. 536-545, 2013. https://doi.org/10.1590/S010029452013000200024

MUEHE, D.; LIMA, C. F.; BARROS, F. M. L. Rio de Janeiro. In: MUEHE, D. Erosão e Progradação do Litoral Brasileiro. Brasília: Ministério do Meio Ambiente, 2006. v. 1, p. 265-296.

OLIVEIRA, I. A.; CAMPOS, M. C. C.; FREITAS, L.; SOARES, M. D. R. Caracterização de solos sob diferentes usos na região sul do Amazonas. Acta Amazônica, v. 45, n. 1, p. 1 12, 2015. https://doi.org/10.1590/1809-4392201400555

PAVÃO, L. L.; SANCHES, L.; PINTO JÚNIOR, O. B.; SPOLADOR, J. The influence of litter on soil hydro-physical characteristics in na area of Acuri palm in the Brazilian Pantanal. $\begin{array}{lllllll}\text { Ecohydrology } \quad \text { \& } & \text { Hydrobiology, } & \text { v. } & 19, & \text { p. }\end{array}$ https://doi.org/10.1016/j.ecohyd.2019.04.004

PIMENTEL-GOMES, F.; GARCIA, C. H. Estatística aplicada a experimentos agronômicos e florestais. 1. ed. Piracicaba: FEALQ, 2002. 309 p.

R CORE TEAM. R: A language and environment for statistical computing. Vienna, 2020.

RABOT, E.; WIESMEIER, M.; SCHLÜTER, S.; VOGEL, H. J. Soil structure as an indicator of soil functions: a review. Geoderma, v. 314, p. 122-137, 2018. https://doi.org/10.1016/j.geoderma.2017.11.009

REICHERT, J. M.; SUZUKI, L. E. A. S.; REINERT, D. J.; HORN, R.; HÅKANSSON, I. Reference bulk density and critical degree-of-compactness for no-till crop, production in subtropical highly weathered soils. Soil \& Tillage Research, v. 102, n. 2, p. 242-254, 2009. https://doi.org/10.1016/j.still.2008.07.002

SANTOS G. L.; PEREIRA, M. G.; LIMA, S. S.; CEDDIA, M. B.; MENDONÇA, V. M. M.; DELGADO, R. C. Landform curvature and its effect on the spatial variability of soil attributes, Pinheiral-RJ/BR, Cerne, v. 22, p. 431-438, 2016. https://doi.org/10.1590/01047760201622042184

SANTOS, H. G.; JACOMINE, P. K. T.; ANJOS, L. H. C.; OLIVEIRA, V. A.; LUMBRERAS, J. F.; COELHO, M. R.; ALMEIDA, J. A.; ARAÚJO FILHO, J. C.; OLIVEIRA, J. B.; CUNHA, T. J. F. Sistema Brasileiro de Classificação de Solos. 5. ed. Brasília: Embrapa; 2018. 356 p.

SANTOS, R. D.; SANTOS, H. G.; KER, J. C.; ANJOS, L. H. C.; SHIMIZU, S. H. Manual de descrição e coleta de solo no campo. 7. ed. Viçosa,MG: SBCS, 2015. 100 p. 
SOUZA, S. O.; VALE, C. C. do. Environmental Vulnerability of the Caravelas (BA) Coastal Plain as Subsidy to Environmental Planning. Sociedade \& Natureza, v. 28: p. 147-160, 2016. https://doi.org/10.1590/1982-451320160110

SHAPIRO, S. S.; WILK, M. B. An analysis of variance test for normality (complete samples). Biometrika, v. 52, p. 591-611, 1965. https://doi.org/10.2307/2333709

STEFANOSKI, D. C.; SANTOS, G. G.; MARCHÃO, R. L.; PETTER, F. A.; PACHECO, L. P. Uso e manejo do solo e seus impactos sobre a qualidade física. Revista Brasileira de Engenharia Agrícola e Ambiental, v. 17, n. 12, p.1301-1309, 2013. https://doi.org/10.1590/S1415-43662013001200008

STOLF, R. Theory and test of formulas for transforming impact penetrometer data in soil resistence. Revista brasileira de Ciência do Solo, v. 15, p. 229-235, 1991.

TEIXEIRA, P. C.; DONAGEMMA, G. K.; FONTANA, A.; TEIXEIRA, W. G. Manual de Métodos de Análise de Solo. 3.ed. Brasília: Embrapa; 2017. 575 p. 


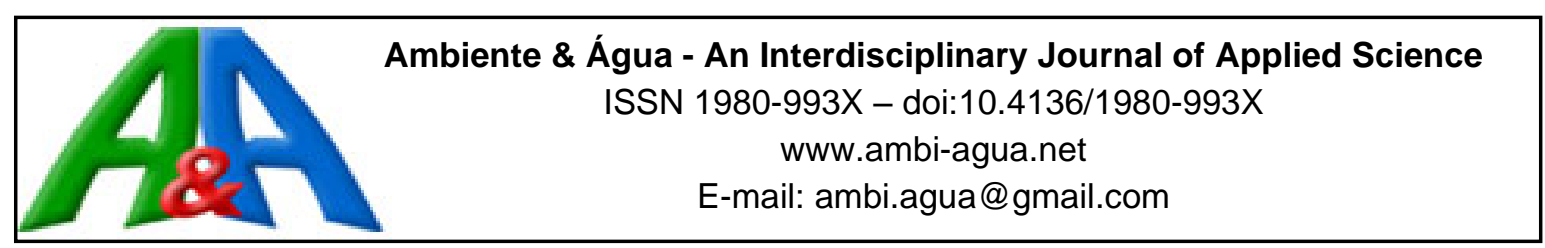

\title{
Quality index of permanent preservation areas of urban water resources: PPAWater
}

\author{
ARTICLES doi:10.4136/ambi-agua.2589
}

Received: 02 Jun. 2020; Accepted: 28 Dec. 2020

\section{Francisca Dalila Menezes Vasconcelos ${ }^{1 *}$; Francisco Suetônio Bastos Mota ${ }^{1}$; Maria Cléa Brito de Figueirêdo 2}

\begin{abstract}
${ }^{1}$ Departamento de Engenharia Hidráulica e Ambiental. Universidade Federal do Ceará (UFC), Campus do Pici, Bloco 713, CEP: 60455.760, Fortaleza, CE, Brazil. E-mail: suetonio@ufc.br ${ }^{2}$ Embrapa Agroindústria Tropical (EMBRAPA), Rua Doutora Sara Mesquita, n 2270, CEP: 60511-110, Fortaleza, CE, Brazil. E-mail: mariacleabrito@gmail.com *Corresponding author. E-mail: menezes.dalila@gmail.com
\end{abstract}

\begin{abstract}
Urban expansion is widely acknowledged to have a substantial impact on water bodies. The objective of this work is to propose and apply a composite index to evaluate the quality of Permanent Preservation Areas (PPAs), which protect urban rivers. The PPAWater index aggregates information from six indicators, namely, sanitary sewage, precarious settlement, urban drainage, level of occupation, conservation units, and preservation area, established by the municipal master plan. When applied to sub-basins in the city of Fortaleza, Ceará, the fifth most-populated city in Brazil, the index shows that the localities lacking sufficient sanitation infrastructure and with fewer hectares of protected areas register as the most vulnerable PPAs. The PPAWater index is an important tool to guide urban environmental planning, formulation, and management of public policies for the protection of urban water resources. It can be used by municipal managers to evaluate environmentally sensitive areas.
\end{abstract}

Keywords: urban development, urban environmental indicators, urban water.

\section{Índice de qualidade das Áreas de Preservação Permanente dos recursos hídricos urbanos: APPHidro}

\section{RESUMO}

Os impactos da expansão urbana nos recursos hídricos é uma relação amplamente aceita. Propor e aplicar um índice composto para avaliar a qualidade das Áreas de Preservação Permanente (APP), que protegem os rios urbanos, é o objetivo deste trabalho. O APPHidro agrega informações de seis indicadores: esgotamento sanitário, assentamento precário, drenagem urbana, nível de ocupação, Unidades de Conservação e Zona de Preservação instituídas pelo plano diretor municipal. Aplicado nas sub-bacias inseridas na cidade de Fortaleza-Ceará, a quinta mais populosa do Brasil. O índice mostra que as localidades menos assistidas por infraestrutura de saneamento, e com menos hectares de áreas protegidas, registram APP mais vulneráveis. O índice APPHidro apresenta-se como uma ferramenta importante na orientação do planejamento urbano ambiental, formulação e gestão de políticas públicas no âmbito da proteção dos mananciais urbanos. Além de subsidiar gestores municipais sobre as zonas ambientalmente sensíveis que necessitam de recuperação. 
Palavras-chave: águas urbanas, desenvolvimento urbano, indicadores urbanos ambientais.

\section{INTRODUCTION}

Studies in several countries have confirmed that increased urbanization affects water quality in cities. Tu (2011) highlighted urban expansion as the main cause of water-resource pollution. Huang et al. (2015) stated that urban sprawl more severely impacts water quality in urbanized hydrographic basins. The definition of water resources in the present work refers to the natural urban rivers, channeled rivers, lagoons, lakes and streams of the city. The primary function of permanent preservation areas (PPAs) of urban water resources is the preservation of water resources and the quality of water available to the urban population. In Brazil, the Forest Code (Federal Law n. 12,651/12) delimits and regulates such areas. Some municipalities delimit their water source areas through municipal zoning established in the Municipal Master Plan (MMP).

In other countries, federal or local legislation delimit and regulate these areas. Some laws adopt delimitation criteria such as a guarantee of environmental services (Switzerland), degree of occupation (Canada), rigorous environmental licensing process (United Kingdom), and a guarantee of space for free flowing water and quality of water ecosystems (France) (Pedroso Jr. et al., 2015; Gass et al., 2016). This delimitation of PPAs, both by the federal and local government, leads to fragmented competencies and legal inconsistencies, hindering the protection of water resources and their area of influence and increasing the vulnerability of these areas to urban expansion. Thus, PPAs of urban water resources frequently present conflicts in regard to their delimitations.

Therefore, it is necessary to study, monitor, and evaluate the quality of PPAs behaving as important soil-water transition zones, which exhibit significant complexities within the urban context. These transition zones are important for the prevention of disasters, help preserve water resources, and guarantee the local hydrological regime. Environmental indexes and indicators are important tools for understanding the level of environmental degradation in urban water body PPAs (Klopp and Petretta, 2017). These tools help in the evaluation of spatiotemporal conditions and trends, allow for the analysis of progress toward established goals of conservation and environmental preservation, support decision making, raise awareness, and encourage political and behavioral changes (Moreno Pires et al., 2014).

In Brazil, the main sets of indicators and indexes relate to geomorphological parameters, urban infrastructure, and demographic data (Freitas et al., 2013; Barros et al., 2015; Ribeiro and Mendes, 2015; Dellamora et al., 2013). Indexes found in international literature pertain to water quality and land use parameters to assess the degradation of water sources owing to urban expansion (Zhao et al., 2015; Uriarte et al., 2011; Singh et al., 2016; Carstens and Amer, 2019), with no emphasis on PPAs.

This work proposes and applies a new index, the PPAWater index, to assess the level of degradation of urban water resources. The unique feature of this index is that it does not employ water quality monitoring data, which are usually unavailable in developing countries. Furthermore, it employs an innovative territorial limit (sub-basins at the territorial limit of the municipality) and is easy to apply as it is based on information available in existing databases. The main objective of this work is to provide a composite index to evaluate the quality of urban water resources PPAs. Evaluation results using this index can help decision makers in the adequate management of PPAs such that environmental services in these areas, essential in the urban context, may be improved. The article includes three further sections: methodological construction of the index; application of the index through a case study of the city of Fortaleza, and final considerations on the index proposal and application experience. 


\section{MATERIALS AND METHODS}

The methodological steps for the construction of the composite index are based on the Handbook on Constructing Composite Indicators by the OECD (Organization for Economic Co-operation and Development) published in 2008 (OECD, 2008).

\subsection{Bibliographic review as support for the selection of indicators}

In order to analyze the existing indicators and determine ones that could compose the PPAWater composite index, the Scielo and Science Direct databases were searched with the following keywords and combinations in Portuguese and English: "areas of preservation of urban watercourses"; "environmental indicators"; "indexes and indicators of urban water bodies"; "environmental management indicators"; "urban indicators"; and "indicators of urban sustainability".

Nine articles were selected that presented indicators more related to the subject under study (Table 1). The selection criteria for the other articles were: 1) models developed for urbanized watersheds; 2) models focused on the relationship of water resources and their protection areas; and 3) models applied to urban centers that underwent an intense urbanization process in a short period of time.

The international models (Table 1) can be applied in Brazil, considering in situ water quality analyses. However, most Brazilian urban centers do not provide data on river water quality, which makes the application of these models difficult. Thus, two scenarios for the construction of indicators for urban water resources PPAs were observed, one for developed countries and another for developing countries. In developed countries and localities such as China (Zhao et al., 2015; Huang et al., 2015; Xie et al., 2018), United States (Cartens and Amer, 2019), and Puerto Rico (Uriarte et al., 2011), water quality, land use, and occupation parameters are used to assess the impact of urban expansion on water resources.

These countries usually display fully functioning urban and sanitation infrastructure, especially in environmentally relevant areas. In these countries, the availability of official information on the monitoring of water quality and land use enables the establishment of a direct relationship between water quality and the state of conservation of water resources PPAs.

On the other hand, developing countries use proxy indicators, mainly due to the absence of water quality data. Some countries like India (Sing et al., 2016) and Argentina (Calderon et $a l ., 2014$ ) have even studied the direct relationship between water quality and urbanization, but these parameters were obtained on the field, and were not a part of a systematic monitoring work. However, it is not of interest to use water quality indicators for the proposed index, because periodic collection and analysis of all parameters would be quite expensive. Thus, the index avoids the in situ collection of data and promotes the use of available official secondary data.

The models currently available for analysis of the situation of urban water resource PPAs do not use management and environmental legislation indicators, which are essential for urban environmental areas (usually managed by local management). Moreover, some often-used indicators, such as proximity to native vegetation, proximity to urban areas, proximity to the road network, risk of erosion (Freitas et al., 2013), slope, and soil type (Barros et al., 2015) are not applicable in urban environments that undergo drastic transformations, with little or no original vegetation fragments. With this context, the PPAWater composite index will be composed of six proxy indicators; these are detailed in subsection 3.1. 
Table 1. Indicators identified from the bibliographic survey for structuring the PPAWater model in 2020.

\begin{tabular}{|c|c|c|c|}
\hline Indexes/ Indicators & Locality/Author/Year & Measurement parameters & Contribution \\
\hline \multirow{5}{*}{$\begin{array}{l}\text { Land use indicators and } \\
\text { Water quality parameters }\end{array}$} & $\begin{array}{l}\text { China. } \\
\text { Zhao et al. (2015). }\end{array}$ & $\begin{array}{l}\text { LUP: level of urbanization, environmental management, expansion } \\
\text { of the industrial zone, land-use composition. } \\
\text { WQP: Biochemical oxygen demand, nitrate, and phosphorus. }\end{array}$ & Correlates urban expansion to water quality. \\
\hline & $\begin{array}{l}\text { Peru. } \\
\text { Carpio and Fath (2011). }\end{array}$ & $\begin{array}{l}\text { LUP: pasture, agriculture, volcanic material, water, empty land. } \\
\text { WQP: fecal coliforms. Absolute numbers of cases of } \\
\text { gastrointestinal diseases. }\end{array}$ & $\begin{array}{l}\text { Studies the direct relationship of urban } \\
\text { expansion with changes in river flow, water } \\
\text { quality, and waterborne diseases. }\end{array}$ \\
\hline & $\begin{array}{l}\text { Puerto Rico. } \\
\text { Uriarte } \text { et al. (2011). }\end{array}$ & $\begin{array}{l}\text { LUP: agriculture, forest, pasture, water, urban area, swamp. } \\
\text { WQP: turbidity, dissolved oxygen, total phosphorus, nitrogen, fecal } \\
\text { coliforms, and streptococci. }\end{array}$ & $\begin{array}{l}\text { Links urban expansion and pasture to water } \\
\text { quality. }\end{array}$ \\
\hline & $\begin{array}{l}\text { India. } \\
\text { Singh et al. (2016). }\end{array}$ & $\begin{array}{l}\text { LUP: agriculture, built area, and vegetation. } \\
\text { Applying the Water Quality Index (WQI). }\end{array}$ & $\begin{array}{l}\text { States that urbanization is the cause of water } \\
\text { pollution. }\end{array}$ \\
\hline & $\begin{array}{l}\text { United States. } \\
\text { Carstens and Amer (2019). }\end{array}$ & $\begin{array}{l}\text { LUP: agriculture, forest, pasture, water, urban area. } \\
\text { WQP: dissolved oxygen, total phosphorus, nitrogen, and fecal } \\
\text { coliform. }\end{array}$ & $\begin{array}{l}\text { The results state that urbanization has a } \\
\text { negative impact on water quality. }\end{array}$ \\
\hline $\begin{array}{l}\text { Environmental indicators } \\
\text { of PPA }\end{array}$ & $\begin{array}{l}\text { Brazil. } \\
\text { Freitas et al. (2013). }\end{array}$ & $\begin{array}{l}\text { Parameters: land use, proximity to vegetation and urban areas, } \\
\text { proximity to the road network, risk of erosion, capacity to sustain } \\
\text { the native forest, order of drainage channels, and PPA category. }\end{array}$ & $\begin{array}{l}\text { The study found that } 44 \% \text { of local PPAs were } \\
\text { in compliance. }\end{array}$ \\
\hline $\begin{array}{l}\text { Urban Environmental } \\
\text { Quality Index }\end{array}$ & $\begin{array}{l}\text { Brazil. } \\
\text { Ribeiro and Mendes (2015). }\end{array}$ & $\begin{array}{l}\text { LUP: vegetation coverage, basic infrastructure, and demographic } \\
\text { data. }\end{array}$ & $\begin{array}{l}\text { Methodological contributions applying remote } \\
\text { sensing and multivariate analysis. }\end{array}$ \\
\hline Sustainability Indicators & $\begin{array}{l}\text { Brazil. } \\
\text { Dellamora et al. (2013). }\end{array}$ & LUP: land use, green areas, water resources, and PPA land. & $\begin{array}{l}\text { Methodological contributions applying remote } \\
\text { sensing and Geographic Information System. }\end{array}$ \\
\hline $\begin{array}{l}\text { Environmental } \\
\text { Vulnerability Index }\end{array}$ & $\begin{array}{l}\text { Brazil. } \\
\text { Barros et al. (2015). }\end{array}$ & $\begin{array}{l}\text { LUP: declivity, land and area of riparian forest PPA, i.e., the } 30 \mathrm{~m} \\
\text { required by law. }\end{array}$ & $\begin{array}{l}\text { Relates PPA with social vulnerability, } \\
\text { infrastructure, and urban flood risk. }\end{array}$ \\
\hline
\end{tabular}

Legend: Index of qualities of Urban Water Resource Preservation Areas; LUP - Land Use Parameters; WQP - Water Quality Parameters. 


\subsection{Hierarchization of indicators: Delphi method}

The objective of hierarchization of the indicators, which are part of the composite index, is to assess which indicators are most influential and relevant in the process, as well as those that are the least relevant. The results of this ranking will support the weighting of the indicators to be carried out in the normalization stage. The hierarchization of indicators that comprise the PPAWater index was carried out using the Delphi method, which has been used and improved by over 2,600 academic articles. This method allows for the collection of insights from a group of experts, whose anonymity is maintained to exclude biases that could arise from the group's interactions (Flostrand et al., 2020). The process followed the steps proposed by Marques and Freitas (2018): 1) Stating the problem and structuring the research; 2) Preparation of the questionnaire; 3) Selection of the expert group; 4) Surveying using questionnaires; 5) Reflection and response of experts; 6) Analysis of the answers by the researcher; 7) Compilation of responses and elaboration of the final report.

According to Godet and Durance (2011), the number of experts in the interviewed group should not be less than 25 . Thus, 25 professionals from agencies and institutions that directly influence the urban environmental planning process of the city of Fortaleza were interviewed. These 25 professionals carried out a peer review through the direct influence matrix. Then, a median of the weights assigned by the experts was extracted. This median was used in the MICMAC® software (Matrix of Cross Impacts and Multiplications Applicable to a Classification) to construct the influence matrix in order to obtain a ranking of importance/influence of indicators.

\subsection{Weight assignment, standardization, and aggregation of indicators}

The Analytic Hierarchy Process (AHP) was applied using the obtained ranking of the six indicators. A decomposition and synthesis of the relationships between the criteria were performed until a prioritization of their indicators was determined (Saaty, 1991). Once the weights of the indicators were assigned, the standardization stage was carried out. According to Reisi et al. (2014), when data present different units of measurement, they become immeasurable. Hence, it is necessary to apply the same unit of measurement to make them compatible; this method is called normalization. The unit adopted for normalization was the percentage of PPA area in hectares, since the analysis of the indicators was carried out via map algebra, using spatial information of the studied territory. In each indicator equation, the sum of the areas in hectares was used, which was later multiplied by 100 to obtain the percentage of each component in the total PPA of the municipality under study. The adopted method for indicator aggregation was the comparable interval scale, where aggregation was carried out based on the arithmetic mean, generating an index with strong data representativity (Feil and Schreiber, 2017).

\subsection{Map algebra in delimiting areas and applying the index}

Once the study area was selected, map algebra was applied to: 1) define the area of water resource and their PPAs; 2) calculate the areas of each indicator comprising the PPAWater index; and, 3) prepare the map with the index scale by sub-river basins. The first step in applying the index was the delimitation of the PPAs of urban water bodies based on existing watercourses and regulations specified by the Brazilian Forestry Code. The cartographic database of the city was used to support the delimitation of PPAs and aid in the preparation of maps. The contour lines were consulted to verify the limits of the water courses for design refinement of the cartographic maps. Satellite images obtained by Bing Maps and Google Earth were also used, with updated images from 2019.

Based on the shape of the water resources, the buffer tool of the QGIS software, Version 7.6.1 (Grass), was used to delimit the PPAs, following the limits specified in the Brazilian Forest Code. The delimitation presented different profiles of protection areas, generating the 
following PPA typologies of the watercourses identified in the river basins: PPA-1: Lakes and ponds with a $30 \mathrm{~m}$ minimum width protection strip; PPA-2: Minimum $30 \mathrm{~m}$ protection strip for watercourses less than $10 \mathrm{~m}$ wide; PPA-3: Minimum $50 \mathrm{~m}$ protection strip for watercourses 10 to $50 \mathrm{~m}$ wide; PPA-4: Minimum $100 \mathrm{~m}$ protection strip for watercourses 50 to $200 \mathrm{~m}$ wide; PPA-5: Minimum $200 \mathrm{~m}$ protection strip for watercourses 200 to $600 \mathrm{~m}$ wide; PPA-6: Minimum $500 \mathrm{~m}$ protection strip for watercourses over $600 \mathrm{~m}$ wide; and PPA-7: Channeled stretches with a $30 \mathrm{~m}$ minimum protection strip.

Maps and area calculations were also obtained using the QGIS software. Remote sensing, geographic information systems, and map algebra are widely used in urban environmental planning (Hegazy and Kaloop, 2015; Coutts et al., 2016; Liu et al., 2017; Tu et al., 2018; Gao et al., 2019; Frick and Tervoonren, 2019). The archives used for the elaboration of the maps and calculation of the areas can be found on the "Fortaleza em mapas" platform (Fortaleza, 2020) of the city of Fortaleza, from 2018 to 2020.

\subsection{Strategy for defining the scale and territorial limit and characterization of the area of study}

Two types of spatial delimitation were integrated in order to delimit the study area, that is, the river basin and the municipal boundaries. The division of the river basin is recommended for the study of water resource management (Aquino and Mota, 2019). However, urban managers and planners, who work with municipal boundaries and are responsible for the elaboration of laws and guidelines for land planning and use, do not usually adopt this division, especially for urban water resources PPAs. The joint application of spatial delimitations (watershed and municipal boundaries) facilitates the needs of urban planners and environmental managers who work with urban water resource management in municipalities. This innovative approach is used here for the first time in the study of PPAs of rivers in urban areas.

This work applies the PPAWater index to the river sub-basins of the municipal territory of the city of Fortaleza (Ceará-Brazil), which was selected owing to its intense urban growth, decrease in environmental areas, and visible socioeconomic inequality of the population In 2018, the population of Fortaleza was estimated to be 2.643 million, with a forecasted population of 2.669 million by 2019 (IBGE, 2019). The municipality has four hydrographic basins in its territory, namely, Cocó River, Maranguapinho River, Pacoti River, and Vertente Marítima; the first two correspond to $82 \%$ of the municipal area (Ceará, 2018). According to Koppen's classification, the climate is rainy tropical, with a strong rainfall irregularity throughout the year, and a rainy season from May to April (Marino et al., 2012). Public water resource policies are relevant to the region, considering the context of water scarcity.

The water supply of a city is sourced from hydrographic basins outside the city (approximately $300 \mathrm{~km}$ away). This integrated hydrographic basin system guarantees water supply for the city, compensating for the water scarcity in the hydrographic basins of the city. The treatment of water distributed to the city is carried out through a concession by a concessionaire, which is also responsible for the sewage system. The urban drainage system is managed by the city government through the Municipal Secretariat of Urban Infrastructure.

\section{RESULTS AND DISCUSSION}

\subsection{Justification of indicators selected to compose the PPAWater index}

The literature review contributed to the selection of six proxy indicators that are categorized in two dimensions as follows:

- Urban indicators (UI): UI-1: sanitary sewage system, UI-2: urban drainage system, and UI-3: precarious settlements. 
- Environmental and management indicators (EI): EI-1: vegetation coverage, EI-2: conservation units (CUs), and EI-3: municipal environmental macro-zoning.

The selection of indicators for the urban dimension accounts for the infrastructure that allows for better functioning of the ecosystem services developed by water resources PPAs. This urban infrastructure (sewage services, drainage system, supply, and collection of solid waste) facilitates more efficient urban water dynamics, avoiding the release of sewage into water bodies and improper disposal of solid waste in water bodies. The indicator "PPA with vegetation cover" behaves as a proxy indicator for permeable areas. This indicator also helps in the identification of occupied PPA fractions, i.e., impermeable areas occupied by buildings. According to Leite et al. (2019), the native vegetation in the vicinity of watercourses plays an important role in maintaining the quantity and quality of water by acting as a sediment filter. Riparian forests with poplar trees reduce the nitrogen and phosphorus content in soil and act as a form of green infrastructure to eliminate nonpoint source pollution for improved ecological watershed management (Bahn and $\mathrm{Na}, 2020$ ). According to Zhao et al. (2015), the environmental management system is the most important contributor to the reduction of pollution in urban districts. They stated that efficient management of water resources improves water quality, even in areas with intense urban expansion.

The main differences between the PPAWater index and existing ones are: its applicability in densely urbanized areas including severely transformed rivers (channeled stretches, which alter the hydraulic regime of the river, silted and eutrophic lagoons, among other changes) by urbanization; the insertion of a territorial limit for sub-basins in the municipality under study; the accessibility of secondary data, without the need for in situ collection; ease of understanding of the colorimetric scale, which can be disseminated to the general public; and the integration of both management and infrastructure indicators in the same index.

Certain aspects of correlation and compensation between indicators are listed, reiterating their importance in the composition of the index. The UI-3 indicator, which pertains to illegal settlements of a location, is different from conventional occupation, which are subject to tribute and generally connected to sanitary sewage systems, water supply, domestic waste collection, and other urban services. For management indicators, the CUs follow the guidelines set by the International Union for the Conservation of Nature (IUCN), which aims to safeguard important natural habitats that are under threat. As for municipal macro-zoning defined by the MMP, the delimitation of the water source preservation areas is the responsibility of the local governments.

\subsection{Weighting and hierarchization of indicators by experts}

The profiles of the specialists revealed that $64 \%$ of them have a master's or doctorate degree, $44 \%$ are working in the area of environmental urban planning, water resources, protected areas and related topics, and 32\% are research professors developing projects and research on the subject. At least $44 \%$ of respondents have been developing work (have been involved in urbanization work), research, or projects within the environment field (urban environmental planning, water resources, environmental protection areas, with an emphasis on urban centers) for over 6 years. In addition, some respondents had a basic education in the areas of exact sciences, for example environmental engineering (40\%), engineering (20\%), and applied social sciences (28\%), among others. This survey reflects the satisfactory academic and professional level of the experts, confirming the reliability and relevance of the responses. The specialists evaluated the indicators using the influence matrix (Table 2), wherein it is possible to observe the relationship, dependence, and influence of the indicators in the studied system.

Using MICMAC, the indicators were evaluated in pairs. The sum of total rows and columns for each indicator provides the following importance/influence ranking: $1^{\text {st }}$ EI-3 (sum 21); $2^{\text {nd }}$ EI-1 (sum 20); $3^{\text {rd }}$ UI-2 (sum 19); $4^{\text {th }}$ UI-1 (sum 15); $5^{\text {th }}$ UI-3 (sum 14); and $6^{\text {th }}$ EI-2 
(sum 13). The result selects the indicator "PPA within the municipality's environmental macrozone" as the most relevant in the system, followed by the indicator "PPA with vegetation coverage".

Table 2. Matrix of influence/importance of indicators in the studied system, according to the experts, for the water resources PPAs in Fortaleza, 2020.

\begin{tabular}{lccccccc}
\hline \multirow{2}{*}{ Indicators } & $\mathbf{1 :}$ & $\mathbf{2 :}$ & $\mathbf{3 :}$ & $\mathbf{4 :}$ & $\mathbf{5 :}$ & $\mathbf{6 :}$ & \multirow{2}{*}{ ( } \\
& UI-1 & UI-2 & UI-3 & EI-1 & EI-2 & EI-3 & Sum of lines \\
\hline 1: UI-1: sewerage coverage around PPA & 0 & 2 & 3 & 1 & 1 & 1 & $\mathbf{8}$ \\
2: UI-2: incidence of precarious settlement in PPA & 2 & 0 & 1 & 2 & 1 & 3 & $\mathbf{9}$ \\
3: UI-3: drainage system around the PPA & 3 & 2 & 0 & 1 & 1 & 1 & $\mathbf{8}$ \\
4: EI-1: PPA with vegetation coverage & 1 & 3 & 1 & 0 & 3 & 3 & $\mathbf{1 1}$ \\
5: EI-2: CU in PPA & 0 & 0 & 0 & 2 & 0 & 2 & 4 \\
6: EI-3: municipal macro-zoning in PPA & 1 & 3 & 1 & 3 & 3 & 0 & $\mathbf{1 1}$ \\
\hline Sum of columns & $\mathbf{7}$ & $\mathbf{1 0}$ & $\mathbf{6}$ & $\mathbf{9}$ & $\mathbf{9}$ & $\mathbf{1 0}$ & \\
\hline
\end{tabular}

Legend: PPA - Permanent preservation areas; UI - Urban indicators; EI - Environmental and management indicators; 0 - Not important (no influence on the system); 1 - Low importance (little influence on the system); 2 - Medium importance (medium influence on the system); 3 - Very important (strong influence on the system).

The MMP of each municipality determines the municipal environmental macro-zone, which delimits the relevant environmental fractions, indicating the use and occupation of land in these areas. The laws that institute MMPs generally consider environmental areas protected by state and federal legislation. Additionally, the municipal environmental licensing process includes the monitoring and control of these environmental macro-zones to avoid occupation and misuse of land in these areas.

\subsection{Model building: equations, standardization, and aggregates of the composite index}

Table 3 presents the results on the weighting for each indicator, obtained by multi-criteria analysis based on the Delphi method. The weights were used to compose Equations 1 through 6 for each indicator.

The urban indicator UI-1 estimates the percentage area of influence of PPAs having sewage systems (Equation 1). In theory, a sanitary sewage system reduces the possibility of undue discharge of effluents into urban water rivers, because residences connected to the sewage system do not directly dump sewage on the ground or into the river. A buffer zone (imaginary margin from the riverbed, similar to a protection zone) delimits the surrounding area based on the linear layout of the existing sewage networks, with a radius of $1 \mathrm{~m}$ on each side.

The UI-1 indicator could be improved by providing the exact number of households that are effectively connected to the sewerage system. However, in addition to the instability and continuous change in interconnected residences, information on the number of households not interconnected to the network is difficult to access. The urban indicator UI-2 partially resolves this problem by identifying the number of precarious settlements - houses with low or no access to infrastructure-located in the preservation area of urban water resources, discharging effluent into rivers, streams, lakes, and ponds.

The UI-3 indicator considers the importance of urban rivers for the drainage of large cities. It is essential that the urban drainage systems in the areas of influence of water resources be completely operational. The coverage of the urban drainage service in the areas of influence of PPAs is an indication of lower incidence of inundations and flooding in wetland areas. A buffer zone delimits this area of influence based on the linear layout of the respective drainage networks, with an adopted radius of $2 \mathrm{~m}$ for each side. 
Table 3. Code, description, weighting (AHP), and equation of each indicator according to the expert assessment for water resources PPAs in Fortaleza, 2020.

\begin{tabular}{|c|c|c|c|c|}
\hline Dimension & Code & Description of the Indicators & Weighting (AHP) & Equations \\
\hline \multirow{3}{*}{ Urban } & UI-1 & Percentage of PPA area with sewage system. & 0.26050 & Equation 1: UI1 $x, y=\left(\frac{\sum \text { APPse }}{\text { PPAtotal }}\right) 100$ \\
\hline & $\mathrm{UI}-2$ & $\begin{array}{l}\text { Percentage of PPA area with no incidence of precarious } \\
\text { settlement. }\end{array}$ & 0.63335 & Equation 2: UI2x,y $=100-\left(\frac{\sum P S}{\sum \text { PPAtotal }}\right) 100$ \\
\hline & UI-3 & Percentage of PPA area served by urban drainage system. & 0.10616 & Equation 3: $U I 3 x, y=\left(\frac{\sum D S}{\sum P P A \text { total }}\right) 100$ \\
\hline \multirow{3}{*}{$\begin{array}{l}\text { Environmental and } \\
\text { managerial }\end{array}$} & EI-1 & Percentage of PPA area with plant coverage. & 0.64339 & Equation 4: $E I 1 x, y=\left(\frac{\sum P P A v c}{\text { PPAtotal }}\right) 100$ \\
\hline & EI-2 & Percentage of PPA area included in CUs. & 0.07377 & Equation 5: EIx, $y=\left(\frac{\sum C U p p a}{\sum P P A t o t a l}\right) 100$ \\
\hline & EI-3 & Percentage of PPA area considered in municipal macro-zoning. & 0.28284 & Equation 6: $E I x, y=\left(\frac{\sum P P A m z}{\text { PPAtotal }}\right) 100$ \\
\hline
\end{tabular}

Legend: AHP = Analytic Hierarchy Process; PPA = Permanent Preservation Area; Code $=$ indicator code $; \mathrm{x}=$ municipality; $\mathrm{y}=\mathrm{year} ; \sum$ PPA total $=$ sum of total PPA area of water resources; $\sum$ PPAse = sum of PPA area that has sewage system; $\sum$ PS = sum of PPA areas without incidence of precarious settlements; $\sum$ DS $=$ sum of PPA area with urban drainage system; $\sum$ PPAvc $=$ sum of PPA area with vegetation coverage; $\sum$ CUppa $=$ sum of conservation units inserted in PPA; $\sum$ PPAmz $=$ sum of PPA areas inserted in municipal macro-zoning.

The environmental indicator EI-1 estimates the percentage area of the PPA with native or non-native plant coverage. The management indicator EI-2 evaluates the percentage of CUs inserted in the territory of the municipality that coincide with the area of the water resources PPAs. The management indicator EI-3 estimates the percentage of PPAs protected by municipal macro-zones. In general, the municipal macro-zoning is provided for in the MMP.

After normalization, integration is carried out by applying the results of the equations (Table 3) in Equation 7, wherein the result of each indicator is multiplied by its weight and divided by the number of indicators, to obtain the arithmetic mean.

PPAWater $=\frac{(0.26 I U 1)+(0.63 I U 2)+(0.10 I U 3)+(0.64 E I 1)+(0.07 E I 2)+(0.28 E I 3)}{6}$

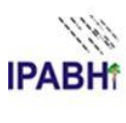

Rev. Ambient. Água vol. 16 n. 1, e2589 - Taubaté 2021 
Table 4 shows the interval scale of the PPAWater index with color distinction according to the intervals. On a scale from zero to 100 , the closer to 100 , the better the quality of the water resources PPAs. The higher the values of the indicators, according to the weights, the higher the quality of the PPAs. Next, possible scenarios are described for each level of the interval scale.

Table 4. Interval scale of the PPAWater* index.

\begin{tabular}{lc}
\hline Description of the levels & Interval \\
\hline Unconcerned management of PPAs & $0-20$ \\
Inefficient PPA management & $21-40$ \\
Regular management of PPAs & $41-60$ \\
Concerned management of PPAs & $61-80$ \\
Efficient management of PPAs & $81-100$ \\
\hline *Index of qualities of Urban Water Resource \\
Preservation Areas.
\end{tabular}

Unconcerned management of PPAs: Partial or total absence of sanitation infrastructure (sewage services, drainage system, water supply, and collection of solid waste) in the studied sub-basins or urban territory. Lack of an urban environmental management structure in the territory. Intense illegal occupation in the PPA areas.

Inefficient management of PPAs: Partial lack of sanitation infrastructure and inefficient sanitation services in the PPA areas. Existence of an agency to address the implementation of the environmental management policy in the studied territory. However, this agency does not operate satisfactorily and efficiently.

Regular management of PPAs: Existence of sanitation infrastructure with opportunities for improvement and greater coverage in the territory. Existence of an agency that deals with environmental management, with opportunities to improve its structure, governance, and implementation.

Concerned management of PPAs: Existence of sanitation infrastructure in most of the PPA areas that contribute to the dynamics of ecosystem services. Agencies responsible for environmental management policies are structured and in operation, but lack a long-term plan.

Efficient management of PPAs: Existence of sanitation infrastructure in the PPA areas. Presence of structured and planned environmental management agencies with an updated environmental information system that undertake environmental monitoring.

\subsection{Pilot study to apply the proposed PPAWater index}

The composite PPAWater index was applied to the seven typologies of the urban water resource PPAs of Fortaleza, Ceará, Brazil using 2018-2020 data. A priori, the PPAWater index was applied to the entire municipal territory of Fortaleza, presenting an overall result equal to 22.32 for PPA quality, on a scale from zero to 100 (the closer to 100, the better the quality of the water resources PPAs); the result classified the city under "inefficient management of PPAs". However, the overall result of PPA quality for the entire territory does not reveal the extremely uneven environmental quality of the city. Thus, the PPAWater index was applied to sub-river basins of the city of Fortaleza, which provided more accurate environmental quality results.

As shown in Figure 1, the sub-basins are classified by letters: "A" Vertente Marítima River Basin, "B" Cocó River Basin, "C" Maranguapinho River Basin, and "D” Pacoti River Basin. 


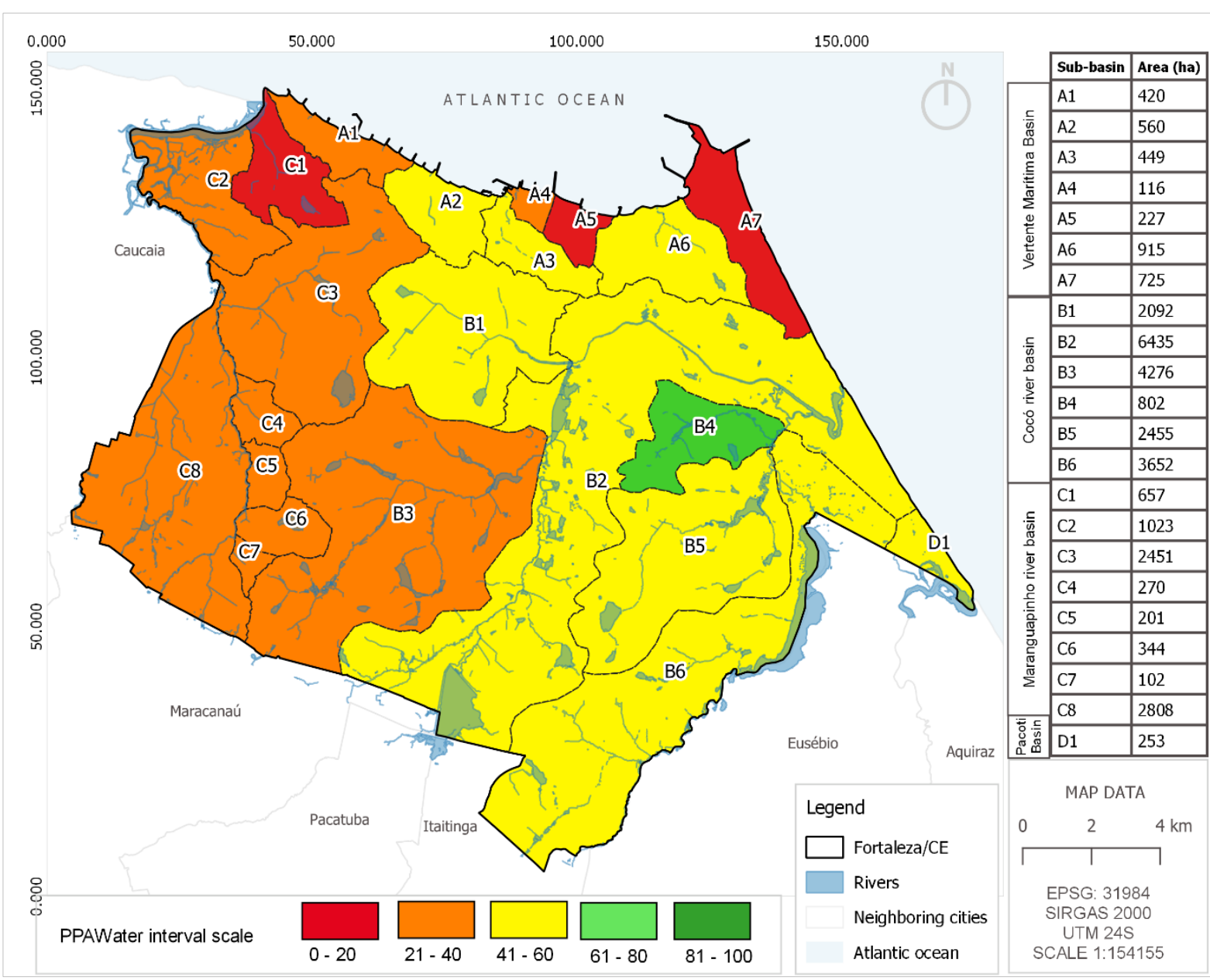

Figure 1. Application of PPAWater index to sub-river basins in Fortaleza, 2020.

Lower scores on the PPAWater scale were obtained for sub-basins with the most populated regions and poorest neighborhoods, revealing the low environmental quality of preservation areas. The sub-basins of Cocó River (B1 to B6), and other sub-basins of Vertente Marítima Basin (A2, A3, and A5), located in the upscale neighborhoods in the city, received a higher score, which can be attributed to urban infrastructure and a greater number of preservation areas. The sub-basins of the southern region of the city (B2, B4, B5, and B6) received the highest score. This region underwent urbanization more recently and the population density is lower compared to the sub-basins of the Maranguapinho River (C1, C2, C3, C4, C5, C6, C7, and C8). The areas with the highest incidence of CUs showed the highest PPA quality. These are areas of moderate urban occupation.

The results obtained for each dimension consider both the research data and field observations. In the urban dimension, according to the history of water quality monitoring in the urban lagoons and main rivers of Fortaleza, a large part of these water bodies are unsuitable for bathing because of a high level of silting. In some parts of the city, some sections of channelized rivers receive contributions from effluents of numerous residences along the banks of the canals. Sewage is released via urban drainage systems, with clandestine installations that drain effluents into rivers and lagoons; this also occurs at various points in the city.

The incidence of precarious settlements in the areas of influence of PPAs increases the vulnerability of urban water resources. The index reflects the inequality of the city, as precarious settlements occupy a total built area of $39,941,014 \mathrm{~m}^{2}$, which accounts for $32 \%$ $(246,231)$ of the residences in the city, of an estimated population of 1,077,059 (Fortaleza, 2015). In practice, the incidence of precarious settlements accompanies the design of urban 
rivers. This fact provides a strong tendency to exclude these areas in the urban context, as they are illegally occupied by individuals living on the margins of society. This situation has continued for several years, and can be interpreted as a local custom. This is a worrying finding in terms of several aspects, not only in relation to environmental issues, but also social, economic, and political concerns. The primary concerns are: people living in high-risk areas are susceptible to extreme events and the possible disposal of waste or untreated sewage in watercourses, as their houses have no sewage systems; proliferation of waterborne diseases from the consumption of polluted water; and consumption of fish from polluted waters, which can cause health problems, in addition to existing health problems.

Considering almost $40 \%$ drainage system coverage in PPAs, it is clear that the problem lies in the insufficient functioning of the systems as a result of the following factors: obstruction of drainage system by solid waste; illegal connections to the sewage system; and modifications that interfere with the flow of water. Additional problems include the fragmentation of the drainage system and its integration with intensely silted urban rivers that do not allow for satisfactory flow of water.

Regarding the environmental and management dimension, in 2019, the total area of the water resources PPAs in the municipality of Fortaleza was 3,530.28 ha. This area was estimated using geoprocessing tools (for example, software QGis), following that established in the New Brazilian Forest Code and its amendments. It was estimated that 596.47 ha $(16.9 \%)$ of the water resource PPAs in the city of Fortaleza were occupied. Within these occupied areas, 52\% were for residential use, $26 \%$ for mixed use, and $14 \%$ for commercial use.

The sum total area of the CUs in Fortaleza is 3,951 ha, with 1,920.68 ha for integral protection and 2,030.32 ha for sustainable use. Some CU areas overlap, leading to double protection. When the coincident areas are subtracted, the total area decreases to 3,693.58 ha. Most CUs in Fortaleza are near water resources, coinciding with the PPAs, that is, $42.02 \%$ $(1,483.66$ ha) of the CU areas are also water resources PPAs. The CUs, namely, Relevant Ecological Interest Area (REIA), Matinha do Pici, Cocó State Park, and Maraponga Lagoon, comprise approximately $50 \%$ of the areas included in PPAs. This coincidence can be considered as positive with regard to the protection of the water resources; however, it leads to legislative and management conflicts, as the Brazilian Forest Code offers more protective measures than certain categories of CUs. The EI-3 indicator estimates the percentage of PPA areas, established via the New Brazilian Forest Code, which are protected by municipality environmental macrozoning (established by the 2009 Master Plan and its amendments).

The calculation of the areas of Environmental Protection Zone-1 (EPZ-1; an environmental macro-zoning zone that functions to protect the water resources in the city of Fortaleza, similar to the environmental functions of the water resource PPAs), was based on the latest update of the Master Plan (Complementary Law No. 250/2018), with an estimated total of 3,530.28 ha of PPAs in the city of Fortaleza. Thus, it is estimated that $78.85 \%$ (2,783.89 ha) of the PPAs are protected by the municipality as EPZ-1. However, all areas considered in this percentage are not preserved, as some areas are occupied by pre-existing urban areas. The selected specialists evaluated this indicator as the most important, conveying the relevance of the Brazilian Forest Code in the considerations of municipal legislation. The data for occupied PPAs indicate that occupations are recurrent, particularly in areas not protected by municipal legislation. These results further confirm the importance of alignment of the MMP and the Brazilian Forest Code.

\section{CONCLUSIONS}

The following final considerations are made based on the development of this work: 
- The results offer an important scientific reference for land planning, use, and occupation, especially in the areas of water resources preservation.

- The PPAWater index is presented as an important tool in guiding urban environmental planning, public policy formulation, and management for protection of urban water resources.

- The accessibility of official data facilitates the application of the index and allows for annual monitoring. This contributes to the reliability of the data, which is essential to maintain the quality of the indicators.

- The application of the index to sub-basins leads to a better understanding of the dynamics of the built environment in relation to water resource preservation areas.

- The assessment of sub-basins in a municipal territory leads to a dialogue with municipal managers and urban planners. The results support and direct possible reformulations of urban legislation regarding the use and planning of environmentally relevant areas.

- The utilized environmental management indicators highlight the overlapping of environmental areas protected by law. This analysis directly supports the unification of environmental areas, especially the conservation units and preservation areas determined by the MMP.

- The index can help identify the areas that require prioritized attention for recovery and revitalization.

- The index colorimetric scale provides a more effective dissemination of the results and one may use it as a reference indicator in the monitoring of urban water resources PPAs.

- The index can be effectively applied on a local scale for urban agglomerations that present water resources in their territory in order to identify possible risk zones. Strategic planning is required for such zones to revitalize the preservation areas, with the participation of society and local researchers.

\section{ACKNOWLEDGEMENTS}

The authors would like to thank the Coordination for the Improvement of Higher Education Personnel (CAPES) for financing this research, through the process: 88882.343992/2019-01.

\section{REFERENCES}

AQUINO, M. D.; MOTA, S. Planejamento Ambiental e ordenamento territorial em bacias hidrográficas. In: PHILIPPI JR., A.; SOBRAL, M. DO C. Gestão de Bacias Hidrográficas e sustentabilidade. São Paulo: Manole, 2019. p. 185-204.

BAHN, G.; NA, B. Analysis of Environmental Purification Effect of Riparian Forest with Poplar Trees for Ecological Watershed Management: A Case Study in the Floodplain of the Dam Reservoir in Korea. Sustainability, v. 12, p. 1-12, 2020. http://dx.doi.org/10.3390/su12176871

BARROS, M. V. F.; MENDES, V.; CASTRO, P. H. M. Vulnerabilidade socioambiental à inundação na área urbana de Londrina/PR. Confins Revista Franco Brasileira de Geografia, v. 24, p. 1-21, 2015. https://doi.org/10.4000/confins.10228

CALDERON, M. R.; GONZÁLEZ, P.; MOGLIA, M.; GONZÁLES, S. O.; JOFRÉ, M. Use of multiple indicators to assess the environmental quality of urbanized aquatic surroundings in San Luis, Argentina. Environmental Monitoring and Assessment, v. 186, p. 44114422, 2014. https://doi.org/10.1007/s10661-014-3707-8 
CARPIO, O. V.; FATH, B. D. Assessing the Environmental Impacts of Urban Growth Using Land Use/Land Cover, Water Quality and Health Indicators: A Case Study of Arequipa, Peru. American Journal of Environmental Sciences, v. 7, n. 2, p. 90-101, 2011. https://doi.org/10.3844/ajessp.2011.90.101

CARSTENS, D.; AMER, R. Spatio-temporal analysis of urban changes and surface water $\begin{array}{lllllll}\text { quality. Journal of hydrology, } & \text { v. 569, p. } & \text { 720-734, }\end{array}$ https://doi.org/10.1016/j.jhydrol.2018.12.033

CEARÁ. Secretaria de Recursos Hídricos. Diagnóstico ambiental das bacias metropolitanas: elaboração do plano de segurança hídrica das bacias hidrográficas estratégicas do Acaraú, metropolitanas e da sub-bacia do Salgado. Fortaleza, 2018. 128 p.

COUTTS, A. M.; HARRIS, R. J.; PHAN, T.; LIVESLEY, S. J.; WILlIAMS, N. S. G.; TAPPER, N. J. Thermal infrared remote sensing of urban heat: Hotspots, vegetation, and an assessment of techniques for use in urban planning. Remote sensing of environment, v. 186, p. 637-651, 2016. https://doi.org/10.1016/j.rse.2016.09.007

DELLAMORA, F.; SILVEIRA, K.; TITOLLA, I. Indicadores de Sustentabilidade: estudo de caso de Erechim/RS. In: SEMINÁRIO NACIONAL DE CONSTRUÇÕES SUSTENTÁVEIS, 2., 7-8 Nov. 2013, Passo Fundo. Proceedings[...] Passo Fundo: SNCS, 2013. p. 1-9.

FEIL, A. A.; SCHREIBER, D. Análise da estrutura e dos critérios na elaboração de um índice de sustentabilidade. Sustentabilidade em debate, v.8, n. 2, p. 30-43, 2017. https://doi:10.18472/SustDeb.v8n2.2017.xxx

FLOSTRAND, A.; PITT, L.; BRIDSON, S. The Delphi technique in forecasting-A 42-year bibliographic analysis (1975-2017). Technological Forecasting \& Social Change, v. 150, 2020. https://doi.org/10.1016/j.techfore.2019.119773

FORTALEZA. Lei Complementar $\mathrm{n}^{\circ} 250$, de 3 de julho de 2018. Modifica a Lei Complementar $\mathrm{n}^{\circ} 62$ de 2 de fevereiro de 2009, que institui o Plano Diretor participativo de Fortaleza. Diário Oficial [do] Município, Fortaleza, 31 July 2018.

FORTALEZA. Instituto de planejamento de Fortaleza. Fortaleza 2040: Fortaleza hoje. 2015. Available at: https://fortaleza2040.fortaleza.ce.gov.br/site/assets/files/publications/fortaleza2040_imostra-virtual_11-09-2015.pdf. Access: March 2020.

FORTALEZA. Prefeitura municipal. Fortaleza em mapas. Available at: https://digital.fortaleza.ce.gov.br/planejamento-e-gestao/fortaleza-em-mapas. Access: Jan. 2020.

FREITAS, E. P.; MORAES, J. F. L.; PECHE FILHO, A.; SANTORINO, M. Indicadores ambientais para Área de Preservação Permanente. Revista Brasileira de Engenharia Agrícola e Ambiental, v. 17, n. 14, p. 443-449, 2013. http://dx.doi.org/10.1590/S141543662013000400013

FRICK, A.; TERVOONREN, S. A Framework for the Long-term Monitoring of Urban Green Volume Based on Multi-temporal and Multi-sensoral Remote Sensing Data. Journal of geovisualization and spatial analysis, v. 3, n. 6, 2019. https://doi.org/10.1007/s41651019-0030-5 
GAO, Z.; KII, M.; NONOMURA, A.; NAKAMURA, K. Urban expansion using remotesensing data and a monocentric urban model. Computers, environment and urban systems, v. 77, 2019. https://doi.org/10.1016/j.compenvurbsys.2017.05.002

GASS, S. L. B.; VERDUM, R.; CORBONNOIS, J.; LAURENT, F. Áreas de Preservação Permanente (APPs) no Brasil e na França: um comparativo. Revista Franco-Brasileira de Geografia Confins, v. 17, 2016. https://doi.org/10.4000/confins.10829

GODET, M.; DURANCE, P. A prospectiva estratégica para as empresas e os territórios. DUNOD: UNESCO, 2011. 180 p.

HEGAZY, I. R.; KALOOP, M. R. Monitoring Urban Growth and Land Use Change Detection with GIS and Remote Sensing Techniques in Daqahlia Governorate Egypt. International Journal of Sustainable Built Environment, v. 4, p. 117-124, 2015. https://doi.org/10.1016/j.ijsbe.2015.02.005

HUANG. L.; WU, J.; YAN, L. Defining and measuring urban sustainability: a review of $\begin{array}{llllll}\text { indicators. Landscape Ecology, } & \text { v. } 30, \quad \text { p. } & 1175-1193,\end{array}$ https://doi.org/10.1007/s10980-015-0208-2

IBGE. Estimativas da população dos municípios para 2019. Rio de Janeiro, 2019.

KLOPP, J. M.; PETRETTA, D. L. The urban sustainable development goal: indicators, complexity and the politics of measuring cities. Cities, v. 63, p. 92-97, 2017. https://doi.org/10.1016/j.cities.2016.12.019

LEITE, L. H.; BARROS, V. C. C.; MONTEIRO, M. E. C.; MORAES FILHO, L. O.; BORGES, L. A. C. Permanent preservation areas in Mantiqueira sierra: perspectives for regularization along watercourses. Revista Ambiente \& Água, v. 15, n. 1, 2019. https://doi:10.4136/ambi-agua.2422

LIU, X.; HE, J.; YAO, Y.; ZHANG, J.; LIANG, H.; WANG, H.; HONG, Y. Classifying urban land use by integrating remote sensing and social media data. International Journal of $\begin{array}{lllllll}\text { Geographical Information } & \text { Science, } & \text { v. } & 31, & \text { n. } & 8, & \end{array}$ http://dx.doi.org/10.1080/13658816.2017.1324976

MARINO, M. T. R. D; FREIRE, G. S. S.; HORN, N. O. F. Aspectos Geológicos e Geomorfológicos da Zona Costeira entre as Praias do Futuro e Porto das Dunas, Região Metropolitana de Fortaleza, (RMF), Ceará, Brasil. Revista de Geologia, v. 25, n. 01, p. 77-96, 2012.

MARQUES, J. B. V.; FREITAS, D. Método Delphi: caracterização e potencialização na pesquisa em Educação. Revista Pro-posições, v. 29, n. 2, p. 389-415, 2018. http://dx.doi.org/10.1590/1980-6248-2015-0140

MORENO PIRES, S. M.; FIDELIS, T.; RAMOS, T. B. Measuring and comparing local sustainable development through common indicators: Constraints and achievements in practice. Cities, v. 63, p. 92-97, 2014. https://doi.org/10.1016/j.cities.2014.02.003

OECD. Handbook on Constructing Composite Indicators: methodology and user guide, Bruxelas: European commission, 2008, 163 p.

PEDROSO JR., N. N.; STEINMETZ, S.; SANTOS, A. de C. dos; CRUZ, J. C. da C. (Coord.). Estratégia Regulatória para Áreas de Preservação Permanente Urbanas. Relatório Final Projeto de APPs urbanas. São Paulo: FGV Direito SP, 2015. 74 p. 
REISI, M.; AYE, A.; RAJABIFARD, A.; NGO, T. Transport sustainability index: Melbourne

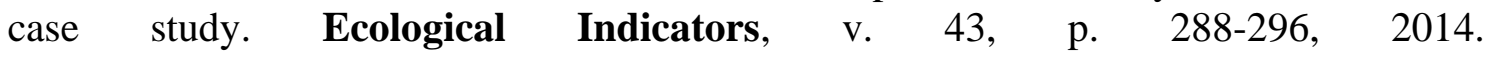
https://doi.org/10.1016/j.ecolind.2014.03.004

RIBEIRO, B. M. G.; MENDES, C. A. B. Índice de Qualidade Ambiental Urbano: uma proposta metodológica aplicada a áreas urbanas de ocupação irregular. In: SIMPÓSIO BRASILEIRO DE SENSORIAMENTO REMOTO, 17., 25-29 Apr. 2015, João Pessoa. Proceedings [...] São José dos Campos: INPE, 2015. p. 6550-6557.

SAATY, T. L. Método de Análise Hierárquica. São Paulo: Makron Books, 1991. 326 p.

SINGH, S. K.; SINGH, P.; GAUTAM, S. K. Appraisal of urban lake water quality through numerical index, multivariate statistics and earth observation data sets. International Journal of Environmental Science and Technology, v. 13, p. 445-456, 2016. http://doi.org/10.1007/s13762-015-0850-x

TU, J. Spatially varying relationships between land use and water quality across na urbanization gradient explored by geographically weighted regression. Applied Geography, v. 31, n. 1, p. 376-392, 2011. https://doi.org/10.1016/j.apgeog.2010.08.001

TU, W.; HU, Z.; LI, L.; CAO, J.; JIANG, J.; LI, Q.; LI, Q. Portraying Urban Functional Zones by Coupling Remote Sensing Imagery and Human Sensing Data. Remote sensing, v. 141, n. 10, p. 1-20, 2018. http://doi:10.3390/rs10010141

URIARTE, M.; YACKULIC, C. B.; LIM, Y.; ARCE-NAZARIO, J. A. Influence of land use on water quality in a tropical landscape: a multi-scale analysis. Landscape Ecology, v. 26, n. 8, p. 1151-1164, 2011. http://doi:10.1007/s10980-011-9642-y

XIE, W.; HUANG, Q.; HE, C.; ZHAO, X. Projecting the impacts of urban expansion on simultaneous losses of ecosystem services: A case study in Beijing, China. Ecological indicators, v. 84, p. 183-193, 2018. https://doi.org/10.1016/j.ecolind.2017.08.055

ZHAO, W.; ZHU, X.; SUN, X.; SHU, Y.; LI, Y. Water quality changes in response to urban expansion: spatially varying relations and determinants. Environmental Science and Pollution Research, v. 22, p. 16997-17001, 2015. http://doi:10.1007/s11356-015-4795-x 


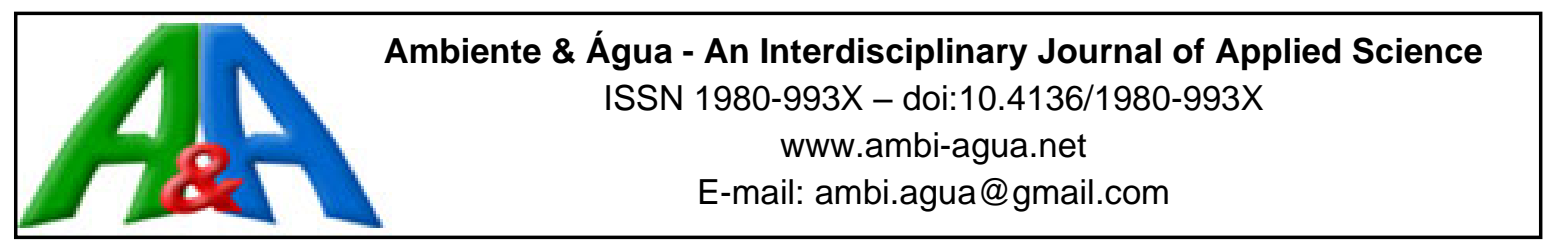

\title{
Probability of rainfall for the city of Cruzeiro do Sul, Acre, Brazil
}

\author{
ARTICLES doi:10.4136/ambi-agua.2593
}

Received: 09 Jun. 2020; Accepted: 03 Nov. 2020

\author{
Jefferson Rodrigues dos Santos Silva ${ }^{1}$; ; Matheus Kucmanski Taveira2 ${ }^{2}$; \\ Rodrigo Otávio Peréa Serrano ${ }^{1}$; Anderson Azevedo Mesquita ${ }^{3}{ }^{(D}$; \\ José Genivaldo do Vale Moreira ${ }^{4 *(i D)}$
}

\author{
${ }^{1}$ Programa de Pós-Graduação em Ciência, Inovação e Tecnologia para a Amazônia (PPG-CITA). \\ Departamento de Filosofia e Ciências Humanas. Universidade Federal do Acre (UFAC), \\ Rodovia BR 364, Km 04, CEP: 69920-900, Rio Branco, AC, Brazil. \\ E-mail: jeffersonrodriguesssilva@gmail.com,ropereas@gmail.com \\ 2Departamento de Agronomia. Universidade Federal do Acre (UFAC), Rodovia BR 364, Km 04, \\ CEP: 69920-900, Rio Branco, AC, Brazil. E-mail: matheustaveira.mt23@gmail.com \\ ${ }^{3}$ Departamento de Filosofia e Ciências Humanas. Universidade Federal do Acre (UFAC), Rodovia BR 364, \\ Km 04, CEP: 69920-900, Rio Branco, AC, Brazil. E-mail: amgeoufac@ hotmail.com \\ ${ }^{4}$ Universidade Federal do Acre (UFAC), Campus Floresta, Gleba Formoso, Lote 245, CEP: 69980-000, Cruzeiro \\ do Sul, AC, Brazil. \\ *Corresponding author. E-mail: genivaldoufac@gmail.com
}

\begin{abstract}
Due to randomness in the occurrence of hydrological phenomena, the estimation of probable rain precipitation in a given region is important in assisting decision-making. This work aimed to adjust the probabilistic model of the Gamma distribution to the monthly and annual rainfall totals recorded in the city of Cruzeiro do Sul, Acre, for the period between 1970 and 2019, in addition to estimating the expected values at different probability levels. Using the maximum likelihood method, the distribution parameters were estimated, with adherence ratified by the Kolmogorov-Smirnov test. The results showed that the Gamma distribution was adequate to adjust the data; the region has two well-defined periods in its rainfall pattern; the mean precipitation values recorded in the locality are between $25 \%$ and $40 \%$ of probability. Finally, probable rainfall values were presented at different probability levels for the city of Cruzeiro do Sul.
\end{abstract}

Keywords: agricultural planning, expected rain precipitation, probability distribution.

\section{Probabilidade de precipitação para a cidade de Cruzeiro do Sul, Acre, Brasil}

\section{RESUMO}

Devido a aleatoriedade na ocorrência dos fenômenos hidrológicos, a estimação das precipitações prováveis em determinada região é importante para auxiliar na tomada de decisão. O presente trabalho objetivou ajustar o modelo probabilístico da distribuição Gama aos totais mensais e anuais de precipitação pluviométrica registrados na cidade de Cruzeiro do Sul, Acre, para o período compreendido entre 1970 e 2019, além de estimar os valores esperados em diferentes níveis de probabilidade. Valendo-se do método da máxima verossimilhança foram 
estimados os parâmetros da distribuição, com aderência ratificada pelo teste de KolmogorovSmirnov. Os resultados apontaram que: a distribuição Gama mostrou-se adequada ao ajuste dos dados; a região possui dois períodos bem definidos em seu padrão pluviométrico; os valores médios de precipitação registrados na localidade estão entre $25 \%$ e $40 \%$ de probabilidade. Finalmente, foram apresentados valores prováveis de precipitação pluviométrica em diferentes níveis de probabilidade para a cidade de Cruzeiro do Sul.

Palavras-chave: distribuição de probabilidades, planejamento agrícola, precipitação esperada.

\section{INTRODUCTION}

Rainfall is a meteorological event with great influence on environmental conditions, as well as on various human activities. In fact, rain is a hydrological element that triggers many other processes, as it is the entry component into the water balance of a region, and the results of such interactions have influenced human activities for milenia (Moreira et al., 2016; Passos et al., 2017; Miguez et al., 2018; Santos et al., 2019).

Rain is the beginning of a process that results in providing basic human needs and boosting important activities, such as industry, agriculture, energy transformation, etc. In modern society, the hydrological elements related to rainfall strongly influence the social and economic development of nations (Baptista and Coelho, 2010; Moreira et al., 2016).

According to Martins et al. (2010), of all segments of the economy, agriculture represents the sector presenting the greatest dependence on climatic variables, especially concerning rainfall, whose impact is responsible for significant fluctuations over the years.

The region under study, for example, has cassava cultivation as the main agricultural product, which is important even in the national market. This crop culture, in turn, depends heavily on the spatial and temporal distribution of rainfall (Brito et al., 2019). Therefore, the results verified in the present study suggest favorable conditions for cassava cultivation, since they point to good rainfall distribution in the region, which presented a monthly average of more than $70 \mathrm{~mm}$, even in the less rainy months.

In this sense, the study conducted by Flores (2015) points out that, in the state of Acre, the cultivation of cassava crops is concentrated in the months at the start of the rainy season (October to December), ensuring the supply of water, indispensable for the initial growth of plants. The adequate rainfall amount is between 1,000 and $1,500 \mathrm{~mm} /$ year, well distributed;however, the crop produces reasonably well in localities with rainfall indexes of up to $4,000 \mathrm{~mm} /$ year, when this occurs on well drained soils (Souza et al., 2006).

Therefore, previous knowledge about the behavior of the rainfall regime in a particular region is of fundamental importance for agricultural planning, because the success of activities involving the sector is directly linked to the occurrence and magnitude of rainfall (Arai et al., 2009; Souza et al., 2018). Cassava crop, for example, of which Brazil is the fourth largest producer in the world, demands climatic conditions as a regulatory factor of its production, especially concerning the precipitation regime, which requires effective management of soil and drainage conditions (Martins et al., 2010; Soman et al., 2016; Moreto et al., 2018).

Given the importance of rainfall, especially in a regional context, the need to quantify and/or predict its occurrences has become an essential condition for the development of agricultural activities, besides many other productive segments. Thus, scientific and technological advances allowed the creation of efficient instruments aiming at this purpose, especially those proposed taking into consideration the basic characteristic of randomness present in the occurrence of these phenomena (Moreto et al., 2018; Bortoluzzi et al., 2019).

Because rainfall is a phenomenon dependent on several stochastic factors, the use of models inserted in the scope of probability distributions becomes coherent, which allows, 
among other things, the estimation of probable amounts of monthly or annual rain precipitation for a given locality. These instruments are important tools to assist decision-making in the planning of various activities related to agriculture, livestock, civil construction, transportation, etc. (Pizzato et al., 2012; Passos et al., 2017).

Indeed, the statistical modeling in hydrological studies is extremely important regarding the prediction of events associated with the probability of their occurrences, as elucidated by the study conducted by Abreu et al. (2018). In the work, the authors inserted the probability models in the relationship of practices allied to the rational planning of the various activities that depend on the dynamics involved in the occurrence of rainfall. In turn, Costa and Fernandes (2015) considered it as one of the basic stages sustaining decision-making, especially in the present context, whose theme is recurrent in the literature of the specialty.

In this sense, there are several distributions to be adjusted to the temporal record of hydrological variables. In the present context, in which it is proposed to estimate the total amounts of probable rainfall in the city of Cruzeiro do Sul, State of Acre, Brazil, contextualized in monthly and annual intervals, the Gamma distribution presents assumptions that give it prominence among the others (Teixeira et al., 2013; Bermudez et al., 2017; Abreu et al., 2018).

In the light of these considerations, the aim of the present work was to estimate the probable values of rainfall amount, at different probability levels, for the city of Cruzeiro do Sul, Acre, Brazil, based on the recorded events occurred in the period between 1970 and 2019, records of which are made available by the National Institute of Meteorology - INMET.

Among many factors to support the research, the productive potential of the region stands out, especially for the cassava cultivation, influenced by its pluviometric regime, which can impact both agricultural activity and other segments.

In addition, the realization of this work is justified, since the estimated values of rainfall precipitation can be influenced over time, due to several factors, among them, the climatic changes credited to anthropic actions, as well as those related to the natural climate variability that, collectively or in isolation, have an effect on the hydrological processes operating in the region (Moreira et al., 2019; Marengo and Souza Júnior, 2018).

\section{MATERIALS AND METHODS}

The city of Cruzeiro do Sul is located in the Vale do Juruá region, in the state of Acre. The predominant climate in the region, according to the Köppen classification, is the humid tropical (Af), with an average annual temperature of approximately $24.5^{\circ} \mathrm{C}$ (Moreira et al., 2016; 2019). However, given the nature of the work, Nimer's model was adopted as a reference, which seeks to integrate traditional and dynamic methods to better understand the complex ecological relationships of Brazilian biodiversity (Nimer, 1979). The climatic classification of Nimer (1979), prioritizes the influence of temperature and humidity on climatic diversity, and in turn, it is based on dynamic climatology and the rhythm of air masses. Thus, for the studied region, the Equatorial hot climate type is observed, with a daily average temperature above $18^{\circ} \mathrm{C}$ in all months, and with the distribution of humidity of the super-humid type to the sub-dry type (Figure 1).

The region has a drier period (May to September) and a notably rainy period (October to April), with annual rainfall averages of approximately 2,000 mm (Moreira et al. 2016; 2019). Therefore, it is observed that among the three zones of humidity variation identified in the classification of Nimer (1979), the Cruzeiro do Sul region is highlighted for having the highest moisture distribution.

In this work, the total monthly and annual rainfall data was used, computed for the city of Cruzeiro do Sul, during the period from 1970 to 2019, recorded at the meteorological station 82704 ( $7^{\circ} 38^{\prime} \mathrm{S} ; 72^{\circ} 40^{\prime} \mathrm{W}$, in datum WGS84), operated by the National Institute of Meteorology (INMET) (Souza et al., 2011; Moreira et al., 2019) (Figure 1). There are occasional failures in 
the records in the years 1991 and 1992, corresponding to $4 \%$ of the records, whose monthly values were filled out using the regional weighting method (Oliveira et al., 2010).

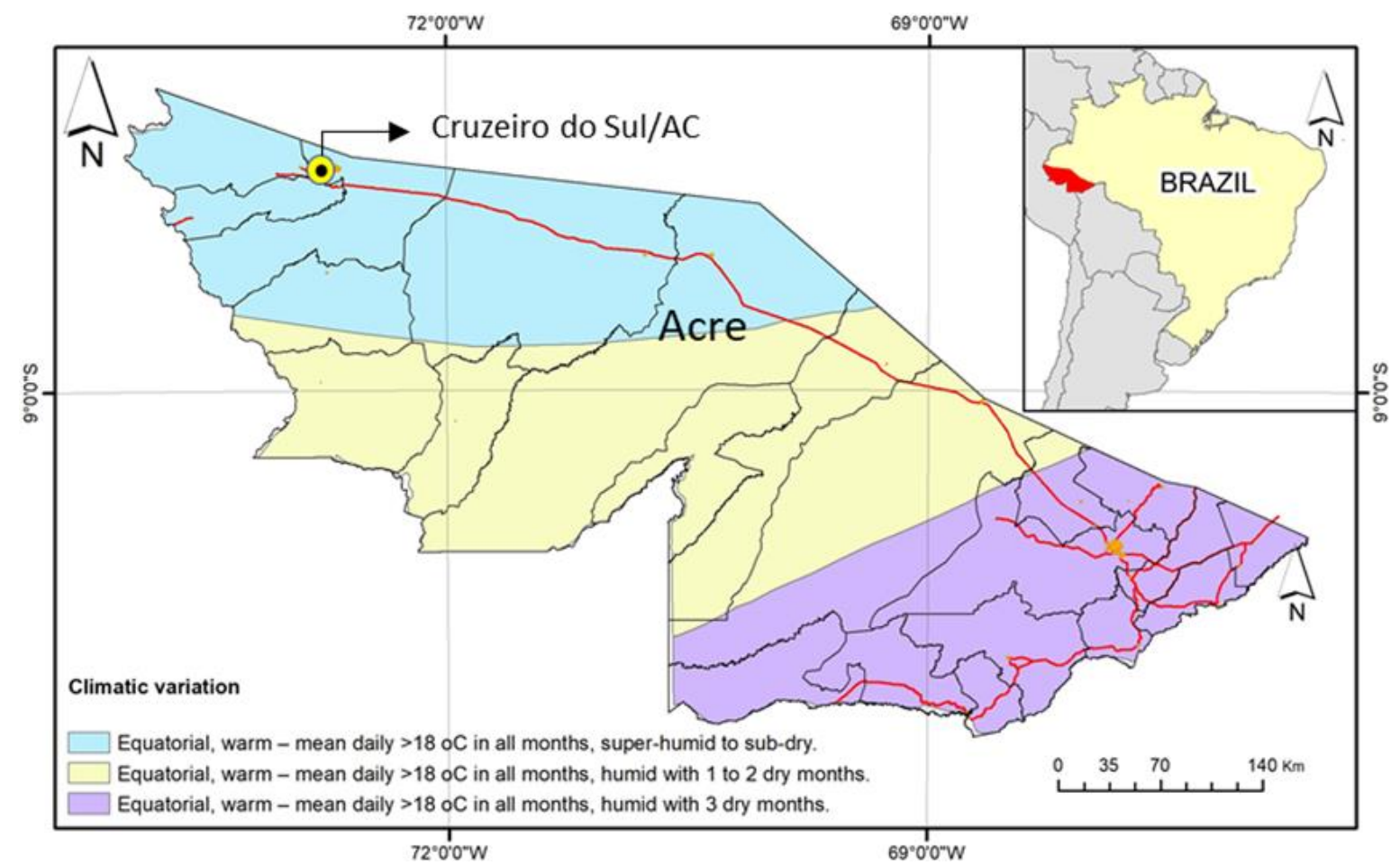

Figure 1. Location of the city of Cruzeiro do Sul and climatic variation throughout the State of Acre (Brazil).

Source: IBGE, 2018.

The data were adjusted to the Gamma distribution, which according to Araújo et al. (2001) and Bazame et al. (2018) is the most-used formulation to adjust total rainfall records. According to Passos et al. (2017), the Gamma distribution has been positively reported in several studies as a reliable probability distribution for the analysis of total rainfall. The authors used it to estimate the probable rainfall at different levels of probability for the Municipality of Chapadinha-MA. Dallacort et al. (2011) used the Gamma distribution in a study of total rainfall distribution in the city of Tangará da Serra, Mato Grosso, and reported satisfactory results.

The distribution parameters were estimated using the maximum likelihood method (Araújo et al., 2001; Barbieri et al., 2019). From there, the probable rainfall for the city of Cruzeiro do Sul was determined at different probability levels. As described by Araújo et al. (2001) and Martins et al. (2010), the cumulative function of probabilities of the distribution (CFP) of Gamma is given by Equation 1:

$\mathrm{F}(\mathrm{x})=\frac{1}{\Gamma(\alpha) \beta^{\alpha}} \int_{0}^{\mathrm{x}} \mathrm{x}^{\alpha-1} e^{-\frac{x}{\beta}} \mathrm{dx}$

In Equation 1, $\alpha$ is the shape parameter and $\beta$ is the scale parameter; $\mathrm{e}$ is the basis of the Napierian logarithm; $x$ represents the total rainfall $(\mathrm{mm})$; and $\Gamma(\alpha)$ is the symbol of the Gamma function, defined according to the function (Equation 2):

$$
\Gamma(\alpha)=\sqrt{2 \pi \alpha} \alpha^{\alpha} e^{\alpha}\left(1+\frac{1}{12 \alpha}+\frac{1}{288 \alpha^{2}}-\frac{139}{51840 \alpha^{3}}\right)
$$


As described by Araújo et al. (2001) and Teixeira et al. (2013), the parameters that allow the cumulative Gamma distribution, estimated by the maximum likelihood method, are determined by the following Equations ( 3 and 4):

In which:

$\beta=\frac{\bar{x}}{\alpha} \quad$ e $\quad \alpha=\frac{1}{4 A}\left(1+\sqrt{1+\frac{4 A}{3}}\right)$

$\mathrm{A}=\ln (\bar{X})-X_{g}$

In Equation 4, $\bar{X}$ represents the arithmetic mean of the observation series, $X_{g}$ the geometric mean, and $\mathrm{N}$ represents the number of elements in the historical series under test.

The adherence of data adjustment to the Gamma distribution was verified using the Kolmogorov-Smirnov test (KS test), at the significance level of 5\% (Marsaglia et al., 2003; Silva, 2015; Moreira et al., 2016).

Finally, the probable rainfall quantiles associated with probability levels of 5, 10, 25, 40, $50,60,75,90$, and $95 \%$ were determined. It should be noted that, because the calculations would require too much effort and complex routine, they were carried out using statistical software specially designed for this purpose, such as the packages base and fitdistrplus $\mathrm{R}$ packages (Delignette-Muller and Dutang, 2015; R Core Team, 2019) in addition to the ALEA (Local Frequency Analysis of Annual Events) (Lima et al., 2015).

\section{RESULTS AND DISCUSSION}

Table 1 presents a descriptive summary related to total, monthly, and annual rainfall recorded for the city of Cruzeiro do Sul, Acre, for the period from 1970 to 2019.

Table 1. Descriptive summary of total, monthly, and annual rainfall observations recorded in Cruzeiro do Sul, Acre, from 1970 to 2019. Estimated parameters $\alpha$ (form) and $\beta$ (scale) of the Gamma distribution and test and p-value statistics referring to the KolmogorovSmirnov adherence test for the data under analysis.

\begin{tabular}{ccccccccc}
\hline \multirow{2}{*}{ Month } & \multirow{2}{*}{$\begin{array}{c}\text { Mean } \\
(\mathrm{mm})\end{array}$} & \multirow{2}{*}{$\begin{array}{c}\text { Minimal } \\
(\mathrm{mm})\end{array}$} & $\begin{array}{c}\text { Maximal } \\
(\mathrm{mm})\end{array}$ & $\begin{array}{c}\mathrm{CV} \\
(\%)\end{array}$ & $\begin{array}{c}\alpha \\
\text { (form) }\end{array}$ & $\begin{array}{c}\beta \\
(\text { scale) }\end{array}$ & \multicolumn{2}{c}{ Test KS } \\
\hline January & 246.20 & 75.50 & 484.00 & 35.87 & 7.12 & 34.57 & 0.10 & $0.69^{\mathrm{NS}}$ \\
February & 246.20 & 61.80 & 454.80 & 35.71 & 6.78 & 36.31 & 0.09 & $0.85^{\mathrm{NS}}$ \\
March & 273.90 & 40.80 & 448.50 & 35.94 & 6.41 & 42.71 & 0.11 & $0.62^{\mathrm{NS}}$ \\
April & 216.40 & 59.80 & 448.70 & 38.48 & 6.37 & 33.95 & 0.11 & $0.55^{\mathrm{NS}}$ \\
May & 148.40 & 42.20 & 308.00 & 43.24 & 5.16 & 28.72 & 0.11 & $0.61^{\mathrm{NS}}$ \\
June & 88.33 & 1.20 & 219.20 & 54.68 & 2.68 & 33.01 & 0.09 & $0.82^{\mathrm{NS}}$ \\
July & 70.26 & 4.20 & 230.90 & 71.65 & 1.87 & 37.63 & 0.08 & $0.83^{\mathrm{NS}}$ \\
August & 77.28 & 10.50 & 194.70 & 46.62 & 4.24 & 18.21 & 0.11 & $0.56^{\mathrm{NS}}$ \\
September & 122.90 & 30.20 & 340.30 & 54.79 & 3.31 & 37.05 & 0.10 & $0.69^{\mathrm{NS}}$ \\
October & 196.70 & 62.60 & 508.70 & 47.49 & 5.26 & 37.39 & 0.15 & $0.20^{\mathrm{NS}}$ \\
November & 210.20 & 54.80 & 480.20 & 44.38 & 5.09 & 41.24 & 0.06 & $0.99^{\mathrm{NS}}$ \\
December & 240.30 & 99.00 & 438.10 & 32.38 & 9.49 & 25.31 & 0.09 & $0.81^{\mathrm{NS}}$ \\
\hline Annual & $2,137.00$ & $1,100.50$ & $2,848.10$ & 18.03 & 27.60 & 77.42 & 0.13 & $0.39^{\mathrm{NS}}$ \\
\hline
\end{tabular}

$\mathrm{CV}=$ Coefficient of Variation; NS = Not significant, at significance level 5\%.

From the descriptive summary presented in Table 1, it was observed that the month of March presented the highest average value of total monthly precipitation for the period under 
analysis, while the lowest value was observed for the month of July, which is typical for a subarid month, with precipitations greater than $60 \mathrm{~mm}$, constructed based in the climate classification of Nimer (1979).

It was also verified that the total monthly precipitation recorded in Cruzeiro do Sul presented great variability, with a coefficient of variation between $32.38 \%$ and $71.65 \%$, being the highest value observed during the dry period (low average value of total monthly precipitation), whereas the lowest variation is associated with the rainy season. Many causes can be related to the variability observed, including the atmospheric circulation patterns prevalent in the Amazon region, influenced by disturbances both on a regional and global scale. Such disturbances affect the hydrological regime of the region in its temporal scale (Nobre et al., 2007; Nóbrega, 2014). In addition, other processes such as ENSO (El Niño - Southern Oscillation), SACZ (Southern Atlantic Convergence Zone), among others, may be related to this variability, since the study proposed by Santos et al. (2013) presented as part of its conclusions that such singularities influence the rainfall regime of the Amazon, which encompasses the region under study. In addition, it was found that the city of Cruzeiro do Sul presented an average annual rainfall value of 2,137 $\mathrm{mm}$ for the period under study.

The descriptive values also show that the locality under study has a rainfall pattern characterized by two well-defined periods: a sub-arid period, according to the climatic classification of Nimer (1979), between the months of May to September, with emphasis on the months of July and August, which presented the lowest mean values of rainfall (Table 1); and a remarkably rainy period, specially from October to April. This verification confirms the characteristics reported by Moreira et al. (2016), whose study also analyzed the rainfall regime in the city of Cruzeiro Sul, but with a different objective than that of this work.

Regarding the period of higher and lower rainfall concentration, the conclusions presented in the study conducted by Silva et al. (2019) indicate that the rainfall regime of the region that covers the municipality of Goiana, in the state of Pernambuco, Brazil, is different than the results found in the present study. In their work, the authors conclude that the month of June is the rainiest, while the month of November has the lowest volume of rainfall. The study conducted by Bezerra et al. (2010), obtained results similar to the present study on the rainfall regime, registered in Porto Velho. The comparisons reveal the importance of studies on a regional scale in relation to the planning of activities that are impacted by the rainfall regime, especially in projects focused on the agricultural sector, because of the particularities of each kind of crop culture and region.

Table 1 also presents the estimated parameters of the Gamma distribution ( $\alpha$ and $\beta$ ), in addition to the results related to the Kolmogorov-Smirnov adherence test (KS test). The results from the KS test were sufficient to conclude that the Gamma distribution was adequately adjusted to the observed rainfall records, both monthly and annual, because the p-value associated with each statistic calculated value of the test was higher than the level of significance adopted (5\%). This conclusion is in accordance with that presented in the study proposed by Silva et al. (2019), where the authors attest that this distribution can thus be used to estimate amounts of probable rainfall.

In relation to the parameters of form and scale ( $\alpha$ and $\beta$ ), estimated by the maximum likelihood method, they were adequate to the rainfall data analyzed, both in monthly and annual interstices, since none of the estimated values for the scale parameter was higher than 100, which condition recommends the use of the Gamma distribution for the determination of probable precipitation values, as reported in several studies (Araújo et al., 2001; Martins et al., 2010; Silva et al., 2019). In relation to the form parameter, Silva et al. (2019) point out that it should not exceed the value of 10 . Thus, the values estimated from the rainfall observations analyzed were below the limiting value and, therefore, the distribution, as it is proposed, is adequate to the estimate of probable rainfall values in the city of Cruzeiro do Sul, and thus it is 
maintained.

It was verified, in the present study, that the interannual variation of the values of total monthly precipitation recorded in Cruzeiro do Sul, represented in Table 1 by the coefficient of variation $(\mathrm{CV})$, is higher for the months in which the form parameter $(\alpha)$ presents its lowest values. The interval is coincident with the dry period, in which the lowest average values of the monthly rainfall records are concentrated.

The study conducted by Martins et al. (2010) presented an inverse conclusion to that of the present study, regarding the relationship between the interannual variation and the form parameter. However, the conclusions of both converge to the indication that this parameter can be used in the determination of regular periods of precipitation.

Table 2 lists the values of probable monthly and annual rainfall at different probability levels estimated for the city of Cruzeiro do Sul according to the Gamma distribution. The results presented show that, in general, the average values of total rainfall, both monthly and annual, recorded for the city of Cruzeiro do Sul during the period in study, are equivalent to estimated values included in the range between the levels of $25 \%$ and $40 \%$ of probability (Table 1 ). This characteristic is observed in many studies related to probable rainfall for different regions and/or hydrological contexts (Martins et al., 2010; Passos et al., 2017). On the other hand, there are reports in which the average records, although close to values verified in this study, are in a different range of probability levels, as was verified by Silva et al. (2013), who studied distribution of rainfall in the city of Sapezal, State of Mato Grosso, Brazil.

The probable rainfall values, shown in Table 2, are important elements to support the rational planning of activities that depend on this hydrological variable, such as agricultural activity. Since the region under study has potential for cassava cultivation (Brito et al., 2019), the probable rainfall values with a certain margin of confidence promote more consistent decision-making in agricultural planning and for the most diverse areas of knowledge.

It is noteworthy, nevertheless, that both the scientific community and other organizations are already reaching the consensus that the impacts of climate change (on a global and/or regional scale) are already influential on the Amazon. As a result, the rainfall regime in the region under study may change its patterns and, consequently, the estimated values, since hydrological processes, especially rainfall regime, are quite sensitive to climate change (Moreira et al., 2019; Marengo and Souza Júnior, 2018).

\section{CONCLUSIONS}

The study produced satisfactory results that may serve as a catalyst for further discussion and development, and reached the following conclusions: 1) The Gamma probability model was adequately adjusted to the total monthly and annual rainfall data computed for the city of Cruzeiro do Sul, Acre; 2) The region under study presents a rainfall pattern defined in two welldefined periods: a sub-dry period, between the months of May and September, in special the months of July and August, in addition to a remarkably rainy period, more evident in the period from October to April; and, 3) The average values of total precipitation, both monthly and annually, recorded in the city of Cruzeiro do Sul during the period from 1970 to 2019, are equivalent to estimated values included in the range between the levels of $25 \%$ and $40 \%$ of probability.

The conclusions are in accordance with the study's objectives, and will serve as a basis for further studies in the region. It will also provide support and decision-making tools, especially with regard to agricultural activity, which depends on estimated rainfall values.

It is important to emphasize that, even with favorable results, it is not intended that the discussion end here; rather, hypotheses regarding the behavior of phenomena that operate in the region must be evaluated, and future studies with suitable methodology must be conducted in similar and dissimilar regions as appropriate.

Rev. Ambient. Água vol. 16 n. 1, e2593 - Taubaté 2021 
Table 2. Probable monthly and annual rainfall for the city of Cruzeiro do Sul, Acre, at different probability levels, estimated according to the Gamma probability distribution.

\begin{tabular}{cccccccccc}
\hline \multirow{2}{*}{ Month } & \multicolumn{7}{c}{ Probable pluviometric precipitation (mm) } \\
\cline { 2 - 9 } & $5 \%$ & $10 \%$ & $25 \%$ & $40 \%$ & $50 \%$ & $60 \%$ & $75 \%$ & $90 \%$ & $95 \%$ \\
\hline January & 414.86 & 369.28 & 300.57 & 258.20 & 234.73 & 212.74 & 179.33 & 137.79 & 116.43 \\
February & 419.47 & 372.45 & 301.73 & 258.24 & 234.20 & 211.70 & 177.63 & 135.43 & 113.85 \\
March & 472.53 & 418.34 & 337.06 & 287.23 & 259.76 & 234.10 & 195.34 & 147.59 & 123.30 \\
April & 373.90 & 330.92 & 266.46 & 226.96 & 205.18 & 184.85 & 154.15 & 116.35 & 97.14 \\
May & 269.50 & 235.79 & 185.75 & 155.47 & 138.94 & 123.64 & 100.79 & 73.26 & 59.59 \\
June & 191.62 & 160.67 & 116.43 & 90.96 & 77.58 & 65.61 & 48.62 & 29.94 & 21.65 \\
July & 170.35 & 138.89 & 95.02 & 70.63 & 58.19 & 47.33 & 32.53 & 17.47 & 11.42 \\
August & 147.48 & 127.54 & 98.24 & 80.74 & 71.29 & 62.61 & 49.82 & 34.75 & 27.47 \\
September & 250.67 & 213.37 & 159.33 & 127.65 & 110.78 & 95.48 & 73.35 & 48.14 & 36.46 \\
October & 335.73 & 311.55 & 245.92 & 206.17 & 184.44 & 164.31 & 134.23 & 97.9 & 79.84 \\
November & 383.01 & 334.85 & 263.39 & 220.20 & 196.64 & 174.82 & 142.30 & 103.15 & 83.76 \\
December & 381.27 & 344.07 & 287.31 & 251.79 & 231.90 & 213.08 & 184.13 & 147.31 & 127.91 \\
\hline Annual & $2,847.02$ & $2,671.97$ & $2,395.46$ & $2,215.18$ & $2,111.20$ & $2,010.53$ & $1,850.39$ & $1,635.06$ & $1,514.73$ \\
\hline
\end{tabular}




\section{ACKNOWLEDGEMENTS}

The authors wish to thank UFAC, INMET, CAPES, and the CNPq for financially supporting this research.

\section{REFERENCES}

ABREU, M. C.; CECILIO, R. A.; PRUSKI, F. F.; SANTOS, G. R.; ALMEIDA, L. T.; ZANETTI, S. S. Critérios para escolha de distribuições de probabilidades em estudos de eventos extremos de precipitação. Revista Brasileira de Meteorologia, v. 33, n. 4, p. 601-613, 2018. http://dx.doi.org/10.1590/0102-7786334004

ARAI, F. K.; GONÇALVES, G. G. G.; PEREIRA, S. B.; PEIXOTO, P. P. P. Estudo do comportamento pluvial na região de Dourados, MS. Revista Agrarian, v. 2, n. 6, p. $105-$ $112,2009$.

ARAÚJO, W. F.; ANDRADE JÚNIOR, A. S.; MEDEIROS, R. D.; SAMPAIO, R. A. Precipitação pluviométrica mensal provável em Boa Vista, Estado de Roraima, Brasil. Revista Brasileira de Engenharia Agrícola e Ambiental, v. 5, n. 3, p. 563-567, 2001. http://dx.doi.org/10.1590/S1415-43662001000300032

BAPTISTA, M. B.; COELHO, M. M. L. P. Fundamentos de engenharia hidráulica. Belo Horizonte: UFMG, 2010. 473p.

BARBIERI, J. D.; DALLACORT, R.; FREITAS, P. S. L.; ARAÚJO, D. V.; TIEPPO, R. F.; FENNER, W. Effects of the ENSO on variability of precipitation and air temperature in agricultural regions do Mato Grosso State. Journal of agricultural Science, v. 11, n. 9, p. 91-102, 2019. https://dx.doi.org/10.5539/jas.v11n9p91

BAZAME, H. C.; ALTHOFT, D.; FILGUEIRAS, R.; ALVES, E. S. Rainfall spatio-temporal distribution of Western Bahia. Water Resources and Irrigation Management, v. 7, n. 2-3, p. 20-30, 2018.

BERMUDEZ, V. A. B.; ABILGOS, A. B. B.; CUARESMA, D. C. N.; RABAJANTE, J. F. Probability Distribution od Philippine Daily Rainfall Data. Preprints, 2017. https://dx.doi.org/10.20944/preprints201712.0150.v1

BEZERRA, R. B.; DANTAS, R. T.; TRINDADE, A. G. Caracterização temporal da precipitação pluvial do município de Porto Velho/RO no período de 1945 a 2003. Revista Sociedade \& Natureza, v. 22, n. 3, p. 609-623, 2010. https://doi.org/10.1590/S198245132010000300015

BORTOLUZZI, D. D.; PRADO, G.; HARA, A. T.; SOUZA, A. C. S. Precipitação mensal provável no noroeste do Paraná. Revista Brasileira de Agricultura Irrigada, v. 13, n. 2, p. 3314-3326, 2019. https://dx.doi.org/10.7127/rbai.v13n2001030

BRITO, R. S.; BRITO, RYCHAELLEN S.; MOREIRA, J. G. V.; OLIVEIRA, A. V. Produtividade de mandioca na região do Vale do Juruá, Amazônia Ocidental. Scientia Naturalis, v. 1, n.1, p. 1-9, 2019.

COSTA, K. T.; FERNANDES, W. S. Avaliação do tipo de distribuição de probabilidades das vazões máximas diárias anuais no Brasil. Revista Brasileira de Recursos Hídricos, v. 20, n. 2, p. 442-451, 2015. 
DALlACORT, R.; MARTINS, J. A.; INOUE, M. H.; FREITAS, P. S. L.; COLETTI, A. J. Distribuição das chuvas no município de Tangará da Serra, médio norte do Estado de Mato Grosso, Brasil. Acta Scientiarum. Agronomy, v. 33, n. 2, p. 193-200, 2011. https://dx.doi.org/10.4025/actasciagron.v33i2.5838

DELIGNETTE-MULlER, M. L.; DUTANG, C. Fitditrplus: An R Package for Fitting Distributions. Journal of Statistical Software, v. 8, p. 1-34, 2015.

FLORES, P. S. Cultivares de mandioca para a produção de farinha no estado do Acre. Rio Branco: Embrapa Acre, 2015.

IBGE. Clima do Brasil. 1:500.000. Available at: http://www.dados.gov.br/dataset/cren_climadobrasil_5000. Access: Dec. 2020.

LIMA, F. N.; NAGHETTINI, M.; ESPÓSITO, T. Avaliação da probabilidade de galgamento de barragem da PCH de Cajuru por simulação de Monte Carlo. Revista Brasileira de Recursos Hídricos, v. 20, n. 3, p. 722-730, 2015.

MARENGO, J. A.; SOUZA JÚNIOR, C. Mudanças Climáticas: impactos e cenários para a Amazônia. São Paulo: ALANA, 2018.

MARSAGLIA, G.; TSANG, W. W.; WANG, J. Evaluating Kolmogorov's Distribution. Journal of Statistical Software, v. 8, n.18, p. 1-4, 2003.

MARTINS, J. A.; DALlACORT, R.; INOUE, M. H.; SANTI, A.; KOLlING, E. M.; COLETTI, A. J. Probabilidade de precipitação pluviométrica para a microrregião de Tangará da Serra, Estado do Mato Grosso. Pesquisa Agropecuária Tropical, v. 40, n. 3, p. 291-296, 2010.

MIGUEZ, M. G.; DI GREGÓRIO, L. T.; VERÓL, A. P. Gestão de riscos e desastres hidrológicos. Rio de Janeiro: Elsevier, 2018.

MOREIRA, J. G. V.; CRAVEIRO, R. L.; SERRANO, R. O. P.; FORMOLO, A. K. Temporal trend and frequency of maximum precipitations in Cruzeiro do Sul, Acre, Brazil. Nativa, v. 4, n. 2, p. 97-102, 2016.

MOREIRA, J. G. V.; AQUINO, A. P. V.; MESQUITA, A. A.; MUNIZ, M. A.; SERRANO, R. O. P. Stationarity in annual daily maximum streamflow series in the upper Juruá River, western Amazon. Revista Brasileira de Geografia Física, v. 12, n. 12, p. 705-713, 2019. https://doi.org/10.26848/rbgf.v12.2.p705-713

MORETO, V. B.; APARECIDO, L. E. O.; ROLIM, G. S.; MORAES, J. R. S. C. Agrometeorological models for estimating sweet cassava yield. Pesquisa Agropecuária Tropical, v. 48, n. 1, p. 43-51, 2018. https://doi.org/10.1590/1983-40632018v4850451

NIMER, E. Um modelo metodológico da classificação de climas. Revista Brasileira de Geografia - IBGE, v. 41, n. 4, p. 59-89, 1979.

NOBRE, C. A.; SAMPAIO, G.; SALAZAR, L. Mudanças climáticas e Amazônia. Ciência e Cultura, v. 59, n. 3, p. 22-27, 2007.

NÓBREGA, R. S. Impactos do desmatamento e de mudanças climáticas nos recursos hídricos na Amazônia ocidental utilizando o modelo SLURP. Revista Brasileira de Meterologia, v. 29, p. 111-120, 2014. 
OLIVEIRA, L. F. C.; FIOREZE, A. P.; MEDEIROS, A. M. M.; SILVA, M. A. S. Comparação de metodologias de preenchimento de falhas de séries históricas de precipitação pluvial anual. Revista Brasileira de Engenharia Agrícola e Ambiental, v. 14, n. 11, p. 11861192, 2010. https://doi.org/10.1590/S1415-43662010001100008

PASSOS, M. L. V.; RAPOSO, A. B.; MENDES, T. J. Estimativa da distribuição da precipitação pluviométrica provável em diferentes níveis de probabilidade de ocorrência. Revista Brasileira de Agricultura Irrigada, v. 11, n. 1, p. 1106-1115, 2017. https://dx.doi.org/10.7127/rbai.v11n100498

PIZZATO, J. A.; DALlACORT, R.; TIEPPO, R. C.; MODOLO, A. J.; CREMON, C.; MOREIRA, P. S. P. Distribuição e probabilidade de ocorrência de precipitação em Cáceres (MT). Pesquisa Agropecuária Tropical, v. 42, n. 2, p. 137-142, 2012. http://dx.doi.org/10.1590/S1983-40632012000200006

SANTOS, D. C.; MEDEIROS, R. M.; CORREIA SANTOS, D.; BRITO, J. I. B. Variabilidade climática de regiões pluviometricamente homogêneas na Amazônia Ocidental. Revista Brasileira de Geografa Física, v. 6, n. 4, p. 903-918, 2013.

SANTOS, V. C.; BLANCO, C.; OLIVEIRA JÚNIOR, J. F. Distribution of rainfall probability in the Tapajos River Basin, Amazonia, Brazil. Revista Ambiente \& Água, v. 14, n. 3, 121, 2019. http://dx.doi.org/10.4136/ambi-agua.2284

SILVA, I. N. Precipitação provável para a região Centro-Sul do Ceará, Brasil. Revista Brasileira de Geografia Física, v. 8, n. 3, p. 751-758, 2015.

SILVA, R. S.; ZAVISLAK, F. D.; DALLACORT, R.; CARVALHO, M. A. C.; ARAÚJO, D. V. Distribuição de probabilidade de chuva no município de Sapezal, MT. Enciclopédia Biosfera, v. 9, n. 17, p. 1112-1122, 2013.

SILVA, E. G. F. A.; POLYCARPO, J. S. M.; MELO, R. F.; MOUSINHO, F. H. G.; OLIVEIRA FILHO, J. E.; CORREA, M. M. Determinação de precipitação provável mensal para o município de Goiana-PE. Revista GEAMA, v. 5, n. 1, p. 41-46, 2019.

SOMAN, S.; BYJU, G.; SREEKUMAR, J. Projected changes in mean temperature and total precipitation and climate suitability of cassava (Manihot esculenta) in maior growing environments of India. Indian Journal of Agricultural Sciences, v. 86, n. 5, p. 647-653, 2016.

SOUZA, L. D.; SOUZA, L. S.; GOMES, J. C. Exigências edáficas da cultura da mandioca. In: SOUZA, L. S.; FARIAS, A. R. N.; MATTOS, P. L. P.; FUKUDA, W. M. G. (Ed.). Aspectos socioeconômicos e agronômicos da mandioca. Cruz das Almas: Embrapa Mandioca e Fruticultura, 2006, p. 170-214.

SOUZA, L. P.; FARIAS, O. S.; MOREIRA, J. G. V.; GOMES, F. A.; FRADE JÚNIOR, E. F. Comparação de métodos de evapotranspiração de referência para o município de Cruzeiro do Sul-Acre. Enciclopédia Biosfera, v. 7, n. 12, p. 1-8, 2011.

SOUZA, D. O.; OLIVEIRA, F. G.; CASTRO, I. L.; SOARES, J. B. S.; REIS, M. M.; FIGUEIREDO, F. P. Frequência de ocorrência de precipitação pluviométrica em Montes Claros-MG. Revista Agrarian, v. 11, n. 42, p. 337-342, 2018. https://doi.org/10.30612/agrarian.v11i42.4175 
R CORE TEAM. R: A language and environment for statistical computing. Vienna: $\mathrm{R}$ Foundation for Statistical Computing, 2019.

TEIXEIRA, C. F. A.; DAMÉ, R. C. F.; BACELAR, L. C. S.; SILVA, G. M.; COUTO, R. S. Intensidade da seca utilizando índices de precipitação. Revista Ambiente \& Água, v. 8, n. 3, p. 203-213, 2013. https://doi.org/10.4136/ambi-agua.1245 


Ambiente \& Água - An Interdisciplinary Journal of Applied Science
ISSN 1980-993X - doi:10.4136/1980-993X
www.ambi-agua.net
E-mail: ambi.agua@gmail.com

\title{
Wastewater reuse in irrigation: short-term effect on soil carbon and nitrogen stocks in Brazilian semi-arid region
}

\author{
ARTICLES doi:10.4136/ambi-agua.2623
}

Received: 17 Jul. 2020; Accepted: 03 Nov. 2020

\author{
Marcus Metri Corrêa ${ }^{1^{*} \text {; }}$; Marília Costa Cavalcanti ${ }^{1(D)}$; Dário Costa Primo ${ }^{2}$ (D); \\ Fernando Cartaxo Rolim Neto ${ }^{1}$; ; Jean Manuel Martins ${ }^{3}{ }^{(D}$; \\ Rômulo Simões Cezar Menezes ${ }^{2}$; Antonio Celso Dantas AntoninoiD; \\ Isaque de Souza Mendes ${ }^{4}$; Lívia Regina dos Santos Medeiros ${ }^{5}$ iD \\ ${ }^{1}$ Departamento de Tecnologia Rural. Universidade Federal Rural de Pernambuco (UFRPE), \\ Rua Dom Manoel de Medeiros, s/n, CEP: 52171-900, Recife, PE, Brazil. \\ E-mail: marilia.costac@gmail.com, fernandocartaxo@yahoo.com.br \\ ${ }^{2}$ Departamento de Energia Nuclear. Universidade Federal de Pernambuco (UFPE), Avenida Professor \\ Luís Freire, n ${ }^{\circ}$ 1000, CEP: 50740-540, Recife, PE, Brazil. \\ E-mail: darioprimo@gmail.com,rmenezes@ufpe.br, antonio.antonino@ufpe.br \\ ${ }^{3}$ Institute Geosciences \& Environment - IGE UMR 5001. University Grenoble Alpes, CNRS, IRD, INP-G. 70, \\ Rue de la Piscine, 38000, Grenoble, France. E-mail: jean.martins@ univ-grenoble-alpes.fr \\ ${ }^{4}$ Programa de Pós-Graduação em Engenharia Agrícola (PGEAGRI). Universidade Estadual do Oeste \\ do Paraná (UNIOESTE), Rua Universitária, n 1619, CEP: 85819-110, Cascavel, PR, Brazil. \\ E-mail: isaque.souzamendes11@gmail.com \\ ${ }^{5}$ Secretaria Executiva de Meio Ambiente. Prefeitura Municipal do Cabo de Santo Agostinho,

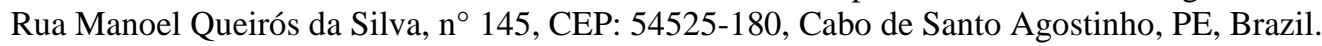 \\ E-mail: dimedeiros.livia@gmail.com \\ *Corresponding author. E-mail: marcus.metri@gmail.com
}

\begin{abstract}
The main process that opposes the Greenhouse Effect is called "carbon sequestration", a phenomenon that essentially seeks to establish a dynamic balance between greenhouse gas (GHG) emissions from the immobilization of its elements, especially $\mathrm{C}$ and $\mathrm{N}$. This work evaluated the stocks of carbon and nitrogen in soils of the Brazilian semi-arid submitted to irrigation with treated wastewater from domestic sewage. For this purpose, the carbon and nitrogen stocks in the soil of the semi-arid region of Brazil were compared for four different uses: Open Native Caatinga (ONC); Treated Wastewater Effluent Irrigation (TSEI); Surface Water Irrigation (SWI); and Traditional Rainfed Agriculture (TRA). The hypothesis considered in this research was that the application of treated effluents in agriculture, besides being an alternative that can mitigate the problem of water scarcity of the semiarid region, is also capable of influencing the storage capacity of $\mathrm{C}$ and $\mathrm{N}$ in the soil, due to its organic load. The results indicate that among the different land uses evaluated, soil $\mathrm{C}$ and $\mathrm{N}$ stocks were highest in $\mathrm{ONC}$, and decreased with the agricultural land use. The greatest accumulation of $\mathrm{C}$ and $\mathrm{N}$ in Caatinga is due to the presence of forest litter, and the influence of irrigation with treated sewage effluent was not detected in the present study. It can be concluded that the contribution of vegetation residues to the soil surface is the main factor contributing to $\mathrm{C}$ and $\mathrm{N}$ storage.
\end{abstract}

Keywords: carbon and nitrogen sequestration, greenhouse effects, land use change, soils.

This is an Open Access article distributed under the terms of the Creative Commons Attribution License, which permits unrestricted use, distribution, and reproduction in any medium, provided the original work is properly cited. 


\section{Reúso de água residual na irrigação: efeito de curto-prazo sobre os estoques de carbono e nitrogênio do solo no semiárido brasileiro}

\section{RESUMO}

O principal processo natural que se contrapõe ao Efeito Estufa é chamado de sequestro de carbono, um fenômeno que essencialmente busca estabelecer um equilíbrio dinâmico entre a emissão dos gases do efeito estufa (GEE) a partir da imobilização de seus elementos, especialmente do $\mathrm{C}$ e $\mathrm{N}$. O presente trabalho teve como objetivo principal avaliar os estoques de $\mathrm{C}$ e $\mathrm{N}$ em solo da região semiárida do Brasil submetido a irrigação com água residual tratada de esgoto doméstico. Para isso, o estoque de carbono e nitrogênio do solo soram comparados para quatro diferentes usos: caatinga nativa aberta $(\mathrm{ONC})$; irrigação com água residual tratada (TSEI); irrigação com água superficial (SWI); e agricultura de sequeiro (TRA). A hipótese levantada na pesquisa foi de que o reuso de efluentes tratados na agricultura, além de ser uma alternativa que pode mitigar a problemática de escassez hídrica da região semiárida, também é capaz de influenciar a capacidade de estocar C e $\mathrm{N}$ no solo devido a sua carga orgânica. Os resultados indicaram que entre os diferentes usos de solos avaliados, os estoques de $\mathrm{C}$ e $\mathrm{N}$ no solo foi maior na ONC diminuindo com o uso do solo para a agricultura. $\mathrm{O}$ maior acúmulo de $\mathrm{C}$ e $\mathrm{N}$ na caatinga deve-se a presença de serrapilheira, não sendo detectado, no presente estudo, influência da irrigação com efluente de esgoto tratado. Conclui-se que o aporte de resíduos de vegetação na superfície do solo vem a ser o fator de maior contribuição para a estocagem de carbono e nitrogênio nos solos estudados.

Palavras-chave: efeito estufa, sequestro de carbono e nitrogênio, solos, variação do uso da terra.

\section{INTRODUCTION}

Although climate variation is part of the evolution of the planet, human activities significantly potentiate greenhouse gas $(\mathrm{GHG})$ emissions and hence global warming (Zhou et al., 2019). Among the factors that contribute most to $\mathrm{CO}_{2}$ emissions are the combustion of fossil fuels (IPCC, 2013) and the conversion of native vegetation areas to areas for human use (Kopittke et al., 2017). The current challenge is to seek to restore GHG concentrations in the atmosphere, and researchers around the world are turning their attention to two main questions: how to reduce GHG emissions and how to immobilize them.

In recent decades, terrestrial ecosystems have been considered as important as oceans in absorbing and storing $\mathrm{C}$ and $\mathrm{N}$ from the atmosphere, thereby minimizing the problem of the greenhouse effect. The largest $\mathrm{C}$ compartment of terrestrial ecosystems is the soil, where it is estimated that up to $30 \mathrm{~cm}$ deep it is about twice the amount of $\mathrm{C}$ present in the atmosphere as $\mathrm{CO}_{2}$ and up to four times that present in plant biomass (Powlson et al., 2011). Therefore, it is clear that any increase or decrease in soil carbon stock has a significant impact on the atmospheric concentration of $\mathrm{CO}_{2}$ affecting the global climate (Gao et al., 2017). Land use changes can also alter the stock of nitrogen $(\mathrm{N})$ in the soil that is closely linked to the Soil Organic Carbon (SOC) stock (Heyn et al., 2019).

Conversely, good management practices can increase soil organic matter content and contribute positively to soil $\mathrm{C}$ and $\mathrm{N}$ stocks (Wells et al., 2019), in addition to reducing $\mathrm{CO}_{2}$ concentration in the atmosphere and potentially mitigating global climate change (Gao et al., 2017). In Brazil, 77\% of $\mathrm{CO}_{2}$ emissions are due to land-use change and the areas most affected are the Cerrado and Amazon biomes (Lapola et al., 2013). There is some research on the influence of land use changes on soil $\mathrm{C}$ and $\mathrm{N}$ stocks in the semi-arid region of Brazil (Sacramento et al., 2013; Santana et al., 2019; Santos et al., 2019), but there are information gaps that have yet to be filled, particular if the reuse of treated effluents in agriculture is 
considered as a sustainable management practice in agriculture. The National Semi-Arid Institute (INSA) has been recommending irrigation of forage palm (Opuntia stricta) with wastewater to provide food security in the livestock activity in the region (Araújo et al., 2019). The reuse of domestic effluents as an alternative source of water in agriculture has been recommended in many studies as a means of increasing water availability in arid and semi-arid regions and addressing water scarcity (Hamilton et al., 2007; Feinerman and Tsur, 2014; Bedbabis et al., 2015; Martinez et al., 2017) and to lessen the use of mineral fertilizers due to the presence of organic material (Marinho et al., 2013).

Therefore, the use of effluents in agriculture can be not only a solution for water, but also an important ally for the mitigation of $\mathrm{CO}_{2}$ concentration in the atmosphere due to the organic material load present. With proper management, some of the carbon can be retained in the soil profile or used for biomass formation, which characterizes the mechanism of carbon sequestration from the atmosphere to the Earth's crust. However, it is known that in order to develop more systematically sustainable management practices and proposals, it is essential to have information on the impacts (positive or negative) on soils and their stocks of $\mathrm{C}, \mathrm{N}$ and other nutrients, caused by the incorporation of new resources and technologies in anthropogenic activities, such as the treatment and reuse of domestic effluent in agriculture.

Given this scenario, this research is based on the assumption that the adoption of new techniques in agricultural systems, such as the agricultural reuse of wastewater, can influence the capacity of soils to accumulate $\mathrm{C}, \mathrm{N}$ and other nutrients. The objective of this work was to assess the stocks of $\mathrm{C}$ and $\mathrm{N}$ in a Planosol soil, located in the municipality of Santana do Seridó, state of Rio Grande do Norte, semi-arid region of Brazil, under four different uses: Open Native Caatinga (ONC); Treated Sewage Effluent Irrigation (TSEI); Surface Water Irrigation (SWI); and Traditional Rainfed Agriculture (TRA).

\section{MATERIALS AND METHODS}

\subsection{Field Site}

The research was conducted in the municipality of Santana do Seridó, located in the southcentral zone of the state of Rio Grande do Norte $\left(6^{\circ} 45^{\prime} 58^{\prime \prime} \mathrm{S} ; 36^{\circ} 44^{\prime} 0^{\prime \prime} \mathrm{W}\right)$. The municipality covers approximately $188.4 \mathrm{~km}^{2}$ and has a population of 2,680 habitants in 2019 (Figure 1). It is characterized by the Caatinga biome, with a semi-arid climate, classified as Bsh according to Köppen and Geiger, with prolonged droughts, low rainfall, annual average of $559 \mathrm{~mm}$, and low hydric potential.

\subsection{Land Use}

In the experimental area, the soil was classified as Planosol, morphologically described and classified according to WRB (FAO, 2014), and four different land use types were identified: 1) Open Native Caatinga vegetation - ONC $\left(6^{\circ} 45^{\prime} 56.2^{\prime \prime} \mathrm{S} ; 36^{\circ} 43^{\prime} 49.9^{\prime \prime} \mathrm{W}\right)$, identified according to the criteria established by the Brazilian Vegetation Technician's Guide (IBGE, 2012); 2) Treated-Sewage Effluent Irrigation -TSEI (6 $\left.6^{\circ} 45^{\prime} 56.9^{\prime \prime} \mathrm{S} ; 36^{\circ} 43^{\prime} 55.7^{\prime \prime} \mathrm{W}\right)$, agriculture with forage palm (Opuntia stricta) irrigated with treated domestic sewage effluent for animal feed; 3) Surface Water Irrigation - SWI (6 $\left.6^{\circ} 46^{\prime} 01.4^{\prime \prime} \mathrm{S} ; 36^{\circ} 44^{\prime} 00.7^{\prime \prime} \mathrm{W}\right)$, agriculture with conventional sprinkler irrigation of tomatoes (Solanum lycopersicum L.), irrigated with surface water; and 4) Traditional Rainfed Agriculture -TRA (6 $45^{\prime} 56.1^{\prime \prime}$ S; 36 $\left.43^{\prime} 54.7^{\prime \prime} \mathrm{W}\right)$, traditional rainfed agriculture, subsistence crops, mainly maize (Zea mays L.) and beans (Phaseolus vulgaris L.), planted during the rainy season with minimum inputs, as shown in Figure 2.

A survey conducted at the site revealed that soil management in the study areas had been in place for at least four years prior to the date of collection of samples. 

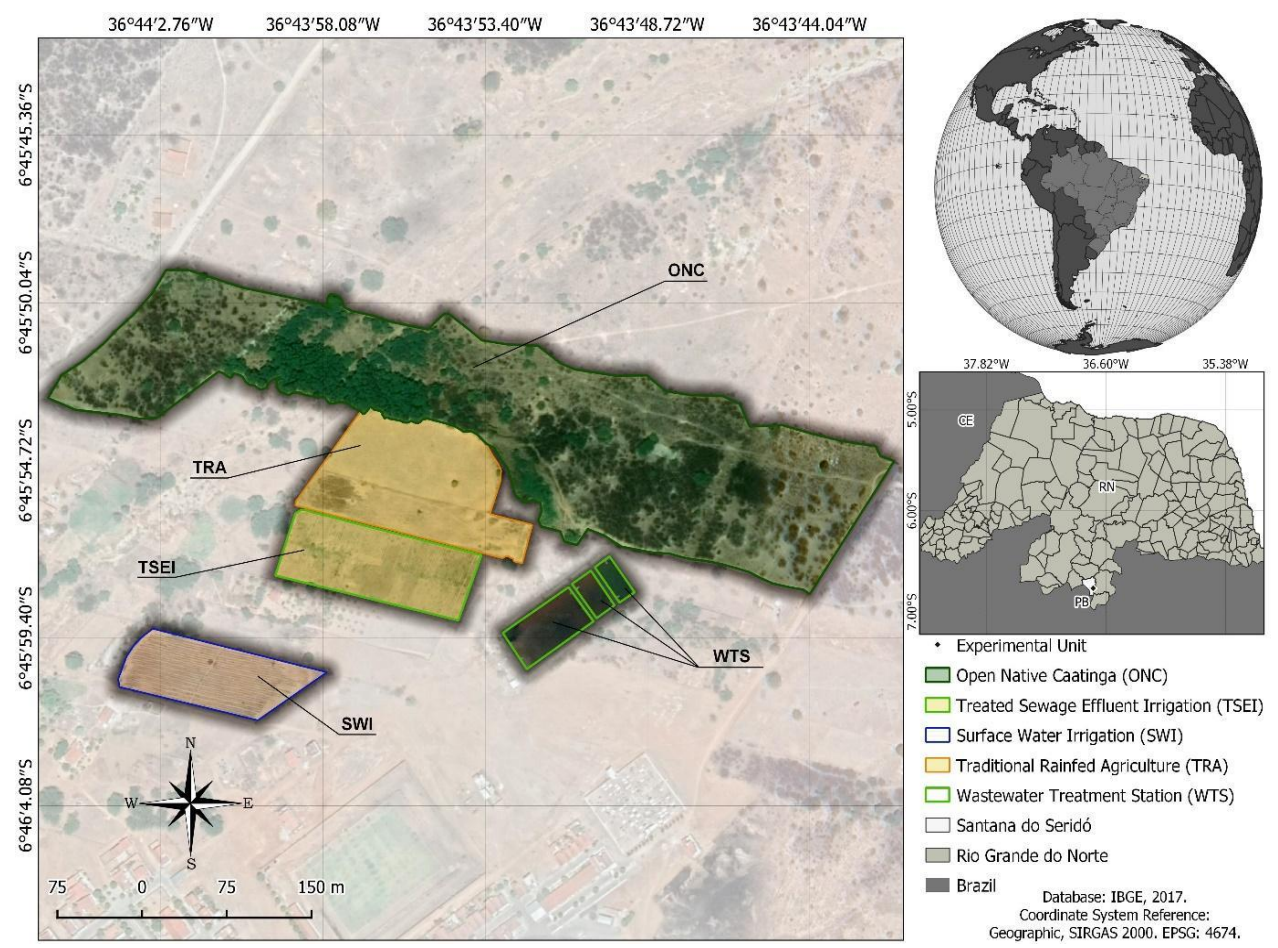

Figure 1. Study area and its location in the state of Rio Grande do Norte, Brazil.
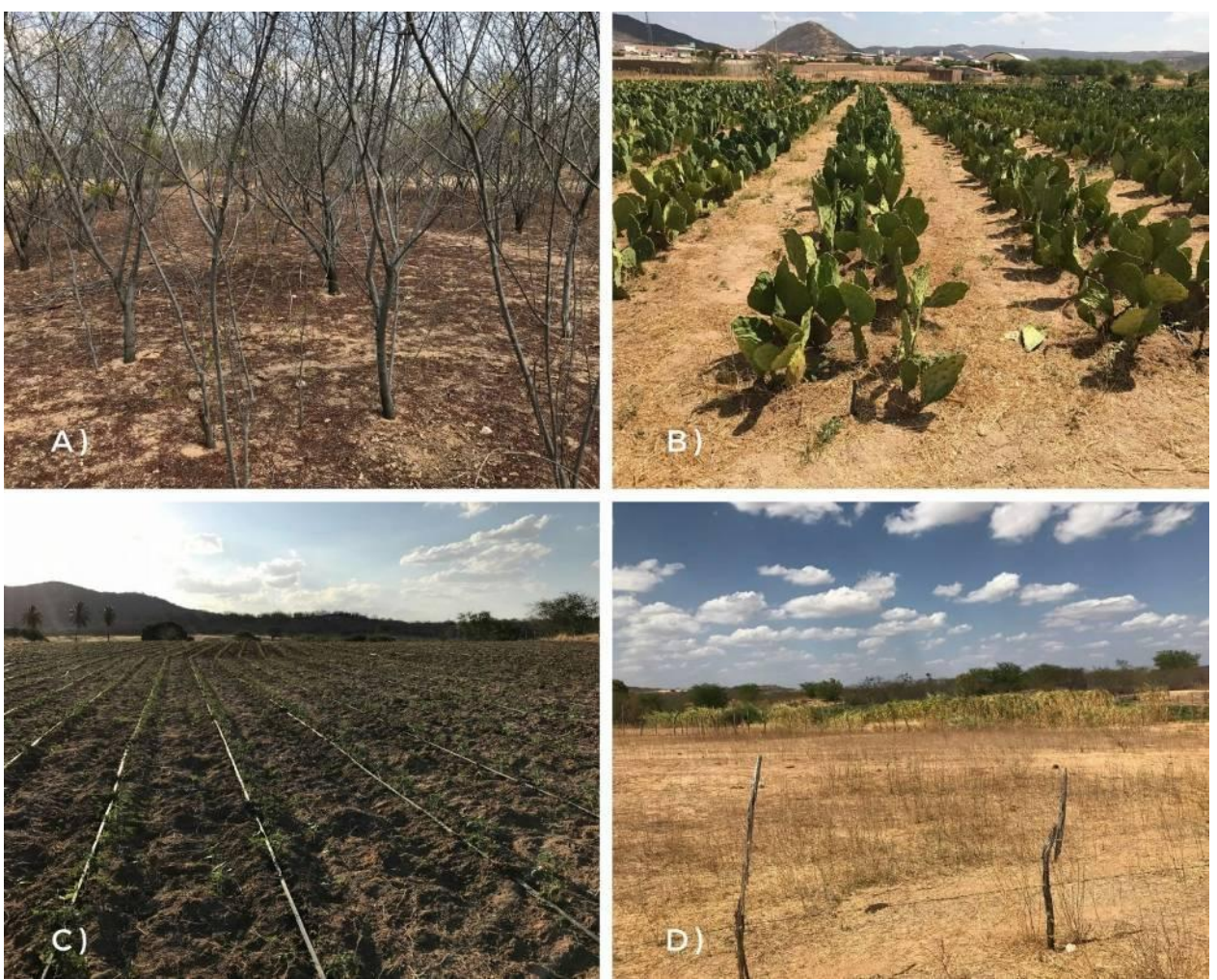

Figure 2. Land uses studied. A) Open Native Caatinga (ONC); B) Treated Sewage Effluent Irrigation (TSEI); C) Surface Water Irrigation (SWI) and D) Traditional Rainfed Agriculture (TRA).

\subsection{Sampling and estimation of soil carbon, nitrogen, calcium, magnesium, potassium and sodium contents}

A total of 32 soil samples were collected for studies on the four land uses, resulting in eight samples per zone. All soil samples collected were packaged in plastic bags, properly labeled 
and sent to the laboratory for processing and analysis. At each site, six soil samples with volumetric rings (core method) were taken to determine soil bulk density, following the methodology of Blake and Hartge (2006).

At the laboratory, the soil samples were air-dried and sieved in $2 \mathrm{~mm}$ mesh size. An aliquot was kept for soil texture characterization, following the methodology presented by Embrapa (2009), and another aliquot was grinded in a ball mill until it passed through a 100 mesh $(0.150$ $\mathrm{mm}$ ). For the quantification of Total Organic Carbon (TOC) levels in the soil, the wet oxidation methodology of Yeomans and Bremner (1988) was used. For the Total Nitrogen (TN) concentration of the soil, the Kjeldahl (Embrapa, 1999) method was used. Stocks were calculated on the basis of $\mathrm{C}$ and $\mathrm{N}$ concentrations and soil volume and density (Veldkamp, 1994) Equation 1:

Stock $=\frac{(\mathrm{T})(\mathrm{Ds})(\mathrm{e})(1-\mathrm{Rv})}{10}$

Where Stock represents the mass of $\mathrm{C}$ or $\mathrm{N}$ per unit area equivalent layer $\left(\mathrm{Mg} \mathrm{ha}^{-1}\right)$; $\mathrm{T}$ is the total $\mathrm{C}$ or $\mathrm{N}$ content in the sampled layer $\left(\mathrm{g} \mathrm{kg}^{-1}\right)$; Ds is the bulk density $\left(\mathrm{kg} \mathrm{dm}^{-3}\right)$; $\mathrm{e}=$ the thickness of the considered layer $(\mathrm{cm})$ and $\mathrm{Rv}$ is the fraction of rock fragments $(>2 \mathrm{~mm})$.

The contents of $\mathrm{Na}$ and $\mathrm{K}$ were extracted with a solution of Mehlich-1 and determined by flame spectrophotometry (Embrapa, 2009) and for $\mathrm{Ca}$ and $\mathrm{Mg}$, the sample extracts obtained with $1 \mathrm{~mol} \mathrm{~L}^{-1} \mathrm{KCl}$ were subjected to atomic absorption (Embrapa, 2009). Phosphorus was determined by colorimetry by reading the intensity of the color of the phosphomolybdic complex produced by the reduction of molybdate with ascorbic acid. The $\mathrm{pH}$ of the samples of soil was determined by direct electrochemical measurement of the effective concentration of $\mathrm{H}^{+}$ions in the soil solution using a combined electrode immersed in a soil/water suspension in a ratio of 1:2.5. To calculate the Sodium Adsorption Ratio (SAR), the concentrations of $\mathrm{Na}, \mathrm{Ca}$ and $\mathrm{Mg}$ determined were used and the following equation was applied Equation 2:

$$
S A R=\frac{N a}{\sqrt{\frac{C a+M g}{2}}}
$$

Where all concentrations were expressed as $\mathrm{mmol} \mathrm{Kg}^{-1}$.

\subsection{Statistical analysis}

The results of the TOC and TN contents and stock variables for all soils were subjected to an analysis of variance (ANOVA) followed by a test of comparison of means (Tukey, 5\%). The statistical program used for the analyzes was Assistant $7.7 \mathrm{pt}$.

\section{RESULTS AND DISCUSSION}

The particle-size distribution of the soil samples collected under the different land uses did not show any significant difference, indicating that they were of the same soil class (Table 1), i.e., sand, thus verifying the predominance of a sand fraction. Sandy soils have a porosity that ensures an important infiltration rate. In addition, soil texture influences its chemical characteristics, such as lower organic matter content and decomposition rate, and low nutrient storage capacity. Sugihara et al. (2012) assessed carbon dynamics in two tropical growing areas in Tanzania with soils of contrasting textures and found that clay soils stored much more carbon than sandy soils. The authors attributed this to the possibility of carbon loss through leaching and macrofauna activity, but this is due to the fact that clays are capable of forming clay-organic complexes, which are less likely to decompose, providing greater physical protection for carbon. Bulk density is considered an attribute that can vary with different management practices. However, as with grain size and despite different land uses, no significant differences 
were identified between bulk density data for the studied areas, including the open native Caatinga area - ONC.

Table 1. Sand, silt and clay contents and density values at two depths in the four studied sites.

\begin{tabular}{|c|c|c|c|c|}
\hline \multirow{2}{*}{ Land Use/Depth } & \multicolumn{3}{|c|}{ Particle Size Distribution (\%) } & \multirow{2}{*}{$\begin{array}{l}\text { Bulk Density } \\
\quad\left(\mathrm{kg} \mathrm{m}^{-3}\right)\end{array}$} \\
\hline & Sand & Silt & Clay & \\
\hline \multicolumn{5}{|c|}{ TSEI } \\
\hline $0-10 \mathrm{~cm}$ & $84.06 \pm 1.14$ & $9.82 \pm 0.77$ & $6.12 \pm 0.83$ & $1.59 \pm 0.03$ \\
\hline $10-20 \mathrm{~cm}$ & $82.85 \pm 1.75$ & $9.60 \pm 1.63$ & $7.56 \pm 1.00$ & $1.69 \pm 0.04$ \\
\hline \multicolumn{5}{|c|}{ SWI } \\
\hline $0-10 \mathrm{~cm}$ & $86.18 \pm 0.83$ & $7.69 \pm 1.06$ & $6.13 \pm 0.45$ & $1.63 \pm 0.04$ \\
\hline $10-20 \mathrm{~cm}$ & $84.85 \pm 1.37$ & $8.10 \pm 1.11$ & $7.05 \pm 2.39$ & $1.67 \pm 0.05$ \\
\hline \multicolumn{5}{|c|}{ TRA } \\
\hline $0-10 \mathrm{~cm}$ & $83.52 \pm 2.63$ & $10.52 \pm 1.55$ & $5.96 \pm 1.18$ & $1.55 \pm 0.04$ \\
\hline $10-20 \mathrm{~cm}$ & $80.17 \pm 1.85$ & $11.60 \pm 1.50$ & $8.24 \pm 1.42$ & $1.62 \pm 0.05$ \\
\hline \multicolumn{5}{|c|}{ ONC } \\
\hline $0-10 \mathrm{~cm}$ & $81.83 \pm 0.44$ & $12.47 \pm 0.99$ & $5.70 \pm 0.61$ & $1.63 \pm 0.06$ \\
\hline $10-20 \mathrm{~cm}$ & $81.05 \pm 0.74$ & $13.63 \pm 1.22$ & $5.32 \pm 0.80$ & $1.65 \pm 0.03$ \\
\hline
\end{tabular}

Mean values obtained from four replicates for Particle-Size Distribution (granulometry) and three replicates for Bulk Density \pm one standard deviation.

Source: Author.

Table 2 shows the total organic carbon (TOC) and total nitrogen (TN) contents for the different land uses. In the $0-10 \mathrm{~cm}$ layer, the native Caatinga vegetation (ONC) had a higher TOC content than the other areas used for agriculture, without significant differences for TN. Similar results were found in the Planosols of the municipality of Jataúba-PE, where concentrations were 8.7 and $8.9 \mathrm{~g} \mathrm{~kg}^{-1} \mathrm{C}$ in conserved areas at depths of $0-14$ and $0-17 \mathrm{~cm}$, while in the degraded environment they were 5.6 and $3.6 \mathrm{~g} \mathrm{~kg}^{-1} \mathrm{C}$ at depths of $0-9$ and $0-20 \mathrm{~cm}$, respectively (Galindo et al., 2008). The presence of higher $\mathrm{C}$ concentrations in open native Caatinga vegetation compared to agriculture areas, confirms the overall behavior that the replacement of forested areas by agriculture areas tends to decrease soil $\mathrm{C}$ and $\mathrm{N}$ concentrations (Wei et al., 2014; Kunlanit et al., 2019). Non-significant differences in N content were also observed by Santana et al. (2019) who attributed this behavior to higher losses of C than $\mathrm{N}$ when land use changes occur. The results obtained here corroborate those of Santana et al. (2019), which resulted in a lower $\mathrm{C} / \mathrm{N}$ ratio of agricultural areas compared to native open Caatinga.

In the Caatinga, TOC levels decrease considerably with increasing depth. This behavior is typical of the situation under native vegetation, because the high input of plant residues on the soil surface favours slow and progressive decomposition, which guarantees the constant incorporation of organic matter into the soil. However, the opposite situation was verified for TN levels, which is probably due to the type of plant residues incorporated (Table 2). As it is a Caatinga-type vegetation, the input of organic waste is poor in $\mathrm{N}$, since, in the semiarid conditions, low soil moisture leads to lower microbial activity near the soil surface, which corroborates the considerations of López-Merino et al. (2015) and Merino et al. (2019). Similarly, the higher $\mathrm{C}$ content in the topsoil may be related to the virtual absence of microbial activity, with the incorporation of the most recalcitrant $\mathrm{C}$ compounds through physical and chemical degradation of the deposited plant residues (Franzluebbers et al., 1996). 
Table 2. Soil C and N contents, Ratio C/N, O.M. content, Soil TOC and TN stocks at two depths in the four studied sites.

\begin{tabular}{|c|c|c|c|c|c|c|}
\hline Land Use & TOC $\left(\mathrm{g} \cdot \mathrm{kg}^{-1}\right)$ & $\mathbf{T N}\left(\mathrm{g}^{\mathrm{kg}}{ }^{-1}\right)$ & $\begin{array}{c}\mathbf{C : N} \\
\left(\mathrm{g} \cdot \mathrm{kg}^{-1}\right)\end{array}$ & $\begin{array}{c}\text { O.M. (Organic Matter) } \\
\left(\mathrm{g} \cdot \mathrm{kg}^{-1}\right)\end{array}$ & $\begin{array}{l}\text { TOC Stock } \\
\left({\left.\mathrm{Mg} \cdot h \mathrm{a}^{-1}\right)}\right.\end{array}$ & $\begin{array}{l}\text { TN Stock } \\
\left({\left.\mathrm{Mg} . h a^{-1}\right)}^{-}\right.\end{array}$ \\
\hline \multicolumn{7}{|c|}{$0-10 \mathrm{~cm}$} \\
\hline TSEI & $3.71 \pm 1.11 \mathbf{b}$ & $1.08 \pm 0.26 \mathbf{a}$ & $3.52 \pm 0.83 \mathbf{a}$ & $6.38 \pm 1.90$ & $7.87 \pm 2.34 \mathbf{b}$ & $2.29 \pm 0.55 \mathbf{a}$ \\
\hline SWI & $5.38 \pm 0.69 \mathbf{a b}$ & $1.00 \pm 0.21 \mathbf{a}$ & $5.52 \pm 0.80 \mathbf{a}$ & $9.25 \pm 1.20$ & $11.73 \pm 1.51 \mathbf{a b}$ & $2.18 \pm 0.46 \mathbf{a}$ \\
\hline TRA & $5.45 \pm 1.37 \mathbf{a b}$ & $0.85 \pm 0.11 \mathbf{a}$ & $6.55 \pm 1.91 \mathbf{a}$ & $9.37 \pm 2.35$ & $11.28 \pm 2.83 \mathbf{b}$ & $1.76 \pm 0.23 \mathbf{a}$ \\
\hline ONC & $9.70 \pm 3.07 \mathbf{a}$ & $0.98 \pm 0.63 \mathbf{a}$ & $13.28 \pm 7.95 \mathbf{a}$ & $16.69 \pm 5.29$ & $21.15 \pm 6.70 \mathbf{a}$ & $2.14 \pm 1.38 \mathbf{a}$ \\
\hline \multicolumn{7}{|c|}{$10-20 \mathrm{~cm}$} \\
\hline TSEI & $2.54 \pm 0.90 \mathbf{a}$ & $0.98 \pm 0.22 \mathbf{a}$ & $2.60 \pm 0.76 \mathrm{a}$ & $4.36 \pm 1.54$ & $5.74 \pm 4.06 \mathrm{a}$ & $2.21 \pm 0.98 \mathrm{a}$ \\
\hline SWI & $3.67 \pm 0.25 \mathbf{a}$ & $1.03 \pm 0.23 \mathbf{a}$ & $3.76 \pm 0.84 \mathrm{a}$ & $6.30 \pm 0.42$ & $8.18 \pm 1.09 \mathrm{a}$ & $2.30 \pm 1.02 \mathrm{a}$ \\
\hline TRA & $4.41 \pm 0.64 \mathbf{a}$ & $1.05 \pm 0.18 \mathbf{a}$ & $4.29 \pm 0.77 \mathrm{a}$ & $7.58 \pm 1.10$ & $9.57 \pm 2.78 \mathrm{a}$ & $2.28 \pm 0.78 \mathrm{a}$ \\
\hline ONC & $3.31 \pm 1.05 \mathbf{a}$ & $1.58 \pm 0.65 \mathbf{a}$ & $2.59 \pm 1.36 \mathrm{a}$ & $5.70 \pm 1.81$ & $7.28 \pm 4.63 \mathrm{a}$ & $3.48 \pm 2.86 \mathrm{a}$ \\
\hline
\end{tabular}

Mean values obtained from four replicates \pm one standard deviation. Means followed by the same letter do not differ statistically from each other for the same soil depth.

Source: Author.

Although high, the soil TOC content in Caatinga may correspond to OM that is not incorporated in the mineral fractions of the soil, thus becoming constantly dependent on the input of residues for its maintenance. During the drought period there would be indeed an increase in the content of soil elements, while during the rainy season, with the activity of the soil microbiota, there would be decomposition of these residues and mineralization of $\mathrm{C}$. In this context, low levels of TOC and TN would be justifiable in the agricultural soils studied (Table 2), since in these cultivated areas, especially palm groves, there is little or no replacement of crop residues.

In relation to the additional contributions of organic compounds, caused by the application of irrigation with treated effluents, contrary to what was expected, the total carbon concentrations in the TSE-irrigated soil were significantly lower than those in other areas studied at a depth of $0-10 \mathrm{~cm}$, although this tends to be in balance with the areas of increasing depth (Table 2). A similar result was described by Leuther et al. (2019) in a study conducted in Israel under similar conditions. They found total C and $\mathrm{N}$ concentrations in samples from a soil without irrigation to be significantly higher than in a soil irrigated with treated effluent at a depth of $0-20 \mathrm{~cm}$, with carbon values of 1.74 and $0.83 \mathrm{~g}^{100 \mathrm{~g}^{-1}}$ and

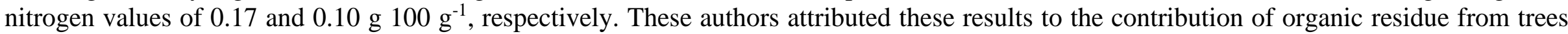
present in the non-irrigated area, without identifying any influence of irrigation water quality on soil carbon $(\mathrm{C})$ and nitrogen $(\mathrm{N})$ concentrations. In the present research, the low quantities of irrigation water applied, due to the fact that the forage palm is a xerophilous plant, combined with the implementation period (4 years) of the reuse project, which can be considered low to promote changes in the organic fraction of the soil, may justify the insignificance of the effect of TSE on soil carbon (C) and nitrogen (N) concentrations. Haynes (2005) suggests that short- to mediumterm crop management is not conducive to significant changes in TOC content. Therefore, in the experimental conditions of the present work, it can be deduced that the contents found would be more reacted to the organomineral complexes of the clay fraction, without irrigation or soil cover interfering with the $\mathrm{C}$ and $\mathrm{N}$ contents. 
The results found for the presence of $\mathrm{C}$ in soils reinforce what Oliveira et al. (2008) verified in their research, showing that the soil surface layers are more sensitive to carbon variations due to the action of microorganisms linked to soil organic matter. Kopittke et al. (2017) argue that $\mathrm{C}$ content tends to decrease in agricultural areas compared to native vegetation, since the conversion of native vegetation to crops reduces the input of plant debris and increases soil temperature, accelerating the decomposition of soil organic matter by microorganisms. Machado (2005) points out that surface C levels tend to decrease, but show little change at greater depths.

The highest $\mathrm{C} / \mathrm{N}$ ratio was observed in Caatinga soils, certainly due to the higher input of plant residues into the soil, while the lowest $\mathrm{C} / \mathrm{N}$ ratio was found in the TSE irrigated soil (Table 2 ). The lower the $\mathrm{C} / \mathrm{N}$ ratio, the greater the decomposition process of organic material. An increase in enzymatic activity has been reported in soils irrigated with treated wastewater (Adrover et al, 2012), suggesting that irrigation with wastewater can stimulate the activity of microorganisms in the biochemical cycle of elements such as $\mathrm{C}, \mathrm{N}$ and $\mathrm{P}$, thus accelerating the mineralization of soil organic matter. This could explain the fact that, in this study, the area irrigated with TSE had the lowest values of $\mathrm{C} / \mathrm{N}$ (more available nitrogen) compared to the other experimental sites. However, in the TSE irrigation site, lower organic matter contents can be found than in the surface water irrigation site. As mentioned above, it is likely that the lower $\mathrm{C} / \mathrm{N}$ ratio favoured rapid mineralization, leading to a decrease in the organic matter content of the soil.

Table 2, which represents TOC and TN stocks in the soils of the different sites studied, indicates that TOC stock in Caatinga exceeds those of the other sites. It was noted that the average TOC and TN stocks for the surface layer of soils are much lower than those verified by Rossato et al. (2007). They found $86 \mathrm{Mg} \mathrm{ha}^{-1}$ and $54 \mathrm{Mg} \mathrm{ha}^{-1}$ of TOC stocks, respectively, in an area of native vegetation and in a corn culture area, sown manually without the use of agricultural input. These authors found also $\mathrm{N}$ stocks of $9 \mathrm{Mg} \mathrm{ha}^{-1}$ and $6 \mathrm{Mg} \mathrm{ha}^{-1}$, respectively, in the same sites. A comparative analysis of the carbon stocks of different Brazilian biomes was carried out by Fidalgo et al. (2007), verifying that the average TOC accumulation for the soils of the Caatinga Biome is $23.7 \mathrm{Mg} \mathrm{ha}^{-1}$. Tiessen et al. (1998) estimated the carbon stock for the soils of this region at $20 \mathrm{Mg} \mathrm{ha}^{-1}$ for the 0-20 cm deep layer, and Fraga and Salcedo (2004) found, in a hyperxerophilic Caatinga, values of $17.9 \mathrm{Mg} \mathrm{ha}^{-1}$ and $28.6 \mathrm{Mg} \mathrm{ha}^{-1}$ for the $0-7.5 \mathrm{~cm}$ and $7.5-15 \mathrm{~cm}$ layers, respectively. These values corroborate the data found in this study for the Caatinga area.

For the other zones studied, the changes resulting from the anthropization process are certainly at the origin of the variation of the soil carbon stock compared to the local native vegetation (Caatinga), with a decrease varying between 44 and $62 \%$. The effect of different cropping systems is highlighted in the study by Giongo et al. (2011), which assessed the carbon stock in preserved Caatinga, altered Caatinga, pastures with Buffel grass and irrigated cropping in a Yellow Argisol, obtaining decreasing values for the TOC stock in the respective order cited, with reductions in the range of 23 to $56 \%$. Giongo et al. (2011) explained these reductions by the assumption that the high temperatures and intensity of sunshine, characteristic of the semiarid climate, associated with high water availability (by irrigation), increase the entropy of the system, resulting in a reduction of the soil carbon stock. In other words, because the rate of mineralization is highly dependent on the soil's water potential, the constant moisture level associated with high temperatures promotes rapid mineralization of organic material added to the soil, a fact also stated by Artiola and Pepper (1992). Thus, effluent irrigation has the potential to modify the recycling processes of $\mathrm{C}$ and $\mathrm{N}$ by increasing soil moisture to levels that stimulate the O.M. decomposition activity of soil microorganisms. These claims may explain the lower values of content and stocks of these nutrients in irrigated areas, especially those irrigated with TSE. It can also be deduced that the deforestation of the native vegetation and of 
soil in rotation for cultivation in the areas studied has led to alteration of the soil structure and intense loss of $\mathrm{C}$ from soil to the atmosphere, considerably reducing the capacity of retention of this element in the soil. Coupled with this, it is likely that little or no input of plant residues in cropping situations will not allow for nutrient recovery and accumulation in the soils studied here.

In Table 3, different from what was observed in the levels of $\mathrm{C}$ and $\mathrm{N}$, it can be seen that the soil irrigated with TSE had higher levels of $\mathrm{Na}$, reaching, at a depth of 10-20 cm, an average value about 10 times higher than that observed in the Caatinga soil, also differing from the treatment with surface water irrigation. Similar results were observed by Barreto et al. (2013) in their study on wastewater irrigation, which increased $\mathrm{Na}^{+}$concentration over the whole profile of soil. Indeed, unlike other cations, $\mathrm{Na}^{+}$has a low affinity for the soil exchange complex found mainly in the soil solution thus facilitating its leachability. Consequently, the $\mathrm{Na}^{+}$added from wastewater moves easily, justifying its higher concentrations with increasing depth (Tarchouna et al., 2010). Barreto et al. (2013) reinforce the above by stating that the rate of water application, the sodium content of the effluent, the absorption capacity of the crop and the soil texture can have a direct influence on the accumulation of this cation along the soil profile.

The high concentration of salts in soil, which may be due to the natural characteristics of the environment itself or to human activities, is capable of affecting the physical and chemical properties of the soil, making it difficult for plants to absorb water. It is noteworthy that high salt concentration in irrigated areas is common, since soluble salts present in irrigation water are added to the soil solution. This is not otherwise the case in the situations studied here, where irrigation water comes from treated sewage and also from a local surface reservoir potentially rich in salts due to the edaphoclimatic characteristics of the semi-arid region.

Salinization probably has the greatest negative impact on irrigated soils in arid and semiarid regions (Diaw et al., 2015), and this risk can be assessed by the soil Sodium Adsorption Ratio (SAR). For the soils in question, analyses indicate a SAR of irrigated soil higher with TSE than with the other waters (Table 3). Medeiros et al. (2005) also found in their studies that a soil that was irrigated had an increased SAR, both when using clean water or wastewater. A similar result was observed by Leuther et al. (2019), who reported that soil sodicity was the most affected factor when comparing non irrigated and irrigated areas with freshwater and treated effluent, with the highest SAR value for plots irrigated with TSE. Although sodicity increased in the soil irrigated with TSE, soils from all treatments can be classified as not affected by salt, with a SAR $<6$ (Rengasamy, 2010). This is due to the fact that the generally very poor sandy clay soils, as in this study, tend to be non-saline and will not have structural problems related to SAR due to their natural high permeability, which facilitates salt leaching during the rainy season. Clay soils, on the other hand, tend to accumulate salts and are rich in sodium, with structural problems that can occur if SAR increases.

For $\mathrm{P}, \mathrm{K}, \mathrm{Ca}$ and $\mathrm{Mg}$ analyses of the soils, in general, the highest results were found in the area irrigated with surface water, followed by the area irrigated with TSE. The excess of soluble salts in soil solution resulting from the accumulation of $\mathrm{Na}^{+}, \mathrm{Ca}^{2+}, \mathrm{Mg}^{2+}$ and $\mathrm{K}^{+}$in the irrigated soil horizons can be due to a combination of several factors, the main ones being soil management (mineral fertilization) and the presence of these elements in wastewater effluents or irrigation water (Qadir and Oster, 2004; Ribeiro, 2010). The average soil phosphorus content differs between treatments, particularly in the area irrigated with water, which presented the highest P content. Kouraa et al. (2002) evaluated the irrigation of potatoes and lettuce with raw sewage, treated wastewater and drinking water, noting that in one cropping year there was no change in the phosphorus content of the cultivated soils. The authors also state that for changes in soil chemical characteristics to take place, several years of irrigation are necessary, since the dynamics of this element are very slow. 
Table 3. Chemical characterization of soil at two soil depths under different uses in Santana do Seridó / RN.

\begin{tabular}{cccccccc}
\hline \multirow{2}{*}{ Land Use/Depths } & \multicolumn{5}{c}{ Elements } \\
\cline { 2 - 7 } & $\begin{array}{c}\mathbf{P} \\
\left(\mathrm{mg} \mathrm{kg}^{-1}\right)\end{array}$ & $\begin{array}{c}\mathbf{K} \\
\left(\mathrm{mg} \mathrm{kg}^{-1}\right)\end{array}$ & $\begin{array}{c}\mathbf{N a} \\
\left(\mathrm{mg} \mathrm{kg}^{-1}\right)\end{array}$ & $\begin{array}{c}\mathbf{C a} \\
\left(\mathrm{mg} \mathrm{kg}^{-1}\right)\end{array}$ & $\begin{array}{c}\mathbf{M g} \\
\left(\mathrm{mg} \mathrm{kg}^{-1}\right)\end{array}$ & $\mathbf{p H}$ & $\mathbf{S A R}$ \\
\hline TSEI & $18.06 \pm 9.55 \mathbf{b}$ & $75.00 \pm 20.27 \mathbf{c}$ & $141.00 \pm 47.88 \mathbf{a}$ & $276.00 \pm 64.30 \mathbf{b}$ & $114.00 \pm 20.98 \mathbf{b}$ & $7.2 \pm 0.65 \mathbf{a}$ & $2.6 \pm 0.94 \mathbf{a}$ \\
SWI & $34.74 \pm 13.13 \mathbf{a}$ & $160.50 \pm 51.68 \mathbf{a}$ & $57.00 \pm 33.80 \mathbf{b}$ & $524.00 \pm 53.73 \mathbf{a}$ & $158.00 \pm 9.10 \mathbf{a}$ & $7.3 \pm 0.34 \mathbf{a}$ & $0.8 \pm 0.48 \mathbf{b}$ \\
TRA & $9.68 \pm 7.46 \mathbf{c}$ & $112.00 \pm 7.35 \mathbf{b}$ & $20.00 \pm 4.56 \mathbf{c}$ & $410.00 \pm 88.59 \mathbf{a}$ & $101.00 \pm 13.88 \mathbf{b}$ & $7.0 \pm 0.08 \mathbf{a}$ & $0.3 \pm 0.09 \mathbf{b}$ \\
ONC & $9.57 \pm 2.98 \mathbf{c}$ & $109.50 \pm 9.10 \mathbf{b}$ & $24.00 \pm 9.38 \mathbf{c}$ & $508.0 \pm 144.53 \mathbf{a}$ & $92.00 \pm 21.07 \mathbf{b}$ & $6.3 \pm 0.07 \mathbf{b}$ & $0.4 \pm 0.10 \mathbf{b}$ \\
\hline & & & $10-20 \mathrm{~cm}$ & & & & \\
\hline TSEI & $13.07 \pm 7.69 \mathbf{b}$ & $80.5 \pm 24.95 \mathbf{c}$ & $215.00 \pm 93.65 \mathbf{a}$ & $274.00 \pm 41.59 \mathbf{b}$ & $119.00 \pm 29.35 \mathbf{b}$ & $7.9 \pm 0.24 \mathbf{a}$ & $3.8 \pm 1.37 \mathbf{a}$ \\
SWI & $28.79 \pm 21.96 \mathbf{a}$ & $140.00 \pm 46.45 \mathbf{a}$ & $82.00 \pm 63.27 \mathbf{b}$ & $500.00 \pm 42.65 \mathbf{a}$ & $154.00 \pm 42.31 \mathbf{a}$ & $7.9 \pm 0.25 \mathbf{a}$ & $1.2 \pm 1.00 \mathbf{b}$ \\
TRA & $5.08 \pm 3.39 \mathbf{c}$ & $121.00 \pm 20.07 \mathbf{b}$ & $23.00 \pm 5.39 \mathbf{c}$ & $379.00 \pm 60.63 \mathbf{b}$ & $113.00 \pm 22.92 \mathbf{b}$ & $7.2 \pm 0.29 \mathbf{b}$ & $0.4 \pm 0.10 \mathbf{b}$ \\
ONC & $4.07 \pm 1.95 \mathbf{c}$ & $113.00 \pm 9.43 \mathbf{b}$ & $22.00 \pm 0.87 \mathbf{c}$ & $357.0 \pm 103.93 \mathbf{b}$ & $94.00 \pm 24.80 \mathbf{c}$ & $6.6 \pm 0.33 \mathbf{c}$ & $0.4 \pm 0.05 \mathbf{b}$ \\
\hline
\end{tabular}

Mean values obtained from four replicates \pm one standard deviation. Means followed by the same letter do not differ statistically from each other for the same soil depth.

Source: Author.

On the other hand, Al-Nakshabandi et al. (1997) contradicted the study mentioned above, because in only five months of growing eggplant irrigated with a treated effluent containing $28 \mathrm{mg} \mathrm{L}^{-1}$ of $\mathrm{PO}_{4}^{-}$, they found a significant increase in soil phosphorus contents. This variation in $\mathrm{P}$ content between studies reinforces what has been said about the influences, not only of the quality of water used for irrigation, but also of irrigation management, vegetation requirements, and the soil and climate characteristics of the region. With regard to the $\mathrm{pH}$ of soils, the values found are close to neutral in all treatments. These results corroborate those obtained by Barreto et al. (2013), who did not observe any change in the pH of soils irrigated with treated effluents. 


\section{CONCLUSIONS}

- Land use had a significant influence on soil carbon and no significant influence on total nitrogen, with native vegetation in Caatinga presenting the highest TOC content compared to the three other areas used for agriculture.

- TOC contents tended to decrease with depth, and the mean TOC and TN stocks for the 0-20 $\mathrm{cm}$ layer were 28.43 $\mathrm{Mg} \mathrm{ha}^{-1}$ and 5.62 $\mathrm{Mg} \mathrm{ha}^{-1}$ for the open Caatinga and 13.61 $\mathrm{Mg} \mathrm{ha}^{-1}$ and $4.50 \mathrm{Mg} \mathrm{ha}^{-1}$ for the TSE irrigation area, respectively.

- The highest $\mathrm{C} / \mathrm{N}$ ratio was found in Caatinga soils, certainly due to the higher natural input of plant residues in the soil, while the lowest $\mathrm{C} / \mathrm{N}$ ratio was observed in the soil irrigated with TSE suggesting that irrigation with wastewater can stimulate the activity of soil microorganisms in the biochemical cycle of elements such as $\mathrm{C}, \mathrm{N}$ and $\mathrm{P}$, thus accelerating the mineralization of soil organic matter.

- The changes in the physicochemical properties of soils due to medium-term irrigation with TSE were mainly observed for significant changes in SAR, reaching, at a depth of 10-20 $\mathrm{cm}$, an average value about 10 times greater than that observed in the Caatinga soil, also differing from the treatment with surface water irrigation.

- The four years of irrigation with TSE in the soil proved to be insufficient to significantly alter the soil TOC and TN stocks in the soil, and under the experimental conditions observed, the treated wastewater reuse technology behaved more like a source of GHGs than a sink.

Finally, it's necessary that long-term research be carried out with the objective of verifying if the reuse of domestic sewage in agriculture (in isolated or combined action) can combat global warming and provide water security needed in semiarid regions.

\section{ACKNOWLEDGMENTS}

The authors of this article would like to thank the CNPq, CAPES and FACEPE for the scholarships awarded to students and researchers as well as for the financial support provided by the following research projects/programs grants: Universal MCTI/CNPq $\mathrm{N}^{\circ}$ 14/2014, MCTI/CNPq No 19/2017 Nexus, MCTI/CNPq/CAPES/FAPS No 16/2014, FACEPE 04/2017, National Observatory of Water and Carbon Dynamics in the Caatinga Biome - NOWCDCB, FACEPE (APQ-0498-3.07/17), CNPq (465764/2014-2), CAPES (88887.136369/2017-00); and CAPES PrInt (88881.318207/2019-01; 88887.371204/2019-00). The authors also thank the Instituto Nacional do Semi Árido (INSA) for providing the structures and materials for the research activities of this study. IGE is part of the Labex OSUG@2020 (ANR10 LABX56).

\section{REFERENCES}

AL-NAKSHABANDI, G. A.; SAQQAR, M. M.; SHATANAWI, M. R.; FAYYAD, M.; ALHORANI, H. Some environmental problems associated with the use of treated wastewater for irrigation in Jordan. Agricultural Water Management, v. 34, p. 81- 94, 1997. https://doi.org/10.1016/S0378-3774(96)01287-5

ADROVER, M.; FARRÚS, E.; MOYÀ, G.; VADELL, J. Chemical properties and biological activity in soils of Mallorca following twenty years of treated wastewater irrigation. Journal of Environmental Management, v. 95, p. S188-S192, 2012. https://doi.org/10.1016/j.jenvman.2010.08.017

ARAÚJO, J. C.; PEREIRA, D. D.; LIRA, E. C.; FÉLIX, E. S.; SOUZA, J. T. A.; LIMA, W. B. Palma forrageira: plantio e manejo. Campina Grande: INSA, 2019. 60p. 
ARTIOLA, J. F.; PEPPER, I. L. Longterm influence of liquid sewage sludge on the organic carbon and nitrogen content of a furrow-irrigated desert soil. Biology and Fertility of Soils, v. 14, p. 30-36, 1992. https://doi.org/10.1007/BF00336299

BARRETO, A. N.; NASCIMENTO, J. J. V. R.; MEDEIROS, E. P.; NÓBREGA, J. A.; BEZERRA, J. R. C. Changes in chemical attributes of a fluvent cultivated with castor bean and irrigated with wastewater. Revista Brasileira de Engenharia Agrícola e Ambiental, v. 17, p. 480-486, 2013. https://doi.org/10.1590/S1415-43662013000500003

BEDBABIS, S.; TRIGUI, D.; BEN AHMED, C.; CLODOVEO, M. L.; CAMPOSEO, S.; VIVALDI, G. A. Long-term effects of irrigation with treated municipal wastewater on soil. yield and olive oil quality. Agricultural Water Management, v. 160, p. 14-21, 2015. https://doi.org/10.1016/j.agwat.2015.06.023

BLAKE, G. R.; HARTGE, K. H. Bulk Density. In: AMERICAN SOCIETY OF AGRONOMY. Methods of Soil Analysis: Part 1-Physical and Mineralogical Methods. SSSA Book Series 5.1. Madison, 2006. p. 377-382.

DIAW, M.; MALL, I.; SANE, S.; MADIOUNE, H. D.; FAYE, S. Assessing of the Suitability for Irrigation Water and Their Repercussions on Land Degradation Process in Delta and Lower Senegal River Valley. American Journal of Water Resources, v. 3, n. 2, p. 32 43, 2015. https://doi.org/10.12691/ajwr-3-2-2

EMBRAPA. Centro Nacional de Pesquisa de Solos. Sistema Brasileiro de Classificação de Solos. Rio de Janeiro, 1999. 412 p.

EMBRAPA. Manual de análises químicas de solos, plantas e fertilizantes. Brasília: Embrapa Solos. Comunicação para Transferência de Tecnologia, 2009. 370p.

FAO. World reference base for soil resources 2014. Roma, 2014. 203 p.

FEINERMAN, E.; TSUR, Y. Perennial crops under stochastic water supply. Agricultural Economics, v. 45, n. 6, p. 757-766, 2014. https://doi.org/10.1111/agec.12120

FIDALGO, E.; BENITES, V.; MACHADO, P.; MADARI, B.; COELHO, M.; MOURA, I.; LIMA, C. Estoque de carbono nos solos do Brasil. Rio de Janeiro: Embrapa Solos, 2007. 27 p.

FRAGA, V. S.; SALCEDO, I. H. Declines of organic nutrient pools in tropical semi-arid soils under subsistence farming. Soil Science Society America Journal, v. 68, p. 215-224, 2004. https://doi.org/10.2136/sssaj2004.2150

FRANZLUEBBERS, A. J.; HANEY, R. L.; HOND, F. M.; ZUBERER, D. A. Determination of microbial biomass and nitrogen mineralization following rewetting of dried soils. Soil Science Society America Journal, v. 60, p. 1133-1139, 1996. https://doi.org/10.2136/sssaj1996.03615995006000040025x

GALINDO, I. C. L.; RIBEIRO, M. R.; SANTOS, M. F. A. V.; LIMA, J. F. W. F.; FERREIRA, R. F. A. L. Relações solo-vegetação em áreas sob processo de desertificação no município de Jataúba-PE. Revista Brasileira de Ciência do Solo, v. 32, p. 1283-1296, 2008. https://doi.org/10.1590/S0100-06832008000300036

GAO, L.; BECKER, E.; LIANG, G.; HOUSSOU, A. A.; WU, H.; WU, X.; CAI, D.; DEGRÉ, A. Effect of different tillage systems on aggregate structure and inner distribution of $\begin{array}{llllll}\text { organic carbon. Geoderma, v. 288, p. 97-104, } 2017 . & \end{array}$ https://doi.org/10.1016/j.geoderma.2016.11.005 
GIONGO, V.; CUNHA, T.; MENDES, A.; GAVA, C. Carbono no sistema solo-planta no Semiárido brasileiro. Revista Brasileira de Geografia Física, v. 4, n. 6, p. 1233-1253, 2011. https://doi.org/10.26848/rbgf.v4i6.232769

HAMILTON, A. J.; STAGNITTI, F.; XIONG, X.; KREIDL, S. L.; BENKE, K. K.; MAHER, P. Waste-water irrigation: the state of play. Vadose Zone Journal, v. 6, p. 823-840, 2007. https://doi.org/10.2136/vzj2007.0026

HAYNES, R. J. Labile organic matter fractions as central components of the quality of agricultural soils: an overview. Advances in Agronomy, v. 85, p. 221-268, 2005. https://doi.org/10.1016/S0065-2113(04)85005-3

HEYN, N.; JOERGENSEN, R. G.; WACHENDORF, C. Soil organic C and N stocks in the first rotation of poplar plantations in Germany. Geoderma Regional, v. 15, n. e00211, 2019. https://doi.org/10.1016/j.geodrs.2019.e00211

IBGE. Indicadores de desenvolvimento sustentável: estudos e pesquisas. Rio de Janeiro, 2012. 350p.

IPCC. Summary for Policymakers. In: IPCC. Climate Change 2013: The Physical Science Basis. Cambridge: Cambridge Univ. Press, 2013. p. 3-29.

KOPITTKE, P. M.; DALAL, R. C.; FINN, D.; MENZIES, N. W. Global changes in soil stocks of carbon, nitrogen, phosphorus, and sulphur as influenced by long-term agricultural production. Global Change Biology, v. 23, p. 2509-2519, 2017. https://doi.org/10.1111/gcb.13513

KOURAA, A.; FETHI, F.; LAHLOU, A.; OUAZZANII, N. Reuse of urban wastewater by combined stabilization pond system in Benslimane (Morocco). Urban Water, v. 4, p. 373-378, 2002. https://doi.org/10.1016/S1462-0758(01)00067-X

KUNLANIT, B.; BUTNAN, S.; VITYAKON, P. Land-Use Changes Influencing C Sequestration and Quality in Topsoil and Subsoil. Agronomy, v. 9, n. 520, p. 1-16, 2019. https://doi.org/10.3390/agronomy9090520

LAPOLA, D. M.; MARTINELLI, L. A.; PERES, C. A.; OMETTO, J. P. H. B.; FERREIRA, M. E.; NOBRE, C. A.; AGUIAR, A. P. D.; BUSTAMANTE, M. M. C.; CARDOSO, M. F.; COSTA, M. H.; JOLY, C. A.; LEITE, C. C.; MOUTINHO, P.; SAMPAIO, G.; STRASSBURG, B. B. N.; VIEIRA, I. C. G. Pervasive transition of the Brazilian landuse system. Nature Climate Change, v. 4, p. 27-35, 2013. https://doi.org/10.1038/nclimate2056

LEUTHER, F.; SCHLUTER, S.; WALLACH, R.; VOGEL, H. Structure and hydraulic properties in soils under long-term irrigation with treated wastewater. Geoderma, v. 333, p. 90-98, 2019. https://doi.org/10.1016/j.geoderma.2018.07.015

LÓPEZ-MERINO, L.; SERRANO, O.; ADAME, M. F.; MATEO, M. Á.; CORTIZAS, A. M. Glomalin accumulated in seagrass sediments reveals past alterations in soil quality due to land-use change. Global and Planetary Change, v. 133, p. 87-95, 2015. https://doi.org/10.1016/j.gloplacha.2015.08.004

MACHADO, P. L. A. Carbono do solo e a mitigação da mudança climática global. Química Nova, v. 28, p. 329-334, 2005. https://doi.org/10.1590/S0100-40422005000200026 
MARINHO, L. E. O.; TONETTI, A. L.; STEFANUTTI, R.; CORAUCCI FILHO, B. Application of reclaimed wastewater in the irrigation of rosebushes. Water Air Soil Pollution, v. 224, n. 1669, p. 1-7, 2013. https://doi.org/10.1007/s11270-013-1669-z

MARTINEZ, P. A.; MARTINEZ, N. G.; MEDINA, J. Q.; ALMELA, L. Domestic wastewaters reuse reclaimed by an improved horizontal subsurface-flow constructed wetland: A case study in the southeast of Spain. Bioresource Technology, v. 233, p. 236-246, 2017. https://doi.org/10.1016/j.biortech.2017.02.123

MEDEIROS, S. S.; SOARES, A. A.; FERREIRA, P. A.; NEVES, J. C. L.; MATOS, A. T.; SOUZA, J. A. A. Utilização de água residuária de origem doméstica na agricultura: Estudo das alterações químicas do solo. Revista Brasileira de Engenharia Agrícola e Ambiental, v. 9, n. 4, p. 603-612, 2005. https://doi.org/10.1590/S141543662005000400026

MERINO, A.; JIMÉNEZ, E.; FERNÁNDEZ, C.; FONTÚRBEL, M. T.; CAMPO, J.; VEGA, J. A. Soil organic matter and phosphorus dynamics after low intensity prescribed burning in forests and shrubland. Journal of Environmental Management, v. 234, p. 214-225, 2019. https://doi.org/10.1016/j.jenvman.2018.12.055

OLIVEIRA, J. T.; SANTOS, A. M. S.; MOREAU, A. M.; MENEZES, A. A.; COSTA, O. V. Características físicas e carbono orgânico de solos sob diferentes tipos de uso da terra. Revista Brasileira de Ciência do Solo, v. 32, p. 2821-2829, 2008. https://doi.org/10.1590/S0100-06832008000700028

POWLSON, D. S.; GREGORY, P. J.; WHALLEY, W. L.; QUINTON, J. N.; HOPKINS, D. W.; WHITMORE, A. P.; HIRSCH, P. R.; GOULDING, K. W. T. Soil management in relation to sustainable agriculture and ecosystem services. Food Policy, v. 36, p. S72S87, 2011. https://doi.org/10.1016/j.foodpol.2010.11.025

QADIR, M.; OSTER, J. D. Crop and irrigation management strategies for saline-sodic soils and waters aime at environmentally sustainable agriculture. Science of The Total $\begin{array}{lllllll}\text { Environment, } & \text { v. } 323, \quad \text { n. } & 1-3, & \text { p. } & 1-19,\end{array}$ https://doi.org/10.1016/j.scitotenv.2003.10.012

RENGASAMY, P. Soil processes affecting crop production in salt-affected soils. Functional Plant Biology, v. 37, n. 7, p. 613-620, 2010. https://doi.org/10.1071/FP09249

RIBEIRO, M. R. Origem e Classificação dos Solos Afetados por Sais. In: GHEYI, H. R.; DIAS, N. S.; LACERDA, C. F. (Eds.). Manejo da Salinidade na Agricultura: Estudos Básicos e Aplicados. Fortaleza: INCTSal, 2010. p.11-19

ROSSATO, M.; BARBIERI, R. L.; SCHÄFER, A.; ZACARIA, J. Caracterização molecular de populações de palmeiras do gênero Butia do Rio Grande do Sul através de marcadores ISSR. Magistra, v. 19, n. 4, p. 311-318, 2007.

SACRAMENTO, J. A. A. S.; ARAÚJO, A. C. de M.; ESCOBAR, M. E. O.; XAVIER, F. A. da S.; CAVALCANTE, A. C. R.; OLIVEIRA, T. S. Soil carbon and nitrogen stocks in traditional agricultural and agroforestry systems in the semiarid region of Brazil. Revista Brasileira Ciência do Solo, v. 37, p. 784-795, 2013. https://doi.org/10.1590/S010006832013000300025 
SANTANA, M. S.; SAMPAIO, E. V. S. B.; GIONGO, V.; MENEZES, R. S. C.; JESUS, K. N.; ALBUQUERQUE, E. R. G. M.; NASCIMENTO, D. M.; PARENY, F. G. C.; CUNHA, T. J. F.; SAMPAIO, R. M. B.; PRIMO, D. C. Carbon and nitrogen stocks of soils under different land uses in Pernambuco state, Brazil. Geoderma Regional, v. 15, n. e00205, 2019. https://doi.org/10.1016/j.geodrs.2019.e00205

SANTOS, U. J. dos; MEDEIROS, E. V. de; DUDA, G. P.; MARQUES, M. C.; SOUZA, E. S. de; BROSSARD, M. Land use changes the soil carbon stocks, microbial biomass and fatty acid methyl ester (FAME) in Brazilian semiarid área. Archives of Agronomy and Soil Science, v. 65, p. 755-769, 2019. https://doi.org/10.1080/03650340.2018.1523544

SUGIHARA, S.; FUNAKAWA, S.; KILASARA, M.; KOSAKI, T. Effects of land management on $\mathrm{CO}_{2}$ flux and soil $\mathrm{C}$ stock in two Tanzanian croplands with contrasting soil texture. Soil Biology \& Biochemistry, v. 46, p. 1-9, 2012. https://doi.org/10.1016/j.soilbio.2011.10.013

TARCHOUNA, L. G.; MERDY, P.; RAYNAUD, M.; PFEIFER, H. R.; LUCAS, Y. Effects of long-term irrigation with treated wastewater. Part 1: Evolution of soil physico-chemical properties. Applied Geochemistry, v. 25, p. 1703-1710, 2010. https://doi.org/10.1016/j.apgeochem.2010.08.018

TIESSEN, H.; CUEVAS, E.; SALCEDO, I. H. Organic matter stability and nutrient availability under temperate and tropical conditions. Advances in GeoEcology, v. 31, p. 415-422, 1998.

VELDKAMP, E. Organic Carbon Turnover in Three Tropical Soils under Pasture after Deforestation. Soil Science Society of America Journal, v. 58, p. 175-180, 1994. https://doi.org/10.2136/sssaj1994.03615995005800010025x

WEI, X.; SHAO, M.; GALE, W.; LI, L. Global pattern of soil carbon losses due to the conversion of forests to agricultural land. Scientific Reports, v. 4, p. 1-6, 2014. https://doi.org/10.1038/srep04062

WELLS, T.; HANCOCK, G. R.; MARTINEZ, C.; DEVER, C.; KUNKEL, V.; GIBSON, A. Differences in soil organic carbon and soil erosion for native pasture and minimum till agricultural management systems. Science of the Total Environment, v. 666, p. 618630, 2019. https://doi.org/10.1016/j.scitotenv.2019.02.097

YEOMANS, J. C.; BREMNER, J. M. A rapid and precise method for routine determination of organic carbon in soil. Communications in Soil Science and Plant Analysis, v. 19, p. 1467-1476, 1988. https://doi.org/10.1080/00103628809368027

ZHOU, Y.; LIU, W.; LV, X.; CHEN, X.; SHEN, M. Investigating interior driving factors and cross-industrial linkages of carbon emission efficiency in China's construction industry: Based on Super-SBM DEA and GVAR model. Journal of Cleaner Production, v. 241, n. 118322, 2019. https://doi.org/10.1016/j.jclepro.2019.118322 


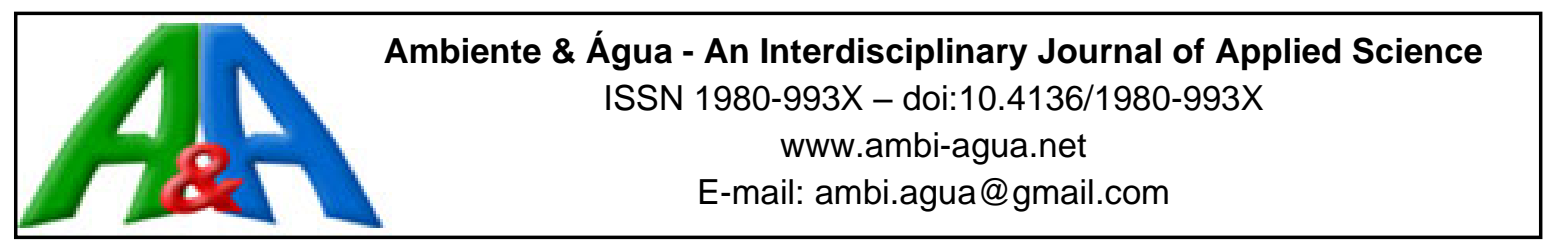

\title{
A predictive growth model for Yarrowia lipolytica ATCC 9773 in wastewater
}

ARTICLES doi:10.4136/ambi-agua.2629

Received: 01 Aug. 2020; Accepted: 17 Nov. 2020

\section{Arnulfo Antonio Tarón Dunoyer ${ }^{*}{ }^{*}$; Rafael Emilio González Cuello1 ${ }^{1 D}$; Fredy Colpas Castillo 2 it}

\author{
${ }^{1}$ Faculty of Engineering, Food Engineering Program. University of Cartagena, Street 30, $\mathrm{n}^{\circ}$ 48-152, 130014, \\ Zaragocilla, Cartagena, Colombia. E-mail: rgonzalezc1@unicartagena.edu.co \\ ${ }^{2}$ Exact and Natural Sciences Faculty. Chemistry program. University of Cartagena, Street 50, n 24120, 130014, \\ Zaragocilla, Cartagena, Colombia. E-mail: fcolpasc1@unicartagena.edu.co \\ *Corresponding author. E-mail: atarond@unicartagena.edu.co
}

\begin{abstract}
This study focuses on the development of a secondary model for Yarrowia lipolytica in a sewage treatment process. The raw data of $Y$. lipolytica growth were adjusted to the Buchanan model in order to obtain growth parameters such as initial count cells $\left(\mathrm{Y}_{0}\right)$, maximum specific growth rate $\left(\mu_{\max }\right)$, latency phase $(\lambda)$ and maximum cell population $\left(\mathrm{Y}_{\max }\right)$. The $\mu$ values obtained at different $\mathrm{pH}$ levels (5.0 to 8.0) were used to build the secondary model based on a linear equation. The results showed a significant effect of $\mathrm{pH}$ on $\mu_{\max }$ values. The validation process of the developed models displays accuracy (Af) and bias factor (Bf) values close to one, while the values of root mean square error (RMSE) were low, confirming that such models can predict the growth of Y. lipolytica in dairy wastewater. This can be interesting to optimize sewage treatments that involve this kind of microorganism. Moreover, the dairy wastewater was a good substrate to support the Yarrowia lipolytica's growth and could be used to produce enzymes.
\end{abstract}

Keywords: biological treatment, predictive microbiology, removal, wastewater, Yarrowia lipolytica.

\section{Modelo preditivo para o crescimento de Yarrowia lipolytica ATCC 9773 em um processo de biodegradação}

\section{RESUMO}

Este estudo tem como foco o desenvolvimento de um modelo secundário para Yarrowia lipolytica em processos de tratamento de esgoto. Os dados brutos de crescimento de $Y$. lipolytica foram ajustados ao modelo de Buchanan a fim de obter parâmetros de crescimento como: contagem inicial de células (Y0), taxa de crescimento específico máximo ( $\mu$ max), fase de latência $(\lambda)$ e população máxima de células (Ymax). Os valores $\mu$ obtidos em diferentes níveis de $\mathrm{pH}(5,0$ a 8,0) foram usados para construir o modelo secundário baseado em uma equação linear. Os resultados mostraram um efeito significativo do $\mathrm{pH}$ nos valores de $\mu$ max. O processo de validação dos modelos desenvolvidos apresenta valores de acurácia (Af) e fator de bias (Bf) próximos a um, enquanto os valores de root mean square error (RMSE) foram baixos, confirmando que tais modelos podem prever o crescimento de Y. lipolytica em águas residuais de laticínios. Isso pode ser interessante para otimizar tratamentos de esgoto que envolvem esse 
tipo de microrganismo. Além disso, as águas residuais do leite eram um bom substrato para apoiar o crescimento da Yarrowia lipolytica e poderiam ser utilizadas para produzir a produção de enzimas.

Palavras-chave: águas residuais, microbiologia preditiva, remoção, tratamento biológico, Yarrowia lipolytica.

\section{INTRODUCTION}

Predictive microbiology is an interdisciplinary area defined as: "the quantitative description of the microbial response in various ecosystems by employing mathematical models". A model is the description of a system or phenomenon that accounts for its known or inferred properties and might be used to further study its characteristics. Usually, predictive models have been built using raw data obtained from a pure culture in microbiological media. The composition and characteristics (broth, solid or semi-solid) of the medium are important factors that affect the behavior of microorganisms in foods. Mathematical models are developed to describe the effect of environmental conditions on microbial growth, thus allowing accurate predictions of microbial behaviors (Ding et al., 2011). Furthermore, the models can be valuable for estimating shifts in microbial concentrations (Fakrudding et al., 2011; Lee et al., 2014). In the area of predictive microbiology, there are primary and secondary models: (i) primary models describe a microbial response as a function of time for a single set of environmental conditions; and, (ii) secondary models quantify the effect of environmental variations on primary model parameters (Whiting, 1995).

Essentially, the function of a primary model is to obtain the growth or inhibition parameters of the microorganisms for each of the treatments established in the experimental design, whereas secondary models are built with parameters estimated from primary models. They are also employed to predict the response of microorganisms against new combinations of the environmental factors included in the experimental design. Once the secondary model has been constructed, it is necessary to corroborate the accuracy of its predictions. Statistical indices such as root mean square error (RMSE), bias (Bf) and accuracy factors (Af) have been proposed for estimating the accuracy of the model (Geitenes et al., 2013; Slongo et al., 2009). However, most of the predictive models have been developed on different food matrices (AntunesRohling et al., 2019; Schlei et al., 2020). Little research has been focused on modeling microbial growth in wastewater. The benefit of creating a secondary model relies on the ability to predict and optimize the duration of the sewage treatment processes.

The food industry has an elevated incidence of environmental contamination, for example, dairy industries produce large quantities of wastewater (Porwal et al., 2015). These wastes are impurities discharged into the environment without any previous decontamination treatment (Liu et al., 2015; Kumari et al., 2017); which significantly impacts public health and environmental sustainability. Hence, dairy waste requires decontamination treatments before it is discharged into sewer systems (Kumari et al., 2017). The principal substances in wastewater are oils, fats and long-chain fatty acids, which are contaminants of aquatic ecosystems (BecerraGutiérrez et al., 2015). Biological treatments have been employed as an alternative to decontaminate wastewater (González et al., 2012; Tarón-Dunoyer et al., 2020). Some yeasts are well-known for their ability to grow and decompose post-industrial wastes. Yarrowia lipolytica has been used as a biological agent for biodegradation of pollutant substrates. Additionally, this yeast is recognized as GRAS (Generally Recognized As Safe) in several industrial processes (Groenewald et al., 2014). This non-pathogenic, aerobic and dimorphic fungus has been studied in biodegradation processes and can be used for multiple biotechnological applications related to the production of enzymes and other compounds of 
industrial interest (da Costa et al., 2020). Nowadays, no investigations have been conducted pertaining to the modeling of $Y$. lipolytica in dairy waste. Thus, this work focuses on the development of a secondary model for predicting the growth of $Y$. lipolytica ATCC 9773 in wastewater.

\section{MATERIALS AND METHODS}

\subsection{Biological material}

Yarrowia lipolytica strain (ATCC 9773) was obtained from Medimark (C) Europe, 38033 Grenoble Cedex 2 - France.

\subsection{Preparation of the inoculum and obtaining the crude enzymatic extract (CEE)}

The activation of $Y$. lipolytica was carried out through incubation at $25^{\circ} \mathrm{C}$ in Petri dishes with PDA (potato dextrose agar) agar and olive oil as a lipid source for three days. Then, $Y$. lipolytica was suspended in a saline solution $(0.9 \% \mathrm{w} / \mathrm{v})$ until reaching $6 \times 10^{8} \mathrm{CFU} / \mathrm{mL}$ and then stored at $4^{\circ} \mathrm{C}$ until use. The dairy wastewater (DWW) was collected from a dairy industry located in Valledupar (Colombia) following the protocol mentioned by Taron-Dunoyer et al. (2020). Then, DWW volume (3 L) was divided into three subsamples with $\mathrm{pH}$ values of each subsample adjusted to 5.0; 6.5 and 8.0, respectively. It is important to note that $\mathrm{pH}$ was controlled by addition of acid $\left(1 \mathrm{~N} \mathrm{H}_{2} \mathrm{SO}_{4}\right)$ or base $(1 \mathrm{~N} \mathrm{KOH})$ taking into account $\mathrm{pH}$-metro readings, which were taken every 10 minutes. In order to obtain each growth curve, each subsample was added to an inoculum of $Y$. lipolytica $\left(6 \times 10^{8} \mathrm{CFU} / \mathrm{mL}\right)$. Likewise, $200 \mathrm{~mL}$ of a synthetic wastewater (SW) based on saltwater $(30 \% \mathrm{SW})$, sodium chloride (5.0\%), yeast extract $(0.5 \%)$, olive oil (1.0\%) and Triton X-100 (0.1\%) (Taron-Dunoyer et al., 2020) was inoculated with a similar amount of $Y$. lipolytica. The subsamples were aerated with filtered air at $2 \mathrm{~L} / \mathrm{min}$ and stirred at $300 \mathrm{rpm}$. Approximately every 20 minutes after inoculation, $1 \mathrm{~mL}$ was taken from each subsample and SW to carry out appropriate dilutions in peptone water and plated onto PDA agar. The petri dishes were incubated at $25^{\circ} \mathrm{C}$ for three days and then colonies were counted to obtain viable cell numbers $(\mathrm{CFU} / \mathrm{mL})$. Experiments lasted between 40 and $50 \mathrm{hrs}$.

\subsection{Primary modeling}

Growth curves of $Y$. lipolytica were constructed by plotting the logarithm of the number of microorganisms versus time at the different $\mathrm{pH}$ investigated. Each point of the growth curve corresponds to the average value of the entire set of samples assessed (at least three replicates of each was used to allow for statistical analysis). For growth curve fitting, the Buchanan model (Huang, 2013) was used to encounter the optimum fit for the growth curve (Equations 1 and 2).

$$
\begin{aligned}
& {\left[Y(t)=y_{0}+y_{\max }-\operatorname{In}\left\{e^{y_{0}}+\left[e^{y_{\max }}-e^{y_{0}}\right] e^{-\mu \max B(t)}\right\}\right]} \\
& {\left[B(t)=t+\frac{1}{\alpha} \operatorname{In} \frac{1+e^{-\alpha(t-\lambda)}}{1+e^{\alpha \lambda}}\right]}
\end{aligned}
$$

Where $y_{0}, y_{\max }$ and $y_{(t)}$ are the bacterial concentration in natural logarithm at initial, maximum, at time $t ; \mu_{\max }$ represents the maximum growth rate $[(\log \mathrm{CFU} / \mathrm{g}) / \mathrm{h}]$, and $\lambda$ represents the latency phase. The latency phase coefficient is $\alpha 4$.

\subsection{Secondary modeling}

The secondary model establishes a linear relationship between the natural logarithm $(\mathrm{Ln})$ of $\mu_{\max }$ and $\mathrm{pH}$ (Equation 3).

$$
\operatorname{Ln}(x)=m x+b
$$

Where, $\mathrm{x}$ is the growth rate, $\mathrm{m}$ is the slope and $\mathrm{b}$ is the $\mathrm{y}$-intercept. 


\subsection{Validation of the secondary model}

The bias factor (Bf), accuracy factor (Af), and root mean square error (RMSE) were employed to evaluate the performance of the generated secondary model (Ross, 1996). The Equations for 4,5 and 6 are the following:

$$
\begin{aligned}
& {\left[A_{f}=10^{\left(\left.\sum\right|^{\log \mu \text { pred }} / \log \mu \text { obs } \mid / n\right)}\right]} \\
& {\left[B f=10^{\left(\sum \log \left(\frac{\text { pobs }}{\mu \text { pred }}\right) / n\right)}\right]} \\
& {\left[R M S E=\frac{\sum(\text { obs }- \text { pred })^{2}}{n}\right]}
\end{aligned}
$$

Where, the variable factors obs, pred, and $\mathrm{n}$ are the observed value, predicted value, and repetition number of the observed data, respectively.

\subsection{Statistical analysis}

The results for growth parameters of $Y$. lipolytica were expressed as means \pm standard deviation. The influence of $\mathrm{pH}$ levels on maximum specific growth rate $\left(\mu_{\max }\right)$ was evaluated through an analysis of variance (ANOVA one way); whereas, post hoc tests (LSD test) were used to determine statistical differences $(\mathrm{P}<0.05)$ using SPSS software version 23.0 for windows. It is important to note that all tests were repeated at least three times to allow for statistical evaluation.

\section{RESULTS AND DISCUSSION}

Growth curves of Yarrowia lipolytica investigated in DWW at different $\mathrm{pH}$ levels $(5,6.5$ and 8.0) were obtained as described in the Materials and Methods section. The growth curves of Y. lipolytica ATCC 9773 were fitted using the Buchanan model and kinetic parameters were obtained. Figure 1 depicts the growth phases (lag, exponential and stationary phase) of $Y$. lipolytica in DWW. Similar behavior was observed for $Y$. lipolytica in SW (data not shown). These findings show the capability of Y. lipolytica of using some compounds present in the wastewater as a source of carbon, nitrogen and energy. Y. lipolytica is a non-conventional yeast due to its diverse biosynthetic potential (Egermeier et al., 2017). Dairy residues are considered highly biodegradable due to Y. lipolytica's ability to reduce BOD5 and COD to $43.32 \%$ and $44.30 \%$, respectively (Taron-Dunoyer et al., 2020). Hence, it could be an interesting model to predict the growth of $Y$. lipolytica in wastewater.

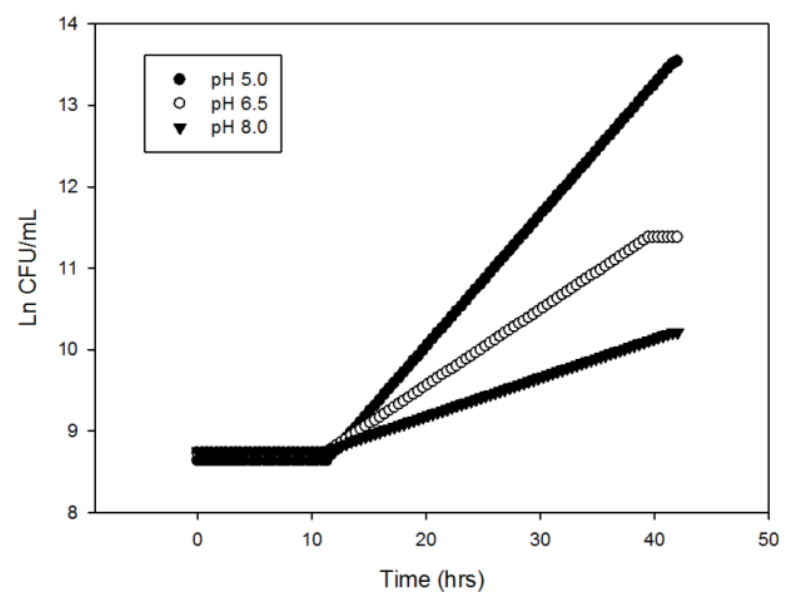

Figure 1. Effect of $\mathrm{pH}$ on growth of Yarrowia lipolytica in dairy wastewater. 
The suitability of primary models employed for developing predictive models is based on two factors: (i) environmental conditions and (ii) the microorganisms involved (Yoon, 2010). In the current study, Buchanan's primary predictive model was applied to model the growth of $Y$. lipolytica in a biodegradation treatment. Fitting the growth curves to the Buchanan model allows for determining growth parameters such as initial count cells $\left(\mathrm{Y}_{0}\right)$, maximum growth rate $(\mu)$, latency phase $(\lambda)$ and maximum cell population $\left(Y_{\max }\right)$ as illustrated Table 1.

Table 1. Growth parameters of $Y$. lipolytica at different $\mathrm{pH}$ values using the Buchanan model.

\begin{tabular}{clcc}
\hline $\mathrm{pH}$ levels & Parameters & Y. lipolytica $(\mathrm{DWW})$ & Y. lipolytica $(\mathrm{SW})$ \\
\hline \multirow{4}{*}{5.0} & $\mathrm{Y}_{0}(\log \mathrm{CFU})$ & $8.630^{\mathrm{a}}$ & $8.820^{\mathrm{a}}$ \\
& $\lambda(\mathrm{h})$ & $8.635^{\mathrm{a}}$ & $9.985^{\mathrm{b}}$ \\
& $\mathrm{Y}_{\max }(\log \mathrm{CFU})$ & $14.020^{\mathrm{a}}$ & $13.540^{\mathrm{a}}$ \\
& $\mu\left(\mathrm{h}^{-1}\right)$ & $0.168^{\mathrm{a}}$ & $0.161^{\mathrm{a}}$ \\
\hline \multirow{4}{*}{6.5} & $\mathrm{Y}_{0}(\log \mathrm{CFU})$ & $8.930^{\mathrm{a}}$ & $8.630^{\mathrm{a}}$ \\
& $\lambda(\mathrm{h})$ & $11.163^{\mathrm{a}}$ & $10.711^{\mathrm{a}}$ \\
& $\mathrm{Y}_{\max }(\log \mathrm{CFU})$ & $12.000^{\mathrm{a}}$ & $11.380^{\mathrm{b}}$ \\
& $\mu\left(\mathrm{h}^{-1}\right)$ & $0.129^{\mathrm{a}}$ & $0.094^{\mathrm{b}}$ \\
\hline \multirow{4}{*}{8.0} & $\mathrm{Y}_{0}(\log \mathrm{CFU})$ & $8.745^{\mathrm{a}}$ & $8.790^{\mathrm{a}}$ \\
& $\lambda(\mathrm{h})$ & $11.325^{\mathrm{a}}$ & $14.302^{\mathrm{b}}$ \\
& $\mathrm{Y}_{\max }(\log \mathrm{CFU})$ & $11.340^{\mathrm{a}}$ & $10.210^{\mathrm{b}}$ \\
& $\mu\left(\mathrm{h}^{-1}\right)$ & $0.094^{\mathrm{a}}$ & $0.048^{\mathrm{b}}$ \\
\hline
\end{tabular}

Rows with no common letter showed statistically significant difference (significance level<0.05).

$\mathrm{Y}_{0}$ values were not modified significantly $(\mathrm{P}>0.05)$ by the substrate (DWW and $\mathrm{SW}$ ) or its pH level. $\mathrm{Y}_{0}$ had values between 8.630 and $8.930 \log \mathrm{CFU}$ indicating that $\mathrm{Y}_{0}$ can be controlled at the beginning of the biodegradation process, that is when the microorganisms are incorporated into the sewage treatment system. $\lambda$, represents the time that microorganisms take to adapt to new environmental or nutritional conditions (Swinnen et al., 2004). This variable showed a tendency to increase with increasing $\mathrm{pH}$ of the substrates (DWW and SW) from 5.0 to 8.0. The highest values were found in SW at different $\mathrm{pH}$ levels: at $\mathrm{pH} 8.0-\lambda-14.302 \mathrm{~h}$; at $\mathrm{pH} 6.5-\lambda-10.711 \mathrm{~h}$ and at $\mathrm{pH} 5.0-\lambda-9.985 \mathrm{~h}$. This result suggests that the $\lambda$ parameter was directly proportional to $\mathrm{pH}$ levels. Similar results were obtained with $Y$. lipolytica in DWW; where, the highest value $(11.325 \mathrm{~h})$ was obtained at $\mathrm{pH}$ of 8.0 , while the lowest value, $8.635 \mathrm{~h}$, was obtained at $\mathrm{pH}$ of 5.0. $\mathrm{Y}_{\max }$ is another parameter calculated by the Buchanan model, which corresponds to the maximum microbial concentration reached at the end of the exponential phase. In DWW, the highest $\mathrm{Y}_{\max }$ value (14.020 $\log \mathrm{CFU}$ ) was reached at $\mathrm{pH} 5.0$ followed by pH 6.5 and 8.0 with 12.000 and $11.340 \log$ CFU, respectively. On the other hand, in regard to $\mathrm{SW}$, the highest value was obtained at $\mathrm{pH}$ of 5.0 (13.540 $\log \mathrm{CFU})$, while the lowest value was reached at $\mathrm{pH} 8.0$ (10.210 $\log \mathrm{CFU})$. Generally, the $\mathrm{Y}_{\max }$ values were higher in DWW than SW indicating that DWW is a good substrate to support $Y$. lipolytica growth and it could be used for biotechnological applications.

$\mu_{\max }$ is a key parameter because it represents the growth rate of microorganisms. Although it must be highlighted that $\mu_{\max }$ values mainly depend on the environmental conditions (ArroyoLópez et al., 2012). This parameter was inversely proportional to the $\mathrm{pH}$ levels. The lowest values were obtained at $\mathrm{pH} 8.0$ for both DWW and SW corresponding to 0.094 and $0.048\left(\mathrm{~h}^{-1}\right)$, respectively. Similar findings were published by da Costa et al. (2020), who cultivated $Y$. lipolytica in yeast peptone media at $29^{\circ} \mathrm{C}$, calculating values of $\mu$ close to $0.1114 \mathrm{~h}^{-1}$. Skandamis and Jeanson (2015) mentioned that $\mu$ reduction is caused mainly by limitations of nutrients, oxygen and production of some metabolites. 


\subsection{Secondary modeling}

The $\mu_{\max }$ values calculated by applying the Buchanan model were employed to develop the secondary model using a linear equation. Besides $\mu_{\max }$ was significantly affected by $\mathrm{pH}$ values and type of substrate. The secondary model describes the effect of $\mathrm{pH}$ on $Y$. lipolytica behavior in a biodegradation process. The changes in $\mu$ of $Y$. lipolytica, according to $\mathrm{pH}$ levels, is illustrated in Figure 2. Where, a reduction in $\mu$ values is observed when $\mathrm{pH}$ increases.

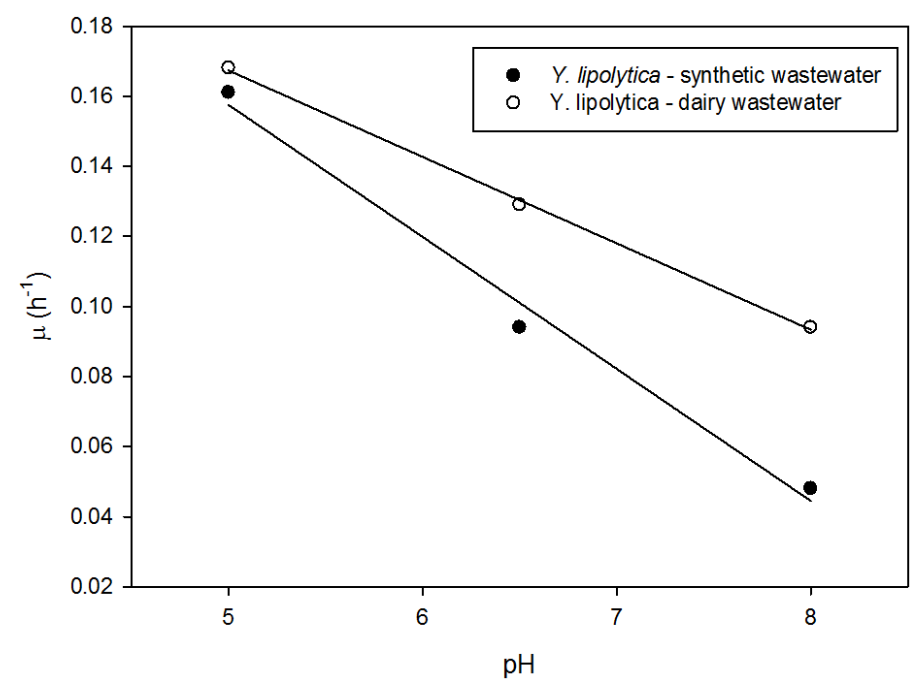

Figure 2. Effect of $\mathrm{pH}$ on maximum growth rates of Yarrowia lipolytica.

Considering that most of the secondary models are developed under real and abusive environmental conditions, a validation process must be carried out in order to verify the predictive accuracy of the models. Therefore, statistical indices such as accuracy (Af) and bias (Bf) have been suggested for validating secondary models (Baranyi et al., 1999; López et al., 2006).

Af is the sum of absolute differences between observed and predicted values of one parameter calculated in the secondary model. Bf represents the relative deviation among observed and predicted; moreover, this parameter allows for determining whether the model over or under-predicts microbial growth (Dalgaard and Jorgensen, 1998). For instance, a Bf value outside the range 0.7 to 1.5 indicates that the model is unsuitable (Choi et al., 2019; Ross, 1996; 1999). A perfect agreement between predictions and observations must have values of Af and Bf equal to 1.0 (Choi et al., 2019; Ross, 1999). Another parameter in a validation process is RSME, which compares observed values in the experiment with those calculated by the predictive model. A good validation process has values of RSME close to zero (Baranyi et al., 1996). The mathematical validation of $Y$. lipolytica growth is summarized in Table 2; where values of $\mathrm{Af}$ and $\mathrm{Bf}$ close to 1 were obtained based on secondary models. This indicates that both linear models developed herein can optimally simulate $Y$. lipolytica's growth in both dairy wastewater and synthetic wastewater at different $\mathrm{pH}$ levels (5.0 to 8.0). Regarding RSME, low values were achieved, corroborating that lineal models were suitable for predicting $Y$. lipolytica's growth in a sewage treatment.

Table 2. Mathematical validation of the secondary model to describe the behavior of $Y$. lipolytica

\begin{tabular}{lccc}
\hline Equation & Af & Bf & RSME \\
\hline In $(\mu)=-0.0247 x+0.2907(D W W)$ & 1.001 & 0.998 & 0.001 \\
In $(\mu)=-0.0377 x+0.3458(C W)$ & 1.009 & 0.990 & 0.006 \\
\hline
\end{tabular}


It is important to emphasize that real wastewater was used to develop a secondary model to predict Yarrowia lipolytica's growth. Interestingly, when microbial growth is carried out in artificial microbiological culture, models usually overestimate the predictions (Pérez and Valero, 2013). Hence, the models constructed herein could be considered consistent for practical use and improve the sewage treatment processes.

\section{CONCLUSIONS}

In the present article, a secondary model was developed to simulate the growth of Yarrowia lipolytica in both dairy wastewater (DWW) and synthetic wastewater at different $\mathrm{pH}$ levels. This model established a linear relationship between $\mu_{\max }$ and $\mathrm{pH}$. The validation process yielded accuracy and bias factors of approximately 1; while values of RSME were low. These results indicate that the secondary model developed can predict $Y$. lipolytica growth in wastewater; hence proving highly valuable for optimizing sewage treatment processes that include this kind of microorganism. Furthermore, DWW proved to be a good substrate to support the growth of Yarrowia lipolytica and could be used for biotechnological approaches such as the production of enzymes.

\section{REFERENCES}

ANTUNES-ROHLING, A.; ARTAIZ, A.; CALERO, S.; HALAIHEL, N.; GUILLÉN, S.; RASO, J.; ÁLVAREZ, I.; CEBRIÁN, G. Modelling microbial growth in modifiedatmosphere-packed hake (Merluccius merluccius) fillets stored at different temperatures. Food Research International, v. 122, n. 1, p. 506-516, 2019. https://doi.org/10.1016/j.foodres.2019.05.018

ARROYO-LÓPEZ, F.; BAUTISTA-GALLEGO, J.; GARRIDO-FERNANDEZ, A. Role of Predictive Microbiology in Food Preservation. In: BHAT, R.; ALIAS, A. K.; PALIYATH, G. Progress in Food Preservation. New York: John Wiley \& Sons, 2012. p. 389-404.

BARANYI, J.; ROSS, T.; MCMEEKIN, T. A.; ROBERTS, T. A. Effects of parameterization on the performance of empirical models used in "predictive microbiology". Food Microbiology, v. 13, n. 1, p. 83-91, 1996. https://doi.org/10.1006/fmic.1996.0011

BARANYI, J.; PIN, C.; ROSS, T. Validating and comparing predictive models. International Journal of Food Microbiology, v. 48, n. 1. p. 159-166, 1999. https://dx.doi.org/10.1016/s0168-1605(99)00035-5

BECERRA-GUTIÉRREZ, L. K.; HORNA-ACEVEDO, M. V.; BARRIONUEVO-ALBÚJAR, K. I. Influence of native microorganisms in treatment of slaughterhouses waste water. Revista del Cuerpo Médico del Hospital Nacional Almanzor Aguinada Asenjo, v. 8, n. 1, p. 15-18, 2015. https://doi.org/10.35434/rcmhnaaa.2015.81.231

CHOI, W. S.; SON, N.; CHO, J. I.; JOO, I. S.; HAN, J. A.; KWAK, H. S.; SUH, S. H. Predictive model of Staphylococcus aureus growth on egg products. Food Science and Biotechnology, v. 28, n. 1, p. 913-922, 2019.

DALGAARD, P.; JORGENSEN L. Predicted and observed growth of Listeria monocytogenes in seafood challenge tests and in naturally contaminated cold smoked salmon. International Journal of Food Microbiology, v. 40, n. 1, p. 105-115, 1998. https://dx.doi.org/10.1016/s0168-1605(98)00019-1 
DA COSTA, A. M.; DE OLIVEIRA LOPES, V. R.; VIDAL, L.; NICAUD, J. M.; DE CASTRO, A. M.; ZARUR, M. A. Poly (ethylene terephthalate) (PET) degradation by Yarrowia lipolytica: Investigations on cell growth, enzyme production and monomers consumption. Process Biochemistry, v. 95, n. 1, p. 81-90, 2020. https://doi.org/10.1016/j.procbio.2020.04.001

DING, T.; SHIM, Y. H.; KIM, H. N.; HA, S. D.; CHUNG, M. S.; HWANG, I. G.; OH, D.H Development of predictive model for the growth of Staphylococcus aureus in Kimbab. Food Science and Biotechnology, v. 20, n. 1, p. 471-476, 2011. https://doi.org/10.1007/s10068-011-0065-y

EGERMEIER, M.; RUSSMAYER, H.; SAUER, M.; MARX, H. Metabolic flexibility of Yarrowia lipolytica growing on glycerol. Frontiers in Microbiology, v. 8, n. 1, p. 1-9, 2017. https://doi.org/10.3389/fmicb.2017.00049

FAKRUDDIN, M.; MAZUMDER, R. M.; MANNAN, K. Predictive microbiology: Modeling microbial responses in food. Ceylon Journal of Science, v. 40, n. 1, p. 121-131, 2011.

GEITENES, S.; OLIVEIRA, M. F. B.; KALSCHNE, D. L.; SARMENTO, C. M. P. Modelagem do crescimento de bactérias láticas e análise microbiológica em apresuntado e presunto cozido fatiados e embalados à vácuo. Revista Ciências Exatas e Naturais, v. 15, n. 1, p. 113-133, 2013.

GONZÁLEZ, D.; AMAÍZ, L.; MEDINA, L.; VARGAS, R.; IZZEDDIN, N.; VALBUENA, O. Biodegradación de residuo graso industrial empleando bacterias endógenas. Revista Latinoamericana de Biotecnologia Ambiental y Algal, v. 3, n. 2, p. 105-118, 2012.

GROENEWALD, M.; BOEKHOUT, T.; NEUVÉGLISE, C.; GAILLARDIN, C.; VAN DIJCK, P. W. M.; WYSS, M. Yarrowia lipolytica: safety assessment of an oleaginous yeast with a great industrial potential. Critical Reviews in Microbiology, v. 40, n. 3, p. 187-206, 2014. https://dx.doi.org/10.3109/1040841X.2013.770386

HUANG, L. H. IPMP-A comprehensive data analysis tool of predictive microbiology. International Journal of Food Microbiology, v. 171, n. 1, p. 100-107, 2013. https://doi.org/10.1016/j.ijfoodmicro.2013.11.019

KUMARI, A.; RAZI, A.; NEGI, S.; KHARE, S. Biodegradation of waste grease by Penicillium chrysogenum for production of fatty acid. Bioresource Technology, v. 226, p. 31-38, 2017. https://doi.org/10.1016/j.biortech.2016.12.006

LEE, Y. J.; JUNG, B. S.; YOON, H. J.; KIM, K. T.; PAIK, H. D.; LEE, J. Y. Predictive model for the growth kinetics of Listeria monocytogenes in raw pork meat as a function of

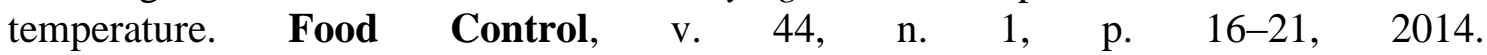
https://doi.org/10.1016/j.foodcont.2014.03.024

LIU, Y.; KANG, X.; LI, X. L.; YUAN, Y. Performance of aerobic granular sludge in a sequencing batch bioreactor for slaughterhouse wastewater treatment. Bioresource technology, v. 190, p. 487-491, 2015. https://doi.org/10.1016/j.biortech.2015.03.008

LÓPEZ, F. N.; QUINTANA, M. C.; FERNÁNDEZ, A. G. The use of a D-optimal design to model the effects of temperature, $\mathrm{NaCl}$, type and acid concentration on Lactobacillus pentosus IGLAC01. Journal of Applied Microbiology, v. 101, n. 1, p. 913-926, 2006. https://dx.doi.org/10.1111/j.1365-2672.2006.02979.x 
PÉREZ, F.; VALERO, A. Predictive microbiology in foods. Heidelberg: Springer, 2013.

PORWAL, H. J.; MANE, A. V.; VELHAL, S. Biodegradation of Dairy Effluent by Using Microbial Isolates Obtained from activated sludge. Water Resources and Industry, v. 9, p. 1-15, 2015. https://doi.org/10.1016/j.wri.2014.11.002

ROSS, T. Indices for performance evaluation of predictive models in food microbiology. Journal of Applied Bacteriology, v. 81, n. 1, p. 501-508, 1996. https://doi.org/10.1111/j.1365-2672.1996.tb03539.x

ROSS, T. Predictive food microbiology models in the meat industry. Sydney: Meat and livestock Australia, 1999. p. 196.

SCHLEI, K.; ANGIOLETTI, B.; FERNANDES DE CARVALHO, L.; BERTOLI, S.; REITER, M.; KREBS DE SOUZA, C. Influence of temperature on microbial growth during processing of kochkase cheese made from raw and pasteurised milk. International Dairy Journal, v. 109, n. 1, p. 1-7, 2020. https://doi.org/10.1016/j.idairyj.2020.104786

SKANDAMIS, P. N.; JEANSON, S. Colonial vs. planktonic type of growth: mathematical modelling of microbial dynamics on surfaces and in liquid, semiliquid and solid foods. Frontiers of Microbiology, v. 6, n. 1, 2015. https://doi.org/10.3389/fmicb.2015.01178

SLONGO, A. P.; ROSENTHAL, A.; CAMARGO, L. M. Q.; DELIZA, R.; MATHIAS, S. P.; ARAGÃO, G. M. F. Modeling the growth of lactic acid bacteria in sliced ham processed by high hydrostatic pressure. LWT - Food Science and Technology, v. 42, n. 1, p. 303-306, 2009. https://doi.org/10.1016/j.lwt.2008.06.010

SWINNEN, I. A.; BERNAERTS, K.; DENS, E. J.; GEERAERD, A. H.; VAN IMPE, J. F. Predictive modelling of the microbial lag phase: a review. International Journal of $\begin{array}{llllllll}\text { Food Microbiology, } & \text { v. 94, n. } 2004 .\end{array}$ https://doi.org/10.1016/j.ijfoodmicro.2004.01.006

TARÓN-DUNOYER， A.; GONZÁLEZ-CUELLO， R. E.; PEREZ-SALINAS, R. Biodegradation of dairy wastes using crude enzymatic extract of Yarrowia lipolytica ATCC 9773. Revista Ambiente \& Água, v. 15, n. 1, p. 1-9, 2020. https://dx.doi.org/10.4136/1980-993X

WHITING, R. C. Microbial modeling in foods. Critical Reviews in Food Science and Nutrition, v. 35, n. 1, p. 467-494, 1995. https://doi.org/10.1080/10408399509527711

YOON, Y. H. Principal theory and application of predictive microbiology. Food Science and Industry, v. 43, n. 1, p. 70-74, 2010. 


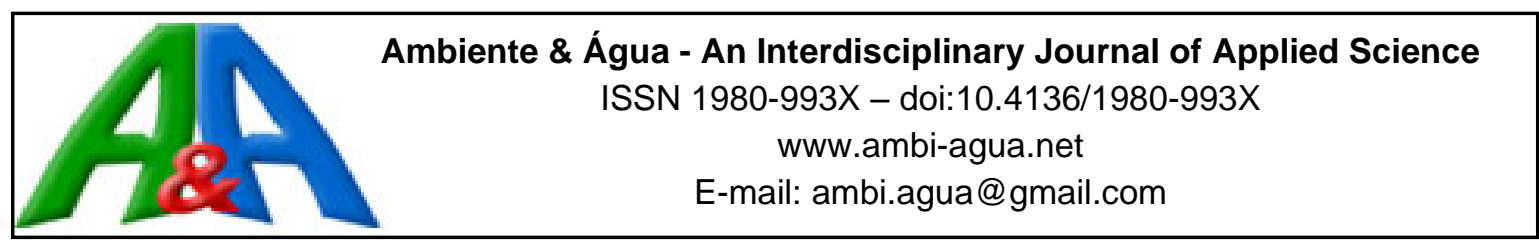

\title{
Physiological responses of inoculated and uninoculated peanuts under saline stress
}

\author{
ARTICLES doi:10.4136/ambi-agua.2643
}

Received: 11 Sep. 2020; Accepted: 15 Dec. 2020

\begin{abstract}
Antonio Fabio da Silva Lima1 ${ }^{1}$; Max Ferreira dos $\operatorname{Santos}^{2}$; Matheus Lima Oliveira ${ }^{1}$; Geocleber Gomes de Sousa ${ }^{1}$; Paulo Furtado Mendes Filho ${ }^{2}$; Lucas Nunes da Luz ${ }^{*}$ (iD
\end{abstract}

\footnotetext{
${ }^{1}$ Instituto de Desenvolvimento Rural. Universidade da Integração Internacional da Lusofonia Afro-Brasileira (UNILAB), Avenida da Abolição, nº 03, CEP: 62790-000, Redenção, CE, Brazil.

E-mail: antfabiosl@gmail.com,mts.lima518@gmail.com, sousagg@unilab.edu.br ${ }^{2}$ Departamento de ciências do solo. Universidade Federal do Ceara (UFC), Rua Cinco, n 100, CEP: 60355-636, Fortaleza, CE, Brazil. E-mail: maxsantosferreira@gmail.com, mendes@ufc.br *Corresponding author. E-mail: lucasluz@unilab.edu.br
}

\begin{abstract}
This work evaluated the effects of water salinity on the physiological indices in inoculated and non-inoculated peanut plants. The study was carried out in a protected environment at the seedling production unit (UPMA) at Campus das Auroras, at the University for International Integration of the Afro-Brazilian Lusophony (UNILAB), Redenção, Ceará. The experimental design used was in a completely randomized (CRD), with treatments in a factorial arrangement, $5 \times 2$, referring to the five salinity levels of the irrigation water - CEa: 0.5, 1.5, 3, 4.5, and 6.0 $\mathrm{dSm}^{-1}$, and inoculated and non-inoculated plants with a mix of rhizobia SEMIA 630, lot 0810, and SEMIA 6144, lot 0312, from Bradyrhizobium sp., isolated, with four replications. Recommended fertilization was done for phosphorus $\left(62.5 \mathrm{~kg} \mathrm{ha}^{-1}\right.$ of $\left.\mathrm{P}\right)$ and potassium $(50 \mathrm{~kg}$ $\mathrm{ha}^{-1}$ of K) to supply the nutritional needs of the plants. The nutritional effect caused by symbiosis with Bradyrhizobium sp. favored inoculated plants to present greater tolerance to salt stress. The availability of nitrogen collaborated to increase the efficiency of plant physiological mechanisms. Uninoculated plants, even with a higher amount of chlorophyll and $\mathrm{CO}_{2}$, were not efficient in the photosynthetic rate. Saline stress affected photosynthesis, transpiration, stomatal conductance, internal $\mathrm{CO}_{2}$ concentration, water use efficiency, and chlorophyll; however, with less intensity when inoculated with Bradyrhizobium sp. The increase in salinity on irrigation water increased the leaf temperature.
\end{abstract}

Keywords: Arachis hypogaea L., Bradyrhizobium, plant-microbial relationship.

\section{Respostas fisiológicas do amendoim inoculado e não inoculado sob estresse salino}

\section{RESUMO}

Objetivou-se neste trabalho avaliar os efeitos da salinidade da água sobre os índices fisiológicos em plantas de amendoim inoculadas e não inoculadas. $\mathrm{O}$ trabalho foi desenvolvido em ambiente protegido, na unidade de produção de mudas (UPMA), no Campus das Auroras, na Universidade da Integração Internacional da Lusofonia Afro-Brasileira (UNILAB), 
Redenção, Ceará. O delineamento experimental utilizado foi o inteiramente casualizado (DIC), com tratamentos arranjados em esquema fatorial, 5 x 2 , referentes aos cinco níveis de salinidade da água de irrigação - CEa: 0,5, 1,5, 3, 4,5 e $6 \mathrm{dSm}^{-1}$, e plantas inoculadas e não inoculadas com mix de rizóbios SEMIA 630, lote 0810 e SEMIA 6144, lote 0312, de Bradyrhizobium sp., isolado, com 4 repetições. Realizou-se também adubação recomendada para o fósforo $(62,5 \mathrm{~kg}$ $\mathrm{ha}^{-1}$ de $\mathrm{P}$ ) e o potássio ( $50 \mathrm{~kg} \mathrm{ha}^{-1}$ de $\mathrm{K}$ ) para suprir as necessidades nutricionais das plantas. $\mathrm{O}$ efeito nutricional ocasionado pela simbiose com Bradyrhizobium sp. favorece as plantas inoculadas a apresentarem maior tolerância ao estresse salino. A disponibilidade de nitrogênio ajudou na maior eficiência dos mecanismos fisiológicos da planta. As plantas não inoculadas, mesmo tendo uma maior quantidade de clorofila e $\mathrm{CO}_{2}$, não foram eficientes na taxa fotossintética. $\mathrm{O}$ estresse salino afetou a fotossíntese, transpiração, condutância estomática concentração interna de $\mathrm{CO}_{2}$, o uso e eficiência da água e a clorofila, porém com menor intensidade quando inoculadas com Bradyrhizobium sp. $\mathrm{O}$ aumento da salinidade da água de irrigação aumentou a temperatura foliar.

Palavras-chave: Arachis hypogaea L., Bradyrhizobium, relação planta-micróbio.

\section{INTRODUCTION}

Peanut culture is found in several tropical countries, although it is native to South America. The genus Arachis has more than 80 species, including cultivated peanuts (Krapovickas and Gregory, 1994). The peanut crop currently demonstrates elevated economic importance, as it is the fourth most-produced oilseed in terms of grain volume in the world (FAO, 2019).

In general, the northeast region of Brazil offers favorable climatic conditions for the development of peanut culture; however, factors that hinder the crop expansion are high evapotranspiration, low precipitation, and sometimes, the low irrigation water quality; these factors may limit the development and production of cultures worldwide (Freire et al., 2014).

Saline stress causes several physiological and biochemical disorders, as it reduces the osmotic potential of the soil, reducing water absorption; furthermore, these excess salts in the plant tissue become toxic to the plant leading to a nutritional disorder (Pereira Filho et al., 2019; Lima et al., 2020).

In legumes such as peanuts, it is known that nitrogen supply is facilitated by the presence of diazotrophic bacteria. Nevertheless, under ideal nutritional conditions, peanuts increase the nodulation rate, as the nitrogen provided by biological fixation will help in the production of organic molecules capable of resistance to various stresses; that is, its antioxidant system is more efficient (Fukami et al., 2018; Freitas et al., 2020).

One of the strategies for growing peanuts under saline stress is the use of Rhizobium spp. and Bradyrhizobium spp., aiming to reduce the use of nitrogen fertilizers. These bacteria are able to fix the $\mathrm{N}$ necessary for better development of the culture and present positive effects for its yield (Rocha et al., 2019). According to Mondal et al. (2020a) this N not only helps in plant nutrition, but it can provide a more sustainable system for culture.

This work evaluated the effects of water salinity on the physiological indices in inoculated and non-inoculated peanut plants.

\section{MATERIAL AND METHODS}

The study was carried out in July 2019 in a protected environment, at the seedling production unit (UPMA), Campus Auroras, of University for International Integration of the Afro-Brazilian Lusophony (Portuguese: Universidade da Integração Internacional da Lusofonia Afro-Brasileira, UNILAB), located in Redenção, Ceará. According to Köppen (1993), the 
climate of the region is classified as Aw' type, that is, rainy, tropical, very warm, with a predominance of rain in the summer and autumn seasons.

The experiment was conducted in $8 \mathrm{~L}$ pots filled with soil from the Campus das Auroras and was removed from the $0-20 \mathrm{~cm}$ layer, classified as Red-Yellow Argisol (Santos et al., 2018). A sampling at a depth of $0-20 \mathrm{~cm}$ was sent for the analysis of chemical attributes to the Soil Laboratory, belonging to the Federal University of Ceará; the results are shown in Table 1.

Table 1. Chemical attributes of the substrate used in the research.

\begin{tabular}{|c|c|c|c|c|c|c|c|c|c|c|c|}
\hline $\mathrm{pH} \mathrm{H} \mathrm{H}_{2} \mathrm{O}$ & $\mathrm{P}$ & $\mathrm{H}+\mathrm{Al}^{3+}$ & $\mathrm{Ca}^{2+}$ & $\mathrm{Mg}^{2+}$ & $\mathrm{Na}^{+}$ & $\mathrm{K}^{+}$ & SB & CEC & V & $\mathrm{OM}$ & CEes \\
\hline & Mg. $\mathrm{kg}^{-1}$ & & & & $\mathrm{l}_{\mathrm{c}} \cdot \mathrm{kg}^{-1}$ & & & & $\%$ & g. $\mathrm{kg}^{-1}$ & $\mathrm{dS} \cdot \mathrm{m}^{-1}$ \\
\hline 7.6 & 2 & 0.33 & 2.50 & 0.30 & 0.57 & 0.06 & 3.43 & 3.76 & 91 & 4.03 & 0.37 \\
\hline
\end{tabular}

Sowing of cultivar BR-1 was carried out in the pot. After ten days of sowing, thinning was done, leaving only two plants per pot.

The experimental design used was completely randomized (CRD), with treatments in a factorial arrangement, $5 \times 2$, referring to the five salinity levels of the irrigation water - CEa: 0.5 , $1.5,3,4.5$, and $6.0 \mathrm{dSm}^{-1}$, and inoculated and non-inoculated plants with a mix of rhizobia SEMIA 630 and SEMIA 6144, from Bradyrhizobium sp., with four replications measurements were made in all four by treatment.

The strains were activated according to the method described by Embrapa (1994), and posteriorly, its multiplication was conducted in a $125 \mathrm{ml}$ flask, with $50 \mathrm{ml}$ of liquid YM medium, incubated on a rotary shaker at $150 \mathrm{rpm}$ and temperature of $28^{\circ} \mathrm{C}$ and propagated in peat.

Two inoculations were performed, the first was made on peanut seeds using the mix of rhizobia spread in a peat medium and adhesive solution of $20 \%$ gum arabic as an adhesive solution. While the second, called "reinforcement inoculation", occurred ten days after sowing (DAS), in which $2.0 \mathrm{~mL}$ of bacterial broth was added to the lap of each plant.

The irrigation waters were prepared using the $\mathrm{NaCl}, \mathrm{CaCl}_{2} \cdot 2 \mathrm{H}_{2} \mathrm{O}$, and $\mathrm{MgCl}_{2} \cdot 6 \mathrm{H}_{2} \mathrm{O}$ in the proportion 7:2:1, following the relationship between CEa and its concentration $\left(\mathrm{mmol}_{\mathrm{c}} \mathrm{L}^{-1}=\right.$ CE x 10) (Rhoades et al., 2000). Irrigation with saline water was started ten days after sowing with a daily irrigation frequency according to the drainage lysimeter principle (Puértolas et al., 2017), providing the volume of water losses by evapotranspiration in every $24 \mathrm{~h}$, to maintain the soil with humidity corresponding to $90 \%$ of the field capacity.

Moreover, recommended fertilization was held for phosphorus $\left(62.5 \mathrm{~kg} \mathrm{ha}^{-1}\right.$ of P) and potassium $\left(50 \mathrm{~kg} \mathrm{ha}^{-1}\right.$ of $\left.\mathrm{K}\right)$ to meet the nutritional needs of plants, following the recommendations of Fernandes (1993).

At 55 DAS, the following variables were analyzed: photosynthesis (A), transpiration (E), and stomatal conductance (gs), leaf temperature (LT), internal CO2 concentration (IC) in fully expanded sheets. To carry out these analyses, a portable infrared carbon gas analyzer was used (IRGA model LC-Pro-SD, Biosciences Inc., Lincoln, Nebraska, USA), in an open system, with an airflow of $300 \mathrm{~mL}$ min-1 between 08:00 and 10:00 h, using light intensity active (PAR) constant $\left(1300 \mu \mathrm{mol}\right.$ photons $\left.\mathrm{m}^{-2} \mathrm{~s}^{-1}\right)$, concentration constant $\mathrm{CO}_{2}(350 \mathrm{ppm})$ with ambient air temperature and relative humidity, on average $30^{\circ} \mathrm{C}$ and $85 \%$, respectively. The instant water use efficiency (WUE), was determined from the ratio between A/E. Chlorophyll was measured with Minolta SPAD-502 portable meter.

The data of the evaluated variables were submitted to analysis of variance and, when significant, by the $\mathrm{F}$ test, and the means were compared by the Tukey test with $\mathrm{p}<0.05$ using 
ASSISTAT, Version 7.7 Beta (Silva and Azevedo, 2016). For the regression analysis, as a criterion for choosing the equations, the significance of the regression coefficients at the significance level of 0.01 and 0.05 probability was used by the $\mathrm{F}$ test and in the largest $\mathrm{R}^{2}$.

\section{RESULTS AND DISCUSSION}

There was a significant effect on the interaction between salinity and inoculation for photosynthesis (A), conductance (gs), transpiration (E), internal $\mathrm{CO}_{2}$ concentration (IC), water use efficiency (WUE), and chlorophyll. While, for leaf temperature (LT), there was an isolated effect for salinity and inoculation (Table 2).

Table 2. Summary of analysis of variance (ANOVA) for photosynthesis (A), conductance (gs), transpiration (E), leaf temperature (LT), internal $\mathrm{CO}_{2}$ concentration (IC), water use efficiency (WUE) and chlorophyll.

\begin{tabular}{lcccccccc}
\hline & \multicolumn{8}{c}{ Medium square } \\
\cline { 2 - 9 } & DF & A & gs & E & LT & IC & WUE & Chlorophyll \\
\hline Salinity (S) & 4 & $2.38^{*}$ & $0.013^{* *}$ & $0.645^{*}$ & $0.880^{*}$ & $3646.21^{* *}$ & $3.58^{* *}$ & $8.554^{\text {ns }}$ \\
Inoculation (I) & 1 & $29.08^{* *}$ & $0.011^{* *}$ & $0.008^{\text {ns }}$ & $1.067^{*}$ & $2736.16^{* *}$ & $7.77^{* *}$ & $5.675^{\text {ns }}$ \\
S x I & 4 & $5.29^{* *}$ & $0.019^{* *}$ & $0.693^{* *}$ & $0.393^{\text {ns }}$ & $1074.64^{* *}$ & $4.15^{* *}$ & $65.54^{* *}$ \\
Residue & 30 & 0.68 & 0.00074 & 0.170 & 0.223 & 110.53 & 0.71 & 4.663 \\
CV $(\%)$ & - & 16.02 & 20.27 & 21.71 & 1.53 & 3.54 & 29.7 & 6.22 \\
\hline
\end{tabular}

SV: Source of variation, DF: Degree of freedom, I: Inoculation, S: Salinity, CV (\%): Coefficient of variation, **: Significant at the level of $1 \%$ probability $(\mathrm{p}<0.01),{ }^{*}$ : Significant at $5 \%$ probability level $(.01=<\mathrm{p}<.05)$, ns: Not significant $(\mathrm{p}>=0.05)$.

Regarding the result obtained for photosynthesis, it might be noticed (Figure 1A) that the increasing linear model was the one that best fit for the inoculated peanut, and decreasing for the non-inoculated with an increase in the electrical conductivity of the water (CEa).

This result may be associated with the efficiency of biological nitrogen fixation (BNF), due to the peanut crop and the participation of bacteria; that is, the greater availability of nitrogen improved the physiological conditions of the plants. Tahjib-Ul-Arif et al. (2019) describe that salts can lead to a lower concentration of chlorophyll (pigment responsible for photosynthesis); however, the $\mathrm{N}$ made available by bacteria may have attenuated the effects of stress caused by salts, favoring the photosynthetic process.

Corroborating this information, Lucio et al. (2013), when inoculating and irrigating the melon culture with saline water, found an increase in the nitrogen concentration in the leaves, providing a higher photosynthetic rate in relation to the treatment without inoculation.

Concerning the stomatal conductance (Figure 1B), for the inoculated plants, the model that best fit was a polynomial, with a maximum conductance of $0.17 \mathrm{~mol} \mathrm{~m}^{-2} \mathrm{~s}^{-1}$ to a CEa of $3.59 \mathrm{dS}$ $\mathrm{m}^{-1}$. While for non-inoculated plants, the decreasing linear model was used.

Mbarki et al. (2017) noted that microorganisms, when present in association with plants, can improve the positive health of the soil, in addition to providing important compounds to mitigate the negative effects of salts, and thus improve the mechanisms of areas of plants in a state of stress. The inoculated plants obtained better results; that is, the nitrogen that was fixed by the inoculation bacteria, produces molecules such as (proline) capable of attenuating the effect of salinity (Taiz et al., 2017).

Alike, Kaschuk et al. (2009) concluded in their study that the nutritional effect brought by symbiosis can improve the gas exchange in plants. Lucio et al. (2013), working with the culture of inoculated and uninoculated melon under saline stress, also found a result similar to the present study. 

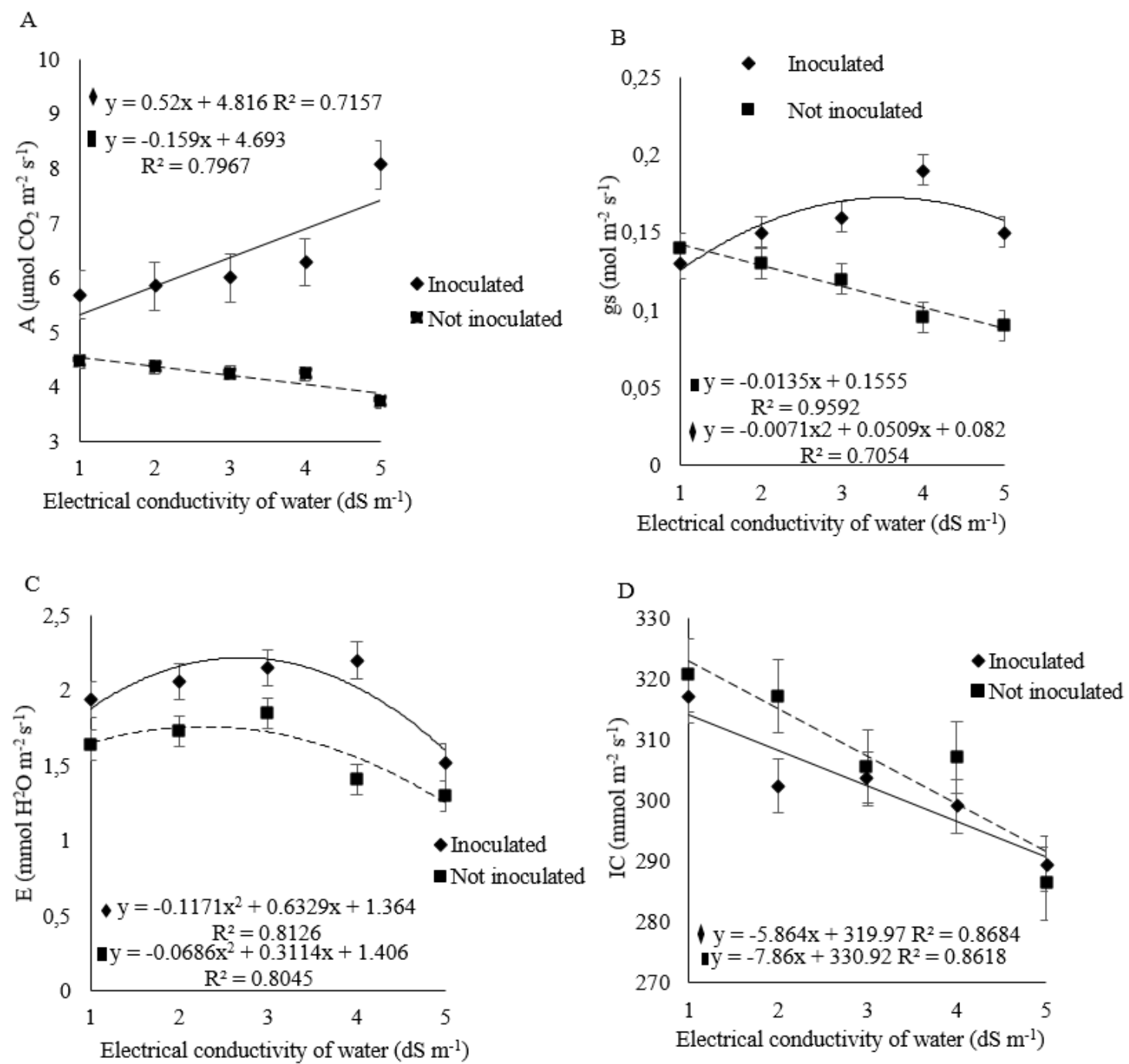

Figure 1. A: Photosynthesis (A), gs: stomatal conductance (B), E: Transpiration (C) and IC: Internal concentration of $\mathrm{CO}_{2}$ (D), of inoculated and non-inoculated peanuts, submitted to different levels of salinity.

According to Figure $1 \mathrm{C}$, both trend lines fit into a quadratic polynomial. The inoculated plants had their maximum point $2.22 \mathrm{mmol} \mathrm{H}_{2} \mathrm{O} \mathrm{m}^{-2} \mathrm{~s}^{-1}$ for a CEa of $2.7 \mathrm{dS} \mathrm{m}^{-1}$, the noninoculated plants, the maximum transpiration was $1.76 \mathrm{mmol} \mathrm{H}_{2} \mathrm{O} \mathrm{m} \mathrm{m}^{-2} \mathrm{~s}^{-1}$ with water of $2.27 \mathrm{dS} \mathrm{m}^{-1}$.

It should be noted that saline stress causes a reduction in water absorption and, consequently, a lower transpiratory rate. Pereira et al. (2019) state that $\mathrm{Na}^{+}$and $\mathrm{Cl}^{-}$when present in the soil alter the osmotic potential, causing the plant to absorb less water, showing a partial closure of the stomata and, therefore, less transpiration.

Regarding the positive effect of inoculation, Doni et al. (2014) affirm in their study that the symbiosis between plants and bacteria/fungi may enhance the entire physiological system of plants, and thus improve their performance in perspiration. Additionally, Lucio et al. (2013) got superior results of sweating in treatments that were inoculated compared to those not inoculated.

Regarding the internal $\mathrm{CO}_{2}$ concentration parameter (Figure 1D), the results showed that both trend lines fit into a decreasing linear model; however, the inoculated plants obtained lower results. Plants under salt stress end up closing their stomata as a strategy to prevent water loss; however, they also reduce $\mathrm{CO}_{2}$ assimilation and the net rate of its concentration in cells (Taiz et al., 2017; Tahjib-Ul-Arif et al., 2019) 
Another aspect may be related to the $\mathrm{N}$ provided by the symbiosis, and this mineral element provides greater enzymatic activity and better osmotic adjustment of the plants (Mondal et al. $2020 \mathrm{~b}$ ) and $\mathrm{K}+$ by fertilization; that is, both improved the structure of RuBP (ribulosebisphosphate carboxylase / oxygenase), making it more efficient (Alvarenga et al., 2019), showing that the inoculated plants were more suitable in the use of available $\mathrm{CO}_{2}$.

Another relevant factor for the behavior of $\mathrm{CO}_{2}$ is related to $\mathrm{RuBP}$ (ribulose-bisphosphate carboxylase / oxygenase), which, when working under favorable conditions, increases carboxylation and suppresses the oxygenation activity of the photosynthetic system, improving the use of $\mathrm{CO}_{2}$; ie , the nitrogen supplied in biological fixation improved the conditions of RuBP and favored its functioning (Hsiao and Jackson, 1999).

Besides, Oliveira et al. (2017), working with cowpea under saline stress, also registered a decrease in the internal concentration of $\mathrm{CO}_{2}$. These same authors also point out that this result may have been caused by the lower diffusion of $\mathrm{CO}_{2}$ evidenced by stomatal closure.

The rise in the salinity of the irrigation water increased the leaf temperature linearly (Figure 2A). This is possible because plants under salt stress have great difficulty in absorbing water from the soil, leading to stomatal closure, consequently reducing perspiration (Taiz et al., 2017) and increasing leaf temperature. Sousa et al. (2012), when assessing physiological responses of physic nuts under salt stress, also identified a linear increase in leaf temperature.
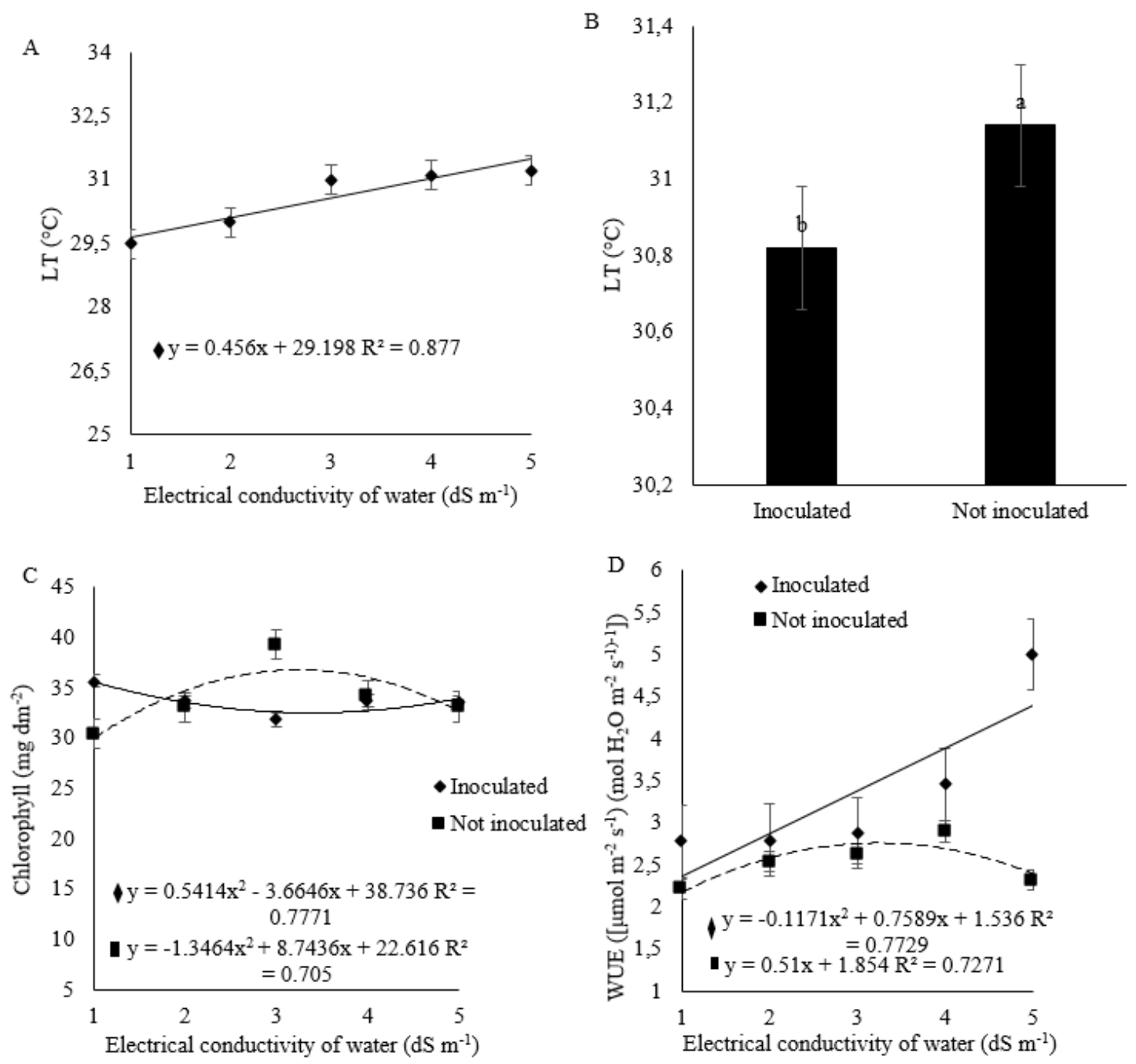

Figure 2. LT: Leaf temperature for the salinity factor (A), LT: leaf temperature for the inoculation factor (B), Chlorophyll (C) and WUE: water use efficiency (D), of the inoculated and non-inoculated peanuts, submitted to different levels of salinity 
The non-inoculated plants showed higher average leaf temperature values than those not inoculated (Figure 2B). The symbiosis between plants and bacteria provides better osmotic adjustment, improving perspiration, and decreasing leaf temperature. It is worth noting that BNF increases nitrate reductase activity, thus increasing the production of plant hormones and improving the antioxidant system of plants (Fukami et al., 2018).

Doni et al. (2014), when inoculating the rice culture, affirm that the presence of nitrogen for the inoculated plants can help in the osmotic adjustment of the plants, therefore increasing their transpiration rate, and in this way facilitating the decrease in leaf temperature.

The results also showed that for chlorophyll the quadratic polynomial model was the one that best fit the data, as shown in Figure 2C. The inoculated plants had a maximum amount of chlorophyll of $32.535 \mathrm{mg} \mathrm{dm}^{-2}$ in the water of $3.38 \mathrm{dS} \mathrm{m}^{-1}$, while the non-inoculated plants had their maximum of $36.81 \mathrm{mg} \mathrm{dm}^{-2}$ for the water of $3.25 \mathrm{dS} \mathrm{m}^{-1}$.

Moreover, the result is in accordance with those reported in the study conducted by Zhang et al. (2010) which found that salt stress causes swelling and rupture of the thylakoids and the chloroplast layer, due to the excess of $\mathrm{Na}^{+}$and $\mathrm{Cl}^{-}$ions that also inhibit the synthesis of new chlorophyll molecules.

It is important to highlight that even with the highest amount of chlorophyll, the noninoculated plants failed to develop well in photosynthesis because the lower availability of nitrogen in their organism led to greater damage to the physiological system (Taiz et al., 2017). On the other hand, the presence of nitrogen for the inoculated plants made them more efficient in the use of $\mathrm{CO}_{2}$ and chlorophyll. This macronutrient is part of the rubisco structure, thus making the enzyme more effective in its physiological activities (Alvarenga et al., 2019).

Cha-um et al. (2013), also found a decline in chlorophyll concentration due to the increase in soil salinity in cowpea and jack bean (Canavalia ensiformis) plants.

In Figure 2D, it is possible to observe for the parameter, water use efficiency (WUE), that the growing linear model was the one that best fits for the inoculated plants. Differently, for the non-inoculated plants, the quadratic polynomial model was the best-adjusted, with a maximum WUE of $\left.3.56\left(\left[\mu \mathrm{mol} \mathrm{m}^{-2} \mathrm{~s}^{-1}\right)\left(\mathrm{mol} \mathrm{H} 2 \mathrm{O} \mathrm{m}^{-2} \mathrm{~s}^{-1}\right)^{-1}\right]\right)$ obtained with the use of water with $3.84 \mathrm{dS}$ $\mathrm{m}^{-1}$.

Tahjib-Ul-Arif et al. (2019) warn that if the transpiration rate is compromised, the WUE values decrease; however, the circumstances that provided better use and water efficiency to the inoculated plants can be explained by the adequate nutritional supply and, consequently, by the osmotic adjustment that improved the transpiration and its ability to absorb water and the production of photoassimilates (Campelo et al., 2019).

Contrary to the results found in this study, Cha-um et al. (2013), when working with cowpea and jack bean cultures, there was a reduction in water use and efficiency.

\section{CONCLUSIONS}

Saline stress affected photosynthesis, transpiration, stomatal conductance, internal $\mathrm{CO}_{2}$ concentration, water use efficiency, and chlorophyll, but with less intensity when inoculated with Bradyrhizobium sp.

The increase in salinity in irrigation water increased the leaf temperature in peanut plants.

The inoculation with mix of rhizobia SEMIA 630 and SEMIA 6144, of Bradyrhizobium $\mathrm{sp}$ is an efficient alternative to attenuate the saline stress in peanut plants regarding the physiological responses.

\section{ACKNOWLEDGMENT}

To the Brazilian National Council for Scientific and Technological Development (CNPq, Portuguese: Conselho Nacional de Desenvolvimento Científico e Tecnológico), for the scholarship. 


\section{REFERENCES}

ALVARENGA, C. F. S.; SILVA, E. M.; NOBRE, R. G.; GHEYI, H. R.; LIMA, G. S.; SILVA, L. A. Morfofisiologia de aceroleira irrigada com águas salinas sob combinações de doses de nitrogênio e potássio. Revista de Ciências Agrárias, v. 42, p. 194-205, 2019. http://dx.doi.org/10.19084/RCA18215

CAMPELO, D. H.; TEIXEIRA, A. S.; MOREIRA, L. C.; LACERDA, C. F. Crescimento, produção e eficiência de uso de água e nitrogênio do milho sob lâmina d'água e adubação nitrogenada. Revista Brasileira de Engenharia Agrícola e Ambiental, v. 23, n. 10, p. 747753, 2019. https://doi.org/10.1590/1807-1929/agriambi.v23n10

CHA-UM, S.; BATIN, C.; SAMPHUMPHUNG, T.; KIDMANEE, C. Physio-morphological changes of cowpea (Vigna unguiculata Walp.) and jack bean (Canavalia ensiformis (L.) DC.) in responses to soil salinity. Australian Journal of Crop Science, v. 7, n. 13, p. 2128 2135, 2013.

DONI, F.; ISAHAK, A.; CHE MOHD ZAIN, C. R.; WAN YUSOFF, W. M. Resposta fisiológica e de crescimento do arroz plantas (Oryza sativa L.) para Trichoderma spp. inoculantes. AMB Express, v. 4, n. 45, 2014. http://dx.doi.org/10.1186/s13568-0140045-8

EMBRAPA. Centro Nacional de Pesquisa de Arroz e Feijão. Manual de métodos empregados em estudos de microbiologia agrícola. Santo Antônio de Goiás, 1994. 542 p.

FAO. Faostat (Crops). 2019. Available at: http://www.fao.org/faostat/en/\#data/QC. Access: 29 Apr. 2020.

FERNANDES, V. L. B. Recomendações de adubação e calagem para o estado do Ceará. Fortaleza: UFC, 1993. 248 p.

FREIRE, J. L. de O.; DIAS, T. J.; CAVALCANTE, L. F.; FERNANDES, P. D.; LIMA NETO, A. J. de. Rendimento quântico e trocas gasosas em maracujazeiro amarelo sob salinidade hídrica, biofertilização e cobertura morta. Revista Ciência Agronômica, v. 45, n. 1, p. 82-91, 2014. http://dx.doi.org/10.1590/S1806-66902014000100011

FREITAS, G. S.; BARBOSA, G. F.; ZUFFO, A. M.; STEINER, F. Coinoculação do amendoim (Arachis hypogaea L.) com Bradyrhizobium e Azospirillum promove maior tolerância à seca. Research, Society and Development, v. 9, p. 1-21, 2020. http://dx.doi.org/10.33448/rsd-v9i7.3690

FUKAMI, J.; CEREZINI, P.; HUNGRIA, M. Azospirillum: benefits that go far beyond biological nitrogen fixation. AMB Express, v. 8, n. 73, p. 1-12, 2018. https://doi.org/10.1186/s13568-018-0608-1

HSIAO, T. C.; JACKSON, R. B. Efeitos interativos do estresse hídrico e elevado CO2 no crescimento, fotossíntese e eficiência do uso da água. In: LUO, Y.; MOONEY, H. A. (ed.). Carbon dioxide and environmental stress. Academic Press, 1999. p. 3-31. https://doi.org/10.1016/B978-012460370-7/50002-4

KASCHUK, G.; KUYPER, T.W.; LEFFELAAR, A. P.; HUNGRIA, M.; GILLER, E.K. As taxas de fotossíntese são estimuladas pela força do sumidouro de carbono das simbioses micorrízicas rizobiais e arbusculares. Soil Biology \& Biochemistry, v. 41, p. 1233-1244, 2009. https://doi.org/10.1016/j.soilbio.2009.03.005 
KRAPOVICKAS, A.; GREGORY, W. C. Taxonomia del genero "Arachis (Leguminosae)". Bonplandia, p. 1-186, 1994.

KÖPPEN, W. Climatologia. México: Fundo de Cultura Econômica, 1993.

LIMA, G. S.; DA SILVA, J. B.; PINHEIRO, F. W. A.; DOS ANJOS SOARES, L. A.; GHEYI, H. R. Potassium does not attenuate salt stress in yellow passion fruit under irrigation management strategies. Revista Caatinga, v. 33, n. 4, p. 1082-1091, 2020. https://doi.org/10.1590/1983-21252020v33n423rc

LUCIO, W. S.; LACERDA, C. F.; MENDES FILHO, P. F.; HERNANDEZ, F. F. F.; NEVES, A. L. R.; GOMES FILHO, E. Crescimento e respostas fisiológicas do meloeiro inoculado com fungos micorrízicos arbusculares sob estresse salino. Semina: Ciências Agrárias, v. 34, n. 4, p. 1587-1602, 2013. https://doi.org/10.5433/1679-0359.2013v34n4p1587

MBARKI, S.; CERDÀ, A.; BRESTIC, M.; MAHENDRA, R.; ABDELLY, C.; PASCUAL, J. A. Vineyard compost supplemented with Trichoderma harzianum T78 improve saline soil quality. Land Degradation \& Development, v. 28, n. 3, p. 1028-1037, 2017. https://dx.doi.org/10.1002/ldr.2554

MONDAL, M.; SKALICKY, M.; GARAI, S.; HOSSAIN, A.; SARKAR, S.; BANERJEE, H., EL SABAGH, A. Nitrogen supplementation in combination with rhizobia inoculation and soil cover in the peanut (Arachis hypogaea L.) production system: Part I. Effects on Productivity, Soil Moisture, and Nutrient Dynamics. Agronomy, v. 10, n. 10, p. 1513, 2020a. https://dx.doi.org/10.3390/agronomy1010151

MONDAL, M.; SKALICKY, M.; GARAI, S.; HOSSAIN, A.; SARKAR, S.; BANERJEE, H.; EL SABAGH, A. Nitrogen supplementation in combination with rhizobia inoculation and soil cover in the peanut (Arachis hypogaea L.) production system: Part II. Effect on phenology, growth, production attributes, pod quality, profitability and nitrogen use

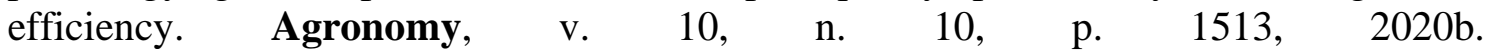
https://dx.doi.org/10.3390/agronomy1010151

OLIVEIRA, W. J. D.; SOUZA, E. R. D.; CUNHA, J. C.; SILVA, Ê. F. DE F. E; VELOSO, V. D. L. Troca de gases foliares no feijão caupi e efluxo de $\mathrm{CO}_{2}$ em solo irrigado com água salina. Revista Brasileira de Engenharia Agrícola e Ambiental, v. 21, p. 32-37, 2017. https://doi.org/10.1590/1807-1929/agriambi.v21n1p32-37

PEREIRA FILHO, J. V.; VIANA, T. V. A.; SOUSA, G. G.; CHAGAS, K. L.; AZEVEDO, B. M.; PEREIRA, C. C. S. Respostas fisiológicas da cultura de febre submetida a estresse salino e hídrico. Revista Brasileira de Engenharia Agrícola e Ambiental, v. 23, n. 12, p. 959-965, 2019. https://doi.org/10.1590/1807-1929/agriambi.v23n12p959-965

PEREIRA, I. C.; CATÃO, H. C.; CAIXETA, F. Qualidade fisiológica de sementes e crescimento de mudas de ervilha sob estresse hídrico e salino. Revista Brasileira de Engenharia Agrícola e Ambiental, v. 24, n. 2, p. 95-100, 2019. https://doi.org/10.1590/1807-1929/agriambi.v24n2p95-100

PUÉRTOLAS, J.; LARSEN, E. K.; DAVIES, W. J.; DODD, I. C. Applying 'drought' to potted plants by maintaining suboptimal soil moisture improves plant water relations. Journal of Experimental Botany, v. 68, n. 9, 2017. https://doi.org/10.1093/jxb/erx116

RHOADES J. D.; KANDIAH, A.; MASHALI, A. M. Uso de águas salinas para produção agrícola. Campina Grande, 2000. 117 p. (Estudos FAO - Irrigação e Drenagem, 48). 
ROCHA, H. G. S.; CASTRO, H. S; FREITAS, J. R. B. Resposta de feijão-caupi à inoculação com estirpe de rizóbio. Revista Mundi Meio Ambiente e Agrárias, v. 4, n. 2, p. 123134, 2019. http://dx.doi.org/10.21575/25254790rmmaa2019vol4n21103

SANTOS, H. G. dos; JACOMINE, P. K. T.; ANJOS, L. H. C. dos; OLIVEIRA, V. A. de; LUMBRERAS, J. F.; COELHO, M. R.; CUNHA, T. J. F. Sistema brasileiro de classificação de solos. Brasília, DF: Embrapa, 2018.

SILVA, F. A. S.; AZEVEDO, C. A. V. The Assistat Software Version 7.7 and its use in the analysis of experimental data. Africa Journal Agriculture Research, v. 11, p. 3733 3740, 2016. https://doi.org/10.5897/AJAR2016.11522

SOUSA, A. E. C.; LACERDA, C.F, GHEYI, H. R, SOARES, F. A. L, UYEDA, C. A. Teores de nutrientes foliares e respostas fisiológicas em pinhão manso submetido a estresse salino e adubação fosfatada. Revista Caatinga, v. 25, n. 2, p. 144-152, 2012.

TAIZ, L.; ZEIGER, E.; MOLLER, I. M.; MURPHY, A. Fisiologia e desenvolvimento vegetal. Porto Alegre: Artmed, 2017.

TAHJIB-UI-ARIF, M.; SOHAG, A. A. M.; AFRIN, S.; BASHAR, K. K.; AFRIN, T.; MAHAMUD, A. G. M.; BRESTIC, M. Resposta diferencial da beterraba sacarina à salinidade leve a severa de longo prazo em uma cultura de solo-vaso. Agricultura, v. 9, n. 10, p. 223, 2019.

ZHANG, S. R.; SONG, J.; WANG, H.; FENG, G. Effect of salinity on seed germination, ion content and photosynthesis of cotyledons in halophytes or xerophyte growing in Central Asia. Journal of Plant Ecology, v. 3, n. 4, p. 259-267, 2010. https://doi.org/10.1093/jpe/rtq005 


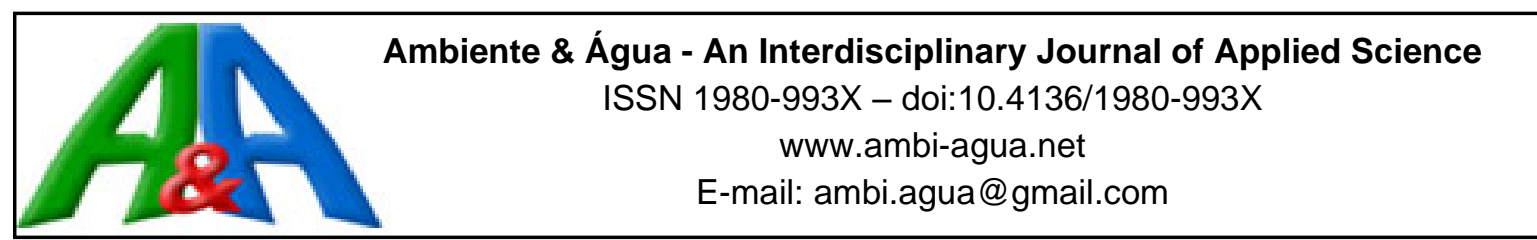

\title{
The role of food/microorganism ratio in denitrification reactors: how it affects the sizing and operation of the denitrification process
}

\author{
ARTICLES doi:10.4136/ambi-agua.2656 \\ Received: 05 Oct. 2020; Accepted: 17 Nov. 2020

\begin{abstract}
Renato Gavasci $^{1(\mathbb{D})}$; Francesco Lombardi ${ }^{1 *}$; Massimo Raboni ${ }^{2}$ (I)
${ }^{1}$ Department of Civil Engineering and Computer Science Engineering. Università degli Studi di Roma Tor Vergata, Via Politecnico 1, 00133, Rome, Italy. E-mail: gavasci@ing.uniroma2.it

${ }^{2}$ Department Hydraulics and Environmental Engineering. University of Pavia, Corso Str. Nuova, n 65, 27100, Pavia, Italy. E-mail: massimo.raboni@gmail.com

*Corresponding author. E-mail: lombardi@ing.uniroma2.it
\end{abstract}

\begin{abstract}
Two calculation models of the Specific Denitrification Rate (SDNR) are analyzed to highlight the sensitivity of this parameter to the Food:Microorganisms ratio in the denitrification reactor $\left(\mathrm{F}: \mathrm{M}_{\mathrm{DEN}}\right)$. One of these models is empirical while the second was

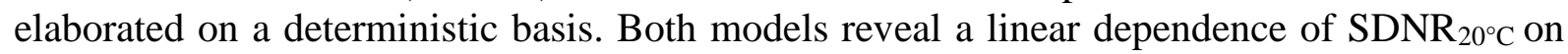
F:M DEN and in a first approximation they are comparable only in a narrow range of concentration of dissolved oxygen (DO) in denitrification, specifically $\mathrm{DO}=0.25-0.35 \mathrm{mg} \mathrm{L}^{-1}$. These values frequently occur in well designed and well operated sewage treatment plants. Outside this range, the role of F:M $\mathrm{M}_{\mathrm{DEN}}$ must necessarily be examined in combination with DO because of the relevant influence of the latter on the efficiency of the denitrification process.
\end{abstract}

Keywords: activated sludge, biological process, denitrification, nitrogen removal, sewage treatment.

\section{O papel da fração alimento/microrganismos nos reatores de desnitrificação: como afeta o dimensionamento e a operação do processo de desnitrificação}

\section{RESUMO}

Dois modelos de cálculo do SDNR-Specific Denitrification Rate são analisados para destacar a sensibilidade deste parâmetro em relação à fração Alimento/Microrganismos no reator de desnitrificação (A: $\left.M_{\mathrm{DEN}}\right)$. Um desses modelos é empírico, enquanto o segundo foi elaborado em uma base determinística. Ambos os modelos revelam uma dependência linear de $\mathrm{SDNR}_{20^{\circ} \mathrm{C}} \mathrm{em} \mathrm{A}: \mathrm{M}_{\mathrm{DEN}} \mathrm{e}$, em primeira aproximação, eles são comparáveis apenas dentro de uma faixa estreita de concentração de oxigênio dissolvido (OD) na desnitrificação, especificamente $\mathrm{OD}=0,25-0,35 \mathrm{mg} \mathrm{L}^{-1}$. Esses valores ocorrem frequentemente em estações de tratamento de esgoto bem projetadas e operadas. Fora dessa faixa, o papel do A:M em combinação com o OD devido à influência relevante deste último na eficiência do processo de desnitrificação.

Palavras-chave: desnitrificação, lodo ativado, processo biológico, remoção de nitrogênio, tratamento de esgoto.

This is an Open Access article distributed under the terms of the Creative Commons Attribution License, which permits unrestricted use, distribution, and reproduction in any medium, provided the original work is properly cited. 


\section{INTRODUCTION}

Physico-Chemical and biological processes are used for the removal of nitrogen from wastewater. The former mainly consists of chlorination or stripping processes and is widely used for the treatment of industrial wastewaters with high concentrations of ammonia (Capodaglio et al., 2015; Raboni et al., 2013a; Raboni and Viotti, 2017). Alternatively, the biological processes are essentially used in the treatment of sewage, as they are significantly cheaper than physico-chemical processes (Copelli et al., 2015; Subtil et al., 2013; Torretta et al., 2014; Collivignarelli et al. 2019, Butzen et al. 2020). At present, the most widely used biological denitrification technology is biological pre-denitrification in activated sludge treatment processes. Figure 1 shows a typical scheme consisting of an anoxic denitrification reactor (DEN) placed upstream of the oxidizing-nitrifying aerobic reactor (OX-NIT), which provides for the removal of $\mathrm{BOD}_{5}$ and the nitrification of total Kjeldhal nitrogen (TKN ) (Ekama et al., 1999; Gerardi, 2002; Ucker et al., 2012; Major Barbosa et al., 2016; Capodaglio et al., 2016; Wuhrmann, 2017; Pereira Ribeiro et al., 2018; Abeysiriwardana-Arachchige et al., 2020; Pires da Silva et al., 2020).

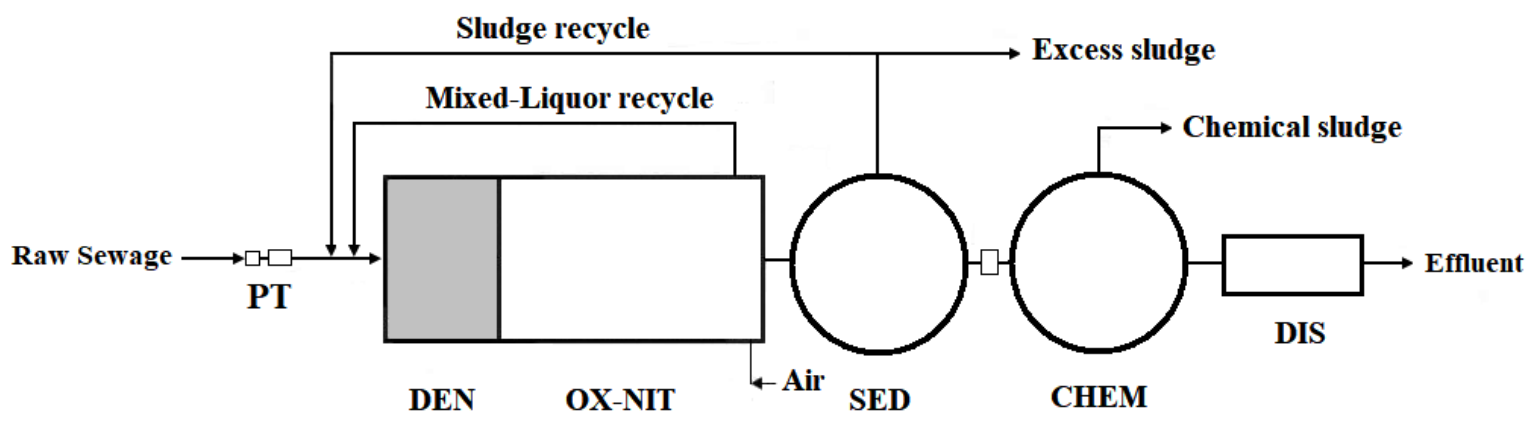

LEGEND:

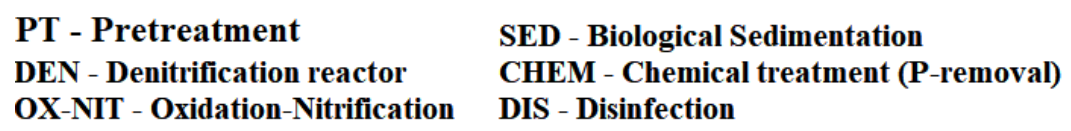

Figure 1. Schematic lay-out of a typical sewage treatment plant with pre-denitrification.

The removal of nitrogen in the pre-denitrification stage is carried out by denitrifying heterotrophic bacteria capable of reducing nitrates to nitrogen gas through a biochemical reaction that uses the $\mathrm{BOD}_{5}$ of the raw sewage as an electron donor. The process has been widely used in full-scale plants for many years. Nevertheless, the scientific research is very active in this field, above all to gain a better understanding of the influence exerted by various parameters on the efficiency of the process, among which is sludge loading in denitrification ( $\left.F: M_{D E N}\right)$. This parameter proved to be important in the sizing of the pre-denitrification reactor.

Currently, the sizing of the denitrification reactor is based on the parameter Specific Denitrification Rate (SDNR) defined as follows (Equation 1):

$S D N R_{T}=\frac{Q N}{V M L V S S}$

The value at the real temperature $T$ of the mixed-liquor can be calculated by the modified Arrhenius Equation 2 (Ekama et al., 2011):

$S D N R_{T}=S D N R_{20}{ }^{\circ} \mathrm{C} \theta^{(T-20)}$

Where: 
$\mathrm{SDNR}_{\mathrm{T}}$ Specific Denitrification Rate at the temperature $\mathrm{T}\left(\mathrm{kgNO}_{3}-\mathrm{N} \mathrm{kgMLVSS}^{-1} \mathrm{~d}^{-1}\right)$

$\mathrm{SDNR}_{20^{\circ} \mathrm{C}}$ Specific Denitrification Rate at the temperature of $20^{\circ} \mathrm{C}\left(\mathrm{kgNO}_{3}-\mathrm{N} \mathrm{kgMLVSS}^{-1} \mathrm{~d}^{-1}\right)$

$\mathrm{Q} \Delta \mathrm{N}$ Load of nitrogen removed in denitrification $\left(\mathrm{kg} \mathrm{d}^{-1}\right)$

MLVSS Mixed-Liquor Volatile Suspended Solids in denitrification ( $\mathrm{kg} \mathrm{VSS} \mathrm{m}^{-3}$ )

$\mathrm{V}$ Volume of the denitrification reactor $\left(\mathrm{m}^{3}\right)$

T temperature $\left({ }^{\circ} \mathrm{C}\right)$

( temperature coefficient: $\theta=1.026$ (USEPA, 2009); $\theta=1.07$ (Tchobanoglous et al., 2003).

As defined, the $\mathrm{SDNR}_{\mathrm{T}}$ is given by two contributions: the biochemical reduction of $\mathrm{NO}_{3}{ }^{-}$ to $\mathrm{N}_{2}$ and the synthesis of new cells.

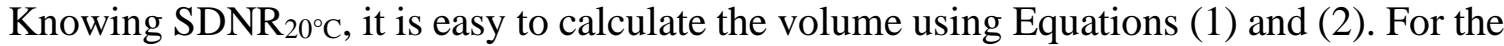
calculation of $\mathrm{SDNR}_{20^{\circ} \mathrm{C}}$ different models are proposed, which take into account the main variables capable of influencing the denitrification kinetics, which specifically are F:M residual oxygen concentration DO.

The present research aims to highlight the influence of $F: M_{D E N}$ in the calculation of

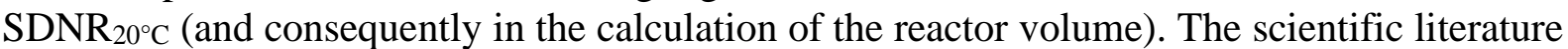
reports various data on this influence (Raboni et al., 2013b; 2014a; 2015)

In full scale plants F:MDEN is often found in the range 0.15-0.40 kg BOD $\mathrm{d}^{-1} \mathrm{kgMLVSS}^{-1}$ (Raboni et al., 2017).

\section{MATERIALS AND METHODS}

The influence of $F: M_{D E N}$ on the sizing of the denitrification reactor can be evaluated

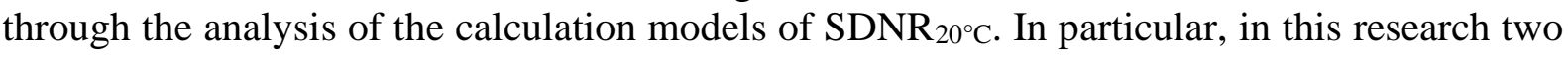
models are considered. The first model (Model I) is very empirical and it correlates $\mathrm{SDNR}_{20}{ }^{\circ} \mathrm{C}$ with only the variable $F: M_{D E N}$. This model was first described by Tchobanoglous et al. (2003). It was later implemented (USEPA, 2010) by introducing a correction factor $F_{b}$ to the $F: M_{D E N}$ (Equation 3).

$S D N R_{20^{\circ} \mathrm{C}}=0.029+0.03 \cdot\left(F_{b} / 0.30\right)\left(F: M_{D E N}\right)$

$F_{b}$ takes into account the greater or lesser concentration of active biomass in the mixedliquor, which in turn depends on the SRT-Sludge Retention Time. For more details on Fb see USEPA (2010). In biological plants with high efficiency for both oxidation-nitrification and denitrification the SRT is normally found in the range 18-20 d. With SRT=20 the factor results $F_{b}=0.35$.

The second model (Model II) is more advanced than the first, as it expresses the dependence of $\mathrm{SDNR}_{20}{ }^{\circ} \mathrm{C}$ not only on $\mathrm{F}: \mathrm{M}_{\mathrm{DEN}}$ but also on DO another variable capable of significantly influencing the efficiency of the denitrification process (Oh and Silverstein, 1999; Plosz et al., 2003; Torti et al., 2013; Urbini et al., 2015; Viotti et al., 2016). This model was elaborated through a deterministic calculation (Raboni et al., 2014b) and then it was validated by a pilot plant study (Raboni et al., 2014a) and by checking many real-scale plants (Raboni and Torretta, 2017) (Equation 4).

$$
S D N R_{20^{\circ} C}=0.0864\left(\frac{K_{O}^{\prime}}{K_{O}^{\prime}+D O}\right)+0.05 F: M_{D E N} \cdot \eta_{B O D} \cdot\left(\frac{D O}{0.2+D O}\right)
$$

Where:

$$
K^{\prime}=0.18 \mathrm{mgO}_{2} \mathrm{~L}^{-1}
$$


$\eta_{B O D}$ : removal efficiency of $\mathrm{BOD}_{5}\left(\eta_{B O D}=0.85-0.95\right.$ depending on the value assumed by $\mathrm{F}: \mathrm{M}_{\mathrm{DEN})}$

\section{RESULTS AND DISCUSSION}

Figure 2 shows the trend of $\mathrm{SDNR}_{20^{\circ} \mathrm{C}}$ as a function of the $\mathrm{F}: \mathrm{M}_{\mathrm{DEN}}$, according to the two models under study. Model II is represented at 5 different DO values. Due to the mathematical structure of the equations, all curves represented are straight lines.

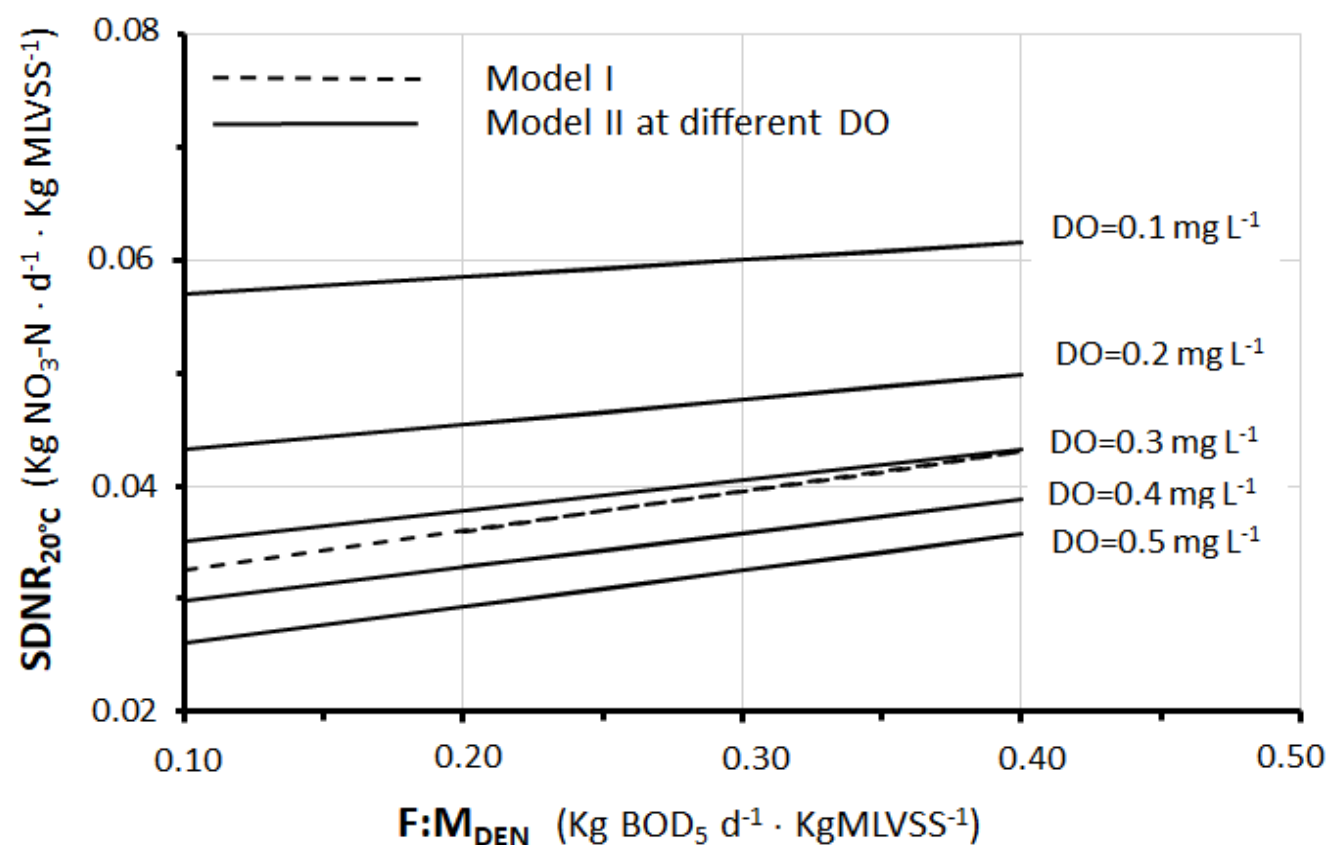

Figure 2. $\mathrm{SDNR}_{20^{\circ} \mathrm{C}}$ as a function of $\mathrm{F}: \mathrm{M}_{\mathrm{DEN}}$, according to the two calculation models (Model II is represented at different DO).

The observation of the Figure leads to three important considerations:

a) the variable $\mathrm{F}: \mathrm{M}_{\mathrm{DEN}}$ affects the $\mathrm{SDNR}_{20^{\circ} \mathrm{C}}$ in a directly proportional way, i.e., each

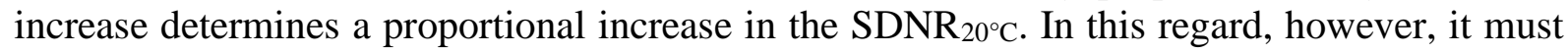
be considered that there is a limit to this progressive growth beyond which a strong wash-out of the denitrifying bacteria can occur. As the denitrifying bacteria are heterotrophic in nature (like BOD oxidizing bacteria), the typical limit not to be exceeded is close to F:M $M_{D E N}=0.40 \mathrm{~kg}$ $\mathrm{BOD}_{5} \mathrm{~d}^{-1} \mathrm{kgMLVSS}^{-1}$ (in plant design a slightly lower values is suggested, close to $0.3 \mathrm{~kg}$ $\left.\mathrm{BOD}_{5} \mathrm{~d}^{-1} \mathrm{kgMLVSS}^{-1}\right)$.

b) DO proves to be a variable of considerable importance, especially if the sizing and operation of the plant are such as to maintain dissolved oxygen concentrations appreciably lower than $\mathrm{DO}=0.3-0.4 \mathrm{mg} \mathrm{L}^{-1}$. For DO below this range, there is a progressive and more than

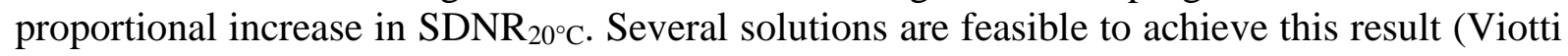
et al., 2016; Urbini et al., 2015)

c) the line of Model I as a first approximation is comparable only with two lines of Model II, those characterized by $\mathrm{DO}=0.3 \mathrm{mg} \mathrm{L}^{-1}$ and $\mathrm{DO}=0.4 \mathrm{mg} \mathrm{L}^{-1}$. In fact, the range $\mathrm{DO}=0.3-0.4$ $\mathrm{mg} \mathrm{L}^{-1}$ is frequently found on full scale plants (Raboni and Torretta, 2017).

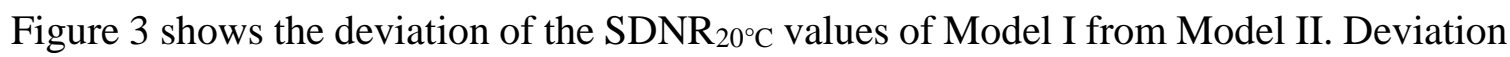
is defined as the \% difference between the $\mathrm{SDNR}_{20}{ }^{\circ} \mathrm{C}$ of the models at the same value of

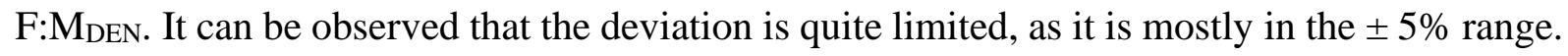


Instead, in Figure 3, which shows the deviation of Model I from Model II (the latter at various DO values), the deviation falls within the range of $5 \%$ only in a very narrow range of DO (approximately DO=0.30-0.35 $\mathrm{mg} \mathrm{L}^{-1}$ ). These findings are a further confirmation of the limited field of validity of the empirical model and also how important is the influence of DO in the denitrification process, especially when the same DO values are outside the above-mentioned range.

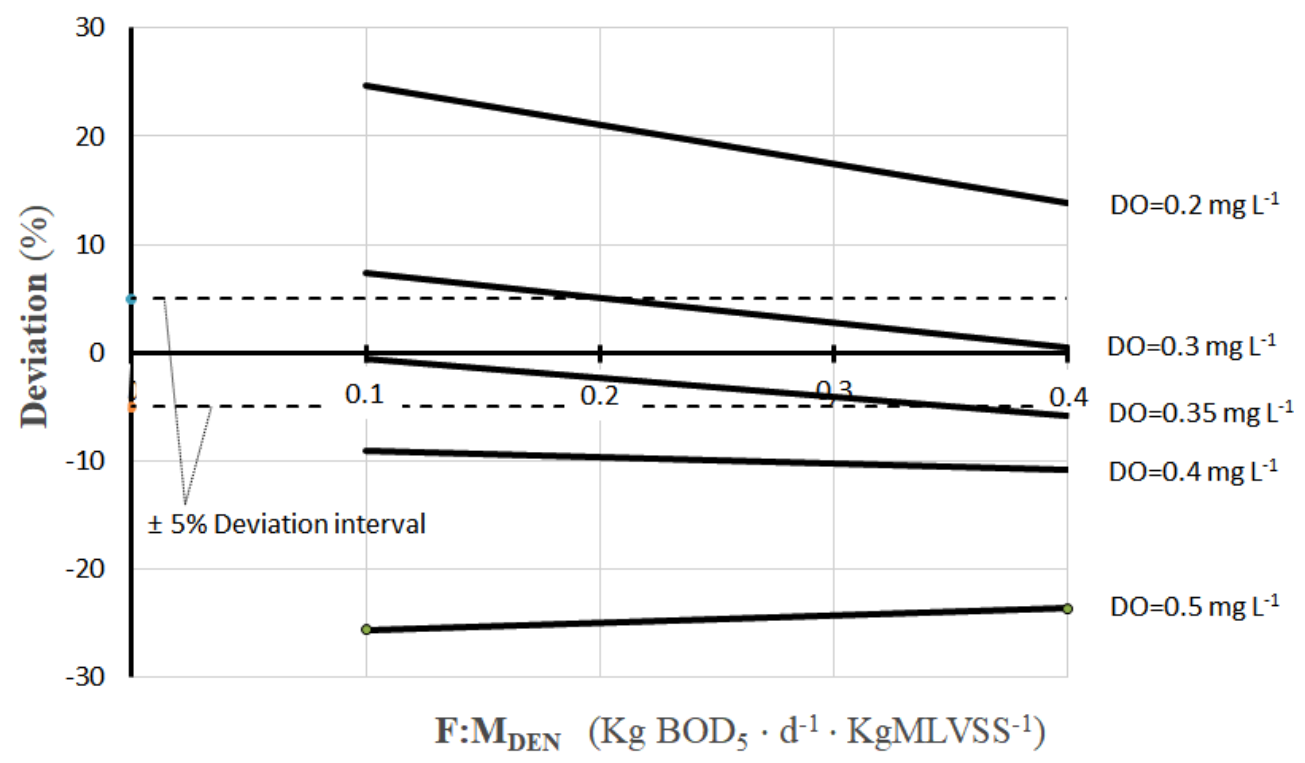

Figure 3. Deviation of $\mathrm{SDNR}_{20^{\circ} \mathrm{C}}$ of Models I from Model II (at different DO), as a function $F: M_{D E N}$.

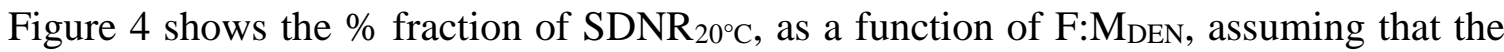
value relative to $\mathrm{F}: \mathrm{M}_{\mathrm{DEN}}=0.3 \mathrm{~kg} \mathrm{BOD}_{5} / \mathrm{kg} \mathrm{MLVSS}^{-1} \mathrm{~d}^{-1}$ is equal to $100 \%$.

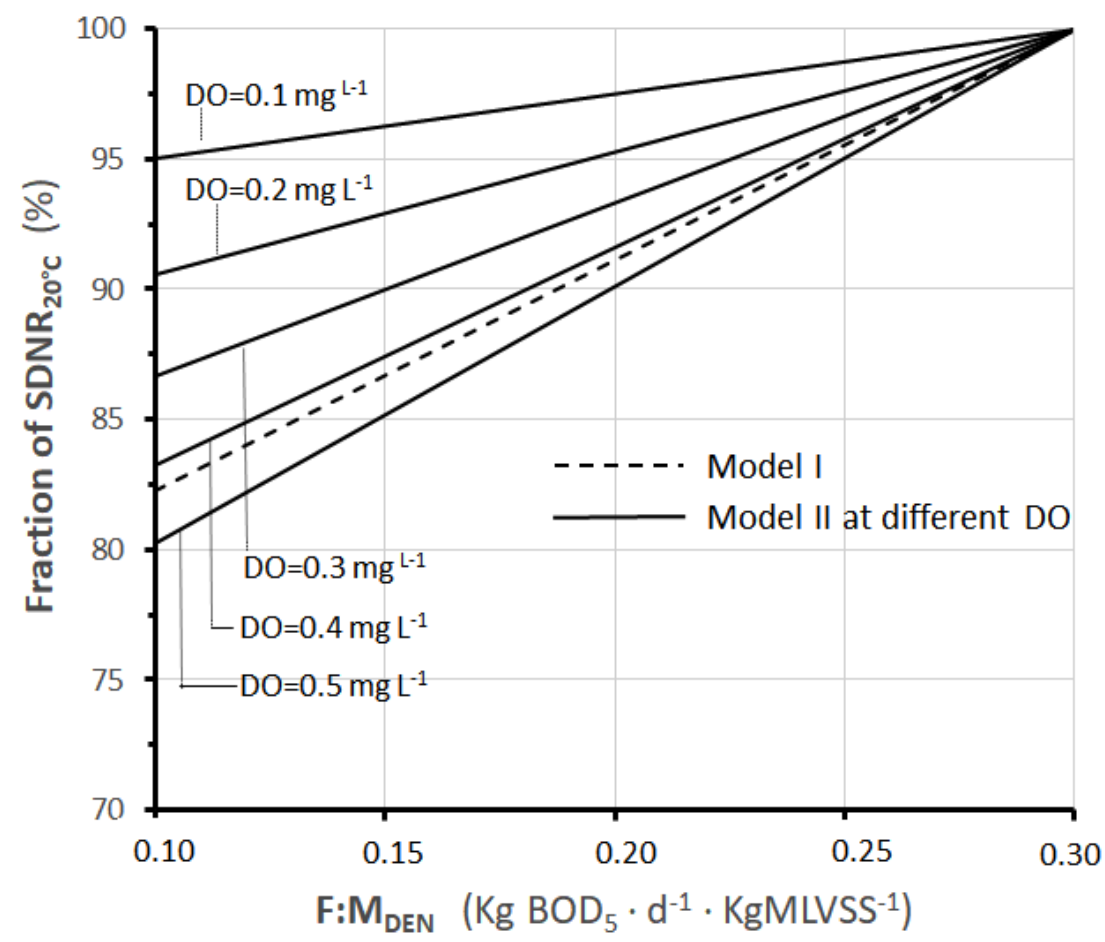

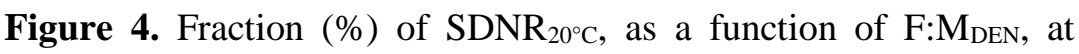

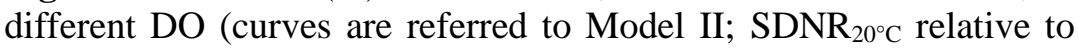
$\mathrm{F}: \mathrm{M}_{\mathrm{DEN}}=0.3$ is assumed equal to $100 \%$ ). 
It is noted the linear trend of all models. As regards to Model II, in correspondence of $\mathrm{DO}=0.3 \mathrm{mg} \mathrm{L}^{-1}$, a $6 \%$ reduction of $\mathrm{SDNR}_{20^{\circ} \mathrm{C}}$ is observed for any reduction of $\mathrm{F}: \mathrm{M}_{\mathrm{DEN}}=0.1$ $\mathrm{kgBOD}_{5} / \mathrm{d}^{-1} \cdot \mathrm{kg} \mathrm{MLVSS}^{-1}$. A reduction less and less marked occurs at lower DO values and vice versa at higher values.

Figure 5 shows the mathematical derivative $\frac{\partial \mathrm{SDNR}_{20^{\circ} \mathrm{C}}}{\partial \mathrm{F}: \mathrm{MDEN}}$ relative to models I and II. In this sensitivity analysis, this derivative has a significant importance because it expresses the direct response of $\mathrm{SDNR}_{20}{ }^{\circ} \mathrm{C}$ to the stresses of $\mathrm{F}: \mathrm{M}$ DEN.

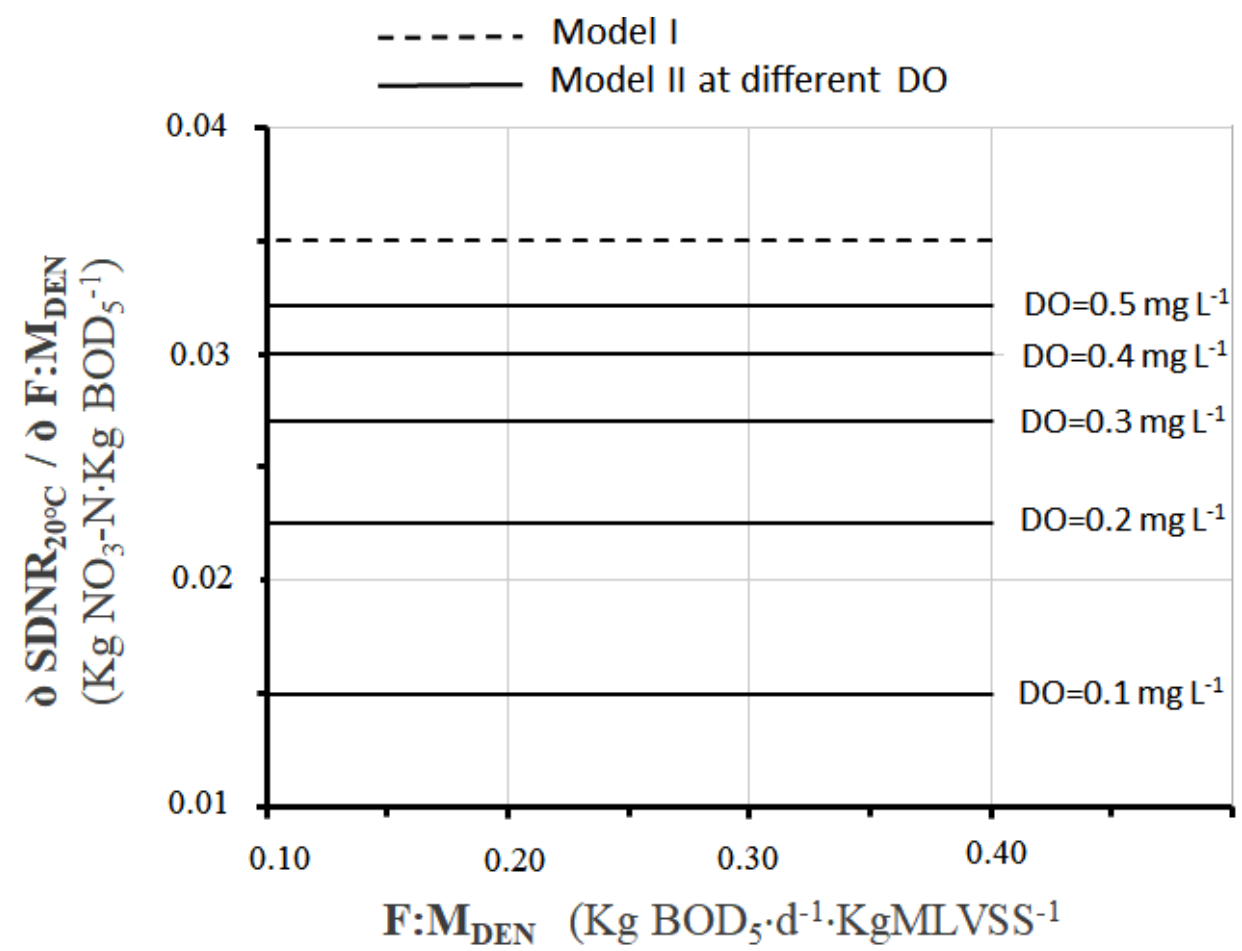

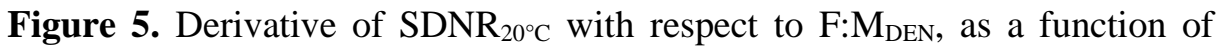
F:M $M_{\text {DEN }}$, according to Models I and Model II (at different DO).

As it can be seen, all derivatives are constant, due to the linear dependence of F: $M_{D E N}$ from

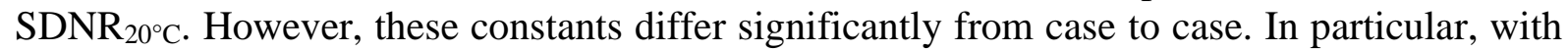
reference to Model II, they tend to get close to each other as DO concentrations increase.

Figure 6 shows very well the trend of the same derivative as a function of the DO. It is an increasing logarithmic curve with an asymptotic tendency to the value $\frac{\partial \mathrm{SDNR}_{20^{\circ} \mathrm{C}}}{\partial \mathrm{F}: \mathrm{MDEN}}=0.45 \mathrm{~kg}$ $\mathrm{NO}_{3}-\mathrm{N} \mathrm{kg} \mathrm{BOD}{ }_{5}^{-1}$. The strong initial gradient of the curve proves the lower sensitivity of $\mathrm{SDNR}_{20^{\circ} \mathrm{C}}$ to $\mathrm{F}: \mathrm{M}_{\mathrm{DEN}}$ at small DO concentrations, and vice versa. This graph is a further confirmation of how much also the DO variable can affect the denitrification kinetics and the consequent performance of the process.

Overall, the results of the present analysis highlight the need to keep the F:M $M_{D E N}$ as high

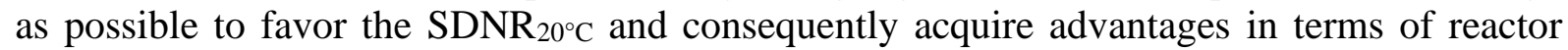
sizing and denitrification efficiency. However, F:M the sludge retention time-SRT is too small to determine the wash-out of the denitrifying heterotrophic bacteria, with consequent losses in efficiency. This limit is approximately in the range $\mathrm{F}: \mathrm{M}_{\mathrm{DEN}}=0.3-0.4 \mathrm{kgNO}_{3}-\mathrm{N} \mathrm{kgMLVSS}^{-1} \mathrm{~d}^{-1}$ where the lower value is suggested. There is

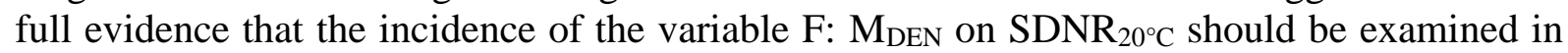
combination with the residual DO values in denitrification, which also significantly affects the efficiency of the process. 


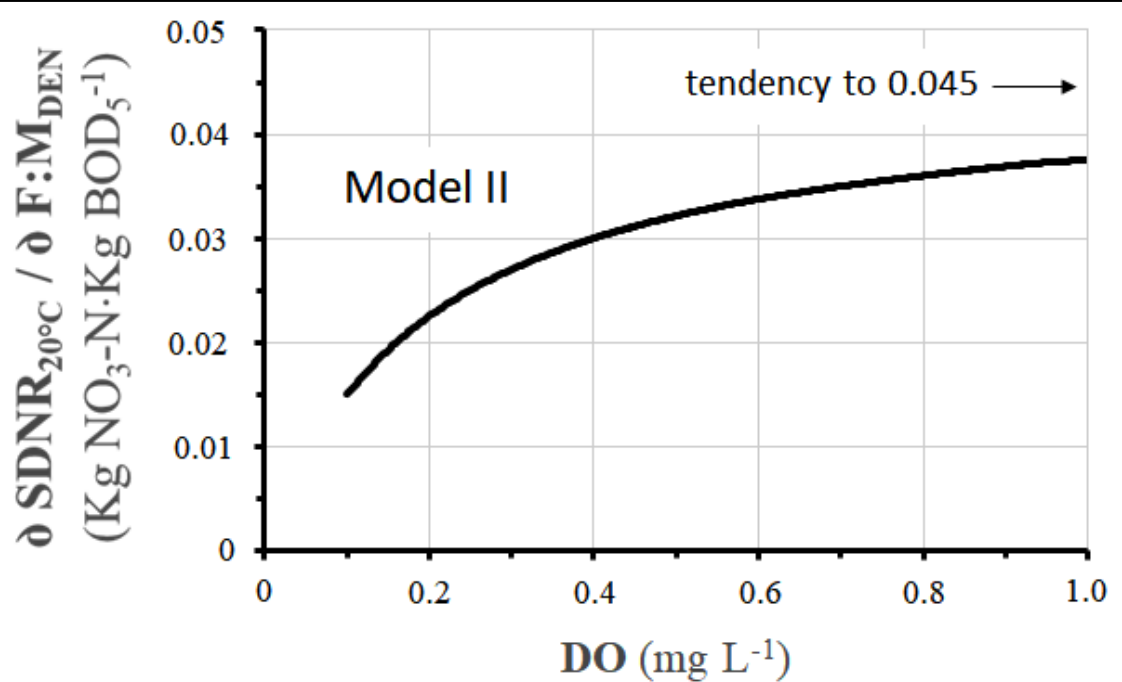

Figure 6. Derivative of $\mathrm{SDNR}_{20^{\circ} \mathrm{C}}$ with respect to $\mathrm{F}: \mathrm{M}_{\mathrm{DEN}}$ (according to Model II) as a function of DO.

\section{CONCLUSIONS}

The sizing of the biological pre-denitrification reactors as well as the denitrification efficiency are closely related to SDNR-specific denitrification rate. Two mathematical models

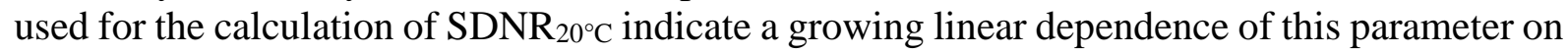
the sludge loading in denitrification (F:M $\left.M_{D E N}\right)$. Therefore high values of $F: M_{D E N}$ favor the $\mathrm{SDNR}_{20}{ }^{\circ} \mathrm{C}$ and consequently the sizing of the denitrification volume as well as the denitrification efficiency. However, F:M $M_{\text {DEN }}$ cannot exceed the limit beyond which the sludge retention time-SRT becomes too small to determine the wash-out of the denitrifying heterotrophic bacteria, with consequent losses in efficiency. This limit is approximately in the range $\mathrm{F}: \mathrm{M}_{\mathrm{DEN}}=0.3-0.4 \mathrm{kgNO}_{3}-\mathrm{N} \mathrm{kgMLVSS}^{-1} \mathrm{~d}^{-1}$ where the lower value is suggested.

Of the two models examined, one is purely empirical and the other more advanced, of a

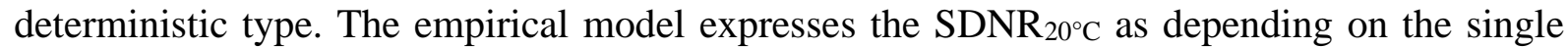
variable F:M $M_{\text {DEN }}$. Instead, the deterministic model expresses the $\mathrm{SDNR}_{20^{\circ} \mathrm{C}}$ as depending also on the dissolved oxygen in denitrification (DO).

The two models prove to be comparable only in a narrow range of DO (about DO $=0.25$ $0.35 \mathrm{mg} \mathrm{L}^{-1}$ ). However, values within this range are frequently found in well-designed and welloperated sewage treatment plants. Outside this range, the incidence of DO is relevant and cannot be neglected. All observations demonstrate a sensitivity of $\mathrm{SDNR}_{20^{\circ} \mathrm{C}}$ to $\mathrm{F}: \mathrm{M}_{\mathrm{DEN}}$ just as lower as smaller the DO concentrations are (DO $\left.<0.3 \mathrm{mg} \mathrm{L}^{-1}\right)$. At $\mathrm{DO}>0.3-0.4 \mathrm{mg} \mathrm{L}^{-1}$ this sensitivity tends progressively to grow towards an asymptotic value. There is extensive evidence that the impact on the process of the variable F:M $M_{D E N}$ should be examined in combination with the residual DO in denitrification.

\section{REFERENCES}

ABEYSIRIWARDANA-ARACHCHIGE, I. S. A.; MUNASINGHE-ARACHCHIGE, S. P. DELANKA-PEDIGE, H. M. K.; NIRMALAKHANDAN, N. Removal and recovery of nutrients from municipal sewage: Algal vs. conventional approaches. Water Research, v. 175, n. 115709, 2020. https://doi.org/10.1016/j.watres.2020.115709

BUTZEN, E. L.; CAPELLARI SANTOS, G.; SLONGO FORTUNA, S.; BARBOSA BRIÃO, V. Membrane bioreactor for mall wastewater treatment. Revista Ambiente \& Água, v. 15, n. 2, 2020. https://dx.doi.org/10.4136/ambi-agua.2489 
CAPODAGLIO, A. G.; HLAVÍNEK, P.; RABONI, M. Physico-chemical technologies for nitrogen removal from wastewaters: a review. Revista Ambiente \& Agua, p. 481-498, 2015. https://dx.doi.org/10.4136/ambi-agua.1618

CAPODAGliO, A. G.; HLAVÍNEK, P.; RABONI, M. Advances in wastewater nitrogen removal by biological processes: State of the art review. Revista Ambiente \& Agua, v. 11, p. 250-267, 2016. https://dx.doi.org/10.4136/ambi-agua.1772

COLlivignARELli, M. C.; ABBÀ, A.; BERTANZA, G.; DAMIANI, S.; RABONI, M. Resilience of a Combined Chemical-Physical and Biological Wastewater Treatment Facility. Journal of Environmental Engineering, v. 145, n. 7, 2019. https://dx.doi.org/10.1061/(ASCE)EE.1943-7870.0001543

COPELLI, S.; RABONI, M.; URBINI, G. Water Pollution: Biological Oxidation and Natural Control Techniques. In: REEDIJK, J. et al. (eds.). Reference module in chemistry, molecular sciences and chemical engineering. Waltham, MA: Elsevier, 2015. p 1-28. https://doi.org/10.1016/B978-0-12-409547-2.11419-2

EKAMA, G. A.; WENTZEL, M. C. Denitrification kinetics in biological N and P removal activated sludge systems treating municipal wastewaters. Water Science Technology, v. 39, n. 6, p. 69-77, 1999. https://doi.org/10.1016/S0273-1223(99)00124-9

EKAMA, G. A.; WILDERER, P. Biological Nutrient Removal. In: WILDERER, P. (ed.). Treatise on Water Science. Oxford: Elsevier, 2011. p. 409-526.

GERARDI, M. H. Nitrification and Denitrification in the Activated Sludge Process. New York: John Wiley \& Sons, 2002.

MAJOR BARBOSA, I.; MIERZWA, J. C.; HESPANHOL, I.; SUBTIL, E. L. Removal of nitrogen and organic matter in a submerged-membrane bioreactor operating in a condition of simultaneous nitrification and denitrification. Revista Ambiente \& Água, v. 11, n. 2, p. 304-315, 2016. https://dx.doi.org.br/10.4136/ambi-agua.1684

OH, J.; SILVERSTEIN, J. Oxygen inhibition of activated sludge denitrification. Water Research, v. 33, n. 8, p. 1925-1937, 1999. https://dx.doi.org/10.1016/S00431354(98)00365-0

PEREIRA RIBEIRO, R.; CYNAMON KLIGERMAN, D.; ZAMBONI DE MELLO, W.; DA PIEDADE SILVA, D.; DA FONSECA CORREIA, R.; LOPES DA MOTA OLIVEIRA, J. Effects of different operating conditions on total nitrogen removal routes and nitrous oxide emissions in a lab-scale activated sludge system. Revista Ambiente \& Água, v. 13, n. 2, 2018. https://dx.do.org/10.4136/ambi-agua.2174

PIRES DA SILVA, I.; BARBOSA DA COSTA, G.; THOMAZ QUELUZ, J.G.; LOUREIRO GARCIA, M. Effect of hydraulic retention time on chemical oxygen demand and total nitrogen removal in intermittently aerated constructed wetlands. Revista Ambiente \& Água, v. 15, n. 3, 2020. http://dx.doi.org/10.4136/ambi-agua.2504

PLÓSZ, B. G.; JOBBÁGY, A.; GRADY JR., C. P. L. Factors influencing deterioration of denitrification by oxygen entering an anoxic reactor through the surface. Water Research, v. 37, p. 853-863, 2003. https://doi.org/10.1016/S0043-1354(02)00445-1 
RABONI, M.; VIOTTI, P.; CAPODAGLIO, A. G. Experimental plant for the physicalchemical treatment of groundwater polluted by Municipal Solid Waste (MSW) leachate, with ammonia recovery. Revista Ambiente \& Agua, v. 8, n. 3, p. 22-32, 2013a. http://dx.doi.org/10.4136/ambi-agua.1250

RABONI, M.; TORRETTA, V.; URBINI, G. Influence of strong diurnal variations in sewage quality on the performance of biological denitrification in small community wastewater treatment plants (WWTPs). Sustainability, v. 5, n. 9, p. 3679-3689, 2013b. http://dx.doi.org/10.3390/su5093679

RABONI, M.; TORRETTA, V.; VIOTTI, P.; URBINI, G. Pilot experimentation with complete mixing anoxic reactors to improve sewage denitrification in treatment plants in small communities. Sustainability, v. 6, n. 1, p. 112-122, 2014a. http://dx.doi.org/10.3390/su6010112

RABONI, M.; TORRETTA, V.; VIOTTI, P.; URBINI, G. Calculating specific denitrification rates in pre-denitrification by assessing the influence of dissolved oxygen, sludge loading and mixed-liquor recycle. Environmental Technology, v. 35, n. 20, p. 2582-2588, 2014b. http://dx.doi.org/10.1080/09593330.2014.913690

RABONI, M.; GAVASCI, R.; VIOTTI, P. Influence of denitrification reactor retention time distribution (RTD) on dissolved oxygen control and nitrogen removal efficiency. Water Science Technology, v. 72, p. 45-51, 2015. https://dx.doi.org/10.2166/wst.2015.188

RABONI, M.; TORRETTA, V. Validation of a new model for the sizing of denitrification reactors, by testing full-scale plants. Environmental Technology, v. 38, p. 1376-1382, 2017. https://doi.org/10.1080/09593330.2016.1228700

RABONI, M.; VIOTTI, P. Predictive model of limestone scaling in ammonia stripping towers and its experimental validation on a treatment plant fed by MSW leachate-polluted groundwater. Waste Management, v. 59, p. 537-544, 2017. https://doi.org/10.1016/j.wasman.2016.10.025

SUBTIL, E. L.; HESPANHOL, I.; MIERZWA, J. C. Biorreatores com membranas submersas (BRMs): alternativa promissora para o tratamento de esgotos sanitários para reuso sp. Revista Ambiente \& Água, v. 8, n. 3, 2013. https://dx.doi.org/10.4136/ambi-agua.1684

TCHOBANOGLOUS, G.; BURTON, F. L.; STENSEL, H. D. Wastewater Engineering: Treatment and Reuse. McGraw-Hill, 2003.

TORRETTA, V.; RAGAZZI, M.; TRULLI, E.; DE FEO, G.; URBINI, G.; RABONI, M.; RADA, E. C. Assessment of biological kinetics in a conventional municipal WWTP by means of the oxygen uptake rate method. Sustainability, v. 6, p. 1833-1847, 2014. https://dx.doi.org/10.3390/su6041833

TORTI, E.; SIBILLA, S.; RABONI, M. An Eulerian-Lagrangian method for the simulation of the oxygen concentration dissolved by a two-phase turbulent jet system. Computers $\boldsymbol{\&}$ Structures, v. 129, p. 207-217, 2013. https://doi.org/10.1016/j.compstruc.2013.05.007

UCKER, F. E.; DE ARAÚJO ALMEIDA, R.; DA CUNHA KEMERICH, P. D. Removal of nitrogen and phosphorus from wastewater in a constructed wetland system using vetiver grass. Revista Ambiente \& Água, v. 7, n. 3, p. 87-98, 2012. http://dx.doi.org/10.4136/ambi-agua.925 
URBINI, G.; GAVASCI, R.; VIOTTI, P. Oxygen Control and Improved Denitrification Efficiency by Means of a Post-Anoxic Reactor. Sustainability, v. 7, n. 2, p. 1201-1212, 2015. https://dx.doi.org/10.3390/su7021201

USEPA. Nutrient Control Design Manual: State of Technology. EPA/600/R-09/0. 12. ed. Washington, 2009.

USEPA. Nutrient Control Design Manual. EPA/600/R-10/100. Washington, 2010.

VIOTTI, P.; COLLIVIGNARELLI, M. C.; MARTORELLI, E.; RABONI, M. Oxygen control and improved denitrification efficiency by dosing ferrous ions in the anoxic reactor. Desalination and Water Treatment, v. 57, n. 39, 2016. https://dx.doi.org/10.1080/19443994.2015.1089200

WUHRMANN, K. Nitrogen removal in sewage treatment processes. Taylor and Francis Online, 2017. p. 580-596. https://doi.org/10.1080/03680770.1962.11895576 


Ambiente \& Água - An Interdisciplinary Journal of Applied Science
ISSN 1980-993X - doi:10.4136/1980-993X
www.ambi-agua.net
E-mail: ambi.agua@gmail.com

\title{
Probability distribution of heavy rainfall and determination of IDF in the city of Caruaru - PE
}

\author{
ARTICLES doi:10.4136/ambi-agua.2555
}

Received: 03 Apr. 2020; Accepted: 15 Dec. 2020

\author{
Kevin Matheus Correia Mendes1 ${ }^{1}$; Aline Lima de Oliveira ${ }^{2}$; \\ Lucas Ravellys Pyrrho de Alcântara ${ }^{2 *}$; Adriana Thays Araújo Alves ${ }^{3}$; \\ Severino Martins dos Santos Neto ${ }^{2}$; Artur Paiva Coutinho' ${ }^{1}$; \\ Suzana Maria Gico Lima Montenegro ${ }^{4}$; José Moura Soares $^{1}{ }^{(D}$; \\ Antonio Celso Dantas Antonino ${ }^{2}$ ic
}

\footnotetext{
${ }^{1}$ Centro Acadêmico do Agreste. Núcleo de Tecnologia. Universidade Federal de Pernambuco (UFPE), Avenida Marielle Franco, s/n, Km 59, CEP: 55014-900, Caruaru, PE, Brazil.

E-mail: kevintjmendes@outlook.com, arthur.coutinho@yahoo.com.br,dscgeo@gmail.com

${ }^{2}$ Departamento de Energia Nuclear. Universidade Federal de Pernambuco (UFPE), Avenida Luiz Freire, $\mathrm{n}^{\circ}$ 1000, CEP: 50740-545, Recife, Pernambuco, Brazil.

E-mail: alinelimadeoliveira.alo@gmail.com, martinsdsn@gmail.com, acdantonino@gmail.com ${ }^{3}$ Centro de Estudos Superiores de Bacabal. Departamento de Ciências Exatas e Naturais. Universidade Estadual do Maranhão (UEMA), Rua Teixeira de Freitas, n² 2492-2706, CEP: 65700-000, Bacabal, MA, Brazil. E-mail: adrianathaaraujo@gmail.com

${ }^{4}$ Centro de Tecnologia e Geociências. Universidade Federal de Pernambuco (UFPE), Avenida da Arquitetura, s/n, CEP: 50740-550, Recife, PE, Brazil. E-mail: suzanam.ufpe@gmail.com

*Corresponding author. E-mail: ravellyspyrrho@gmail.com
}

\begin{abstract}
In the design of hydraulic engineering works, the estimation of project precipitation is fundamental. Rain forecasting depends on several factors, which makes estimating it simpler with stochastic processes. In this sense, the distributions of Gumbel (GUM), Log-Normal twoparameter (LN2P), Generalized Extreme Value (GEV), Fréchet with two and three parameters (FRE2P and FRE3P), Weibull with two and three parameters (W2P and W3P), Gamma (GAM2P), and Pareto with two and three parameters (PAR2P and PAR3P) were evaluated to the annual maximum daily precipitation (AMDP) adjustment in the city of Caruaru (Pernambuco's Agreste). A series of AMDP was used, based on data obtained from the National Water Agency (Agência Nacional de Águas - ANA). Anderson Darling (AD), KolmogorovSmirnov (KS) and Pearson Chi-square $(\chi 2)$ adherence tests, and the determination coefficient $\left(\mathrm{R}^{2}\right)$ were used to assess the adherence quality of the distributions. The Likelihood Method presented a better fit quality than the Moment Method. The GEV distribution obtained the best results for the AD test in both methods to estimate the parameters. Among the adherence tests used, the AD test was considered the most restrictive. To verify the quality parameters' fitness to the IDF relations, the Willmott performance coefficient was used. For all distributions employed in this study, Willmott performance coefficients presented values above 0.99 , giving a perfect fit of IDF relations with determination coefficients close to 1.0.
\end{abstract}

Keywords: likelihood method, method of moments, statistical hydrology.

This is an Open Access article distributed under the terms of the Creative Commons Attribution License, which permits unrestricted use, distribution, and reproduction in any medium, provided the original work is properly cited. 


\section{Distribuição de probabilidade de chuvas intensas e determinação de IDF no município de Caruaru - PE}

\section{RESUMO}

No projeto de obras de engenharia hidráulica, a estimativa de uma precipitação de projeto é extremamente importante. A previsão de chuva depende de vários fatores, o que simplifica sua estimativa com processos estocásticos. Nesse sentido, as distribuições de Gumbel (GUM), dois parâmetros Log-Normal (LN2P), valor extremo generalizado (GEV), Fréchet com dois e três parâmetros (FRE2P e FRE3P), Weibull com dois e três parâmetros (W2P e W3P), Gamma (GAM2P) e Pareto com dois e três parâmetros (PAR2P e PAR3P) foram avaliadas quanto ao ajuste de precipitação diária máxima anual (AMDP) na cidade de Caruaru (agreste de Pernambuco). Foi utilizada uma série de AMDP, com base em dados obtidos na Agência Nacional de Águas (ANA). Para avaliar a qualidade da aderência das distribuições, foram utilizados os testes de aderência Anderson Darling (AD), Kolmogorov-Smirnov (KS), Quiquadrado de Pearson $(\chi 2)$ e o coeficiente de determinação $\left(\mathrm{R}^{2}\right)$. O Método da Verossimilhança apresentou uma qualidade de ajuste melhor que o Método do Momento. A distribuição GEV obteve os melhores resultados para o teste $\mathrm{AD}$ nos dois métodos para estimar os parâmetros. Entre os testes de adesão utilizados, o teste de $\mathrm{AD}$ foi considerado o mais restritivo. Para verificar a adequação dos parâmetros de qualidade às relações IDF, foi utilizado o coeficiente de desempenho Willmott. Para todas as distribuições empregadas neste estudo, os coeficientes de desempenho de Willmott apresentaram valores acima de 0,99, proporcionando um ajuste perfeito das relações IDF com coeficientes de determinação próximos de 1,0.

Palavras-chave: hidrologia estatística, método da verossimilhança, método dos momentos.

\section{INTRODUCTION}

For the proper management of the waters of a region, hydrological knowledge is necessary, with the characterization of water flow and extreme events of maximum and minimum precipitation. In the case of intense rain events, studies can be applied to understand the hydrological behavior of river basins to control floods, as well as to estimate project flows for the design of hydraulic structures (Caldeira et al., 2015). As a rain event is a continuous random variable, it can be represented by theoretical probability distributions (Gandini and Queiroz, 2018).

Therefore, Junqueira Jr. et al. (2015) indicates that the adjustment to a probabilistic model that best describes the process is necessary for the estimation of extreme events. There are several probabilistic models applicable to modeling maximum annual events of hydrological variables. In Brazil, the adjustment by more simplified theoretical probability models has been commonly observed, such as Log-Normal (with two and three parameters) and Gumbel distributions (Caldeira et al., 2015). However, according to Back (2001), even if a distribution provides a good fit for a series of data, its application cannot be generalized, and it is recommended that several distributions for a data set be tested. Thus, Blain and Meschiatti (2014) analyzed the performance of the Wakeby, Kappa, and Generalized Extreme Value distributions in estimating annual maximum total precipitation (daily, two, and three days) in the city of Campinas - SP. Borges and Thebaldi (2016) used the models of Gumbel, Fréchet, Gama, and Log-Normal (with two and three parameters) in the analysis of AMDP for the municipality of Formiga - MG.

Another important factor in the characterization of rainfall is the estimation of the parameters of the distributions of random variables, which can be done numerically. In general, Method of Moments (MM) (Oliveira et al., 2008; Silva and Oliveira, 2017) and Maximum 
Likelihood Method (ML) (Alves et al., 2013; Rodrigues et al., 2013; Cotta et al., 2016; Santos et al., 2018), or both (Mello and Silva, 2005; Franco et al., 2014; Alcântara et al., 2019a; 2019b) are widely used in the literature.

In this sense, the state of Pernambuco has different rainfall activities throughout its territory. In general, the pluviometric index increases as it approaches the coast, where the extreme precipitations are more significant and intense. Comparatively, according to Ferreira et al. (2018), in the State of Pernambuco, monthly rainfall has greater variability and less predictability in the regions near Zona da Mata and Agreste than in the Sertão mesoregion. In addition to this characteristic, the rains in Agreste of the state are increasingly punctual, which increases annual maximum daily precipitation (AMDP), resulting in a higher occurrence of extremely dry events compared to other mesoregions (Nóbrega et al., 2015). Thus, this study evaluated the distribution of random variables of Gumbel (GUM), Log-Normal two-parameter (LN2P), Generalized Extreme Value (GEV), Fréchet with two and three parameters (FRE2P and FRE3P), Weibull with two and three parameters (W2P and W3P), Gamma (GAM2P), Pareto with two and three parameters (PAR2P and PAR3P) adjusted to AMDP events, in the city of Caruaru, in the Agreste region of the state of Pernambuco. It also obtained and evaluated the intensity-duration-frequency (IDF) equations parameters from the aforementioned probabilistic models.

\section{MATERIALS AND METHODS}

\subsection{Location and characterization of the experimental area}

The study was carried out for the city of Caruaru, in the Agreste of Pernambuco's state, $130 \mathrm{~km}$ away from the capital, Recife. Caruaru is located in an area with a tropical climate of semi-arid type. But, due to its modest altitude, it presents less severe aridity, with hot and dry summers and mild and relatively rainy winters. According to the Köppen classification, the climate of Caruaru is classified as hot and humid tropical, with a dry season in winter (Medeiros et al., 2018).

\subsection{Acquisition of rainfall data}

The data were collected on the Hidroweb portal of the National Water Agency (ANA, 2019). The chosen station was the rainfall station with the code 835106 (Latitude -8.302792; Longitude -36.010798), operated by the Mineral Resources Research Company (Companhia de Pesquisa de Recursos Minerais - CPRM), under the responsibility of ANA.

The years 2006 and 2012 had no data. The maximum daily rainfall in those years was obtained using data from pluviometric stations of the Pernambuco's Water and Climate Agency (APAC, 2019). Therefore, the analysis of the years of interest resulted in data from three stations $(24,211$, and 484), from which the values 48.9 and 49.4 were obtained, for 2006 and 2012, respectively. With this information, the missing data of the historical series of the station to be studied were filled in, resulting in the data in Table 1.

\subsection{Empirical Distribution}

The data obtained were organized in decreasing order, and from these values, the empirical function was determined using the California Method (Equation 1).

$$
F_{e m p}=\frac{i}{n}
$$

Where $\mathrm{F}_{\mathrm{emp}}$ is the surplus empirical frequency; $\mathrm{n}$ is the size of the historical series; $i$ is the position occupied by the data in the series. 
Table 1. The historical series of annual maximum daily rainfall for the city of Caruaru after filling the missing data.

\begin{tabular}{lccc}
\hline Year & Annual maximum precipitation $(\mathbf{m m})$ & Year & Annual maximum precipitation $(\mathbf{m m})$ \\
\hline 1979 & 47.3 & 1999 & 39 \\
1980 & 47.3 & 2000 & 55.4 \\
1981 & 58.3 & 2001 & 82.6 \\
1982 & 72 & 2002 & 56.4 \\
1983 & 76 & 2003 & 27.1 \\
1984 & 92 & 2004 & 62.9 \\
1985 & 186.8 & 2005 & 89.7 \\
1986 & 59 & 2006 & 48.9 \\
1987 & 50 & 2007 & 36.6 \\
1988 & 80.8 & 2008 & 50 \\
1989 & 48.6 & 2009 & 50 \\
1990 & 46.4 & 2010 & 134.2 \\
1991 & 68.8 & 2011 & 75.2 \\
1992 & 30.4 & 2012 & 49.4 \\
1993 & 61.9 & 2013 & 40.7 \\
1994 & 42.7 & 2014 & 21.3 \\
1995 & 49.8 & 2015 & 20.9 \\
1996 & 26.6 & 2016 & 26.2 \\
1997 & 40.5 & 2017 & 150.6 \\
1998 & 36.1 & & 36.3 \\
\hline 504 & 2018 & \\
\hline
\end{tabular}

Source: ANA (2001); adapted APAC (2019).

\subsection{Theoretical Distribution}

In this work, the extreme precipitations were adjusted to the probability distributions of Gumbel (GUM), Weibull (W2P), Log-Normal (LN2P), Gamma (GAM2P), Pareto (PAR2P), Frechet (FRE2P), Generalized Extreme Value (GEV), Weibull with 3 parameters (W3P), Fréchet three parameters (FRE3P), Pareto with 3 parameters (PAR3P). Table 2 shows the Probability Density Functions (PDFs) and the description of their respective parameters expressed by Equations 2 through 11.

\subsection{Parameter Estimation}

In this study, two methods were used, the Maximum Likelihood Method (ML) and the Method of Moments (MM). Naghetthini and Pinto (2007) describe these methods.

The function FindDistributionParameters (Find distribution parameters) was used for adjusting the data to the probabilistic distribution. This function receives the rain data, the probabilistic model, and the parameter estimator as input. The parameter estimator is the numerical method used to estimate the values of the parameters. 
Table 2. Probability Density Functions used and the description of the respective parameters.

\begin{tabular}{|c|c|c|c|}
\hline Distribution & Probability Density Function & & Description of parameters \\
\hline GUM & $f_{x}(x)=\frac{e^{-\frac{-x+\alpha}{\beta}}+\frac{-x+\alpha}{\beta}}{\beta}$ & (2) & $\begin{array}{l}\alpha-\text { location parameter } \\
\beta-\text { scale parameter }\end{array}$ \\
\hline W2P & $f_{x}(x)=\frac{e^{-\left(\frac{x}{\beta}\right)^{\alpha} \alpha\left(\frac{x}{\beta}\right)^{-1+\alpha}}}{\beta}$ & (3) & $\begin{array}{l}\alpha-\text { shape parameter } \\
\beta-\text { scale parameter }\end{array}$ \\
\hline LN2P & $f_{x}(x)=\frac{e^{-\frac{(-\alpha+\log [x])^{2}}{2 \beta^{2}}}}{\sqrt{2 \pi} x \beta}$ & (4) & $\begin{array}{l}\alpha-\text { first sample moment } \\
\beta-\text { second sample moment }\end{array}$ \\
\hline GAM2P & $f_{x}(x)=\frac{e^{-\frac{x}{\beta}} x^{-1+\alpha} \beta^{-\alpha}}{\Gamma(\alpha)}$ & (5) & $\begin{array}{l}\alpha-\text { shape parameters } \\
\beta-\text { scale parameter }\end{array}$ \\
\hline PAR2P & $f_{x}(x)=x^{-1-\beta} \alpha^{\beta} \beta$ & (6) & $\begin{array}{l}\alpha-\text { minimum value parameter } \\
\beta-\text { shape parameter }\end{array}$ \\
\hline FRE2P & $f_{x}(x)=\frac{e^{-\left(\frac{x}{\beta}\right)^{-\alpha}} \alpha\left(\frac{x}{\beta}\right)^{-1-\alpha}}{\beta}$ & (7) & $\begin{array}{l}\alpha-\text { shape parameter } \\
\beta-\text { scale parameter }\end{array}$ \\
\hline GEV & $=\frac{e^{-\left(1+\frac{(x-\alpha) \kappa}{\beta}\right)^{\frac{-1}{\kappa}}}\left(1+\frac{(x-\alpha) \kappa}{\beta}\right)^{-1-\frac{1}{\kappa}}}{\beta}$ & (8) & $\begin{array}{l}\alpha-\text { location parameter } \\
\beta-\text { scale parameter } \\
\kappa-\text { shape parameter }\end{array}$ \\
\hline W3P & $f_{x}(x)=\frac{e^{-\left(\frac{x-\kappa}{\beta}\right)^{\alpha}} \alpha\left(\frac{x-\kappa}{\beta}\right)^{-1+\alpha}}{\beta}$ & (9) & $\begin{array}{l}\alpha-\text { shape parameter } \\
\beta-\text { scale parameter } \\
\kappa-\text { location parameter }\end{array}$ \\
\hline FRE3P & $f_{x}(x)=\frac{e^{-\left(\frac{x-\kappa}{\beta}\right)^{-\alpha} \alpha\left(\frac{x-\kappa}{\beta}\right)^{-1-\alpha}}}{\beta}$ & (10) & $\begin{array}{l}\alpha-\text { shape parameter } \\
\beta-\text { scale parameter } \\
\kappa-\text { location parameter }\end{array}$ \\
\hline PAR3P & $f_{x}(x)=\frac{\beta\left(\frac{x+\alpha-\kappa}{\alpha}\right)^{-1-\beta}}{\alpha}$ & (11) & $\begin{array}{l}\alpha-\text { minimum value parameter } \\
\beta-\text { shape parameter } \\
\kappa-\text { location parameter }\end{array}$ \\
\hline
\end{tabular}

\subsection{Adherence Test}

To assess the adherence of theoretical statistical distributions to the empirical probability distribution, if Fexc is suitable for $F_{\text {emp }}$, the tests of Anderson Darling (AD) (Equation 12), Kolmogorov-Smirnov (KS) adherence tests (Equation 13) and Pearson's chi-square $(\chi 2)$ were used (Equation 14).

$$
\begin{aligned}
A D & =\int_{-\infty}^{+\infty}\left(\frac{\left[F_{e m p}-F_{e x c}\right]^{2}}{F_{e x c}\left[1-F_{e x c}\right]} P D F\right) d x \\
\mathrm{D}_{\mathrm{N}} & =\sup _{-\infty<\mathrm{x}<\infty}\left|\mathrm{F}_{\mathrm{N}}(\mathrm{x})-\mathrm{F}(\mathrm{x})\right| \\
\chi^{2} & =\sum_{i=1}^{n} \frac{\left[F_{e m p}-F_{e x c}\right]^{2}}{F_{e m p}}
\end{aligned}
$$


The determination coefficient $\left(\mathrm{R}^{2}\right)$ was used to quantify the quality of statistical adjustments (Equation 15). $\mathrm{R}^{2}$ determines the correlation of the variance in the experienced values that can be attributed to those observed, thereby expecting the value of $100 \%$.

$R^{2}=1-\frac{S Q_{E}}{S Q_{T}}$

Where $\mathrm{SQ}_{\mathrm{E}}$ is the sum of the residue squares, and $\mathrm{SQ}_{\mathrm{T}}$ is the sum of the total squares.

\subsection{Rainfall Disaggregating}

The method of disaggregating rainfall developed by DAEE/CETESB (1980) adopts the average factor of 1.14 for the transformation of maximum rainfall of 1 day into a rainfall of 24 hours. Factors of $0.85 ; 0.82 ; 0.78 ; 0.72$; and 0.42 are used to reduce the rainfall of 24 hours into rains of $12 \mathrm{~h}, 10 \mathrm{~h}, 8 \mathrm{~h}, 6 \mathrm{~h}$, and $1 \mathrm{~h}$, respectively. The 30 -minute rainfall is obtained by multiplying the 1-hour rainfall by 0.74 ; and to obtain the $25,20,15,10$, and 5 min rains, the rain of $30 \mathrm{~min}$ is multiplied by $0.91 ; 0.81 ; 0.70 ; 0.54$; and 0.34 , respectively.

\subsection{Intense rain equation}

For the characterization of extreme rainfall, it is necessary to determine empirical equations called intensity-duration-frequency (IDF) equations, or intense rainfall equations (Equation 16) (Bertoni and Tucci, 1993):

$i=\frac{a T^{b}}{(t+c)^{d}}$

Where $\mathrm{i}=$ is the precipitation intensity in $\mathrm{mm} / \mathrm{h} ; \mathrm{T}=$ is the precipitation return period in years; $\mathrm{t}=$ is the duration of precipitation in minutes; $\mathrm{a}, \mathrm{b}, \mathrm{c}$, and $\mathrm{d}=$ are statistical adjustment parameters.

The NonLinearModelFit function was used for performing the non-linear adjustment of the IDF parameters. This function receives as input the disaggregated rain data and the distribution parameters and makes the numerical adjustment of the IDF parameters.

The routine used to calculate the distribution parameters, the IDF parameters, and the adjustments can be observed in: https://github.com/ravellys/PAER.

\subsection{Statistics of the IDFs' adjustment}

To evaluate the performance of this adjustment, the coefficient $\left(\mathrm{R}^{2}\right)$ (Equation 15), Root Mean Squared Error (RMSE) (Equation 17), and the performance coefficient (C) (Equation 18) were used, proposed by Camargo and Sentelhas (1997), obtained by the multiplication of the Willmott index (d) (Equation 19) with Pearson's correlation coefficient (r) (Equation 20).

$$
\begin{aligned}
& \text { RMSE }=\left\{\frac{1}{\mathrm{n}}\left[\sum_{\mathrm{i}=1}^{\mathrm{n}}(\text { Fobs }- \text { Fcalc })^{2}\right]\right\}^{\frac{1}{2}} \\
& C=r \times d \\
& D=1-\left[\frac{\sum(\text { Fobs }- \text { Fcalc })^{2}}{\sum(\mid \text { Fcalc }-\bar{F} o b s|-| F o b s-\bar{F} o b s \mid)^{2}}\right] \\
& r=\sqrt{\frac{\sum(\text { Fcalc }-\bar{F} o b s)^{2}}{\sum(F o b s-\bar{F} o b s)^{2}}}
\end{aligned}
$$


Where Fcalc: calculated frequencies, Fobs: observed frequencies, Fobs: average of observed frequencies.

As a method to interpret the performance of the distributions' adjustment, the criteria of the index C was used. According to Camargo and Sentelhas (1997), this indicator is excellent for $\mathrm{C}$ values higher than 0.85 .

\section{RESULTS AND DISCUSSION}

Table 3 shows the results of the parameters for each model of distribution of random variables estimated by the MM and the ML with the respective adherence and determination coefficient tests for the set of Caruaru's city rainfall data.

Table 3. Parameters of the distributions of random variables estimated by the MM and the ML with the respective adherence tests and determination coefficients for the city of Caruaru.

\begin{tabular}{|c|c|c|c|c|c|c|}
\hline \multirow{3}{*}{ Distribution } & \multicolumn{6}{|c|}{ Parameters of random distributions } \\
\hline & \multicolumn{3}{|c|}{ MM } & \multicolumn{3}{|c|}{ ML } \\
\hline & $\alpha$ & $\boldsymbol{\beta}$ & $\kappa$ & $\alpha$ & $\boldsymbol{\beta}$ & $\kappa$ \\
\hline GUM & 46.01 & 20.84 & - & 44.26 & 26.17 & - \\
\hline $\mathrm{W} 2 \mathrm{P}$ & 1.91 & 67.35 & - & 1.83 & 66.81 & - \\
\hline LN2P & 3.96 & 0.48 & - & 3.95 & 0.53 & - \\
\hline GAM2P & 4.21 & 14.10 & - & 3.05 & 19.47 & - \\
\hline PAR2P & 20.90 & 1.09 & - & 39.78 & 3.03 & - \\
\hline FRE2P & 2.30 & 41.63 & - & 3.32 & 45.68 & - \\
\hline GEV & 43.71 & 18.76 & 0.21 & 43.93 & 22.16 & 0.11 \\
\hline W3P & 41.20 & 1.19 & 20.52 & 1.00 & 33.56 & 25.80 \\
\hline FRE3P & 4.76 & 89.21 & -45.49 & 3.02 & 13.57 & 18.52 \\
\hline PAR3P & 92675.41 & 2409.95 & 20.90 & 171358.42 & 4473.06 & 21.19 \\
\hline
\end{tabular}

The GUM distribution presents position and scale parameters close to those of the GEV distribution. These parameters were estimated according to MM and ML, respectively. In a study similar to this one, for the municipalities of Afogados da Ingazeira, Recife, Rio Formoso, Petrolina and Toritama, Alcântara et al. (2019a) also found this similarity. On the one hand, there is also a similarity between the parameters estimated by GUM, W2P, LN2P, GAM2P, FRE2P, and GEV, according to MM, and FRE3P, which was estimated according to ML. On the other hand, the values predicted by PAR2P, W3P, and PAR3P show significant differences when comparing the determinations done by MM and ML. It is also possible to observe that the value estimated by PAR3P is very different from the other two, according to MM and ML.

The results of the tests of adherence and determination coefficient $\left(\mathrm{R}^{2}\right)$ were obtained and ordered in decreasing sequence, and are presented in Table 4.

At the analysis of the statistical tests, the distributions whose results were less than 0.05 (significance level of 5\%) were considered unsatisfactory. In general, it is observed that the ML presented more satisfactory distributions than the MM, which was also observed by Back (2001) and Alves et al. (2013). For MM, it is observed that the distributions of PAR2P and FRE3P failed in all adhesion tests. According to ML, PAR2P was also unsatisfactory for all analyses, while the distribution of PAR3P did not obtain good results in either case. W2P was another distribution that did not present a sound adjustment to the tests at a level of 5\% of significance. This fact goes against those found in the literature, where distributions to two parameters are often determined as excellent (Silva et al., 2012; Aragão et al., 2013; Finkler et al., 2015). 
Table 4. Ranking in decreasing order of the adhesion tests and determination coefficients for MM and ML.

\begin{tabular}{|c|c|c|c|c|c|c|c|c|}
\hline & Distribution & $x^{2}$ & Distribution & AD & Distribution & KS & Distribution & $\mathbf{R}^{2}$ \\
\hline \multirow{10}{*}{ MM } & FRE2P & 0.97 & GEV & 0.76 & GEV & 0.97 & GEV & 0.988 \\
\hline & GUM & 0.80 & LN2P & 0.73 & LN2P & 0.93 & LN2P & 0.985 \\
\hline & GEV & 0.71 & GUM & 0.37 & GUM & 0.88 & GUM & 0.973 \\
\hline & LN2P & 0.56 & GAM2P & 0.32 & W3P & 0.75 & W3P & 0.968 \\
\hline & GAM2P & 0.56 & W2P & 0.17 & GAM2P & 0.71 & GAM2P & 0.966 \\
\hline & PAR3P & 0.27 & PAR3P & 0.08 & W2P & 0.68 & FRE2P & 0.966 \\
\hline & W3P & 0.21 & FRE2P & $0.03 *$ & FRE2P & 0.41 & W2P & 0.951 \\
\hline & W2P & $0.02 *$ & W3P & $0.01 *$ & PAR3P & 0.27 & PAR3P & 0.937 \\
\hline & PAR2P & $0.00 *$ & PAR2P & $0.00 *$ & PAR2P & $0.01 *$ & PAR2P & 0.861 \\
\hline & FRE3P & $0.00 *$ & FRE3P & $0.00 *$ & FRE3P & $0.00^{*}$ & FRE3P & 0.000 \\
\hline \multirow{10}{*}{ ML } & LN2P & 0.95 & FRE3P & 0.93 & FRE3P & 0.99 & LN2P & 0.992 \\
\hline & GEV & 0.89 & GEV & 0.93 & GEV & 0.99 & GUM & 0.991 \\
\hline & FRE3P & 0.89 & LN2P & 0.85 & LN2P & 0.95 & FRE3P & 0.990 \\
\hline & W3P & 0.38 & GUM & 0.70 & GUM & 0.79 & GEV & 0.990 \\
\hline & GUM & 0.27 & FRE2P & 0.63 & W3P & 0.75 & GAM2P & 0.984 \\
\hline & GAM2P & 0.24 & W3P & 0.56 & FRE2P & 0.75 & W3P & 0.977 \\
\hline & FRE2P & 0.21 & GAM2P & 0.49 & GAM2P & 0.71 & FRE2P & 0.973 \\
\hline & PAR3P & 0.21 & W2P & 0.18 & W2P & 0.63 & W2P & 0.956 \\
\hline & W2P & 0.08 & PAR3P & 0.08 & PAR3P & 0.24 & PAR3P & 0.934 \\
\hline & PAR2P & $0.00 *$ & PAR2P & $0.00 *$ & PAR2P & $0.00 *$ & PAR2P & 0.739 \\
\hline
\end{tabular}

* Not significant in significance level of $5 \%$.

Considering each adherence test individually, the AD test proved to be the most rigorous, failing five distributions, which were FRE2P, W3P, PAR2P, FRE3P (by MM), and PAR2P (by ML). When comparing the rigor of the adhesion methods, Beskow et al. (2015) and Franco et al. (2014) affirm the severity of the AD test compared to KS and $\chi^{2}$. This occurrence may have happened due to the greater precision that the AD test showed in the upper and lower tails of the distribution (Naghettini and Pinto, 2007). In this perspective of rigor, Douka and Karacostas (2018) indicate that $\mathrm{AD}$ is more appropriate for assessing extreme precipitation events. The KS test was the least rigorous, as pointed out by Caldeira et al. (2015), failing only the distributions of PAR2P and FRE3P (by MM) and PAR2P (by ML). The coefficient of determination $\mathrm{R}^{2}$ showed a good or very good fit $(>0.90)$ for all distributions, except for PAR2P, FRE3P (by $\mathrm{MM}$ ), and PAR2P (by ML); this last one failed at all significance levels by the ML adherence tests. Almost as strict as the AD test, the $\chi 2$ test rejected four methods, which were W2P, PAR2P, FRE3P (by MM), and PAR2P (by ML). For this test, Finkler et al. (2015) indicate a rigor in the interpretation of results and should be considered when choosing the most appropriate function for the series of minimum flows.

Gumbel distribution has been used in several studies of extreme rainfall, showing a better adjustment to $60 \%$ of the data series of 100 pluviometric stations in the state of Santa Catarina (Back, 2001). However, based on the previously discussed arrangements, it was not satisfactory for the test in the present study, neither by MM nor ML. This result reinforces the need for evaluating different estimation methods. Other studies have also found better adherence to other distributions when compared to Gumbel, such as Weibull (Aragão et al., 2013) and GEV (BenZvi, 2009).

As for MM, the GEV distribution showed the best results for the AD and KS tests, in addition to having the best $\mathrm{R}^{2}$. The FRE2P distribution showed an excellent result for the $\chi^{2}$ test, coming very close to the unit, even though it failed the AD test. For the ML, the FRE3P distribution, which was not adjusted by any statistical test by MM, obtained the best results for 
the $\mathrm{AD}$ and $\mathrm{KS}$ tests. Therefore, it was bound with the GUM distribution in the second position in the $\chi^{2}$ test and presented an $\mathrm{R}^{2}$ very close to the unit (0.990). Another highlight is the GEV distribution, which, as in the previous case, was well in all tests, showing an $\mathrm{R}^{2}$ tied with the FRE3P distribution. Some works found in the literature point to better adequacy of GEV compared to GUM (Alves et al., 2013; Franco et al., 2014; Nguyen and Nguyen, 2016). The distribution of LN2P presented the best result for the $\chi^{2}$ test and the $\mathrm{R}^{2}$.

Regarding the Weibull distribution, the insertion of three parameters (W3P), compared to two parameters (W2P), showed a simple increase in the adhesion and $\mathrm{R}^{2}$ tests, except for the AD test by MM. Even with this increase, Weibull's distribution was not so satisfactory. The sound adherence to the Log-Normal variable, in this study, showed that W2P, may be related to the fact that the variable is positive and has an asymmetry coefficient greater than zero, making it widely applied in studies of maximum precipitation (Naghettini and Pinto, 2007).

Given these results, it is possible to infer the distributions that best fit. GEV, LN2P, and GUM were applied using the MM method. For the ML, the three best distributions were LN2P, GEV, and FRE3P. Figure 1 shows a comparison between them, where their theoretical curves are an interpolation of the empirical data.

A

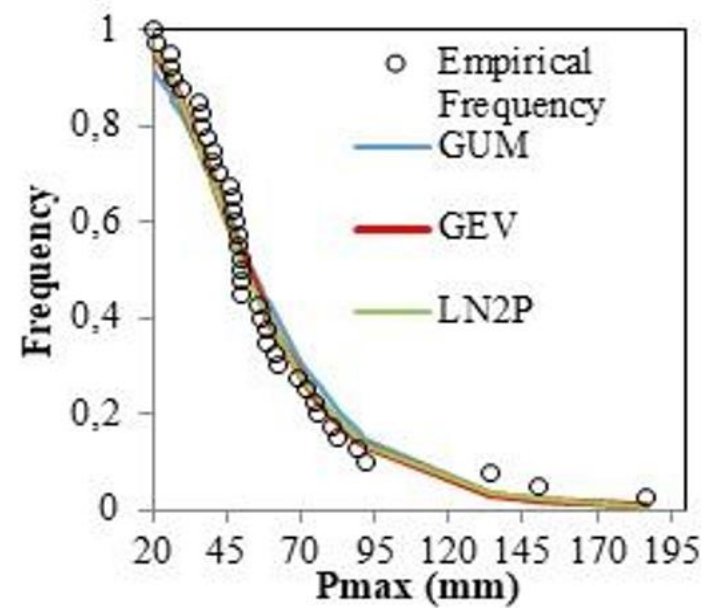

B

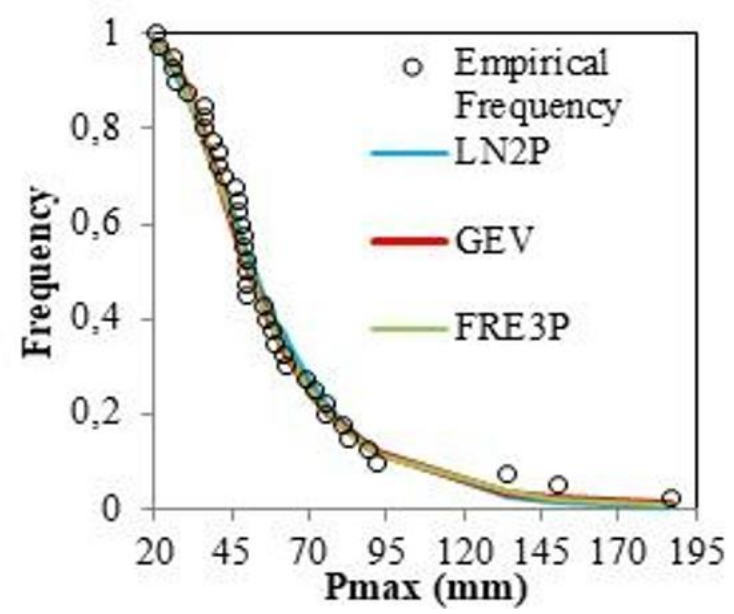

Figure 1. Comparison between Observed and Estimated Frequency for the 3 best adjustments according to MM (A) and ML (B).

For MM, it is observed that the three distributions show very similar behavior with the GUM distribution going slightly out of the pattern of the others in the case of events with high frequency. This result was expected, considering that these distributions were the best classified by the adhesion and $\mathrm{R}^{2}$ tests. Also, similar results for the GEV and LN2P distributions are reflected in the behavior of their almost overlapping curves.

The distribution of GEV also showed a proper adjustment by the ML. The same result can be seen in Blain (2013), who analyzed a pluviometric station in the city of Campinas, in the state of São Paulo from the year 1980 to 2012. It is noticeable that the three distributions are almost entirely overlapping, indicating the consistency of the excellent results obtained in the tests for them and their capability of representing the behavior of the rain data. In comparison with the theoretical frequency curves obtained by MM, the curves obtained by ML visually fit better with the empirical frequency data. This result was also expected because, according to the results of the two methods, the parameters obtained by ML did better in all tests and also had a better $\mathrm{R}^{2}$ determination coefficient.

In possession of the parameters of the theoretical frequency distributions estimated by both methods (MM and ML), it was possible to determine the IDF parameters that fit Equation 14, and which represent one of the final objectives of this work. Table 5 presents the parameters 'a', 
'b', 'c', and 'd' from MM and ML with their respective statistical criteria: ${ }^{2}$, RMSE, r, D, and C.

Table 5. IDF parameters estimated by MM and ML for the distribution of random variables with the statistics and classification of the adjustment of the IDF parameters obtained by disaggregating extreme precipitations.

\begin{tabular}{|c|c|c|c|c|c|c|c|c|c|c|c|}
\hline & \multirow{2}{*}{ Distribution } & \multicolumn{4}{|c|}{ Parameters IDF } & \multirow[b]{2}{*}{$\mathbf{R}^{2}$} & \multicolumn{4}{|c|}{ Statistics } & \multirow{2}{*}{ Performance } \\
\hline & & $\mathbf{a}$ & b & c & d & & RMSE & $\mathbf{R}$ & D & C & \\
\hline \multirow{10}{*}{ MM } & GUM & 783.43 & 0.22 & 11.83 & 0.77 & 0.999 & 2.29 & 0.999 & 1.000 & 0.999 & Excellent \\
\hline & W2P & 856.73 & 0.18 & 11.83 & 0.77 & 0.999 & 3.28 & 0.999 & 0.999 & 0.998 & Excellent \\
\hline & LN2P & 719.09 & 0.25 & 11.83 & 0.77 & 0.999 & 2.48 & 0.999 & 1.000 & 0.999 & Excellent \\
\hline & GAM2P & 803.41 & 0.21 & 11.83 & 0.77 & 0.999 & 2.71 & 0.999 & 0.999 & 0.998 & Excellent \\
\hline & PAR2P & 499.04 & 0.33 & 11.83 & 0.77 & 1.000 & 8.67 & 1.000 & 1.000 & 1.000 & Excellent \\
\hline & FRE2P & 553.14 & 0.31 & 11.83 & 0.77 & 1.000 & 2.37 & 1.000 & 1.000 & 1.000 & Excellent \\
\hline & GEV & 704.50 & 0.25 & 11.83 & 0.77 & 0.999 & 2.10 & 0.999 & 1.000 & 0.999 & Excellent \\
\hline & W3P & 725.22 & 0.25 & 11.83 & 0.77 & 0.999 & 3.35 & 0.999 & 0.999 & 0.998 & Excellent \\
\hline & FRE3P & 344.15 & 0.23 & 11.83 & 0.77 & 1.000 & 2.10 & 1.000 & 1.000 & 1.000 & Excellent \\
\hline & PAR3P & 746.70 & 0.27 & 11.83 & 0.77 & 0.999 & 3.97 & 0.999 & 0.999 & 0.998 & Excellent \\
\hline \multirow{10}{*}{ MS } & GUM & 738.83 & 0.19 & 11.83 & 0.77 & 0.999 & 2.97 & 0.999 & 0.999 & 0.998 & Excellent \\
\hline & W2P & 860.32 & 0.17 & 11.83 & 0.77 & 0.999 & 3.41 & 0.999 & 1.000 & 0.999 & Excellent \\
\hline & LN2P & 719.23 & 0.23 & 11.83 & 0.77 & 0.999 & 2.77 & 0.999 & 0.999 & 0.999 & Excellent \\
\hline & GAM2P & 792.07 & 0.19 & 11.83 & 0.77 & 1.000 & 3.29 & 1.000 & 1.000 & 1.000 & Excellent \\
\hline & PAR2P & 262.16 & 0.92 & 11.83 & 0.77 & 1.000 & 1.41 & 1.000 & 1.000 & 1.000 & Excellent \\
\hline & FRE2P & 500.78 & 0.44 & 11.83 & 0.77 & 1.000 & 1.51 & 1.000 & 1.000 & 0.999 & Excellent \\
\hline & GEV & 627.55 & 0.29 & 11.83 & 0.77 & 0.999 & 2.53 & 0.999 & 0.999 & 0.998 & Excellent \\
\hline & W3P & 769.38 & 0.22 & 11.83 & 0.77 & 1.000 & 3.35 & 1.000 & 1.000 & 0.999 & Excellent \\
\hline & FRE3P & 627.55 & 0.29 & 11.83 & 0.77 & 0.999 & 0.74 & 0.999 & 0.999 & 0.998 & Excellent \\
\hline & PAR3P & 746.01 & 0.27 & 11.83 & 0.77 & 0.999 & 3.85 & 0.999 & 1.000 & 0.999 & Excellent \\
\hline
\end{tabular}

For MM, parameters $\mathrm{c}$ and $\mathrm{d}$ presented identical values for all distributions. The 'b' parameter shows little variation between distributions. The 'a' parameter, however, was the one with the most significant values disparity when comparing the distributions. Focusing on the distributions that passed the adhesion tests and obtained better results, namely, GUM, GEV and LN2P the results of 'a' are relatively similar. The results for 'a' that are most discrepant from the others are precisely the distributions that did not fit the probabilistic model by any test, FRE3P, and PAR2P.

As for the ML, it is worth noting that parameters ' $c$ ', and ' $d$ ' showed the same values as their counterparts estimated by MM. The values of parameter ' $b$ ' varied more in relation to its counterpart estimated by MM. The 'a' parameters estimated by ML are similar to those estimated by MM for their respective distributions. Exceptions are the PAR2P and FRE3P distributions, which did not pass any adherence tests when having their parameters estimated by the MM. Even though the FRE3 distribution was well adjusted when having its parameters evaluated by the ML.

Both parameters estimated by MM and ML achieved optimum performance for all distributions, showing that the IDF equation can describe the theoretical behavior of all distributions, even for those that failed the adherence tests. In a similar study for the capitals of the northeastern Brazilian states, Silva and Oliveira (2017) obtained very satisfactory results for the distribution of GUM. For all cities, it had an excellent performance with $\mathrm{C}$ ranging from 0.95 to 0.99 and $\mathrm{R}^{2}$ of 0.99 in all capitals. Besides, Santos et al. (2009) carried out similar works for the state of Mato Grosso, obtaining an average $\mathrm{R}^{2}$ determination coefficient of 0.98 .

Figure 2 shows the IDF curves for the return times of 2, 10, 50, and 100 years for the distributions that adhered to the empirical data for MM (Figure 2A) and ML (Figure 2B). 
A
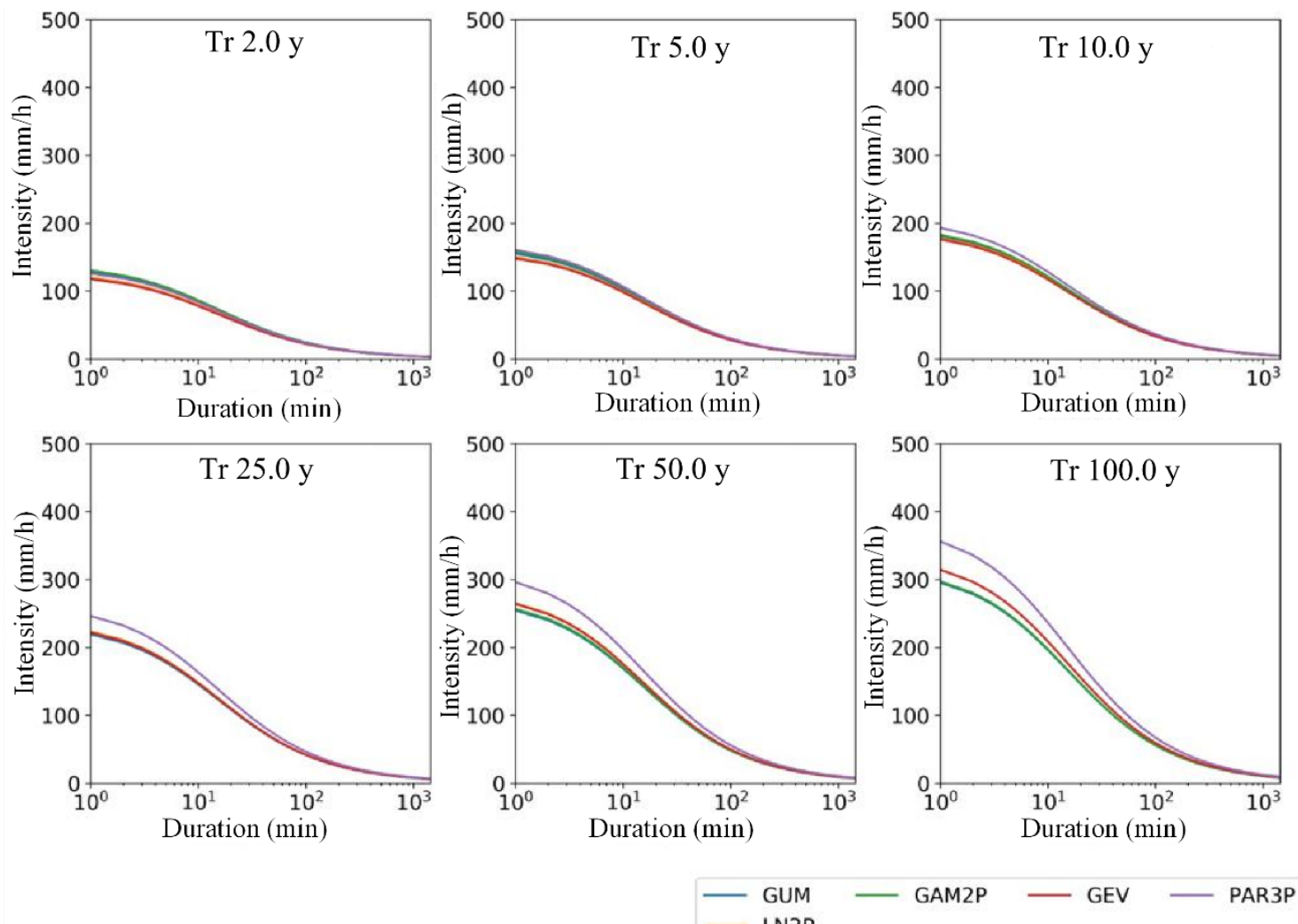

B
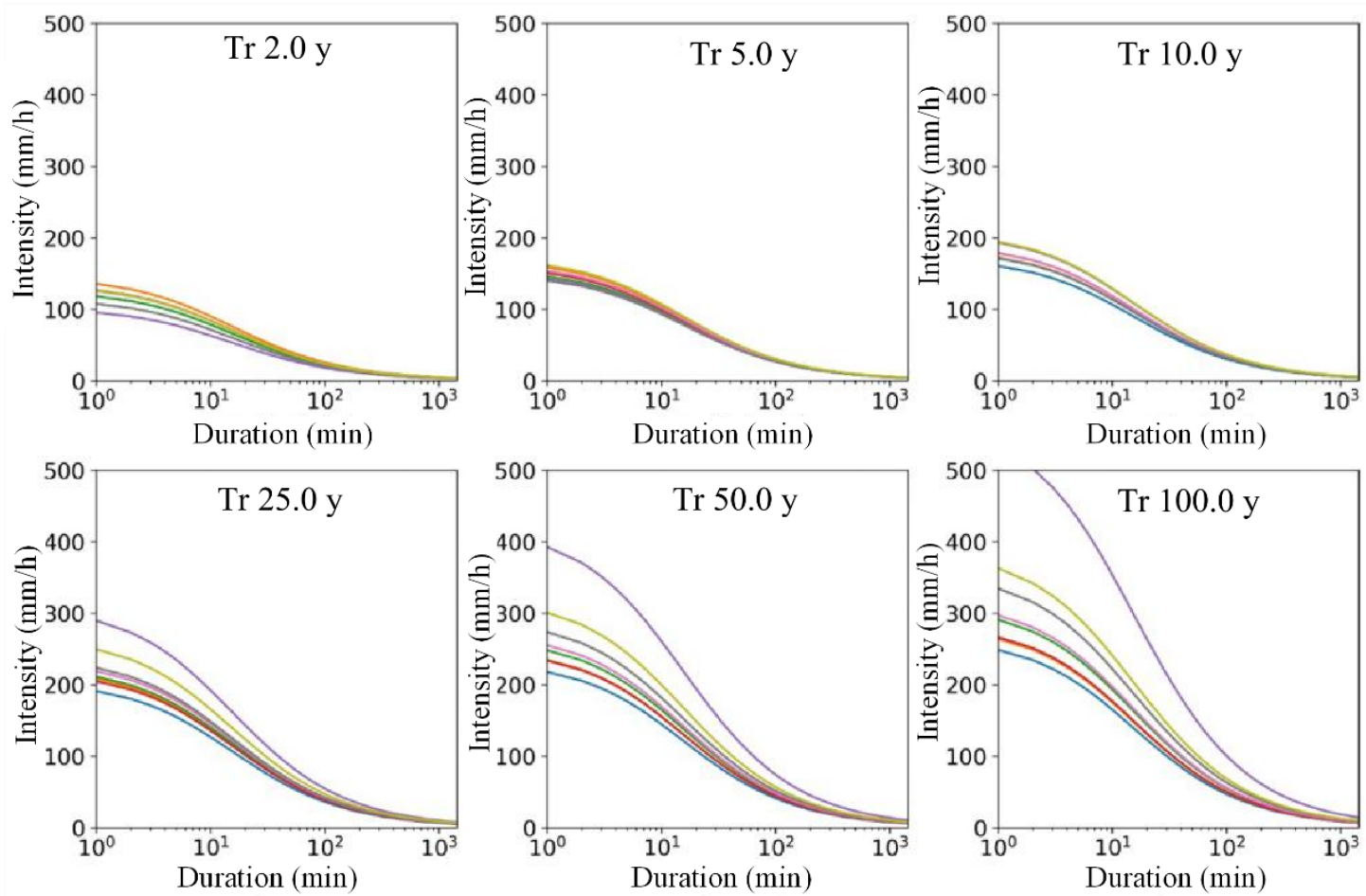

Figure 2. IDF curves for distributions that fit the empirical data by MM (A) and ML (B) in the municipality of Caruaru-PE. 
The distribution of GEV to MM (Figure 2A) obtained the best result in the AD test. Hence, its curve is better able to describe extreme events, even if in comparison with other curves, predicting less heavy rains for the same duration in the return times of 2 and 10 years. For return times of 50 and 100 years, its curve was in the middle, where the PAR3P distribution overestimated the rain intensity for these return times.

In the case of the curves developed from ML (Figure 2B), the IDF curves of FRE3P and GEV appear overlapping all the time, making it impossible to separate them visually. This outcome was expected since both obtained surprisingly similar results in the adhesion tests. Both were also tied with the best performance in the AD test, so they are recommended to predict extreme events. Its curves occupy an intermediate position among the others. It is interesting to notice that the FRE2P distribution curve (ML) estimates the lowest intensities for the 2-year return time. However, with the increase of the return time, it starts to have expected intensity values much higher than the others, reaching intensities estimations close to $200 \mathrm{~mm} / \mathrm{h}$ for a return time of 100-year (ML).

\section{CONCLUSIONS}

Both estimation methods were able to adjust the parameters of the theoretical distributions to the annual maximum daily precipitation data. However, ML was more effective than MM. Distributions parameters estimated by ML fared better than MM in all cases, except for FRE2P, which did not adjust in any of the cases. The three distributions that stood out for the MM were those of GEV, LN2P, and GUM. By the ML, the three best distributions according to the statistical tests and validated by the $\mathrm{R}^{2}$ were LN2P, GEV, and FRE3P. The distribution of GEV also showed a reasonable adjustment by MM.

The distribution of GEV by MM obtained the best result in the AD test, so its curve is the best able to describe extreme events. In the case of curves made from ML, the IDF curves of FRE3P and GEV obtained surprisingly similar results in the adhesion tests. Both were also tied with the best performance in the AD test, so they are recommended to predict extreme events. All IDF equations had optimal adjustments, in addition to $\mathrm{R}^{2}$, which indicates a fit with excellent quality. It was also found that it is possible to use the GUM-MM distribution to predict precipitation events with satisfactory accuracy within the parameters used in this work.

\section{ACKNOWLEDGMENTS}

This work was supported by the Conselho Nacional de Desenvolvimento Científico e Tecnológico (CNPq), No 465764/2014-2, the Coordenação de Aperfeiçoamento de Pessoal de Nível Superior - Brasil (CAPES), No 88887.136369/2017-00, and the Fundação de Amparo à Ciência e Tecnologia de Pernambuco (FACEPE), APQ-0498-3.07/17, and by the Project: "Observatório Nacional da Dinâmica da Água e de Carbono no Bioma Caatinga (ONDACBC)".

\section{REFERENCES}

AGÊNCIA PERNANBUCANA DE ÁGUAS E CLIMA. Website. 2019. Available at: https://www.apac.pe.gov.br/. Access: Jan. 2021.

ALCÂNTARA, L. R. P. de; COUTINHO, A. P.; SANTOS NETO, S. M. dos; MELO, T. dos A. T. de; COSTA, L. F.; RIBAS, L. V. da S.; ANTONINO, A. C. D.; ALVES, E. M. Modelos probabilísticos para eventos de precipitações extremas na cidade de PalmaresPE. Revista Brasileira de Geografia Física, v. 12, n. 04, p. 1355-1369, 2019 b.

Rev. Ambient. Água vol. 16 n. 1, e2555 - Taubaté 2021 
ALCÂNTARA, L. R. P. de; MARTINS, L. A.; COSTA, I. R. de A.; BARROS, V. H. de O.; SANTOS NETO, S. M. dos; COUTINHO, A. P.; ANTONINO, A. C. D. Avaliação de modelos probabilísticos para chuvas intensas nas mesorregiões do estado de Pernambuco. Journal of Environmental Analysis and Progress, v. 4, n. 1, p. 090-103, 2019a. https://doi.org/10.24221/jeap.4.1.2019.2332.090-103

ALVES, A. V. P.; SANTOS, G. B. da S.; MENEZES FILHO, F. C. M. de; SANCHES, L. Análise dos métodos de estimativa para os parâmetros das distribuições de Gumbel e gev em eventos de precipitações máximas na cidade de CUIABÁ-MT. Revista Eletrônica de Engenharia Civil, v.6, n.1, p.32-43, 2013.

ANA (Brasil). Hidroweb: Sistema de informações hidrológicas. 2001. Available at: http://hidroweb.ana.gov.br. Access: 15 June 2019.

ARAGÃO, R.; DE SANTANA, G. R.; DA COSTA, C. E.; CRUZ, M. A.; DE FIGUEIREDO, E. E.; SRINIVASAN, V. S. Chuvas intensas para o estado de Sergipe com base em dados desagregados de chuva diária. Revista Brasileira de Engenharia Agricola e Ambiental-Agriambi, v. 17, n. 3, p.243-252, 2013. http://dx.doi.org/10.1590/S141543662013000300001

BACK, A. J. Seleção de distribuição de probabilidade para chuvas diárias extremas do Estado de Santa Catarina. Revista Brasileira de Meteorologia, v. 16, n. 2, p. 211-222, 2001.

BEN-ZVI, A. Rainfall intensity-duration-frequency relationships derived from large partial duration series. Journal of Hydrology, v. 367, n. 1-2, p.104-114, 2009. https://doi.org/10.1016/j.jhydrol.2009.01.007

BERTONI, J. C.; TUCCI, C. E. M. Precipitação. In: TUCCI, C. E. M. (Org.). Hidrologia Ciência e Aplicação. 2. ed. Porto Alegre: Universidade/UFRGS; ABRH, 1993. cap. 5. p. 177-231.

BESKOW, S.; CALDEIRA, T. L.; MELlO, C. R.; FARIA, L. C.; GUEDES, H. A. S. Multiparameter probability distributions for heavy rainfall modeling in extreme Southern Brazil. Journal of Hydrology: Regional Studies, v. 4, p. 123-133, 2015. https://doi.org/10.1016/j.ejrh.2015.06.007

BLAIN, G. C. Seasonal variability of maximum daily rainfall in Campinas, State of São Paulo, Brazil: trends, periodicities, and associated probabilities. Acta Scientiarum Agronomy, v. 35, n. 3, p. 557-564, 2013. https://doi.org/10.4025/actascitechnol.v35i3.16222

BLAIN, G. C.; MESCHIATTI, M. C. Using multi-parameters distributions to assess the probability of occurrence of extreme rainfall data. Revista Brasileira de Engenharia Agrícola e Ambiental, v.18, n. 3, p. 307-313, 2014. http://dx.doi.org/10.1590/S141543662014000300010

BORGES, G. M. R.; THEBALDI, M. S. Estimativa da precipitação máxima diária anual e equação de chuvas intensas para o município de Formiga, MG, Brasil. Revista Ambiente \& Água, v. 11, n. 4, p.891-902, 2016. http://dx.doi.org/10.4136/ambi-agua.1823

CALDEIRA, T. L.; BESKOW, S.; MELLO, C. R. de; FARIA, L. C.; SOUZA, M. R. de; GUEDES, H. A. S. Modelagem probabilística de eventos de precipitação extrema no estado do Rio Grande do Sul. Revista Brasileira de Engenharia Agrícola e Ambiental, v. 19, n. 3, p. 197-203, 2015. https://doi.org/10.1590/1807-1929/agriambi.v19n3p197203 
CAMARGO, A. P. de; SENTELHAS, P. C. Avaliação do desempenho de diferentes métodos de estimativa da evapotranspiração potencial no Estado de São Paulo, Brasil. Revista Brasileira de Agrometeorologia, v. 5, v. 1, p. 89-97, 1997.

COTTA, H. H. A.; CORREA, W. de S. C.; AlBUQUERQUE, T. T. de A. Aplicação da distribuição de Gumbel para valores extremos de precipitação no município de Vitória, ES. Revista Brasileira de Climatologia, v. 19, p. 203-217, 2016. http://dx.doi.org/10.5380/abclima.v19i0.39440

DOUKA, M.; KARACOSTAS, T. Statistical analyses of extreme rainfall events in Thessaloniki, Greece. Atmospheric Research, v. 208, p. 60-77, 2018. https://doi.org/10.1016/j.atmosres.2017.08.025

FERREIRA, D. V. de S.; SILVA, A. S. A. da; STOSIC, T.; MENEZES, R. S. C.; IRMÃO, R. A.; SOUZA, W. S. Análise da variabilidade espaço temporal da chuva mensal no estado de Pernambuco utilizando o método entropia de permutação. Revista Brasileira de Biometria, v. 36, n. 2, p.276-289, 2018. https://doi.org/10.28951/rbb.v36i2.179

FINKLER, N. R.; MENDES, L. A.; SCHEIDER, E. H. M.; BORTOLIN, T. A.; SCHEIDER, V. E. Comparação de funções de distribuição de probabilidades na determinação de vazão mínima anual e sazonal. Scientia Cum Industria, v. 3, n. 2, p. 42-49, 2015. http://dx.doi.org/10.18226/23185279.v3iss2p42

FRANCO, C. S.; MARQUES, R. F. P. V.; OlIVEIRA, A. S.; OlIVEIRA, L. F. C. de Distribuição de probabilidades para precipitação máxima diária na Bacia Hidrográfica do Rio Verde, Minas Gerais. Revista Brasileira de Engenharia Agrícola e Ambiental, v. 18 , n. 7, p. 735-741, 2014

GANDINI, M. L. T.; QUEIROZ, P. I. B. de. Análise de modelos probabilísticos de frequência para obtenção de equações IDF na cidade de Cunha-SP. Revista DAE, v. 66, n. 211, p.105-117, 2018.

JUNQUEIRA JR., J. A.; MELLO, C. R. de; ALVES, G. J. Eventos extremos de precipitação no Alto Rio Grande, MG: Análise probabilística. Revista Brasileira de Engenharia Agrícola e Ambiental, 19, n. 4, p.301-308, 2015. https://doi.org/10.1590/18071929/agriambi.v19n4p301-308

MEDEIROS, R. M. de; HOLANDA, R. M. de; VIANA, M. A.; SILVA, V. de P. Climate classification in Köppen model for the state of Pernambuco - Brazil. Revista de Geografia (Recife), v. 35, n. 3, p. 219-234, 2018.

MELLO, C. D.; SILVA, A. M. da. Métodos estimadores dos parâmetros da distribuição de Gumbel e sua influência em estudos hidrológicos de projeto. Irriga, v. 10, n. 4, p. 334350, 2005. https://doi.org/10.15809/irriga.2005v10n4p334-350

NAGHETTINI, M.; PINTO, E. J. de A.; Hidrologia Estatística. Belo Horizonte: CPRM, 552. 2007.

NGUYEN, V.; NGUYEN, T. Statistical Modeling of Extreme Rainfall Processes (SMExRain): A Decision Support Tool for Extreme Rainfall Frequency Analyses. Procedia Engineering, v. 154, p. 624-630, 2016. https://doi.org/10.1016/j.proeng.2016.07.561 
NÓBREGA, R. S., FARIAS, R. F. de L., SANTOS, C. A. C. dos. Variabilidade temporal e espacial da precipitação pluviométrica em Pernambuco através de índices de extremos climáticos. Revista Brasileira de Meteorologia, v. 30, n. 2, p. 171-180, 2015. https://doi.org/10.1590/0102-778620130624

OLIVEIRA, Luiz F. C. de et al . Métodos de estimativa de precipitação máxima para o Estado de Goiás. Revista brasileira de Engenharia agrícola e ambiental, v. 12, n. 6, p. 620625, 2008. http://dx.doi.org/10.1590/S1415-43662008000600008.

RODRIGUES, T. R.; PAULO, S. R. de; NOVAIS, J. W. Z.; CURADO, L. F. A.; NOGUEIRA, J. S.; OLIVEIRA, R. G. de; LOBO, F, de A.; VOURLITIS, G. L. Temporal patterns of energy balance for a Brazilian tropical savanna under contrasting seasonal conditions. International Journal of Atmospheric Sciences, v. 2013, p.1-9, 2013.

SANTOS, G. G.; FIGUEIREDO, C. C. de; OliVEIRA, L. F. C. de; GRIEBELER, N. P. Intensity-duration-frequency of rainfall for the State of Mato Grosso do Sul. Revista Brasileira de Engenharia Agrícola e Ambiental, v. 13, p. 899-905, 2009. http://dx.doi.org/10.1590/S1415-43662009000700012

SANTOS, R. S. dos; VIEIRA, P. D.; EVANGELISTA, D. H. R.; OLIVEIRA, L. J. C.; NONATO, D. Caracterização de extremos mensais de precipitação em Cacoal (RO). Revista Brasileira de Climatologia, v. 22, n. 14, p. 267-280, 2018. http://dx.doi.org/10.5380/abclima.v22i0.55285

SILVA, B. M.; MONTENEGRO, S. M. G. L.; SILVA, F. B. da; ARAÚJO FILHO, P. F. de Chuvas Intensas em Localidades do Estado de Pernambuco. Revista Brasileira de Recursos Hídricos, v. 17, n. 3, p. 135-146, 2012.

SILVA, C. B.; OLIVEIRA, L. F. C. Relação Intensidade-Duração-Frequência de Chuvas Extremas na Região Nordeste do Brasil. Revista Brasileira de Climatologia, v. 20, p. 267-283, 2017. http://dx.doi.org/10.5380/abclima.v20i0.49286 


Ambiente \& Água - An Interdisciplinary Journal of Applied Science
ISSN 1980-993X - doi:10.4136/1980-993X
www.ambi-agua.net
E-mail: ambi.agua@gmail.com

\title{
Simulation of nitrate and potassium concentrations in soil solution using parametric models and Hydrus-2D
}

\author{
ARTICLES doi:10.4136/ambi-agua.2606
}

Received: 25 Jun. 2020; Accepted: 15 Dec. 2020

\author{
Beatriz Santos Conceição ${ }^{1}$; ; Eugênio Ferreira Coelho ${ }^{2}$; \\ João José da Silva Junior ${ }^{3 *}$; ; José Antonio do Vale Sant'Ana1 ${ }^{1}$; \\ Mauro Aparecido Martinez ${ }^{4}$ (D)
}

\footnotetext{
${ }^{1}$ Departamento de Agronomia. Instituto Federal de Educação, Ciência e Tecnologia de Mato Grosso (IFMT), Avenida Vilmar Fernandes, $n^{\circ}$ 300, CEP: 78652-000, Confresa, MT, Brazil.

E-mail: beatriz.conceicao@cfs.ifmt.edu.br, jose.santana@cfs.ifmt.edu.br

${ }^{2}$ Embrapa Mandioca e Fruticultura (EMBRAPA), Rua Embrapa, s/n, CEP: 44380-000, Cruz das Almas, BA, Brazil. E-mail: eugenio.coelho@embrapa.br

${ }^{3}$ Faculdade de Agronomia e Medicina Veterinária. Universidade de Brasília (UnB), Campos Universitário Darcy Ribeiro, Asa Norte, CEP: 70910-900, Brasília, DF, Brazil.

${ }^{4}$ Departamento de Ciência do Solo. Universidade Federal de Viçosa (UFV), Avenida Peter Henry Rolfs, s/n, CEP: 36570-000, Viçosa, MG, Brazil. E-mail: mmauro@ufv.br

*Corresponding author. E-mail: jjsjunior@unb.br
}

\begin{abstract}
This study estimated the nitrate and potassium concentration in the soil solution of drainage lysimeter using the mathematical models developed by Vogeler et al. (1996) and MuñozCarpena et al. (2005) and the computational model Hydrus-2D, while comparing the simulated and observed data using statistical parameters. The cultivar used for the study was 'Prata Gorutuba'. The experimental plots were six lysimeters of drainage. Fertigation was performed weekly. The mathematical models developed by Vogeler et al. (1996) and Muñoz-Carpena et al. (2005) were used to determine the specific concentration of a given ion (Ci). The Hydrus software was used to simulate the dynamics of nutrients. The concentrations of nitrate and potassium in the soil solution were estimated by the model of Vogeler et al. (1996), adapted to the linear type CEw-Ci ratio and simulated by the Hydrus model, resulting in an acceptable characterization of the distribution of these nutrients.
\end{abstract}

Keywords: banana, fertigation, lysimeter, modeling, nutrients.

\section{Simulações das concentrações de nitrato e potássio na solução do solo utilizando modelos paramétricos e o Hydrus-2D}

\section{RESUMO}

O objetivo deste trabalho foi estimar a concentração de nitrato e potássio na solução do solo, em lisímetro de drenagem com o uso dos modelos matemáticos desenvolvidos por Vogeler et al. (1996) e Muñoz-Carpena et al. (2005) e do modelo computacional Hydrus-2D e comparar os dados simulados e observados usando parâmetros estatísticos. A cultivar utilizada para o estudo foi a 'Prata Gorutuba'. As parcelas experimentais foram seis lisímetros de drenagem. A fertirrigação foi realizada semanalmente. Os modelos matemáticos desenvolvidos por Vogeler et al. (1996) e Muñoz-Carpena et al. (2005), foram utilizados para determinar a concentração 
específica de um determinado íon (Ci). O software Hydrus foi utilizado para simular a dinâmica de nutrientes. As concentrações de nitrato e potássio na solução do solo, estimados por meio do modelo de Vogeler et al. (1996) adaptado para a relação CEw-Ci do tipo linear e simulado pelo modelo Hydrus apresentou uma caracterização aceitável da distribuição desses nutrientes.

Palavras-chave: bananeira, fertirrigação, lisimetro, modelagem, nutrientes.

\section{INTRODUCTION}

Water is one of the main factors limiting crop development, with special importance in certain phenological phases in which its deficiency can more or less significantly compromise productivity (Vanhove et al., 2012; Ravi et al., 2013; Muthusamy et al., 2014; Kissel et al., 2015).

A few years ago, a change in the traditional form of fertilization of irrigated crops occurred with the application of fertilizer via irrigation water. According to Langoni et al. (2019), in order for the irrigated crop to be viable it is necessary to adopt management that contributes to the increase of productivity and profit, in which fertigation is a technology that offers easy benefits in the parceling of fertilizer, providing nutrients according to the phenological stages of the crop more responsive to absorption.

In fertigated areas, the monitoring of the spatial and temporal variation of the water content $(\theta)$, the electrical conductivity of the soil (CEs), the electrical conductivity of the soil solution (CEss) and the ionic concentration (Ci), makes it possible to estimate the loss of water to deep percolation and evapotranspiration of the crop, in addition to determining the regions of nutrient extraction by the plants and the possible loss of nutrients to leaching (Santana et al., 2007).

For monitoring the distribution of water and ionic solutes in the soil, time domain reflectometry (TDR) has been used successfully in several studies (Vogeler et al., 1996; Persson and Uvo, 2003; Santos et al., 2010), due to the relationship between the apparent electrical conductivity of the soil and the electrical conductivity of the soil solution (CEw), and between $\mathrm{CEw}$ and the ionic concentration $(\mathrm{Ci})$.

Considering the computational advances in recent years, a viable alternative is the use of analytical and numerical models that predict the processes of water and solute transfer between the soil surface and the groundwater table. Among the computational models available in the literature, the Hydrus model has been distinguished by the accuracy of the results (Nimmer et al., 2009; Silva et al., 2015; Kanzari et al., 2012; Pinho and Miranda 2014; Ramos et al., 2013), and also by its graphical interface that allows for a good interaction with different types of users. However, the approach for calibration and validation of the model can vary greatly, depending on the complexity of the experiment.

The main advantage of using models is that it saves time and capital, since field experiments and laboratories are usually laborious, expensive and time-consuming (Martinez et al., 2010). Nevertheless, it is worth noting that field measurements are indispensable, since mathematical models require local calibration and validation (Rivera et al., 2008).

Techniques for solving equations and the available computational resources can predict the contamination risks and impacts that the chemical components might cause to the soilwater-plant system (Garcia et al., 2012).

The use of multidimensional modeling is indispensable for developing fertigation practices, and optimized to achieve optimal nutritional efficiency for plants. Thus, in recent decades several analytical and numerical models have emerged to predict the processes of water and solute transfer between the soil surface and groundwater (Pinho and Miranda, 2014).

According to Kunz et al. (2014), the use of simulation models describing the flux of water in the soil, such as Hydrus 2D/3D, can be useful to explain the behavior of water in porous media, provided they are properly calibrated and validated from field experiments. 
Elmi et al. (2012) investigated the vertical distribution of water in a soil column using Hydrus and observed that the estimated soil moisture values did not correspond to the measured values. According to the authors, the result may be associated with heterogeneity in soil profile, which was not considered in the discretization of the model. This result differs from that of Silva et al. (2015) who, seeking to model soil moisture dynamics through the Hydrus Model, reported that the results ensure the possibility of using the model to estimate soil moisture at a daily scale for the type of soil and coverage conditions investigated.

Kanzari et al. (2012) also characterized water movement by using TDR probes installed up to $4 \mathrm{~m}$ deep, using Hydrus to model water movement in a semi-arid region of Tunisia, and found that the simulated data showed the same trend as the measured data. Pinho and Miranda (2014), evaluating the application of the Hydrus model as well as its performance in potassium and water displacement simulations (in Red-Yellow Latossoil and Red Nitossoil), concluded that the Hydrus model was efficient in potassium and water displacement simulations in the two soil materials studied.

Ramos et al. (2013) used the Hydrus model to simulate the dynamics of water and nitrogen forms in a soil cultivated with saccharine sorghum, bearing different salt contents and fertigation levels, and reported that simulations with Hydrus were useful to understanding the best strategies to increase nutrient uptake by plants and reduce losses to leaching.

Thus, the present work aimed to estimate the concentration of nitrate and potassium in the soil solution in drainage lysimeter using the mathematical models developed by Vogeler et al. (1996) and Muñoz-Carpena et al. (2005) and the computational model Hydrus-2D, while comparing the simulated and observed data using statistical parameters.

\section{MATERIAL AND METHODS}

The experiment was conducted at the National Center of Cassava and Fruticulture Research (CNPMF), belonging to the Brazilian Agricultural Research Corporation (EMBRAPA), located in the municipality of Cruz das Almas - BA $\left(12^{\circ} 40^{\prime} 12^{\prime \prime} \mathrm{S} ; 3^{\circ} 06^{\prime} 07^{\prime \prime} \mathrm{W}\right.$; $220 \mathrm{~m}$ altitude) The climate is Aw and Am, classified in the Koppen classification as tropical hot and humid. The cultivar used for the study was the 'Prata Gorutuba' (Musa AAB 'Prata Anã' clone: Gorutuba).

The treatments used in this experiment were obtained by the combination of two soils of distinct texture (sandy clay and sandy frank sand) and three concentrations (3.0, 6.0 and $9.0 \mathrm{~g}$ $\mathrm{L}^{-1}$ ) for application of potassium nitrate in the irrigation water for the banana tree 'Prata Gorutuba', totaling six treatments (sandy clay soil with $3 \mathrm{~g} \mathrm{~L}^{-1}(\mathrm{~T} 1)$, sandy clay soil with $6.0 \mathrm{~g}$ $\mathrm{L}^{-1}$ (T2), sandy clay soil with $9.0 \mathrm{~g} \mathrm{~L}^{-1}$ (T3), free sand soil with $3.0 \mathrm{~g} \mathrm{~L}^{-1}$ (T4), free sand soil with $6.0 \mathrm{~g} \mathrm{~L}^{-1}$ (T5), and free sand soil with $9.0 \mathrm{~g} \mathrm{~L}^{-1}$ (T6), which were distributed in an experimental design entirely randomized with four repetitions. The repetitions were composed of the four radial planes, containing TDR probes and solution extractors (installed at 0.20, 0.40, 0.60 and $0.80 \mathrm{~m}$ distance and depth $(\mathrm{r}, \mathrm{z})$ on each lysimeter.

The lysimeters have a capacity of $5.0 \mathrm{~m}^{3}$, measuring $2.0 \mathrm{~m}$ wide, $2.5 \mathrm{~m}$ long and $1.0 \mathrm{~m}$ deep. To create a free drainage system, the last $0.2 \mathrm{~m}$ of the profile was divided in two layers of $0.1 \mathrm{~m}$, the lower one composed of a drainage system with perforated PVC tubes at $0.05 \mathrm{~m}$ and zero gravel, and the upper one with washed sand. Samples of the soils were taken at depths of $0.0-0.4 \mathrm{~m}$ before the plantation of the banana tree and sent to the soil and nutrition laboratory of Embrapa - CNPMF for chemical analysis (Table 1).

Table 2 shows the physical characteristics of the two types of soil used in lysimeters.

The usual practices of management of a banana tree (thinning, defoliation, propping, heart pruning, control of diseases, pests and invaders) were carried out according to need, according to Borges and Souza (2004). Fertigation was performed weekly, during which nitrogen (N) and potassium $(\mathrm{K})$ were applied in the form of potassium nitrate, obeying the following distribution: 
$10 \%$ in the first three months of planting, $75 \%$ from the third to the eighth month, in the bloom phase, and $15 \%$ from this until harvest, with applications in concentrations 3,6 and $9 \mathrm{~g} / \mathrm{L}$ (Borges and Souza, 2004).

Table 1. Chemical characterization of soils studied.

\begin{tabular}{lcc}
\hline Characteristics & Sandy-clay soil & Sandy soil \\
\hline $\mathrm{pH}$ & 5.0 & 7.6 \\
$\mathrm{P}\left(\mathrm{mg} \mathrm{d}^{-3}\right)$ & 2 & 28 \\
$\mathrm{~K}\left(\mathrm{cmolc} \mathrm{dm}^{-3}\right)$ & 0.06 & 0.06 \\
$\mathrm{Ca}\left(\mathrm{cmolc} \mathrm{dm}^{-3}\right)$ & 0.68 & 1.41 \\
$\mathrm{Mg}\left(\mathrm{cmolc} \mathrm{dm}^{-3}\right)$ & 0.46 & 0.30 \\
$\mathrm{Ca}+\mathrm{Mg}\left(\mathrm{cmolc} \mathrm{dm}^{-3}\right)$ & 1.14 & 1.71 \\
$\mathrm{Al}\left(\mathrm{cmolc} \mathrm{dm}^{-3}\right)$ & 0.5 & 0.0 \\
$\mathrm{Na}\left(\mathrm{cmolc} \mathrm{dm}^{-3}\right)$ & 0.33 & 0.02 \\
$\mathrm{H}+\mathrm{Al}\left(\mathrm{cmolc} \mathrm{dm}^{-3}\right)$ & 3.19 & 0.00 \\
$\mathrm{SB}$ & 1.53 & 1.84 \\
$\mathrm{CTC}$ & 4.72 & 1.84 \\
$\mathrm{~V}(\%)$ & 32.0 & 100 \\
$\mathrm{MO}\left(\mathrm{g} \mathrm{kg}^{-3}\right)$ & 12.0 & 9.0 \\
\hline
\end{tabular}

Table 2. Physical characteristic of the lysimeter soil.

\begin{tabular}{|c|c|c|c|c|c|c|c|c|}
\hline \multirow{2}{*}{ Characteristics } & \multicolumn{8}{|c|}{ Soil layers (m) } \\
\hline & $0.0-0.2$ & $0.2-0.4$ & $0.4-0.6$ & $0.6-0.8$ & $0.0-0.2$ & $0.2-0.4$ & $0.4-0.6$ & $0.6-0.8$ \\
\hline & \multicolumn{4}{|c|}{ Sandy soil } & \multicolumn{4}{|c|}{ Sandy-clay soil } \\
\hline Ps $(\%)$ & 36.47 & 31.49 & 35.49 & 35.97 & 43.93 & 44.49 & 48.33 & 45.56 \\
\hline $\mathrm{BD}\left(\mathrm{g} \mathrm{cm}^{-3}\right)$ & 1.62 & 1.76 & 1.71 & 1.66 & 1.41 & 1.46 & 1.34 & 1.40 \\
\hline Sand (\%) & 84.65 & 84.80 & 84.90 & 83.90 & 51.40 & 47.60 & 51.40 & 47.00 \\
\hline Silt (\%) & 8.75 & 8.65 & 8.50 & 9.55 & 10.10 & 9.90 & 7.10 & 8.50 \\
\hline Clay (\%) & 6.60 & 6.55 & 6.60 & 6.55 & 38.50 & 42.50 & 41.50 & 44.50 \\
\hline
\end{tabular}

Ps: porosity; BD: bulk density.

The development phases of the banana tree were: initial: 15/11/2014 to 04/01/2015 - 1 to 138 days after planting (DAP); vegetative growth: 02/04 to 07/20/2015 - 139 to 248 DAP; blooming: $21 / 07 / 2015$ to $09 / 07 / 2015$ - 249 to 297 DAP fruit growth: $07 / 09 / 2015$ to $12 / 02 / 2015$ - 298 to 383 DAP. The emission of the banana tree inflorescence planted on sandy clay soil occurred on 07/21/2015 and on sandy soil on 08/10/2015.

The irrigation management was carried out based on the data of water content measured using TDR probes, while calculating the volume of water necessary to return the water content values to the field capacity. The irrigation was performed with a fixed irrigation shift and an interval of two days, therefore making the irrigation water depth variable, and adopting as reference the data of water availability in the soil.

To determine the volumetric water content, from the apparent dielectric constant (Ka), the calibration of the TDR for the soils was previously performed according to (Equation 1) and (Equation 2).

$$
\begin{aligned}
& \theta_{\text {Areia franca }}=4.10^{-5} \varepsilon^{3}-0.0012 \varepsilon^{2}+0.0277 \varepsilon-0.1238 \\
& \theta_{\text {Argiloarenoso }}=6.10^{-5} \varepsilon^{3}-0.0032 \varepsilon^{2}+0.0631 \varepsilon-0.2422
\end{aligned}
$$


Where,

$\varepsilon$ - dielectric constant of the soil.

The precipitation was measured by means of a rain gauge installed in the area near the lysimeter, and was included in the irrigation calculation. The water depth drained in the lysimeters were measured at the outlets of the drainage systems. This way the water storage in the soil was calculated for the four radial planes $(0.20 \mathrm{~m} \times 0.20 \mathrm{~m})$, corresponding to the horizontal and vertical distances $(0.20 ; 0.40 ; 0.60$ and $0.80 \mathrm{~m})$ using (Equation 3$)$ :

$A(z)=\int_{0}^{L} \theta(z) d z$

Where:

$\theta(\mathrm{z})=$ is the representative function of the moisture profile $\left(\mathrm{L}^{3} \mathrm{~L}^{-3}\right)$;

$\mathrm{Z}=$ vertical coordinate $(\mathrm{L})$;

$\mathrm{L}=$ is the total depth $(\mathrm{L})$;

$\mathrm{A}(\mathrm{z})=$ water storage in the soil $(\mathrm{L})$.

The Simpson rule was used to solve the numerical integral.

The evapotranspiration of the crop was obtained by means of (Equation 4). The soil-water balance was carried out with the water depth infiltrated and extracted from the system in the times immediately before the day's irrigation, after irrigation and before the next irrigation.

$\Delta \mathrm{A}=\mathrm{I}+\mathrm{P}-\mathrm{D}-\mathrm{ET}$

In which:

$\Delta \mathrm{A}=$ storage variation $(\mathrm{L})$;

$\mathrm{I}=$ irrigation $(\mathrm{L})$;

$\mathrm{P}=$ precipitation $(\mathrm{L})$;

$\mathrm{D}=$ drainage $(\mathrm{L})$;

$\mathrm{ET}=$ Evapotranspiration $(\mathrm{L})$.

The mathematical models developed by Vogeler et al. (1996) and Muñoz-Carpena et al. (2005) related the electrical conductivity of the soil solution (CEw), apparent electrical conductivity (CEa) and soil moisture $(\theta)$, (Equation 5) and (Equation 6), respectively.

$$
\begin{aligned}
& \mathrm{CE}_{\mathrm{w}}=\frac{\mathrm{CEa}-(\mathrm{a} \theta+\mathrm{b})}{\mathrm{c} \theta-\mathrm{d}} \\
& \mathrm{CE}_{\mathrm{w}}=\frac{\mathrm{CEa}-\mathrm{c} \theta^{2}}{\mathrm{a} \theta^{2}-\mathrm{b} \theta}
\end{aligned}
$$

Where:

$\mathrm{a}, \mathrm{b}, \mathrm{c}$ and $\mathrm{d}$ - equation adjustment parameters. 
The CEa conductivity values were corrected for a temperature of $25^{\circ} \mathrm{C}$ by multiplying them by the correction factor $\left(\mathrm{f}_{\mathrm{T}}\right)$, which was calculated with (Equation 7) (Richards, 1954).

$$
\mathrm{f}_{\mathrm{T}}=1+\frac{(25-\mathrm{T})}{49.7}+\frac{(25-\mathrm{T})^{2}}{3728}
$$

Where:

$\mathrm{T}=$ Soil temperature, ${ }^{\circ} \mathrm{C}$.

After adjusting the parameters of the models that relate $\mathrm{CEw}, \mathrm{CEa}$ and $\theta$ it was possible to relate $\mathrm{CEw}$ to the specific concentration of a certain ion (Ci) present in the soil solution using (Equation 8) and (Equation 9) (Santana et al., 2007; Muñoz-Carpena et al., 2005):

Potential type $\mathrm{CEw}-\mathrm{Ci}$ relationship:

$C E_{w}=\alpha C i^{\mu}$

CEw-Ci ratio of linear type:

$C E_{w}=\alpha+\mu C i$

Where:

$\mathrm{Ci}$ - is the nitrate concentration $\left(\mathrm{mg} \mathrm{L}^{-1}\right)$

$\mathrm{CE}_{\mathrm{w}}$ - is the electrical conductivity of the soil solution $\left(\mathrm{dS} \mathrm{m}^{-1}\right)$ and

$\alpha$ e $\mu$ - are adjustment parameters of the equation.

The concentrations of nutrients were determined by means of (Equation 10), (Equation 11), (Equation 12) and (Equation 13).

Model de Vogeler et al. (1996) adapted for the potential-type CEw-Ci relationship:

$C i=\left\{\frac{1}{\mu} \frac{[C E a-(a \theta-b)]}{c \theta-d}\right\}^{\frac{1}{\mu}}$

Model of Vogeler et al., (1996) adapted for the linear-type CEw-Ci relationship:

$C i=\left\{\frac{[C E a-(a \theta-b)]}{c \theta-d}-\alpha\right\} \frac{1}{\mu}$

Model of Muñoz-Carpena et al. (2005) adapted for the potential-type CEw-Ci relationship:

$C i=\left\{\frac{1}{\mu}\left(\frac{C E a-c \theta^{2}}{a \theta^{2}-b \theta}\right)\right\}^{\frac{1}{\mu}}$

Model of Muñoz-Carpena et al. (2005) adapted for the linear-type CEw-Ci relationship:

$C i=\left\{\left(\frac{C E a-c \theta^{2}}{a \theta^{2}-b \theta}\right)-\alpha\right\} \frac{1}{\mu}$

The calibration of Equations 10, 11, 12 and 13 was performed through a lysimeter test, in which different values of electrical conductivity and water content of the soil were established. The values of electrical conductivity in the soil were obtained from the application of potassium 
nitrate solution in different concentrations $\left(3,6\right.$ and $\left.9 \mathrm{~g} \mathrm{~L}^{-1}\right)$ and the water content of the soil, which varied in values from borderline saturation to the minimum water content necessary for the extractor to remove the solution.

The soil solution was extracted by applying a suction of $70 \mathrm{kPa}$ four hours after the soil solution samples were collected.

While the extractor removed the solution to determine the electrical conductivity of the soil solution $(\mathrm{CEw})$, the $\mathrm{CEa}$ and $\theta$ readings were monitored every 10 minutes with the TDR, starting at the time of suction application and ending at the time of solution collection.

The electrical conductivity of the soil solution and the leached volume of the lysimeters were evaluated with the bench conductivimeter. The concentrations of nitrate and potassium present in these samples were monitored using the rapid determination kit (Card Horiba), according to Coelho et al. (2014).

The adjustment of the equations to the data and the evaluation of the models were based on the coefficient of determination $\left(\mathrm{R}^{2}\right)$ (Equation 14), Willmott's concordance index (d) (Equation 15) and the root-mean-square error (RMSE) (Equation 16).

$$
\begin{aligned}
& \mathrm{R}^{2}=1-\frac{\mathrm{SQR}}{\text { SQtot }} \\
& \mathrm{d}=1-\left[\sum_{\mathrm{i}=1}^{\mathrm{n}}\left(\mathrm{E}_{\mathrm{i}}-\mathrm{O}_{\mathrm{i}}\right)^{2} / \sum_{\mathrm{i}=1}^{\mathrm{n}}\left(\left|\mathrm{E}_{\mathrm{i}}-\overline{\mathrm{O}}\right|+\left|\mathrm{O}_{\mathrm{i}}+\overline{\mathrm{O}}\right|\right)^{2}\right] \\
& R M S E=\sqrt{\frac{1}{n} \sum_{i=1}^{n}\left(O_{i}-E_{i}\right)^{2}}
\end{aligned}
$$

Where:

$\mathrm{SQR}=$ residual sum of squares;

SQtot = sum of total square;

$\mathrm{n}=$ number of data;

$O_{i}=$ observed value;

$\bar{O}=$ average of estimated value;

$\mathrm{E}_{\mathrm{i}}=$ estimated value.

In addition to these statistical indicators, Pearson's correlation coefficient (r) (Figueiredo Filho and Silva Júnior, 2009) and the "c" index (according to the methodology presented by Ponciano, 2012) were also used to indicate the performance of the model.

The "c" index brings together the correlation coefficient $(r)$ and the agreement index $(d)$ (Equation 17), expressed as follows:

$$
\mathrm{c}=\mathrm{rxd}
$$

The criterion for interpreting the performance of the model according to index "c" (Equation 17) is: > 0.85 - Great; 0.76 to 0.85 - Very good; 0.66 to 0.75 - Good; 0.61 to 0.65 Average; 0.51 to 0.60 - Sufferable; 0.41 to 0.50 - Bad and $\leq 0.41$ - Very bad.

After adjusting the parameters of the models and identifying the one that best explains the relation between $\mathrm{CEw}, \mathrm{CEa}$ and $\theta$ in conjunction with the specific concentration of $\mathrm{NO}_{3}{ }^{-}$and $\mathrm{K}^{+}$present in the soil solution, the model selected in the lysimeter can be gradually validated during fertigation by collecting weekly extractions of the soil solution in the phases of 
vegetative growth, flowering and fruit growth of the banana tree.

For the evaluation of the simulated and observed values, the following statistical indexes were used: the concordance coefficient (d) (Equation 15), proposed by Willmontt (1981); the root-mean-square error (RMSE) (Equation 16); the degree of adjustment of the dependent variable $(\mathrm{Y})$ with the independent variable $(\mathrm{X})$, by establishing an equation of the type $\mathrm{Y}=\beta \mathrm{X}$ (" $\beta$ " is the angular coefficient); and the correlation coefficient of Pearson (r).

The modeling of water flow and solute transport was performed for all experimental plots with the Hydrus-2D software (Šimůnek et al., 2008), which simulated the three-dimensional axisymmetric and transient movement of water and nutrients in the soil. The transport domain was defined as a rectangle with a width of $100 \mathrm{~cm}$ (half the width of the lysimeter) and a depth of $100 \mathrm{~cm}$, as the sides of the flow domain the boundary conditions were defined as without water or nutrient flow. At the upper boundary of the flow domain the boundary condition was defined as an atmospheric boundary condition (variable flow condition of daily irrigation events, rainfall, and evapotranspiration), while at the lower boundary the condition was defined as free drainage, with 4 observation points at depths of 20,40, 60 and $80 \mathrm{~cm}$ inserted in the transport domain (Figure 1).

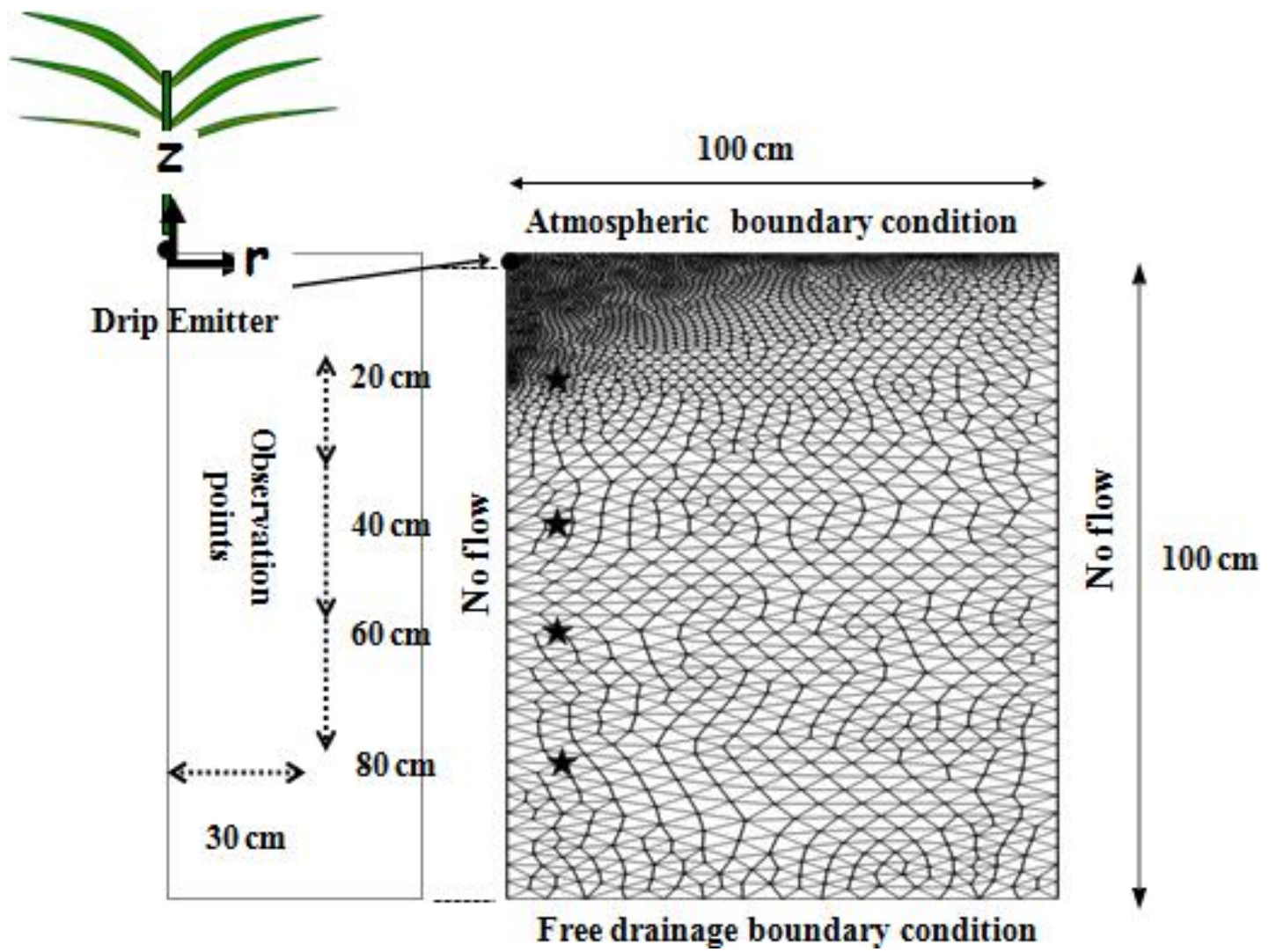

Figure 1. Location of the observation points in the soil profile and flow domain geometry with the boundary conditions used in the Hydrus-2D simulations.

The Hydrus-2D numerically solves the Richards equation describing water flow variability in a radially symmetrical domain as well as the convection-dispersion equation for the transport of solutes. The hydraulic properties of soil used to describe water flow were described using the van Genuchten-Mualem model (van Genuchten, 1980), (Table 3).

The distribution of solutes between the solid and liquid phases was described using a linear adsorption isothermal model. The parameters involved in the transport of the solute (coefficient of diffusion-dispersion $\mathrm{D}$, coefficient of retardation, $\mathrm{R}$ and velocity of water in the pore) were obtained by the method of miscible displacement (Table 4). 
Table 3. Parameters of the van Genuchten model for the two soils (Sandy-soil and Clay-sand) used in lysimeters.

\begin{tabular}{ccccccc}
\hline Soil & Soil layer & $\theta \mathrm{r}\left(\mathrm{cm}^{3} \mathrm{~cm}^{-3}\right)$ & $\theta \mathrm{s}\left(\mathrm{cm}^{3} \mathrm{~cm}^{-3}\right)$ & $\alpha\left(\mathrm{cm}^{-1}\right)$ & $\mathrm{N}$ & $\mathrm{Ks}\left(\mathrm{mm} \mathrm{day}^{-1}\right)$ \\
\hline \multirow{3}{*}{ Sandy Soil } & $0.00-0.20$ & 0.043 & 0.365 & 0.235 & 2.297 & 28.94 \\
& $0.20-0.40$ & 0.037 & 0.315 & 0.612 & 1.605 & 81.77 \\
& $0.40-0.60$ & 0.042 & 0.354 & 0.339 & 2.100 & 243.51 \\
& $0.60-0.80$ & 0.030 & 0.360 & 0.598 & 1.761 & 243.51 \\
\hline \multirow{3}{*}{ Clay sandy } & $0.00-0.20$ & 0.174 & 0.439 & 0.133 & 1.982 & 20.88 \\
& $0.20-0.40$ & 0.198 & 0.483 & 0.105 & 2.338 & 58.72 \\
& $0.40-0.60$ & 0.179 & 0.483 & 0.201 & 1.811 & 85.37 \\
& $0.60-0.80$ & 0.189 & 0.456 & 0.128 & 1.841 & 85.37 \\
\hline
\end{tabular}

Table 4. Parameters of nitrate and potassium transport: delay factor $(\mathrm{R})$, diffusive dispersive coefficient (D), number of Peclet (P), adsorption coefficient (KD) and (l).

\begin{tabular}{|c|c|c|c|c|c|c|c|c|c|c|}
\hline \multirow{3}{*}{ Conc. } & \multicolumn{9}{|c|}{ Nitrate } & \\
\hline & \multicolumn{4}{|c|}{ Sandy soil } & \multicolumn{6}{|c|}{ Sandy clay soil } \\
\hline & $\mathrm{R}$ & $\mathrm{KD}$ & $\mathrm{D}\left(\mathrm{cm}^{2} \mathrm{~h}^{-1}\right)$ & $\mathrm{P}(\mathrm{e})$ & $\lambda(\mathrm{cm})$ & $\mathrm{R}$ & $\mathrm{KD}$ & $\mathrm{D}\left(\mathrm{cm}^{2} \mathrm{~h}^{-1}\right)$ & $\mathrm{P}(\mathrm{e})$ & $\lambda(\mathrm{cm})$ \\
\hline 3 & 1.33 & 0.07 & 59.48 & 13.02 & 1.72 & 1.63 & 0.20 & 92.19 & 5.02 & 4.47 \\
\hline 6 & 1.40 & 0.08 & 73.70 & 10.93 & 2.05 & 1.68 & 0.22 & 76.18 & 6.34 & 3.54 \\
\hline \multirow[t]{2}{*}{9} & 1.68 & 0.14 & 43.80 & 17.36 & 1.29 & 1.71 & 0.23 & 64.23 & 7.16 & 3.13 \\
\hline & \multicolumn{9}{|c|}{ Potassium } & \\
\hline 3 & 1.71 & 0.14 & 27.12 & 28.56 & 0.79 & 1.96 & 0.31 & 73.14 & 6.33 & 3.55 \\
\hline 6 & 1.75 & 0.15 & 54.01 & 14.91 & 1.51 & 1.93 & 0.30 & 35.66 & 13.54 & 1.66 \\
\hline 9 & 1.92 & 0.18 & 56.44 & 13.47 & 1.67 & 2.11 & 0.36 & 46.07 & 9.99 & 2.25 \\
\hline
\end{tabular}

The methods of water absorption and root solute were determined by the model of Feddes et al. (1978) (Equation 18) for water absorption and for solute as a model without solute deficit:

$W U(h, r, z)=\gamma(h) * R D F(r, z) * W * T_{p o t}$

Where:

$\gamma(\mathrm{h})=$ water deficit function in the soil (adimensional);

$\mathrm{RDF}=$ normalized distribution of water absorption by the roots $(\mathrm{T})$;

Tpot $=$ potential perspiration rate $\left(\mathrm{L} \mathrm{T}_{-1}\right)$;

$\mathrm{W}=$ radius of soil surface associated with perspiration $(\mathrm{L})$.

$\mathrm{WU}=$ function of water absorption and solute by the roots $(\mathrm{T})$.

The parameters used by the model to simulate the potential of water extracted by the roots are presented in (Table 5). For such parameters, Hydrus assumes its nomenclature. The method of Feddes (1978) was applied. It relates the amount of water extracted from the soil as a function of root depth, with variables adopted by the software standard. Under optimal humidity conditions, the extraction of water by the root zone is equal to the potential perspiration rate.

For the items in the (Table 5), consider that $\mathrm{P} 2 \mathrm{H}=$ limit value for stress, below which roots cannot extract water at the maximum possible rate (assuming the potential rate of $\mathrm{r} 2 \mathrm{H}$ ); $\mathrm{P} 2 \mathrm{~L}=$ the same as above with potential perspiration rate of $r 2 \mathrm{~L} ; \mathrm{r} 2 \mathrm{H}=$ is the potential perspiration rate 
fixed at $0.5 \mathrm{~cm} \mathrm{day}^{-1}$ and $\mathrm{r} 2 \mathrm{~L}=$ potential perspiration rate fixed at $0.1 \mathrm{~cm}$ per day ${ }^{-1}$.

Table 5. Parameters used by the model to simulate the potential of water extracted by the root.

\begin{tabular}{cccccccc}
\hline Hydrus parameter & $\mathrm{P} 0(\mathrm{~cm})$ & $\mathrm{P} 0 \mathrm{pt}$ & $\mathrm{P} 2 \mathrm{H}$ & $\mathrm{P} 2 \mathrm{~L}$ & $\mathrm{P} 3$ & $\mathrm{r} 2 \mathrm{H}$ & $\mathrm{r} 2 \mathrm{~L}$ \\
\hline & \multicolumn{7}{c}{$\mathrm{cm}$} \\
\hline Adopted value & -10 & -25 & -300 & -1500 & -8000 & 0.5 & 0.1 \\
\hline
\end{tabular}

In the Hydrus model, a database for different plants regarding the parameters of water absorption by the roots is provided based on studies by Taylor and Ashcroft (1972).

In Hydrus, the model of solute absorption by the roots was also selected, for which it was assumed that the absorption of solutes was proportional to the product of the flow of water absorbed by the roots and the concentration of the solute dissolved in water.

The simulations along the lysimeter drainage profile were performed for the different phases of the crop for a total of 372 days, and compared the nitrate and potassium concentrations simulated by the Hydrus model during fertigation through the data observed from the extraction of the soil solution in the phases of vegetative growth, flowering and fruit growth of the banana tree.

The procedure for minimizing errors between measured and simulated data was outlined in the calibration using an iterative process in which the values of the model parameters were changed with each attempt. The scenarios considered the variations of: the water content obtained from the TDR sensors installed in the lysimeter; the hydraulic properties; time; the solute transport parameters and the initial concentrations of the solute. These were used as a basis for changes and adjustments in the model to make it safer to allow a better understanding of the water and nutrient dynamics involved, as well as the prediction of future scenarios. The observation period used for the calibration was the initial phase of the banana tree. During this phase, manual calibration was used to estimate the values of the parameters that best represented the observed values. Once the parameters of the model had been calibrated, it was validated for the other periods of banana cultivation.

After the simulations with the Hydrus-2D computer model, the following statistical indexes were used: Willmontt's (1981) concordance coefficient (d) (Equation 15); the rootmean-square error (RMSE) (Equation 16); the degree of adjustment of the dependent variable (Y) with the independent variable $(X)$, by establishing an equation of the type $Y=\beta X$ ( " $\beta$ " is the angular coefficient); and the correlation coefficient of Pearson (r) to compare the mean values of nitrate and potassium measured in the soil solution and simulated by the Hydrus-2D software.

\section{RESULTS AND DISCUSSION}

The models of Vogeler et al. (1996) and Muñoz-Carpena et al. (2005) presented low RMSE $(<0.1920)$ and agreement index (d) values close to the unit $(0.9999)$.

The model of Vogeler et al. (1996) showed a higher coefficient of regression determination for the soils under study, which led to a better classification (Very good: sandy soil and sandy clay) as to the ability to estimate $\mathrm{CEw}$ from $\mathrm{CEa}$ and $\theta$, when compared to the model of MuñozCarpena et al. (2005) (Good: sandy soil and sandy clay) (Table 6).

These results are corroborated by those of Ponciano (2012), who observed that in CEw's estimate the model of Vogeler et al. (1996) adjusts better to soils with clay texture characteristics both by the application of $\mathrm{KCl}$ and by the application of $\mathrm{KNO}_{3}$ via irrigation water, and in sandy soil the models from Vogeler et al. (1996) and Munõz-Carpena et al. (2005) presented a similar quality of adjustments being classified as "Very good". 
Table 6. Models for CEw estimation of sandy clay and sandy soils.
Soil
Model
$\mathrm{R}^{2}$
r
d RMSE Classif. of the Method $(c=r \times d)$

\begin{tabular}{|c|c|c|c|c|c|c|c|}
\hline \multirow{2}{*}{ Sandy Soil } & Vogeler et al., (1996) & $\mathrm{CE}_{\mathrm{w}}=\frac{\left[\mathrm{CE}_{\mathrm{a}}+2.5438 \theta-0.3730\right]}{-0.0871 \theta+0.7388}$ & 0.818 & 0.859 & 0.998 & 0.1677 & Very good \\
\hline & Muñoz-Carpena et al., (2005) & $C E_{w}=\frac{C E_{a}+19.6472 \theta^{2}}{-41.3941 \theta^{2}+19.4093 \theta}$ & 0.754 & 0.871 & 0.999 & 0.1537 & Good \\
\hline \multirow{2}{*}{ Sandy clay } & Vogeler et al., (1996) & $\mathrm{CE}_{\mathrm{w}}=\frac{\left[\mathrm{CE}_{\mathrm{a}}-0.0315 \theta-0.1111\right]}{-0.4152 \theta+0.4264}$ & 0.779 & 0.883 & 0.999 & 0.1538 & Very good \\
\hline & Muñoz-Carpena et al., (2005) & $\mathrm{CE}_{\mathrm{w}}=\frac{\mathrm{CE}_{\mathrm{a}}-1.0981 \theta^{2}}{-10.0371 \theta^{2}+4.3187 \theta}$ & 0.655 & 0.830 & 0.999 & 0.1920 & Good \\
\hline
\end{tabular}

For both soils, there was a positive correlation $(\mathrm{r}+$ ) for the estimation of nitrate and potassium concentration in the soil solution from water content data $(\theta)$ and apparent electrical conductivity $(\mathrm{CEa})$ when a linear or power type relation is introduced to the adapted models (Vogeler $e t$ al., 1996; Munõz-Carpena et al., 2005). This can be seen in the slight differences between the determination coefficients, thus presenting the same classification for the "c" index for the $\mathrm{CEw}-\mathrm{NO}_{3}{ }^{-}$ratio of the linear type and power type (Table 7), which was also observed in the $\mathrm{CEw}-\mathrm{K}^{+}$ratio of the linear type and power type (Table 8).

In general, despite the concordance index (d) close to the unit (0.9999), the model of Vogeler et al. (1996) was superior to the model of Muñoz-Carpena et al. (2005), and always presented lower RMSE and higher coefficient of determination $\left(\mathrm{R}^{2}\right)$. This led the model of Vogeler $e t$ al. (1996) to present a better classification according to the "c" index for the models estimating nitrate and potassium concentration (mg $\mathrm{L}^{-1}$ ) for sandy soil and sandy clay (Table 7 and 8 ).

The results of this study agree with those obtained by Santana et al. (2006), who reported that, regarding the models used, Rhoades et al., (1976) and Vogeler et al. (1996) provided the best estimates of K concentration in soil solution. For both soils, the model of Vogeler et al. (1996) adapted to the linear type $\mathrm{CEw}-\mathrm{Ci}$ ratio (Equation 9) was chosen to estimate the concentration of nitrate and potassium in the soil solution after the first cycle of banana crop in the drainage lysimeter. 
Table 7. Models for estimation of nitrate concentration $\left(\mathrm{mg} \mathrm{L}^{-1}\right)$ for sandy soil and sandy clay.
Soil
Model
$\mathrm{R}^{2} \quad \mathrm{r}$
d RMSE Classif. of the Method $(c=r x d)$

Adapted for linear type $\mathrm{CEw}-\mathrm{NO}_{3}{ }^{-}$ratio

\begin{tabular}{|c|c|c|c|c|c|c|c|}
\hline Sandy soil & Vogeler et al., (1996) & $\begin{array}{l}\mathrm{NO}_{3}{ }^{-} \\
=[\mathrm{CEw}-0.0283] \frac{1}{0.0024}\end{array}$ & 0.7581 & 0.867 & 0.9999 & 66.7749 & Very good \\
\hline Sandy soil & Muñoz-Carpena et al., (2005) & $\begin{array}{l}\mathrm{NO}_{3}{ }^{-} \\
=[\mathrm{CEw}-0.0860] \frac{1}{0.0024}\end{array}$ & 0.6158 & 0.785 & 0.9999 & 90.0959 & Average \\
\hline $\begin{array}{l}\text { Sandy } \\
\text { clay }\end{array}$ & Vogeler et al., (1996) & $\begin{array}{l}\mathrm{NO}_{3}{ }^{-} \\
=[\mathrm{CEw}-0.0955] \frac{1}{0.0034}\end{array}$ & 0.8568 & 0.926 & 0.9999 & 35.1413 & Great \\
\hline $\begin{array}{l}\text { Sandy } \\
\text { clay }\end{array}$ & Muñoz-Carpena et al., (2005) & $\begin{array}{l}\mathrm{NO}_{3}{ }^{-} \\
=[\mathrm{CEw}-0.2126] \frac{1}{0.0027}\end{array}$ & 0.8352 & 0.917 & 0.9995 & 37.6901 & Very good \\
\hline
\end{tabular}

Adapted for power type $\mathrm{CEw}-\mathrm{NO}_{3}{ }^{-}$ratio

\begin{tabular}{lccccccc}
\hline Sandy soil & Vogeler et al., (1996) & $\mathrm{NO}_{3}{ }^{-}=\left[\frac{1}{0.0038} \mathrm{CEw}\right]^{\frac{1}{0.9257}}$ & 0.7596 & 0.868 & 0.9999 & 69.1431 & Very good \\
Sandy soil & $\begin{array}{c}\text { Muñoz-Carpena } \text { et al. }, \\
(2005)\end{array}$ & $\mathrm{NO}_{3}{ }^{-}=\left[\frac{1}{0.0074} \mathrm{CEw}\right]^{\frac{1}{0.8242}}$ & 0.6212 & 0.786 & 0.9998 & 90.0767 & Average \\
$\begin{array}{c}\text { Sandy } \\
\text { clay }\end{array}$ & Vogeler et al., (1996) & $\mathrm{NO}_{3}{ }^{-}=\left[\frac{1}{0.0108} \mathrm{CEw}\right]^{\frac{1}{0.7994}}$ & 0.8658 & 0.940 & 0.9998 & 32.5036 & Great \\
$\begin{array}{c}\text { Sandy } \\
\text { clay }\end{array}$ & $\begin{array}{c}\text { Muñoz-Carpena } \text { et al. } . \\
(2005)\end{array}$ & $\mathrm{NO}_{3}{ }^{-}=\left[\frac{1}{0.0231} \mathrm{CEw}\right]^{\frac{1}{0.6623}}$ & 0.8202 & 0.909 & 0.9998 & 39.3716 & Very good \\
\hline
\end{tabular}


Table 8. Models for potassium concentration estimation $\left(\mathrm{mg} \mathrm{L}^{-1}\right)$ for sandy soil and sandy clay.

\begin{tabular}{|c|c|c|c|c|c|c|c|}
\hline Soil & \multicolumn{2}{|c|}{ Model } & $\mathrm{R}^{2}$ & $\mathrm{r}$ & $d$ & RMSE & $\begin{array}{l}\text { Classif. of the Method } \\
\qquad(\mathrm{c}=\mathrm{r} \times \mathrm{d})\end{array}$ \\
\hline & & & \multicolumn{5}{|c|}{ Adapted for linear type $\mathrm{CEw}-\mathrm{K}^{+}$ratio } \\
\hline Sandy soil & Vogeler et al., (1996) & $\mathrm{K}^{+}=[\mathrm{CEw}-0.0274] \frac{1}{0.0076}$ & 0.7134 & 0.840 & 0.9999 & 23.6440 & Good \\
\hline Sandy soil & Muñoz-Carpena et al., (2005) & $\mathrm{K}^{+}=[\mathrm{CEw}-0.0731] \frac{1}{0.0077}$ & 0.5580 & 0.747 & 0.9999 & 29.0023 & Sufferable \\
\hline Sandy clay & Vogeler et al., (1996) & $\mathrm{K}^{+}=[\mathrm{CEw}+0.0191] \frac{1}{0.0059}$ & 0.6563 & 0.822 & 0.9994 & 41.4654 & Good \\
\hline Sandy clay & Muñoz-Carpena et al., (2005) & $\mathrm{K}^{+}=[\mathrm{CEw}-0.1637] \frac{1}{0.0039}$ & 0.6222 & 0.789 & 0.9999 & 43.4716 & Average \\
\hline
\end{tabular}

Adapted for power type $\mathrm{CEw}-\mathrm{K}^{+}$ratio

\begin{tabular}{lccllllll}
\hline Sandy soil & Vogeler et al., (1996) & $\mathrm{K}^{+}=\left[\frac{1}{0.0121} \mathrm{CEw}\right]^{\frac{1}{0.9073}}$ & 0.7165 & 0.843 & 0.9999 & 23.5022 & Good \\
Sandy soil & Muñoz-Carpena et al., (2005) & $\mathrm{K}^{+}=\left[\frac{1}{0.0167} \mathrm{CEw}\right]^{\frac{1}{0.8529}}$ & 0.5614 & 0.749 & 0.9998 & 28.8929 & Sufferable \\
Sandy clay & Vogeler et al., (1996) & $\mathrm{K}^{+}=\left[\frac{1}{0.0094} \mathrm{CEw}\right]^{\frac{1}{0.9041}}$ & 0.6430 & 0.827 & 0.9964 & 41.5647 & Average \\
Sandy clay & Muñoz-Carpena et al., (2005) & $\mathrm{K}^{+}=\left[\frac{1}{0.0173} \mathrm{CEw}\right]^{\frac{1}{0.7562}}$ & 0.6098 & 0.782 & 0.9998 & 44.1795 & Average \\
\hline
\end{tabular}


During the validation of the model in the drainage lysimeter, there was an underestimation of the nitrate and potassium values predicted as a function of the ion measured in the soil solution (Table 9). In sandy soil, mean nitrate values were underestimated by $2 \%, 13 \%$, and $11 \%$, and mean potassium values by $4 \%, 12 \%$, and $9 \%$ for concentrations of 3,6 , and $9 \mathrm{~g} \mathrm{~L}^{-1}$, respectively. In the sandy clay soil, there was also an underestimation of the mean values of nitrate $\left(13 \%, 6 \%\right.$ and $4 \%$ for 3,6 and $\left.9 \mathrm{~g} \mathrm{~L}^{-1}\right)$ and potassium $(8 \%, 6 \%$ and $9 \%$ for 3,6 and $9 \mathrm{~g}$ $\left.\mathrm{L}^{-1}\right)$ (Table 9).

Table 9. Statistical indications for comparison of mean values of nitrate and potassium measured in the soil solution and estimated by the Vogeler et al. (1996) model adapted to the linear type CEw-Ci ratio.

\begin{tabular}{ccccccccccc}
\hline \multirow{2}{*}{ Soil } & \multirow{3}{*}{ Concentration $\mathrm{g} \mathrm{L}^{-1}$} & \multicolumn{4}{c}{ Nitrate } & \multicolumn{7}{c}{ Potassium } \\
\cline { 3 - 10 } & & $\beta$ & $\mathrm{R}^{2}$ & $\mathrm{~d}$ & $\mathrm{RMSE}$ & $\beta$ & $\mathrm{R}^{2}$ & $\mathrm{~d}$ & $\mathrm{RMSE}$ \\
\hline \multirow{3}{*}{ sand and soil } & 3.0 & 0.98 & 0.72 & 0.99 & 27.20 & 0.96 & 0.69 & 0.99 & 6.638 \\
& 6.0 & 0.87 & 0.67 & 0.99 & 32.17 & 0.88 & 0.72 & 0.99 & 7.89 \\
& 9.0 & 0.89 & 0.70 & 0.99 & 18.63 & 0.91 & 0.74 & 0.99 & 9.201 \\
\hline \multirow{3}{*}{ sand and clay } & 3.0 & 0.87 & 0.85 & 0.99 & 31.98 & 0.92 & 0.67 & 0.99 & 10.20 \\
& 6.0 & 0.94 & 0.72 & 0.99 & 23.54 & 0.84 & 0.71 & 0.99 & 16.24 \\
& 9.0 & 0.96 & 0.69 & 0.99 & 22.78 & 0.91 & 0.74 & 0.99 & 15.01 \\
\hline
\end{tabular}

Andrade Neto et al. (2012), while using a potential model combined with the model of Vogeler et al. (1996), reported a general variation of $20.0 \%$ (average of normalized errors) for the measured values compared to those estimated in Yellow Latosol with sandy soil texture. According to Andrade Neto and Coelho (2014), these variations in the values may be acceptable in soil ion management due to the spatial variability of soil chemical attributes. Thus, the results shown in (Table 9) validate the model used to estimate the nitrate and potassium ion in soil solution.

These results corroborate those of Andrade Neto et al. (2012), who concluded that it is feasible to estimate the concentration of $\mathrm{K}^{+}$in the soil solution from water content data and $\mathrm{CEa}$, obtained using the time domain reflectometry (TDR) technique for field conditions, while using an equation from the combination of a linear model and a potential. Santos et al. (2009) concluded that the TDR technique, together with the use of adjusted models, proved to be able to monitor the transport of solutes in the soil, regardless of the type of soil in use and the nutrient dosage applied.

The transport analysis of solutes contemplated the two-dimensional model. To evaluate the performance of the Hydrus-2D model, a joint analysis with statistical index "d" was performed to verify if there was an agreement between the simulated and experimental values. The value $\mathrm{d}=0$ shows that there is no agreement and the value $\mathrm{d}=1$ shows that there is total agreement.

It has been noted that in general the simulations performed for the displacement of nitrate and potassium in the soil showed high rates of agreement (d) and the values of RMSE were lower (Table 10) than those observed using the parametric model (Table 9), indicating that the values simulated by the Hydrus-2D software showed less dispersion of data.

The " $\beta$ " indexes confirm the performance of Hydrus-2D software in simulating the concentration of nitrate and potassium ion in the soil solution throughout the crop cycle. All the values of " $\beta$ " were close to the unit, presenting little difference with an overestimation of $6 \%$ of the nitrate values in the concentration of $3 \mathrm{~g} \mathrm{~L}^{-1}$ (sandy soil) and $7 \%$ and $2 \%$ of the nitrate values in the concentration of $3 \mathrm{~g} \mathrm{~L}^{-1}$ and $9 \mathrm{~g} \mathrm{~L}^{-1}$, respectively (sandy clay soil), while the other simulations in the Hydrus-2D software underestimated the nitrate and potassium values. 
Table 10. Statistical indicators for comparison of mean nitrate and potassium values measured in the soil solution and simulated by Hydrus-2D software.

\begin{tabular}{cccccccccc}
\hline \multirow{2}{*}{ Soil } & \multicolumn{4}{c}{ Nitrate } & \multicolumn{4}{c}{ Potassium } \\
\cline { 3 - 10 } & & \multicolumn{1}{c}{ Concentration $\mathrm{gL}^{-1}$} & $\mathrm{R}^{2}$ & $\mathrm{~d}$ & $\mathrm{RMSE}$ & $\beta$ & $\mathrm{R}^{2}$ & $\mathrm{~d}$ & RMSE \\
\hline \multirow{3}{*}{ Sandy soil } & 3.0 & 1.06 & 0.65 & 0.99 & 18.36 & 0.96 & 0.64 & 0.99 & 6.99 \\
& 6.0 & 0.97 & 0.57 & 0.99 & 14.83 & 0.92 & 0.75 & 0.99 & 8.85 \\
& 9.0 & 0.85 & 0.68 & 0.99 & 22.81 & 0.95 & 0.56 & 0.99 & 8.01 \\
\hline \multirow{3}{*}{ Sandy clay } & 3.0 & 1.07 & 0.70 & 0.99 & 19.06 & 0.86 & 0.68 & 0.99 & 9.66 \\
& 6.0 & 0.93 & 0.72 & 0.99 & 16.07 & 0.94 & 0.70 & 0.99 & 7.17 \\
& 9.0 & 1.02 & 0.64 & 0.99 & 17.38 & 0.97 & 0.71 & 0.99 & 6.78 \\
\hline
\end{tabular}

Montenegro et al. (2010), Silva et al. (2013), Montenegro et al. (2013), and Pinho and Miranda (2014) also used statistical indices to assess the quality of the fit between measured and simulated values.

The correlations between the average values of nitrate and potassium measured in the soil solution with the values simulated by the Hydrus-2D software and the values estimated by the Vogeler et al. (1996) model adapted to the linear type CEw-Ci ratio in loam sand and sandy clay soils, may be observed in Figure 2.
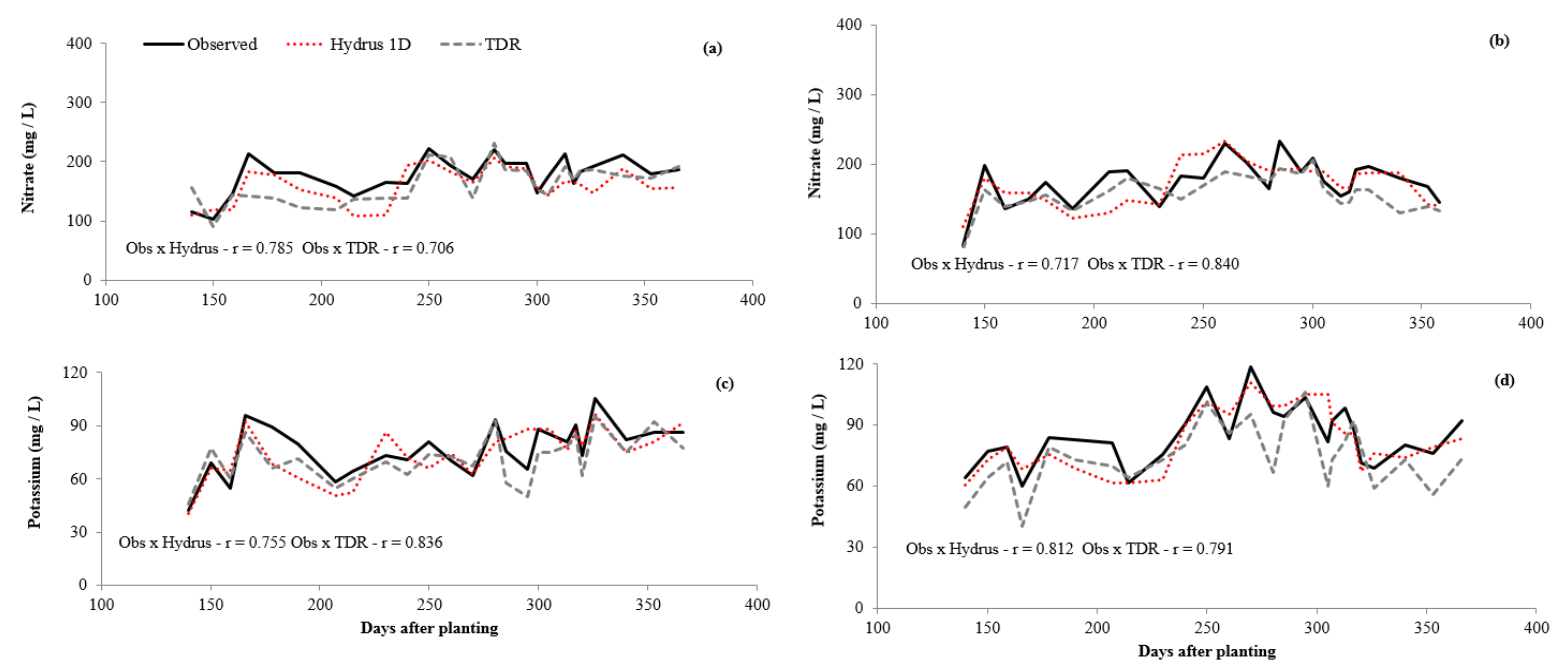

Figure 2. Average values of nitrate and potassium for concentrations 3,6 and $9 \mathrm{~g} \mathrm{~L}^{-1}$, measured in the soil solution with the values simulated by the Hydrus-2D software and the values determined by means of the TDR through the Vogeler et al. (1996) model adapted to the CEw-Ci ratio of the linear type in the sandy soil (a and c) and sandy clay (b and d).

It appears that the measured data differed little from the simulated data, in which both the Vogeler et al. (1996) adapted to the linear type CEw-Ci relationship and Hydrus-2D showed positive correlation $(\mathrm{r}+)$ with the measured data, which demonstrates the adequacy of these models for modeling the levels of nitrate and potassium in the soil solution. These results are in agreement with those obtained by Oliveira et al. (2010), Ribeiro et al. (2011) and Pinho and Miranda (2014) who stated that the Hydrus model was efficient in simulating the displacement of potassium and water.

In this study, all $\mathrm{r}$ values were above 0.70 , which shows a high correlation between measured and estimated data (Figure 2), according to the Cohen (1988) classification. Thus, it notes that the mathematical model used and the Hydrus-2D software have been proven as feasible tools that can be used satisfactorily to describe the nitrate and potassium concentration of the soil solution under field conditions. However, the possibility of variations in the 
parameter values required by the model needs precise adjustments to reflect the quality of the simulations, as the amount of input data required increases with the complexity of the simulations, due to the need for larger amounts of input parameters.

\section{CONCLUSIONS}

The mathematical models proved effective in estimating the concentration of nitrate and potassium in the soil solution during the banana crop cycle under field conditions, with greater accuracy and less dispersion for Vogeler et al. (1996) combined with the linear model.

The Hydrus-2D computer program proved to be feasible as a good tool for describing the nitrate and potassium concentration of the soil solution under the conditions under which the work was performed.

The concentrations of nitrate and potassium in the soil estimated by adapting the Vogeler et al. (1996) model to the linear type $\mathrm{CEw}-\mathrm{Ci}$ ratio, and simulated by the Hydrus model, presented an acceptable characterization of the distribution of these nutrients and their oscillations in the soil solution during the banana crop cycle, demonstrating satisfactory performance and feasibility of both methods.

\section{REFERENCES}

ANDRADE NETO, T. M.; COELHO, E. F. Concentração de potássio em função da condutividade elétrica da solução do solo. Water Resources and Irrigation Management , v. 3, p. 13-19, 2014. http://dx.doi.org/10.1590/S141543662012000600005

ANDRADE NETO, T. M. de; COELHO, E. F.; SANTANA, J. A. do V.; SANTANA JÚNIOR, E. B.; ALVES, M. da S. Estimativa de potássio na solução do solo baseada na condutividade elétrica e umidade do solo. Revista Brasileira de Engenharia Agrícola e Ambiental, v. 16, n. 6, p. 618-623, 2012.

BORGES, A. L.; SOUZA, L. da F. O Cultivo da bananeira. Cruz das Almas: Embrapa Mandioca e Fruticultura, 2004. 279 p.

COHEN, J. Statistical Power analysis for the behavioral sciences. Hillsdale: Erlbaum, 1988.

COELHO, E. F.; COSTA, F. da S.; SILVA, A. C. P. da; CARVALHO, G. C. Concentração de nitrato no perfil do solo fertigado com diferentes concentrações de fontes nitrogenadas. Revista Brasileira de Engenharia Agrícola e Ambiental, v. 18, n. 3, p. 263-269, 2014. http://dx.doi.org/10.1590/S1415-43662014000300004

ELMI, A.; NOHRA, J. S. A.; MADRAMOOTOO, C. A.; HENDERSHOT, W. Estimating phosphorus leachability in reconstructed soil columns using Hydrus-1D model.

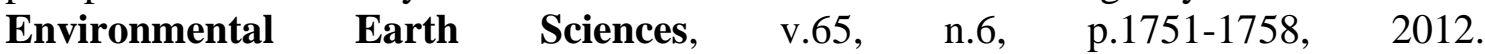
https://doi.org/10.1007/s12665-011-1154-1

FEDDES, R. A.; KOVALIK, P. J.; ZARADNY, H. Simulation of field water use and crop yield. New York: John Wiley,1978.188 p.

FIGUEIREDO FILHO, D.; SILVA JÚNIOR, J. A. da. Desvendando os Mistérios do Coeficiente de Correlação de Pearson (r). Revista Política Hoje, v. 18, n. 1, 2009.

GARCIA, W. V.; AlCÂNTARA, M. A. K.; CAMARGO, O. A.; IZÁRIO FILHO, H. J.; ANDREOTE, F. D. Deslocamento miscível de um efluente de indústria de explosivo em colunas de solo. Bragantia, v. 71, n. 1, p. 98-105, 2012. https://doi.org/10.1590/S000687052012000100015 
KANZARI, S.; HACHICHA, M.; BOUHLILA, R.; BATTLE-SALES, J. Characterization and modeling of water movement and salts transfer in a semi-arid region of Tunísia (BouHajla, Kairouan) - Salinization risk of soils and aquifers. Computers and $\begin{array}{llllll}\text { Electronics in } & \text { Agriculture, v. 86, p. 34-42, }\end{array}$ https://doi.org/10.1016/j.compag.2011.09.010

KISSEL, E.; VAN ASTEN, P.; SWENNEN, R.; LORENZEN, J.; CARPENTIER, S.C. Transpiration efficiency versus growth: Exploring the banana biodiversity for drought $\begin{array}{llllll}\text { tolerance. Scientia Horticulturae, v. } 2015 . & \text { 185, p.175-182, }\end{array}$ https://doi.org/10.1016/j.scienta.2015.01.035

KUNZ, J.; ÁVILA, V. S. de; PETRY, M. Distribuição temporal e espacial da umidade do solo em sistemas de irrigação por gotejamento subsuperficial. Revista Monografias Ambientais - REMOA, v. 13, n. 5, p. 3963-3976, 2014. https://doi.org/10.5902/2236130815123

LANGONI, J. A.; ASSIS, G. A.; SANTOS, L. C.; REZENDE, M. A. A.; VALOTO, B.; LEÃO, T. V. M. Produtividade de cafeeiros fertirrigados sob diferentes níveis de adubação na região do cerrado mineiro na primeira safra. Revista de Ciências Agroambientais, v. 17, p. 1-7, 2019. https://doi.org/10.5327/rcaa.v17i1.2128

MARTINEZ, M. A.; SILVA, J. B. G.; PEREIRA, D. R. Modelagem do movimento de sais no solo. In: RAJGHEYI, H.; DIAS, N. da S.; LACERDA, C. F. de. (Org.). Manejo da salinidade na agricultura: estudos básicos e aplicados. 1. ed. Fortaleza: INCTsal, 2010. v. 1, p. 93-113.

MONTENEGRO, S. G. L.; DA SILVA JUNIOR, J. G. ;MONTENEGRO, A. A. de A.; de CARVALHO, J. F.; ALBUQUERQUE FILHO, J. A. C. Experimentação e modelagem do avanço de sais no perfil do solo em área cultivada com repolho sob alternativas de manejo de irrigação, no semiárido de Pernambuco. Agrária - Revista Brasileira de Ciências Agrárias, v. 8, n. 1, 2013. https://dx.doi.org/10.5039/agraria.v8i1a1391

MONTENEGRO, S. G.; MONTENEGRO, A. A. de A.; RAGAB, R. Improving agricultural water management in the semiarid region of Brazil: experimental and modelling study. Irrigation Science, v. 28, n. 4, p. 301-316, 2010. https://doi.org/10.1007/s00271-0090191-y

MUÑOZ-CARPENA, R.; REGALADO, C. M.; RITTER, A.; ALVAREZ-BENEDÍ, J.; SOCORRO, A. R. TDR estimation of electrical conductivity and saline solute concentration in a volcanic soil. Geoderma, v. 124, p. 399-413, 2005. https://doi.org/10.1016/j.geoderma.2004.06.002

MUTHUSAMY, M.; UMA, S.; BACKIYARANI, S.; SARASWATHI, M. S. Computational prediction, identification, and expression profiling of microRNAs in banana (Musa spp.) during soil moisture deficit stress. The Journal of Horticultural Sciences \& $\begin{array}{llllllll}\text { Biotechnology, } & \text { v. } & 89, \quad \text { n. } & 2, & \text { p. } & 208- & 214,\end{array}$ https://doi.org/10.1080/14620316.2014.11513070

NIMMER, M.; THOMPSON, A; MISRA, D. Water table Mounding Beneath stormwater infiltration Basins. Environmental \& Engineering Geoscience, v. 19, n. 2, p. 67-79, 2009. https://doi.org/10.2113/gseegeosci.15.2.67

OLIVEIRA, N. T.; CASTRO, N. M. R.; GOLDENFUM, J. A. Influência da palha no balanço hídrico em lisímetros. Revista Brasileira de Recursos Hídricos, v. 15, p. 93-103, 2010. 
PERSSON, M.; UVO. C. B. Estimating soil solution electrical conductivity from time domain reflectometry measurements using neural networks. Journal of Hydrology, v. 273, n. 14, p. 249-256, 2003. https://doi.org/10.1016/S0022-1694(02)00387-6

PINHO, R. E. da C. de; MIRANDA, J. H. de. Avaliação do modelo Hydrus-1D na simulação do transporte de água e potássio em colunas preenchidas com solos tropicais. Engenharia Agrícola, v. 34, n. 5, p. 899-911, 2014. https://doi.org/10.1590/S010069162014000500009

PONCIANO, I. de M. Aplicação da reflectometria no domínio do tempo (TDR) na estimativa da condutividade elétrica da solução do solo e de concentrações de nitrato, potássio e cloreto em coluna de solo não saturado. 2012. Tese (Doutorado) Escola Superior de Agricultura "Luiz de Queiroz”, Piracicaba, 2012.

RAMOS. B. Z.; PAIS. P. S. M.; FREITAS. W. A.; D. JUNIOR. M. S. D. Avaliação dos atributos físico-hídricos em um Latossolo Vermelho distroférricosob diferentes sistemas de manejo-Lavras/Minas Gerais/Brasil. Revista de Ciências Agrárias, v. 36, n. 3, 2013.

RAVI, I.; UMA, S.; VAGANAM, M.M.; MUSTAFFA, M. M. Phenotyping bananas for drought resistance. Frontiers in physiology, v. 4, n. 1, p. 1-15, 2013. https://doi.org/10.3389/fphys.2013.00009

RHOADES, J. D.; RAATS, P. A.; PRATHER, R. J. Effects of liquid phase electrical conductivity, water content and surface conductivity on bulk soil electrical conductivity. Soil Science Society of America Journal, v. 40, n. 5, p. 651-655, 1976.

RIBEIRO, D. P.; MARTINEZ, M. A.; MATOS, A. T.; RUIZ, H. A.; PARREIRAS, M. S. N.; CECON, P. R. Relação da velocidade de escoamento da solução e do comprimento da coluna de solo com os parâmetros de transporte de potássio em um Latossolo e um Neossolo. Revista Brasileira de Ciência do Solo, v. 35, n. 6, p. 1907-1916, 2011. http://dx.doi.org/10.1590/S0100-06832011000600007

RICHARDS, L. A. Diagnosis and improvement of saline and alkali soils. Riverside: LWW, 1954.

RIVERA, R. N. C.; MIRANDA, J. H.; DUARTE, S. N.; BOTREL, T. A. Modelo aplicado à dinâmica da água e do potássio no solo sob irrigação por gotejamento - análise de sensibilidade. Revista de Engenharia Agrícola, v. 28, n. 3, p.448-459, 2008. http://dx.doi.org/10.1590/S0100-69162008000300006

SANTANA, G. S.; COELHO, E. F.; SILVA, T. S. M.; RAMOS, M. M. Relação entre potássio na solução do solo, umidade e condutividade elétrica aparente do solo. Revista Brasileira de Engenharia Agrícola e Ambiental, v. 11, n. 2, p. 142-157, 2007. http://dx.doi.org/10.1590/S1415-43662007000200003

SANTOS, M. R. dos; MARTINEZ, M. A.; ZONTA, J. H.; MATOS, A. T. de; OLIVEIRA, R. A. de. Uso da Reflectometria no Domínio do Tempo para avaliar a distribuição de nitrato em colunas de solos fertirrigados. Revista Ambiente \& Água, v. 4, n. 3, p. 67-81, 2009. https://dx.doi.org/10.4136/ambi-agua.103

SANTOS, M. R.; MARTINEZ, M. A.; ZONTA, J. H. Modelos para determinação de fósforo e nitrato em neossolo quartzarênico e latossolo vermelho usando TDR. Engenharia na Agricultura, v. 18, p. 30-39, 2010. https://doi.org/10.13083/reveng.v18i1.162 
SILVA, J. R. L.; MONTENEGRO, A. A. A.; MONTEIRO, A. L. N.; SILVA JUNIOR, V. P. Modelagem da dinâmica de umidade do solo em diferentes condições de cobertura no semiárido pernambucano. Agrária, v. 10, p. 293-303, 2015. https://dx.doi.org/10.5039/agraria.v10i2a4219

SILVA, L. L.; RAGAB, R.; DUARTE, I.; LOURENÇO, E.; SIMÕES, N.; CHAVES, M. M. Calibration and validation of SALTMED model under dry and wet year conditions using chickpea field data from Southern Portugal. Irrigation Science, v. 31, p. 651-659, 2013. https://doi.org/10.1007/s00271-012-0341-5

ŠIMU゚NEK, J.; VAN GENUCHTEN, M.Th.; ŠEJNA, M. Development and Applications of the Hydrus and STANMOD Software Packages and Related Codes. Vadose Zone Journal, v. 7, p. 587-600, 2008. https://doi.org/10.2136/vzj2007.0077

TAYLOR, S. A.; ASHCROFT, G. M. Physical edaphology. San Francisco: Freeman, 1972. $533 \mathrm{p}$.

VAN GENUCHTEN, M. Th. A closed-form equation for predicting the hydraulic conductivity of unsaturated soils. Soil science society of America journal, v. 44, n. 5, p. 892-898, 1980. https://doi.org/10.2136/sssaj1980.03615995004400050002x

VANHOVE, A. C.; VERMAELEN, W.; PANIS, B.; SWENNEN, R.; CARPENTIER, S. C. Screening the banana biodiversity for drought tolerance: can an in vitro growth model and proteomics be used as a tool to discover tolerant varieties and understand homeostasis. Frontiers in Plant Science, v. 3, n. 176, p. 1-10, 2012. https://doi.org/10.3389/fpls.2012.00176

VOGELER, I.; CLOTIER, B. E.; GREEN, S. R.; SCOTTER, D. R.; TILLMAN, R. W. Characterizing water and solute movement by TDR and disk permeametry. Soil Science Society of America Journal, v. 60, n. 1, p. 5-12, 1996. https://doi.org/10.2136/sssaj1996.03615995006000010004x

WILLMOTT, C. J. On the validation of models. Physical Geography, v. 2, n. 2, p. 184-194, 1981. https://doi.org/10.1080/02723646.1981.10642213 


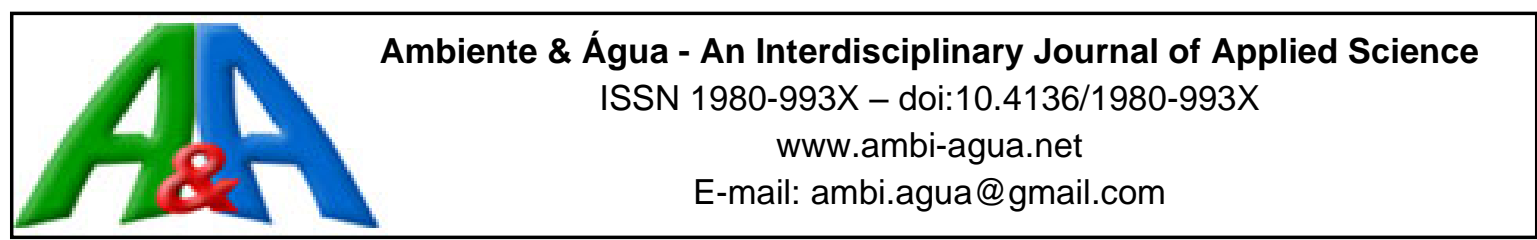

\title{
Assessing glyphosate concentrations in six reservoirs of Paraíba do Sul and Guandu River Basins in southeast Brazil
}

\author{
ARTICLES doi:10.4136/ambi-agua.2615
}

Received: 05 Jul. 2020; Accepted: 03 Nov. 2020

\author{
Carolina da Silva Cristofaro ${ }^{1 *(D)}$; Christina Wyss Castelo Branco ${ }^{2}$; \\ Maria Isabel de Almeida Rocha ${ }^{3}$; Samira da Guia Mello Portugal ${ }^{4}(\mathbb{C})$ \\ ${ }^{1}$ Departamento de Ciências Naturais. Universidade Federal do Estado do Rio de Janeiro (UNIRIO), \\ Avenida Pasteur, n 296, CEP: 22290-240, Rio de Janeiro, RJ, Brazil. \\ 2Instituto de Biociências. Departamento de Zoologia. Universidade Federal do Estado do Rio de Janeiro \\ (UNIRIO), Avenida Pasteur, n 458, CEP: 22290-240, Rio de Janeiro, RJ, Brazil. E-mail: cbranco@ unirio.br \\ ${ }^{3}$ Instituto de Biociências. Universidade Federal do Estado do Rio de Janeiro (UNIRIO), Avenida Pasteur, $\mathrm{n}^{\circ} 458$, \\ CEP: 22290-240, Rio de Janeiro, RJ, Brazil. E-mail: isabel-rocha@uol.com.br \\ ${ }^{4}$ Instituto de Biociências. Departamento de Ciências Naturais. Universidade Federal do Estado do Rio de \\ Janeiro (UNIRIO), Avenida Pasteur, n 296, CEP: 22290-240, Rio de Janeiro, RJ, Brazil. \\ E-mail:samiraportugal@gmail.com \\ *Corresponding author. E-mail: carol.cristofaro@gmail.com
}

\begin{abstract}
Glyphosate is a popular herbicide used worldwide, and several studies consider it to be an environmental hazard affecting human health. The present study aimed to detect glyphosate in six different reservoirs of Paraíba do Sul and Guandu River Basins in Southeast Brazil, used for multiple purposes, including fishery activities and domestic water supply. Ion chromatography was used to analyze the water samples, as it is a fast and environmentally friendly technique to detect glyphosate. Our results revealed that, despite differences related to trophic state, season of the year or distance to urban areas, glyphosate was detected in all reservoirs and in three of them with concentrations above the limit imposed by Brazilian legislation. Among the environmental variables studied, turbidity presented the highest correlation with glyphosate concentrations. The effect of rainfall increasing turbidity in the rivers reinforces the importance of draining waters from surrounding areas that transport glyphosate into the aquatic ecosystems. The detection of the herbicide in the various systems confirms the wide use of this compound in the drainage basins of the studied reservoirs and highlights the importance of water monitoring. Further, the results reveal how urgent and important it is to explore through laboratory experiments the pathways of degradation of this herbicide in tropical and subtropical aquatic environments together with its effects on flora and fauna.
\end{abstract}

Keywords: herbicide, ion chromatography, tropical reservoir.

\section{Avaliação das concentrações de glifosato em seis reservatórios das bacias dos rios Paraíba do Sul e Guandu, no sudeste do Brasil}

\section{RESUMO}

O glifosato é um herbicida popularmente usado em todo o mundo, vários estudos estão

This is an Open Access article distributed under the terms of the Creative Commons Attribution License, which permits unrestricted use, distribution, and reproduction in any medium, provided the original work is properly cited. 
considerando-o como um risco ambiental e como afetando a saúde humana. O presente estudo teve como objetivo detectar o glifosato em seis diferentes reservatórios das bacias dos rios Paraíba do Sul e Guandu, no sudeste do Brasil, utilizados para diversos fins, incluindo atividades pesqueiras e abastecimento doméstico. A cromatografia iônica foi a técnica escolhida para analisar glifosato nas amostras de água como uma técnica rápida e ecologicamente amigável. Nossos resultados revelaram que, apesar das diferenças relacionadas ao estado trófico, estação do ano ou distância das áreas urbanas, glifosato foi detectado em todos os reservatórios e em três deles com concentrações acima do limite imposto pela legislação brasileira. Dentre as variáveis ambientais estudadas, a turbidez foi a que apresentou maior correlação com as concentrações de glifosato. O efeito das chuvas aumentando a turbidez nos rios reforça a importância do escoamento da água das áreas circundantes que transportam glifosato para os ecossistemas aquáticos. A detecção do herbicida nos diversos sistemas confirma o amplo uso desse composto nas bacias de drenagem dos reservatórios estudados e destaca a importância do monitoramento da água para este composto. Além disso, os resultados revelam quão urgente e importante é explorar, através de experimentos de laboratório, as vias de degradação desse herbicida em ambientes aquáticos tropicais e subtropicais, juntamente com seus efeitos na flora e fauna.

Palavras-chave: cromatografia iônica, herbicida, reservatório tropical.

\section{INTRODUCTION}

The increasing availability of inorganic fertilizers and pesticides changed the course of world agriculture. In Brazil, glyphosate is mainly used in the cultivation of rice, coffee, cocoa, corn, sugarcane, soybeans, citrus fruits, bananas, to control aquatic plants, and likewise is applied in urban areas including sidewalks and gardens (Abreu et al., 2008). Other South American countries are also familiar with glyphosate, which is the most commonly used herbicide in Argentina (Lozano et al., 2018). Glyphosate was also widely applied in Colombia to control weeds in coffee plantations (Schrübbers et al., 2014).

Glyphosate or N-phosphonomethyl glycine is considered a non-selective, systemic and post emergent herbicide. Glyphosate (CAS number 1071-83-6) is a crystalline solid, with a water solubility of $12 \mathrm{~g} \mathrm{~L}^{-1}$ at $25^{\circ} \mathrm{C}$ (Okada et al., 2018). The endurance of glyphosate in water is subjected to physical, chemical and microbial characteristics of the environment (Mallat and Barcelo, 1998). Glyphosate can remain active in water ranging between 7 and 100 days depending on environmental conditions such as $\mathrm{pH}$, temperature, suspended matter, cation concentration, aluminum, and iron content and microbial activity (Fouodjouo et al., 2015). Further, temporal variation in environmental glyphosate concentrations can directly depend on the time of application and rain events (Hanke et al., 2010).

When correctly applied, this herbicide inhibits an important enzyme in plants responsible for the production of essential aromatic amino acids. Animals do not produce this enzyme and get the amino acids in question through food. Therefore, this substance was considered nontoxic to many living beings by many regulations and agencies (Moore et al., 2012). Though the accepted dogma was that glyphosate was harmless to humans because our cells do not have the enzyme pathway that glyphosate inhibits, our gut bacteria do have this pathway and we depend on them to supply us with essential amino acids (Samsel and Seneff, 2013).

The environmental threat of glyphosate due to its residual presence in crops and food was linked with respiratory problems in men such as pulmonary edema and trouble with breathing. In addition, laboratory experiments have shown that glyphosate can increase the induction of sister chromatid exchange, chromosomal aberrations, lesions in DNA and, in some cases, breaking of genetic material (Roustan et al., 2014). Short-term rodent studies have not shown that glyphosate has high toxicity, but long-term ones related this herbicide with kidney and liver 
failure, besides an increased risk of developing cancer (Samsel and Seneff, 2013). Other studies also link glyphosate with autism (Nevison, 2014) and breast cancer (Mesnage et al., 2015).

In general, herbicides can also contribute to food contamination and environmental degradation. Glyphosate can be retained in soils and transported to surface and groundwater. Soil pollution is primarily related to the phenomena of leaching and runoff. Leaching promotes migration of these substances to deeper layers of the soil and can contaminate groundwater; while runoff spreads the herbicide and may favor the contamination of surface water bodies (Borggaard and Gimsing, 2008).

From a broader environmental perspective, the direct application of herbicides in aquatic systems might affect the water quality as well as ecosystem functioning. This type of compound can interfere with species biology and interactions besides decreasing biodiversity, affecting this way the stability and resilience of aquatic environments (Relyea, 2012). The magnitude of those effects can be related to glyphosate's persistence in the environment (Pérez et al., 2011).

Freshwater ecosystems flora and fauna can be affected by glyphosate-based herbicides, as shown by laboratory and outdoor experiments such as those with phytoplankton and periphyton (Pérez et al., 2011; Lozano et al., 2018), invertebrates and vertebrates like fish (Folmar et al., 1979; Cuhra et al., 2013; Geyer et al., 2016) and with larvae and adults of amphibians. Recently, an increase in deviations in ontogenetic development was shown in tropical tadpoles because of chronic exposure to Roundup® (Tuhran et al., 2020).

In natural lakes and reservoirs, those effects can be serious, since glyphosate can affect the structure of primary producers' communities (Lozano et al., 2018; Hernández-Garcia and Martínez-Jerónimo, 2020) as well as consumers' assemblages (Rico-Martínez et al., 2012; Vajargah et al., 2018), besides being a potential hazard to human health. Evidence like this highlights the threats posed by the presence of glyphosate in multiple-use reservoirs.

In the United States, the maximum concentration of glyphosate allowed by the Environmental Protection Agency is $0.700 \mathrm{mg} \mathrm{L}^{-1}$. In Europe, the Council of the European Union established the value of $0.0010 \mathrm{mg} \mathrm{L}^{-1}$ as the limit for drinking water (European Council, 1998). In Brazil, the National Environmental Council (CONOMA) stipulates the concentration of $0.065 \mathrm{mg} \mathrm{L}^{-1}$ as the limit for waters of Class 1 and 2 .

Brazil has a rich network of river basins that supports more than sixty percent of the country's electricity through power generation in hydroelectric reservoirs. Ubiquitous throughout the country, most of those systems frequently have multiple purposes, with the water being used for agriculture, industrial and domestic supply. Brazilian reservoirs have been widely studied in the last decades, especially regarding water quality, biodiversity of aquatic communities, eutrophication and cyanobacteria blooms (Soares et al., 2013). Few studies analyzed glyphosate in Brazilian waters, and the existing ones were in rivers near agricultural and urban areas. Only Pires et al. (2020) studied glyphosate concentrations close to soybeangrowing fields in the Brazilian Amazon, including a reservoir within the freshwater ecosystem. Still, there is a lack of studies relating to glyphosate in Brazilian reservoirs. This study is therefore a step to close this gap.

Glyphosate detection conventionally is associated with requiring a high cost-analysis and sophisticated methods, such as liquid chromatography coupled with an ultraviolet detector, fluorescence and mass spectrometry (Peruzzo et al., 2008; Catrinck et al., 2014). The determination of glyphosate by ion chromatography (IC) is considered a clean-up procedure, and also a direct, fast and relatively inexpensive method for glyphosate quantification (Zhu et al., 1999; Lambropoulou and Albanis, 2007).

Considering the context above, the objective of the present study was to quantify the concentration of glyphosate in six different reservoirs of Paraíba do Sul and Guandu River Basins, applying the ion chromatography technique. The values found were compared with the ones stipulated by Brazilian legislation. All the reservoirs belong to an energy-generating grid, 
are influenced by agriculture and urban drainages, and most of them are used for industrial and domestic water supply, small-scale fishing and aquaculture. Regarding the anthropic influences, it was expected a greater possibility of finding glyphosate in reservoirs under a stronger anthropic influence attested by their respective tropic conditions. We also tried to investigate the possible influence of environmental features and rainfall on glyphosate concentrations in the aquatic environments.

\section{MATERIALS AND METHODS}

\subsection{Chemicals and materials}

For decontamination of all the materials applied in this study, we used a solution of hydrochloric acid $18 \%(\mathrm{~m} / \mathrm{v})$ (prepared from the dilution of concentrated acid) and $2 \%(\mathrm{v} / \mathrm{v})$ solution of Extran ${ }^{\circledR}$ MA02. Glyphosate 45521 - PESTANAL® Sigma Aldrich ${ }^{\circledR}$ standard and Milli-Q water (Direct-Q3® UV, Millipore, resistivity $18.2 \mathrm{~m} \Omega \mathrm{cm}^{-1}$ at $25^{\circ} \mathrm{C}$ ) were used to prepare the solutions of the calibration curve. The water samples were filtered with a membrane

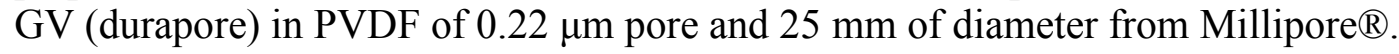

\subsection{Study Area}

The water samples were collected in six distinct reservoirs belonging to Paraíba do Sul River Basin (Tocos, Santana, Vigário and Santa Branca) and the Guandu River Basin (Ribeirão das Lajes and Ponte Coberta) (Figure 1).

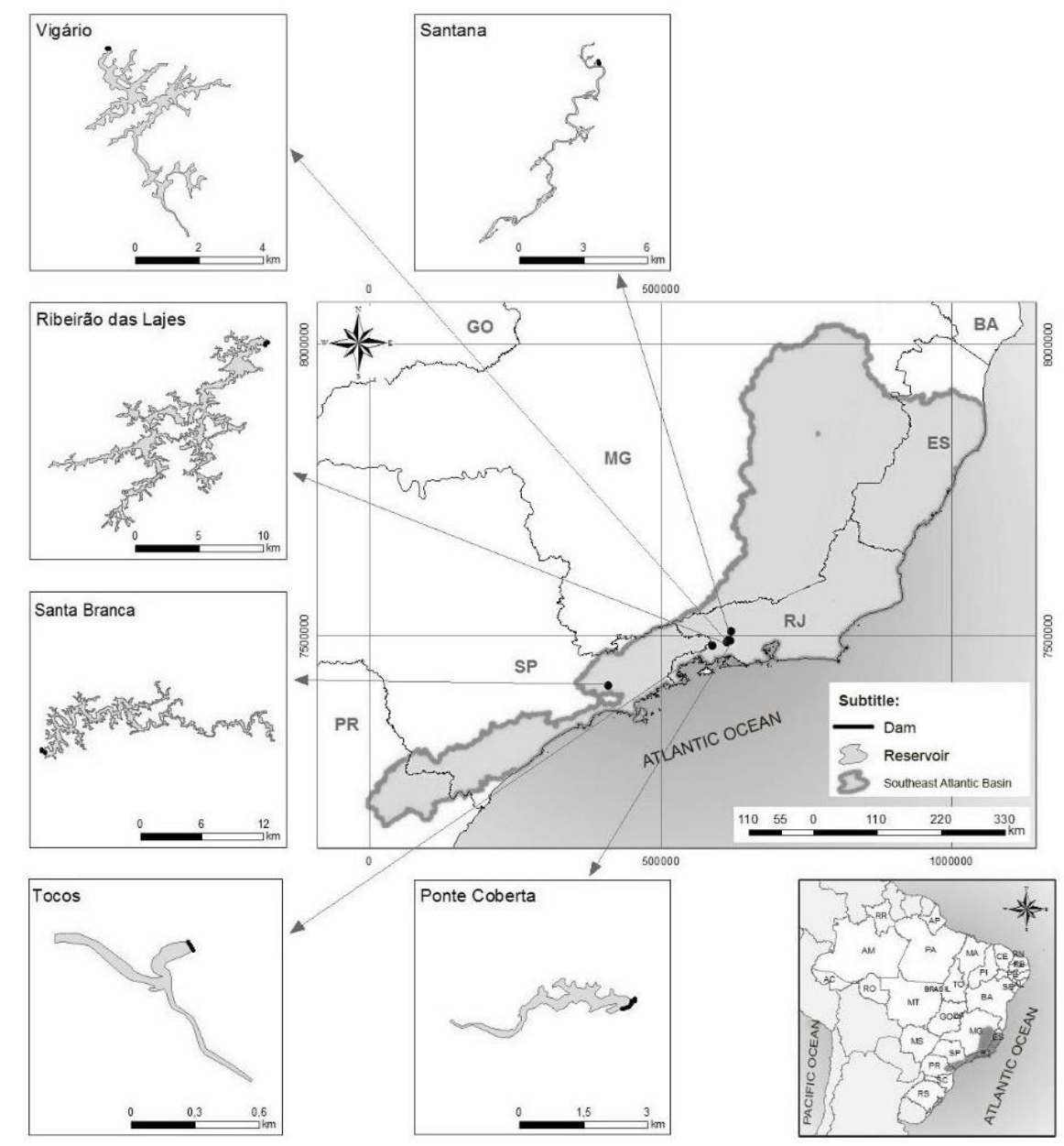

Figure 1. Location of the reservoirs: Santana, Vigário, Ribeirão das Lajes, Santa Branca, Tocos and Ponte Coberta, included in the present study. 
The climate of the region is sub-humid, considered as Aw in Köppen's system composed of a rainy summer (from January to March) and dry winter (from July to September). The reservoir of Santa Branca is in the main axis of Paraíba do Sul River; the others form a complex of reservoirs, which comprises a hydroelectric generating system and are the main water supply system for the city of Rio de Janeiro. These reservoirs have different characteristics related to morphometric features, anthropogenic impacts and trophic conditions (Klippel et al., 2020). In accordance with Resolution 357 related to water quality (CONAMA, 2005), Ribeirão das Lajes and Santa Branca are considered Class 1 (better quality, they can be used for water supply after simple chlorination) and oligo-mesotrophic, while all the others are Class 2 (they need conventional treatment for domestic supply) and considered mesotrophic to eutrophic. The number of sampling points was according to the size of the reservoir, one sampling point in the smallest (Tocos) and five in the largest (Ribeirão das Lajes Reservoir).

The geographic coordinates of each point are in Table 1. Ribeirão das Lajes Reservoir was sampled monthly from January 2013 to April 2014 (except December). All the other reservoirs were sampled in January 2013, July 2013 and January 2014. January is the rainy season while in July starts the dry season.

Table 1. Geographic coordinates of the sampling points.

\begin{tabular}{|c|c|c|c|c|c|}
\hline Reservoir & $\begin{array}{c}\text { Surface area } \\
\left(\mathbf{k m}^{2}\right)\end{array}$ & $\begin{array}{l}\text { Retention time } \\
\text { (days) }\end{array}$ & Sample Point & Latitude South & Longitude West \\
\hline \multirow{5}{*}{ Ribeirão das Lajes } & \multirow{5}{*}{30.7} & \multirow{5}{*}{300.1} & L1 & $22^{\circ} 47^{\prime} 18^{\prime \prime}$ & $44^{\circ} 01^{\prime} 48^{\prime \prime}$ \\
\hline & & & L2 & $22^{\circ} 49^{\prime} 44^{\prime \prime}$ & $43^{\circ} 59^{\prime} 45^{\prime \prime}$ \\
\hline & & & L3 & $22^{\circ} 46^{\prime} 19^{\prime \prime}$ & $43^{\circ} 57^{\prime} 54^{\prime \prime}$ \\
\hline & & & L4 & $22^{\circ} 42^{\prime} 33^{\prime \prime}$ & $43^{\circ} 54^{\prime} 51^{\prime \prime}$ \\
\hline & & & L5 & $22^{\circ} 42^{\prime} 09^{\prime \prime}$ & $43^{\circ} 52^{\prime} 58^{\prime \prime}$ \\
\hline \multirow{2}{*}{ Ponte Coberta } & \multirow{2}{*}{1.09} & \multirow{2}{*}{1.1} & PC1 & $22^{\circ} 41^{\prime} 32^{\prime \prime}$ & $43^{\circ} 51 ' 24^{\prime \prime}$ \\
\hline & & & $\mathrm{PC} 2$ & $22^{\circ} 41^{\prime} 12^{\prime \prime}$ & $43^{\circ} 49^{\prime} 41^{\prime \prime}$ \\
\hline \multirow{4}{*}{ Santa Branca } & \multirow{4}{*}{27.23} & \multirow{4}{*}{62.6} & SB1 & $23^{\circ} 21^{\prime} 07^{\prime \prime}$ & $45^{\circ} 46^{\prime} 01^{\prime \prime}$ \\
\hline & & & SB2 & $23^{\circ} 18^{\prime} 36^{\prime \prime}$ & $45^{\circ} 45^{\prime} 59^{\prime \prime}$ \\
\hline & & & SB3 & $23^{\circ} 19^{\prime} 55^{\prime \prime}$ & $45^{\circ} 47^{\prime} 54^{\prime \prime}$ \\
\hline & & & SB4 & $23^{\circ} 22^{\prime} 26^{\prime \prime}$ & $45^{\circ} 52^{\prime} 09^{\prime \prime}$ \\
\hline \multirow{3}{*}{ Santana } & \multirow{3}{*}{5.23} & \multirow{3}{*}{1} & $\mathrm{~S} 1$ & $22^{\circ} 31^{\prime} 30^{\prime \prime}$ & $43^{\circ} 49^{\prime} 20^{\prime \prime}$ \\
\hline & & & $\mathrm{S} 2$ & $22^{\circ} 34^{\prime} 36^{\prime \prime}$ & $43^{\circ} 50^{\prime} 18^{\prime \prime}$ \\
\hline & & & S3 & $22^{\circ} 36^{\prime} 29^{\prime \prime}$ & $43^{\circ} 52^{\prime} 06^{\prime \prime}$ \\
\hline \multirow[t]{2}{*}{ Tocos } & 0.36 & $<1$ & $\mathrm{~T} 1$ & $22^{\circ} 47^{\prime} 07^{\prime \prime}$ & $44^{\circ} 04^{\prime} 39^{\prime \prime}$ \\
\hline & \multirow{3}{*}{3.33} & \multirow{3}{*}{2} & V1 & $22^{\circ} 38^{\prime} 09^{\prime \prime}$ & $43^{\circ} 53^{\prime} 49^{\prime \prime}$ \\
\hline \multirow[t]{2}{*}{ Vigário } & & & $\mathrm{V} 2$ & $22^{\circ} 39^{\prime} 23^{\prime \prime}$ & $43^{\circ} 53^{\prime} 17^{\prime \prime}$ \\
\hline & & & V3 & $22^{\circ} 40^{\prime} 13^{\prime \prime}$ & $43^{\circ} 52^{\prime} 51^{\prime \prime}$ \\
\hline
\end{tabular}

\subsection{Samples Analysis}

Water samples for glyphosate analysis were taken at the sub-surface of each point. Environmental variables were measured at the same time in situ with a multi-probe 6920 Yellow Spring Instrument. The variables measured were: water temperature, $\mathrm{pH}$, electrical conductivity, total suspended solids, dissolved oxygen, turbidity, and chlorophyll- $a$. Water transparency was evaluated using a Secchi disk. All the rainfall data as well as the reservoir water levels were obtained from meteorological and hydrological stations of the Light Energy 
Company located near the reservoirs. The ion chromatography technique was used to determine the presence of pesticide in water. This technique dispenses with the use of cartridges, reagents and solvents that can potentially contribute to environmental degradation and waste generation. The calibration curve was constructed from nine aqueous solutions of glyphosate standard, with concentrations ranging from $0.01 \mathrm{mg} \mathrm{L}^{-1}$ to $1.0 \mathrm{mg} \mathrm{L}^{-1}$. Six replicates were analyzed for each concentration.

The filtered samples, with a membrane GV (durapore) in PVDF of $0.22 \mu \mathrm{m}$ pore Millipore ${ }^{\circledR}$, were analyzed on an ion chromatograph ICS-2100 (Dionex Inc.) equipped with AS-19A and AG-19A columns, self-regenerating suppressor ASRS-Ultra II, with a sample loop of $500 \mu \mathrm{L}$ and flow rate of $0.3 \mathrm{~mL} \mathrm{~min}^{-1}$. KOH was the eluent, from 0-10 minutes its concentration was $10 \mathrm{mM}$ and from 10-23 it was $60 \mathrm{mM}$, the retention time was 20.5 minutes. Each analyzed sample had six replicates and all of them were tested.

\subsection{Statistical Analysis}

Normality of data was assessed with a Shapiro-Wilk test. Due to non-normality, the Kruskal-Wallis test on ranks was performed to detect significant differences $(p<0.05)$ in glyphosate concentrations among reservoirs. In order to explore the relationship between glyphosate concentrations and environmental variables, we calculated Spearman rank correlation coefficients in the software Statistic Version 7.0. For statistical analysis, only results where glyphosate was detected above the quantification limit (QL) were used. In the specific case of pluviometry, monthly values were taken into consideration as well as rainfall values that occurred three days before the sampling day and also in the previous week.

\section{RESULTS AND DISCUSSION}

\subsection{Detection and quantification of glyphosate}

The analytical method of ion chromatography has the advantage of allowing the quantification of glyphosate in water through direct injection, without the need for preconcentration or derivatization, steps that involve sample manipulation render the analysis expensive and time-consuming. In the chromatograms, the peak retention time corresponding to glyphosate was of $20.5 \mathrm{~min}$ (Figure 2A). The calibration curve obtained for the standard solutions was adjusted using a linear regression equation, relating the results to the concentration of the analyte (Figure 2B). The correlation coefficient found was 0.99121 .

The detection limit (DL) and the quantification limit (QL) were 2.8x10-4 $\mathrm{mg} \mathrm{L}^{-1}$ and 8.5x10-4 $\mathrm{mg} \mathrm{L}^{-1}$, respectively. They were calculated according to Equations 1 and 2:

$$
\begin{aligned}
& \mathrm{DL}=3.3 \times \mathrm{s} / \mathrm{S} \\
& \mathrm{QL}=10 \times \mathrm{s} / \mathrm{S}
\end{aligned}
$$

Where $\mathrm{s}$ is the standard deviation of the blank sample and $\mathrm{S}$ is the slope of the regression line equation. The recovery was calculated according to Ribani et al. (2004) using known values of glyphosate added in an exempted matrix. The recovery mean values were between $59 \%$ and $103 \%$. These numbers are within the acceptable range established in the literature; the US-FDA recommends the recovery trend to be between $50 \%$ - 150\%, while the European Union Commission says 40\% - 160\% (Imoto and Freitas, 2008). The precision of the value obtained in this study was $13.98 \%$, and it was determined by the relative standard deviation (RSD). This parameter represents the dispersion of the results, and in case of experiments with trace elements, it is accepted a RSD of up to $20 \%$ (Ribani et al., 2004). 

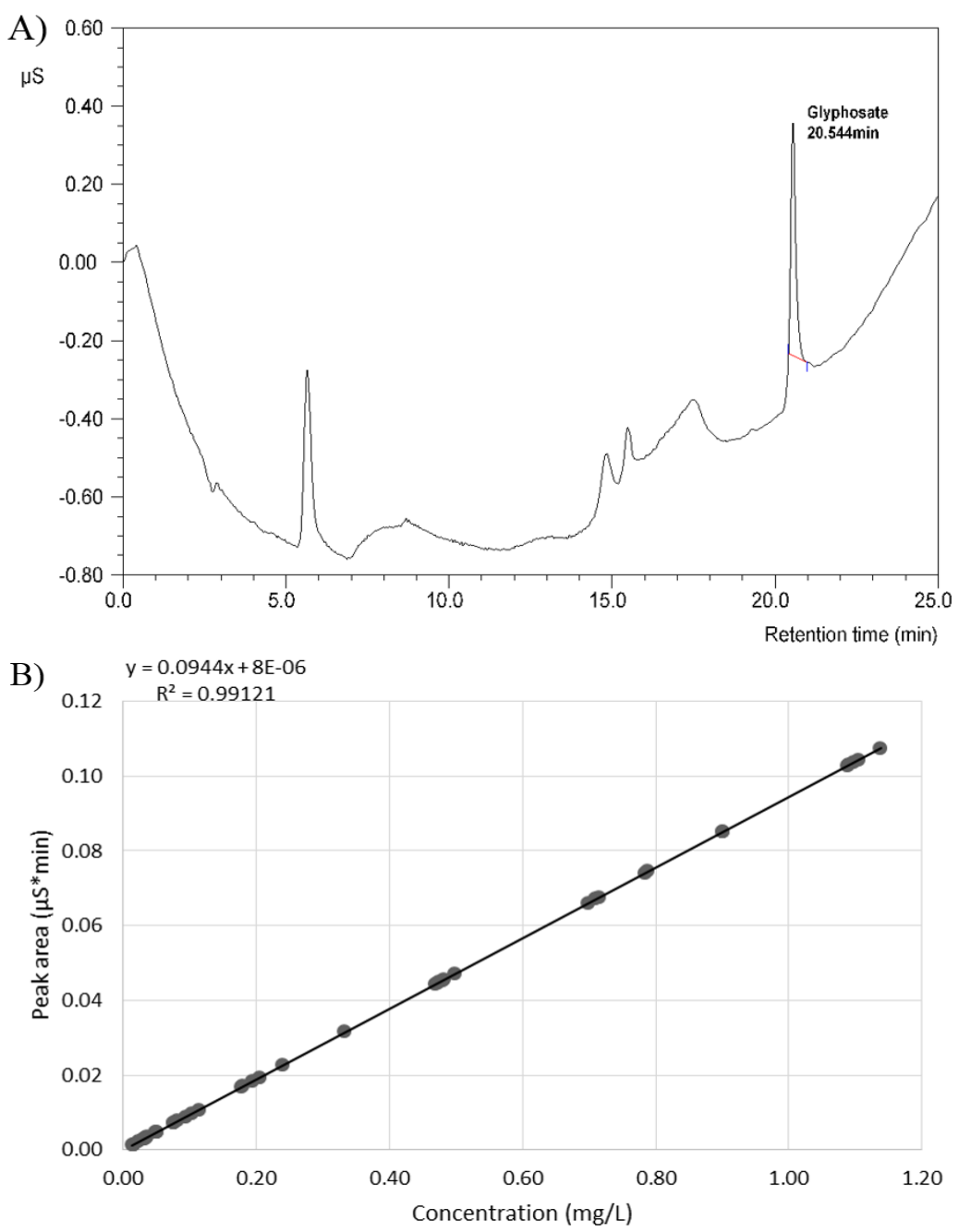

Figure 2. A. Chromatogram of aqueous standard solution $\left(1.033 \mathrm{mg} \mathrm{L}^{-1}\right)$; B. Analytical curve of different standard concentrations.

\subsection{Glyphosate in the six reservoirs}

In the present study, glyphosate was detected in all six reservoirs, regardless of their trophic state or closeness to anthropic areas. According to the Kruskal-Wallis test, there were no differences in glyphosate concentrations among reservoirs $(\mathrm{H}=7.9486(15, \mathrm{~N}=47), \mathrm{p}=0.1591)$.

The herbicide was found above the quantification limit in $43 \%$ of all analyzed water samples. The percentage of positive results were different among the reservoirs. Glyphosate was detected in $100 \%$ of the water samples from the following reservoirs: Tocos, Vigário and Ponte Coberta. In Ribeirão das Lajes Reservoir, 32\% of the samples showed the presence of glyphosate, while in Santa Branca that number was equal to $50 \%$ of the samples. The lowest percentage was found in Santana Reservoir, with $11 \%$ of the samples contaminated with the herbicide.

Systematic assessments of glyphosate presence in lakes and rivers in South America are scarce, despite the widespread use of this herbicide. In the present study, the percentage of $43 \%$ of samples in which glyphosate was detected was similar to the results of a survey of glyphosate in Pampean lakes (40\%) (Berman et al., 2018), in which the samples were analyzed by high performance liquid chromatography and mass spectrometry (HPLC-MS) after derivatization with 9- fluorenylmethoxycarbonyl chloride. However, these results were higher than other glyphosate studies, such in surface waters of agricultural basins in Argentina, where the maximum percentage of surface water samples containing glyphosate reached $35 \%$ (Aparicio 
et al., 2013).

Our results were also higher when compared with the first survey of glyphosate on a basinwide scale in the main tributaries of the Paraná River Basin in Brazil. In this case, $30 \%$ of the water samples reported the presence of the herbicide (Ronco et al., 2016). These authors related the positive results to intensive agriculture activities.

Considering all analyzed samples, the concentrations of glyphosate varied from $0.0003 \mathrm{mg}$ $\mathrm{L}^{-1}$ to $0.1684 \mathrm{mg} \mathrm{L}^{-1}$, and in three samples the concentration exceeded the maximum allowed by Brazilian legislation (CONAMA 357) (Figure 3). The higher values were found in both Class 1 (Ribeirão das Lajes and Santa Branca) and Class 2 (Vigário) oligo-mesotrophic reservoirs (Klipell et al., 2020).

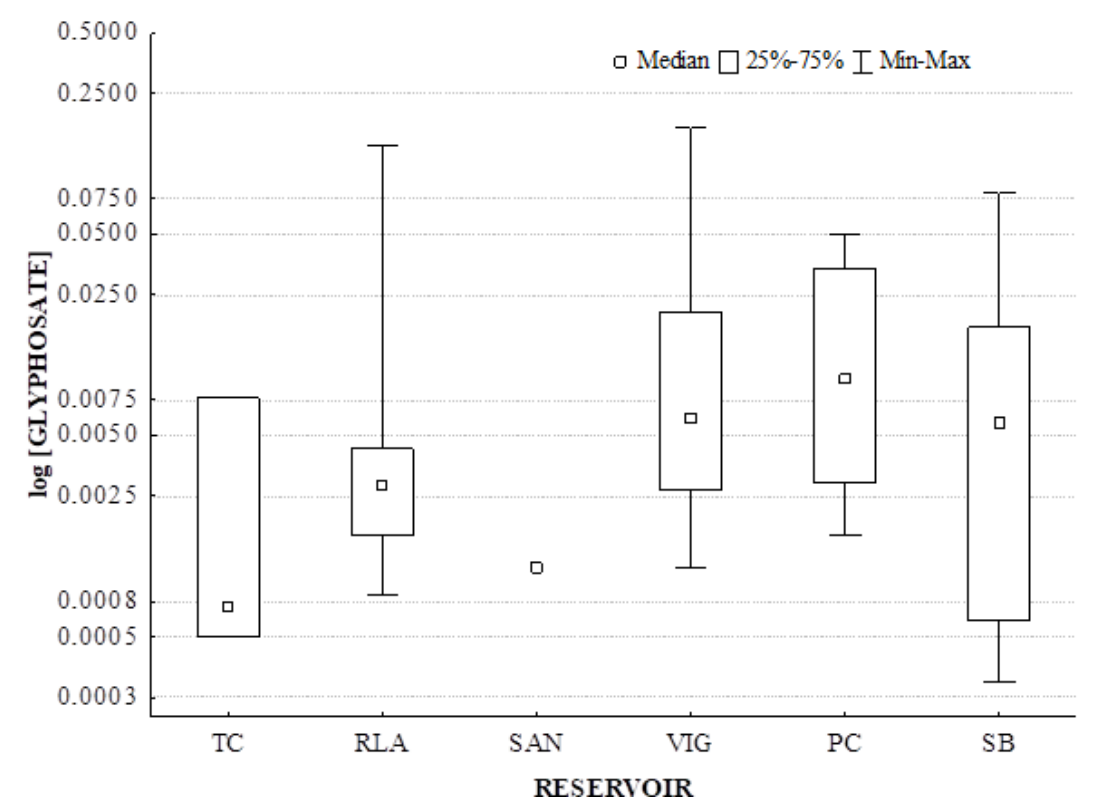

Figure 3. Log of Glyphosate concentration $\left(\mathrm{mg} \mathrm{L}^{-1}\right)$ in the six reservoirs during the period of the study. RLA=Ribeirão das Lajes, TC=Tocos, PC=Ponte Coberta, SB=Santa Branca, $\mathrm{SAN}=$ Santana and VIG = Vigário.

Once again, the results found in the present study (between $0.0003 \mathrm{mg} \mathrm{L}^{-1}$ and $0.1684 \mathrm{mg}$ $\mathrm{L}^{-1}$ ) were higher when compared with the other two mentioned researches in aquatic ecosystems in South America. The shallow lakes in Argentina showed glyphosate concentration values of up to $0.00452 \mathrm{mg} \mathrm{L}^{-1}$ (Berman et al., 2018), while Paraná River and tributaries presented values between 0-0.0012 $\mathrm{mg} \mathrm{L}^{-1}$ (Ronco et al., 2016). However, areas under agricultural influence showed higher results than ours, such as in a wetland of a stream receiving flowing from a soybean field near Buenos Aires where glyphosate ranged from 0.1 to $0.7 \mathrm{mg} \mathrm{L}^{-1}$ (Peruzzo et al., 2008).

\subsection{Trophic conditions and glyphosate}

Regarding the anthropic influences on the reservoirs, we noticed that at some sampling sites glyphosate was always found above the quantification limit, independently of the trophic conditions. This happened in the eutrophic Vigário Reservoir (V3), and in the oligomesotrophic Santa Branca (SB2) and Ribeirão das Lajes (L1) Reservoirs. Vigário Reservoir presented a concentration 2.6 times higher $\left(0.1684 \mathrm{mg} \mathrm{L}^{-1}\right)$ than the ones determined by law, Santa Branca, 1.24 times $\left(0.0804 \mathrm{mg} \mathrm{L}^{-1}\right)$, and Ribeirão das Lajes, 2.1 times higher $(0.01366$ $\left.\mathrm{mg} \mathrm{L}^{-1}\right)$. The wide use of glyphosate in several crops and in other agricultural activities, such as weed control in pastures along the Paraíba do Sul and Guandu River Basins, can explain the 
frequent presence of this herbicide in the studied systems. Except for Ribeirão das Lajes Reservoir, all the other reservoirs are under the influence of former coffee farm areas that were transformed into pasture or Eucalyptus plantation during the last century.

Within the eutrophic reservoirs (Vigário, Santana and Ponte Coberta), only Santana Reservoir showed dissimilar results (Figure 3) with a comparatively lower concentration of glyphosate.

Although receiving anthropically impacted waters from the Paraíba do Sul River, Santana Reservoir differs from the others, since it presents intense colonization by aquatic macrophytes (Pitelli et al., 2008). This condition suggests a possible reduction in glyphosate levels in water by aquatic macrophytes as reported in other studies (Brogan and Relyea, 2013; Moore et al., 2017). Still, further experimental studies to check and confirm such correlation are needed.

Even though Ribeirão das Lajes Reservoir is considered oligo-mesotrophic, has the surrounding area covered by remains of the Atlantic Forest, and possesses the best water quality among the reservoirs studied, still glyphosate was found in it. The detection of this herbicide at point L1 reflects the degradation of this reservoir area, which is influenced by drainage from pastures and upstream waters impacted by different types of crops and chicken farms. Therefore, we suggest that glyphosate enters the reservoir from runoff and leaching of upstream areas or from direct contamination by the use of this herbicide to control weeds in a nearby pasture.

In this way, our results for Ribeirão das Lajes Reservoir confirmed the main tributary as an important source of glyphosate into the lake and the relevance of the surrounding rainforest to prevent any input of the herbicide from land into other parts of the reservoir. Even with a high concentration of glyphosate at L1, the other sampling points seemed not to be affected by this herbicide, showing very low concentrations of glyphosate.

Since this reservoir is used for domestic supply through simple chlorination, the study of herbicides in its waters is highly important in terms of public health, especially if we consider that the Report of the International Agency for Research on Cancer (IARC, 2015) has classified this herbicide as belonging to the Group 2A, which means, as an agent probably carcinogenic to humans.

Glyphosate was detected at all sampling points in the Santa Branca, the other reservoir considered as oligo-mesotrophic. Although its waters are used for domestic supply, this reservoir suffers anthropic influences related to the Pinus plantation, industrial and mining activities in its marginal area. Sampling Point 2, which presents a high glyphosate content, is located near the entrance of the Capivari River, which has intensive agricultural activities in its basin that can introduce the herbicide to the reservoir. Yet, it is important to highlight that other sources of the herbicide cannot be discarded, because aside from agriculture, inputs from maintenance of roadsides and effluents of wastewater treatment plants can also be an important source of such substance (Hanke et al., 2010).

The detection of glyphosate throughout the year in the reservoirs of Ribeirão das Lajes and Santa Branca in both rainy and dry seasons, as well as in all other reservoirs, reflected the constant use of the herbicide in the drainage basins of these water bodies. Local processes, such as application by farmers to control undesirable weeds, would likely play important roles in the highly dynamic and complex processes of herbicide transport and degradation (Berman et al., 2018).

\subsection{Relationship of rainfall and environmental factors with glyphosate concentrations in the six reservoirs}

The pluviosity in reservoirs was as expected, with higher rainfall in the summer (January) and lower in the winter (July) samplings (Figure 4). However, rainfall was higher in the rainy season of 2013 than in 2014. 


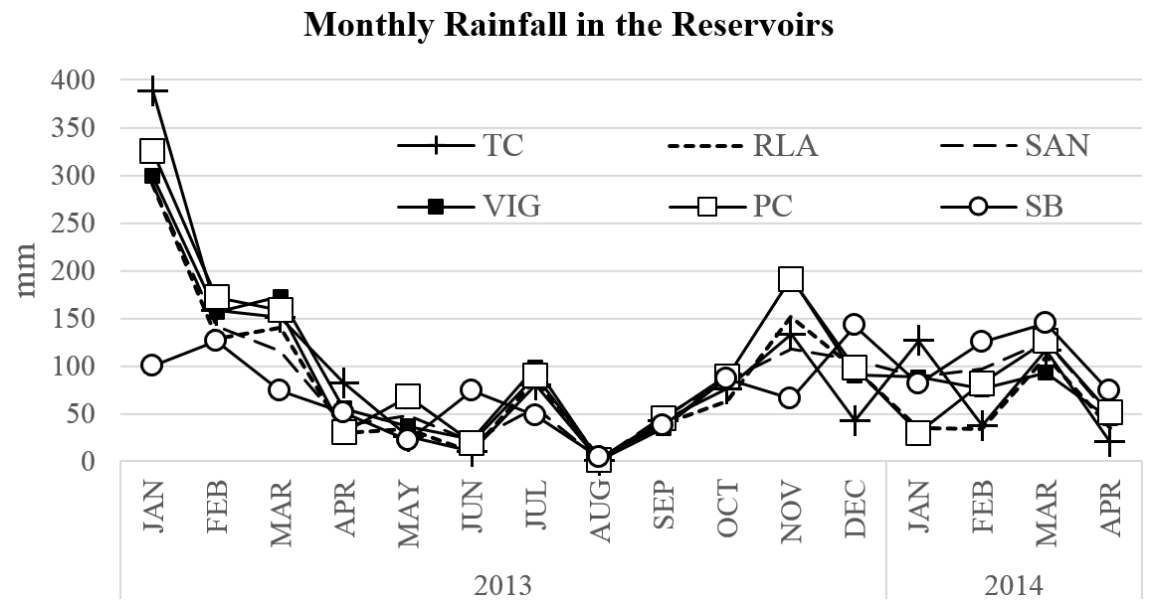

Figure 4. Monthly rainfall $(\mathrm{mm})$ in the six reservoirs during the period of the study. RLA=Ribeirão das Lajes, $\mathrm{TC}=\mathrm{Tocos}, \mathrm{PC}=\mathrm{Ponte}$ Coberta, $\mathrm{SB}=$ Santa Branca, SAN= Santana and VIG = Vigário.

The results of the correlation analysis between rainfall data and glyphosate concentrations in water showed no significant interrelation when considering monthly rainfall $(R h o=0.029$; $\left.\mathrm{P}_{\text {value }}<0.05\right)$. However, when considering the rainfall in the days before the sampling, the results were different. There was a higher correlation between rainfall in the three days before the sampling $(R h o=0.056$; Pvalue $<0.05)$ and glyphosate concentration, and a significant correlation between rainfall in the seven days before the sampling and glyphosate $(R h o=0.155$; $\left.\mathrm{P}_{\text {value }}<0.05\right)$.

The influence of rains on glyphosate dispersion has been discussed by several authors, most of them in the temperate region. In tropical Brazil, where rainfall governs most of the dynamics of the aquatic systems, the pathways of glyphosate from soils to water is scarcely documented (Correia et al., 2020; Pires et al., 2020). Even so, the existence of mechanisms of dilution of the surface material with adsorbed glyphosate by runoff cannot be discarded. Rainfall has been linked with the decrease in glyphosate concentrations in the soil. These lowering levels can be explained by the high solubility of glyphosate in water and by the existence of adsorption sites, which have already been linked with glyphosate in soils causing the carriage of the non-adsorbed glyphosate to streams (Peruzzo et al., 2008). Furthermore, surface runoff with the movement of soil particles can carry glyphosate adsorbed and end up in streams where glyphosate can be desorbed, biodegraded and accumulated in sediments (Aparicio et al., 2013). A significant increase in glyphosate concentrations in water due to rainfall is explained by the carrying of glyphosate present in soil through mechanisms of dilution of surface material by runoff (Peruzzo et al., 2008).

In relation to the environmental variables (Table 2), the reservoirs were characterized by water temperature average ranging from 21.9 to $25.8{ }^{\circ} \mathrm{C}$, waters around neutrality $(\mathrm{pH}$ average from 6.96 to 7.35), lower turbidity in the less impacted Tocos, Ribeirão das Lajes and Santa Branca reservoirs (from 4.35 to $8.59 \mathrm{NTU}$ ) and higher in the others (from 18.89 to $27.55 \mathrm{NTU}$ ). Total dissolved solids (TDS) and electrical conductivity were lower $\left(<20 \mathrm{mg} \mathrm{L}^{-1}\right.$, and $<30 \mu \mathrm{S} \mathrm{cm}^{-}$ ${ }^{1}$, respectively) in the less impacted and higher in the others (average between, respectively, 36.89 and $38.50 \mathrm{mg} \mathrm{L}^{-1}$ and 80.63 and $84.38 \mu \mathrm{S} \mathrm{cm}^{-1}$ ). Average water transparency was higher in Ribeirão das Lajes and Santa Branca Reservoirs (respectively, 2.07 and $2.31 \mathrm{~m}$ ). Chlorophyll$a$ average concentrations were considered low in all reservoirs $\left(<2.5 \mu \mathrm{g} \mathrm{L}^{-1}\right)$. We found a significant positive correlation between glyphosate and water turbidity $(R h o=0.366 ; \mathrm{N}=47 ; \mathrm{P}<$ $0.05)$ and a negative between glyphosate and water transparency $(R h o=-0.375)$. On the other hand, as expected, turbidity was negatively correlated with water transparency $(R h o=-0.88)$ and positively with total dissolved solids $(R h o=0.31)$, and with monthly rainfall $(R h o=0.33)$. 
Table 2. Average and standard deviation (SD) of environmental variables in the studied reservoirs.

\begin{tabular}{ccccccccccc}
\hline Variable & & $\mathrm{Temp}^{1}\left({ }^{\circ} \mathrm{C}\right)$ & $\mathrm{DO}^{2}\left(\mathrm{mg} \mathrm{L}^{-1}\right)$ & $\mathrm{pH}$ & $\mathrm{Turb}^{3}(\mathrm{NTU})$ & $\mathrm{TDS}^{4}\left(\mathrm{mg} \mathrm{L}^{-1}\right)$ & $\mathrm{SD}^{5}(\mathrm{~m})$ & $\mathrm{EC}^{6}\left(\mu \mathrm{cm}^{-1}\right)$ & $\mathrm{Chl}^{-} a^{7}\left(\mu \mathrm{L} \mathrm{L}^{-1}\right)$ \\
\hline Tocos & average & 21.9 & 7.86 & 7.00 & 8.59 & 11.00 & 1.20 & 26.63 & 0.57 \\
$(\mathrm{~N}=3)$ & $\mathrm{SD}$ & 4.2 & 1.68 & 1.04 & 6.20 & 0.00 & 0.35 & 2.82 & 0.40 \\
\hline Ribeirão das Lajes & average & 24.6 & 7.00 & 7.12 & 6.59 & 13.61 & 2.07 & 28.60 & 2.43 \\
$(\mathrm{~N}=80)$ & $\mathrm{SD}$ & 3.7 & 1.32 & 0.56 & 10.07 & 4.22 & 1.10 & 4.75 & 2.15 \\
\hline Santana & average & 25.1 & 4.99 & 7.37 & 26.03 & 36.89 & 0.80 & 81.21 & 2.31 \\
$(\mathrm{~N}=10)$ & $\mathrm{SD}$ & 3.3 & 2.06 & 0.71 & 17.66 & 4.34 & 0.36 & 8.22 & 1.01 \\
\hline Vigário & average & 24.8 & 5.80 & 7.35 & 27.55 & 37.11 & 0.65 & 84.38 & 1.94 \\
$(\mathrm{~N}=10)$ & $\mathrm{SD}$ & 3.1 & 0.92 & 0.39 & 22.75 & 5.16 & 0.30 & 13.75 & 1.58 \\
\hline Ponte Coberta & average & 25.6 & 7.31 & 7.29 & 18.89 & 38.50 & 0.91 & 80.63 & 1.90 \\
$(\mathrm{~N}=6)$ & $\mathrm{SD}$ & 3.6 & 1.03 & 0.18 & 14.88 & 9.09 & 0.44 & 14.21 & 1.40 \\
\hline Santa Branca & average & 25.8 & 6.24 & 6.96 & 4.35 & 18.33 & 2.31 & 36.08 & \\
(N=12) & SD & 4.2 & 1.15 & 1.21 & 4.49 & 4.83 & 0.84 & 5.27 & 1.30 \\
\hline
\end{tabular}

${ }^{1}$ temperature, ${ }^{2}$ dissolved oxygen, ${ }^{3}$ turbidity, ${ }^{4}$ total dissolved solids, ${ }^{5}$ transparency, ${ }^{6}$ electrical conductivity, ${ }^{7}$ chlorophyll- $a$. N= number of samples.

Ponte Coberta and Tocos reservoirs presented higher glyphosate concentrations during the rainy period, when turbidity was also higher. The plausible explanation for this is that during the rainy period the soil runoff is more intense, dragging soil and consequently glyphosate into the water, increasing in this way the concentration of the herbicide in both reservoirs during this season.

Despite a low correlation between daily rainfall and glyphosate, the positive correlation between glyphosate and turbidity suggests an indirect relation between rainfall and the herbicide. This variable is one of the most monitored along the river basins, since several uses of the water depend on its value. The increase in turbidity in tropical rivers during rainfall, associated with the draining of the surroundings areas' soil into the aquatic systems is well recognized (Branco et al., 2019), making it possible to associate this draining with the carriage of glyphosate into the water. 


\section{CONCLUSIONS}

The ion chromatography used in this study allowed the quantification of glyphosate in the water of reservoirs, with the advantage of eliminating any prior treatment, resulting in time gain and low waste generation.

We expected a greater possibility of finding the presence of glyphosate in reservoirs under greater anthropic influence and trophic conditions, but our results showed that regardless the size of the reservoir or its anthropic influences and trophic condition, the presence of glyphosate was detected. The constant presence of glyphosate in water is evidence of the frequent use of this herbicide throughout the reservoirs' river basins and corroborates how human activities can influence and impact aquatic ecosystems. This fact highlights the need for continuous monitoring to obtain a more accurate view of the emission sources and their control, since environmental standards levels for glyphosate in water have been exceeded.

Due to the ubiquity of glyphosate use in countries of South America, such as Argentina and Brazil, the need for laboratory experiments to explore the pathways of degradation of this herbicide in tropical and subtropical aquatic environments and its effects on resident flora and fauna are preeminent and unpostponable. This is especially true in cases like those reported here, where the water stored in reservoirs is not only used for generating electricity but also for providing water supply to households, fishing activities and farming.

\section{ACKNOWLEDGEMENTS}

The authors would like to thank Light Energia S.A. for field support in data acquisition and all the people involved in the monitoring programs in the six reservoirs of this study. The authors are grateful to Prof. Dr. Ira Mark Brinn for English revision and to anonymous reviewers for valuable comments that have significantly improved the manuscript.

\section{REFERENCES}

ABREU, A. B. G.; MATTA, M. H. de R.; MONTAGNER, E. Desenvolvimento e validação de método de análise de glifosato em grãos de soja. Química Nova, v. 31, n. 1, p. 5-9, 2008. https://doi.org/10.1590/S0100-40422008000100002

APARICIO, V. C.; De GERÓNIMO, E.; MARINO D.; PRIMOST, J.; CARRIQUIRIBORDE, P.; COSTA, J. L. Environmental fate of glyphosate and aminomethylphosphonic acid in surface waters and soil of agricultural basins. Chemosphere, v. 93, n. 9, p. 1866-1873, 2013. https://doi.org/10.1016/j.chemosphere.2013.06.041

BERMAN, M. C.; MARINO, D. J. G.; QUIROGA, M. V.; ZAGARESE, H. Occurrence and levels of glyphosate and AMPA in shallow lakes from the Pampean and Patagonian regions of Argentina. Chemosphere, v. 200, p. 513-522, 2018. https://doi.org/10.1016/j.chemosphere.2018.02.103

BORGGAARD, O. K.; GIMSING, A. L. Fate of glyphosate in soil and the possibility of leaching to ground and surface waters: a review. Pest Management Science, v. 64, p. 441-456, 2008. https://doi.org/10.1002/ps.1512

BRANCO, C. W. C.; LEAL, J. J. F.; HUSZAR, V. L. M.; FARIAS, D. S., SAINT'PIERRE; T. D.; SOUSA-FILHO, I. F.; KOZLOWSKY-SUZUKI, B. New lake in a changing world: The construction and filling of a small hydropower reservoir in the tropics (Rio de Janeiro. Brazil). Environmental Science and Pollution Research, v. 26, p. 36007-36022, 2019. https://doi.org/10.1007/s1135 6-019-06665-y 
BROGAN, W. R.; RELYEA, R. A. Mitigating with macrophytes: Submersed plants reduce the toxicity of pesticide-contaminated water to zooplankton. Environmental Toxicology and Chemistry, v. 32, n. 3, p. 699-706, 2013. https://doi.org/10.1002/etc.2080

CATRINCK, T. C. P. G.; DIAS, A.; AGUIAR, M. C. S.; SILVÉRIO, F. O.; FIDÊNCIO, P. H.; PINHO, G. P. A simple and efficient method for derivatization of glyphosate and AMPA using 9-fluorenylmethyl chloroformate and spectrophotometric analysis. Journal of the Brazilian Chemical Society, v. 25, n. 7, p. 1194-1199, 2014. https://doi.org/10.5935/0103-5053.20140096

CONAMA (Brasil). Resolução n 357 de 17 de março de 2005. Dispõe sobre a classificação dos corpos de água e diretrizes ambientais para o seu enquadramento, bem como estabelece as condições e padrões de lançamento de efluentes, e dá outras providências. Diário Oficial [da] União: seção 1, Brasília, DF, n. 053, p. 58-63, 18 mar. 2005.

CORREIA, N. M.; CARBONARI, C. A.; VELINI, E. D. Detection of herbicides in water bodies of the Samambaia River sub-basin in the Federal District and eastern Goiás. Journal Environmental Science and Health, Part B, v. 55, n. 6, p. 574-582, 2020. https://doi.org/10.1080/03601234.2020.1742000

CUHRA, M.; TRAAVIK, T.; BØHN, T. Clone- and age-dependent toxicity of a glyphosate commercial formulation and its active ingredient in Daphnia magna. Ecotoxicology, v. 22, n. 2, p. 251-262, 2013. https://doi.org/10.1007/s10646-012-1021-1

EUROPEAN COUNCIL. Council Directive 98/83/EC on the quality of water intended for human consumption. Official Journal of the European Communities, L330, p. 32-54. 1998.

FOLMAR, L. C.; SANDERS, H. O.; JULIN, A. M. Toxicity of the herbicide glyphosate and several of its formulations to fish and aquatic invertebrates. Archives of Environmental $\begin{array}{llllllll}\text { Contamination and Toxicology, v. } & \text { 8, n. } 3, & \text { p. 269-278, } & 1979 .\end{array}$ https://doi.org/10.1007/BF01056243

FOUODJOUO, M.; LAMINSI, S.; KAMGANG, G. Y.; MENGUE, M. T.; DEBACHER, N. A. A non-thermal plasma induced total mineralization of glyphosate in water in the presence of iron II ions. Journal of the Brazilian Chemical Society, v. 26, n. 3, p. 411419, 2015. https://doi.org/10.5935/0103-5053.20140292

GEYER, R. L.; SMITH, G. R.; RETTIG, J. E. Effects of Roundup formulations, nutrient addition, and Western mosquitofish (Gambusia affinis) on aquatic communities. Environmental Science and Pollution Research, v. 23, n. 12, p. 11729-11739, 2016. https://doi.org/10.1007/s11356-016-6381-2

HANKE, I.; WITTMER, I.; BISCHOFBERGER, S.; STAMM, C.; SINGER, H. Relevance of urban glyphosate use for surface water quality. Chemosphere, v. 81, n. 3, p. 422-429, 2010. https://doi.org/10.1016/j.chemosphere.2010.06.067

HERNÁNDEZ-GARCÍA C. I.; MARTÍNEZ-JERÓNIMO F. Multistressor negative effects on an experimental phytoplankton community. The case of glyphosate and one toxigenic cyanobacterium on Chlorophycean microalgae. Science of the Total Environment, v. 717, p. 137186, 2020. https://doi.org/10.1016/j.scitotenv.2020.137186

IMOTO, M. N.; FREITAS, R. J. Determinação dos Limites de Detecção (Ld) e Quantificação (LQ) em Análise de Resíduos de Pesticidas Organohalogenados por Cromatografia em Fase Gasosa. Pesticidas: Revista de Ecotoxicologia e Meio Ambiente, v. 18, p. 35-44, 2008. 
INTERNATIONAL AGENCY FOR RESEARCH ON CANCER. Biennial Report 20142015. Lyon, 2015. https://doi.org/978-92-832-0430-5

KLIPPEL, G.; MACÊDO, R. L.; BRANCO, C. W. C. Comparison of different trophic state indices applied to tropical reservoirs. Lakes \& Reservoirs Research \& Management, v. 5, n. 2, p. 214-229, 2020. https://doi.org/10.1111/lre.12320

LAMBROPOULOU, D. A.; ALBANIS, T. A. Liquid-phase micro-extraction techniques in pesticide residue analysis. Journal of Biochemical and Biophysical Methods, v. 70, n. 2, p. 195-228, 2007. https://doi.org/10.1016/j.jbbm.2006.10.004

LOZANO, V. L.; VINOCUR, A.; SABIO Y GARCÍA, C. A.; ALLENDE, L.; CRISTOS, D. S.; ROJAS, D.; PIZARRO, H. Effects of glyphosate and 2,4-D mixture on freshwater phytoplankton and periphyton communities: a microcosms approach. Ecotoxicology and $\begin{array}{llllll}\text { Environmental Safety, } & \text { v. } 148, \quad \text { p. }\end{array}$ https://doi.org/10.1016/j.ecoenv.2017.12.006

MALLAT, E.; BARCELO, D. Analysis and degradation study of glyphosate and of aminomethylphosphonic acid in natural waters by means of polymeric and ion exchange solid-phase extraction columns followed by ion chromatography-post column derivatization with fluorescence detection. Journal of Chromatography A, v. 823, n. 12, p. 129-136, 1998. https://doi.org/10.1016/S0021-9673(98)00362-8

MESNAGE, R.; DEFARGE, N.; SPIROUX DE VENDÔMOIS, J.; SÉRALINI, G. E. Potential toxic effects of glyphosate and its commercial formulations below regulatory limits. Food

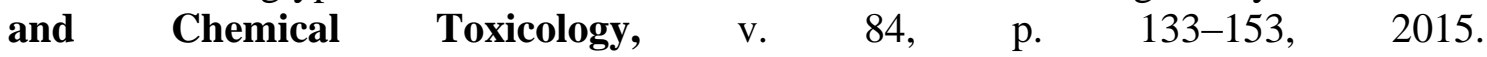
https://doi.org/10.1016/j.fct.2015.08.012

MOORE, L. J.; FUENTES, L.; RODGERS, J. H.; BOWERMAN, W. W.; YARROW, G. K.; CHAO, W. Y.; BRIDGES, W. C. Relative toxicity of the components of the original formulation of Roundup ${ }^{\circledR}$ to five North American anurans. Ecotoxicology and $\begin{array}{llllll}\text { Environmental Safety, } & \text { v. } & \text { 78, } & \text { p. }\end{array}$ https://doi.org/10.1016/j.ecoenv.2011.11.025

MOORE, M. T.; LOCKE, M. A.; KRÖGER, R. Mitigation of atrazine, S-metolachlor, and diazinon using common emergent aquatic vegetation. Journal of Environmental Sciences, v. 56, p. 114-121, 2017. https://doi.org/10.1016/j.jes.2016.09.009

NEVISON, C. D. A comparison of temporal trends in United States autism prevalence to trends in suspected environmental factors. Environmental Health: A Global Access Science Source, v. 13, n. 1, p. 1-16, 2014. https://doi.org/10.1186/1476-069X-13-73

OKADA, E.; COGGAN, T.; ANUMOL, T.; CLARKE, B.; ALLINSON, G. A simple and rapid direct injection method for the determination of glyphosate and AMPA in environmental water samples. Analytical and Bioanalytical Chemistry, 411, p. 715-724, 2018. https://doi.org/10.1007/s00216-018-1490-z

PÉREZ, G. L.; VERA, M. S.; MIRANDA, L. A. Effects of Herbicide Glyphosate and Glyphosate-Based Formulations on Aquatic Ecosystems. In: KORTEKAMP, A. (ed.). Herbicides and the Environment. London: InTechOpen, 2011. p. 343-368. https://doi.org/10.5772/12877

PERUZZO, P. J.; PORTA, A. A.; RONCO, A. E. Levels of glyphosate in surface waters, sediments and soils associated with direct sowing soybean cultivation in north pampasic region of Argentina. Environmental Pollution, v. 156, p. 61-66, 2008. https://doi.org/10.1016/j.envpol.2008.01.015 
PIRES, N. L.; PASSOS, C. J. S.; MORGADO, M. G. A.; MELLO, D. C.; INFANTE, C. M. C.; CALDAS, E. D. Determination of glyphosate, AMPA and glufosinate by high performance liquid chromatography with fluorescence detection in waters of the Santarém Plateau, Brazilian Amazon. Journal of Environmental Science and Health, Part B, v. 55, n. 9, p. 794-802, 2020. https://doi.org/10.1080/03601234.2020.1784668

PITELLI, R. L. C. M.; TOFFANELI, C. M.; VIEIRA, E. A.; PITELLI, R. A.; VELINI, E. D. Dynamics of the Aquatic Macrophyte community in the Santana Reservoir in Pirai-RJ. Planta Daninha, v. 26, n. 3, p. 473-480, 2008. https://doi.org/10.1590/S010083582008000300001

RELYEA, R. A. New effects of Roundup on amphibians: Predators reduce herbicide mortality ; herbicides induce antipredator morphology. Ecological Applications, v. 22, n. 2, p. 634 647, 2012. https://doi.org/10.1890/11-0189.1

RIBANI, M.; BOTTOLI, C. B. G. B.; COLLINS, C. H.; JARDIM, I. C. S. F.; MELO, L. F. C. Validação em métodos cromatográficos e eletroforéticos. Química Nova, v. 27, n. 5, p. 771-780, 2004. https://doi.org/10.1016/j.msec.2014.12.030

RICO-MARTÍNEZ, R.; ARIAS-ALMEIDA, J. C.; PÉREZ-LEGASPI, I. A.; ALVARADOFLORES, J.; RETES-PRUNEDA, J. L. Adverse Effects of Herbicides on Freshwater Zooplankton. In: HASANEEN, M. N. (ed.). Herbicides-Properties, Synthesis and Control of Weeds. London: InTechOpen, 2012. p. 405-434.

RONCO, A. E.; MARINO, D. J. G.; ABELANDO, M.; ALMADA, P.; APARTIN, C. D. Water quality of the main tributaries of the Paraná Basin: glyphosate and AMPA in surface water and bottom sediments. Environmental Monitoring and Assessment, v. 188, n. 8, 2016. https://doi.org/10.1007/s10661-016-5467-0

ROUSTAN, A.; AYE, M.; DE MEO, M.; DI GIORGIO, C. Genotoxicity of mixtures of glyphosate and atrazine and their environmental transformation products before and after $\begin{array}{llllll}\text { photoactivation. Chemosphere, v. 108, p. 93-100, } 2014 . & \end{array}$ https://doi.org/10.1016/j.chemosphere.2014.02.079

SAMSEL, A.; SENEFF, S. Glyphosate's Suppression of Cytochrome P450 Enzymes and Amino Acid Biosynthesis by the Gut Microbiome: Pathways to Modern Diseases. Entropy, Basel, v. 15, n. 4, p. 1416-1463, 2013. https://doi.org/10.3390/e15041416

SCHRÜBBERS, L. C.; VALVERDE, B. E.; SØRENSEN, J. C.; CEDERGREEN, N. Glyphosate spray drift in Coffea arabica - Sensitivity of coffee plants and possible use of shikimic acid as a biomarker for glyphosate exposure. Pesticide Biochemistry and Physiology, v. 115, p. 15-22, 2014. https://doi.org/10.1016/j.pestbp.2014.08.003

SOARES, M. C. S.; HUSZAR, V. L. M.; MIRANDA, M. N.; MELLO, M. M.; ROLAND, F.; LÜRLING, M. Cyanobacterial dominance in Brazil: Distribution and environmental preferences. Hydrobiologia, v. 717, n. 1, p. 1-12, 2013. https://doi.org/10.1007/s10750013-1562-1

TUHRAN, D. Ö.; GÜNGÖRDÜ, A.; OZMEN, M. Developmental and lethal effects of glyphosate and a glyphosate-based product on Xenopus laevis embryos and tadpoles. Bulletin of Environmental Contamination and Toxicology, n. 104, p. 173-179, 2020. https://doi.org/10.1007/s00128-019-02774-z 
VAJARGAH, M. F.; YALSUYI, A. M.; SATTARI, M.; HEDAYATI, A. Acute toxicity effect of glyphosate on survival rate of common carp, Cyprinus carpio. Environmental Health Engineering and Management Journal, v. 5, n. 2, p. 61-66, 2018. https://doi.org/10.15171/EHEM.2018.09

ZHU, Y.; ZHANG, F.; TONG, C.; LIU, W. Determination of glyphosate by ion chromatography, Journal of Chromatography A, v. 850, p. 297-301, 1999. 


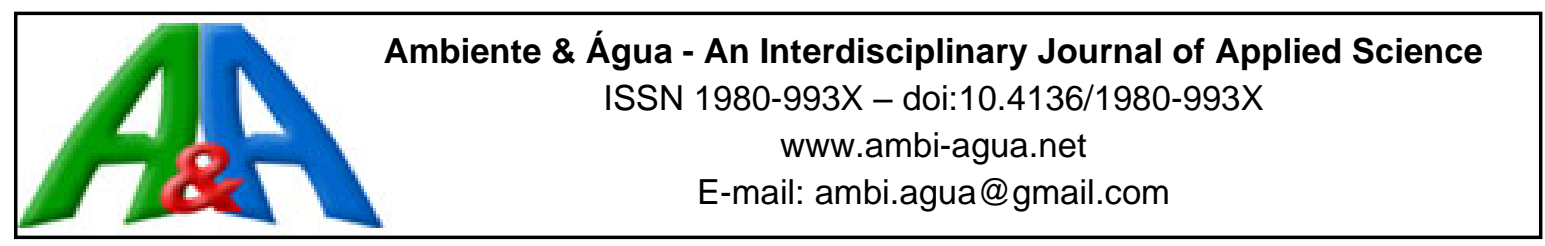

\title{
Hydrological modeling in a basin of the Brazilian Cerrado biome
}

\author{
ARTICLES doi:10.4136/ambi-agua.2639
}

Received: 03 Sep. 2020; Accepted: 18 Dec. 2020

\author{
Jéssica Assaid Martins Rodrigues ${ }^{*}{ }^{*}$; Alberto Carlos de Oliveira Andrade ${ }^{1}$ iD; \\ Marcelo Ribeiro Viola ${ }^{1}$; Danton Diego Ferreira ${ }^{2}$; \\ Carlos Rogério de Mello1 ${ }^{1}$; Michael Silveira Thebaldi ${ }^{1}$ \\ ${ }^{1}$ Departamento de Recursos Hídricos. Universidade Federal de Lavras (UFLA), Caixa Postal 3037, \\ CEP: 37200-900, Lavras, MG, Brazil. E-mail: alberto.ufla@gmail.com, \\ marcelo.viola@ufla.br, crmello@ufla.br,michael.thebaldi@ufla.br \\ ${ }^{2}$ Departamento de Automática. Universidade Federal de Lavras (UFLA), Caixa Postal 3037, \\ CEP: 37200-900, Lavras, MG, Brazil. E-mail: danton@ufla.br \\ *Corresponding author. E-mail: je_assaid@yahoo.com.br
}

\begin{abstract}
The Brazilian Cerrado biome (BCB) is among 25 biodiversity hotspots identified worldwide, and covers the recharge area of important aquifers and rivers in South America. The increase in deforestation has been threatening water availability in this region. In order to assist in the water-resource management of the BCB, this study models the daily streamflow in a basin of the Cerrado, using two approaches: a process-based model (Soil and Water Assessment Tool - SWAT) and the data-driven model (Artificial Neural Network - ANN). The performance of the models was evaluated by the Nash-Sutcliffe coefficient (NSE), coefficient of determination $\left(\mathrm{R}^{2}\right)$ and flow-duration-curves (FDC). The results indicate that SWAT (NSE $\left.>0.61 ; \mathrm{R}^{2}>0.68\right)$ and ANN (NSE > 0.91; $\left.\mathrm{R}^{2}>0.79\right)$ models are suitable tools in daily streamflow modeling of the studied basin, with the ANN model being the most accurate. Based on FDC, the ANN model was also better than the SWAT model for all frequencies evaluated. Thus, the ANN model is a promising new approach for daily streamflow modelling in this region. Moreover, the results of this study can help water-resource managers in planning and implementing appropriate water allocation and conservation measures in the Brazilian Cerrado biome.
\end{abstract}

Keywords: brazilian savannah, hydrologic model, water resources.

\section{Modelagem hidrológica em uma bacia do bioma Cerrado brasileiro}

\section{RESUMO}

O bioma Cerrado brasileiro (BCB) está entre os 25 hotspots de biodiversidade identificados em todo o mundo, e abrange a área de recarga de importantes aquíf́eros e rios da América do Sul. O aumento do desmatamento vem ameaçando a disponibilidade de água na região. A fim de auxiliar na gestão dos recursos hídricos da BCB, este estudo tem como objetivo modelar a vazão diária em uma bacia do Cerrado, utilizando duas abordagens: um modelo baseado em processo (Soil and Water Assessment Tool - SWAT) e um modelo orientado por dados (Artificial Neural Network - ANN). O desempenho dos modelos foi avaliado pelo coeficiente de Nash-Sutcliffe (NSE), coeficiente de determinação $\left(\mathrm{R}^{2}\right)$ e curvas de duração de 
fluxo (FDC). Os resultados indicam que os modelos SWAT (NSE $\left.>0,61 ; \mathrm{R}^{2}>0,68\right)$ e ANN (NSE > 0,91; $\left.\mathrm{R}^{2}>0,79\right)$ são ferramentas adequadas na modelagem diária de vazões da bacia estudada, sendo o modelo ANN o mais preciso. Com base no FDC, o modelo ANN também foi melhor do que o modelo SWAT para todas as frequências avaliadas. Assim, o modelo ANN é uma nova abordagem promissora para modelagem de fluxo diário nesta região. Além disso, os resultados deste estudo podem ajudar os gestores de recursos hídricos no planejamento e implementação de medidas adequadas de alocação e conservação de água no bioma Cerrado brasileiro.

Palavras-chave: modelo hidrológico, recursos hídricos, savana brasileira.

\section{INTRODUCTION}

The Brazilian Cerrado biome is one of the most important areas in South America, covering the recharge areas of important aquifers and rivers, and approximately 204 million ha, which corresponds to 24\% of Brazil (Medrado and Lima, 2014); it is recognized as the "cradle of Brazil's water" (Lima, 2011). Besides that, the Brazilian Cerrado biome is one of 25 biodiversity hotspots in the world, with high biological and endemic diversity, has suffered loss of vegetation due to agriculture and pasture expansion (Silva et al. 2006), which has resulting in a large number of endangered species (Myers et al., 2000; Rodrigues et al., 2020). These agriculture and pasture expansions also threaten the stream flows from watersheds (Silva and Bates, 2002); however, the understanding of their impacts on streamflow in the Cerrado biome is still limited (Beuchle et al. 2015). Improving the knowledge base on hydrological modeling in the Cerrado biome is therefore important for water-resource management, since it allows the quantification of current and future water availability, which is essential to ensure water security and economic development.

Hydrological models provide a representation of the processes in the hydrological cycle of a basin and help in understanding, predicting and managing water resources (Devia et al., 2015). Among the various hydrological models that have been developed, the Soil and Water Assessment Tools (SWAT) model is one of the most applied for simulating at basin-scale around the world. SWAT is a semi-conceptual and semi-distributed hydrological model developed by the Agricultural Research Service (ARS/USA) and Texas A\&M University in the early 1990s (Arnold et al., 1998). The SWAT has been used to predict streamflow time series, hydrological processes, water balance, and for evaluating the impacts of climate change, landuse change, and different management practices on the surface hydrological cycle, sediment yield, water quality (Abbaspour et al. 2007). Many researchers have applied the SWAT model for different basins. Pontes et al. (2016) applied the SWAT hydrological model to estimate daily and monthly discharges for the Camanducaia River Basin, Brazil, and to evaluate the performance of these calibrations in a contiguous drainage basin. Monteiro et al. (2015) used two precipitation grids, CFSR (Climate Forecast System Reanalysis) and WFDEI (WATCH Forcing Data methodology applied to ERA-Interim), as inputs to a SWAT model for river discharge simulation in the Tocantins catchment, Brazil. Choubin et al. (2019) compared the SWAT and Identification of Hydrographs and Components from Rainfall, Evaporation, and Stream (IHACRES) models in the streamflow regionalization for the Karkheh River Basin, Iran. Rodrigues et al. (2020) applied a SWAT model to simulate the monthly streamflow for three basins of the Brazilian Cerrado biome. Alvarenga et al. (2020) compared the SWAT and Variable Infiltration Capacity (VIC) models in the monthly streamflow simulation for the Verde River Watershed, located in the Minas Gerais state in southern Brazil. However, despite the wide use of the SWAT model, it requires a large amount of temporal and spatial data, maps, and input parameters, that are sometimes hard to predict (Makwana and Tiwari, 2014). 
Therefore, it is not applicable (or presents a worse performance) to basins in which input data for hydrological modeling are not available (Yaseen et al., 2019). This is the case of most of the Brazilian Cerrado biome basins where there is a significant lack of data (Nóbrega et al., 2017).

An alternative to conceptual models is the Artificial Neural Network (ANN), which is an empirical model capable of learning nonlinear relationships between the variables of a process, and relating inputs and outputs without the need of a detailed understanding of its physical characteristics. This feature makes ANN an effective tool for modeling complex hydrological processes (Talebizadeh and Moridnejad, 2011). Thus, ANN has been widely applied to solve several water-resource problems, and it was found to be a powerful tool for streamflow simulation (Aichouri et al., 2015). Kothari and Gharde (2015) applied ANN for the streamflow modeling of Savitri catchment, India. Zhou et al. (2018) forecasted the monthly streamflow of the Jinsha River by using three (ANN) architectures: extreme learning machine, radial basis function network, and Elman network. Vilanova et al. (2019) applied ANN to simulate daily streamflows for Brazilian Atlantic Rainforest basins. Papalaskaris (2020) applied ANN for the daily low streamflows forecast of Iokastis Stream, Kavala City, NE Greece, NE Mediterranean Basin. However, no study has applied the ANN model to simulate streamflow in basins of the Brazilian Cerrado biome.

The implementation of models with different approaches to the same problem allows exploring the advantages and disadvantages of the models and finding the best and most efficient structure for a given region. Few studies have compared SWAT and ANN models for streamflow estimation (Tan et al., 2020). Demirel et al. (2009) assessed the performance of SWAT and ANN models for the daily flow forecasting in the Pracana Basin, Portugal, and determined that the ANN model yielded the highest accuracy ratio. Noori and Kalin (2016) assessed the performance of SWAT and ANN models for the daily runoff simulation in the Gwinnett and Atlanta watersheds, and determined that the ANN model showed the better performance. Jimeno-Saiez et al. (2018) assessed the performance of SWAT and ANN models for daily streamflows simulation in different climatic zones of Peninsular Spain, and reported that ANN model had performed better for maximum values and for minimum values the SWAT model performance had been better. To the best of our knowledge, there is no study regarding streamflow estimation by comparing the SWAT and ANN in a Brazilian basin. Thus, such assessment is still limited in the literature, and therefore requires more investigation.

In this context, in order to assist in the water-resource management of the Cerrado biome, this study assesses the suitability of the SWAT and ANN models to simulate the daily streamflow in the Manuel Alves da Natividade River Basin (MRB), located in the Brazilian Cerrado biome, and compares their performances to determine which is more appropriate for the studied basin. The MRB was selected based on the great importance that it represents, since it serves several hydroelectric projects, and one of the major irrigation projects in Brazil, the Manuel Alves irrigation project, is installed on it (Tocantins, 2012). This study will provide a basis for the use of local and public administrations in improving a successful basin management strategy in the MRB. It will also help spread the research to different regions of the world.

\section{MATERIALS AND METHODS}

\subsection{Study area}

The Manuel Alves da Natividade River Basin (MRB) has a drainage area of 14,344 $\mathrm{km}^{2}$ (Figure 1) and is one of the main sub-basins of the Tocantins-Araguaia River Basin (TARB), which in turn is the largest basin entirely inserted in the Brazilian territory. The MRB is fully inserted in the Cerrado biome, and the streamflow produced by it directly feeds the Luís Eduardo Magalhães hydropower plant, with an installed capacity of 903 MW (ONS, 2020), 
corresponding to $25 \%$ of its incremental contributing area. It also feeds the Manuel Alves irrigation project, with an irrigable area of 20 thousand hectares, which is one of the major irrigation projects in Brazil (Tocantins, 2012). The MRB is located in southeastern Tocantins state, north Brazil, between latitude $11^{\circ} 09^{\prime} 45^{\prime \prime}$ to $12^{\circ} 14 ' 54^{\prime \prime} S$ and longitude $46^{\circ} 33^{\prime} 04^{\prime \prime}$ to $48^{\circ} 18^{\prime} 40^{\prime \prime} \mathrm{W}$, and is limited by the basins of the Rivers Palma from south, Balsas from north, Tocantins from west and São Francisco from east.

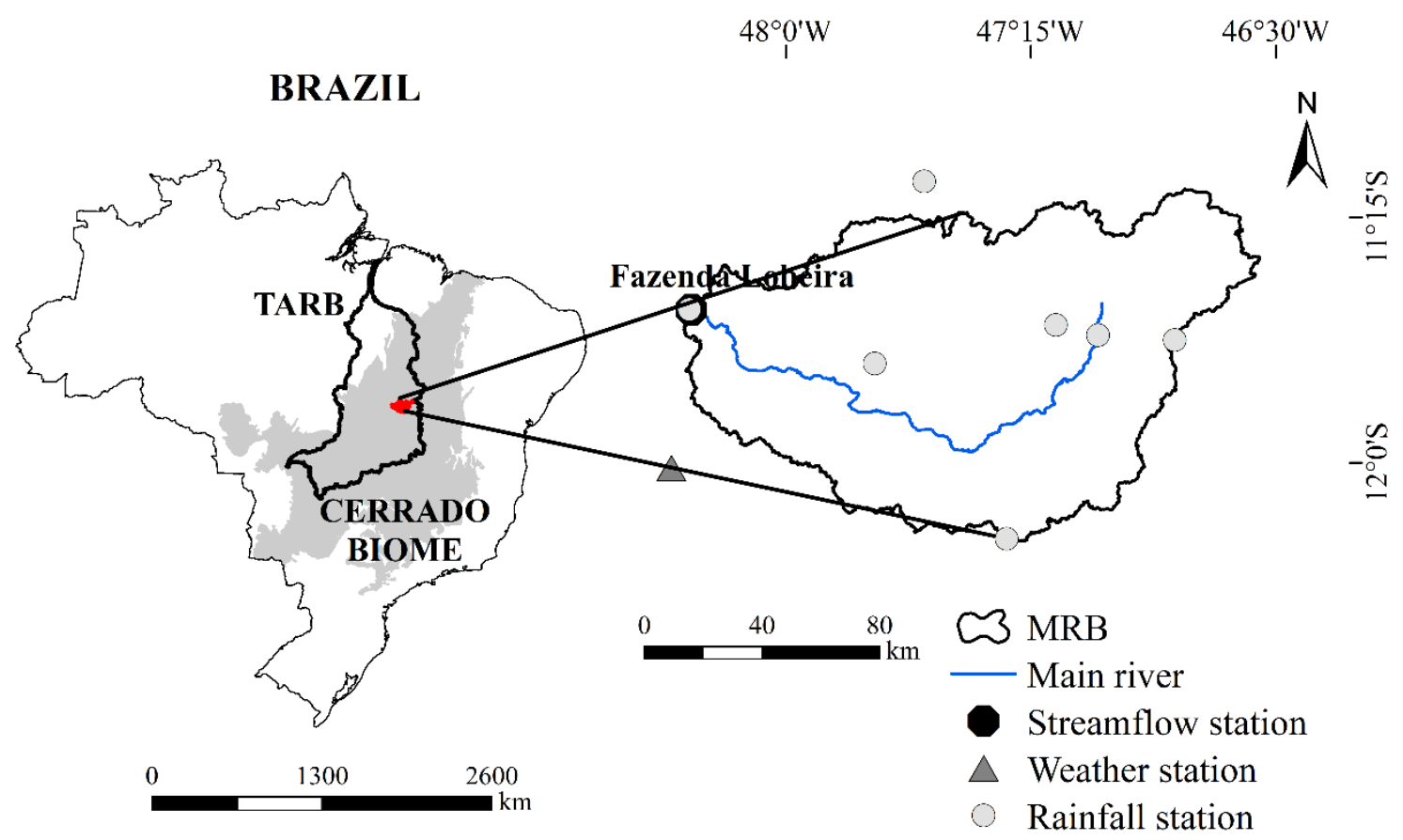

Figure 1. Location of the Manuel Alves da Natividade River Basin and monitoring stations.

According to the Köppen classification, the basin climate is Aw (tropical savanna), characterized by a rainy summer and dry winter (Kottek et al., 2006). The average annual precipitation is $1500 \mathrm{~mm}$ and the average annual temperature is $25^{\circ} \mathrm{C}$.

\subsection{Soil and Water Assessment Tool (SWAT)}

The SWAT is a physically based semi-distributed hydrological model, free of charge, available at (http://swat.tamu.edu/), and widely used across the world. To execute the model, various inputs are required, such as hydrometeorological data, soil and land-use maps and a digital elevation model (DEM) in the basin. The SWAT model divides the basin into multiple sub-basins based on the river network and topography. Each sub-basin is further divided into Hydrologic Response Units (HRU), which consist of unique combinations of soil class, land use and slope (Arnold et al., 1998). SWAT simulations are based on water balance, are performed for each HRU and are accumulated to obtain the total for the sub-basins and basin. Equation 1 describes the water balance adopted by the SWAT model.

$$
\mathrm{SW}_{\mathrm{t}}=\mathrm{SW}_{0}+\sum_{\mathrm{i}=1}^{\mathrm{n}}\left(\mathrm{R}_{\text {day }}-\mathrm{Q}_{\text {surf }}-\mathrm{E}_{\mathrm{a}}-\mathrm{W}_{\text {seep }}-\mathrm{Q}_{\mathrm{gw}}\right)
$$

Where SWt is the final amount of soil water for the day $(\mathrm{mm}), \mathrm{SW}_{0}$ is the initial amount of soil water for the day ( $\mathrm{mm}$ ), $R_{\text {day }}$ is the total rainfall for the day $(\mathrm{mm}), Q_{\text {surf }}$ is the surface runoff for the day $(\mathrm{mm}), \mathrm{E}_{\mathrm{a}}$ is the evapotranspiration for the day $(\mathrm{mm}), \mathrm{W}_{\text {seep }}$ is the total amount of water that seeps through the base of the soil profile for the day $(\mathrm{mm})$, and $\mathrm{Q}_{\mathrm{gw}}$ is the groundwater flow for the day $(\mathrm{mm})$. For a detailed description of the SWAT model, refer to Arnold et al. (1998) and Neitsch et al. (2011). 
To perform the hydrological simulation, SWAT requires hydrometeorological data (rainfall, maximum and minimum air temperatures, solar radiation, relative humidity, and wind speed), and geospatial data, which include the digital elevation model (DEM), land-use map and soil map. For the MRB, daily hydrometeorological data were obtained from seven rainfall gauge stations and one weather station (Figure 1) in the Brazilian National Water Agency (ANA-Hidroweb) and the Meteorological Database for Education and Research (BDMEP) of the Brazilian National Institute of Meteorology (INMET). The ASTER DEM of the MRB (Figure 2a), with spatial resolution of $30 \mathrm{~m}$, was obtained from the USGS (United States Geological Survey), and showed elevations ranging from 197 to $960 \mathrm{~m}$. The land-use map of the MRB (Figure 2b) was provided by the Tocantins Planning and Budget Secretariat (SEPLAN) (Tocantins, 2012), and its land-use classes consist of Cerrado (79.24\%), Riparian Forest $(8,38 \%)$, Pasture (6.56\%), Amazon Forest (5.56\%), Water bodies (0.18\%), Urban Area $(0.04 \%)$, Agriculture $(0.02 \%)$ and bare soils $(0.02 \%)$. The soil map of the MRB (Figure $2 \mathrm{c}$ ) was obtained from the Brazilian Agricultural Research Corporation (EMBRAPA, 2011) at a 1:5,000,000 scale. The soil classes in the MRB are Red-Yellow Argisol (PVA; 52.85\%), Litholic Neosol (RL; 14.08\%), Red-Yellow Latosol (RYL; 10.69\%), Endopetric Plinthosol (FF; 8.46\%), Haplic Cambisol (CX; 5.04\%), Quartzarenic Neosol (RQ; 4.73\%), Yellow Latosol (LA; 2.16\%), Haplic Gleysol (GX; 1.24\%) and Haplic Plinthosol (FX; 0.75\%).

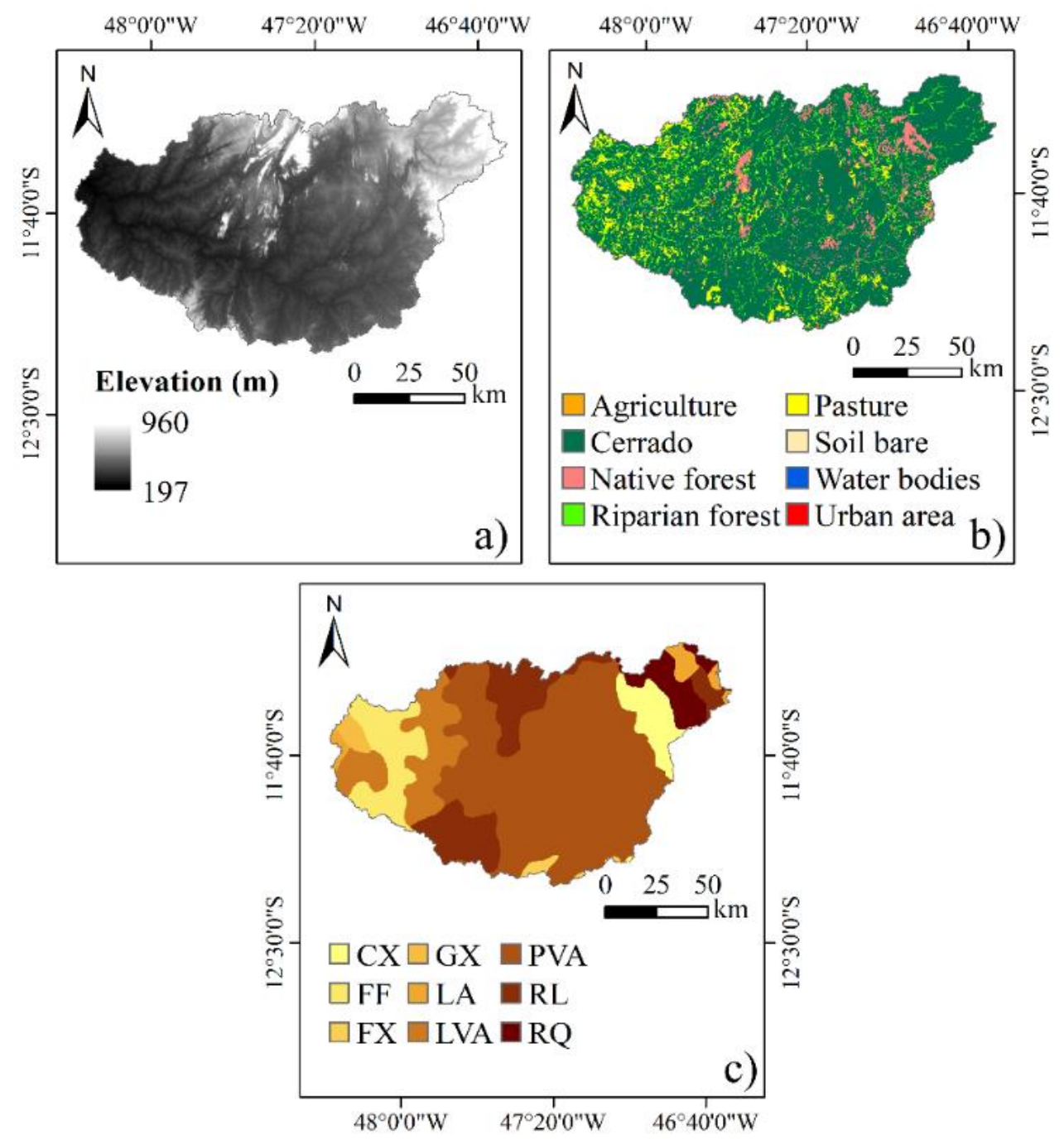

Figure 2. Digital elevation model (a), land use map (b) and soil map (c) of the Manuel Alves da Natividade River Basin. 
For the streamflow modeling, the SWAT model was set up for the period between 1983 and 2005 with daily precipitation, maximum and minimum temperature, solar radiation, wind speed and relative humidity data. The first three years were used as a warm-up period to reduce the uncertainties regarding the initial conditions of the surface domain (Mello et al., 2008). The period from 1986 to 1995 was used for calibration, whereas the period from 1996 to 2005 was used for validation.

The parameters used in calibration (Table 1) were selected based on previous studies conducted in the Cerrado biome, such as Oliveira et al. (2019), Rodrigues et al. (2020) and Amorim et al. (2020), and based on Latin Hypercube One-factor- At-a-Time sensitivity analysis (LH-OAT) method (Van Griensven et al., 2006). LH-OAT was applied using the SUFI2 algorithm in the SWAT-CUP software. Following sensitivity analysis, the daily streamflow calibration was performed manually by changing one parameter at a time, as performed by Nyeko (2015), Pereira et al. (2016) and Rodrigues et al. (2020), and the validation was performed updating the SWAT model with the parameters obtained in the calibration period.

Table 1. SWAT model parameters and their final calibrated values in the daily time step for the MRB.

\begin{tabular}{|c|c|c|}
\hline Parameters & Description & Calibrated value \\
\hline V_ESCO.hru & Soil water evaporation compensation coefficient & 0.500 \\
\hline R_CN2.mgt & Initial curve-number for moisture conditions II & -0.040 \\
\hline V_ALPHA_BF.gw & Baseflow recession coefficient (days) & 0.069 \\
\hline A_GW_DELAY.gw & Time interval for aquifer recharge (days) & 42.00 \\
\hline V_CANMX.hru & Maximum canopy storage (mm) & 28.00 \\
\hline V_CH_K2.rte & Effective hydraulic conductivity of the main channel $\left(\mathrm{mm} \cdot \mathrm{h}^{-1}\right)$ & 3.690 \\
\hline V_CH_N2.rte & Manning's number for the main channel & 0.056 \\
\hline V_GW_REVAP.gw & Water seepage coefficient for the unsaturated zone & 0.200 \\
\hline R_SOL_AWC ().sol & Soil water storage capacity $\left(\mathrm{mm}_{\text {water }} \cdot \mathrm{mm}_{\text {soil }}{ }^{-1}\right)$ & 0.230 \\
\hline R_SOL_K (). Sol & Saturated hydraulic conductivity $\left(\mathrm{mm} \cdot \mathrm{h}^{-1}\right)$ & -0.072 \\
\hline V_CH_N1.sub & Manning's number for the secondary channel & 0.520 \\
\hline V_CH_K1.sub & Effective hydraulic conductivity of the tributary channel $\left(\mathrm{mm} \cdot \mathrm{h}^{-1}\right)$ & 4.740 \\
\hline V_SLSOIL.hru & Slope length (m) & 17.629 \\
\hline V_LAT_TTIME.htm & Lateral flow propagation time (days) & 5.000 \\
\hline
\end{tabular}

Note: Prefixes "V," "R" and "A" correspond to the operations "replace by a given value," "relative - an existing parameter value is multiplied by" and "add to the existing parameter value," respectively.

\subsection{Artificial Neural Network (ANN)}

The ANN model is a data-driven mathematical model that was developed to imitate the structure of a human brain neural network and has been widely applied to solve water-resource problems (Minns and Hall, 1996). To execute the model, prior knowledge of the physical 
characteristics of the process is not required, only hydrological and meteorological data from the basin. The ANN model uses interconnected artificial neurons that receive input information $(\mathrm{x} 1, \mathrm{x} 2, \ldots, \mathrm{xn})$, perform operations and provide an output (y). Each connection between neurons (or synapse) has an associated intensity, expressed by a weight (w1, w2, .., wn). Each neuron determines an input value (net) through the sum of the products of the input weighted by respective values. The weights are the values that represent the degree of importance of each input to the neuron, obtained at the time of neural network training. Once the weight is determined, it becomes the activation value of the respective neuron. This value is a function of the input $(\mathrm{y}=\mathrm{f}(\mathrm{net}))$. An activation function precedes the transfer function and has the task of passing the signal obtained through the inputs to the transfer function (Haykin, 2007).

Multilayer perceptron (MLPs) ANN model has hidden layers, and according to Haykin (2007) they have three main characteristics: a) the model of each neuron has a non-linear activation function; b) the network has at least one hidden layer; and c) the network has a high degree of connectivity between its processing elements.

In this study, a feedforward neural network was defined with three layers: input, internal (or hidden) and output layers. This type of network is widely used in signal filtering, data compression, pattern recognition and inter-comparison of patterns. For this neural network, the hyperbolic tangent activation function (tansig) was used for the neurons of the middle layer; the linear activation function (purelin) for the output neuron; and the Bayesian approximation algorithm (trainbr) for network training (Haykin, 2007).

For structuring the MLP artificial neural network, 17 input nodes were used, referring to rainfall, maximum temperature, minimum temperature, solar radiation, potential evaporation, mean temperature, relative humidity, wind speed and streamflow of the previous day. To avoid polarization of the neural network and delays in the learning process, the input variables were normalized between -1 and 1 . For this purpose, each variable was divided by the absolute maximum value of the set of corresponding variables. Concerning the middle layer, the number of neurons ranged from 1 to 10 , and 30 replicates were generated for each neuron. Because the goal of the network was to model the streamflow of the MRB, only one neuron was used in the output layer. Figure 3 shows the MLP artificial neural network architectures analyzed.

To generate the MLP, the MATLAB ${ }^{\circledR}$ software was used, and to compare the results of the various neural models, Tukey's test (TSD - Tukey's Significant Difference) was applied to determine whether there was a significant difference (5\% significance level) between the mean Nash-Sutcliffe coefficients (NSE) (Tukey, 1949).

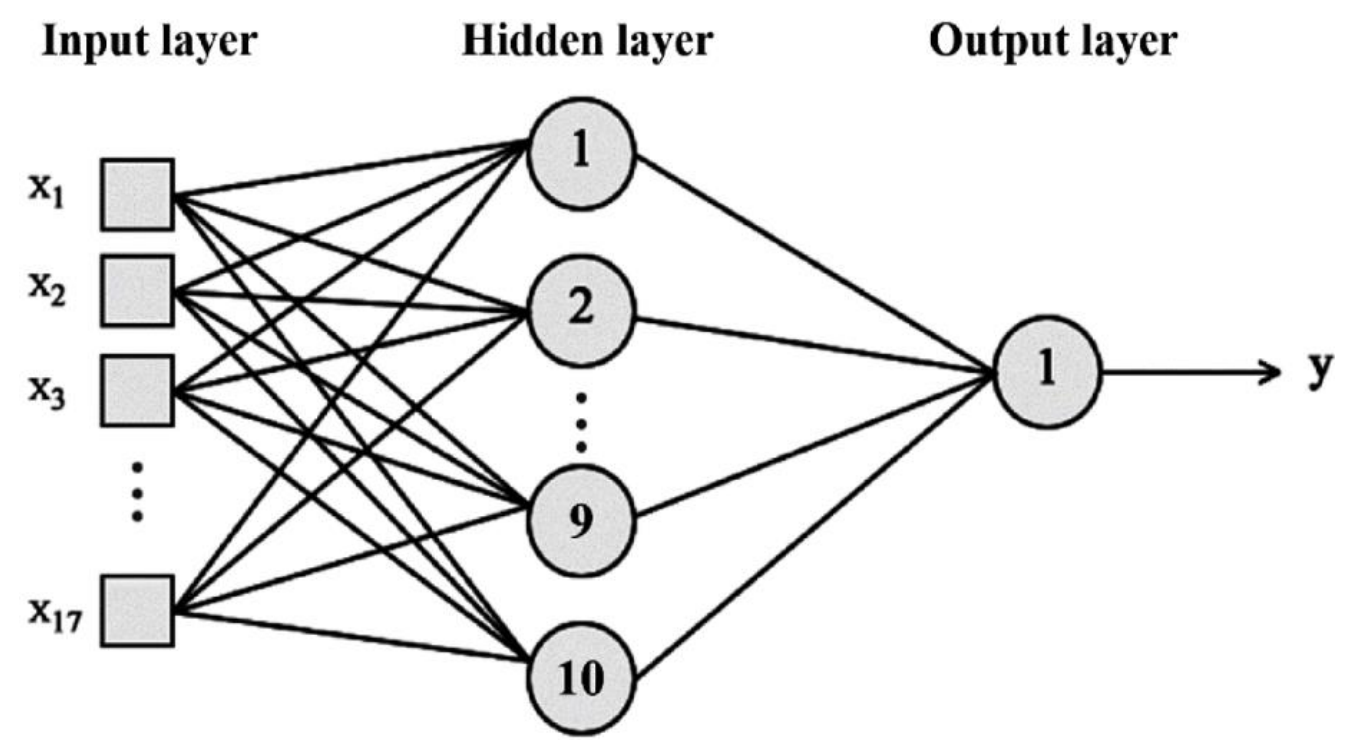

Figure 3. Multilayer perceptron neural network architectures analyzed in this study. 


\subsection{Model Performance Evaluation}

In order to evaluate the performance of the SWAT and ANN models, both in the calibration/training and validation periods, the coefficient of determination $\left(\mathrm{R}^{2}\right)$ and the NashSutcliffe coefficient (NSE) were used. $\mathrm{R}^{2}$ describes the proportion of the variance in observed data that can be explained by the model. It ranges from 0 to 1 , and the higher its value, the better the fit. $\mathrm{R}^{2}$ is calculated by Equation 2 and, in general, values greater than 0.6 are considered acceptable (Moriasi et al., 2015).

$R^{2}=\left[\frac{\sum_{i=1}^{n}\left(Q_{o b s i}-\overline{Q_{o b s}}\right) \cdot\left(Q_{s i m i}-\overline{Q_{s l m}}\right)}{\sqrt{\sum_{i=1}^{n}\left(Q_{o b s i}-\overline{Q_{o b s}}\right)^{2} \cdot \sum_{i=1}^{n}\left(Q_{s i m i}-\overline{Q_{s l m}}\right)^{2}}}\right]^{2}$

Where $Q_{\text {obs }}$ is the observed streamflow, $\mathrm{m}^{3} \cdot \mathrm{s}^{-1}, \mathrm{Q}_{\text {sim }}$ is the simulated streamflow, $\mathrm{m}^{3} \cdot \mathrm{s}^{-1}$, $\overline{Q_{o b s}}$ is the observed mean streamflow, $\mathrm{m}^{3} \cdot \mathrm{s}^{-1}, \overline{Q_{s l m}}$ is the simulated mean streamflow, $\mathrm{m}^{3} \cdot \mathrm{s}^{-1}$, and $\mathrm{n}$ is the number of data points.

NSE indicates how well the plot of observed versus simulated data fits the 1:1 line. It ranges from $-\infty$ to 1 , and the higher the value, the better the fit of the simulated to the observed data (Krause et al., 2005). NSE is calculated using the following Equation 3:

$N S E=1-\frac{\sum_{i=1}^{n}\left(Q_{o b s i}-Q_{s i m i}\right)^{2}}{\sum_{i=1}^{n}\left(Q_{o b s i}-\overline{Q_{o b s}}\right)^{2}}$

Moriasi et al. (2015) proposed the following classification for NSE using a daily time step for simulations: NSE $>0.8$, the model is considered very good; $0.7<\mathrm{NSE}<0.8$, the model is considered good; and $0.5<\mathrm{NSE}<0.7$, the model is considered satisfactory.

\section{RESULTS AND DISCUSSION}

\subsection{Calibration and validation of the SWAT model}

The SWAT model has been calibrated from 1986 to 1995 and validated from 1996 to 2005 using daily streamflow data from the Fazenda Lobeira gauging station, which delimits the MRB. The performance of the SWAT model in terms of $R^{2}$ was acceptable $\left(R^{2}>0.6\right)$, with values of 0.70 and 0.68 for the calibration and validation periods, respectively. Regarding the NSE, values of 0.67 and 0.61 were obtained for the calibration and validation periods, respectively. These values allow classifying the model as "satisfactory" in both periods (Moriasi et al. 2015). These results demonstrate that the model is able to satisfactorily simulate the observed daily streamflow. Studies on the application of SWAT in different basins in Brazil have used NSE to evaluate the performance of the simulations. Durães et al. (2011) evaluated the performance of the SWAT model in hydrological simulation of the Paraopeba River Basin, with a $10,200 \mathrm{~km}^{2}$ drainage area, and obtained NSE value of 0.79 for both the calibration and validation periods. Pereira et al. (2016) evaluated the performance of the SWAT model in hydrologic simulations of the Pomba River Basin, with a drainage area of $8,600 \mathrm{~km}^{2}$, and obtained NSE of 0.76 in both the calibration and validation periods. Rodrigues et al. (2020) evaluated the performance of the SWAT model in monthly streamflow simulation of three hydrographic basins located in the Cerrado biome, and obtained NSE values ranging from 0.56 to 0.84 and 0.70 to 0.81 , respectively, for calibration and validation periods.

Table 1 presents the parameters that were used in the SWAT model, which were selected from the literature review and the LH-OAT sensitivity analysis method, and the final calibrated values of the best simulation generated in calibration for MRB. A detailed description of the 
parameters used in this study can be obtained in Neitsch et al. (2011).

\subsection{Training and validation of $A N N$ model}

The ANN model was developed using the same hydrometeorological dataset and the same training/calibration (1986 to 1995) and validation (1996 to 2005) periods used in the SWAT model. The training and validation of the ANN model was carried out with the number of neurons in the middle layer (NNML) between 1 and 10, and the NSE results for different ANN architectures are presented in Table 2. Considering the classification of Moriasi et al. (2015) as reference, the NSE values for the ANNs are classified as "very good" (>0.8). The results showed an increase in the quality of the simulation when increasing the NNML up to 3. However, above this threshold, no improvement was observed in the NSE values with increasing the NNML.

Table 2. NSE of ANN model with the NNML between 1 and 10.

\begin{tabular}{lcccccccccc}
\hline NNML & $\mathbf{1}$ & $\mathbf{2}$ & $\mathbf{3}$ & $\mathbf{4}$ & $\mathbf{5}$ & $\mathbf{6}$ & $\mathbf{7}$ & $\mathbf{8}$ & $\mathbf{9}$ & $\mathbf{1 0}$ \\
\hline Training & 0.90 & 0.90 & 0.91 & 0.91 & 0.91 & 0.91 & 0.91 & 0.91 & 0.91 & 0.91 \\
Validation & 0.89 & 0.90 & 0.91 & 0.91 & 0.91 & 0.91 & 0.91 & 0.91 & 0.91 & 0.91 \\
\hline
\end{tabular}

Figure 4 shows Tukey's statistical test results at the 5\% significance level for the mean NSE obtained from the 30 replicates for each ANN architecture. Taking the result of the network with a single neuron in the middle layer as reference (Figure 4a), a significantly different behavior of the ANNs with a higher NNML is observed. For the network with the NNML set to 2 (Figure $4 \mathrm{~b}$ ), the behavior was statistically similar to that of the networks with the NNML set to 3 and 4, and distinct from the others. The networks with the NNML set to 3 and 4 were significantly different from the network with the NNML set to 1 . For networks with the NNML $\geq 5$, there was an analogous behavior that was significantly different from networks with the NNML set to 1 and 2. Thus, the structure of 5 NNML was chosen as the proper structure in the Manuel Alves da Natividade River Basin and for the remainder of the analysis, since it was the least complex among those with the best results. The $\mathrm{R}^{2}$ values (for 5 NNML) were 0.97 and 0.79 for the training and validation periods, respectively.

\subsection{Comparison of model performance}

The comparison of the process-based SWAT model and the data-driven ANN model was carried out to study the suitability of these models to simulate the daily streamflow in a basin of the Brazilian Cerrado biome. Table 3 shows the comparison of SWAT and ANN models for the calibration/training and validation periods. The results suggest that the ANN model had greater performance (higher NSE and $\mathrm{R}^{2}$ ) than SWAT for the entire simulation period. This result is similar to those obtained by Makwana and Tiwari (2017), Jimeno-Sáez et al. (2018) and Ahmadi et al. (2019), which observed a better performance of the ANN model than the SWAT model, considering both $\mathrm{R}^{2}$ and NSE coefficients.

SWAT and ANN performances can also be observed by means of scatter plots (Figure 5a, b), for the calibration/training and validation periods, respectively. From these graphics, it can be observed that the scattered SWAT points are concentrated above the 1: 1 line (perfect fit), which means a tendency to overestimate the streamflow. In addition, the ANN model presented better estimates for almost all the streamflow values. In general, the scattered ANN points are closer to the 1:1 line (perfect fit) than SWAT points, which means greater precision. 

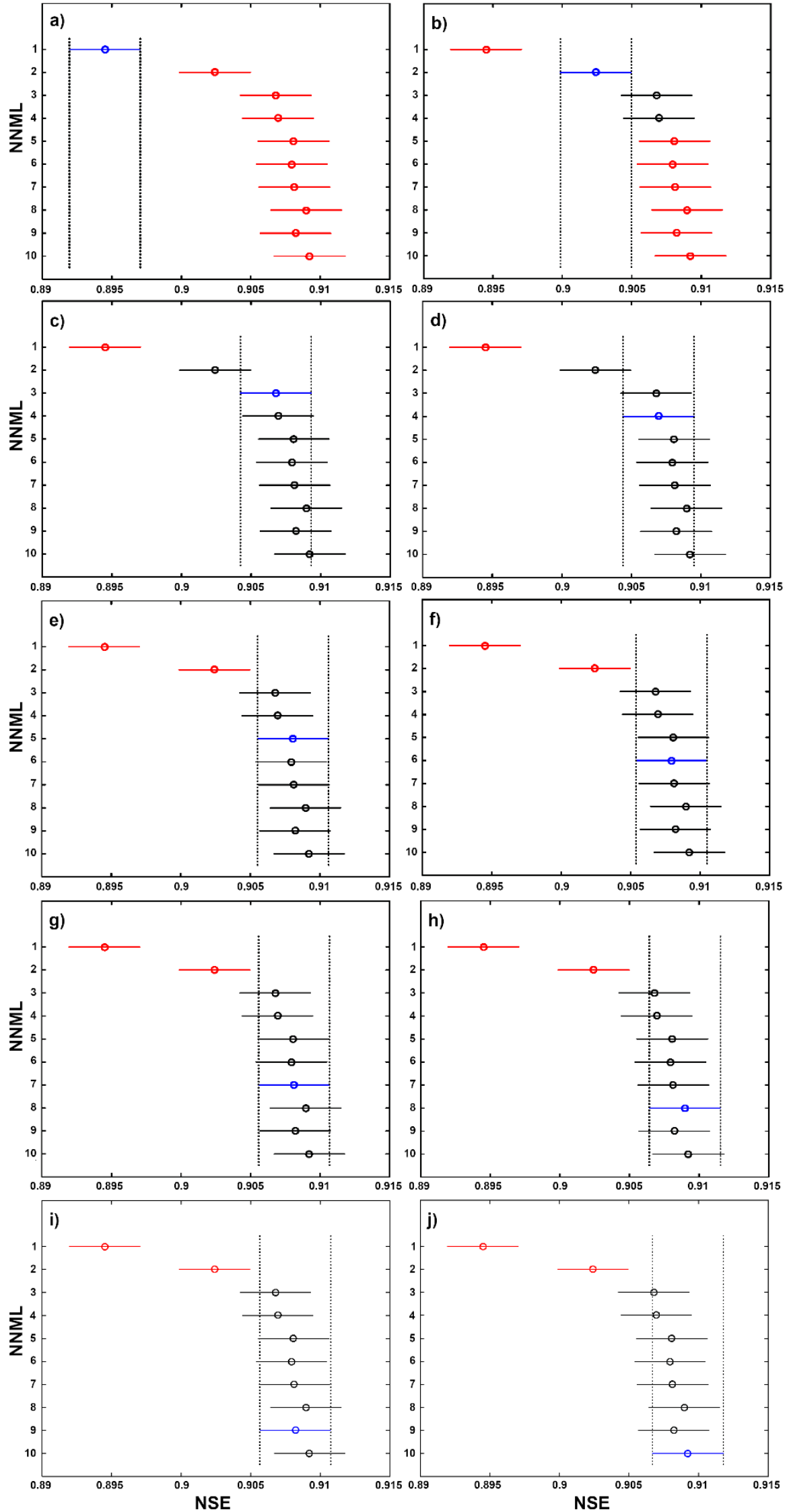

Figure 4. Tukey's test at the 5\% probability significance level for the mean NSE for ANN configurations with 1 (a), 2 (b), 3 (c), 4 (d), 5 (e), 6 (f), 7 (g), 8 (h), 9 (i) and 10 (j) neurons in the middle layer. 
Table 3. Performances of SWAT and ANN models in the calibration/training and validation periods with a daily time step.

\begin{tabular}{ccccc}
\hline \multirow{2}{*}{ Model } & \multicolumn{2}{c}{ Calibration/Training } & \multicolumn{2}{c}{ Validation } \\
\cline { 2 - 5 } & NSE & $\mathbf{R}^{\mathbf{2}}$ & NSE & $\mathbf{R}^{\mathbf{2}}$ \\
\hline SWAT & 0.67 & 0.70 & 0.61 & 0.68 \\
ANN & 0.91 & 0.97 & 0.91 & 0.79 \\
\hline
\end{tabular}
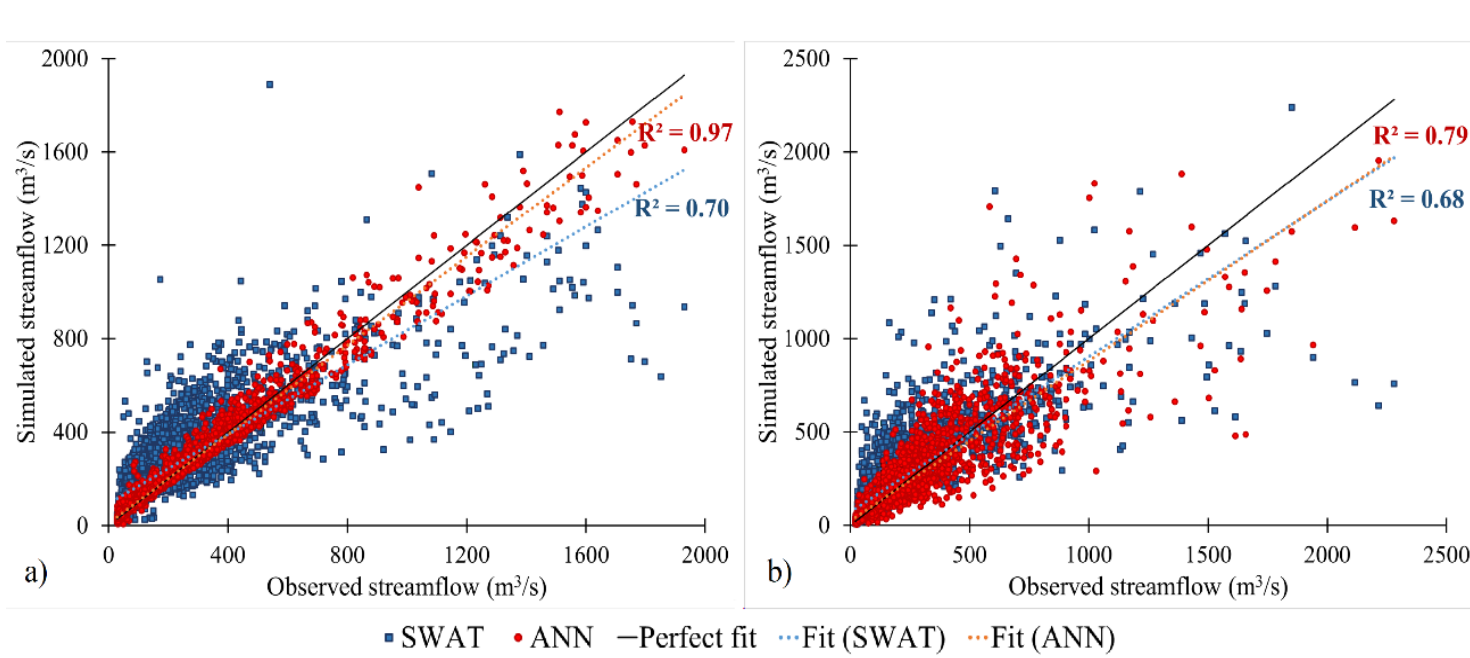

Figure 5. Scatter plots between the observed daily streamflow and the results of SWAT and ANN models during (a) calibration/training period and (b) validation period.

Figure 6 shows the observed daily rainfall and streamflow data along with the streamflow data simulated by the ANN (a) and the SWAT (b) models for the calibration and validation periods. The results indicate that both models showed a good performance when compared against the observed streamflow. However, the adherence of the simulated to the observed data shows an underestimation of the maximum streamflow values by both models. The peak discharges are related to the surface runoff as a response to the intense rainfall events. However, the magnitude of the maximum streamflow depends not only on the magnitude of the intense rainfall but also on other factors, such as soil moisture, topography and land-use, making the modeling of maximum events a hard task in the context of continuous simulations. Otherwise, for recession periods, a greater agreement between the curves was observed. The greater performance of the models in the recession periods is explained based on the predominance of groundwater runoff, which is easier to model than direct surface runoff, given that its genesis is related to the discharge of the aquifer, following the Darcy's law for fluidity in porous media.

In order to further assess the difference between the SWAT and ANN models in the streamflow simulation in the MRB, the flow duration curves (FDC) were developed (Figure 7). It can be observed that the simulated curves presented good agreement with the observed one. The ANN model performed better in all streamflow simulations, and the SWAT model performed worse in estimating intermediate streamflow-frequency values. 


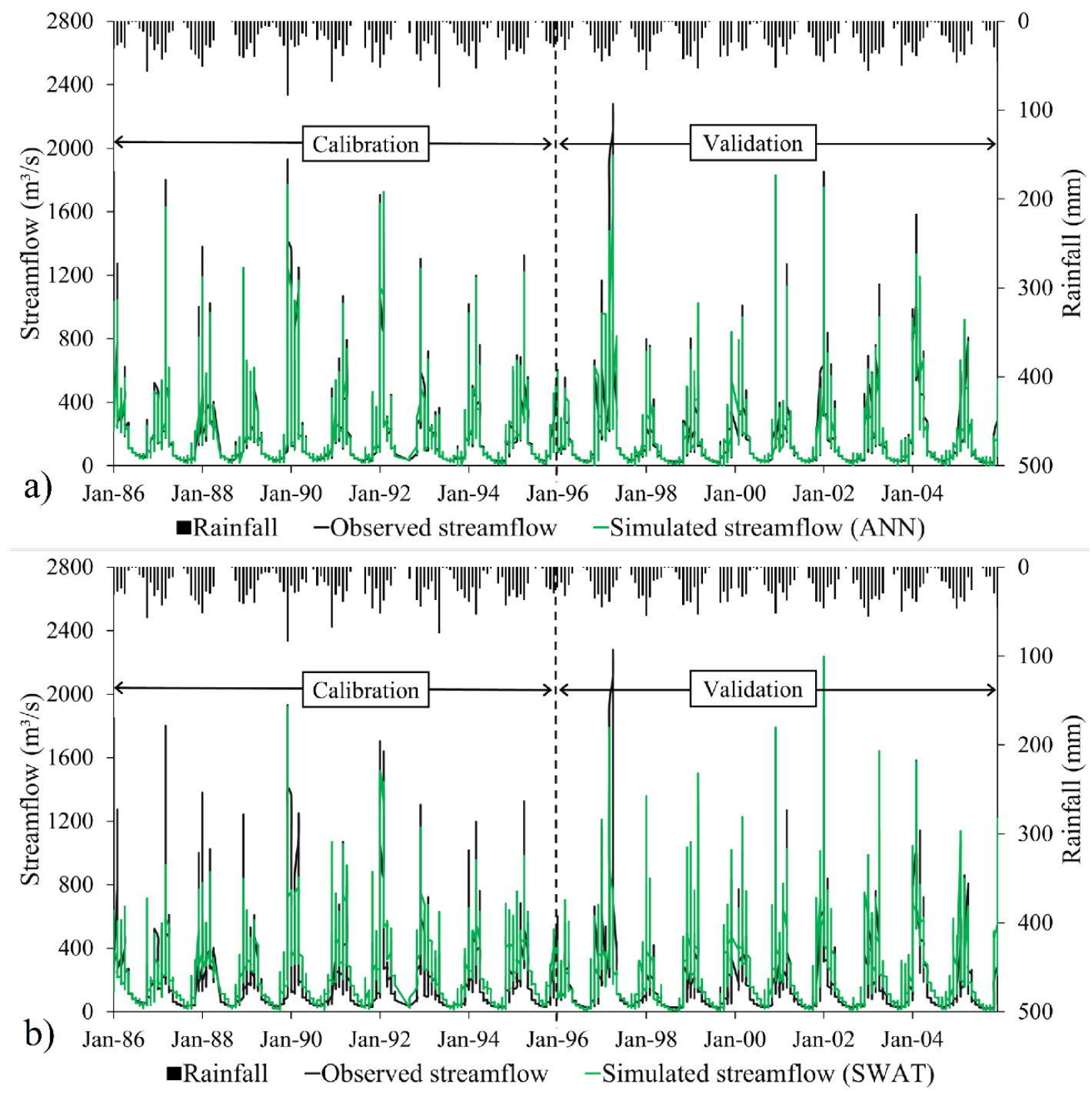

Figure 6. Observed and simulated hydrographs (ANN (a) and SWAT (b)) during the calibration and validation periods for MBR.

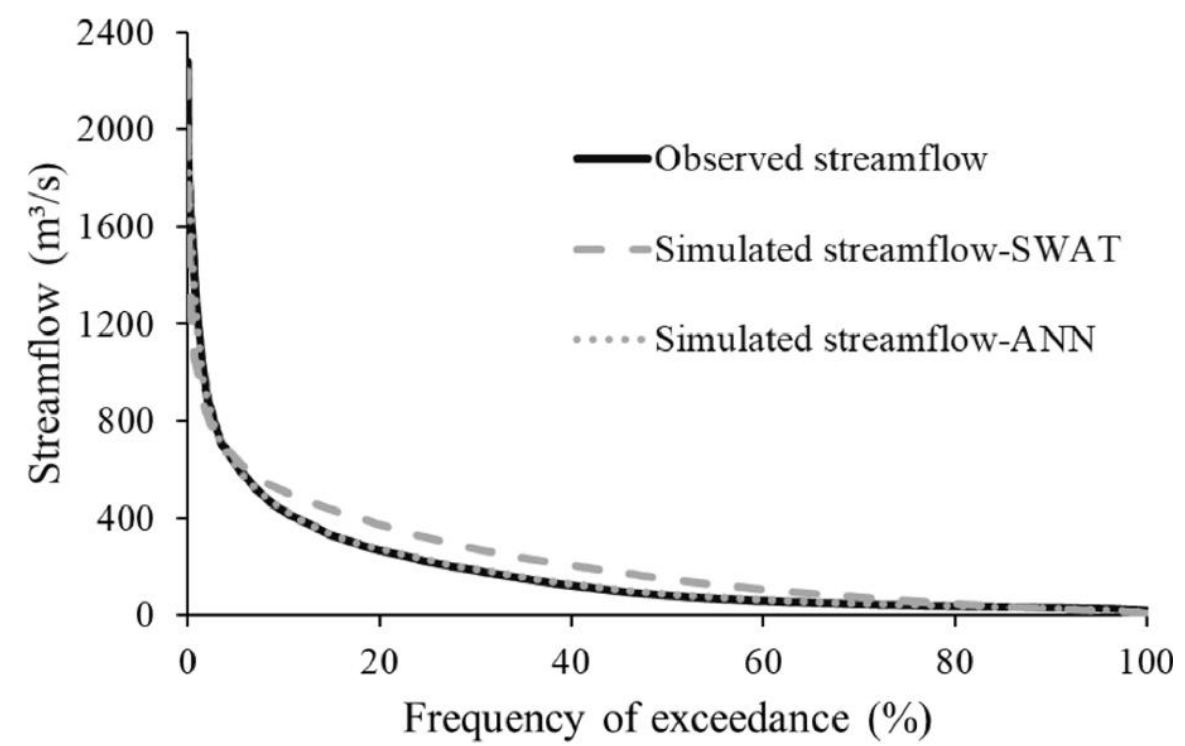

Figure 7. Exceedance frequency curves of observed streamflow, and of simulated SWAT and ANN streamflows. 
Table 4 shows the percentage difference of simulated streamflows with different frequencies of exceedance by the SWAT and ANN models compared to the observed streamflows. The best results were obtained from the ANN model, so its error rates were lower than those of the SWAT model for all simulated streamflows. The ANN model had a very good performance in estimating maximum values and a good performance in estimating minimum values, with error rates ranging from 0.5 to $20.3 \%$. In turn, the SWAT model had a good performance in estimating maximum values, but in estimating average values, its performance was poor, showing error rates ranging from 4.5 to $83.1 \%$. When similar studies in the literature are examined, results similar to this study are obtained. Singh (2016), evaluating the ANN and SWAT models to simulate the streamflow for an Agricultural Watershed in India, reported that the ANN model estimates the streamflow values more accurately and with less uncertainty. Koycegiz and Buyukyildiz (2019), evaluating the ANN and SWAT models to simulate the streamflow at the headwater of Çarsamba River, located at the Konya Closed Basin, Turkey, reported that the ANN model was more successful than the SWAT model. Ahmadi et al. (2019), evaluating the ANN and SWAT models to simulate the daily, monthly, and annual streamflows for the Kan Watershed, Iran, reported that the ANN model performed better in all streamflow simulations. However, when evaluating the literature, studies with diferente results are also found. Zakizadeh et al. (2020) analyzed the performance of the SWAT and ANN models in the runoff simulation for the Darake Watershed, Iran. They found that, for the maximum values, the performance of ANN model was better than that of SWAT, and for the minimum values the performance of SWAT model was better than that of ANN. Kim et al. (2015) analyzed the SWAT and ANN models for streamflow estimation of the Samho gauging station at Taehwa River, Korea. They found that the ANN was better at estimating high flows, while the SWAT model was better at simulating low flows. Pradhan et al. (2020) analyzed the SWAT and ANN models to simulate daily streamflow in three different river basins in different climatic regions of Asia. They found that in general, in two basins, the performance of the ANN model is better than the SWAT, whereas, in the other basin, the SWAT model performance is better than the ANN. Also, the SWAT model was found to be better for low flow simulation and the ANN model performed better for high flow simulation in the three river basins. Jimeno-Sáez et al. (2018) analyzed the SWAT and ANN models to simulate streamflow in two catchments in Peninsular Spain. They reported that the SWAT was more successful in relation to better simulation of lower flows, while ANN was superior at estimating higher flows in all cases. Thus, it can be seen that there is not a better model for all regions; thereby, one can highlight the importance of this analysis for the proper management of water resources.

Table 4. Observed streamflows, in $\mathrm{m}^{3} \mathrm{~s}^{-1}$, with exceeding of $5 \%\left(\mathrm{Q}_{5 \%}\right), 10 \%\left(\mathrm{Q}_{10 \%}\right)$, $20 \%\left(\mathrm{Q}_{20 \%}\right), 50 \%\left(\mathrm{Q}_{50 \%}\right), 90 \%\left(\mathrm{Q}_{90 \%}\right)$ and $95 \%\left(\mathrm{Q}_{95 \%}\right)$, and the percentage differences $\left(\Delta_{\mathrm{Q}}\right)$ of these simulated streamflows by the SWAT and ANN model in comparison against the observed streamflow.

\begin{tabular}{cccc}
\hline Percentage exceedance & Qobserved $\left(\mathrm{m}^{3} \mathrm{~s}^{-1}\right)$ & $\Delta \mathrm{Q}-\mathrm{SWAT}(\%)$ & $\Delta \mathrm{Q}-\mathrm{ANN}(\%)$ \\
\hline $\mathrm{Q}_{5 \%}$ & 618.7 & 4.5 & -0.5 \\
$\mathrm{Q}_{10 \%}$ & 430.0 & 19.1 & 1.0 \\
$\mathrm{Q}_{20 \%}$ & 265.9 & 40.2 & 2.8 \\
$\mathrm{Q}_{50 \%}$ & 81.9 & 83.1 & 7.0 \\
$\mathrm{Q}_{90 \%}$ & 32.6 & -14.1 & -10.6 \\
$\mathrm{Q}_{95 \%}$ & 29.2 & -36.0 & -20.3 \\
\hline
\end{tabular}

Therefore, our results suggest that the use of ANN and SWAT models is suitable for simulating the daily streamflow in the MRB, with the ANN model showing better performance. However, although the ANN model showed better streamflow simulation ability than SWAT, 
ANN model is a data-driven model, which does not consider the hydrological processes involved. Therefore, it is not recommended for situations in which there are alterations of the physical characteristics of the basin, like simulating hydrologic impacts under climate or land use change scenarios, since the rainfall network and land-use types are changed. In contrast, the process-based SWAT model describes the rainfall-streamflow transformation processes in detail; thus, it can better simulate the response of streamflow to changes in environmental factors than the data-driven model.

\section{CONCLUSIONS}

The objective of this study was to model the daily streamflow in a basin of the Brazilian Cerrado biome, using two approaches: a process-based model (the Soil and Water Assessment Tool - SWAT) and the data-driven ANN model, comparing their performance to determine which is more appropriate for the studied basin. It was concluded that both SWAT and ANN were suitable to simulate daily streamflow in the MRB. However, ANN model was better than the SWAT model during calibration and validation periods in all evaluations performed.

The multilayer perceptron artificial neural network was used to model daily streamflow in the MRB based on rainfall, streamflow and meteorological data. The best configuration had 5 neurons in the middle layer. The results of the statistical coefficients showed very good performance in the daily streamflow modeling. In addition, one of the advantages of the ANN model is that it does not require any physical characteristics of the basin and, therefore, its implementation is easier. However, it does not consider hydrological processes, thus, the ANN model cannot be used to simulate the streamflow if the physical characteristics in the basin change. Therefore, ANN is recommended for situations requiring real-time streamflow predictions, as is the case for civil surveillance.

The SWAT hydrological model produced adequate results for daily streamflow modeling in the MRB. It is concluded that the greater complexity of this method, the need for hydrological experience and the higher computational demand are justified for situations in which the analysis of processes of the hydrological cycle are important in a particular drainage basin, as for example in the simulation of land-use changes or climate changes scenarios.

Therefore, the results of this study can help in understanding the capabilities of both models to simulate daily streamflow in the MRB, and contribute to the proper management of water resources in the Brazilian Cerrado biome.

\section{REFERENCES}

ABBASPOUR, K. C.; YANG, J.; MAXIMOV, I.; SIBER, R.; BOGNER, K.; MIELEITNER, J. Modelling hydrology and water quality in the pre-alpine/alpine Thur watershed using SWAT. Journal of Hydrology, v. 333, n. 2-4, p. 413-430, 2007. https://doi.org/10.1016/j.jhydrol.2006.09.014

AHMADI, M.; MOEINI, A.; AHMADI, H.; MOTAMEDVAZIRI, B.; ZEHTABIYAN, G. R. Comparison of the performance of SWAT, IHACRES and artificial neural networks models in rainfall-runoff simulation (case study: Kan watershed, Iran). Physics and Chemistry of the Earth, Parts A/B/C, v. 111, p. 65-77, 2019. https://doi.org/10.1016/j.pce.2019.05.002

AICHOURI, I.; HANI, A.; BOUGHERIRA, N.; DJABRI, L.; CHAFFAI, H.; LALLAHEM, S. River flow model using artificial neural networks. Energy Procedia, v. 74, p. 1007-1014, 2015. https://doi.org/10.1016/j.egypro.2015.07.832 
ALVARENGA, L. A.; CARVALHO, V. S. O.; OLIVEIRA, V. A. D.; MELLO, C. R. D.; COLOMBO, A.; TOMASELLA, J.; MELO, P. A. Hydrological simulation with SWAT and VIC Models in the Verde River Watershed, Minas Gerais. Revista Ambiente \& Água, v. 15, n. 4, 2020. https://doi.org/10.4136/ambi-agua.2492

AMORIM, J. D. S.; VIOLA, M. R.; JUNQUEIRA, R.; OLIVEIRA, V. A. D.; MELLO, C. R. D. Evaluation of Satellite Precipitation Products for Hydrological Modeling in the Brazilian Cerrado Biome. Water, v. 12, n. 9, p. 2571, 2020. https://doi.org/10.3390/w12092571

ARNOLD, J. G.; SRINIVASAN, R.; MUTTIAH, R. S.; WILLIAMS, J. R. Large area hydrologic modeling and assessment part I: model development 1. JAWRA Journal of the American Water Resources Association, v. 34, n. 1, p. 73-89, 1998. https://doi.org/10.1111/j.1752-1688.1998.tb05961.x

BEUCHLE, R.; GRECCHI, R. C.; SHIMABUKURO, Y. E.; SELIGER, R.; EVA, H. D.; SANO, E.; ACHARD, F. Land cover changes in the Brazilian Cerrado and Caatinga biomes from 1990 to 2010 based on a systematic remote sensing sampling approach. Applied Geography, v. 58, n. 2, p. 116-127, 2015. https://dx.doi.org/10.1016/j.apgeog. 2015.01.017

CHOUBIN, B.; SOLAIMANI, K.; REZANEZHAD, F.; ROSHAN, M. H.; MALEKIAN, A.; SHAMSHIRBAND, S. Streamflow regionalization using a similarity approach in ungauged basins: Application of the geo-environmental signatures in the Karkheh River Basin, Iran. Catena, v. 182, p. 104128, 2019. https://doi.org/10.1016/j.catena.2019.104128

DEMIREL, M. C.; VENANCIO, A.; KAHYA, E. Flow forecast by SWAT model and ANN in Pracana basin, Portugal. Advances in Engineering Software, v. 40, n. 7, p. 467-473, 2009. https://doi.org/10.1016/j.advengsoft.2008.08.002

DEVIA, G. K.; GANASRI, B. P.; DWARAKISH, G. S. A review on hydrological models. Aquatic Procedia, v. 4, p. 1001-1007, 2015. https://doi.org/10.1016/j.aqpro.2015.02.126

DURÃES, M. F.; MELLO, C. R.; NAGHETTINI, M. Applicability of the SWAT model for hydrologic simulation in Paraopeba River Basin, MG. Cerne, v. 17, n. 4, p. 481-488, 2011.

EMBRAPA. Mapa de solos do Brasil. 2011. Available at: http://mapoteca.cnps.embrapa.br/geoacervo/det_mapa.aspx. Access: 15th March 2017.

HAYKIN, S. Redes neurais: princípios e prática. São Paulo: Bookman, 2007.

JIMENO-SÁEZ, P.; SENENT-APARICIO, J.; PÉREZ-SÁNCHEZ， J.; PULIDOVELAZQUEZ, D. A Comparison of SWAT and ANN models for daily runoff simulation in different climatic zones of peninsular Spain. Water, v. 10, n. 2, p. 192, 2018. https://doi.org/10.3390/w10020192

KIM, M. et al. Comparative studies of different imputation methods for recovering streamflow observation. Water, v. 7, n. 12, p. 6847-6860, 2015. https://doi.org/10.3390/w7126663

KOTHARI, M.; GHARDE, K.D. Application of ANN and fuzzy logic algorithms for stream flow modeling of Savitri catchment. Journal of Earth System Science, v. 124, p. 933943, 2015. https://doi.org/10.1007/s12040-015-0592-7

KOTTEK, M.; GRIESER, J.; BECK, C.; RUDOLF, B.; RUBEL, F. World map of the KöppenGeiger climate classification updated. Meteorologische Zeitschrift, v. 15, n. 3, p. 259-263, 2006. 
KOYCEGIZ, C.; BUYUKYILDIZ, M. Calibration of SWAT and Two Data-Driven Models for a Data-Scarce Mountainous Headwater in Semi-Arid Konya Closed Basin. Water, v. 11, n. 1, p. 147, 2019. https://doi.org/10.3390/w11010147

KRAUSE, P.; BOYLE, D. P.; BÄSE, F. Comparison of different efficiency criteria for hydrological model assessment. Advances in Geosciences, v. 5, p. 89-97, 2005.

LIMA, J. E. F. W. Situação e perspectivas sobre as águas do cerrado. Ciência e cultura, v. 63, n. 3, p. 27-29, 2011.

MAKWANA, J. J.; TIWARI, M. K. Intermittent streamflow forecasting and extreme event modelling using wavelet based artificial neural networks. Water Resources Management, v. 28, p. $4857-4873,2014$.

MAKWANA, J. J.; TIWARI, M. K. Hydrological stream flow modelling using soil and water assessment tool (SWAT) and neural networks (NNs) for the Limkheda watershed, Gujarat, India. Modeling Earth Systems and Environment, v. 3, n. 2, p. 635-645, 2017.

MEDRADO, E.; LIMA, J. E. F. W. Development of pedotransfer functions for estimating water retention curve for tropical soils of the Brazilian savanna. Geoderma Regional, v. 1, p. 59-66, 2014. https://dx.doi.org/10.1016/j.geodrs.2014.08.003

MEllO, C. D.; VIOLA, M. R.; NORTON, L. D.; SILVA, A. M.; WEIMAR, F. A. Development and application of a simple hydrologic model simulation for a Brazilian headwater basin. Catena, v. 75, n. 3, p. 235-247, 2008.

MINNS, A. W.; HALL, M. J. Artificial neural networks as rainfall-runoff models. $\begin{array}{lllllll}\text { Hydrological Sciences Journal, } & \text { v. } & 41, & \text { n. } & 3, & 1996 .\end{array}$ https://doi.org/10.1080/02626669609491511

MONTEIRO, J. A.; STRAUCH, M.; SRINIVASAN, R.; ABBASPOUR, K.; GÜCKER, B. Accuracy of grid precipitation data for Brazil: application in river discharge modelling of the Tocantins catchment. Hydrological processes, v. 30, n. 9, p. 1419-1430, 2015.

MORIASI, D. N.; GITAU, M. W.; PAI, N.; DAGGUPATI, P. Hydrologic and water quality models: Performance measures and evaluation criteria. Transactions of the ASABE, v. 58, n. 6, p. 1763-1785, 2015.

MYERS, N.; MITTERMEIER, R. A.; MITTERMEIER, C. G.; DA FONSECA, G. A.; KENT, J. Biodiversity hotspots for conservation priorities. Nature, v. 403, n. 6772, p. 853-858, 2000 .

NEITSCH, S. L. et al. SWAT Model User's Manual. Texas: Texas A\&M University, 2011.

NÓBREGA, R. L.; GUZHA, A. C.; TORRES, G. N.; KOVACS, K.; LAMPARTER, G.; AMORIM, R. S.; GEROLD, G. Effects of conversion of native cerrado vegetation to pasture on soil hydro-physical properties, evapotranspiration and streamflow on the Amazonian agricultural frontier. PloS one, v. 12, n. 6, 2017.

NOORI, N.; KALIN, L. Coupling SWAT and ANN models for enhanced daily streamflow prediction. Journal of Hydrology, v. 533, p. 141-151, 2016. https://doi.org/10.1016/j.jhydrol.2015.11.050 
NYEKO, M. Hydrologic Modelling of Data Scarce Basin with SWAT Model: Capabilities and Limitations. Water Resources Management, v. 29, p. 81-94, 2015. https://doi.org/10.1007/s11269-014-0828-3

ONS. Manual de Procedimentos da Operação. Módulo 10 - Submódulo 10.18. CDOR.TO.TOC Cadastro de Informações Operacionais Hidráulicas da Bacia do rio Tocantins. 2020. Available at: http://www.ons.org.br/ Access: 20th Oct. 2020.

OLIVEIRA, V. A.; DE MELlO, C. R.; BESKOW, S.; VIOLA, M. R.; SRINIVASAN, R. Modeling the e ects of climate change on hydrology and sediment load in a headwater basin in the Brazilian Cerrado biome. Ecological Engineering, v. 133, p. 20-31, 2019. https://doi.org/10.1016/j.ecoleng.2019.04.021

PAPALASKARIS, T. Artificial Neural Network for Daily Low Stream Flow Rate Prediction of Iokastis Stream, Kavala City, NE Greece, NE Mediterranean Basin. Environmental Sciences Proceedings, Multidisciplinary Digital Publishing Institute, v. 2, n. 1, p. 70, 2020. https://doi.org/10.3390/environsciproc2020002070

PEREIRA, D. R.; MARTINEZ, M. A.; PRUSKI, F. F.; SILVA, D. D. Hydrological simulation in a basin of typical tropical climate and soil using the SWAT model part I: Calibration and validation tests. Journal of Hydrology: Regional Studies, v. 7, p. 14-37, 2016. https://doi.org/10.1016/j.ejrh.2016.05.002

PONTES, L. M.; VIOLA, M. R.; SILVA, M. L. N.; BISPO, D. F.; CURI, N. Hydrological modeling of tributaries of cantareira system, Southeast Brazil, with the Swat model. Engenharia Agrícola, v. 36, n. 6, p. 1037-1049, 2016. https://doi.org/10.1590/1809-4430eng.agric.v36n6p1037-1049/2016

PRADHAN, P.; TINGSANCHALI, T.; SHRESTHA, S. Evaluation of Soil and Water Assessment Tool and Artificial Neural Network models for hydrologic simulation in different climatic regions of Asia. Science of the Total Environment, v. 20, n. 701, p. 134308, 2020. http://dx.doi.org/10.1016/j.scitotenv.2019.134308

RODRIGUES, J. A.; VIOLA, M. R.; ALVARENGA, L. A.; MELlO, C. R.; CHOU, S. C.; OLIVEIRA, V. A.; UDDAMERI, V.; MORAIS, M. A. Climate change impacts under representative concentration pathway scenarios on streamflow and droughts of basins in the Brazilian Cerrado biome. International Journal of Climatology, v. 40, n. 5, p. 25112526, 2020. https://doi.org/10.1002/joc.6347

SILVA, J. M. C.; BATES, J. M. Biogeographic patterns and conservation in the south American Cerrado: a tropical savanna hotspot. Bioscience, v. 52, n. 3, p. 225-234, 2002.

SILVA, J. F.; FARIÑAS, M. R.; FELFILI, J. M.; KLINK, C. A. Spatial heterogeneity, land use and conservation in the Cerrado region of Brazil. Journal of Biogeography, v. 33, p. 536548, 2006. https://doi.org/10.1111/j.1365-2699.2005.01422.x

SINGH, A. Modeling Stream Flow with Prediction Uncertainty by Using SWAT Hydrologic and RBNN Models for an Agricultural Watershed in India. National Academy Science Letters, v. 39, p. 213-216, 2016. https://doi.org/10.1007/s40009-016-0436-2

TALEBIZADEH, M.; MORIDNEJAD, A. Uncertainty analysis for the forecast of lake level fluctuations using ensembles of ANN and ANFIS models. Expert Systems with applications, v. 38, n. 4, p. 4126-4135, 2011. https://doi.org/10.1016/j.eswa.2010.09.075 
TAN, M. L.; GASSMAN, P.; YANG, X.; HAYWOOD, J. A review of SWAT applications, performance and future needs for simulation of hydro-climatic extremes. Advances in $\begin{array}{llllll}\text { Water Resources, } & \text { v. } & 143, & \text { n. }\end{array}$ https://doi.org/10.1016/j.advwatres.2020.103662

TOCANTINS. Secretaria de Planejamento e da Modernização da Gestão Pública. Estudo da dinâmica da cobertura e uso da terra do estado do Tocantins: dinâmica do Tocantins. Palmas, 2012.TUKEY, J. W. Comparing individual means in the analysis of variance. Biometrics, v. 5, n. 2, p. 99-114, 1949.

VAN GRIENSVEN, A.; MEIXNER, T.; GRUNWALD, S.; BISHOP, T.; DILUZIO, M.; SRINIVASAN, R. A global sensitivity analysis tool for the parameters of multi-variable catchment models. Journal of Hydrology, v. 324, n. 1-4, p. 10-23, 2006. https://doi.org/10.1016/j.jhydrol.2005.09.008

VILANOVA, R. S.; ZANETTI, S. S.; CECILIO, R. A. Assessing combinations of artificial neural networks input/output parameters to better simulate daily streamflow: Case of Brazilian Atlantic Rainforest watersheds. Computers and Electronics in Agriculture, v. 167, p. 105080, 2019. https://doi.org/10.1016/j.compag.2019.105080

YASEEN, Z. M.; SULAIMAN, S. O.; DEO, R. C.; CHAU, K.-W. An enhanced extreme learning machine model for river flow forecasting: State-of-the-art, practical applications in water resource engineering area and future research direction. Journal of Hydrology, v. 569, p. 387-408, 2019. https://doi.org/10.1016/j.jhydrol.2018.11.069

ZAKIZADEH, H.; AHMADI, H.; ZEHTABIAN, G.; MOEINI, A.; MOGHADDAMNIA, A. A novel study of SWAT and ANN models for runoff simulation with application on dataset of metrological stations. Physics and Chemistry of the Earth, Parts A/B/C, v. 120, p. 102899, 2020. https://doi.org/10.1016/j.pce.2020.102899

ZHOU, J.; PENG, T.; ZHANG, C.; SUN, N. Data pre-analysis and ensemble of various artificial neural networks for monthly streamflow forecasting. Water, v. 10, p. 628, 2018. https://doi.org/10.3390/w10050628 